\title{
REVOLUÇÃO MEXICANA: O DIREITO EM TEMPOS DE TRANSFORMAÇÃO SOCIAL
}

TESE DE DOUTORADO

ORIENTADOR: PROFESSOR TITULAR

JOSÉ EDUARDO CAMPOS DE OLIVEIRA FARIA

FACULDADE DE DiREITO DA UNIVERSIDADE DE SÃo PAULO SÃO PAULO

2016 


\section{REVOLUÇÃO MEXICANA: O DIREITO EM TEMPOS DE TRANSFORMAÇÃO SOCIAL}

Tese apresentada como requisito parcial para a obtenção do título de Doutora, junto ao Departamento de Filosofia e Teoria Geral do Direito da Faculdade de Direito da Universidade de São Paulo, sob a orientação do Prof. Titular Dr. José Eduardo Campos de Oliveira Faria.

FACULDADE DE DiREITO DA UNIVERSIDADE DE SÃo PAUlO

SÃO PAULO

2016 
"Não é, porém, a esperança um cruzar de braços e esperar. Movo-me na esperança enquanto luto e, se luto, com esperança espero." Paulo Freire

Dedico esta tese aos muitos revolucionários que, com a esperança de um mundo (ou de uma vida) melhor, decidiram lutar. Ao sangue e à vida de vocês devemos tanto. Nesse tanto, também nossos direitos sociais. Os que já existem e os que, previstos na Constituição, ainda demandam outras tantas lutas para se efetivar.

Dedico também à Teodora, que desde que nasceu revolucionou minha vida. Com muito amor. 


\section{AgradeCiMENTOS}

"Cada criatura humana traz duas almas consigo: uma que olha de dentro para fora, outra que olha de fora para dentro." Machado de Assis, $O$ Espelho.

"Fixemo-nos no concreto. O espelho, são muitos, captando-lhe as feições; todos refletem-lhe o rosto, e o senhor crê-se com aspecto próprio e praticamente imudado, do qual lhe dão imagem fiel. Mas que espelho? Há-os 'bons' e 'maus', os que favorecem e os que detraem; e os que são apenas honestos, pois não." Guimarães Rosa, $O$ Espelho.

Tal qual a 'alma externa' do conto de Machado de Assis, os olhares de todas as pessoas que estão nestes agradecimentos compõem o que sou. Sem o espelho que enxerguei em suas feições e seus olhos generosos, carinhosos, orgulhosos e confiantes, provavelmente eu não teria conseguido chegar até o fim deste trabalho. Sem vocês, eu não acreditaria ser capaz. Ao lado de todos vocês, porém, não só fui capaz como de alguma forma me orgulho deste texto que aqui está. Ele é o resultado de um processo ao mesmo tempo solitário e de tanta troca. Parecido com a vida, talvez.

Assim, agradeço a meu orientador José Eduardo Faria, por conseguir enxergar qualidades e caminhos de pesquisa em meus textos, mesmo quando estavam apenas esboçados. Sua tranquilidade me fez bem. Depois de tantos anos de orientação, no mestrado e no doutorado, tenho tantos bons encontros e conversas a agradecer.

Aos professores que participaram de minha banca de qualificação, José Reinaldo de Lima Lopes e Jorge Grespan, pela leitura e disponibilidade para discussão das ideias iniciais. Também aos professores das disciplinas do doutorado, que possibilitaram momentos de intensas trocas intelectuuais: Álvaro de Vita, Bernardo Ricupero, Cicero Araújo, Gilberto Bercovici, Roberto Gargarella e Walquíria Leão Rego.

Agradeço também àqueles que me ajudaram no difícil período de encerramento do trabalho, lendo, revisando e sugerindo aprimoramentos em todos os longos textos. Muito obrigada pelo carinho, incentivo e disponibilidade para o trabalho intenso neste final Clívia Ramiro, Marina Tranjan e Tiago Tranjan. 
Aos primeiros historiadores, e queridos amigos, que leram parte deste trabalho e me incentivaram a permanecer na história, apesar das dificuldades iniciais com o que para mim era um novo campo: Felipe Loureiro e José Augusto Dias. Também agradeço ao meu amigo mexicano Carlos Vargas Tamez, militante do direito à educação e interessado em Revolução Mexicana, que fez a versão para o espanhol do resumo.

Em 2014, organizei um curso para o PET-Sociologia Jurídica, da Faculdade de Direito da USP, chamado "O papel do direito em tempos de transformação social". Agradeço aos petianos Bárbara Simão, Felipe Gretschischkin, Fernanda Coutinho, Fernanda Gomes, Gabriela Avelino, Gabriel Maia, Maria Luciano, Mariana Buzzo, Mateus Tormin, Olívia Bonan, Rodrigo Marambaia, Tarcila Tojal e Vinícius Novo pelos excelentes debates e pela possibilidade de discutir em grupo questões teóricas que estão no horizonte deste trabalho. Também agradeço aos amigos José Rodrigo Rodriguez, Marcos Nobre, Thiago Barison e Walter Andrade pelas discussões e por compartilharem comigo inquetações, desconfianças e expectativas em relação ao direito.

Ao longo do doutorado, aos poucos fui deixando de ser advogada e me tornei cada vez mais a professora que sou hoje. Agradeço aos estudantes com quem dividi a sala de aula, por manterem (na maior parte do tempo) os olhares atentos e interessados e pela disponibilidade para trocar. Doutorado e docência se cruzaram, sobretudo neste último ano. Quando o trabalho de pesquisa estava difícil, procurava forças na sala de aula para poder continuar. E vice-versa.

A todos os meus muitos amigos e colegas professores da Faculdade Cásper Líbero e da Universidade Presbiteriana Mackenzie, que tiveram paciência para me ouvir falar monotematicamente sobre o direito na Revolução Mexicana. Pelo interesse, carinho e amizade agradeço a Bianca Santana, Michelle Prazeres e Alexander Hilsenbeck, representando todos os professores da Cásper, e a Bruna Angotti e Danilo Tavares, representando os professores do Mackenzie.

Na Ação Educativa, aprendi na prática da defesa jurídica e política do direito à educação o quão importante é haver direitos sociais constitucionalizados. Desse período, muitas coisas ficaram comigo, das quais me orgulho. As mais preciosas, porém, são os amigos: Salomão Ximenes, Fernanda Campagnucci, Denise Carreira e Hugo Fanton. 
Agradeço às minhas amigas queridas: Marina Menezes, sempre amorosa e com elogios fora de hora e Lucia Del Picchia, que em um jantar ajudou-me a delimitar o tema desta tese. Passados esses quatro anos de doutorado, obrigado por continuarem tendo ouvidos e olhos atentos a tudo o que me diz respeito.

Agradeço a todos os amigos queridos que acompanharam com interesse o desenvolvimento desta tese: Fernando Rugitsky, Bruno Lupion, Manuel Bonduki, Anaí Rodrigues, Laura Benda, Renan Quinalha, Bianca Galafassi, Rui Barossi, Ian Guerriero, Eloísa Machado, Marianna Sampaio, Stefan Klein, Guilherme Grandi, Rita Alvares.

Aos meus pais, Luiz e Regina, por terem me criado como eu sou, pelo interesse e por todo amor, sempre; aos meus irmãos Raquel e João Pedro, por estarem sempre junto comigo. À Maria Alice e ao Paride, representando toda a família Gammardella, e à Helena, representando toda a família Rizzi, muito obrigada por existirem e por estarem perto. À família Cervone Tranjan - Nilce, Marina, Ercílio - pelo carinho e amor com que continuam acolhendo a mim e aos meus temas de reflexão.

Agradeço também às bibliotecas, em que passei horas, muitas horas, estudando e trabalhando nesta tese. Foram inúmeras: Biblioteca da Faculdade de Direito da USP, no Largo São Francisco; outras bibliotecas da USP: Florestan Fernandes (FFLCH), FEA, Faculdade de Saúde Pública, IME, Medicina; Biblioteca da Faculdade Cásper Líbero; Biblioteca Alceu Amoroso Lima; Biblioteca do Centro Cultural São Paulo; Biblioteca Mario de Andrade. A todos esses espaços de silêncio e concentração, e aos bibliotecários que deles cuidam, meus sinceros agradecimentos.

Agradeço à Teodora pelo olhar paciente e compreensivo. Agradeço também por seu modo particular de mostrar interesse por este trabalho. Com frequência dizia "quero ver as fotos do doutorado". E lá ia eu mostrar os “chapeludos".

Ao Tiago Tranjan agradeço a vida tão intensamente compartilhada, o entusiasmo com a Revolução Mexicana e todo o amor, sempre. Agradeço também o olhar de quem me conhece.

Agradeço a todos porque fazem parte, de diferentes maneiras, das qualidades da presente pesquisa. Minha é, no entanto, a responsabilidade por suas insuficiências ou equívocos. 
"La nostalgia se codifica en un rosario de muertos y da un poco de vergüenza estar aquí sentado frente a una máquina de escribir, aun sabiendo que eso es también una especie de fatalidad, aun si uno pudiera consolarse con la idea de que es una fatalidad que sirve para algo.” Rodolfo Walsh 


\section{RESUMO}

Em 5 de fevereiro de 2017 a Constituição Política dos Estados Unidos Mexicanos completa cem anos. Corolário da Revolução Mexicana que a antecedeu, a Constituição Mexicana de 1917 é a primeira no mundo a assegurar direitos sociais regulação da propriedade e reforma agrária, direitos dos trabalhadores, direito à educação laica - em seu texto. A criação de um constitucionalismo social transformou o próprio conceito de Estado, ampliando consideravelmente tanto sua capacidade de intervenção na realidade como as expectativas e demandas sociais de ação estatal. $\mathrm{O}$ objetivo desta tese foi descrever e analisar o desenrolar revolucionário mexicano entre 1910 e 1917, principalmente a partir dos planos e documentos jurídicos produzidos pelos diferentes grupos que dele participaram, para compreender o contexto histórico que possibilitou as formulações originais e a inclusão de direitos sociais na Constituição de 1917.

A análise dessa porção da história do direito mexicano mostra que, ao adotarem a forma jurídica para escrever seus anseios de transformação social, as diferentes correntes revolucionárias mexicanas decidiram deliberadamente disputar a forma-direito que seria responsável por ordenar a sociedade. Assumiram que o conteúdo das normas jurídicas futuras estava também sujeito ao resultado da luta social que eles vinham travando. E que não se tratava de uma batalha perdida contra uma forma que lhes era necessariamente desfavorável, mas sim de uma disputa que poderia ser vencida. Além disso, a análise dos textos de planos, decretos e outros documentos revolucionários fontes primárias escritas em linguagem jurídica - trouxe importantes elementos para a compreensão e interpretação da própria Revolução Mexicana. A história do direito que aqui se reconstrói contribuiu para novos olhares sobre aquele momento histórico, levando a divergências consideráveis frente à historiografia consagrada, em especial no que diz respeito à avaliação política do processo revolucionário. Permitiu também conclusões importantes acerca do papel do direito na história, particularmente na história das revoluções.

Palavras-chave: Revolução Mexicana; História do Direito; História do Constitucionalismo; Constituição Mexicana de 1917; Constituição Social; Reforma Agrária; Direito do Trabalho. 


\begin{abstract}
On the fifth of January, 2017, the Political Constitution of the United Mexican States celebrates a hundred years of existence. Corollary to the Mexican Revolution which preceded it, the Mexican Constitution of 1917 is the first in the world to secure social rights - property limitations and agrarian reform, labor rights, right to a secular education - in its text. The creation of a social constitutionalism transformed the very concept of State, considerably enlarging its capacity to intervene upon reality and, at the same time, augmenting social demands and expectancies for state action. The purpose of this doctoral thesis was to describe and analyze the development of Mexican Revolution between 1910 and 1917, with particular emphasis upon juridical plans and documents ensued by the different groups that took part in it, in order to better understand the historical context that made possible the original ideas incorporated in the 1917 Constitution, especially the inclusion of social rights.

Analysis of this portion of Mexican Law History shows that, by adopting the juridical form to inscribe their demands for social transformation, the distinct revolutionary parties deliberately opted for disputing the Law-form, as responsible for shaping society. They assumed that the content of future juridical rules was subject also to the result of the social struggles they had been engaged in; that this was not a battle doomed to be lost against a form necessarily contrary to their interests, but a dispute that could turn out in their favor. Moreover, analysis of the text of different plans, decrees and other revolutionary documents - primary sources written in juridical language - brought important elements for the understanding and interpreting of Mexican Revolution itself. The legal history which was here reconstructed contributed to shape a new way of looking to that historical period, with considerable disagreement with established historiography, particularly as regards the political evaluation of the revolutionary process. It also allowed important conclusions as to the role played by law in History, particularly in the history of revolutions.
\end{abstract}

Keywords: Mexican Revolution; Law History; Constitutional History; Mexican Constitution of 1917; Social Constitution; Agrarian Reform; Labor Law. 


\section{RESUMEN}

El 5 de febrero de 2017 la Constitución Política de los Estados Unidos Mexicanos cumple 100 años. Es el corolario de la Revolución Mexicana, que le antecedió, y la primera en el mundo en asegurar en su texto derechos sociales como la regulación de la reforma agraria, los derechos de los trabajadores, el derecho a una educación laica. La creación de un constitucionalismo social transformó el concepto mismo del Estado, ampliando considerablemente tanto su capacidad de intervención en la realidad, como las expectativas y demandas sociales de acción estatal. El objetivo de esta tesis fue describir y analizar el recorrido revolucionario mexicano entre $1910 \mathrm{y}$ 1917, principalmente a partir de los planes y documentos jurídicos producidos por los diferentes grupos que participaron en él, con el fin de comprender el contexto histórico que posibilitó las formulaciones originales y la inclusión de derechos sociales en la Constitución de 1917.

El análisis de esta parte de la historia del derecho mexicano muestra que, mediante la adopción de una forma jurídica con la que escribir sus deseos para el cambio social, las distintas corrientes revolucionarias mexicanas decidieron, deliberadamente, defender sus puntos de vista sobre los mejores medios de ordenar jurídicamente la sociedad. Asumieron, así, que el contenido de las futuras normas jurídicas estaba también sujeto a los resultados de la lucha social en que venían trabajando y que no se trataba de una batalla perdida contra una forma que les fuera necesariamente desfavorable, pero sí de una disputa que podría ser ganada. Además, el análisis de los planes, de los textos, decretos y otros documentos revolucionarios fuentes primarias escritas en lenguaje jurídico - brinda elementos importantes para la comprensión e interpretación de la propia Revolución Mexicana. La historia del derecho que aquí se reconstruye contribuye con nuevas perspectivas de ese momento histórico, dando lugar a diferencias considerables frente a la historiografía consagrada; en particular, con respecto a la evaluación política del proceso revolucionario. Permite también conclusiones importantes sobre el papel del derecho en la historia, especialmente en la historia de las revoluciones.

Palabras clave: Revolución Mexicana; Historia del Derecho; Historia del Constitucionalismo; Constitución Mexicana de 1917; Constitución Social; Reforma Agraria; Derecho del Trabajo. 


\section{SUMÁRIO}

INTRODUÇÃO

Capítulo 1

Desenrolar Revolucionário e Organização Política da Realidade

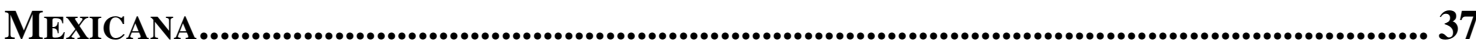

1.1 Tensões do governo de Porfírio Díaz em 1910 .................................................... 39

1.1.1 Desenvolvimento do transporte ferroviário no México do final do século XIX

1.1.2 A regulamentação jurídica da economia mexicana no porfiriato: ferrovias, petróleo, mineração e instituições financeiras.................................. 47

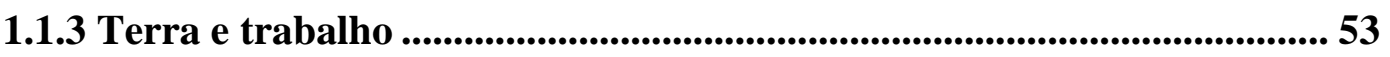

1.1.4 Tensões entre centralismo e localismo (características do federalismo mexicano) (............................................................................................................55

1.1.5 Liberdades públicas, processo eleitoral fraudulento e alistamento compulsório................................................................................................................5 59

1.2 Antecedentes da revolução: Partido Liberal Mexicano e os irmãos Flores

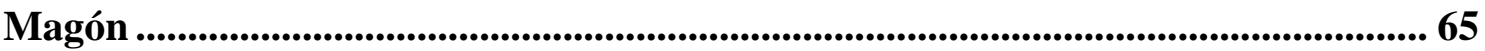

1.2.1 Programa del Partido Liberal Mexicano ..................................................... 71

1.3 Luta liberal contra a reeleição personificada: Francisco Madero ...................... 82

1.3.1 La sucesión presidencial en 1910 ........................................................................ 83

1.3.2 O Partido Antirreeleicionista inicia suas atividades políticas................. 91

1.3.3 Plan de San Luís Potosí e a revolução com hora marcada ....................... 93

1.4. Francisco 'Pancho' Villa e o início da Revolução Maderista: os levantamentos

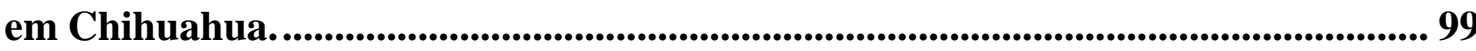

1.5 Novos focos revolucionários, suspensão de garantias individuais, temor de invenção norte-americana e renúncia de Porfírio Díaz

1.5.1 Governo provisório de Francisco León de la Barra............................... 110

1.6 Emiliano Zapata e a decisão por manter-se em armas .......................................... 112

1.7 A Presidência de Francisco Madero .......................................................................... 119

1.8 A Decena Trágica, o governo autoritário de Victoriano Huerta e a Revolução Constitucionalista ................................................................................................ 125

1.9 A Convenção de Aguascalientes e a disputa entre as correntes revolucionárias

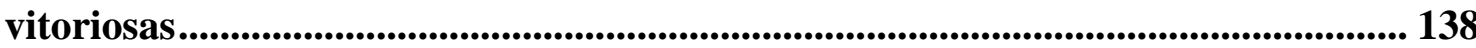

1.10 Virada militar dos constitucionalistas liderados por Venustiano Carranza. 155 
Capítulo 2

O Direito e a Organização Fundiária MEXiCANa ........................................... 169

2.1 Antecedentes: México colonial ........................................................................................ 172

2.2 Antecedentes: México independente............................................................ 180

2.2.1 Decretos de colonização: o desafio de ocupar e controlar o território e a política de formação dos latifúndios............................................................................ 183

2.2.1.1 Decreto de 4 de janeiro de 1823: Iturbide privilegia os estrangeiros

2.2.1.2 Decreto de 14 de outubro de 1823: tripartição dos baldíos da Província do Istmo..

2.2.1.3 Decreto de 18 de agosto de 1824: a República Mexicana apresenta suas normas para a colonização 188

2.2.1.4 Decreto de 15 de setembro de 1829: uma vez mais a abolição da escravatura

2.2.1.5 Decreto de 6 de abril de 1830: a fronteira norte deve ser ocupada por mexicanos

2.2.1.6 Decreto de 27 de novembro de 1846: povoar o território para impedir a cobiça estrangeira e desenvolver o país

2.2.1.7 Decreto de 16 de fevereiro de 1854: agentes para promoção da colonização são enviados à Europa.

2.2.1.8 Lei de 20 de julho de 1863: a primeira política de ocupação de terrenos "baldíos" efetiva e o necessário fincanciamento do Estado Mexicano

2.2.1.9 Decreto de 31 de maio de 1875: as empresas colonizadoras realizam atividade antes reservada ao Estado e recebem um terço das terras ocupadas. 208

2.2.1.10 Lei de 15 de dezembro de 1883: novamente um terço das terras para companhias deslindadoras - a concentração se aprofunda. 210

2.2.1.11 Lei de 26 de março de 1894: “baldíos, demasías e excedencias”- a prevalência do título de propriedade sobre a posse efetiva

2.2.1.12 Características das políticas de colonização do século XIX mexicano: formalistas, racistas, concentradoras, cruéis ou equivocadas 222

2.2.2 Desamortizações: propriedades coletivas indígenas e propriedades da Igreja Católica sob ataque

2.2.2.1 Ley de desamortización de los bienes de las corporaciones civiles y eclesiásticas - Ley Lerdo, de 25 de junho de 1856.

2.2.2.2 Ley de Nacionalización de los Bienes del Clero Regular y Secular, de 12 de julho de 1859, e outras leis da Reforma. 
2.2.3 Enfrentamento da espoliação indígena e defesa da pequena propriedade

no século XIX: a luta perdida 252

2.2.3.1 Legislação agrária do Segundo Império - Lei de 18 de dezembro de 1865 e Decreto de 16 de setembro de 1866 254

2.2.3.2 Plan Socialista Proclamado por los Representantes de los Pueblos de los Estados de Querétaro y Guanajuato ou Plan de La Barranca, de $1^{\circ}$ de junho de 1879

2.2.3.3 Plan Socialista de Sierra Gorda, de 15 de julho de 1879 269

2.3 A demanda pela terra nos primeiros documentos dos movimentos revolucionários mexicanos

2.3.1 Programa do Partido Liberal Mexicano de $1^{\circ}$ de Julho de 1906: a aposta na dicotomia propriedade produtiva $x$ propriedade improdutiva 275

2.3.2 Programa del Partido Antireeleccionista, Plan de San Luís Potosí (1910) e a justa promessa de restituir terras expropriadas 277

2.3.3 Plan Político-Social, de 18 de março de 1911: proteção dos índios, dos arrendatários, devolução de terras e moradia................................................ 280

2.3.4 Plan de Tacubaya de 31 de outubro de 1911: o problema agrário como objeto único da revolução 281

2.3.5 Plan de Ayala, de 28 de novembro de 1911: os zapatistas e a dupla solução para a concentração fundiária mexicana

2.3.6 Plan de Santa Rosa, de 3 de fevereiro de 1912: o Estado como dono exclusivo das terras

2.3.7 Plan de la Empacadora e Manifesto de Pascual Orozco, de 8 e 25 de março de 1912: deslegitimados pela história

2.4. Presidência de Francisco Madero: resposta insatisfatória para o principal problema mexicano - o Relatório da Comissão Nacional Agrária, de 7 de fevereiro de 1912

2.4.1 Projeto de reforma constitucional de Juan Sarabia, de 24 de outubro de 1912: a relativa legalidade dos despojos agrários injustos 299

2.4.2 Projeto de lei de Luís Cabrera: a crítica às "soluções ingênuas" do problema agrário mexicano e as diferentes formas de organização da apropriação da terra: individual e coletiva

2.5. Os documentos revolucionários pós-Madero: a disputa de concepções agrárias entre as correntes revolucionárias

2.5.1 Ley Agraria de Venustiano Carranza, Decreto de 6 de janeiro de 1915

2.5.2 Ley Agraria de Francisco Villa, de 24 de maio de 1915: a primazia da pequena propriedade individual 
2.5.3 Ley Agraria zapatista-convencionista de 26 de outubro de 1915: a defesa da autonomia política dos "pueblos" e comunidades, e a convivência pacífica entre propriedade coletiva e pequena propriedade individual 329

2.5.4. Decreto regulamentador da Ley agraria carrancista no Estado de Yucatán, de 3 de dezembro de 1915: Salvador Alvarado e o controle estatal rígido das propriedades coletivas 338

2.6. A regulamentação da terra no artigo 27 da Constituição Mexicana de 1917341

\section{Capítulo 3}

A Regulamentação Jurídica das RelaÇões de Trabalho no México

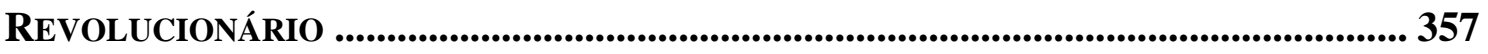

3.1 O trabalho no México do início do século XX: assalariado e livre? ................. 357

3.2 Trabalho rural: peonaje, aparceria, arrendamiento, mediería ........................... 362

3.3 Trabalho urbano: mineração, petroleiras e indústria têxtil ............................. 369

3.3.1 A greve de Cananea ............................................................................................ 371

3.3.2 A greve de Tlaxcala e Puebla e os conflitos em Río Blanco................... 377

3.4 As propostas de regulação das relações de trabalho nos documentos revolucionários............................................................................................................. 390

3.4.1 Programa do Partido Liberal Mexicano (1906) ..................................... 390

3.4.2 La sucesión presidencial en 1910 (1908), o Plan de San Luís Potosí (1910) e a criação do Departamento del Trabajo: Madero e a questão trabalhista . 396 3.4.3 Plan Político-Social (1911) .............................................................................. 399

3.4.4 Plan de la Empacadora (março 1912) ................................................. 402

3.4.7 Reglamento para las Fábricas de Hilados y Tejidos en la República (1912): o primeiro contrato coletivo de trabalho industrial do México ....... 407

3.4.8 A Casa del Obrero Mundial: apolitismo, sindicalismo e a adesão à Revolução

3.4.9 Regulação das relações de trabalho nos diferentes estados mexicanos: a revolução faz suas regras.

3.4.10 Decretos de 29 de janeiro de 1915 e 22 de junho de 1915 (Venustiano Carranza)

3.4.11 Projeto de Lei de 12 de abril de 1915 (Rafael Zubarán Capmany)... 441

3.4.12 A Soberana Convención Revolucionaria e o trabalho: Ley sobre accidentes del trabajo (1915); Proyecto de Ley General del Trabajo (1915) e Programa de Reformas Político-Sociales (1916) ............................................. 453

3.5 O artigo 123 da Constituição dos Estados Unidos Mexicanos de 1917 ............ 456 
CONCLUSÃo 467

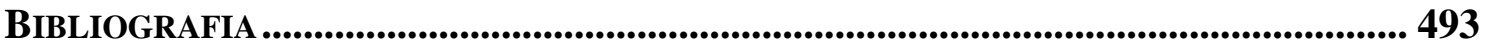

MÉXICO E REVOLUÇÃo MEXICANA .......................................................................... 493

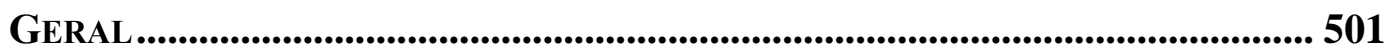

Leis, decretos, Planos ReVolucionários e outras fontes PRimárias CITADAS, EM ORDEM CRONOLÓGICA ......................................................................... 504 


\section{INTRODUÇÃO}

Em 5 de fevereiro de 2017 a Constituição Política dos Estados Unidos Mexicanos completa cem anos, ainda em pleno vigor, apesar de já ter sofrido mais de duzentas reformas ${ }^{1}$. Corolário do processo revolucionário que a antecedeu, a Constituição Mexicana de 1917 é a primeira no mundo a assegurar direitos sociais regulação da propriedade e reforma agrária, direitos dos trabalhadores, direito à educação laica - em seu texto. Quanto à Revolução Mexicana, um dos mais importantes movimentos organizados de transformação social da história moderna, foi uma insurreição popular que se estendeu de 1910 a $1917^{2}$ e, estima-se, deixou um milhão de mortos. Forneceu o ambiente político, jurídico e social que antecedeu e motivou a formulação da nova Constituição.

Friedrich Katz, historiador dedicado ao período, chama a atenção para o fato de a Revolução Mexicana ser uma das poucas que, tendo ocorrido no início do século XX, ainda desfruta no século XXI de enorme prestígio e legitimidade no país e junto ao povo que a engendrou ${ }^{3}$. Em 2010, foi comemorado oficialmente no México o centenário do início do processo revolucionário. Universidades, governo, congresso preparam-se para celebrar o centenário da Constituição, daqui a um ano. Nomes de rua, feriados nacionais, monumentos e estátuas celebram seus líderes e momentos mais importantes. Historiadores debatem acaloradamente ainda hoje os legados e efeitos da Revolução para o país. Seja qual for a corrente, são unânimes ao afirmar a importância desse evento que marcou de forma definitiva o início do século XX mexicano e toda sua

\footnotetext{
${ }^{1}$ Todas as reformas - desde a primeira em julho de 1921, até a última realizada, $225^{\mathrm{a}}$, em julho de 2015 disponíveis em: 100 años Constitución 1917-2017. Cidade do México: Instituto de Investigaciones Jurídicas de la UNAM, 2015. <http://www.100constitucion.unam.mx/constitucion-online/> Consulta realizada em 08/01/2016.

${ }^{2}$ Há divergências quanto ao marco de seu fim. Neste trabalho, adota-se a promulgação da Constituição Mexicana em 5 de fevereiro de 1917 como marco para o fim da instabilidade institucional revolucionária. 3 "Igualmente excepcional es que el movimiento de Villa forme parte de una de las pocas revoluciones del siglo XX que aún disfruta de una enorme legitimidad a los ojos de su propio pueblo. Mientras en Rusia Leningrado ha sido rebautizado como San Petersburgo y en China los estudiantes cuestionan la revolución de Mao en la plaza Tiananmén, nadie en México piensa en rebautizar las calles que llevan los nombres de Villa y de otros héroes revolucionarios. De hecho, no solo el partido gubernamental oficial, sino también el principal partido de oposición y el nuevo movimiento guerrillero surgido en Chiapas se proclaman herederos legítimos de los revolucionarios de 1910-1920, entre los que el movimiento de Villa constituyó una fuerza decisiva." KATZ, Friedrich. Pancho Villa - Vol. 1. Trad. Paloma Villegas. México: Ediciones Era, 1998. P. 15.
} 
história posterior. Ainda hoje, dois dos três maiores partidos mexicanos invocam a herança simbólica revolucionária em seus nomes: o Partido Revolucionario Institucional (PRI) e o Partido de la Revolución Democrática (PRD) ${ }^{4}$.

Se não há como negar a importância do processo revolucionário mexicano para o próprio México, sua relevância para o mundo também merece ser destacada, não de maneira meramente retórica, mas em contornos que felizmente podem ser muito bem precisados. De fato, o constitucionalismo social e o Estado de bem-estar social, dos quais o México fornece a primeira clara manifestação histórica, ganharam boa parte do globo ao longo do século XX. Entender o contexto que levou à criação da primeira constituição desse tipo assume, assim, relevância que transcende as fronteiras nacionais do país latino. As constituições sociais modificaram o próprio conceito de Estado, quando comparado com as concepções liberais do século XIX, ampliando consideravelmente sua capacidade de intervenção na realidade e as expectativas sobre as realizações possíveis a partir da ação estatal. Compreender o significado dessa mudança jurídico-política no contexto mexicano, bem como a forma como os movimentos revolucionários se relacionam com o direto foram objetivos que motivaram a realização deste trabalho.

Em novembro de 1914, Francisco Villa e Zapata avançam e tomam com suas tropas a Cidade do México, capital e centro do poder político do país. Desde 1910, a Revolução Mexicana já havia derrotado - com armas - dois governos autoritários: de Porfírio Díaz e de Victoriano Huerta.

Pouco antes, em outubro de 1914, as diferentes frentes da luta armada constitucionalistas-carrancistas, villistas, zapatistas, obregonistas, orozquistas - se reuniam na Soberana Convención Revolucionaria de Aguascalientes para decidir como dar continuidade ao movimento revolucionário, uma vez que o objetivo imediato de deposição de Victoriano Huerta já fora cumprido. O desafio dessa vez era construir alguma proposta conjunta para a reorganização da sociedade mexicana pós-

\footnotetext{
${ }^{4} \mathrm{O}$ primeiro manteve-se no poder por 71 anos consecutivos a partir de 1929 , e acaba de reassumir a presidência do país em 2012.
} 
revolucionária, e não mais unir forças para derrotar um inimigo comum. Havia dificuldades e divergências entre os líderes das diferentes tropas insurgentes. Apesar da grande adesão inicial à convenção, o espaço não cumpriu seu objetivo de construir um programa de ação comum. Cada um dos diferentes movimentos revolucionários tinha sua própria opinião - e, em muitos casos, programas detalhadamente elaborados - a respeito de quais seriam as medidas necessárias para, entre outros pontos, fazer avançar e possivelmente resolver a mais premente das questões mexicanas: a questão agrária.

Fracassada a Convenção de Aguascalientes, a ação revolucionária dividiu-se. E como o que estava em questão, após a derrota do regime anterior, era a possibilidade de realizar a própria concepção de reordenação do país, os diferentes movimentos passaram a agir para garantir que seu plano fosse executado. Francisco Villa e Emiliano Zapata uniram tropas visando a defender as propostas formuladas no espaço coletivo e, segundo eles, legítimo da Convenção. Por isso, ficaram conhecidos a partir de novembro de 1914 como convencionistas. Foi na formação dessa aliança que Zapata e Villa dirigiram-se com suas tropas para a Cidade do México, visando a enfrentar as forças armadas e as propostas de Venustiano Carranza.

Durante o período que permaneceram na cidade do México, Villa e Zapata conseguiram estabelecer uma convivência relativamente pacífica. Os dois líderes revolucionários tinham em comum uma visão geral sobre a melhor forma de organizar politicamente uma sociedade. Contra os desejos centralizadores de Carranza, ambos defendiam a autonomia política local. Os municípios e suas diferentes estruturas organizacionais pareciam ser, nas concepções dos caudilhos, as melhores instâncias para a realização democrática. Essa concepção, porém, gerava um problema prático: nem Zapata nem Villa desejavam exercer o poder central capaz de reorganizar um Estado soberano sobre todo o território mexicano. As propostas que defendiam de reorganização fundiária - em tese válidas e possíveis para todo o México - careciam de um aparato estatal capaz de implementá-las. Zapata e Villa não estavam dispostos a trocar sua vivência local para exercer o poder desde a Cidade do México. Além disso, antes de se estabelecerem como poder de fato, precisavam vencer batalhas contra o exército leal a Carranza, que se reorganizava. Enquanto isso, fixado na cidade de Veracruz, o próprio Carranza tentava reestruturar, por meio de decretos, o desmantelado Estado Mexicano. 
Ao final do encontro inicial da Convenção de Aguascalientes, em novembro de 1914, as tropas convencionistas de Villa, Zapata e outros aliados estavam no comando de cerca de $80 \%$ do território mexicano. Passado um ano - e após Carranza ter promulgado os decretos de 6 e 29 de janeiro de 1915, em que prometia avanços, respectivamente, quanto à questão agrária e aos direitos trabalhistas - o território fora todo dominado pelos constitucionalistas.

El efecto de esta sola ley [Ley de 6 de enero de 1915, que declara nulas todas las enajenaciones de tierras, aguas y montes pertenecientes a los pueblos, otorgadas en contravención a lo dispuesto en la ley de 25 de junio de 1856] fue decisivo para que la balanza de la lucha se inclinara a favor del constitucionalismo. ${ }^{5}$

Essa impressionante 'virada' militar obtida pelo exército constitucionalista entre 1915 e 1916 desperta uma importante linha de indagação, que a presente tese pretende investigar e desdobrar em suas consequências, dela extraindo algumas reflexões teóricas. A questão está em saber qual a relação que os resultados militares tiveram com a decisão jurídica de Venustiano Carranza de aprovar e publicar decretos que de alguma forma respondiam aos anseios sociais daqueles que entraram na luta armada. A partir da vitória militar, Carranza consolidou sua supremacia no território mexicano, convocou o Congresso Constituinte em outubro de 1916 e, a partir do trabalho dos constituintes, consolidou as novas características do Estado mexicano. Em 5 de fevereiro de 1917 a Constituição Mexicana foi promulgada e a partir dela definiram-se as feições gerais de um estado constitucional que se perpetuam até hoje.

O direito não é um mero coadjuvante na história da Revolução Mexicana, tanto no que diz respeito a suas causas como no que diz respeito a seu desenrolar. Pode-se dizer que ele foi responsável, em grande medida, por forjar as desigualdades e o esgarçamento social que levaram à eclosão do movimento revolucionário. A história da concentração fundiária no país, nesse sentido, pode ser recontada a partir das normas que regulamentaram o direito à propriedade rural - o que se pretendeu fazer no início do segundo capítulo do presente trabalho. Ao longo de todo o processo revolucionário, vemos uma intensa e constante disputa em torno de projetos jurídicos para a construção da nova sociedade. Pode-se atribuir também ao direito a legitimidade conferida às estratégias de Carranza para assumir o poder em 1915 e 1916.

${ }^{5}$ CÓRDOVA, Arnaldo. La ideología de la Revolución Mexicana - la formación del nuevo régimen. $8^{\mathrm{a}}$ Edición. Ciudad del México: Ediciones Era, 1980, p. 204. 
Nessa história complexa, que será esmiuçada nas próximas páginas, o direito desempenha muitos papéis. Não se pode dizer, certamente, que tenha sido apenas vilão. Foi ele que permitiu a correção de injustiças históricas em relação à propriedade de terras indígenas e de comunidades campesinas após a revolução, por meio do texto normativo da Constituição de 1917. Além disso, a mesma constituição estabeleceu uma série de direitos trabalhistas que transformaram profundamente as relações de trabalho no México. De um modo ou de outro - ou deveríamos dizer: de um lado ou de outro -, o fenômeno jurídico revela-se absolutamente central para a compreensão desse período da história mexicana.

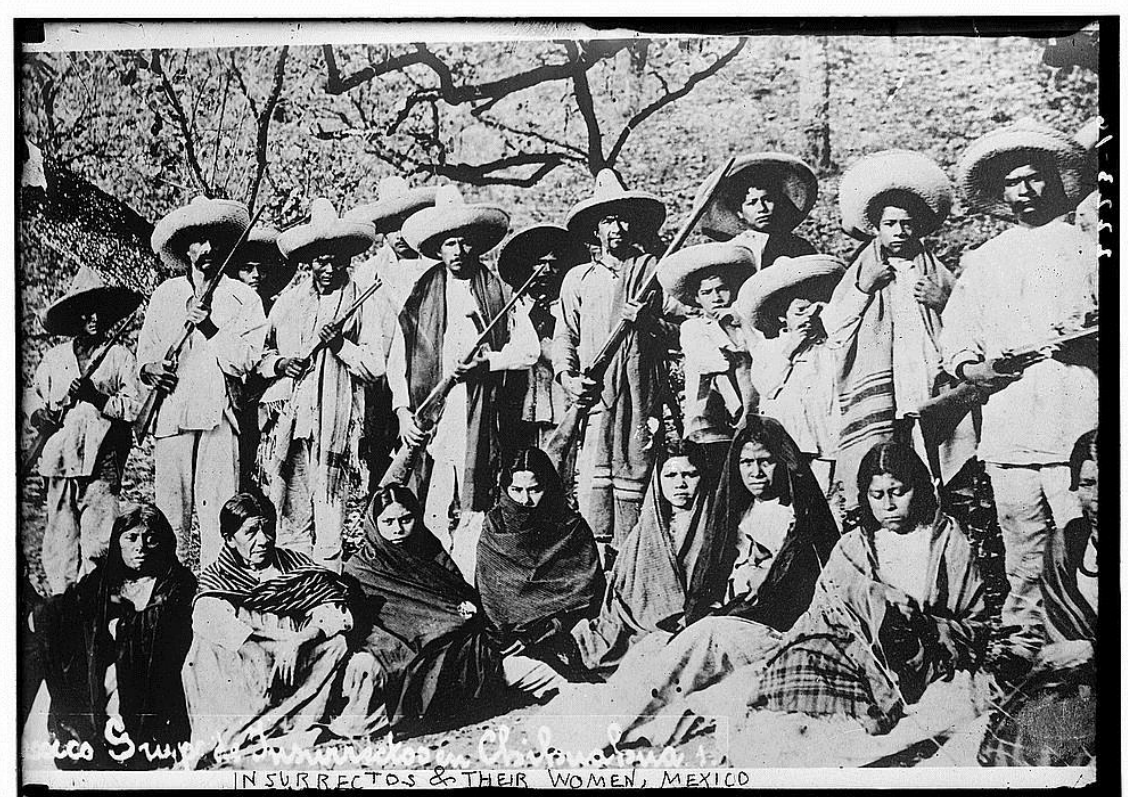

Revolucionários de Chihuahua, norte do México.

O presente trabalho teve início com um projeto de pesquisa, elaborado em 2012, que tinha por objetivo analisar a história jurídica de três diferentes revoluções: Revolução Russa, Revolução Alemã e Revolução Mexicana. Naquele momento inicial, eu queria investigar as características e a forma de destruição e de surgimento dos ordenamentos jurídicos que antecediam e sucediam as revoluções. A proposta de analisar três diferentes processos revolucionários tinha por objetivo refletir sobre uma questão teórica mais ampla: como mudanças sociais profundas afetam os ordenamentos 
jurídicos existentes (assim como suas interpretações) e, em sentido inverso, como e em que medida as mudanças jurídicas têm capacidade de transformar as sociedades, sobretudo em contextos revolucionários. Eu estava especialmente interessada na forma de produção do direito em circunstâncias extremas, em examinar quais seriam suas fontes e, em paralelo, suas diferentes formas de legitimação.

Ao colocar a pesquisa em andamento, provou-se inviável realizar o objetivo inicial. Aproximar-se de três diferentes países e culturas, de incrível quantidade de fontes primárias (os atos normativos das mais diferentes hierarquias, além de textos de época), compreender as relações entre os grupos sociais em conflito, os contextos, as motivações das lideranças revolucionárias e as divergências políticas dos inúmeros movimentos existentes em cada uma das revoluções era projeto por demais ambicioso para apenas quatro anos de pesquisa.

O objetivo teórico inicial foi, porém, mantido. As questões suscitadas pela realidade mexicana do início do século XX fornecem, por si só, abundante material para uma reflexão mais ampla sobre o papel do direito em tempos de transformação social. As formas de produção normativa, as fontes e a legitimidade dos dispositivos jurídicos, a efetividade desses mesmos dispositivos - são temas que permeiam constantemente minhas análises sobre essa realidade histórica delimitada. Meu esforço, assim, foi refletir, a partir de um momento histórico particular, e levando em conta todas as suas especificidades, acerca de problemas próprios da teoria e sociologia do direito.

Essas explicações talvez não fossem necessárias, contudo. Afinal, o que quer um historiador? Walter Benjamin expressou-se assim: "Articular historicamente o passado não significa conhecê-lo 'como ele de fato foi'. Significa apropriar-se de uma

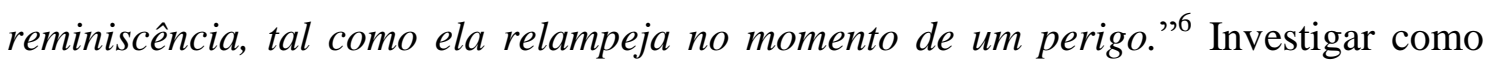
outros seres humanos - constrangidos por diferentes estruturas econômicas, políticas e sociais -, resolveram ou enfrentaram seus problemas nos impele necessariamente para a reflexão sobre nossa própria época e nossas soluções. Em sentido semelhante, Cervantes também refletiu sobre a postura dos historiadores e o papel da história:

(...) Cosa mal hecha y peor pensada, habiendo y debiendo ser los historiadores puntuales, verdaderos y nonada apasionados, y que ni el interés ni el miedo, el rancor ni la afición, no les hagan torcer del camino de la verdad, cuya madre es la historia, émula del tiempo,

\footnotetext{
${ }^{6}$ BENJAMIN, Walter. Sobre o Conceito de História. In Magia e técnica, arte e política. Ensaios sobre literatura e história da cultura. São Paulo: Brasiliense, 1994, p. 224. (Obras escolhidas, v. 1)
} 
depósito de las acciones, testigo de lo pasado, ejemplo y aviso de lo presente, advertencia de lo por venir. ${ }^{7}$

Ora, ser o depósito das ações realizadas e o testemunho do passado é o papel da história que, ao mesmo tempo, quer servir de exemplo e aviso ao presente e advertência para o futuro. Necessariamente, assim, a reflexão sobre a história jurídica da Revolução Mexicana está, ao mesmo tempo, interessada em refletir sobre o fenômeno jurídico do passado, presente e futuro. Sobre o próprio fenômeno jurídico e seu significado. A história é, assim, um rico ponto de partida para começar a pensar.

No momento em que elaborei o projeto, intrigava-me também a razão por que inúmeros teóricos elegem como seus inimigos o Estado e o direito. Principalmente aqueles teóricos que desejam transformar a realidade com o objetivo de torná-la socialmente mais justa, a partir da perspectiva marxista.

Encarar o Estado e o direito como espaços de disputa política, que refletem os conflitos e a correlação de forças de uma determinada sociedade - e não apenas como instrumentos de dominação e exploração - seria uma posição teórica defensável? Haveria algo intrinsecamente viciado na estrutura e na organização do Estado, na forma de produção do direito, que justificasse a aversão que eles provocam em inúmeros pesquisadores comprometidos com uma transformação estrutural da sociedade? A democracia liberal, reconhecidos todos os seus limites, seria mesmo uma forma a ser descartada ou, pelo contrário, poderia ser vista como um espaço de efetiva disputa política de concepções de sociedade? Norberto Bobbio também identifica e formula esse problema:

Para Marx, direito e Estado pertencem ambos à esfera da superestrutura, denominada "superestrutura jurídica e política", na conhecida passagem que constitui um texto da Crítica da Economia Política. É como se se tratasse de um conjunto difícil de distinguir em partes diversas e separadas, de tal maneira que a extinção do Estado comporta também a extinção do direito e vice-versa. Em geral, todas as correntes sociais, tais como as correntes anárquicas e socialistas utópicas, moveram guerra contra o Estado, e moveram guerra contra o direito. E qual melhor prova de identificação entre direito e Estado no pensamento político que acompanha o crescimento do Estado moderno e da concepção prevalecente do direito como fenômeno estatal do que essa polêmica simultânea contra o Estado e o direito da

\footnotetext{
${ }^{7}$ CERVANTES SAAVEDRA, Miguel de. El Ingenioso Hidalgo de Dom Quijote de la Mancha. Madrid: Saturnino Calleja, 1904. P. 51.
} 
parte das correntes libertárias e socialistas? ${ }^{8}$

Direito e Estado parecem ganhar as feições de formas abomináveis. Embora socialistas utópicos, marxistas e anarquistas discordassem totalmente em inúmeros pontos de suas análises, concordavam em elegê-los,direito e Estado, como seus principais inimigos, segundo Bobbio. Hespanha, historiador do direito português, também identifica essa característica na tradição marxista, que ora considera o direito como simples instrumento (a ser eliminado) para domínio das classes dominantes, ora como mero reflexo do modo de produção econômico:

As concepções materialistas do direito têm frequentemente caído no impasse do mecanicismo ou do instrumentalismo; o primeiro vendo no direito um reflexo directo da base económica, o segundo um puro instrumento de domínio das classes dominantes.

No entanto, a análise marxista das relações entre as instâncias do económico e do jurídico sempre foi muito mais matizada, como já se referiu. $^{9}$

Diferente de Bobbio, porém, Hespanha não atribui a interpretação disseminada diretamente à obra de Marx. Em sua leitura dos textos marxistas, como já se depreende do texto acima citado, o agudo autor propõe uma relação muito mais complexa das relações que poderiam se estabelecer entre as chamadas estrutura e superestrutura. As visões mecanicistas, deterministas ou instrumentalistas do direito seriam para ele interpretações estreitas de uma parte dos intérpretes marxistas, mas que não estariam respaldadas em uma leitura abrangente da obra de Marx.

É inegável que a tradição materialista produziu muitas obras de reflexão importantes sobre os mais diversos temas sociais, incluindo o direito. Rosa Luxemburgo; Antonio Gramsci; os inúmeros teóricos da Escola de Frankfurt, Otto Kirchheimer, Franz Neumann e Jürgen Habermas incluídos; Bob Jessop entre tantos outros analisaram com muita acuidade o fenômeno jurídico partindo de um referencial teórico marxista. No entanto, a interpretação marxista que despreza o direito e o Estado não é nada desprezível, e goza de bastante prestígio.

\footnotetext{
${ }^{8}$ BOBBIO, Norberto. Direito. In BOBBIO, Norberto, MATTEUCCI, Nicola \& PASQUINO, Gianfranco (Editores). Dicionário de Política. 5ªdição. Brasília: Editora Universidade de Brasília, 1993. P. 350.

${ }^{9}$ HESPANHA, António M. A história do direito na história social. Lisboa: Livros Horizonte, 1978. P. 35 36.
} 
Apenas a título de exemplo, trazemos abaixo alguns trechos de importantes obras - escritas pelo próprio Marx e por famosos marxistas - que abrem o caminho para análises que atacam a importância do direito como forma.

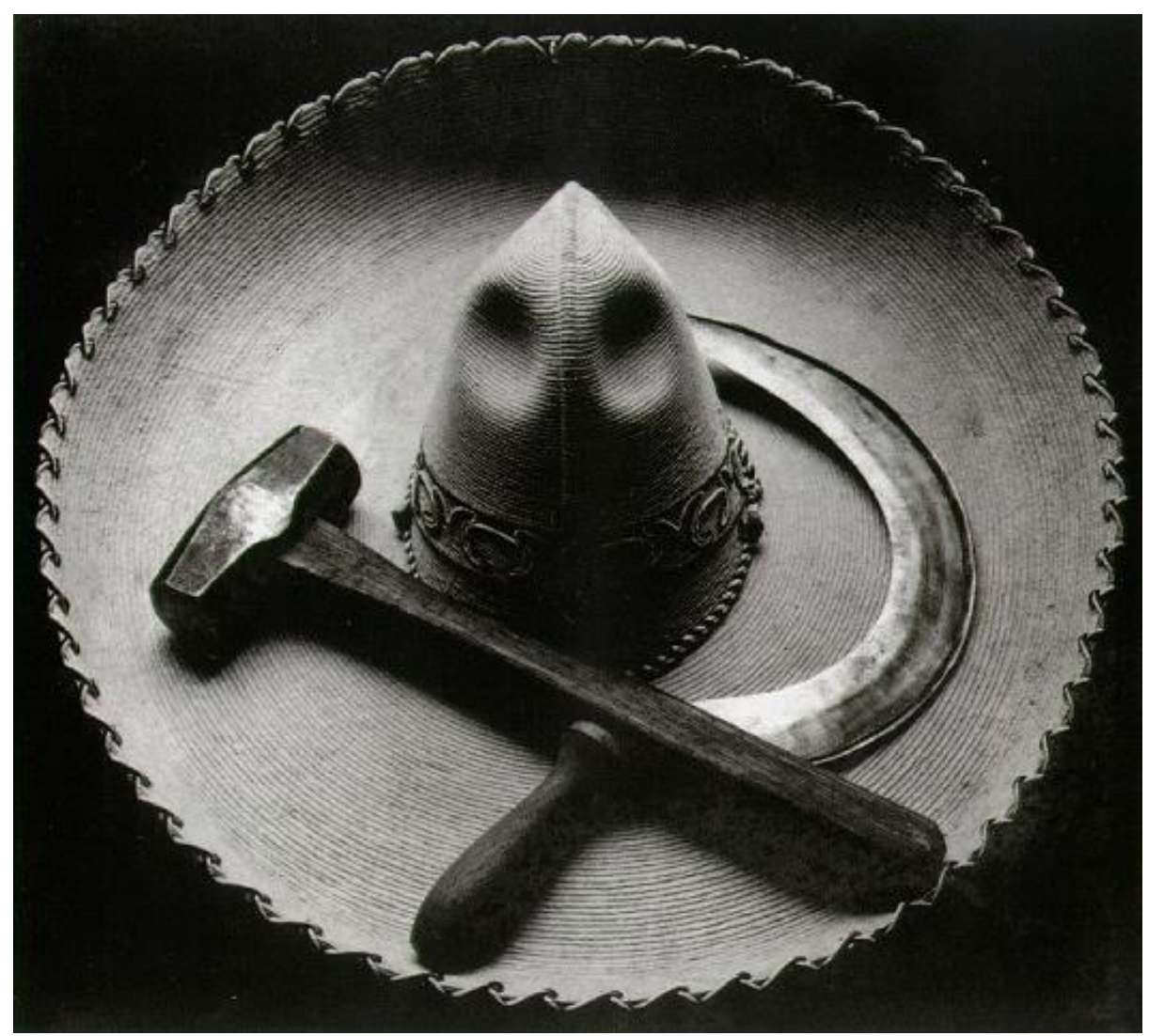

Tina Modotti, "Mexican sombrero with hammer and sickle"(Sombrero mexicano com a foice e o martelo). México, década de 1920. Reprodução: Taringa

\section{Comecemos com o próprio Marx.}

Descrita como uma grande ficção jurídica, a suposta situação de igualdade em que empregadores e empregados firmam um contrato de trabalho é um dos objetos de análise de Marx. A transformação da força de trabalho em mercadoria e, por consequência, a existência de um meio institucionalizado para que as trocas dessa mercadoria ocorram - o mercado de trabalho - parecem ser a origem da desconfiança do autor sobre o fenômeno jurídico. 
A igualdade jurídica - pré-requisito para que as relações de troca se estabeleçam no mercado de trabalho - não existiria, segundo ele. Sua função seria a de encobrir relações extremamente desiguais e conflituosas. $\mathrm{O}$ direito e a estrutura jurídica de uma sociedade teriam como função, seguindo a mesma linha de raciocínio, perpetuar as relações desiguais que têm origem na forma de organização do modo de produção capitalista, em que poucos detêm os meios de produção, enquanto muitos precisam vender sua força de trabalho.

É no modo de produção que se encontraria a verdade da organização política e social. Instituições estatais e ordem jurídica seriam nessa perspectiva instrumentos que teriam como função perpetuar e reforçar as relações fundamentais, exatamente aquelas que organizam o modo de produção. Uma vez que as relações de produção sejam modificadas, toda a estrutura institucional e jurídica - meros epifenômenos das relações de produção - também teria, logicamente, que mudar.

Nesse contexto, as instituições encontradas para a contenção do exercício do poder arbitrário pela Revolução Francesa, como a separação de poderes, trariam um vício de origem insanável: foram reivindicações de uma classe específica - a burguesia - para satisfazer seus próprios interesses. Tais interesses são nitidamente diferentes dos interesses da classe trabalhadora, e, nessa linha de raciocínio, uma vez que a classe trabalhadora haja conquistado o poder, suas instituições e mecanismos de ordenação social também seriam diferentes.

Em um de seus últimos trabalhos, "Crítica ao Programa de Gotha", Marx explicita a desigualdade que subjaz a toda suposta igualdade do ordenamento jurídico burguês e que também se alimenta de diferenças de habilidades e capacidades individuais. Diferenças essas que são transformadas em desigualdades.

Por isso, aqui, o igual direito é ainda, de acordo com seu princípio, o direito burguês, embora princípio e prática deixem de se engalfinhar, enquanto na troca de mercadorias a troca de equivalentes existe apenas em média, e não para o caso individual.

Apesar desse progresso, esse igual direito continua marcado por uma limitação burguesa. $\mathrm{O}$ direito dos produtores é proporcional a seus fornecimentos de trabalho; a igualdade consiste, aqui, em medir de acordo com um padrão igual de medida: o trabalho. (...) Esse igual direito é direito desigual para trabalho desigual. Ele não reconhece nenhuma distinção de classe, pois cada indivíduo é apenas trabalhador tanto quanto o outro, mas reconhece tacitamente a desigualdade dos talentos individuais como privilégios naturais e, por conseguinte, a desigual capacidade dos trabalhadores. Segundo seu 
conteúdo, portanto, ele é, como todo direito, um direito da desigualdade." ${ }^{10}$

Nesse texto, Marx arrisca-se a fazer um exercício de imaginação institucional, e se pergunta sobre as estruturas estatais e jurídicas que vigorariam em uma sociedade comunista - que, por meio da sua teoria e atuação política, almeja construir. Reafirma que todo o direito está intrinsecamente ligado às formas econômicas que estruturam a sociedade. Assim, um período de transição não poderia apresentar desde logo uma revolucionária ordem jurídica, restando para ele a forma da ditadura do proletariado.

Marx não responde à pergunta sobre qual seria a forma estatal e jurídica da nova sociedade, mas desdenha das conquistas já existentes, simplesmente porque elas já fazem parte do repertório de instituições do período burguês. Com esta afirmação Marx deixa claro não ter uma avaliação positiva sobre as soluções encontradas pelos burgueses para a contenção do exercício arbitrário do poder. Afirma que esta forma de Estado, vivenciada por alguns estados já no fim do século XIX, não está aos pés da democracia que poderia ser alcançada em uma sociedade comunista:

Mas essas distorções são inevitáveis na primeira fase da sociedade comunista, tal como ela surge, depois de um longo trabalho de parto, da sociedade capitalista. $\mathrm{O}$ direito nunca pode ultrapassar a forma econômica e o desenvolvimento cultural, por ela condicionado, da sociedade. ${ }^{11}$

Pergunta-se, então, por que transformações passará o ordenamento estatal numa sociedade comunista? Em outras palavras, quais as funções sociais, análogas às atuais funções estatais, nela permanecerão? Essa pergunta só pode ser respondida de modo científico, e não é associando de mil maneiras diferentes a palavra povo à palavra Estado que se avançará um pulo de pulga na solução do problema.

Entre a sociedade capitalista e a comunista situa-se o período da transformação revolucionária de uma na outra. A ele corresponde também um período político de transição, cujo Estado não pode ser senão a ditadura revolucionária do proletariado.

Mas o programa [de Gotha, que Marx está criticando] é alheio tanto a esta última quanto ao futuro ordenamento estatal da sociedade comunista.

Suas reivindicações políticas não contêm mais do que a velha cantilena democrática, conhecida de todos: sufrágio universal, legislação direta, direito do povo, milícia popular etc. São um mero eco do Partido Popular burguês, da Liga da Paz e da Liberdade. Não

\footnotetext{
${ }^{10}$ MARX, Karl. Crítica do Programa de Gotha. Seleção, tradução e notas de Rubens Enderle. São Paulo: Boitempo, 2012. P. 30-31

${ }^{11}$ MARX, Karl. Crítica do Programa de Gotha. P. 31
} 
passam de reivindicações que, quando não são exageros fantasiosos da imaginação, já estão realizadas. ${ }^{12}$

Também Engels, em texto finalizado por Kautsky, reforça a desconfiança na organização jurídica da sociedade:

\begin{abstract}
A concepção materialista da história de Marx ajuda a classe trabalhadora a compreender essa condição de vida, demonstrando que todas as representações dos homens - jurídicas, políticas, filosóficas, religiosas etc. - derivam, em última instância, de suas condições econômicas de vida, de seu modo de produzir e trocar produtos. ${ }^{13}$

Qualquer que seja a acolhida que essa 'passagem decisiva' venha a encontrar, em todo caso cremos poder assegurar que os socialistas do presente e do futuro dispensam todos os direitos fundamentais do sr. Menger, ou renunciam à tentativa de disputar com ele esse seu 'produto integral do trabalho'.
\end{abstract}

A disputa que Engels e Kautsky travam com Anton Menger em "O Socialismo Jurídico" diz respeito aos "direitos fundamentais" anunciados por Menger. Segundo este último, o socialismo se reduziria a três deles: $\mathrm{O}$ direito ao produto integral do trabalho, o direito à existência e o direito ao trabalho. Boa parte dos esforços de Engels e Kautsky consiste em denunciar quão longe estava a teoria marxista em enunciar o direito ao produto integral do trabalho.

Aproveitando a oportunidade, porém, Engels e Kautsky elaboram uma reflexão sobre o lugar do jurídico na obra de Marx. É elucidativa a afirmação de que " $O$ direito jurídico, que apenas reflete as condições econômicas de determinada sociedade, ocupa posição muito secundária nas pesquisas teóricas de Marx; (...)."14 Reforça-se, assim como em outras passagens, a ideia de que o direito reflete a infraestrutura de produção, devendo sofrer profunda transformação quando a infraestrutura social for revolucionada. Há também em Engels e Kautsky um desprezo pelos direitos apresentados por Menger por serem direitos essencialmente burgueses.

Não obstante, após dedicar quase todo seu texto à crítica do direito como forma, os próprios autores veem-se obrigado a reconhecer, de maneira um tanto problemática, a importância que a forma jurídica deve assumir nos processos de transformação social. O que ele diz então, quase a contragosto, parece alinhar-se bastante com as hipóteses

\footnotetext{
${ }^{12}$ MARX, Karl. Crítica do Programa de Gotha. P. 42-43.

13 ENGELS, Friedrich; KAUTSKY, Karl. O Socialismo Jurídico. Tradução Lívia Cotrim e Márcio Brilharinho Naves. $2^{\mathrm{a}}$ ed. rev. São Paulo: Boitempo, 2012. P. 21.

14 ENGELS, Friedrich; KAUTSKY, Karl. O Socialismo Jurídico. P. 34.
} 
extensamente exploradas na presente tese, e para as quais a Revolução Mexicana constitui um caso notavelmente interessante de estudo. Trata-se da ideia de que toda força de atuação política deve formular suas reivindicações em termos jurídicos:

Isso naturalmente não significa que os socialistas renunciem a propor determinadas reivindicações jurídicas. É impossível que um partido socialista ativo não as tenha, como qualquer partido político em geral. As reivindicações resultantes dos interesses comuns de uma classe só podem ser realizadas quando essa classe conquista o poder político e suas reivindicações alcançam validade universal sob a forma de leis. Toda classe em luta precisa, pois, formular suas reivindicações em um programa, sob a forma de reivindicações jurídicas. ${ }^{15}$

Rosa Luxemburgo é das poucas autoras e intérpretes marxistas do início do século XX que reflete e escreve sobre o problema da liberdade: sobre a necessidade de criar instituições que a preservem, especialmente para aqueles que discordem da maioria. Em texto de 1918, em que reflete sobre a Revolução Russa recém-realizada, a autora defende:

Mas a Assembleia Constituinte e o direito de voto não esgotam a questão: é preciso considerar ainda a supressão das garantias democráticas essenciais a uma vida pública sadia e à atividade política das massas trabalhadoras - liberdade de imprensa, direito de associação e de reunião, ilegais para todos os adversários do governo soviético. A argumentação de Trotsky, citada anteriormente, sobre o peso das instituições eleitorais democráticas não basta, nem de longe, para justificar esses ataques. Em contrapartida, é um fato patente, incontestável, que sem imprensa livre, sem livre associação e reunião, a dominação de vastas camadas populares é totalmente impensável. ${ }^{16}$

As tarefas gigantescas que os bolcheviques enfrentam, com coragem e determinação, exigiam precisamente a mais intensiva formação política das massas e acúmulo de experiências... (Liberdade somente para os partidários do governo, somente para os membros de um partido - por mais numeroso que sejam -, não é liberdade. Liberdade é sempre liberdade de quem pensa de modo diferente. Não por fanatismo pela "justiça", mas porque tudo quanto há de vivificante, salutar, purificador na liberdade política depende desse caráter essencial e deixa de ser eficaz quando a "liberdade" se torna privilégio.) ${ }^{17}$

O texto de Rosa Luxemburgo chama a atenção de forma bastante enfática para a necessidade da garantia da liberdade, ausente ou insuficiente no contexto pós-

\footnotetext{
${ }^{15}$ ENGELS, Friedrich; KAUTSKY, Karl. O Socialismo Jurídico. P. 46-47.

16 LUXEMBURGO, Rosa. A Revolução Russa. In Textos Escolhidos: Volume II, 1914-1919. Organização, tradução e notas Isabel Loureiro. São Paulo: Editora Unesp, 2011. P. 204-205.

${ }^{17}$ LUXEMBURGO, Rosa. A Revolução Russa. In Textos Escolhidos: Volume II. P. 205-206.
} 
revolucionário soviético, segundo ela. Seu texto segue defendendo a importância da democracia como meio para encontrar caminhos que não foram previamente estipulados por teóricos, mas que deveriam ser descobertos no cotidiano de uma nova organização social. Para que esta nova ordem consiga fazer emergir um sistema mais justo, livre e democrático, defende que sua forma de implantação deve obedecer aos mesmos cânones que quer ver realizados. Se o objetivo é construir uma sociedade democrática, a luta pela sua efetivação tem que ser, ela também, democrática.

Processos revolucionários, nos quais estruturas institucionais são colocadas em xeque, suspensas, destruídas para algo novo ser recolocado em seu lugar, são ambientes propícios para que se perca o zelo e o cuidado com a liberdade, privilegiando-se a alteração da ordem social. Ou, pelo contrário, para que se coloque em primeira linha a reorganização da ordem política e deixe-se para um segundo plano a ordem social e econômica. A história da Revolução Mexicana e suas diferentes vertentes teóricas explicitam permanentemente esta tensão. Antes de passarmos a ela, no entanto, é interessante ver como Lukács comenta criticamente o texto de Rosa Luxemburgo e acrescenta ainda mais uma posição da tradição marxista sobre o direito e o Estado:

Nesse escrito, Rosa Luxemburgo junta-se àqueles que condenam decididamente a dissolução da Assembleia Constituinte, a construção do sistema de sovietes, a supressão de direitos da burguesia, a falta de "liberdade", o recurso ao terror etc. Encontramo-nos, assim, diante da tarefa de revelar quais posições teóricas fundamentais levaram Rosa Luxemburgo - que sempre foi uma divulgadora insuperável, a mestra e dirigente inesquecível do marxismo revolucionário - a uma oposição tão aguda à política revolucionária dos bolcheviques. ${ }^{18}$

No interesse do desenvolvimento da Revolução, é importante que $o$ proletariado use todos os recursos para conservar o poder de Estado sob seu controle em quaisquer circunstâncias. O proletariado vitorioso não deve estabelecer antecipadamente sua política, de maneira dogmática, nem no plano econômico, nem no ideológico. Assim como tem que manobrar livremente sua política econômica (socialização, concessões etc.), conforme a estratificação das classes, a possibilidade e a necessidade de conquistar certas camadas dos trabalhadores para a ditadura, ou pelo menos neutralizá-las, não podem ser rígidas na questão da liberdade. No período da ditadura, o tipo e a medida da "liberdade" dependerão do estado da luta de classes, do poder do inimigo, da intensidade da ameaça à ditadura, das reivindicações das camadas a conquistar, da maturidade daquelas classes aliadas ao proletariado e influenciadas por ele etc. A liberdade não pode (assim como, por exemplo, a socialização) representar um

${ }^{18}$ LUKÁCS, György. Notas críticas sobre a Crítica da Revolução Russa, de Rosa Luxemburgo. In História e Consciência de Classe: estudos sobre a dialética marxista. Trad. Rodnei Nascimento; rev. da tradução Karina Jannini. $2^{\mathrm{a}}$ ed. São Paulo: Editora WMF Martins Fontes, 2012. P. 497. 
valor em si. É ela que tem que estar a serviço da dominação do proletariado, e não o contrário. ${ }^{19}$

Apesar de a crítica ter sido formulada após a morte de Rosa Luxemburgo, Lukács não foi suave. Afirma que a companheira "divulgadora do marxismo revolucionário" estava equivocada quanto às condições enfrentadas pelo exército bolchevique em 1917. Havendo risco de contrarrevolução iminente, o proletariado pode - e deve, segundo ele - usar todos os meios que tem à sua disposição para manter o poder do Estado em suas mãos. Dado que o texto de Rosa falava em liberdade para grupos minoritários discordantes, podemos entender aqui que "todos os meios" incluem silenciar à força a parcela da população que discordava dos rumos que a revolução vinha tomando.

Lukács, ao defender a teoria revolucionária leninista - implementada ao longo da Revolução Russa - explicita bem a posição majoritária do marxismo no período: a liberdade não é um valor em si, deve-se avaliar no contexto histórico a pertinência de preservá-la. Não sendo valor absoluto, por sua vez, a ordem jurídica e as instituições responsáveis por garanti-la - pois aqui partimos do pressuposto de um nexo íntimo entre estas duas coisas: liberdade civil e os mecanismos jurídicos de sua proteção - também seriam prescindíveis.

Por fim, um trecho famoso do texto "A origem da família, da propriedade privada e do Estado", de Friedrich Engels, deixa claro qual o destino que parte da tradição marxista antevê para o Estado e sua forma jurídica:

As classes vão desaparecer, e de maneira tão inevitável quanto no passado surgiram. Com o desaparecimento das classes, desaparecerá inevitavelmente o Estado. A sociedade, reorganizando uma forma nova a produção, na base de uma associação livre de produtores iguais, mandará toda a máquina do Estado para o lugar que lhe há de corresponder: o museu de antiguidades, ao lado da roca de fiar e do machado de bronze. ${ }^{20}$

O objeto da presente tese é a história do direito da Revolução Mexicana, e não a discussão teórica a partir das diferentes perspectivas da tradição marxista sobre o direito e o Estado. Os textos que foram trazidos aqui têm como objetivo apenas ilustrar como e

19 LUKÁCS, György. Notas críticas sobre a Crítica da Revolução Russa, de Rosa Luxemburgo. In História e Consciência de Classe: estudos sobre a dialética marxista. Trad. Rodnei Nascimento; rev. da tradução Karina Jannini. $2^{\mathrm{a}}$ ed. São Paulo: Editora WMF Martins Fontes, 2012. P. 521.

${ }^{20}$ ENGLES, Friedrich. A origem da família, da propriedade privada e do Estado. 2a ed. São Paulo: Expressão popular, 2010., p. 218. 
por que parte dessa tradição cultiva um desprezo pelo direito. Essa linha de pensamento, longe de insignificante, teve e tem alguns efeitos. Entre eles, a pouca quantidade de pesquisas que se debrucem seriamente sobre o direito em suas relações com processos revolucionários. Mais ainda, a tendência recorrente de não levar a sério, nos estudos feitos sobre determinado período histórico, as contradições que o direito pode encarnar, como fruto de um processo de embate. Como se verá na conclusão deste trabalho, a historiografia marxista perde, ao diminuir a importância da Constituição Mexicana de 1917, um importante elemento de análise sobre o significado da revolução para o México.

A Revolução Mexicana é a matéria prima da reflexão contida neste trabalho. A sucessão de eventos históricos ligados (ou não) ao direito; a percepção dos revolucionários sobre o fenômeno jurídico; os documentos e planos produzidos pelas diferentes correntes revolucionárias com o objetivo de regular as relações sociais; a decisão de elaborar uma nova Constituição; todos esses aspectos foram objeto de análise. Ao realizá-la, buscou-se também refletir sobre o papel do direito e do Estado, com suas possibilidades de intervir na organização e transformação da sociedade mexicana - questão especialmente aguda em períodos revolucionários. Manter a tensão entre elementos particulares da realidade mexicana e reflexões gerais sobre o fenômeno jurídico, sobre sua capacidade de transformar a realidade e sobre as formas de legitimação do exercício do poder, foi um objetivo constante desta tese.

Uma característica distingue o processo revolucionário mexicano como excelente objeto de análise para alguém interessado em história do direito. Trata-se do fato de os diferentes grupos políticos que participaram dos diferentes momentos da Revolução - antireeleicionistas, maderistas, constitucionalistas, villistas, zapatistas, carrancistas, orozquistas, convencionalistas - terem escrito suas demandas e divergências em uma grande quantidade de planos e projetos políticos que na maioria das vezes propunham novas formas jurídicas de organização social. Além disso, os 
documentos históricos mexicanos estão muito bem preservados, organizados e quase totalmente disponíveis de forma digital ${ }^{21}$.

Três temas frequentemente eram objeto desses planos: a forma da organização política do Estado Mexicano, a grande concentração agrária e as condições de vida dos trabalhadores mexicanos. Esses três temas foram usados, assim, para organizar os capítulos da tese. Diversos documentos permitem ao pesquisador acompanhar, passo a passo, por meio de fontes primárias, os debates jurídicos que permearam a revolução, até culminar com a Constituição de 1917.

Para encerrar esta introdução, cabe ainda discorrer brevemente acerca das principais controvérsias e perguntas que permeiam e motivam debates na historiografia sobre a Revolução

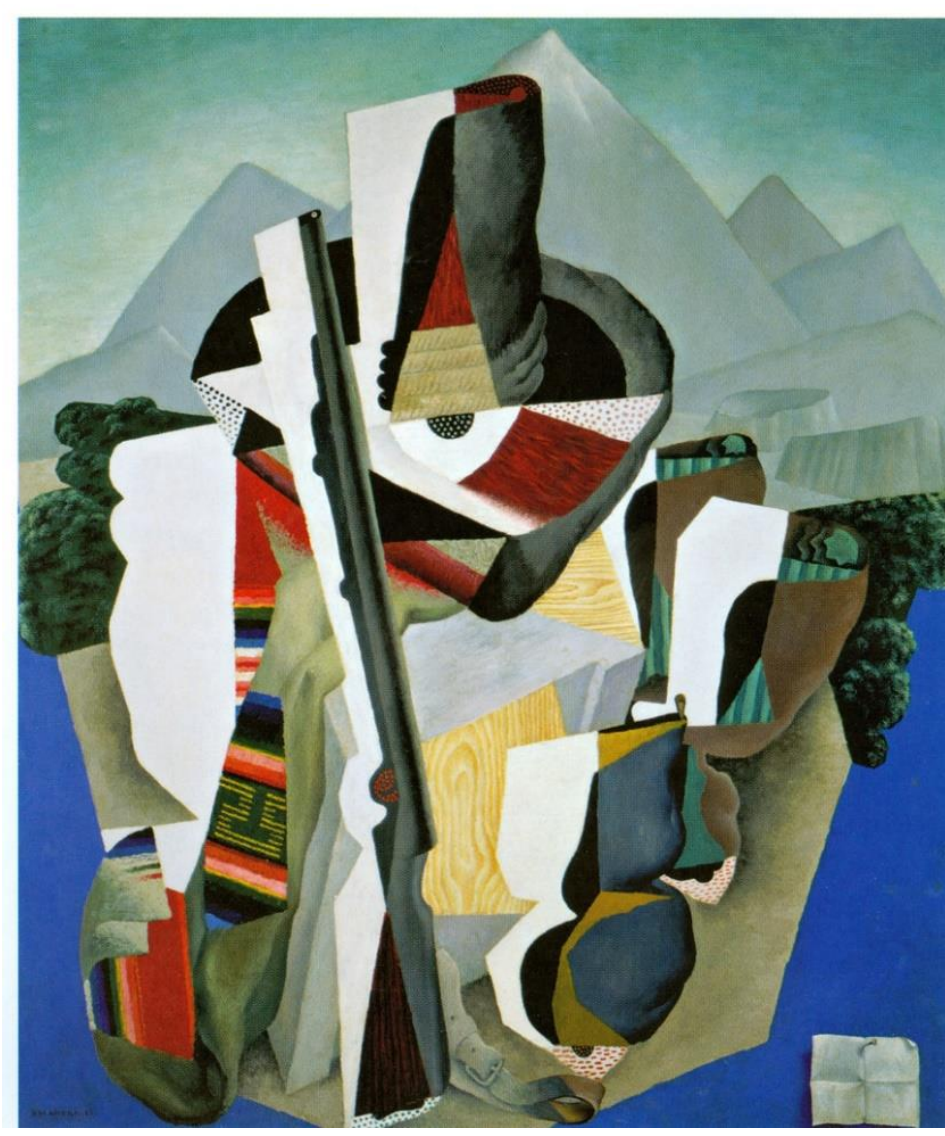

Paisaje Zapatista (1915), Diego Rivera. Mexicana. Esboçar desde logo essa discussão tem como objetivo oferecer ao leitor a possibilidade de questionar, à medida que avance no texto, se a história do direito realizada neste trabalho é ou não capaz de trazer elementos para a compreensão e interpretação daquele período histórico. Se a análise detalhada dos textos de planos, decretos normativos e outros documentos revolucionários - fontes primárias escritas em linguagem jurídica - de fato contribui para lançar novos olhares sobre a Revolução Mexicana, caberá ao leitor decidir.

\footnotetext{
${ }^{21}$ A lista completa das fontes primárias consultadas e o local em que foram encontradas está na bibliografia ao final do trabalho.
} 
Pedro Salmerón Sanginés, no artigo "Pensar el Villismo", apresenta uma análise crítica das diferentes correntes teóricas que refletem sobre o movimento campesino e popular liderado por Francisco Villa no norte do México. Ao enfrentar seu objetivo principal, realiza também uma reflexão sobre os momentos da historiografia da Revolução Mexicana. Afirma que os trabalhos sobre o tema publicados a partir da década de 1970 são substancialmente diferentes dos que os antecederam porque partiram de questões diferentes:

Los nuevos historiadores de la Revolución, llamados genéricamente revisionistas, se empezaron a preguntar cosas que antes habían sido soslayadas: ¿quiénes hicieron la Revolución?, ¿de dónde venían?, ¿qué los llevó a la Revolución y qué hicieron en ella? Las preguntas empezaron a dejar de ser qué, cuándo, dónde, cómo, para dar lugar a los porqué y los paraqué. La Revolución dejó de ser asunto de caudillos y prohombres, para empezar a ser acción social, colectiva, $\mathrm{y}$ de paso perdió su carácter unitario y nacional: de aquel movimiento unívoco y comprensible los revisionistas fueron extrayendo otro, múltiple y complejo, fragmentado casi hasta la inasibilidad. ${ }^{22}$

Quem fez a revolução? De onde vinham e o que queriam os revolucionários? Qual foi o descontentamento principal que os teria levado à ação? Essas perguntas - que se afastam da mera narração e organização da sucessão fatos, buscando para eles um sentido - seriam características da segunda fase da historiografia sobre a Revolução Mexicana, segundo Salmerón. A diferença essencial que o autor identifica entre os historiadores anteriores à década de 70 e os chamados revisionistas seriam as perguntas por eles formuladas e, consequentemente, o campo possível das respostas.

Alan Knight tem outra visão acerca dos revisionistas. Afirma que seus projetos de pesquisa visam a, efetivamente, revisar posições sobre as características principais da Revolução Mexicana, bem como a avaliação geral do processo histórico. Assim, logo na introdução de sua obra fundamental, apresenta esse debate e sua própria posição em relação a ele:

No puede haber alta política sin una buena cantidad de política baja. Esto resulta particularmente cierto porque la Revolución fue un movimiento genuinamente popular y, por lo tanto, ejemplo de esos episodios relativamente escasos de la historia en los que las masas influyen de manera profunda en los acontecimientos. (...) Muchos nuevos historiadores de la Revolución han dispuesto sus vastos conocimientos e investigaciones para demostrar que aquélla fue no

\footnotetext{
${ }^{22}$ SALMERÓN SANGINÉS, Pedro. Pensar el villismo. Estudios de Historia Moderna y Contemporánea de México, No. 020, julio 2000. P. 112.
} 
tanto un movimiento autónomo, agrario y popular, cuanto una serie de episodios caóticos, en los cuales las fuerzas revolucionarias fueron, en el mejor de los casos, instrumentos que manipularon caciques, líderes burgueses en ascenso o pequeño burgueses. Para estos historiadores, la Revolución no es el movimiento grande y heroico representado por Zapata y descrito por Tannenbaum, sino el sórdido recurso individual usado por Calles que esboza Jean Meyer. En todo esto soy, sin pudor, conservador o antirrevisionista. Es decir, creo que Tannenbaum y su generación captaron el carácter esencial de la Revolución de 1910 como movimiento popular y agrario. ${ }^{23}$

Se um levante popular, capaz de influenciar efetivamente os rumos dos acontecimentos sociais e políticos daquele momento, esteve ou não em curso durante a Revolução Mexicana é questão sobre a qual Knight não tem dúvida. Sua resposta é resolutamente afirmativa: sim, a Revolução Mexicana foi popular e tinha como objeto principal de suas demandas uma distribuição mais justa da terra e a restituição de propriedades injustamente espoliadas. Apresenta, no entanto, outra linha de historiadores - da qual discorda e que nomeia de revisionistas - que consideraram a revolução como um processo manipulado, caótico, dirigido por líderes burgueses ou pequeno-burgueses. Seus efeitos seriam condizentes com essas características.

Knight chama a atenção para os diferentes matizes que essas posições podem assumir, havendo infinitas posições intermediárias. Assim, ao tentar responder à questão sobre o que levou o México à insurgência revolucionária, os historiadores se dividem. Entre eles, há uma predominância em identificar no contexto social do campo - a questão da terra, especificamente - como motivadora principal dos conflitos. Nessa interpretação, as insatisfações relacionadas à organização política teriam sido apenas o estopim, mas não a causa social profunda da revolução.

A divisão inicial, por sua vez, reverbera e se desdobra em pelo menos uma segunda discussão. Quem são os protagonistas desse momento histórico? Se a questão é agrária, ligada à distribuição de terras, os protagonistas são os espoliados, os sem-terra, os campesinos que foram engolidos por novas grandes fazendas, criadas a partir da reorganização fundiária ocorrida no final do século XIX. Nesse caso, a Revolução tem claramente uma identidade popular. Se o problema principal está ligado, por outro lado, a uma disputa entre elites pelo poder - parte delas afastada em função dos desmandos autoritários de Porfírio Díaz -, a Revolução tem como protagonistas rostos de classes

\footnotetext{
${ }^{23}$ KNIGHT, Alan. La Revolución mexicana. Del Porfiriato al nuevo régimen constitucional. Trad. Luis Cortés Bargalló. México: FCE, 2010, p. 16-17.
} 
médias e altas, personagens intelectuais e urbanos, burgueses e pequeno-burgueses na definição de Knight. Para esses, além das questões políticas, trata-se de controlar, ditar as orientações e se beneficiar do processo de modernização por que passava o México.

Éste es um libro acerca de unos campesinos que no querían cambiar y que, por eso mismo, hicieron una revolución. (...)

Hacia principios de este siglo, otras personas, poderosos empresarios éstas, habitantes de las ciudades, creyeron necessário echar a los campesinos con el fin de progresar ellas mismas. Y entre los hombres de empresa y los campesinos fue cobrando um vívido conflicto. No sólo em Morelos, sino también em distritos semejantes de otros estados (...). ${ }^{24}$

John Womack Jr., importante historiador americano sobre o zapatismo, inicia seu livro sobre "Zapata y la Revolución Mexicana" com uma peculiar interpretação histórica do conflito mexicano do início do século XX. Nem os conflitos agrários, nem a insatisfação com a política porfirista - ou a disputa entre elites pelo poder - estariam entre as causas principais da Revolução Mexicana. Womack Jr. opõe como polos opostos campesinos e empresários. De um lado, os defensores do atraso, enraizados na realidade rural: os camponeses. De outro, os propagadores da mudança, que querem desenvolvimento em benefício próprio - mas defendem também o "vigor de la nación", como Womack afirma no parágrafo seguinte -, aqueles que vivem na cidade: os empresários.

Estas duas concepções diferentes sobre o futuro do México estariam no pano de fundo da Revolução Mexicana, como se o conflito se desse entre subjetividades, sem estruturas institucionais e decisões do Estado Mexicano subjacentes. De um lado, o desejo de permanência arcaica dos campesinos; de outro, o desejo desenvolvimentista dos empresários-fazendeiros que cultivavam cana de açúcar e fomentavam o início da industrialização mexicana. Ainda que a partir de uma perspectiva diferente, o conflito para Womack Jr. também vinha do campo. O segundo capítulo dessa tese tem por objetivo traçar o percurso de normas e decisões estatais que possibilitaram que esta "subjetividade" dos fazendeiros viesse à tona em detrimento do direito à terra das comunidades indígenas e campesinas mexicanas.

Para além das razões e sujeitos da Revolução Mexicana, a historiografia sobre o período também coleciona outros embates. Entre eles, um dos mais importantes diz

\footnotetext{
${ }^{24}$ WOMACK JR, John. Zapata y la Revolución Mexicana. Secretaría de Educación Pública y Siglo XXI Editores. México, $1^{\text {a }}$ ed. 1969. Reimpresión 1985. P. XI.
} 
respeito à avaliação dos caudilhos, ou seja, das lideranças militares e políticas que estiveram à frente do processo. Embora uma parte dos pesquisadores rejeite a ideia de deslocar o centro de suas análises para as figuras individuais e considere mais profícuo entender as feições mais amplas dos movimentos que elas lideraram, saber qual a importância de figuras como os irmãos Flores Magón, Francisco Madero, Emiliano Zapata, Francisco Villa, Álvaro Obregón e Venustiano Carranza para a Revolução Mexicana divide opiniões e afetos. Alguns dos pesquisadores que escreveram logo após o movimento revolucionário eram mais próximos de uns ou outros líderes. Assim, uma parte da bibliografia sobre a Revolução Mexicana está permeada por afinidades com as lideranças revolucionárias. E muitas vezes a percepção do processo como um todo é influenciada por essa afinidade inicial e pessoal.

Outro elemento que está presente em diversos trabalhos sobre a Revolução Mexicana diz respeito a seus efeitos e resultados. Teria sido a Revolução um processo político e social vitorioso? Aqueles que dela participaram ficaram satisfeitos com a Constituição dos Estados Unidos Mexicanos de 1917? Ou, pelo contrário, a revolução popular e camponesa foi traída por Venustiano Carranza e seu movimento constitucionalista? A conciliação entre o ideário liberal e social na Constituição de 1917 seria a prova dessa derrota? Há vencedores e derrotados na Revolução Mexicana? A derrota foi militar ou ideológica? Como e quão intensa foi a participação da diplomacia norte-americana [e de outras forças internacionais] no desenrolar dos levantes no México?

Adolfo Gilly não discute quais foram as causas ou quem foram os principais agentes da Revolução, mas sim qual momento pode ser considerado seu ápice e, paralelamente, quais os motivos do que considera ser a derrota dos camponeses:

(...) en otras palabras, en el trazado específico de la curva de la revolución y la ubicación de su ponto más alto en diciembre de 1914, cuando los ejércitos campesinos de Villa y Zapata ocuparon la ciudad de México, y no en febrero de 1917, cuando fue sancionada la nueva Constitución de la República, tal como ha seguido sosteniendo la historiografia institucional. ${ }^{25}$

En realidad el poder está vacante. Pues no basta que la oligarquía lo pierda y la burguesía no tenga fuerzas para sostenerlo: alguien debe tomarlo. Y la dirección campesina no lo toma, nomás lo tiene 'en custodia', como al Palacio Nacional, para entregarlo a los dirigentes

\footnotetext{
${ }^{25}$ GILLY, Adolfo. La Revolución Interrumpida. $1^{\text {a }}$ ed. digital. Cidade do México: Ediciones Era, 2013. P.
} 11. 
pequeñoburgueses de la Convención. Ejercer el poder exige un programa. Aplicar un programa demanda una política. Llevar una política requiere un partido. Ninguna de las tres cosas tenían los campesinos, ni podían tenerlas.

El proletariado, como fuerza política independiente, estaba ausente. Había proletarios, particularmente mineros y ferroviarios, en el ejército de Villa; pero como individuos, no como fuerza o tendencia de clase. ${ }^{26}$

Segundo Gilly, o ápice da Revolução Mexicana não foi a aprovação da Constituição Política dos Estados Unidos Mexicanos em 1917, mas sim a ocupação da Cidade do México por Villa e Zapata, no final de 1914. Em sua análise, esse seria o momento crítico, pois foi nele que os movimentos agrários e populares estiveram com o poder "sob custódia". Suas forças armadas juntas eram mais fortes do que quaisquer outras e eles tinham chegado supostamente ao centro do exercício do poder. Faltavalhes, segundo Gilly, um programa político e um partido. Tampouco os trabalhadores organizados estavam presentes. No que considera ser o ápice da Revolução Mexicana, revelam-se as razões de seu fracasso. O grupo social que teria condições militares de implementar seu programa simplesmente não possuía um. Sem essa formulação ideológica, passado algum tempo, foi derrotado.

Arnaldo Córdova, por sua vez, concorda com o diagnóstico amplo de Gilly. As causas do fracasso do movimento camponês teriam sido sua baixa capacidade programática de exercer o poder no momento em que estiveram com ele à sua disposição. Comentando o mesmo momento histórico que Gilly, Córdova afirma:

Su odio a los terratenientes no se tradujo en una acción programática coherente (...) y su localismo impedió que pudieran hacer frente al programa reformista de los constitucionalistas y luchar por la conquista del poder político, objetivo que, en el fondo, ni siquiera se llegaron a proponer y que cuando lo tuvieron a su alcance no supieron qué hacer con él. ${ }^{27}$

Localismo de propósitos - e não a afirmação programática de que as decisões políticas deveriam ocorrer sobretudo em âmbito local - e uma inaptidão para exercer o

\footnotetext{
${ }^{26}$ Ibidem. P. 173.

${ }^{27}$ CÓRDOVA, Arnaldo. La ideología de la Revolución Mexicana - la formación del nuevo régimen. $8^{\mathrm{a}}$ Edición. Ciudad del México: Ediciones Era, 1980. P. 25. A ideia é reforçada neste trecho:“[El Programa de la Convención] es el canto del cisne de los campesinos armados, el ultimo testimonio de la sapiencia política de las masas populares, de su espíritu democrático; la confesión postrera y virtual de una equivocación que causó su ruina: el no haber sabido o no haber podido luchar por el poder político, aferrados a su única demanda, la tierra, y al temor y la desconfianza que habian heredado de los gobiernos." Arnaldo Córdova. La ideología de la Revolución Mexicana. P. 167-168.
} 
poder quando ele esteve ao seu alcance seriam as causas da derrota política e militar dos revolucionários camponeses mexicanos. Zapatistas e villistas não teriam sido capazes de enfrentar o programa reformista de Carranza e, nessa incapacidade, residiria as razões do fracasso de seus projetos.

Arturo Warman, por sua vez, discorda veementemente das interpretações apresentadas por Womack Jr., Gilly e de Córdova:

En los últimos años, en los que tanto ha avanzado el conocimiento sobre los movimientos campesinos mexicanos, también se ha extendido la visión analítica que destaca sus limitaciones, deficiencias, imposibilidades. Exagerando un poco: estudiamos a las demás clases de la sociedad desde la perspectiva de su potencialidad como agentes transformadores de la sociedad, mientras que al campesino lo analizamos por su limitación. Todavía en el terreno de la exageración: un pronunciamento burgués en 1780 es visionario del futuro, es precursora una huelga derrotada en los primeros diez años de este siglo, mientras que el zapatismo es el epígono del pasado, como también lo son las rebeliones indígenas coloniales y lo siguen siendo las reivindicaciones campesinas en la actualidad. Las derrotas de otros movimientos sociales se explican por la brutal desproporción con las fuerzas enemigas, mientras que las de los campesinos se deben a su debilidad intrínseca. La exageración nunca describe, solamente ilustra. (...)

En este ensayo se pretende mostrar, de manera previa e incompleta, que el zapatismo generó un proyecto político radical y coherente para la transformación global de la sociedad compleja desde una posición de clase. ${ }^{28}$

La suma de las propuestas programáticas formales con las práticas políticas concretas integran un proyecto complejo y coherente para la transformación radical del conjunto de la sociedad y de su aparato estatal, aunque este proyecto no esté codificado ni formalizado en un conjunto ordenado de propuestas legislativas. Aquí vale una digresión. La formulación de un proyecto revolucionário para la transformación de la sociedad nunca cuenta con este tipo de instrumentos como punto de partida. Todas las revoluciones políticas han partido de una formulación básica elemental, que puede estar mejor o peor expresada formalmente, que sólo se convierte en un proyecto verbal, global, coherente, después del triunfo y como una consecuencia de la lucha. La formulación del proyecto de una nueva sociedad no es un acto visionario, sino el resultado de un complejo y contradictorio proceso social. El zapatismo no triunfó. Las comparaciones formales entre su proyecto y los proyectos organizados de los movimientos triunfantes no es pertinente y resulta irrelevante. Este tipo de comparaciones no puede aducirse para sostener que el zapatismo carecía de un programa o que éste era simplesmente defensivo. Es la codificación del proyecto zapatista la

\footnotetext{
${ }^{28}$ WARMAN, Arturo. El proyecto político del zapatismo. In KATZ, Friedrich. Revuelta, Rebelión y Revolución: La lucha rural en México del siglo XVI al siglo XX. Cidade do México: Ediciones Era, 2008. P. 291-292.
} 
que no existe, pero es cada vez más claro que están presentes sus elementos. Rescatarlos y ordenalos ya no es trabajo de los combatientes sino de los historiadores. ${ }^{29}$

Segundo a visão de Warman, só o preconceito contra qualquer manifestação do campesinato é que poderia afirmar ser o zapatismo representante do passado. Warman denuncia um preconceito disseminado contra todas as manifestações políticas que vêm do campo, estejam elas no passado ou no presente. Esse preconceito contra os camponeses, segundo ele, nubla e distorce a percepção sobre a Revolução Mexicana. Em seu texto, promete identificar e explicitar qual foi o programa político completo e coerente produzido pelo zapatismo para a transformação completa e radical da sociedade. Em sua exposição, contudo, aparece ainda uma afirmação geral bastante sensível que pretendemos debater em nosso trabalho: a de que esse projeto político zapatista não logrou codificar-se ou formalizar-se, vale dizer, não conseguiu assumir a forma de um conjunto ordenado de propostas legislativas. Segundo o autor, essa deficiência derivaria, natural e necessariamente, da circunstância de que o movimento não foi triunfante. Por esse mesmo motivo, não se poderia comparar as formulações dos carrancistas com a dos zapatistas. Os primeiros foram vencedores da revolução. Os segundos, derrotados. Os vencedores têm mais tempo e recursos para elaborar suas próprias propostas. O projeto de sociedade não é algo que se formula a priori, mas sim um processo de construção ao longo do tempo e do desenrolar histórico. Quando o processo político zapatista foi interrompido, interrompidas foram também suas possibilidades de formulação política. Segundo o autor, seria descabida, assim, qualquer comparação entre as duas situações.

O presente estudo, além de reafirmar a característica popular e agrária da Revolução Mexicana, pretende defender e justificar uma visão diferente das citadas acima sobre o saldo revolucionário. Apesar de os movimentos agrários e revolucionários de Francisco Villa, Emiliano Zapata e dos convencionistas terem sido derrotados militarmente, acreditamos poder indicar que foram parcialmente vitoriosos do ponto de vista ideológico, sobretudo nos textos normativos do artigo 27 e 123 da Constituição Mexicana de 1917. Afasta-se da visão de Womack Jr., Córdova e Gilly ao afirmar que, sim, os camponeses tinham um projeto político para a sociedade mexicana.

\footnotetext{
${ }^{29}$ WARMAN, Arturo. El proyecto político del zapatismo. In KATZ, Friedrich. Revuelta, Rebelión y Revolución: La lucha rural en México del siglo XVI al siglo XX. Cidade do México: Ediciones Era, 2008. P. 292-293.
} 
Diferentemente de Warman, porém, o estudo da história do direito não permite afirmar que eles não assumiram forma jurídica, nem que tenham sido totalmente derrotados. Apesar de terem perdido, boa parte de seus programas foi incorporada - à revelia de Carranza - no texto constitucional. Além disso, os municípios também ampliaram seu grau de autonomia, em resposta às suas demandas por democracia local. A história do direito do período ajuda a formular diversas respostas para questões como essas.

Feita esta breve exposição acerca de alguns debates presentes na historiografia sobre a Revolução Mexicana, passemos agora ao Capítulo 1. Aí será oferecida uma visão abrangente do desenrolar revolucionário e dos debates relacionados à melhor forma de organizar politicamente a sociedade.

Custa-lhes acreditar, não?

- Custa-me até entender, respondeu um dos ouvintes.

- Vai entender. Os fatos explicarão melhor os sentimentos: os fatos são tudo. A melhor definição do amor não vale um beijo de moça namorada; e, se bem me lembro, um filósofo antigo demonstrou o movimento andando. Vamos aos fatos. (Machado de Assis, $O$ Espelho) 


\title{
Capítulo 1
}

\section{Desenrolar Revolucionário e OrganizaÇão Política DA REALIDADE MEXICANA}

\author{
Francisco Madero e Emiliano Zapata proferem, em 1910 e 1914, \\ respectivamente, discursos representativos das posições extremas presentes no \\ panorama político em embate ao longo da Revolução Mexicana. Entre os extremos \\ havia, evidentemente, uma série de posições intermediárias.
}

A partir do diagnóstico de que o principal problema do México no início do século XX era a sua organização política autoritária, F. Madero elogia a liberdade como direito fundamental para a construção de uma sociedade melhor. Liberdade e só liberdade. As outras conquistas seriam alcançadas por meio de seu exercício. Zapata, por outro lado, despreza os direitos políticos e as conquistas liberais e afirma que o povo tem fome de pão e de terra. Segundo ele, são esses desejos concretos que levaram à insurreição. Além disso, constata: com ou sem liberdades públicas, os problemas sociais que assola(va)m o México permaneceram intocados ao longo dos diferentes regimes políticos. Conclui que, enquanto não houver mudança na estrutura social do país, importam pouco as feições políticas de seu Estado:

Discurso de Francisco Madero em Orizaba, em 22 de maio de 1910:

Del gobierno no depende aumentarmos el salario ni disminuir las horas de trabajo, y nosostros, que encarnamos vuestras aspiraciones, no venimos a ofreceros tal cosa, porque no es eso lo que vosotros deseáis; vosotros deseáis libertad, deseáis que se respeten vuestros derechos, que se os permita agruparos en sociedades poderosas, a fin de que unidos podáis defender vuestros derechos; vosotros deseáis que haya libertad de emitir vuestro pensamiento, a fin de que todos los que aman al pueblo, todos los que se compadecen de vuestros sufrimientos, puedan ilustraros, puedan enseñaros cuál es el camino que os llevará a vuestra felicidad... Vosotros no queréis pan, queréis únicamente libertad, porque la libertad os servirá para conquistar el $\operatorname{pan} ;(\ldots.){ }^{30}$

\footnotetext{
${ }^{30}$ CÓRDOVA, Arnaldo. La ideología de la Revolución Mexicana - la formación del nuevo régimen. $8^{\mathrm{a}}$
} 
En agosto de 1914, desde el campamento revolucionario de Milpa Alta, Zapata y sus jefes militares lanzan un manifiesto en el que establecen las verdaderas causas de la Revolución:

'El campesino tenía hambre - dicen -, padecía miseria, sufría explotación, y si se levantó en armas fue para obtener el pan que la avidez del rico le negaba; para adueñarse de la tierra que el hacendado, egoístamente, guardaba para sí; para reivindicar su dignidad, que el neguro atropellaba inicuamente todos los días. Se lanzó a la revuelta no para conquistar ilusorios derechos políticos que no dan de comer, sino para procurarse el pedazo de tierra que ha de proporcionarle alimentos y libertad, un hogar dichoso y un porvenir de independiencia y engrandecimiento.

Gobierno militar primero y parlamentario después, reformas en la administración, responsabilidades oficiales, libertad de imprenta para los que saben escribir, libertad de votar para los que no conocen los candidatos, correcta administración de justícia para los que jamás ocupan un abogado, todas esas belezas democráticas, todas esas grandes palabras con que nuestros abuelos y nuestros padres se deleitaron, han perdido hoy su mágico atractivo y su significación para el pueblo. Este ha visto que con elecciones y sin elecciones, con sufragio efectivo y sin él, con dictadura porfiriana y con democracia maderista, con prensa amordazada y con libertinaje de prensa, siempre y de todos los modos él sigue ruminando sus amarguras, padeciendo sus miserias, devorando sus humillaciones inacabables, y por eso, teme, con razón, que los libertadores de hoy vayan a ser iguales a los caudillos de ayer, que en Ciudad Juaréz abdicaron de su hermoso radicalismo y en el Palacio Nacional echaron en olvido sus seductoras promesas. ${ }^{31}$

Tanto a reivindicação por mudanças na forma política do Estado Mexicano e pela (ou "e por uma ampliação", ou "e a ampliação") ampliação de sua feição democrática, quanto as preocupações com a reforma social, em especial com a justa distribuição de terra e as condições de trabalho, permearam toda a história da Revolução Mexicana.

A organização do presente trabalho reflete essa presença: neste primeiro capítulo conta-se em ordem cronológica, em linhas gerais, os principais eventos caracterizados como Revolução Mexicana, até a promulgação da Constituição de 1917. Essa narrativa dos fatos, por sua vez, está bastante ligada à sucessão de momentos e contextos políticos que viveu o México desde o início do século XX até a instituição dessa nova Constituição. Já o segundo e o terceiro capítulos serão dedicados à organização

\footnotetext{
Edición. Ciudad del México: Ediciones Era, 1980, p. 110.

${ }^{31}$ CÓRDOVA, Arnaldo. La ideología de la Revolución Mexicana - la formación del nuevo régimen. $8^{\mathrm{a}}$ Edición. Ciudad del México: Ediciones Era, 1980, p. 152.
} 
fundiária e à regulação do trabalho no México revolucionário, e completam o panorama sobre as razões sociais que levaram à Revolução.

Interessante notar, porém, desde já, que a tensão entre o político e o social estava presente na própria sociedade, ao longo dos embates revolucionários. Essa presença parece ser um elemento relevante para a análise de um dos documentos-chave deste trabalho: a Constituição Mexicana de 1917 e sua decisão por incorporar em seu texto tanto liberdades públicas quanto direitos sociais.

Nos extremos do espectro político, havia narrativas e reivindicações que desprezavam as conquistas e as demandas do extremo oposto. Ao longo da tumultuada história do México no início do século XX, porém, chegou-se a uma decisão política por incorporar os dois extremos em um mesmo documento normativo, que aparentemente consegue consolidar em si o espírito de sua época: a Constituição Mexicana de 1917. Saber como esse resultado foi alcançado, e avaliar se a sua existência representa a vitória ou a derrota de alguma parte do embate revolucionário, é um dos objetivos do presente trabalho.

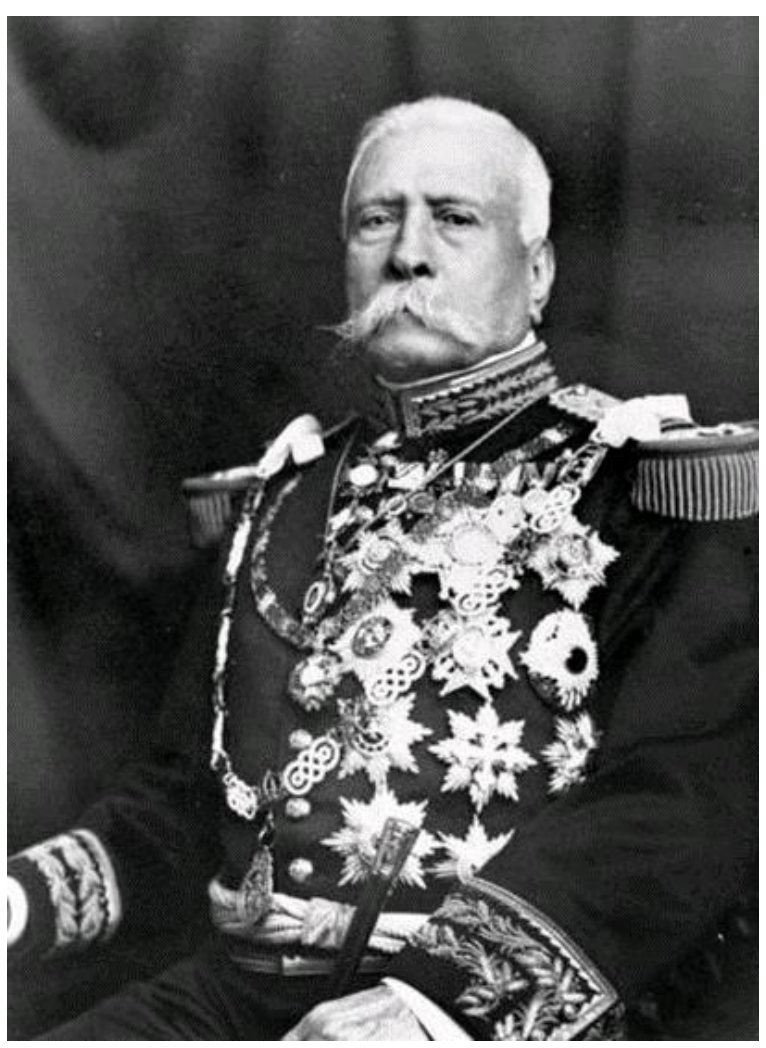

Porfírio Díaz

\subsection{Tensões do governo de Porfírio Díaz em 1910}

Porfírio Díaz foi um militar, com importante participação nos confrontos contra o exército francês e sua ocupação do território mexicano (1862-1867), período no qual ganhou projeção e alguma notoriedade. Benito Juárez, de ascendência indígena e origem humilde, desempenhava então a função de Presidente do México. Após infligir a derrota aos invasores franceses $\mathrm{e}$ determinar o fuzilamento do Imperador Maximiliano, tornou-se herói nacional ${ }^{32}$.

Tanto em 1867 quanto em 1871,

\footnotetext{
${ }^{32}$ Para mais informações acerca dessa passagem da história mexicana, ver seção 2.2.3.1 do presente trabalho.
} 
anos em que houve eleições, Porfírio Díaz concorreu à Presidência, tendo sido derrotado nos dois momentos por Benito Juárez. Logo após as eleições de 1871, Díaz e alguns apoiadores ensaiaram uma revolta armada, que tinha como mote o desconhecimento do resultado eleitoral. Alegavam fraudes e a impossibilidade constitucional de reeleição. Foram contidos pelo exército oficial, leal a Juárez.

Em julho de 1872, porém, Juárez morre e, de acordo com a Constituição de 1857, o sucessor na presidência era Sebastián Lerdo de Tejada, Presidente da Suprema Corte de Justiça do país. Ao assumir o cargo em 1872, Lerdo convocou novas eleições e legitimou--se na função pelos quatro anos seguintes, período do mandato constitucional. A mesma Constituição de 1857 , entretanto, não previa a possibilidade de reeleição. $\mathrm{Na}$ verdade, o texto do artigo 78 era omisso, não admitia nem proibia a segunda candidatura. Lerdo, então, aproveitando-se da ausência de definição, tentou concorrer novamente às eleições em 1876. Foi impedido por Porfírio Díaz que, após confrontos armados, desmontou as pretensões de permanência de Lerdo, e defendeu que a reeleição deveria ser impedida. Foi candidato e se elegeu Presidente em 1877.

Assim, em 1877 tem início o chamado "porfiriato", longo período sob a influência política direta de Porfírio Díaz. Antes de Porfírio Díaz, o século XIX mexicano se caracterizava por inúmeras instabilidades políticas ${ }^{33}$. Para além da guerra pela independência do início do século, o frequente embate entre liberais e conservadores levou a sucessivas substituições extraordinárias de líderes que ocuparam a Presidência. O país também sofreu uma invasão dos Estados Unidos, em 1847 (que teve como consequência a perda de boa parte de seu território norte); a invasão e ocupação francesa (1862-1867); a coexistência de dois centros de poder simultâneos, em mais de um período - no mais longo foram os três anos de convivência entre o regime constitucional republicano (com Benito Juárez à frente) e o regime imperial, liderado por Maximiliano, entre 1863 e 1867. Além disso, em meados do mesmo século XIX, o país decidiu enfrentar a Igreja Católica (instituição então bastante poderosa e rica) e limitar suas funções públicas e propriedades.

No mesmo período, o Estado Mexicano tinha ainda como grandes objetivos declarados se consolidar como unidade nacional, ser reconhecido internacionalmente,

\footnotetext{
${ }^{33} \mathrm{O}$ início do capítulo 2 do presente trabalho é dedicado à análise de documentos normativos que regulam o direito de propriedade ao longo do século XIX. Nele há um panorama, ainda que superficial, das inúmeras reviravoltas políticas vividas nesse período pelo país.
} 
garantir seu território e resolver problemas sociais e econômicos. Definitivamente, o século XIX não foi fácil nem para o México nem para os mexicanos.

Assim, após incontáveis conflitos internos e externos, as conjunturas nacional e internacional permitiram um período de trégua nos embates políticos. Porfírio Díaz - e a chamada Pax Porfiriana - foram ao mesmo tempo promotores e beneficiários dessa mudança conjuntural.

Apesar de o "porfiriato" compreender usualmente o período identificado entre 1877 e 1910 - ano em que eclode a Revolução Mexicana -, em 1881 foram realizadas eleições e, respeitando na sucessão de seu primeiro mandato a norma constitucional que proibia reeleições, Porfírio Díaz foi sucedido por Manuel González no posto de Presidente da República ${ }^{34}$. O fato de seu sucessor ter sido escolhido pessoalmente por Porfírio Díaz, o fato do gabinete de governo de González ser composto por inúmeros políticos leais ao seu antecessor, =constata-se que a escolha de González se deveu, em parte, à facilidade de voltar ao poder anos mais tarde. Assim, a historiografia mexicana considera que de alguma forma houve continuidade entre os mandatos. Todo o período compreendido entre 1977 e 1910, assim, é considerado porfiriato. O governo de Manuel González ficou conhecido pela corrupção que permitiu,, pela revogação do Código de Minas espanhol - que distinguia a propriedade superficial da terra da propriedade dos minérios subterrâneos, sendo a última reservada ao Estado mexicano -, e pela aprovação da Lei de 15 de dezembro de 1883, que regulamentava a demarcação e a ocupação dos terrenos baldíos por companhias demarcadoras que, como pagamento/recompensa pela atividade, receberiam um terço das propriedades demarcadas. Em 1884, novas eleições são realizadas e Porfírio Díaz retorna ao posto presidencial.

O texto original do artigo 78 da Constituição de 1857 não disciplinava a reeleição. Dispunha apenas que "El presidente entrará á ejercer sus funciones el primero de Diciembre, y durará en su encargo cuatro años.”. Em 5 de maio de 1878,

\footnotetext{
${ }^{34}$ Friedrich Katz comenta a escolha de Manuel González para sucessão de Díaz: "Mantendo sua promessa, Díaz não foi candidato nas eleições presidenciais de 1880; em seu lugar, concorreu o general Manuel González, um sucessor escolhido a dedo. Muitos cínicos admiraram-se da ingenuidade da escolha de Díaz. Muitos achavam que González era o mais corrupto e o menos capaz dos protegidos de Díaz. Provavelmente seria um adversário fraco se Díaz decidisse concorrer a outro mandato em 1884. González destacou-se por sua corrupção, embora haja muito exagero nos boatos de que levou consigo todos os móveis do Palácio Nacional quando deixou o cargo. Foi muito menos inepto do que frequentemente se supôs e nomeou um gabinete capaz de porfiristas, mas não era Porfírio Díaz." KATZ, Friedrich. O México: A República Restaurada e o Porfiriato, 1867-1910. In BETHELL, Leslie (org.) História da América Latina vol. V: de 1870 a 1930. São Paulo: Edusp, 2008. P. 46-47.
} 
porém, durante o primeiro mandato de Porfírio Díaz e sob sua chancela, fora realizada uma mudança constitucional. $\mathrm{O}$ artigo 78 passou a valer com a seguinte redação:

\section{8}

Art. 78. El presidente entrará á ejercer su encargo el 1o. de diciembre, y durará en él cuatro años, no pudiendo ser reelecto para el periodo inmediato, ni ocupará la presidencia por ningun motivo sino hasta pasados cuatro años de haber cesado en el ejercicio de sus funciones.

A nova redação do artigo proibia que o Presidente fosse reeleito ou mesmo que exercesse o cargo de Presidente, sob qualquer pretexto, nos quatro anos seguintes ao término de seu mandato. Este tema político seria a causa de tensões - e, por fim, da articulação de um movimento político que viria a afastá-lo do poder - anos mais tarde. Em 1878, a decisão clara e cristalizada no texto constitucional era contrária à possibilidade de reeleição presidencial. Como já foi dito, Díaz cumpriu a norma constitucional em 1881, e efetivamente passou a faixa presidencial para Manuel González, que exerceu seu mandato até 1884, quando Díaz foi novamente eleito.

Passados quase dez anos da alteração de 1878, em 21 de outubro de 1887, às vésperas do fim do segundo mandato de Porfírio Díaz, o Congresso Nacional (controlado por ele, é importante dizer) aprova uma nova redação para o mesmo artigo 78. Dessa vez, volta atrás e autoriza a reeleição por apenas um período:

\section{7}

Art. 78. El presidente entrará á ejercer su encargo el 1o. de diciembre y durará en él cuatro años, pudiendo ser reelecto para el periodo constitucional inmediato; pero quedará inhábil en seguida para o cupar la presidencia por nueva eleccion, á no ser que hubiesen transcurrido cuatro años, contados desde el día en que cesó en el ejercicio de sus funciones.

É apenas em 20 de novembro de 1890, com Porfírio Díaz já reeleito por um período, que o texto da norma constitucional retoma sua redação original, completamente silente a respeito da possibilidade ou proibição de reeleição presidencial. Porfírio Díaz desejava permanecer no poder. Não estava em questão a coerência política em relação a suas lutas iniciais contra as reeleições de Juárez e Lerdo. Com o Congresso a seu favor e a oposição reprimida, fora aprovada a nova redação:

1890

Art. 78. El presidente entrará a ejercer sus funciones el 1o. de 
diciembre y durará en su encargo cuatro años. ${ }^{35}$

Assim, Porfírio Díaz foi eleito pela primeira vez, indiretamente tal como previa a Constituição, em 1877. Cumpriu seu mandato até o final de 1881, quando Manuel González foi eleito. Após o mandato de González (1881-1884), elege-se sucessivamente em 1884, 1888, 1892, 1896, 1900, 1904, quando há nova mudança constitucional.

Em 1904, é instituída a figura da vice-presidência - responsável por substituir o presidente na função em caso de ausência temporária, ou tomar posse em seu lugar em caso de falta absoluta. Na mesma reforma, aumenta-se o período do mandato presidencial para seis anos. Assim, novas eleições estariam previstas para 1910, com uma novidade: o debate sobre quem seria o vice-presidente na chapa de Porfírio Díaz e o acompanharia nos seis anos seguintes. É importante lembrar que Díaz, que nasceu em 1830, completaria oitenta anos em 1910. Havia uma chance de, se eleito para presidir o México no período seguinte de seis anos, não completar seu mandato. A disputa pela vice-presidência, assim, representava uma efetiva disputa pela sucessão de Díaz na função principal e, por isso, foi bastante concorrida.

Para completar a tensão política de 1910, anos antes, em 18 de março de 1908, foi publicada uma entrevista de Díaz ao jornalista norte-americano James Creelman, da revista 'The Pearson's Magazine'. Na entrevista declarou que deixaria a Presidência e não seria candidato em 1910. Literalmente afirmou "No importa lo que al respecto digan mis amigos y partidarios, me retiraré cuando termine el presente periodo y no volveré a gobernar otra vez. Para entonces tendré ya ochenta años." ${ }^{\text {36 }}$. A entrevista, que apresenta uma versão romanceada do político - e dos feitos de seu mandato de 27 anos para o país -, parece ter o claro objetivo de incentivar investidores norteamericanos a apoiar empreendimentos no México. Além da declaração surpreendente sobre sua não candidatura, há outros trechos da entrevista em que Díaz analisa as instituições políticas mexicanas.

\footnotetext{
${ }^{35}$ Referência para as mudanças realizadas sobre o texto da Constituição de 1857, ver: FLORES, Imer B. La Constitución De 1857 Y Sus Reformas: A 150 Años De Su Promulgación. In VALADÉS, Diego; CARBONELL, Miguel (Coord.). El Proceso Constituyente Mexicano. A 150 Años De La Constitución De 1857 Y 90 de La Constitución De 1917. Instituto De Investigaciones Jurídicas De La Universidad Nacional Autónoma De México, 2007. P. 299-300. Disponível em http://biblio.juridicas.unam.mx/libros/5/2389/12.pdf Consulta realizada em 08/09/2015.

${ }^{36}$ A íntegra da entrevista, já traduzida para o espanhol, aqui: Em BIBLIOTECA GARAY. 500 años de México en documentos. México, 2011.

<http://www.bibliotecas.tv/zapata/bibliografia/indices/entrevista_diaz_creelman01.html>. Consulta realizada em 09/09/2015.
} 
'Es un error suponer que el futuro de la democracia en México ha sido puesto en peligro por la prolongada permanencia en el poder de un solo presidente -dijo en voz baja-. Puedo con toda sinceridad decir que el servicio no ha corrompido mis ideales políticos y que creo que la democracia es el único justo principio del gobierno, aun cuando llevarla al terreno de la práctica sea posible sólo en pueblos altamente desarrollados'. (...)

'Puedo dejar la presidencia de México sin ningún remordimiento, pero lo que no puedo hacer, es dejar de servir a este país mientras viva' - añadió. (...)

Creelman: ¿Sabe usted que en Estados Unidos tenemos graves problemas por la elección del mismo presidente por más de tres periodos?' (...)

'Sí. Sí lo sé - repuso. Es un sentimiento natural en los pueblos democráticos el que sus dirigentes deban ser cambiados. Estoy de acuerdo con este sentimiento.' (...)

'He esperado pacientemente porque llegue el día en que el pueblo de la República Mexicana esté preparado para escoger y cambiar sus gobernantes en cada elección, sin peligro de revoluciones armadas, sin lesionar el crédito nacional y sin interferir con el progreso del país. Creo que, finalmente, ese día ha llegado'. (...)

'No importa lo que al respecto digan mis amigos y partidarios, me retiraré cuando termine el presente periodo y no volveré a gobernar otra vez. Para entonces tendré ya ochenta años.'

'Doy la bienvenida a cualquier partido oposicionista en la República Mexicana -dijo. Si aparece, lo consideraré como una bendición, no como un mal. Y si llegara a hacerse fuerte, no para explotar sino para gobernar, lo sostendré y aconsejaré, y me olvidaré de mí mismo en la victoriosa inauguración de un gobierno completamente democrático en mi país. ${ }^{37}$

A última resposta, a respeito das boas-vindas que daria aos partidos oposicionistas - caso eles viessem a existir -, foi motivada pela provocação do jornalista: como garantir instituições livres se os partidos de oposição não existem? O jornalista parece ter partido de um dado de realidade, natural, "os partidos oposicionistas simplesmente não existem". Como se essa situação não tivesse sido alcançada com muita ação repressora do Estado. Poderia ter complementado com informações sobre as perseguições, as prisões e os exílios promovidos pelo aparato estatal de Díaz, que não permitiu em seus longos anos de governo que houvesse oposição. Poderia completar ainda com informações sobre a repressão sofrida pela liberdade de expressão, e o enorme esforço para garantir que jornais oposicionistas não

\footnotetext{
${ }^{37}$ A íntegra da entrevista, já traduzida para o espanhol, aqui: Em BIBLIOTECA GARAY. 500 años de México en documentos. México, 2011.

<http://www.bibliotecas.tv/zapata/bibliografia/indices/entrevista_diaz_creelman01.html>. Consulta realizada em 09/09/2015.
} 
existissem. O jornalista, porém, não foi tão longe. E deu a possibilidade de o ditador simplesmente dizer que, a partir de agora, os partidos de oposição seriam bem-vindos.

As declarações de Díaz, no entanto, não se sustentaram. Além de ele ter sido efetivamente candidato em 1910, logo antes das eleições os principais membros do Partido Antirreeleicionista foram presos.

Não é possível saber quais foram as razões íntimas que levaram Díaz a formular tais declarações. Inegável, porém, que elas tiveram efeitos sobre o cenário político mexicano, motivando inclusive a reorganização do Partido Liberal que, depois de dissonâncias internas, veio a se tornar o Partido Antirreeleicionista, sob a liderança de Francisco Madero. Do exílio, após ser preso às vésperas da eleição, Madero contribuiu de forma decisiva para o início do levante popular em 20 de novembro de 1910, levante que seria o responsável pela queda do presidente Porfírio Díaz, no ano seguinte. Antes de chegar à insurreição de 1910, entretanto, deve-se apresentar em linhas bastante gerais o cenário político e econômico do México durante o porfiriato.

\subsubsection{Desenvolvimento do transporte ferroviário no México do final do século XIX}

Em $1^{\circ}$ de janeiro de 1873, foi inaugurada a primeira grande ferrovia do México, que ligava a cidade portuária de Veracruz, no Golfo do México, à capital da República Distrito Federal ou Cidade do México.

O primeiro projeto de construção de uma linha férrea nesse percurso - que tem 470 quilômetros de extensão - é de 22 de agosto de 1837, no entanto. Em 1837, Anastasio Bustamante, então Presidente da República, conferiu autorização e exclusividade para Francisco de Arrillaga, que deveria construir um caminho de ferro entre Veracruz e a capital. Outras concessões para a construção dessa linha foram dadas em 1842 e 1848. Em 1850, foi inaugurado o primeiro trecho, que tinha apenas 13 quilômetros de extensão. Nesse mesmo ano, circulou o primeiro trem em território mexicano.

Em 1857, 1861, 1863, 1864 e 1868 foram feitas novas concessões ou transferidas as concessões existentes. Em 1869, o presidente Benito Juárez realizou a 
inauguração do trecho da linha férrea que ligava a Cidade do México a Apizaco, com 139 quilômetros construídos, e um ramal entre Apizaco e Puebla, com 47 quilômetros.

Em 1873, quatro anos após a inauguração dos 139 quilômetros iniciais, foi inaugurada a linha México-Veracruz, já sob a presidência de Sebastián Lerdo de Tejada. Benito Juárez, entusiasta do projeto, havia morrido em 1872. Ao final do governo de Lerdo, em 1876, o México contava com 630 quilômetros de linhas férreas. Além dos pouco mais de 470 quilômetros da via principal, havia 15 quilômetros que ligavam Veracruz a Medellín; 16 quilômetros que ligavam Mérida a Progresso; 17 quilômetros que ligavam a Cidade do México a Cuautitlán; 47 quilômetros entre Apizaco e Puebla e, por fim, 112 quilômetros entre Veracruz e Jalapa.

Quatro anos depois, em 1880, findo o primeiro governo de Porfírio Díaz, o país já contava com aproximadamente 1.080 quilômetros de linhas férreas. A expansão concentrada do sistema ferroviário, porém, se deu nos anos seguintes. Durante o seu segundo governo, que tem início em 1884, com o objetivo de incentivar e garantir a efetiva e rápida expansão das linhas férreas, Porfírio Díaz autoriza investimentos estrangeiros para viabilizar a construção desse tipo de empreendimento. Assim, em pouco mais de quinze anos, no momento em que eclode a Revolução Mexicana de 1910, o México contava com aproximadamente 19.280 quilômetros de linhas construídas. Em 30 anos, entre 1880 e 1910, foram construídos mais de 18.000 quilômetros de linhas férreas. Tal expansão, bastante rápida e extensa em números absolutos, é semelhante à ocorrida em outros países da América Latina, como Argentina e Brasil. No México, porém, tem a peculiar característica, diferente da malha brasileira, de estar muito bem distribuída e interligada em todo o território do país.

Na página seguinte, o mapa ferroviário do México em 1910, no início do processo revolucionário: ${ }^{38}$

\footnotetext{
${ }^{38}$ Mapa em: BETHELL, Leslie (org.) História da América Latina vol. V: de 1870 a 1930. São Paulo: Edusp, 2008. P. 22.
} 


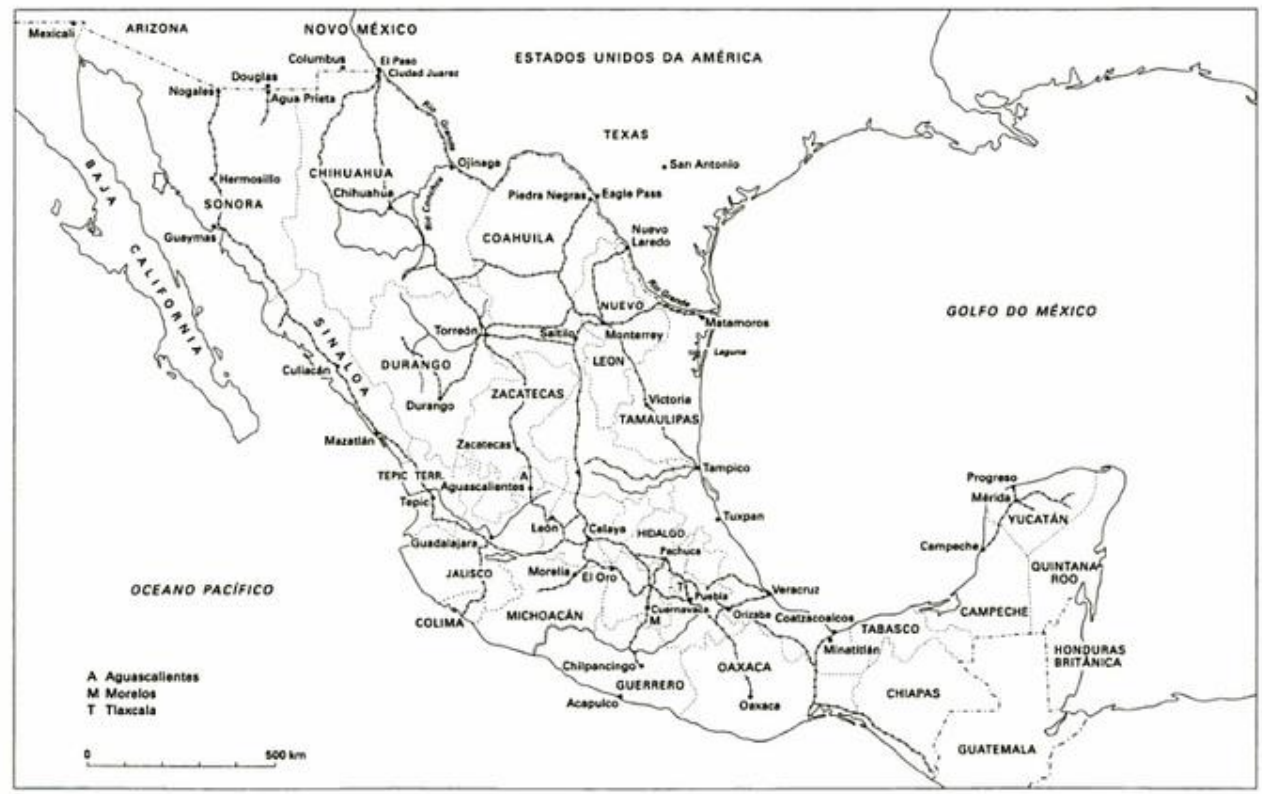

O México revolucionário

O fato de o território nacional ter sido cortado por linhas férreas, de norte a sul e em praticamente todas as regiões, tem ligação direta com o crescimento econômico e a valorização da produção agrícola mexicana. A possibilidade de cultivar a terra e vender o produto para regiões mais populosas do México e também para o mercado internacional estava garantida, a partir dessa malha, por meio do transporte ferroviário.

\subsubsection{A regulamentação jurídica da economia mexicana no porfiriato: ferrovias, petróleo, mineração e instituições financeiras}

Além de autorizações para a construção de ferrovias, organização das concessões ligadas às diferentes linhas de trem, impostos (ou isenções) sobre a atividade - como fez, por exemplo, a Ley sobre Ferrocarriles, de 29 de abril 1899 - outros três temas estiveram bastante presentes nas regulamentações jurídicas sobre a economia mexicana durante o porfiriato: petróleo, mineração e instituições financeiras.

As ferrovias possibilitavam a integração política e econômica do país. Garantiam o escoamento da produção agrícola, da extração de minérios e da indústria nascente. Para acompanhar o crescimento econômico, o país precisava se estruturar com uma boa 
rede bancária, capaz de garantir crédito para os empreendimentos, moeda única circulante, meio e segurança para as trocas comerciais.

Assim, em 19 de março de 1897, o Congresso Mexicano aprovou a Ley General de Instituciones de Credito $^{39}$, em que são estabelecidas regras para a criação de instituições de intermediação de crédito. Os três tipos previstos na lei (Bancos de Emisión; Bancos Hipotecarios; Bancos Refaccionarios) diferenciam-se pelo tipo de títulos de crédito que concedem (curto ou longo prazo, título ao portador, título hipotecário ou de pagamento a curto prazo) e pelo tipo de garantia que obtêm de seus credores. A partir da edição da lei que regulamentou tais instituições, seu número cresceu consideravelmente no México cresceu consideravelmente. Em 19 de junho de 1908, outra lei regulamentadora de instituições de crédito foi sancionada.

Além disso, em 31 de março de 1905, todas as instituições que tinham competência para cunhar moedas nos diferentes estados mexicanos foram fechadas. A partir dessa data, as novas moedas só eram produzidas na Cidade do México. Essas foram medidas tomadas pelo governo para aumentar a previsibilidade e a certeza das relações econômicas mexicanas.

Minérios e petróleo, por fim. A regulamentação jurídica dessas duas áreas obedeceu a um mesmo princípio: facilitar ao máximo a exploração dos bens naturais do país, também por investidores estrangeiros.

Assim, em 22 de novembro de 1884, Manuel González aprovou o Código de Minas de los Estados Unidos Mexicanos, o qual determina que aquilo que antes poderia ser apenas propriedade da nação - as riquezas minerais do subsolo mexicano - passava às mãos de donos privados, por tempo ilimitado, por meio de concessão. Esse código favoreceu a exploração tanto dos muitos minérios existentes no México como também de seu petróleo. Em seus artigos iniciais, após a definição no artigo $1^{\circ}$ de quais bens estão submetidos à lei, lê-se:

Art. $2^{\circ}$ - Las minas y placeres de que tratan las fracciones I y II del artículo antecedente, forman un inmueble distinto del suelo en el cual o bajo cuya superficie se encuentren, aunque lleguen a pertenecer a un mismo dueño.

39 Íntegra da Ley General de Instituciones de Credito, de 19 de março de 1897, disponível aqui: CARMONA, Doralicia. Memoria política de México. Guanajuato: Universidade de Guanajuato, 2014. http://www.memoriapoliticademexico.org/Textos/5RepDictadura/1897LGD.html Consulta realizada em 14 de setembro de 2015. 
Art. $3^{\circ}$ - La propiedad de las minas, placeres, haciendas de beneficio y aguas, a que se refiere el artículo $1^{\circ}$, se adquiere en virtud del descubrimiento y denuncio, mediante concesión hecha por la autoridad respectiva, conforme las reglas y bajo las condiciones que en adelante se fijan en el presente Código.

Art. $4^{\circ}$ - La Ley concede a los particulares, conforme al artículo anterior, la propiedad de las minas por tiempo ilimitado, bajo condición de trabajarlas y explotarlas según los preceptos de este Código y de los reglamentos que se dicten para su ejecución, a fin de proveer a la conservación de las minas y seguridad de los trabajadores.

Art. $5^{\circ}$ - Toda persona capaz de adquirir legalmente bienes raíces en la República, puede adquirir las minas, placeres, haciendas de benefício y aguas comprendidas en el artículo $1^{\circ}$.

Art. $6^{\circ}$ - Los extranjeros pueden adquirir la propiedad minera en los términos y con las restricciones que las leyes de la República los consideran capaces de adquirir, poseer y trasmitir la común; sometiéndose, como los mexicanos, a las prescripciones de esta ley y a las demás que se expidieren, relativas al ramo de Minería. ${ }^{40}$

Ora, a propriedade dos bens presentes no subsolo mexicano poderia - a partir do Código de 1884 - ser privada. Para isso, porém, era necessário que o pretendente a proprietário identificasse a própria existência da riqueza mineral, notificasse o governo e obtivesse uma concessão, mediante o pagamento de um imposto para o reconhecimento da propriedade. Tal como na propriedade fundiária superficial, o reconhecimento de novos bens a serem adquiridos por procedimentos de identificação e demarcação colaborou para garantir o funcionamento do Estado Mexicano.

Além disso, era vedado às instituições religiosas e às "corporações civis" pessoas jurídicas que representavam comunidades indígenas legalmente - adquirir bens imóveis, o que lhes tirava imediatamente a possibilidade de possuir e explorar bens do subsolo, mesmo que estivessem sob suas terras comuns. Além dessa vedação que afetava boa parte dos habitantes originais do México, o próprio Código autoriza - em igualdade absoluta com os mexicanos - que os estrangeiros pleiteiem e tornem-se proprietários das riquezas minerais do subsolo mexicano. O objetivo, assim, fica explícito: quer-se atrair investimentos (estrangeiros) e aumentar a produtividade da extração mineral no país.

\footnotetext{
${ }^{40}$ A íntegra do Código de Minas de 22 de novembro de 1884 pode ser encontrada aqui: ARCHIVO HISTÓRICO DE PEMEX. Fuentes para la historia del Petroleo en México. http://petroleo.colmex.mx/images/stories/archivos/misc/CODIGO_DE_MINAS_1884.pdf Consulta realizada em 14 de setembro de 2015.
} 
A estratégia foi bem-sucedida. Entre 1877 e 1910, o México cresceu, sua indústria nacional foi criada e se desenvolveu, a população aumentou ${ }^{41}$. É verdade que esse processo contou com a participação ativa de Porfírio Díaz - as normas analisadas aqui são prova - que, também por meio da estabilização política autoritária do país, garantiu um ambiente mais atraente para investimentos estrangeiros. Entre as consequências da política de crescimento baseada em investidores internacionais, tal como analisado por Katz, ao final do período "os setores mais importantes da economia estavam nas mãos do capital estrangeiro"42. O mercado externo era também o destinatário prioritário dos produtos produzidos, extraídos e cultivados no país. Alguns dados que quantificam e ilustram o crescimento econômico vivido pelo México nesse período:

A produção desse último mineral [prata] subiu de 607.037 quilos em $1877 / 1878$ para 1.816 .605 quilos em 1900/1901 (e 2.305.094 quilos em 1910/1911). A produção de chumbo começou com 38.360 toneladas em 1891/1892 e subiu para 79.011 toneladas em 1900/1901 (e 120.525 toneladas em 1910/1911). O cobre aumentou sua produção de 6.483 toneladas em 1891/1892 para 28.208 toneladas em 1900/1901 (e 52.116 toneladas em 1910/1911). O cultivo comercial de produtos agrícolas também cresceu a passos largos. O exemplo mais espetacular foi o sisal, cuja produção subiu de 11.383 toneladas em 1877 para 78.787 em 1900 (e 128.849 toneladas em 1910). A produção de outras mercadorias de exportação, como a borracha, o guaiule (um substituto da borracha), o café e a cochonilha, também cresceu de forma impressionante. Além disso, a indústria orientada para a exportação começou a consolidar-se. Em 1891, os Estados Unidos aprovaram a tarifa McKinley, que impunha altas taxas alfandegárias sobre a importação de minérios não processados. Como as tarifas para os minérios processados eram muito mais baixas, as maiores companhias mineiras dos Estados Unidos, principalmente a American Smelting and Refining Company, controlada pelos Guggenheim, preferiram instalar fundições de ferro no México. ${ }^{43}$

\footnotetext{
${ }^{41}$ Moisés González Navarro, em seu livro Población y sociedade em México (1900-1970) comenta a explosão demográfica do período. Se até o fim do século XIX os dados populacionais eram baseados em estimativas, em 1895 foi realizado o primeiro censo no país. A ele seguiram-se dois outros, em 1900 e 1910: "La población aumentó de 6 a 15 millones de habitantes, 145\%, de 1810 a 1910, sobre todo en el tercio de siglo del porfiriato. Gilberto Loyo atribuyo el incremento de la población urbana al desarrollo de las comunicaciones, la industrialización y a la paz en esta época; la población rural creció más lentamente a causa del latifundismo. El triunfo republicano sobre el Imperio originó el incremento de la población, ‘causa demopsíquica de la Revolución'." GONZÁLEZ NAVARRO, Moisés. Población y sociedade em México (1900-1970). Ciudad de México: Universidad Autónoma de México, 1974. P. 43.

${ }^{42}$ KATZ, Friedrich Katz. O México: A República Restaurada e o Porfiriato, 1867-1910. In BETHELL, Leslie (org.) História da América Latina vol. V: de 1870 a 1930. São Paulo: Edusp, 2008. P. 53.

${ }^{43}$ KATZ, Friedrich. O México: A República Restaurada e o Porfiriato, 1867-1910. In BETHELL, Leslie (org.) História da América Latina vol. V: de 1870 a 1930. São Paulo: Edusp, 2008. P. 50-51.
} 
A mesma política liberal foi adotada em relação ao petróleo. Em 24 de dezembro de 1901, foi promulgada por Díaz a Ley del Petróleo. Diferentemente das concessões previstas no Código de Minas, de 1884, a autorização para investigar a existência de petróleo em terras públicas, lagos e mares tinha prazo determinado e improrrogável de um ano. Se fossem identificadas reservas ou mananciais do óleo nesse período, a Secretaria de Fomento teria então competência para expedir patentes autorizando a extração e exploração do petróleo pelo prazo de dez anos. Tal exploração limitada no tempo, no entanto, acontecia a partir de inúmeros incentivos públicos:

Art. 3o. Las patentes de explotación durarán diez años, a contar desde la fecha de su publicación en el "Diario Oficial". Terminado este plazo, cesarán las franquicias y concesiones otorgadas a los explotadores, así como las obligaciones contraídas y que se especifican en los artículos correspondientes de esta ley.

Los descubridores de petróleo o carburos gaseosos de hidrógeno, que de acuerdo con la ley obtuvieron su patente respectiva, gozarán para la explotación de aquellas substancias, de las franquicias siguientes:

I. Exportar libres de todo impuesto los productos naturales, refinados o elaborados que procedan de la explotación.

II. Importar libres de derechos, por una sola vez, las máquinas para refinar petróleo o carburos gaseosos de hidrógeno y para elaborar toda clase de productos que tengan por base el petróleo crudo, las tuberías necesarias para estas industrias, así como los accesorios para estas tuberías, bombas, tanques de hierro o de madera, barriles de hierro o de madera, gasómetros y materiales para los edificios destinados a la explotación, quedando estas importaciones sujetas a las disposiciones y reglas que dicte la Secretaría de Hacienda.

III. El capital invertido en la explotación de petróleo o carburos gaseosos de hidrógeno, será libre por diez años de todo impuesto federal, excepto el del Timbre. ${ }^{44}$

Os incisos do artigo $3^{\circ}$ da lei de 1901 isentam de impostos praticamente toda a cadeia produtiva do petróleo: capital investido na exploração do petróleo, importação de maquinário para realização de refino e exportação dos produtos obtidos não precisavam recolher nenhum dos impostos federais. Além da lucratividade própria da atividade econômica de exploração de petróleo, as múltiplas isenções concedidas pelo Estado Mexicano tornavam a atividade petrolífera no México do início do século XX quase irresistível para os estrangeiros.

\footnotetext{
44 A íntegra da Ley del Petróleo24 de dezembro de 1901 pode ser encontrada aqui: BIBLIOTECA GARAY. 500 años de México en documentos. México, 2011. http://www.biblioteca.tv/artman2/publish/1901_204/Ley_del_Petr_leo_emitida_por_Porfirio_D_az_1407 .shtml Consulta realizada em 14 de setembro de 2015.
} 
Anos antes, em 6 de junho de 1887, Porfírio Díaz já havia isentado as minas de carvão de pedra; a extração de petróleo; as minas de ferro e o mercúrio, muito usado na extração de metais. Além do já citado ferro, em todos os seus estados, também o ouro, a prata e todos os metais que pudessem ser extraídos do solo mexicano:

Art. 1o. Desde la promulgación de esta ley estarán libres de toda contribución federal, local y municipal, excepto el Impuesto del Timbre, las minas de carbón de piedra, en todas sus variedades, las de petróleo, las de hierro y azogue, así como los minerales productos de ellas; el hierro nacional dulce y colado en varillas, barras o lingotes, madejas, soleras y rieles, y el azogue nacional líquido producto del beneficio de los minerales de donde se extrae.

Art. 2o. Será libre de derechos de alcabala o de portazgo y de todo impuesto, cualquiera que sea el nombre que pueda dársele a la circulación en el interior de la República, del oro y de la plata mineral, en pasta o acuñados, la de los demás metales y la de todos los productos de las minas.

A política de diminuição de impostos para a extração mineral, assim, começou antes de 1901, mas se aprofundou ainda mais no início do século XX, com isenções garantidas também para a importação de maquinários e para a exportação do petróleo, para além da circulação interna dessas mercadorias.

Essa prodigalidade mexicana em relação a seus bens naturais foi revertida parcialmente apenas por Francisco Madero que, em 3 de junho de 1912, aprovou o decreto em que criava, entre outros, um imposto sobre a exploração e produção de petróleo nacional. Lia-se no referido documento normativo: "Impuestos interiores que se causan en toda la Federación. (...) XIV. Productos de la Renta del Timbre: (...) K. Impuesto Especial del Timbre sobre el petróleo crudo de producción nacional, a razón de veinte centavos por tonelada, conforme al reglamento que expida el Ejecutivo." Alguns historiadores identificam nessa norma (e na tentativa de taxação de atividades que antes eram mantidas sem qualquer ônus) um dos motivos que levaram ao golpe político sofrido por Madero (e arquitetado por Victoriano Huerta) em fevereiro de 1913. A deposição violenta de Madero foi apoiada pelo então Embaixador americano no México, Henry Lane Wilson, como será narrado a seguir.

A regulamentação liberal em relação à extração dos mais diferentes minerais gerou uma intensificação expressiva dessa atividade nos anos sob a presidência de Porfírio Díaz. Tal crescimento não veio acompanhado de uma melhora de qualidade de 
vida e ganhos salariais para a população de trabalhadores mexicanos. Com o mercado interno enfraquecido, o crescimento não se sustentou:

Depois de 1900 o desenvolvimento industrial diminuiu enormemente seu ritmo. Isso se deveu em parte a uma queda do padrão de vida depois da virada do século, fazendo com que o mercado de produtos industriais se expandisse de maneira muito mais limitada do que antes. Além disso, algumas políticas do governo reduziram o crescimento industrial. A administração Díaz nunca fez muito esforço para ajudar os produtores nacionais em dificuldades. A Nova Lei das Indústrias, promulgada em 1881, concedeu algumas generosas isenções de impostos às indústrias locais em formação e ofereceu uma proteção tarifária seletiva a determinadas indústrias locais, como as têxteis. Mas nunca proporcionou à indústria pesada o tipo de proteção especial muito comum nos países europeus, como, por exemplo, obrigar os empresários ferroviários norte-americanos a comprar dos produtores mexicanos o material de que necessitavam. A indústria pesada também não teve acesso preferencial ao crédito. ${ }^{45}$

Apesar de ter vivido um período de crescimento e relativa prosperidade econômica no governo de Porfírio Diaz, o México pré-revolucionário vivia uma situação de esgarçamento social. O ritmo de crescimento havia diminuído; a produção agrícola, voltada ao mercado externo, havia provocado o aumento de preços dos alimentos de consumo diário e o salário dos agricultores e dos trabalhadores havia caído. Além disso, inúmeros camponeses haviam sido retirados de suas terras. A situação econômica e social das camadas mais baixas da população, assim, era muito ruim.

\subsubsection{Terra e trabalho}

Se as práticas autoritárias de Porfírio Díaz tinham objetivos econômicos claros e o principal deles era a estabilidade política capaz de criar um ambiente favorável a investimentos estrangeiros no território do México, nesse processo não foram protegidos os mexicanos que já viviam no território e desenvolviam suas atividades econômicas e de subsistência.

\footnotetext{
${ }^{45}$ KATZ, Friedrich. O México: A República Restaurada e o Porfiriato, 1867-1910. In BETHELL, Leslie (org.) História da América Latina vol. V: de 1870 a 1930. São Paulo: Edusp, 2008. P. 51.
} 
Especialmente a população rural - maioria expressiva ao final do século XIX foi atropelada pelo desenvolvimento rápido de ferrovias e súbita valorização das terras. A situação no campo talvez seja a razão de maior insatisfação social da população no período.

Foi no governo de Porfírio Díaz que se realizou a mais ampla desapropriação de terras comunitárias e de pequenos proprietários da história do México. Esse processo se deu, entre outros motivos, porque as novas ferrovias permitiam que a produção agrícola circulasse mais e por mais longas distâncias tanto no território nacional quanto para a exportação. Além disso, o mercado consumidor norte-americano e também europeu aumentou sua demanda, fazendo com que o México aumentasse suas vendas. Isso gerou maior interesse em terras - e outros recursos naturais que passaram a ser disputados, como a água - que antes não existia. E o embate se deu, principalmente, entre, de um lado, as comunidades de agricultores, indígenas e mestiços e, de outro, as grandes fazendas.

Tendo a legislação e o aparato estatal - incluído o Judiciário - a seu lado, não foi difícil que inúmeros fazendeiros se apropriassem de terras coletivas, muitas delas sem a proteção de um título de propriedade formal. Consideradas "terrenos baldios", as terras comunitárias possuídas coletivamente foram cedidas formalmente pelo Estado a fazendeiros. Com esse processo, comunidades inteiras passaram a "pertencer" a fazendeiros que, devido ao título de propriedade recém-adquirido, se sentiam no direito de, por exemplo, utilizar a mão de obra que "acompanhava" sua propriedade. Quer impondo uma lógica de regime de trabalho, quer estabelecendo com os antigos possuidores contratos de arrendamento, em que uma parte da produção deveria ser entregue aos novos proprietários, estes passaram a exercer controle sobre comunidades que eram livres e, como tal, dispunham livremente do produto de seu trabalho.

Assim, aqueles que antes eram camponeses livres muitas vezes se tornaram peões e empregados, em geral em péssimas condições de trabalho e remuneração. Nesse processo, o cultivo de alimentos diminuiu, elevando por sua vez o preço dos gêneros alimentícios. Os trabalhadores recebiam baixos salários cada vez menos capazes de garantir as condições de sua subsistência.

A partir de diferentes modelos de organização da produção e com especificidades locais, o processo de desapropriação de terras de pequenos produtores e comunidades se deu em todo o território mexicano, estimulado por leis como a Ley 
sobre ocupación y enajenación de terrenos baldios, de 1863; os decretos do Poder Executivo sobre colonização e companhias demarcadoras, de 1875 e 1883; e, principalmente, a Ley sobre Ocupación y Enajenación de Terrenos Baldíos, de 1884. Se as normas que possibilitavam a desapropriação de pequenas propriedades e a concentração das terras mexicanas nas mãos de poucos proprietários já existiam antes de Porfírio Díaz, foi seu governo que efetivou amplamente o conjunto normativo que recebeu, aprofundando suas características em alguns casos.

A retrospectiva histórica das normas e condições que levaram o México do início do século XX ao esgarçamento extremo das relações sociais no campo é objeto do capítulo 2 do presente trabalho. O capítulo 3, por sua vez, aborda as questões trabalhistas envolvidas na tensão social pré-revolucionária.

\subsubsection{Tensões entre centralismo e localismo (características do federalismo mexicano)}

O México do final do século XIX resistia em adotar um projeto político nacional. País formado por diversos estados, províncias e municípios, cada qual com lideranças políticas e especificidades locais (composição demográfica, características geológicas, climas e relevos distintos), suas partes ressentiam-se e agiam contra decisões com validade para o território todo, tomadas na Cidade do México.

Versos da campanha para eleições de deputados em 1826 são ilustrativas da resistência que, no século XIX, as decisões políticas centralizadas sofriam no país:

\section{OCTAVA}

Debe tener talento despejado, desinterés y mucho patriotismo; debe ser al estudio dedicado, y católico ser sin fanatismo. En fin, debe tener valor probado para hacer guerra cruel al centralismo. El que llegue a reunir tales virtudes, será buen diputado, no lo dudes. México, julio 26 de 1826. El Pensador. ${ }^{46}$

\footnotetext{
${ }^{46}$ Trova de José Joaquín Fernández de Lizardi. O texto integral do manifesto político escrito por ele em 1826 pode ser encontrado aqui: CARMONA, Doralicia. Memoria política de México. Guanajuato: Universidade de Guanajuato, 2014.
} 
Desse modo, ao assumir o poder Porfírio Díaz tinha o desafio de consolidar o México como um Estado nacional. Para isso, precisava arrecadar dinheiro para financiar sua estrutura institucional e aprimorar seus aparatos de controle e repressão (aos quais recorreu frequentemente em seu governo). Foi descartada, porém, a criação de novos impostos que incidissem diretamente sobre a produção agrária e sobre as atividades extrativista e industrial. $\mathrm{O}$ objetivo não era criar mais entraves para o desenvolvimento econômico. Nesse contexto, o Estado mexicano obteve dinheiro sobretudo por meio da política de demarcação e venda de terras, que, conforme explicado anteriormente, tiveram uma valorização nesse período.

O Estado Mexicano se financiou, então, por meio da venda de terras e riquezas minerais de seu subsolo a pessoas físicas e empresas privadas. Essas vendas (objeto de análise do segundo capítulo) tiveram como objeto, muitas vezes, terras já ocupadas e cultivadas por camponeses, índios e mestiços. Sem a formalização de um título de propriedade, as terras que estavam em posse dessas comunidades por gerações foram declaradas baldíos e vendidas. Com o dinheiro arrecadado e com o acesso rápido aos diferentes pontos de seu território, o que se tornou possível a partir da construção das inúmeras ferrovias, o Estado Mexicano se consolidou.

Além da obtenção de dinheiro e fortalecimento das instituições centralizadas do Estado, outras estratégias foram adotadas por Porfírio Díaz para garantir a estabilidade no poder. O famoso lema de Maquiavel "dividir para governar” foi aplicado por Díaz à exaustão em suas intervenções nas políticas locais dos Estados. Desconstruir o poder de uma elite local para fortalecer sua inimiga, nomear um político que sequer vive no Estado para ser seu governador, fraudar e manipular eleições locais, ou só admitir a permanência de políticos leais a seu governo foram algumas das estratégias usadas para garantir o controle centralizado do território.

Com relação a esta última [classe alta], Díaz praticou uma política do 'dividir para reinar'. Afastou do poder os caciques locais leais a seus antecessores, como o governador de Chihuahua, Luis Terrazas, e os substituiu por adversários de origens sociais idênticas. No entanto, enquanto não lhe ofereceram resistência, permitiu que os homens que afastara conservassem seus bens e expandissem sua influência econômica. Para muitos hacendados, a perda do poder político foi mais do que compensada pela política de Díaz relacionada com a

<http://www.memoriapoliticademexico.org/Textos/2ImpDictadura/1826JFL-ElecBorb.html> realizada em 16 de setembro de 2015. 
venda das terras públicas, que lhes ofereceu grandes oportunidades de enriquecimento. ${ }^{47}$

A perda do poder político por parte de antigas lideranças locais foi, portanto, compensada, de alguma forma, por ganhos econômicos possibilitados pela política agrária de Díaz. De qualquer forma, a indicação inicial para ocupar cargos de poder dependia da afirmação de lealdade ao governo central e, em especial, à própria figura de Porfírio Díaz.

Tal como no caso das eleições presidenciais (art.78), outro artigo da Constituição de 1857 foi modificado em 1887 para permitir a reeleição de governadores. O artigo 109, que tratava da forma política dos estados mexicanos, passou a vigorar com a seguinte redação: “Los Estados adoptarán para su régimen interior la forma de gobierno republicano representativo popular y determinarán en sus respectivas Constituciones la posibilidad de reelección de los governadores."

Assim, não só os políticos aliados a Díaz se elegiam - também por meio de processos eleitorais fraudulentos, como se verá a seguir - como também se perpetuavam no poder, tal qual o padrinho político no governo central:

La mayoría de las élites locales permanecieron herméticamente locales. Con los años, a medida que la movilidad política de las guerras civiles fue dando paso al immobilisme del último Porfiriato, las élites envejecieron, se compactaron y se volvierón aún más exclusivas. En San Luis Potosí, los hermanos Díez Gutiérrez se alternaron en la cámara legislativa estatal a lo largo de 20 años; Sonora estuvo dominada por el general Luis Torres, que estuvo cinco periodos en la gubernatura, con un testaferro torresista entre periodo y periodo. Los Rabasa dirigían Chiapas: (...) En Puebla, un viejo compañero de armas de Díaz, Mucio Martínez, detentó la gubernatura por espacio de 18 años (esto no era un récord: Cahuantzi, en Tlaxcala, sirvió durante 26 años y otros más de 20). (...) Díaz, sin embargo, dejó bien claro que la perpetuación de estas satrapías dependía de su propia voluntad. $^{49}$

Porfírio Díaz assumiu o poder em 1877. Assim, apesar do breve período de governo de Manuel González, em 1907 o México conhecia há trinta anos as práticas e

\footnotetext{
${ }^{47}$ KATZ, Friedrich. O México: A República Restaurada e o Porfiriato, 1867-1910. In BETHELL, Leslie (org.) História da América Latina vol. V: de 1870 a 1930. São Paulo: Edusp, 2008. P. 41.

${ }^{48}$ FLORES, Imer B.. La Constitución De 1857 Y Sus Reformas: A 150 Años De Su Promulgación. In Valadés, Diego; Carbonell, Miguel (Coord.). El Proceso Constituyente Mexicano. A 150 Años De La Constitución De 1857 Y 90 De La Constitución De 1917. Instituto De Investigaciones Jurídicas De La Universidad Nacional Autónoma De México, 2007. P. 300.

${ }^{49}$ KNIGHT, Alan, La Revolución mexicana. Del Porfiriato al nuevo régimen constitucional. Trad. Luis Cortés Bargalló. México: FCE, 2010, p. 43.
} 
táticas de seu Presidente. Tal como as elites que privilegiou, as estratégias de estabilização política usadas por Díaz envelheceram nesse período. Na primeira década do século XX mexicano, tais estratégias estavam no limite de sua continuidade. Isso é ainda mais verdadeiro quando se considera que suas políticas locais sempre geraram algum grau de descontentamento e nunca foram aceitas plena e pacificamente.

Las municipalidades de México poseían largas tradiciones democráticas que se remontaban a los autogobiernos de los poblados españoles y los pueblos indígenas de la Colonia, mismas que se conservaron después en las constituciones liberales del siglo XIX. ${ }^{50}$

Como resultado, las elecciones locales se habían convertido en una farsa efectuada entre la apatía y la indiferencia; (...). ${ }^{51}$

"Este pueblo se rehúsa a que lo abandone en manos de un extraño llegado de fuera". ${ }^{2}$

A intervenção política e a "eleição" de governantes aliados a Díaz enfrentavam resistências que passavam pela falta de legitimidade democrática dos processos eleitorais realizados. Tais resistências, porém, tinham raízes ainda mais profundas: os municípios (e estados) mexicanos, antes da centralização efetiva de Díaz, mantinham alto grau de autonomia e tradição democrática. Os autogovernos foram forma política bastante disseminada no território mexicano. Porfírio Díaz, assim, atuou contra uma prática bastante enraizada na tradição política do país. A tensão gerada em função dessa crescente centralização permanecia latente e pulsante na sociedade mexicana. Assim, quando eclode a Revolução em 1910, não apenas Díaz e sua política eram o alvo da revolta, mas também seus representantes nos diferentes estados.

\footnotetext{
${ }^{50}$ KNIGHT, Alan. La Revolución mexicana. Del Porfiriato al nuevo régimen constitucional. Trad. Luis Cortés Bargalló. México: FCE, 2010, p. 54.

${ }^{51}$ KNIGHT, Alan. La Revolución mexicana. Del Porfiriato al nuevo régimen constitucional. Trad. Luis Cortés Bargalló. México: FCE, 2010, p. 55.

52 De Margarito Vázquez, Cuajimalpa, a Gobernación, 10 de julio de 1911, AG 898. Apud KNIGHT, Alan. La Revolución mexicana. Del Porfiriato al nuevo régimen constitucional. Trad. Luis Cortés Bargalló. México: FCE, 2010, p. 58.
} 


\subsubsection{Liberdades públicas, processo eleitoral fraudulento e alistamento compulsório}

Para além do descontentamento com as lideranças escolhidas para protagonizar os governos locais, muitas outras condutas distorciam e viciavam os processos políticos no México governado por Porfírio Díaz.

$\mathrm{O}$ autoritarismo onipresente colocava em xeque todas as conquistas liberais duramente realizadas, nas quais foram importantes atores Benito Juaréz, Margarida Maza, Ignacio Zaragoza, Ponciano Arriaga, Miguel Lerdo de Tejada e outros. Tanto a Constituição de 1857, de clara inspiração liberal, quanto documentos legais anteriores foram elaborados a partir das lutas contra a ditadura de Antonio López de Santa Anna, em meados do século XIX. Podemos citar algumas mudanças que caracterizaram o período conhecido como 'Reforma': Ley de libertad de imprenta, de 1855; Ley de Nacionalización de los Bienes Eclesiásticos, de 1859; Ley sobre libertad de cultos, de 1860; Ley de Administración de Justicia Orgánica de los Tribunales de la Federación, de 1855. Esse conjunto normativo, que foi consolidado por meio da Constituição dos Estados Unidos Mexicanos de 1857, tinha por objetivo garantir as principais liberdades que caracterizam uma democracia liberal.

A desconstrução desse aparato normativo durante o governo Díaz se deu por vezes na prática, sem necessidade de alterar ou revogar as leis vigentes; em alguns casos, porém, algumas mudanças normativas indicavam a mudança de conduta com relação às liberdades. É o caso, por exemplo, da liberdade de imprensa.

A Constituição de 1857 trazia, em seu artigo $7^{\circ}$, a proteção à liberdade de expressão. Durante o Congresso Constituinte de 1856-57, o mencionado artigo teve sua redação debatida, principalmente em relação às limitações impostas a essa liberdade que seriam em relação à "vida privada, moral e paz pública”. Como amenizador dessas limitações amplas e abstratas, combatidas por alguns, incluiu-se a figura do jurado, um julgador leigo, da sociedade, responsável por julgar os possíveis excessos cometidos por meio da imprensa. ${ }^{53}$

\footnotetext{
${ }^{53}$ Para uma história da liberdade de imprensa no México, ver: FERREIRO GALGUERA, Juan. Libertad de imprenta en México: hacia una ley federal de comunicación social. Anuario da Facultade de Dereito da Universidade da Coruña. Universidade da Coruña: Servicio de Publicaciones, 2001. P. 291-292.
} 


\section{Constitución 1857}

Art. $7^{\circ}$. Es inviolable la libertad de escribir y publicar escritos sobre cualquiera materia. Ninguna ley ni autoridad puede establecer la previa censura, ni exigir fianza á los autores ó impresores, ni coartar la libertad de imprenta, que no tiene más límites que el respecto á la vida privada, á la moral y á la paz pública. Los delitos de imprenta serán juzgados por un jurado que califique el hecho, y por otro que aplique la ley y designe la pena.

O texto constitucional foi alterado exatamente para mudar a competência de julgar delitos de imprensa em 1883:

Empero, con el decreto del 15 de mayo de 1883, se modificó la última parte para que la jurisdicción recayera en los tribunales establecidos: 'Los delitos que se cometan por medio de la imprenta serán juzgados por los tribunales competentes de la Federación ó por los de los Estados, los del Distrito federal y territorio de la Baja California, conforme á su legislación penal'(Decreto núm. 13). ${ }^{54}$

O que antes deveria ser avaliado e, depois, julgado (por dois jurados diferentes e leigos) passou, a partir da reforma constitucional, a ser de competência comum das instituições do Poder Judiciário mexicano. Note-se que na proteção original não estavam incluídos os excessos da liberdade de expressão; regulava-se especificamente os excessos cometidos por meio da imprensa. Imprensa essa que deveria, segundo os constituintes, ser mais protegida. E isso seria alcançado através dos jurados leigos, menos próximos do poder do que os juízes togados.

Porém, foi exatamente a imprensa livre a principal vítima do regime porfirista. Com respaldo do Poder Judiciário, periódicos foram fechados; jornalistas, articulistas e cartunistas presos; sedes arrombadas. Todas as estratégias foram usadas para coibir e intimidar aqueles que ousavam criticar o governo. Garantir o crescimento econômico e preservar a estabilidade política eram mais importantes, na visão de Díaz, do que garantir as liberdades públicas.

Enrique Flores Magón, irmão mais novo de Ricardo Flores Magón, escreve para a revista La Protesta, em 1925, a respeito de suas inúmeras tentativas fracassadas de

\footnotetext{
Disponível em: http://dialnet.unirioja.es/servlet/oaiart?codigo=1217396 Consulta realizada em 21/09/2015.

${ }^{54}$ FLORES, Imer B.. La Constitución De 1857 Y Sus Reformas: A 150 Años De Su Promulgación. In VALADÉS, Diego; CARBONELL, Miguel (Coord.). El Proceso Constituyente Mexicano. A 150 Años De La Constitución De 1857 Y 90 De La Constitución De 1917. Instituto De Investigaciones Jurídicas De La Universidad Nacional Autónoma De México, 2007. P. 304-305.
} 
criar um veículo de imprensa livre, capaz de disseminar ideias sociais que os representasse - e que pudesse ser crítico ao então governo presidencial do México:

Cuando Ricardo y Jesús cayeron presos en mayo de 1901, Eugenio Arnoux y yo, aunque torpes para el manejo de la pluma, y con la ayuda de algunos artículos que los presos lograban enviar de contrabando desde sus calabozos, sostuvimos vivo a Regeneración, hasta que el dictador lo mató. (...)

El hijo del Ahuizote fue asesinado por Díaz; pues aunque estábamos presos, escribíamos desde nuestros calabozos como cuando estuvimos en la prisión militar. Excélsior, nuestro periódico serio y en el cual cada uno firmaba sus artículos, para dar aliento con nuestro ejemplo de valor civil, sólo alcanzó a publicarse hasta el cuarto número. Muertos nuestros dos periódicos, publicamos El alacrán, que al tercer número murió. Entonces publicamos El padre del Ahuizote, y muerto éste, El nieto del Ahuizote; después El bisnieto del Ahuizote; todos ellos con vida efímera, pues pronto eran suprimidos. Hasta que Porfirio Díaz decretó que ningún periódico o escrito nuestro podría ser publicado en México, so pena de severos castigos a los impresores que lo hicieran y decomisación de imprenta. ${ }^{55}$

A liberdade de imprensa foi extinta por meio de políticas repressoras do aparato estatal, muitas vezes legitimadas por meio da mudança constitucional que atribuía a competência para decidir sobre casos de imprensa ao Poder Judiciário.

Em 1898, outra mudança constitucional impunha restrições, dessa vez à liberdade de trabalho. Novamente o Poder Judiciário protagonizava a mudança: ninguém pode ser obrigado a trabalhar, salvo quando o trabalho for imposto como pena por autoridade judicial.

No mesmo Decreto de 10 de junho de 1898, em que a pena de trabalhos forçados foi criada, criou-se um novo inciso no artigo 31 da Constituição (no texto original, havia apenas o texto dos incisos I e III):

\section{Constitución 1857}

Art. 31. Es obligación de todo mexicano:

I. Defender la independencia, el territorio, el honor, los derechos é intereses de su patria.

II. Prestar sus servicios en el Ejército ó Guardia Nacional, conforme á las leyes orgánicas respectivas.

III. Contribuir para los gastos públicos, así de la federación como del

\footnotetext{
${ }^{55}$ Discurso completo de Enrique Flores Magón em: FLORES MAGÓN, Ricardo. Los pobres son la fuerza: discursos de Ricardo Flores Magón. $1^{a}$ Ed. Ciudad Autónoma de Buenos Aires: EGodot Argentina, 2015. E-book.
} 
Estado y municipio en que resida, de la manera proporcional y equitativa que dispongan las leyes.

Nessa mudança constitucional, está a origem de um grande descontentamento social dos últimos anos do governo Díaz e talvez também a causa da falta de lealdade de parte do corpo do Exército ao Estado mexicano: os membros de seu exército eram alistados compulsoriamente, em uma prática conhecida então como "la leva". Homens em idade produtiva muitas vezes se aterrorizavam com a possibilidade de serem alistados e terem que entrar para as fileiras do exército. Tal obrigação era imposta às camadas mais pobres da população, aos desempregados e até mesmo a presos que, libertados, tinham que se juntar obrigatoriamente às fileiras militares. Esta obrigatoriedade estava respaldada, após 1898, na própria Constituição, que não admitia nenhuma reserva de consciência ou forma de oposição ao alistamento ${ }^{56}$.

Além dessas violências que tinham como destinatários prioritários os mais pobres e, em segundo lugar, os adversários políticos, somavam-se ainda outras. No México os poderosos - econômicos ou políticos, possivelmente ambos - usavam de sua posição social para o abuso sexual de mulheres que viviam em suas propriedades. Tal situação é retratada, por exemplo, na peça de Ricardo Flores Magón chamada "Tierra y Libertad”, de 1916. Em sua introdução, Flores Magón afirma: “'Tierra y Libertad' es un drama sacado de la vida real.". Além dela, inúmeros historiadores relatam as violências sexuais praticadas reiteradamente contra as mulheres das classes baixas mexicanas, atribuindo para a prática o nome pelo qual era conhecida: "derecho de pernada". Embora não tivesse relação direta com o governo central, a prática era realizada por lideranças políticas locais e não coibida pelo aparato estatal, que abandonava seus cidadãos sem mecanismos para resistir e se proteger das ilegalidades sofridas.

No rol de arbitrariedades sofridas pelo povo mexicano e realizadas diretamente pelo poder instituído, há ainda pelo menos duas a considerar. A aplicação de multas altas, muitas vezes não acompanhadas de razões claras e sem ser garantido o direito de

\footnotetext{
${ }^{56}$ Alan Knight descreve assim os vínculos frágeis de lealdade entre os membros do exército mexicano: "Lo que no pudo cambiar la Revolución - si comparamos la década de 1900 con la de 1920 - fue la posición de la tropa, formada en su mayoría por conscriptos renuentes, acorralados por las autoridades para pagar cuotas requeridas o, incluso, reclutados en los calabozos. (...) No es de sorprender, pues, que fueran poco confiables.” KNIGHT, Alan. La Revolución mexicana. Del Porfiriato al nuevo régimen constitucional. Trad. Luis Cortés Bargalló. México: FCE, 2010, p. 46.
} 
defesa ao cidadão multado diminuía ainda mais os já escassos meios econômicos de subsistência da população.

Além das multas, o processo eleitoral fraudulento completava o rol de arbitrariedades. Um texto de outubro de 1826 a propósito das eleições que ocorreram no referido ano oferece um panorama sobre os diferentes momentos e as diferentes formas de fraude em eleições mexicanas. Joaquín Villa, seu autor, identifica práticas fraudulentas que podem ocorrer antes, durante e depois de processos eleitorais. Compra de votos, suborno do presidente da seção de votação e indicação de mesários que sejam vinculados a um partido são práticas fraudulentas que visam alterar o resultado eleitoral antes que a votação aconteça. Permitir que um mesmo cidadão vote em mais de uma seção eleitoral; multiplicar os votos de uma mesma seção; permitir propaganda eleitoral nas cabines de votação; hostilizar e impedir que votem eleitores claramente identificáveis com a posição política oposta são práticas que fraudam o processo eleitoral enquanto ele está acontecendo. Por fim, Joaquín Villa identifica fraudes que podem acontecer no momento da apuração dos votos: contabilização de maior número de votos para o partido ou candidato que quer favorecer e diminuição dos votos recebidos pelo opositor. ${ }^{57}$

Quer no século XIX, quer no século XX, as estratégias para adulteração de resultados eleitorais - ao menos enquanto as urnas eletrônicas não haviam sido criadas não sofreram grandes alterações. Assim, há relatos que esses expedientes organizados e catalogados por Joaquín Villa em 1826 eram também utilizados no período do porfiriato. Porém, além deles, havia ainda outros. Somados, comprometiam definitivamente a legitimidade das eleições realizadas no período:

\footnotetext{
57 "Desordenes que se cometen antes de la elección

$1^{\circ}$ Ganar al presidente de la sesión. $2^{\circ}$ Poner de secretarios y escrutadores, individuos que obren de acuerdo con el partido á que pertenecen. $3^{\circ}$ Imprimir listas con el objeto de repartirlas á centenares entre los gefes que pueden ganar, para que éstos las distribuyan entre sus subalternos y dependientes. $4^{\circ}$ Ganar por medio del cohecho y soborno los votos de hombres de ninguna moral.

Desordenes que se cometen al tiempo de votar

$1^{\circ}$ Votar los individuos que no disfrutan de ese derecho. $2^{\circ}$ Votar un mismo individuo en dos, tres ó mas secciones de la municipalidad. $3^{\circ}$ Duplicar, triplicar y aun cuadruplicar algunos su voto en una misma seccion. $4^{\circ}$ Introducir en las listas que hay en la mesa, paquetes de aquellas que pertenecen al partido del secretario y escrutadores. $5^{\circ}$ Impedir que voten libremente los del partido contrario, hasta el grado de romperles las listas que llevan y de maltratarlos de palabra y obra.

Desordenes que se cometen concluida la votacion

Aumentar el número de votos en favor del partido á que pertenecen los individuos de la mesa, ó disminuir al contrario."

VILLA, Joaquín. Sesión de la legislatura del estado de México de 9 de octubre de 1826, en Actas del Congreso Constituyente del Estado de México, Toluca, Imprenta del gobierno del Estado, 1826, vol. VIII, p. 651 .
} 
En época de elecciones, [Pita, jefe martinista de Puebla] se dedicaba personalmente a cerrar las casillas que pudieran favorecer una votación antigubernamental y hacía arrestar a sus supervisores. El jefe de la población minera de Batopilas, en Chihuahua, de manera similar, privaba de los derechos civiles a la oposición, negándoles casillas y enviando una lista de mineros - que, se creía, simpatizaban con la oposición - al administrador norteamericano, con la esperanza de que éste ejerciera la presión adequada. ${ }^{58}$

O fechamento de seções eleitorais inteiras com o objetivo de impedir que líderes oposicionistas votassem era prática recorrente, ao menos no período em que os partidos de oposição existiam. Passados os dois primeiros mandatos de Díaz, nem mesmo as aparências eram mantidas: o processo eleitoral não precisava ser fraudado simplesmente porque não existiam partidos de oposição.

Ao longo de seu mandato e por meio de suas "estratégias de estabilização política" autoritárias, Porfírio Díaz foi transformando o México cada vez mais em uma ditadura. Nessa escalada concentradora de poder e violadora de direitos, também a prática da separação de poderes foi suprimida: Judiciário e Legislativo existiam, porém atuavam alinhados às orientações do Poder Executivo central.

La Suprema Corte, comentó un crítico, era más una "cortesana" que una corte; esto reflejaba el estado global del poder judicial. Los grupos de oposición en el Congreso, aún resonantes en la década de 1880, fueron gradualmente silenciados en la medida en que sus miembros eran víctimas del acoso y las elecciones eran manipuladas para garantizar una legislatura cada vez más leal. La parentela del presidente, así como sus amigos, llenaban la Cámara, y los paisanos oaxaqueños llegaban muy alto en el gobierno y la administración. (...) Así, tanto a nivel estatal como nacional, la legislatura era efectivamente designada por el ejecutivo y sus miembros no eran más que nulidades; (...). La irrelevancia del Congreso se volvió proverbial. $^{59}$

Alistamento militar obrigatório; violências do aparato repressor policial; fim da liberdade de imprensa; perseguição de jornalistas e recolhimento de jornais; múltiplas fraudes no processo eleitoral; perseguição de opositores políticos; fim do respeito à separação de poderes - todos os elementos descritos nesta seção apontam em um mesmo sentido: o governo do México sob a presidência de Porfírio Díaz era uma ditadura

\footnotetext{
58 'Casilla electoral' é o que no Brasil conhecemos como seção eleitoral. Estrutura organizada ao redor de uma mesa diretora composta por um presidente, um secretário e dois mesários, além de três suplentes. KNIGHT, Alan. La Revolución mexicana. Del Porfiriato al nuevo régimen constitucional. Trad. Luis Cortés Bargalló. México: FCE, 2010, p. 56.

${ }^{59}$ KNIGHT, Alan. La Revolución mexicana. Del Porfiriato al nuevo régimen constitucional. Trad. Luis Cortés Bargalló. México: FCE, 2010, p. 49.
} 
perfeita. E fora instaurada após um período de intensas lutas, em meados do século XIX, para se construir um estado de feições liberais.

Nesse contexto, é interessante refletir sobre a relação que os cidadãos mexicanos estabeleciam com a legalidade. Se a lei é (em teoria) o meio capaz de limitar o exercício arbitrário do poder, como reconhecer sua legitimidade em um contexto em que ela formalmente existe mas é reiteradamente desrespeitada?

Além disso, os poderes estatais, nos trinta anos que antecederam a Revolução Mexicana, foram responsáveis sobretudo por restringir direitos, espoliar a população de suas terras, promover violência e arbitrariedade contra os cidadãos mexicanos. De que forma essas experiências alteram e marcam a percepção e o entendimento dos revolucionários em relação ao direito e às instituições estatais? Uma revolução que sucede um regime ditatorial, que recorrentemente praticou atos arbitrários, tem como característica a desconfiança de seus líderes em relação aos instrumentos legais e à própria estrutura do Estado?

\title{
1.2 Antecedentes da revolução: Partido Liberal Mexicano e os irmãos Flores Magón
}

\begin{abstract}
Así pues, mi querido Nicolás, estoy condenado a cegar y a morir en la prisión; más prefiero esto que volver la espalda a los trabajadores y tener las puertas de la prisión abiertas a precio de mi vergüenza. No sobreviviré a mi cautiverio, pues ya estoy viejo; pero cuando muera, mis amigos quizá inscriban en mi tumba "Aquí yace un soñador", y mis enemigos "Aquí yace un loco". Pero no habrá nadie que se atreva a estampar esta inscripción "Aquí yace un cobarde y traidor a sus ideas. ${ }^{60}$
\end{abstract}

\section{Ricardo Flores Magón}

Gastón Garcia Cantú, autor de "El socialismo en México", identifica em seus estudos duas correntes liberais existentes desde, pelo menos, a Constituinte de 1856-57. Essas duas correntes liberais, identificadas como "liberalismo social" e "liberalismo clássico", divergiam sobre o papel do Estado e sobre o papel da Constituição na

\footnotetext{
${ }^{60}$ Ricardo Flores Magón. Apud ALVARADO, Adrian. El Partido Liberal Mexicano y la Revolución.
} Disponível em: <http://www.laizquierdasocialista.org/node/1438> Consulta realizada em 06/10/2015. 
definição de normas protetoras de direitos sociais como educação, regulação do trabalho e direito à terra ${ }^{61}$.

Ignacio Ramírez, Juan Morales Ayala, Ponciano Arriaga, Isidoro Olvera e José Maria Castillo Velasco advogaram, a partir de diferentes pontos de vista, a inclusão de direitos sociais no texto constitucional. Foram derrotados e a Constituição de 1857 assumiu as feições do liberalismo clássico. No entanto, esse grupo de liberais preocupados com as condições materiais para a realização da liberdade deixou seguidores.

Em 1899, Camilo Arriaga (sobrinho do homenageado) funda o Club Liberal Ponciano Arriaga, juntamente com Juan Sarabia, Antonio Díaz Soto y Gama e Rosalío Bustamante. O objetivo desse clube era organizar-se politicamente contra as violações às conquistas liberais do século XIX - liberdades públicas e a não interferência da igreja no Estado - e, consequentemente, contra o governo de Porfírio Díaz, então no início de seu terceiro mandato. Com sede em San Luís Potosí, o primeiro Club Liberal realiza um chamado para que outros clubes fossem criados, e incentiva que periódicos e revistas críticos ao governo e de matriz liberal fossem lançados. A partir da iniciativa do Club Liberal Ponciano Arriaga efetivamente inúmeros outros clubes liberais foram criados no México. Em fevereiro de 1901, ano em que se realiza em San Luís Potosí o primeiro Congresso Liberal nacional, o país já contava com 49 clubes liberais, provenientes de 14 diferentes estados mexicanos. Assistem ao Congresso 57 representantes desses 49 clubes. Nesse Congresso é fundada a "Confederación de Clubes Liberales", cujo principal objetivo é "velar por el cumplimiento de las leyes y hacer pacífica propaganda liberal".

O governo de Porfírio Díaz, porém, percebe a ameaça política que essa nova organização representava - embora o enfrentamento direto de Díaz não fosse objetivo da Confederación. Promoveu, então, a partir da informação sobre os participantes do Congresso de fevereiro de 1901, a perseguição das lideranças dos diversos clubes. Em janeiro de 1902, membros do exército mexicano invadem a sede do Club Liberal Ponciano Arriaga e prendem seus principais membros. Este clube, além de ser o mentor do Congresso Nacional e aquele que havia estimulado a criação dos outros, preparava-

\footnotetext{
${ }^{61}$ GARCÍA CANTÚ, Gastón. El socialismo en México. $4^{\mathrm{a}}$ Reedición. Ciudad del México: Ediciones Era, 1986, p. 32.
} 
se também para a formalização de um partido político de oposição: o Partido Liberal Mexicano.

Também os periódicos liberais foram reiteradamente perseguidos. Regeneración; El hijo del Ahuizote; Excélsior; El alacrán; El padre del Ahuizote; El nieto del Ahuizote; El bisnieto del Ahuizote; El Demócrata; Renacimiento; El Diario del Hogar; El Porvenir; El Hogar; El Demófilo; Revista Potosina e El Pensamiento Libre são só alguns títulos das muitas publicações criadas e extintas por meio da ação do aparato repressor do governo Díaz.

Em meio à repressão, com diversos membros dos clubes liberais presos ou no exílio, o Partido Liberal Mexicano foi criado e lançou seu programa político em $1^{\circ}$ de julho de 1906. O "Programa del Partido Liberal Mexicano" é, provavelmente, o documento político pré-revolucionário com maior influência na década que o seguiu, incluindo aí a elaboração da Constituição Mexicana de 1917.

El Partido Liberal, dispersado por las persecuciones de la Dictadura, débil, casi agonizante por mucho tiempo, ha logrado rehacerse, y hoy rápidamente se organiza. ${ }^{62}$

Jesús, Ricardo e Enrique Flores Magón foram três irmãos que atuaram politicamente antes e durante a Revolução Mexicana. Estudantes de direito e responsáveis pela publicação de diversos periódicos críticos ao Poder Judiciário e ao regime de Porfírio Díaz, foram presos diversas vezes e exilados em razão de sua oposição às instituições, sobretudo às jurídicas. Jesús e Ricardo estiveram presentes no Congresso Liberal nacional de fevereiro de 1901 e eram membros ativos da Confederação Liberal fundada nessa ocasião.

\footnotetext{
${ }^{62}$ Programa del Partido Liberal Mexicano, publicado em $1^{\circ}$ de Julho de 1906. Íntegra disponível em: MEXICO. Cidade do México: Secretaria de Gobernación: Unidade General de Asuntos Jurídicos. http://www.ordenjuridico.gob.mx/Constitucion/CH6.pdf Consulta realizada em 23/09/2015.
} 
Marca do início da atuação política dos irmãos Flores Magón, em 7 de agosto de 1900 é publicado o primeiro exemplar do periódico semanal "Regeneración"63. O objetivo da publicação fica explícito no início de seu texto de abertura:

\section{REGENERACIÓN}

Este periódico es el producto de una convicción dolorosa. (...) Lic. Luis Méndez [decía] 'Cuando la justicia se corrompe, cundo alguna vez las causas se deciden más por consideraciones estrañas à la ley que por ella misma, ¿Qué corresponderá hacer a los que ejercen la noble profesión del postulante ó á los que velan por intereses que no tienen mas garantía para su vida y su desarrollo, que una honrada administración de justicia? P. 1 (...)

No constituimos una falange, repetimos, pero sí ayudaremos con todas nuestras fuerzas, y pese á quien le pesare, á todos aquellos, que en lugar de recibir justicia de las autoridades judiciales, hayan recibido, con mengua del derecho de la moral, la vergüenza de una derrota injusta.

Por estos motivos vamos hacer públicos los actos de las autoridades judiciales. Los actos buenos, aquellos que estén arreglados á los preceptos de la justicia, los aplaudiremos; pero aquellos que haciendo á un lado la verdad, y que desquiciando las fórmulas severas de la justicia, solo sean el producto malsano del voluntarioso capricho de los miembros del Poder Judicial, serán objeto de nuestros ataques. ${ }^{64}$

\section{REGENERACIÓN, $\mathbf{n}^{\circ}$. 17, 7 de dezembro de 1900}

Donde quiera que hemos observado una transgresión a la ley; donde quiera que la arbitrariedad y el abuso han dejado su huella bestial, y donde quiera, que la tiranía con sus prácticas rudas y despóticas, ha hecho víctimas al ultrajar el derecho de los ciudadanos, en el acto hemos levantado la voz, para hacer oír nuestras protestas enérgicas y francas, cual corresponde hacer a hombres libres, que odian las manifestaciones autocráticas y simpatizan con todos los actos encaminados a sostener y guardar las instituciones liberales, que dan honor y lustre a nuestra Patria.

No somos, pues, enemigos del orden; somos enemigos del desorden. El orden consiste en la armonía entre los ciudadanos y los mandatarios; de este acuerdo y de esta armonía somos amigos. Pero cuando el mandatario (la autoridad) desobedeciendo las ordenes terminantes que tiene de su mandante (el pueblo) hace burla del mandato y quiere imponerse como amo, a despecho de los asociados que reclaman la integridad de sus vejados derechos; cuando la autoridad, abusando de la fuerza que le delegó el pueblo, pisotea los

\footnotetext{
${ }^{63} \mathrm{O}$ arquivo completo do periódico Regeneración que, com intervalos, circulou até 1918, pode ser encontrado no arquivo eletrônico de Ricardo Flores Magón: Archivo Electrónico Ricardo Flores Magón. Cidade do México: Instituto Nacional de Antropología e História. http://archivomagon.net/periodicos/regeneracion-1900-1918/ Consulta realizada em 30/09/2015.

${ }^{64} \mathrm{O}$ fac-símile da primeira edição do periódico pode ser encontrada aqui: Archivo Electrónico Ricardo Flores Magón. Cidade do México: Instituto Nacional de Antropología e História. http://archivomagon.net/wp-content/uploads/e1n1.pdf Consulta realizada em 30/09/2015.
} 
derechos y hace pedazos las garantías individuales; destruyendo, lo que debe guardar; disolviendo, lo que debe procurar que esté unido; haciendo colmar de amargura el vaso bien lleno de decepciones, entonces se produce el desorden, al evaporarse las simpatías que debe haber entre las autoridades y los asociados, y entonces, también, protestamos contra ese desorden, contra esa situación anárquica producida por una autoridad descomedida y arbitraria. Somos, pues, amigos del orden y por lo mismo de la paz. ${ }^{65}$

A partir de sua formação jurídica, os Flores Magón idealizaram um jornal capaz de trazer à tona e discutir publicamente decisões judiciais orientadas menos pelo respeito à lei do que por outros interesses. No primeiro período de sua publicação, as longas edições - em média com dezesseis páginas - analisavam quase exclusivamente casos judiciais mexicanos, suas justificativas e critérios (ou falta deles) e suas consequências sociais. Essa foi a tônica da primeira fase da publicação, entre 1900 e 1901. O jornal voltou a ser publicado apenas em 1904, já com objetivos editoriais mais amplos. Não só as decisões do Poder Judiciário mexicano estavam em questão, mas a própria organização política da sociedade mexicana.

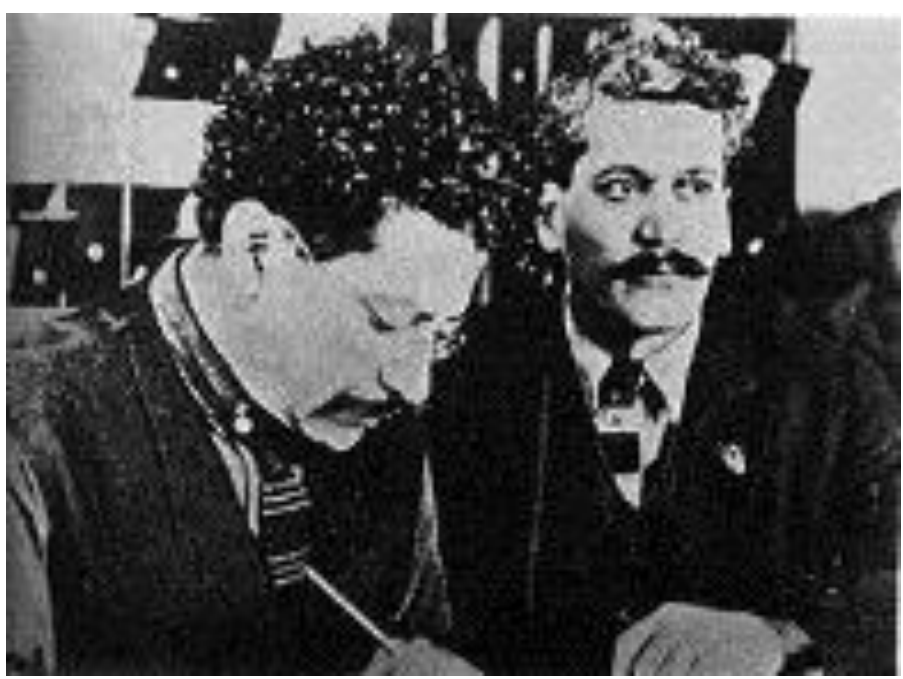

Os irmãos Ricardo e Enrique Flores Magón

Entre os irmãos, destacou-se Ricardo Flores Magón, por sua produção de textos e por seu protagonismo nas organizações políticas de que participou. No momento em que o Programa do Partido Liberal Mexicano é lançado, em julho de 1906, havia sido eleito para ocupar a função de Presidente do partido que estava sendo criado. Assina o documento, então, como presidente e idealizador do importante Programa.

Anos mais tarde, após períodos de prisão e exílio nos Estados Unidos, Ricardo Flores Magón escreve uma peça de teatro chamada "Tierra y Libertad" que, segundo o

\footnotetext{
${ }^{65}$ A íntegra do artigo "Lo que somos" de Ricardo Flores Magón, publicado no n. 17, de 7 de dezembro de 1900, pode ser encontrado aqui: Archivo Electrónico Ricardo Flores Magón. Cidade do México: Instituto Nacional de Antropología e História. http://archivomagon.net/obras-completas/art-periodisticos-19001918/1900/art191/ Consulta realizada em 05/10/2015.
} 
próprio autor, "revela en pocas páginas las causas que han producido el movimiento revolucionario que sacude a México desde hace catorce años, y explica por qué está en pie ese cataclismo social." ${ }^{\text {66 }}$ Ora, o documento, ainda que ficcional, é, segundo o autor, um “drama sacado de la vida real”. Logo em seu primeiro ato, a peça expõe a visão crítica de Ricardo sobre o Poder Judiciário e sobre a própria forma jurídica, incapaz de proteger os cidadãos que dela dependem para defender seus direitos, sem troca de favores e influência social.

\section{MARTA}

Imploraremos a un juez para que nos haga justicia... La ley nos ampara.

\section{JUAN}

(Sombrío) ¡La Ley! Mira, Marta mía, la Ley es una cosa que no beneficia al pobre. En nombre de la Ley se cobran las contribuciones al pobre; en nombre de la Ley se obliga al pobre a prestar servicios gratuitos a la Autoridad; en nombre de la Ley se arranca al pobre del seno de su familia para hacerlo soldado, y si la familia abandonada de ese modo, roba o se prostituye para no perecer de hambre, en nombre de la Ley se le castiga... ¡La Ley ha sido hecha por los ricos para proteger a los ricos...!

Os vários anos de militância política não tornaram Ricardo Flores Magón um entusiasta do Poder Judiciário ou mesmo das garantias legais para a proteção de direitos. Antes, o contrário. A influência de pensadores anarquistas como Proudhon, Kropotkin e Malatesta em sua obra fez com que, progressivamente, ele se tornasse um descrente na própria capacidade da organização estatal para promover direitos para a população. O Estado, segundo ele, era responsável pela promoção e manutenção de privilégios, e não pela garantia universal de direitos. Em razão desse diagnóstico, passou a lutar pela sua extinção.

Da luta por um governo democrático e que respeitasse o ordenamento jurídico objetivo explicitado no Programa do Partido Liberal de $1906^{67}$ - passou à luta contra o próprio Estado. A destruição da instituição estatal era, segundo ele, o único meio de se

\footnotetext{
${ }^{66}$ A íntegra da peça "Tierra y Libertad" pode ser consultada aqui: Archivo Electrónico Ricardo Flores Magón. Cidade do México: Instituto Nacional de Antropología e História. http://archivomagon.net/obrascompletas/obra-literaria-1910-1917/teatro/tierralibertad/ Consulta realizada em 30/09/2015.

${ }^{67}$ No programa do Partido Liberal Mexicano, lê-se: “(...) siendo rudimentarios principios de liberalismo que el Gobierno debe sujetarse al cumplimiento de la Ley é inspirar todos sus actos en el bien del pueblo, se sobreentiende que todo funcionario liberal ajustará su conducta á este principio." Programa del Partido Liberal Mexicano, publicado em $1^{\circ}$ de Julho de 1906. Íntegra disponível em: MEXICO. Cidade do México: Secretaria de Gobernación: Unidade General de Asuntos Jurídicos. http://www.ordenjuridico.gob.mx/Constitucion/CH6.pdf Consulta realizada em 23/09/2015.
} 
garantir a efetiva liberdade para os seres humanos. Seu liberalismo social anarquista, porém, não estava bem resolvido: como enfrentar as desigualdades sociais existentes empecilhos para o exercício da liberdade por toda a população - sem uma instituição capaz de intervir na realidade? ${ }^{68}$

As biografias e as produções dos irmãos Flores Magón são relevantes para este trabalho porque destacam a importância do direito e das decisões do Poder Judiciário na construção da realidade iníqua e autoritária mexicana do início do século. Além do jornal Regeneración (o mais importante entre outros), da peça de teatro e do vasto legado epistolar que Ricardo Flores Magón deixou, o principal documento político coelaborado por ele talvez seja mesmo o próprio Programa del Partido Liberal Mexicano. Atribui-se a esse importante documento (que oferece um diagnóstico bastante amplo da situação política e social do México no início do século XX) influência tanto no desenrolar revolucionário quanto na redação da Constituição de 1917. Enquanto Ricardo e Enrique seguem trajetórias políticas próximas, Jesús se distancia politicamente à medida que eles se aproximam do ideário anarquista.

\subsubsection{Programa del Partido Liberal Mexicano}

Dividido em três partes - exposição de motivos; propostas normativas objetivas e manifesto à nação -, o Programa del Partido Liberal Mexicano tem por objetivo apresentar um diagnóstico dos principais problemas políticos e sociais do México que mereciam, segundo seus autores, ser modificados por meio da ação política coletiva e organizada. Em suas duas partes iniciais, o programa se inspira no formato típico de projetos de lei, talvez pela presença expressiva de advogados na Junta Organizadora responsável por sua elaboração.

Tal como a Declaração de Direitos do Homem e do Cidadão que, na França de 1789, prescreve em seu artigo 16: “A sociedade em que não esteja assegurada a garantia

\footnotetext{
${ }^{68}$ Arnaldo Córdoba sobre o pensamento liberal de Ricardo Flores Magón: “Antes de 1906, año en que se publicó el Programa del Partido Liberal, pensaba, como todos los liberales, que bastaba un gobierno democrático, respetuoso de las leyes y firme garante de las libertades ciudadanas, para que los hombres fueran libres. En los años siguientes fue descubriendo que no bastaba un buen gobierno para realizar la libertad de los hombres, y incluso, que la propia existencia del Estado era el primer obstáculo con el que ese propósito se topaba, que mientras los humanos siguieran divididos por diferencias económicas no serían libres; unos serían masa y otros vivirían de ella como hasta entonces habia sucedido." CORDOVA, Arnaldo. La ideología de la Revolución Mexicana - la formación del nuevo régimen. $8^{\mathrm{a}}$ Edición. Ciudad del México: Ediciones Era, 1980, p. 174-175.
} 
dos direitos nem estabelecida a separação dos poderes não tem Constituição", o Programa do Partido Liberal Mexicano impõe a todos os partidos ou grupos políticos que queiram participar do debate público mexicano a obrigação de apresentar por escrito seu programa, sua carta de intenções:

Todo partido político que lucha por alcanzar influencia efectiva en la dirección de los negocios públicos de su país está obligado á declarar ante el pueblo, en forma clara y precisa, cuáles son los ideales por que lucha y cuál el programa que se propone llevar á la práctica, en caso de ser favorecido por la victoria. ${ }^{69}$

Essa obrigação presente no início da exposição de motivos do Programa - como a justificar a própria existência - teve repercussão na história política do México. Quando identificada a divergência entre os movimentos revolucionários, por exemplo, esses se apressaram em explicitar suas razões e diferenças por meio de documentos. Tais manifestos políticos, por sua vez, assumiam muitas vezes o formato de um projeto de lei. As disposições normativas eram precedidas com frequência de textos que expunham os motivos que levaram o grupo a adotá-las como guia da ação.

Quanto ao Programa do Partido Liberal Mexicano, o compromisso democrático foi um dos primeiros cristalizados em seu texto que, afinal, insurgia-se contra o que definiam como ditadura porfiriana. "La vigilancia del pueblo sobre sus mandatarios, denunciando sus malos actos y exigiéndoles la más estrecha responsabilidad por cualquier falta en el cumplimiento de sus deberes" 70 é o único meio de garantir que um governo não se afaste de suas obrigações, do caminho honrado e justo da representação dos interesses populares. Vigilância e participação popular constante daqueles que se submetem ao poder seriam as únicas formas de garantir bons governos e evitar as tiranias. A adesão a valores democráticos é o primeiro compromisso assumido pelos liberais mexicanos do início do século.

O texto introdutório passa, em seguida, para questões mais práticas e concretas da realidade política mexicana: os liberais declaram ilegais todas as reformas realizadas na Constituição de 1857 (cujo texto e programa político originais defendem); por derivação, declaram inconstitucional a reeleição praticada por Porfírio Díaz e o mandato

\footnotetext{
${ }^{69}$ Programa del Partido Liberal Mexicano, publicado em $1^{\text {o }}$ de Julho de 1906. Íntegra disponível em: MEXICO. Cidade do México: Secretaria de Gobernación: Unidade General de Asuntos Jurídicos. http://www.ordenjuridico.gob.mx/Constitucion/CH6.pdf Consulta realizada em 23/09/2015.

${ }^{70}$ Programa del Partido Liberal Mexicano, publicado em $1^{\circ}$ de Julho de 1906. Íntegra disponível em: MEXICO. Cidade do México: Secretaria de Gobernación: Unidade General de Asuntos Jurídicos. http://www.ordenjuridico.gob.mx/Constitucion/CH6.pdf Consulta realizada em 23/09/2015.
} 
de seis anos, bem como a transformação do serviço militar em obrigatório. O Programa defende ainda a liberdade de expressão e de imprensa e rechaça a criação de Tribunais Especiais para julgar delitos de imprensa ${ }^{71}$.

Entre os direitos sociais, o primeiro a aparecer no texto do documento é o direito à educação. Pode-se especular sobre os motivos que levaram a essa prioridade. $\mathrm{O}$ objetivo explícito tem relação com a importância da educação das crianças para o desenvolvimento da pátria. O Programa faz um elogio ao ensino direcionado a formar força de trabalho produtivo, técnico, "útil”; do ponto de vista simbólico, voltado a combater na juventude o "desprecio aristocrático hacia el trabajo manual" 72 presente, segundo eles, na visão viciada da juventude.

Entre os objetivos não-declarados, está a importância da educação para o enfrentamento do poder da Igreja no Estado Mexicano. Objetivo histórico dos liberais no país desde o século XIX, o avanço na garantia da laicidade do Estado é reiterado como objetivo político prioritário dos liberais do início do século XX. Tanto é verdade que, logo depois de ressaltar a importância da oferta educacional às crianças mexicanas, o Programa trata da extinção das escolas do clero e da adequação das escolas particulares à educação laica. Para que a extinção das escolas religiosas fosse possível, por sua vez, seria necessária a criação de novas escolas estatais e laicas. Consequentemente, esse era um objetivo prioritário do $\mathrm{PLM}^{73}$. Além do fim das escolas

\footnotetext{
${ }^{71}$ Lê-se na primeira parte do Programa do PLM: "Desde el momento que se consideran ilegales todas las reformas hechas á la Constitución de 57 por el Gobierno de Porfirio Díaz, podría parecer innecesario declarar en el Programa la reducción del período presidencial á cuatro años y la no reelección. Sin embargo, son tan importantes estos puntos, y fueron propuestos con tal unanimidad y empeño, que se ha considerado oportuno hacerlos constar expresamente en el Programa. (...) El servicio militar obligatorio es una tiranía de las más odiosas (...). Las manifestaciones del pensamiento deben ser sagradas para un Gobierno liberal de verdad; la libertad de palabra y de prensa no deben tener restricciones que hagan inviolable al Gobierno en ciertos casos y que permitan á los funcionarios ser indignos y corrompidos fuera de la vida pública. (...) No se puede, sin faltar á la igualdad democrática, establecer tribunales especiales para juzgar los delitos de imprenta." Programa del Partido Liberal Mexicano, publicado em $1^{\circ}$ de Julho de 1906. Íntegra disponível em: MEXICO. Cidade do México: Secretaria de Gobernación: Unidade General de Asuntos Jurídicos. http://www.ordenjuridico.gob.mx/Constitucion/CH6.pdf Consulta realizada em 23/09/2015.

${ }_{72}$ Programa del Partido Liberal Mexicano, publicado em $1^{\circ}$ de Julho de 1906. Íntegra disponível em: MEXICO. Cidade do México: Secretaria de Gobernación: Unidade General de Asuntos Jurídicos. http://www.ordenjuridico.gob.mx/Constitucion/CH6.pdf Consulta realizada em 23/09/2015.

${ }^{73}$ Lê-se na primeira parte do Programa do PLM: “Al suprimirse las escuelas del Clero, (...) La necesidad de crear nuevas escuelas hasta dotar al país con todas las que reclame su población escolar (...). Para lograr que la instrucción laica se imparta en todas las escuelas sin ninguna excepción, conviene reforzar la obligación delas escuelas particulares de ajustar estrictamente sus programas á los oficiales, estableciendo responsabilidades y penas para los maestros que falten á este deber. La supresión de las escuelas del Clero es una medida que producirá al país incalculables beneficios. Suprimir la escuela clerical es acabar con el foco de las divisiones y los odios entre los hijos de México; es cimentar sobre la más sólida base, para un
} 
religiosas e dos conteúdos religiosos nas escolas privadas, o enfrentamento do Clero passava, na visão do Programa, por extinguir a imunidade fiscal a que as atividades religiosas faziam jus. Se todas as atividades lucrativas eram taxadas, por que não seriam as também lucrativas atividades da Igreja ${ }^{74}$, defendiam eles.

Sendo o México um país também de imigrantes - e estando na sua história política do século XIX o esforço pela colonização e ocupação de seus territórios ${ }^{75}$ - é compreensível que o Programa de 1906 posicione-se sobre esse tema. É a própria Constituição de 1857, dirão os liberais no texto, que estabelece a preferência dos mexicanos sobre os estrangeiros para fins de políticas públicas. Como defendem o texto constitucional $^{76}$, não há que se questionar a norma. Acrescentam, porém, que "para evitar la preponderancia extranjera y garantizar la integridad de nuestro territorio' nada parece tan conveniente como declarar ciudadanos mexicanos á los extranjeros que adquieran bienes raíces"77. Assim, aos estrangeiros que possuíssem propriedades privadas no território mexicano deveria ser reconhecida sua cidadania como nacional. Tratamento diferente, porém, recebem os chineses. O Partido Liberal Mexicano defende a proibição da imigração chinesa como forma de proteção aos trabalhadores mexicanos e de outras nacionalidades. Em seu programa, dizem que os trabalhadores chineses estão dispostos a receber baixos salários, são submissos e mesquinhos em seus anseios profissionais $^{78}$.

futuro próximo, la completa fraternidad de la gran familia mexicana." Programa del Partido Liberal Mexicano, publicado em $1^{\circ}$ de Julho de 1906. Íntegra disponível em:

http://www.ordenjuridico.gob.mx/Constitucion/CH6.pdf Consulta realizada em 23/09/2015.

${ }^{74}$ Lê-se na primeira parte do Programa do PLM: "La actitud agresiva del Clero ante el Estado liberal, obliga al Estado á hacerse respetar enérgicamente. Se ve con todo esto un lucro exagerado á costa de la ignorancia humana, ya es muy justo que el Estado, que cobra impuesto sobre todo lucro ó negocio, los cobre también sobre éste, que no es por cierto de los más honrados." Programa del Partido Liberal Mexicano, publicado em $1^{\circ}$ de Julho de 1906. Íntegra disponível em:

http://www.ordenjuridico.gob.mx/Constitucion/CH6.pdf Consulta realizada em 23/09/2015.

${ }^{75}$ As normas do século XIX que têm por objetivo promover a colonização do território do México são objeto de Estudo do Capítulo 2 do presente trabalho.

${ }^{76}$ Terceira parte do Programa do PLM, "Manifiesto a la Nación": "Se tacha de utópico lo que es redentor para justificar que se le ataque ó se le destruya: todos los que han atentado contra nuestra sabia Constitución se han querido disculpar declarándola irrealizable; hoy mismo, los lacayos de Porfirio Díaz repiten esa necesidad para velar el crimen del tirano, y no recuerdan esos miserables que esa Constitución que llaman tan utópica, tan inadecuada para nuestro pueblo, tan imposible de practicar, fue perfectamente realizable para gobernantes honrados como Juárez y Lerdo de Tejada." Programa del Partido Liberal Mexicano, publicado em $1^{\circ}$ de Julho de 1906. Íntegra disponível em:

http://www.ordenjuridico.gob.mx/Constitucion/CH6.pdf Consulta realizada em 23/09/2015.

${ }^{77}$ Programa del Partido Liberal Mexicano, publicado em $1^{\circ}$ de Julho de 1906. Íntegra disponível em: http://www.ordenjuridico.gob.mx/Constitucion/CH6.pdf Consulta realizada em 23/09/2015.

${ }^{78}$ Lê-se na primeira parte do Programa do PLM: "La prohibición de la inmigración china es, ante todo, una medida de protección á los trabajadores de otras nacionalidades, principalmente á los mexicanos. El chino, dispuesto por lo general á trabajar con el más bajo salario, sumiso, mezquino en aspiraciones, es un 
Além da educação, o trabalho também é direito social que figura entre os objetivos prioritários do Partido Liberal. Jornada máxima de oito horas de trabalho; salário mínimo de um peso; regulamentação do trabalho doméstico; condições de higiene e salubridade nos locais de trabalho; proibição do trabalho infantil e descanso semanal obrigatório são alguns dos temas que estão no Programa. Essas propostas para a regulamentação do trabalho foram as que de forma mais evidente influenciaram o texto da Constituição Mexicana de $1917^{79}$.

Não se pode atribuir a mesma influência ao Programa quando se trata da questão fundiária. Diferentemente da Constituição de 1917, as reflexões e as propostas para a organização da terra seguem o ideário individualista liberal. Salvo quando propõem a expropriação das propriedades dos funcionários públicos, os liberais legitimam a apropriação individual e majoritariamente latifundiária das terras mexicanas feitas a partir de meados do século XIX. As terras espoliadas, antes eram detidas coletivamente por comunidades indígenas e mestiças, que tinham como principal reivindicação a restituição de suas propriedades.

O Programa reconhece o processo ilegítimo, realizado sobretudo pelo governo de Porfírio Díaz e que teve por consequência "que unos cuantos afortunados sean los acaparadores de la tierra, mientras infinidad de honrados ciudadanos lamentan en la miseria la pérdida de sus propiedades" ${ }^{80}$. Como solução para o problema, porém, estabelece o critério da produtividade da terra e o respeito às normas trabalhistas. A reversão de situações em que a propriedade tenha sido constituída ilegitimamente - e foram muitos casos na história mexicana até 1906, como se verá no capítulo 2 - não é proposta que figura no Programa, salvo no que diz respeito às propriedades adquiridas por funcionários diretos da administração porfiriana.

Ao contrário do Programa do PLM, Francisco Madero, em 5 de outubro de 1911, ao publicar o que ficou conhecido como Plan de San Luis Potosí, determina a restituição dos terrenos adquiridos por meio de procedimentos arbitrários a seus antigos possuidores. Como se verá a seguir, o Plano de Madero era muito menos preocupado e

gran obstáculo para la prosperidad de otros trabajadores. Su competencia es funesta y hay que evitarla en México. En general, la inmigración china no produce á México el menor beneficio.” Programa del Partido Liberal Mexicano, publicado em $1^{\mathrm{o}}$ de Julho de 1906. Íntegra disponível em: http://www.ordenjuridico.gob.mx/Constitucion/CH6.pdf Consulta realizada em 23/09/2015.

${ }^{79} \mathrm{O}$ Capítulo 3 do presente trabalho analisa de forma mais detida a história da regulamentação dos direitos trabalhistas até chegar à formulação da Constituição de 1917.

${ }^{80}$ Programa del Partido Liberal Mexicano, publicado em $1^{\circ}$ de Julho de 1906. Íntegra disponível em: http://www.ordenjuridico.gob.mx/Constitucion/CH6.pdf Consulta realizada em 23/09/2015. 
icomprometido com o contexto social em que vivia o México do que o Programa do Partido Liberal de cinco anos antes. Mesmo assim, no que diz respeito à terra, foi mais sensível ao propor em abstrato a restituição das propriedades que haviam sido tomadas por atos autoritários do Estado Mexicano.

Arnaldo Córdova, jurista e cientista político que se dedicou a identificar as ideologias que influenciaram a Revolução Mexicana, chama a atenção para a concepção que inspira Ricardo Flores Magón - e que pode ser estendida para a concepção que anima o Programa do PLM: "Flores Magón ve todos los hechos sociales a través del prisma del individuo libre." ${ }^{81}$. Se o indivíduo é a unidade básica para o entendimento da vida em sociedade, é compreensível que as propostas do Programa não pudessem reforçar traços coletivistas antes presentes na realidade mexicana - e muitas das propriedades expropriadas de comunidades indígenas e mestiças eram usufruídas em posse coletiva.

O texto do programa parece defender que a restituição das propriedades coletivas poderia ser o mais justo do ponto de vista da história da organização fundiária mexicana, mas não contribuiria para que os indivíduos que vivem sob as comunidades agrárias fossem verdadeiramente livres. Assim, ele não se opõe firmemente contra a reorganização da propriedade da terra levada a cabo desde meados do século XIX até o final do século. Tal concepção fica explícita em um trecho do livro Semilla Libertaria, de Ricardo Flores Magón, coletânea de artigos publicada pela primeira vez em 1923 que discute o papel do indivíduo frente à massa:

\begin{abstract}
No hay que ser masa: hay que ser conjunto de individualidades pensantes, unidades entre sí para conseguir fines comunes a todos; pero que cada uno, sea hombre o sea mujer, piense con su propia cabeza, que cada uno haga esfuerzos para dar una opinión sobre lo que es preciso hacer para obtener el logro de nuestras aspiraciones, que no son otras que la libertad de todos fundada en la libertad de cada uno; el bienestar de todos, fundado en el bienestar de cada uno, hoy para llegar a esto, necesario es destruir lo que se opone: la desigualdad, haciendo que la tierra, las herramientas, las máquinas, las provisiones y las casas, todo cuanto existe, ya sea producto natural o producto de la industria y de la inteligencia del hombre, pasen de las pocas manos que actualmente las tienen, a las manos de todos, hombres y mujeres, para producir en común, cada quien según sus fuerzas o aptitudes, y consumir cada quien según sus necesidades. ${ }^{82}$
\end{abstract}

\footnotetext{
${ }^{81}$ CÓRDOVA, Arnaldo. La ideología de la Revolución Mexicana - la formación del nuevo régimen. $8^{a}$ Edición. Ciudad del México: Ediciones Era, 1980, p. 173.

${ }^{82}$ Ricardo Flores Magón. Semilla Libertaria. Tomo II. P. 60-61. Disponível em:
} 
Muito embora o liberalismo professado por Flores Magón seja um liberalismo social, em que as desigualdades relacionadas à terra, às ferramentas, às máquinas, aos insumos e às moradias são criticadas; liberalismo em que a concentração desses bens nas mãos de poucos detentores é uma das causas da não realização da liberdade, há ainda a exaltação da liberdade individual como forma de realização social. Essa concepção reflete-se ainda em outros pontos do Programa do Partido Liberal Mexicano. Redução dos impostos, incentivo à pequena indústria, mecanismo judicial de defesa de cidadãos frente às arbitrariedades cometidas por autoridades públicas (instrumento denominado Juício de Amparo) são exemplos disso.

A necessidade de distribuir riqueza para alcançar desenvolvimento e bem-estar social, que está na obra pessoal de Flores Magón, também é reforçada no texto do Programa:

La aplicación práctica de esta y de la siguiente parte del Programa Liberal, que tienden á mejorar la situación económica de la clase más numerosa del país, encierra la base de una verdadera prosperidad nacional. Es axiomático que los pueblos no son prósperos sino cuando la generalidad de los ciudadanos disfrutan de particular y siquiera relativa prosperidad. Unos cuantos millonarios, acaparando todos las riquezas y siendo los únicos satisfechos entre millones de hambrientos, no hacen el bienestar general sino la miseria pública, como lo vemos en México. En cambio el país donde todos ó los más pueden satisfacer cómodamente sus necesidades será próspero con millonarios ó sin ellos.

El mejoramiento de las condiciones del trabajo, por una parte, y por otra, la equitativa distribución de las tierras, con las facilidades de cultivarlas y aprovecharlas sin restricciones, producirán inapreciables ventajas á la nación.

Keynesianos antes de Keynes, os liberais mexicanos afirmam que a prosperidade do México só virá quando houver distribuição de riquezas para a parcela mais numerosa da população, que passará a ser mercado consumidor interno. Bem-estar social está diretamente ligado à prosperidade da maior parte dos indivíduos que vivem no país. Esses, ao satisfazerem suas necessidades básicas, movimentam a economia. Tal bemestar não depende da existência de milionários: a sociedade sobrevive bem sem eles. Os liberais encerram afirmando que concentração de terras e más condições de trabalho são

http://archivomagon.net/wp-content/uploads/flores_magonricardo semilla_libertaria_1923.pdf Consulta realizada em 05/10/2015. Apud CÓRDOVA, Arnaldo. La ideología de la Revolución Mexicana - la

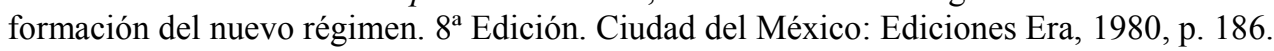


os dois pontos que devem ser enfrentados para que o México alcance esse novo patamar de organização social ${ }^{83}$.

Outras propostas estão presentes ainda no texto do Programa: fim da distinção entre filhos legítimos e ilegítimos; substituição de penitenciárias e cárceres por colônias penais, em que o estudo e o trabalho devem organizar o cotidiano dos presos; multiplicação e fortalecimento de municípios, associados ao fim dos chefes políticos locais; proteção de indígenas; fortalecimento de laços políticos de confiança entre países latino-americanos, também como estratégia para manutenção da integridade do território nacional; vedação do aumento da dívida externa; e, como arremate da exposição dos motivos que levam o Partido Liberal Mexicano a se constituir como um partido, a reafirmação da luta contra o despotismo e a afirmação da soberania popular. $\mathrm{O}$ programa reforça que aqueles que derramarem seu sangue para a destituição do governo despótico devem ver, em um novo governo, seus anseios realizados.

Encerrada a exposição de motivos, o Programa passa à segunda parte, que conta com 52 diretrizes normativas objetivas, que deveriam ser observadas caso o PLM chegasse ao poder. Essas normas repetem, em linhas gerais, aquilo que já fora apresentado na exposição de motivos.

A terceira e última parte do programa chama-se "Manifiesto a la Nación". Como o nome indica, trata-se de um discurso político que convida e insta os mexicanos a aderirem ao Partido Liberal, às suas bandeiras, e à possível revolução necessária para sua implementação.

(...) Pensad, mexicanos, en lo que significa para la patria la realización de este Programa que hoy levanta el Partido Liberal como un pendón fulgurante para llamaros á una lucha santa por la libertad y la justicia, para guiar vuestros pasos por el camino de la redención, para señalaros la meta luminosa que podéis alcanzar con sólo que os decidáis á unir vuestros esfuerzos para dejar de ser esclavos. El Programa, sin duda, no es perfecto: no hay obra humana que lo sea; pero es benéfico, y para las circunstancias actuales de nuestro país es salvador. Es la encarnación de muchas nobles aspiraciones, el remedio de muchos males, el correctivo de muchas injusticias, el término de muchas infamias. Es una transformación radical: todo un mundo de opresiones, corrupciones, de crímenes que desaparecen, para dar paso á otro mundo más libre, más honrado, más justo.

Todo cambiará en el futuro.

\footnotetext{
${ }^{83}$ Este trabalho de alguma forma compartilha o diagnóstico do PLM, ao ter seus capítulos 2 e 3 organizados em torno dos temas da regulação jurídica da terra e do trabalho nesse período.
} 
(...) todas las libertades serán restituidas al pueblo, y no sólo habrán conquistado los ciudadanos sus derechos políticos, sino también un gran mejoramiento económico; no sólo será un triunfo sobre la tiranía, sino también sobre la miseria. Libertad, prosperidad: he ahí la síntesis del Programa. (...) venid á nuestro lado, contribuid á fortalecer nuestro Partido y así apresuraréis la realización de lo que todos anhelamos. Unámonos, sumemos nuestros esfuerzos, unifiquemos nuestros propósitos, y el Programa será un hecho.(...)

Si escucháis el llamamiento y acudís al puesto que os designa vuestro deber de mexicanos, mucho tendrá que agradeceros la patria, pues apresuraréis su redención; si veis con indiferencia la lucha santa á que os invitamos, si negáis vuestro apoyo á los que combatimos por el derecho y la justicia, si, egoístas ó tímidos, os hacéis con vuestra inacción cómplices de los que nos oprimen, la patria no os deberá más que desprecio, y vuestra conciencia sublevada no dejará de avergonzaros con el recuerdo de vuestra falta. Los que neguéis vuestro apoyo á la causa de la libertad merecéis ser esclavos.

Programa salvador, redenção, encarnação, promessa de um outro mundo e luta santa: o vocabulário religioso utilizado no manifesto compromete-se, a partir do confronto político, a criar o paraíso na terra. "Tudo mudará no futuro", afirma. Não deixa de ser curioso que aqueles que defendem a laicidade do Estado Mexicano e o enfraquecimento político da Igreja como pautas prioritárias recorram à sua força simbólica como estratégia de convencimento.

No paraíso descrito por eles, liberdades, direitos políticos e prosperidade econômica serão realidade para todos os cidadãos. Bastaria que, para isso, os mexicanos se unissem à causa e à luta do Partido Liberal. Aos que não ouvirem o chamado, aos que se recusarem a atendê-lo por egoísmo, timidez ou desconfiança, restará o purgatório da história e a legitimação da escravidão que os oprime, ameaça o manifesto. A forma de escrita crítica, racional, reflexiva da exposição de motivos cede lugar a um discurso messiânico no manifesto à nação. A opção talvez se justifique a partir da convicção de que este seria o mais apto a gerar adesão e convencimento da população mexicana, majoritariamente religiosa.

O Partido Liberal Mexicano tinha como aliados, na difícil tarefa de divulgação e convencimento, importantes veículos de imprensa. Estima-se que o jornal "Regeneración", por exemplo, veículo em que o Programa do Partido Liberal foi originalmente publicado, tenha chegado à tiragem de trinta mil exemplares por edição em 1906. Elaborado e impresso nos Estados Unidos sob a direção de Ricardo Flores 
Magón, tendo como editores Juan Sarabia, Antonio Villareal e Enrique Flores Magón, o jornal era enviado a diferentes cidades e estados do México por correio. Havia ainda outras publicações críticas que circulavam pelo país. A repressão porfiriana, porém, não respeitou fronteiras: a polícia norte-americana prendeu os irmãos Flores Magón e os outros responsáveis pelo jornal, e sua publicação foi interrompida.

Com ou sem jornais, o fato é que, apesar das ameaças de purgatório na terra publicadas pelo partido, o chamado do manifesto à nação foi pouco atendido. Após tentativas fracassadas e reprimidas de insurreição em 1906 e 1908, as lideranças do PLM foram perseguidas, presas, mortas e, entre as sobreviventes, muitas se resignaram ao autoexílio. A população - cujos direitos tinham por objetivo defender - não tomou as armas maciçamente para defendê-los. O partido foi colocado na clandestinidade e, apesar de grande influência teórica, não colecionou grandes feitos práticos. No momento em que a insurreição de novembro de 1910 tem início, os irmãos Flores Magón e grande parte das lideranças do PLM estão presos. Mesmo assim, iniciada a luta, os resquícios de organização liberal que havia em território mexicano lutaram ao lado de Francisco Madero.

O ápice da organização política e influência do Partido Liberal Mexicano foi mesmo 1906. Em 1911, Ricardo Flores Magón sai da prisão e volta à sua atividade de analista e articulador político. Elabora então um novo manifesto liberal publicado em 23 de setembro de 1911. Logo em seu primeiro parágrafo afirma que "la desigualdade de fortunas nace del principio de la propiedad privada" ${ }^{\wedge 4}$. Segue o manifesto, deixando explícita sua concepção anarquista e sua desconfiança em relação a todas as instituições, inclusive à estatal e à jurídica:

Abolir ese principio significa el aniquilamiento de todas las instituciones políticas, económicas, sociales, religiosas y morales que componen el ambiente dentro del cual se asfixian la libre iniciativa y la libre asociación de los seres humanos que se ven obligados, para no perecer, a entablar entre sí una encarnizada competencia (...). Sin el principio de la propiedad privada no tiene razón de ser el gobierno $(\ldots){ }^{85}$

\footnotetext{
${ }^{84}$ A íntegra do "Manifiesto del Partido Liberal Mexicano", de 23 de setembro de 1911, pode ser encontrada aqui: UNAM. Cidade do México: Instituto de Investigaciones Jurídicas. http://info5.juridicas.unam.mx/libros/6/2625/54.pdf Consulta realizada em 06 de outubro de 2015.

${ }^{85}$ A íntegra do "Manifiesto del Partido Liberal Mexicano", de 23 de setembro de 1911, pode ser encontrada aqui: UNAM. Cidade do México: Instituto de Investigaciones Jurídicas. http://info5.juridicas.unam.mx/libros/6/2625/54.pdf Consulta realizada em 06 de outubro de 2015.
} 
É nesse manifesto que os irmãos Flores Magón, acompanhados por Librado Rivera e Anselmo Figueroa, proclamam o famoso lema “Tierra y Libertad!", tão diferente em significado daquele firmado em 1906: "Reforma, Libertad y Justicia". O segundo documento não tem nem a mesma distribuição nem a mesma repercussão do Programa distribuído em 1906. O "Plan de Ayala", por exemplo, documento elaborado pelos zapatistas em 28 de novembro de 1911, repete o lema do documento liberal de 1906, acrescentando a ele apenas uma palavra, surpreendente: "Reforma, Libertad, Justicia y Ley". Além do lema, zapatistas e liberais compartilhavam ainda o advogado que defendia causas em que tinham interesses: Pancho Serralde. Por outro lado, o anarquismo mais consistente e a rejeição às instituições estatais do manifesto de 1911 influenciaram a forma de atuação política da Casa del Obrero Mundial, por exemplo.

Muito embora Ricardo Flores Magón tenha se mantido politicamente ativo até sua morte, em 1923, e principalmente durante os anos em que o México viveu de forma mais intensa seu processo revolucionário (1910-1918), a partir de 1908 o que temos é o seu lento ocaso ao lado do Partido Liberal Mexicano, que perde protagonismo na luta contra a ditadura de Porfírio Díaz.

Muitos historiadores se perguntam por que a insurreição iniciada pelos organizadores do Partido Liberal Mexicano não deu certo. Por que, apenas cinco anos mais tarde, a organização liderada por Francisco Madero teve sorte tão diversa. Talvez porque o partido tenha se restringido ao diálogo com a intelectualidade urbana, sem aproximação com as populações campesinas. Talvez a revolução que teve início em 1910 só ocorreu porque o PLM já havia iniciado o processo de organização política de resistência e, só depois dele, as bases materiais e simbólicas para o fim da ditadura mexicana foram construídas. Talvez porque o governo Díaz ainda não estivesse totalmente desgastado em 1906. Talvez porque o programa do Partido Liberal Mexicano não oferecesse uma efetiva solução para o problema agrário. E talvez, provavelmente, uma soma de todos os motivos anteriores. O fato é que a insurreição organizada pelo PLM não teve frutos concretos, enquanto a idealizada e liderada por Francisco Madero foi capaz de encerrar o longo porfiriato. 


\subsection{Luta liberal contra a reeleição personificada: Francisco Madero}

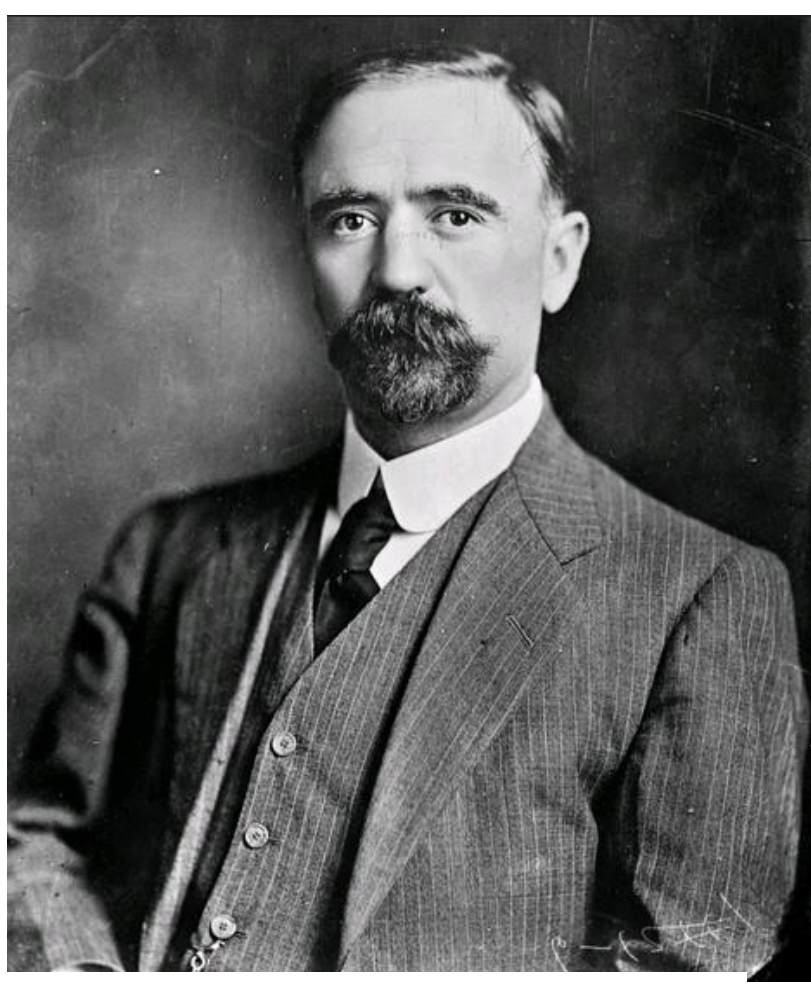

Francisco I. Madero
También será necesario tomar en consideración que no soy el historiador frío, sereno y desapasionado que trata los acontecimientos importantes después de transcurridos muchos años, con datos oficiales y otros de no menor importancia, y que juzga los hechos por sus resultados; sino el pensador que ha descubierto el precipicio hacia donde va la patria, y que con ansiedad se dirige á sus conciudadanos para enseñarles el peligro; que debe hablar alto, muy alto, para ser oído; que quiere pintar la situación con colores tan vivos, que logre representarla palpitante y amenazadora, como realmente es; que necesita hablar con vehemencia, para sacudir fuertemente á este pueblo, otras veces heroico y que ahora ve con criminal indiferencia los atentados más inícuos contra su libertad, contra sus sagradas prerrogativas de ciudadanía y, lo que es peor, contra los inviolables derechos del hombre. ${ }^{86}$

En los atentados contra los pueblos, hay dos culpables: el que se atreve, y los que permiten; el que emprende y los que permiten que se emprenda contra las leyes, el que usurpa y los que abdican. ${ }^{87}$

Para apresentar Francisco Madero, importante político da Revolução Mexicana, parece boa estratégia partir de sua autodefinição publicada na introdução do livro " $L a$ sucesión presidencial en 1910”, em outubro de 1908:

\footnotetext{
${ }^{86}$ Francisco Madero "La sucesión presidencial en 1910". Biblioteca del Político, INEP-AC. Coahuila, 1908. Disponível em: CARMONA, Doralicia. Memoria política de México. Guanajuato: Universidade de Guanajuato, 2014 http://www.memoriapoliticademexico.org/Textos/6Revolucion/1910LSP.pdf Consulta realizada em 26/10/2015. P. 9.

${ }^{87}$ Francisco Madero "La sucesión presidencial en 1910". Biblioteca del Político, INEP-AC. Coahuila, 1908. Disponível em: CARMONA, Doralicia. Memoria política de México. Guanajuato: Universidade de Guanajuato, 2014 http://www.memoriapoliticademexico.org/Textos/6Revolucion/1910LSP.pdf Consulta realizada em 26/10/2015. P. 9.
} 
Pertenezco, por nacimiento, á la clase privilegiada; mi familia es de las más numerosas é influyentes en este Estado, y ni yo, ni ninguno de los miembros de mi familia tenemos el menor motivo de queja contra el General Díaz, ni contra sus ministros, ni contra el actual Gobernador del Estado, ni siquiera contra las autoridades locales.

Los múltiples negocios que todos los de mi familia han tenido en los distintos ministerios, en tos tribunales de la República, siempre han sido despachados con equidad y justicia. (...) Por lo expuesto, ningún odio personal, ni de familia, ni de partido me guía á escribir este libro. (...) Los numerosos miembros de mi familia siguen la corriente general por donde van encauzadas las energías de la Nación: dedican sus esfuerzos y su fortuna al desarrollo de la agricultura, la industria, la minería, y gozan de las garantías necesarias para el fomento de sus empresas. ${ }^{88}$

Madero pertence a uma família rica, sem queixas pessoais quer contra o governo de Porfírio Díaz quer contra as autoridades do Estado de Coahuila, no qual nasceu e onde desenvolveu suas atividades econômicas. Nem ele nem sua família nunca foram vítimas de um sistema estatal injusto ou autoritário, antes o contrário. Seus negócios encontraram no porfiriato estabilidade e segurança jurídicas para se desenvolverem tranquilamente. E os efeitos foram sentidos: suas riquezas aumentaram. Como, então, F. Madero chegou a personificar a oposição ao governo de Porfírio Díaz? Suas justificativas estão na mesma seção introdutória do livro em que está sua definição.

\subsubsection{La sucesión presidencial en 1910}

“La sucesión presidencial en 1910”, escrito e publicado em 1908, tem início com uma dedicatória, que faz homenagem a todos aqueles que lutaram pela independência do México e pela consolidação republicana e liberal de seu Estado. Madero deixa explícita sua posição em relação ao ordenamento jurídico liberal mexicano: um código de leis sábias é o legado dos heróis que ele exalta. Homenageia também a imprensa livre que soube bravamente protestar contra os abusos de poder, os direitos ultrajados, a Constituição escarnecida e as leis burladas ${ }^{89}$. Francisco Madero só

88 Francisco Madero “La sucesión presidencial en 1910”, publicado em 1908. Disponível em: http://www.memoriapoliticademexico.org/Textos/6Revolucion/1910LSP.pdf Consulta realizada em 26/10/2015. P. 8

89 “[Los heróes que] nos legaron un código de leyes tan sabias, que constituyen uno de nuestros más legítimos timbres de gloria, y que nos han de servir para trabajar, todos unidos, siguiendo el grandioso principio de fraternidad, para obtener, por medio de la libertad, la realización del magnífico ideal democrático de la igualdad ante la ley. En segundo lugar, dedico este libro á la Prensa Independiente de la República, que con rara abnegación ha sostenido una lucha desigual por más de 30 años contra el 
tem elogios ao ordenamento jurídico mexicano pré-revolucionário. O problema político do país está relacionado à não observância e ao não cumprimento das normas existentes. Se a Constituição e as leis fossem respeitadas, os problemas do México teriam fim.

Depois da dedicatória, Madero explicita as "Motivações que me levaram a escrever este livro". ("Móbiles que me han guiado a escribir este libro”). Aí está sua descrição como membro da elite mexicana e as razões para, mesmo sendo um privilegiado pelo regime porfirista, organizar-se politicamente contra sua continuidade. Apresenta a "evolución que han sufrido mis ideas á medida que se han desarrollado los acontecimientos" 90 .

Acontecimentos e ideias estão, portanto, relacionados. Segundo a narrativa que constrói, Madero acreditava haver problemas sérios no regime de Porfírio Díaz. Liberdade e igualdade perante a lei - valores que exalta ao longo do texto - eram sistematicamente violados por meio de ações estatais. Acreditava, porém, que tais problemas se solucionariam tão logo seu governo acabasse, quando seria restabelecida a ordem jurídica e constitucional existente antes de seus arroubos autoritários. No entanto, essa convicção da transitoriedade do regime autoritário representado por Díaz teria se esvaído quando fora incluída na Constituição a figura do vice-presidente, em 1904. Afirma Madero que, por meio do instituto, Díaz passou a controlar não só o governo, mas também o processo de transição.

Para Madero, a criação da vice-presidência foi o primeiro indício de que os vícios da administração porfirista não iriam se esgotar espontaneamente, sem uma organização política que impulsionasse mudanças. Para que a população mexicana reconquistasse seus direitos ultrajados, talvez fosse necessário recorrer à força, previa em 1908. Além disso, a experiência dos clubes liberais do início do século XX não deixava esperanças para a via pacífica de reversão do cenário político autoritário no início do século.

poder omnímodo que ha centralizado en sus manos un solo hombre; á esa prensa que, tremolando la bandera constitucional, ha protestado contra todos los abusos del poder y defendido nuestros derechos ultrajados, nuestra Constitución escarnecida, nuestras leyes burladas (...)." Francisco Madero "La sucesión presidencial en 1910”, publicado em 1908. Disponível em: CARMONA, Doralicia. Memoria política de México. Guanajuato: Universidade de Guanajuato, 2014

http://www.memoriapoliticademexico.org/Textos/6Revolucion/1910LSP.pdf Consulta realizada em 26/10/2015. P. 2

90 Francisco Madero “La sucesión presidencial en 1910”, publicado em 1908. Disponível em: http://www.memoriapoliticademexico.org/Textos/6Revolucion/1910LSP.pdf Consulta realizada em 26/10/2015. P. 3 
Também a repressão ao ato político organizado em 1903 em Monterrey foi, para Madero, um importante momento de virada em sua análise política. Quinze mortos e centenas de feridos foi o saldo da repressão que se impôs contra um evento que tinha como única finalidade lançar um candidato de oposição ao governo de Nuevo León, sustentado por Díaz ${ }^{91}$. Inspirado no exemplo da capital do estado vizinho, em 1905, ele e um grupo de aliados políticos decidiram lançar uma candidatura de oposição para o governo do Estado de Coahuila. Mesmo com eleições fraudadas, seu grupo foi vitorioso em diversos municípios do estado. Tal vitória, porém, não se efetivou em razão da fraude no momento da apuração dos votos. Questionar esse resultado levaria, necessariamente, a um confronto direto entre seu grupo e o governo de Porfírio Díaz, o que decidiram evitar. A estratégia eleita pelo grupo de Madero foi concorrer às eleições seguintes e desgastar aos poucos a legitimidade do governo central. Para isso, era necessário organizar um partido, com grande número de filiados. Convocar mexicanos a integrar seu partido era a intenção de Madero ao escrever o livro "La sucesión presidencial en 1910". Tal esforço, de disputa por meio das instituições, trazia subjacente a convicção de que outro conflito armado na história do México seria nefasto para sua população.

(...) retrocedimos ante esa idea, no por miedo, sino por principio; porque no queremos más revoluciones, porque no queremos ver otra vez el suelo patrio ensangrentado con sangre hermana, porque tenemos fe en la democracia. Los triunfos que se obtienen por el sistema democrático, son más tardíos, pero más seguros y más fructíferos, como procuraré demostrarlo en el curso de mi trabajo. ${ }^{92}$

El principal objeto que perseguiré en este libro será hacer un llamamiento á todos los mexicanos, á fin de que formen este partido; que será la tabla de salvación de nuestras instituciones, de nuestras libertades y quizás hasta de nuestra integridade nacional. ${ }^{93}$

Francisco Madero mantém, ao longo do texto, uma tensão e uma posição dúbia em relação à figura e ao homem Porfírio Díaz. Se por um lado, não hesita criticar a figura autoritária e centralizadora de Díaz - responsável por perseguições a veículos de imprensa, mortes em manifestações pacíficas e fraudes escancaradas em processos

\footnotetext{
${ }^{91}$ Para mais informações sobre a repressão à "La Convención Electoral Neoleonesa”, ver periódico: "El Hijo del Ahuizote”, núm. 846, 12 de abril de 1903, pp. 234-235.

92 Francisco Madero "La sucesión presidencial en 1910”, publicado em 1908. Disponível em: http://www.memoriapoliticademexico.org/Textos/6Revolucion/1910LSP.pdf Consulta realizada em 26/10/2015. P. 5.

93 Francisco Madero “La sucesión presidencial en 1910”, publicado em 1908. Disponível em: http://www.memoriapoliticademexico.org/Textos/6Revolucion/1910LSP.pdf Consulta realizada em 26/10/2015. P. 6-7.
} 
eleitorais - Madero afirma que seu livro é também destinado ao presidente, que deveria ser consciente e mudar sua conduta a partir das críticas realizadas. De alguma forma, Madero elege também Díaz como seu interlocutor, o que torna a análise de seu texto mais difícil. Seu objetivo ao escrever e conclamar os mexicanos a entrarem em seu partido é verdadeiramente organizar um partido de oposição ao porfiriato ou, por outro lado, apesar das duras críticas, ele vislumbra um governo de conciliação com esse passado?

Madero invoca em seu texto o percurso contraditório de Porfírio Díaz, que lutara contra a reeleição de Juárez e Lerdo Tejada e, depois, “contra seus princípios”, instituíra a reeleição indefinida no país. O apelo emocional à consciência de Díaz é feito de forma quase a eximir as decisões pessoais do estadista, que estaria compelido por pressões econômicas e políticas para sua permanência - mesmo sabendo que o melhor para o país seria o seu afastamento e o restabelecimento democrático. Madero parece acreditar nessa narrativa e invoca a entrevista que Díaz dera a Creelman para sustentá-la. Condenar os atos de governo sem trégua, por um lado; salvar a pessoa de Porfírio Díaz, por outro. Essa parece ser a fórmula de F. Madero para conciliar seus antigos comprometimentos com o papel de oposição que almeja assumir a partir do livro publicado em 1908.

Por que enfrentar essa luta? Porque Madero foi formado e educado a partir das referências liberais da segunda metade do século XIX e pelo legado dos muitos "heróis" deixado para a história mexicana. Também porque ele refletia - e foi capaz de personificar - uma insatisfação com o governo de Porfírio Diaz que crescia entre diversos setores da sociedade na época.

O livro "La sucesión presidencial en 1910" convoca os mexicanos a integrar o Partido Antirreeleicionista. Ao apresentar seu programa, F. Madero expõe não só os ideais que irá defender, mas também uma concepção de como a organização política deve se dar no México.

Mientras más extenso sea el programa y encierre más principios, será más reducido el número de quienes lo aprueben em su integridad.

Partiendo de este principio, convendrá que el programa del Partido Antirreeleccionista, sea lo más conciso posible, á fin de que quienes ingresen, á su seno puedan encontrar el medio de satisfacerse sus 
diversas tendencias, siempre que fueren sanas y patrióticas. ${ }^{94}$

Concisão do programa político, com objetivo de ser capaz de aglomerar o maior número possível de pessoas, parece ser o preceito norteador da proposta de Madero. Se o projeto político de conciliação de diferentes correntes e posicionamentos era viável ou almejável como solução, é questão que a histórica mexicana foi responder apenas anos mais tarde. Os posicionamentos políticos de Madero - que se concentravam nas liberdades públicas, nos procedimentos democráticos, e não nas questões sociais do país - pareciam ter como objetivo buscar a conciliação de diferentes setores e alinhamentos da realidade política mexicana. Ou, visto de outra perspectiva, seus posicionamentos públicos tinham como objetivo não ferir interesses e privilégios de uma classe alta que também buscava representar. Um conflito entre elites - de um lado a que está no poder; de outro a alijada dele - parece estar subjacente neste embate. A questão que se coloca é: seria tal conflito suficiente para impulsionar os eventos ocorridos no México a partir de 1910 ?

Embora na parte programática de seu texto de 1908 Francisco Madero se restrinja a defender a) a submissão do poder à Constituição, especialmente no que tange à liberdade de manifestação pública, b) a liberdade de voto e o princípio da não reeleição, o diagnóstico de seu livro é mais amplo. Ele parece acreditar que, por meio das medidas concretas propostas, seria garantida a representatividade dos mandatários do povo e, por meio de maior representatividade, novas demandas democráticas e sociais seriam atendidas.

\begin{abstract}
Una vez obtenido el triunfo del primer principio y establecido en nuestra Constitución el segundo, entonces será tiempo de estudiar con entera calma y con las luces de la experiencia, qué reformas conviene hacer á la ley electoral; estudiar si debemos modificar la Constitución adoptando definitivamente el parlamentarismo con ministros responsables y un Presidente que no gobierne á fin de que presida con más majestad los destinos de la Nación. Con este motivo, habrá acaloradas discusiones en las Cámaras, y el Partido Antireeleccionista se dividirá á su vez en los dos grandes partidos que en todos los países del mundo han representado las tendencias opuestas de la opinión: el liberal y el conservador. ${ }^{95}$
\end{abstract}

\footnotetext{
${ }^{94}$ Francisco Madero “La sucesión presidencial en 1910”. Biblioteca del Político, INEP-AC. Coahuila, 1908. Disponível em: http://www.memoriapoliticademexico.org/Textos/6Revolucion/1910LSP.pdf Consulta realizada em 26/10/2015. P. 98.

95 Francisco Madero “La sucesión presidencial en 1910”. Biblioteca del Político, INEP-AC. Coahuila, 1908. Disponível em: http://www.memoriapoliticademexico.org/Textos/6Revolucion/1910LSP.pdf Consulta realizada em 26/10/2015. P. 98.
} 
Em 1908, Madero se questiona sobre a conveniência de uma reforma constitucional para a transição de um sistema presidencialista a um parlamentarista. Um novo Congresso Constituinte, tal como aconteceu em 1916-17, não estava no horizonte de expectativas, desejos ou possibilidades. $\mathrm{O}$ primeiro passo para qualquer mudança no país era reconhecer a Constituição Mexicana de 1857 como válida e submeter-se a seus preceitos e limites para o exercício do poder. O segundo passo, ainda segundo Madero, era reintroduzir em seu texto constitucional a vedação à reeleição e garantir a prática de eleições e manifestações políticas livres.

Somente após percorrer esses passos é que reformas do sistema eleitoral ou de representação poderiam ser gestadas. Mesmo assim, um Congresso Constituinte não era vislumbrado. Se a crítica ao governo de Porfírio Díaz dizia respeito ao ultraje ao sistema jurídico existente, frequentemente desrespeitado ${ }^{96}$, a oposição deveria exigir exatamente o cumprimento do direito constitucional e do ordenamento jurídico mexicano, e não sua reforma.

Além disso, elogios ao legado jurídico deixado pelos responsáveis pela independência mexicana e pelos políticos liberais do século XIX são frequentes na análise de Madero. A igualdade perante a lei; as normas garantidoras de liberdades públicas presentes na Constituição são a salvação. Não haveria motivos para modificálas. Sua implementação, no entanto, ainda é um desafio. Sobretudo porque a ditadura porfiriana, segundo sua análise, não é absolutamente explícita em suas violações:

\footnotetext{
${ }^{96}$ Madero escreve no livro "La sucesión...": "En cambio, el actual régimen de gobierno nos presenta un pasivo aterrador; acabó con las libertades públicas, ha hollado la Constitución, desprestigiado la ley que ya nadie procura cumplir, sino evadir ó atormentar para sus fines particulares, y por último, acabó con el civismo de los mexicanos." P. 74

Também no início de sua obra, sobre as razões que motivam a sua tentativa de organização política, a despeito das advertências e apreensões de seus amigos: "O bien no es cierto que el peligro sea tan grande, y en tal caso tenemos alguna libertad aprovechable para trabajar por el provecho de nuestra patria procurando la formación de un Partido Nacional Independiente; ó bien es real el peligro, lo cual demuestra que no hay ninguna libertad, que nuestra Constitución es burlada, que nuestras instituciones son holladas, que la opresión ejercida por el gobierno es insoportable; y en esos casos supremos, cuando la libertad peligra; cuando las instituciones están amenazadas; cuando se nos arrebata la herencia que nos legaron nuestros padres y cuya conquista les costó raudales de sangre, no es el momento de andar con temores ruines, con miedo envilecedor, hay que arrojarse á la lucha resueltamente, sin contar el número ni apreciar la fuerza del enemigo, de esta manera lograron nuestros padres conquistas tan gloriosas, y necesitamos observar la misma conducta, seguir su noble ejemplo para salvar nuestras instituciones del naufragio con que las amenazan las embravecidas olas de la tiranía, que pretenden hacer de ellas su presa y sumergirlas en el abismo insondable del olvido." Francisco Madero "La sucesión presidencial en 1910". Biblioteca del Político, INEP-AC. Coahuila, 1908. Disponível em: CARMONA, Doralicia. Memoria política de México. Guanajuato: Universidade de Guanajuato, 2014 http://www.memoriapoliticademexico.org/Textos/6Revolucion/1910LSP.pdf Consulta realizada em 26/10/2015. P. 9.
} 
mantém a aparência, contraditória com a prática, de respeito à lei como estratégia de manutenção de legitimidade ${ }^{97}$.

Seja como for, na análise de Madero a posição do direito na organização da sociedade mexicana é absolutamente central. A salvação do país passa pela observância das normas existentes. Não há muitas críticas ao sistema jurídico vigente no México salvo nas mudanças constitucionais realizadas por Porfírio Díaz para assegurar sua manutenção no poder. Franciso Madero assume o típico papel de intelectual liberal, preocupado com o funcionamento do direito e das instituições, sem uma visão crítica sobre quais interesses são representados nessas normas. E, em linhas gerais, essa é uma descrição fidedigna da posição de sua figura política e de sua obra de 1908.

Não seria totalmente justo se simplesmente ignorássemos alguns dos capítulos de "La sucesión presidencial en 1910", porém. Francisco Madero dedica um capítulo de seu livro para tratar do conflito fundiário entre o governo central e os índios Yaquis. Defende que as terras antes cultivadas pelos índios eram produtivas, e deveria ser conferido reconhecimento oficial à propriedade dos indígenas, já que a lei estabelecia como requisito vinte anos de posse pacífica, requisito mais do que atingido no caso de inúmeros grupos que ocupavam a região desde tempos imemoriais. Para além da crítica a um processo concreto de desapropriação ilegítima e transferência de terras para pessoas próximas ao governo, Madero chama a atenção para os procedimentos autoritários, pouco transparentes e pouco legítimos de resolução dos conflitos agrários. Para conter os índios insurgentes, tropas federais foram enviadas ao local e muitos índios, que resistiram violenta e permanentemente aos atos de espoliação de suas terras, foram mortos. Os sobreviventes capturados foram enviados para outros estados, nos quais se tornaram mão de obra escrava.

Madero, portanto, não ignora completamente o problema da desapropriação ilegítima de terrenos ao longo do mandato de Porfírio Díaz. É verdade que explicitamente trata de um só caso, mas usa-o como exemplar para criticar os procedimentos autoritários e não-republicanos (foram beneficiadas com terras pessoas próximas ao governo) de distribuição de terras no país. Seu texto, assim, identifica um importante conflito mexicano, derivado de práticas despóticas: a política fundiária do

\footnotetext{
97 "En cambio, cuando la dictadura se establece en el fondo y no en la forma, cuando hipócritamente aparenta respetar todas las leyes y apoyar todos sus actos en la Constitución, entonces va minando en su base la causa de la libertad, los ciudadanos se ven oprimidos suavemente por una mano que los acaricia(...)" Ibidem, P. 6.
} 
porfiriato (ainda que sua análise se restrinja ao caso específico dos índios Yaquis, quando, de fato, o problema era muito mais amplo). O livro traz ainda uma rápida menção ao conflito com os índios Mayas.

Para além da questão da terra, também a situação do trabalhador tem espaço na obra de Madero. Ele relata a greve do setor algodoeiro no Estado de Puebla e a reação dos empregadores de Orizaba que, contrários à decisão dos trabalhadores do estado vizinho, decidem fechar suas fábricas (lockout) para impedir que seus próprios empregados colaborem e sejam solidários à greve de Puebla. Em Orizaba o conflito fica mais intenso, já que os operários seriam descontados em seus salários pela decisão unilateral de seus empregadores de fechar as fábricas. Nesse contexto, uma intervenção do governo de Porfírio Díaz deixa muitos trabalhadores que faziam protestos pacíficos mortos. Muito embora Madero seja muito parcimonioso em opinar sobre o conflito envolvendo as condições de trabalho efetivas na produção algodoeira, ele critica a condução do conflito pelo governo central e, sobretudo, a decisão final pelo uso da violência extrema para a contenção de protestos legítimos e pacíficos.

Além desses casos, Madero explicita o conflito ocorrido em Cananea, em que muitos mineiros recém-demitidos ou com salários rebaixados foram contidos por tropas do governo federal que os impediu de protestar contra a precarização de sua situação laboral motivada por uma queda no valor de venda do cobre para os Estados Unidos. Afirma Madero ao final dessa seção que “ $; E l$ General Díaz permanece impasible ante las catástrofes obreras; lo único que le conmueve es que peligre su poder, pues su principal papel con sorte en ser el celoso guardián del absolutismo!",98

Catástrofes operárias é uma expressão bastante forte para quem supostamente só está interessado em liberdades públicas e questões políticas. Francisco Madero passa por temas sociais em seu texto. Desapropriações ilegítimas de terras indígenas, repressões violentas e condenáveis a organizações de trabalhadores, direito à educação e combate ao analfabetismo são temas que estão no diagnóstico que elabora sobre a realidade política mexicana. No entanto, tais temas não se convertem em pautas políticas a serem abraçadas pelo partido antirreeleicionista. O objetivo de sua ação

\footnotetext{
${ }^{98}$ Francisco Madero "La sucesión presidencial en 1910". Biblioteca del Político, INEP-AC. Coahuila, 1908. Disponível em: http://www.memoriapoliticademexico.org/Textos/6Revolucion/1910LSP.pdf Consulta realizada em 26/10/2015. P. 68.
} 
política é o fim do poder absoluto, do qual - segundo sua análise - as mazelas sociais são consequência.

Transformando-se o regime político, deixando de lado o regime absolutista e partindo-se à democracia, também a repressão violenta das manifestações de trabalhadores e o desrespeito à lei que as espoliações de terras indígenas representam seriam interrompidos, segundo Madero. Tjambém as mazelas sociais têm origem e causa na forma do regime político que ele está disposto a modificar.

Entre as razões que o político identifica para a perpetuação dos problemas está o silêncio da imprensa, que é absolutamente omissa na divulgação de atos ilegítimos, autoritários e antirrepublicanos do governo de Porfírio Díaz. E seu silêncio também é fruto do poder absoluto conferido a Díaz. Além da falta de oposição da imprensa, Madero identifica outras características na organização social da República Mexicana que indicam a existência de uma ditadura militar que exerce seu poder de forma arbitrária: o fato de todos os funcionários públicos serem nomeados com unanimidade de votos; o Poder Legislativo sempre apoiar as iniciativas do Poder Executivo; a perpetuação dos mesmos funcionários leais em seus cargos são exemplos do regime ditatorial.

\subsubsection{O Partido Antirreeleicionista inicia suas atividades políticas}

Um ano depois de "La sucesión presidencial en 1910”, o Partido Antireeleicionista é criado na Cidade do México. Sua fundação se dá após Porfírio Díaz ter deixado claro que não manteria a afirmação que fizera ao jornalista Creelman em março de 1908 e voltaria a concorrer às eleições presidenciais. Os princípios que orientam o partido são os elaborados e divulgados por Madero no livro do ano anterior: respeito e submissão à Constituição, eleições livres e não reeleição. Para tornar-se conhecido, para influir no cenário político pré-eleitoral e para incentivar a criação de clubes antireeleicionistas regionais, Francisco Madero percorreu o território mexicano entre o segundo semestre de 1909 e o primeiro semestre de 1910. Acompanhado apenas de sua mulher e uma pequena comitiva (Roque Estrada e Elías de los Ríos), sua primeira carreata teve como destino os Estados de Veracruz, Yucatán e Nuevo León. Na 
segunda etapa de sua viagem, já em 1910, passou por Jalisco, Colima, Sinaloa, Puebla, Querétaro e Sonora. Por fim, percorre o centro do país ${ }^{99}$.

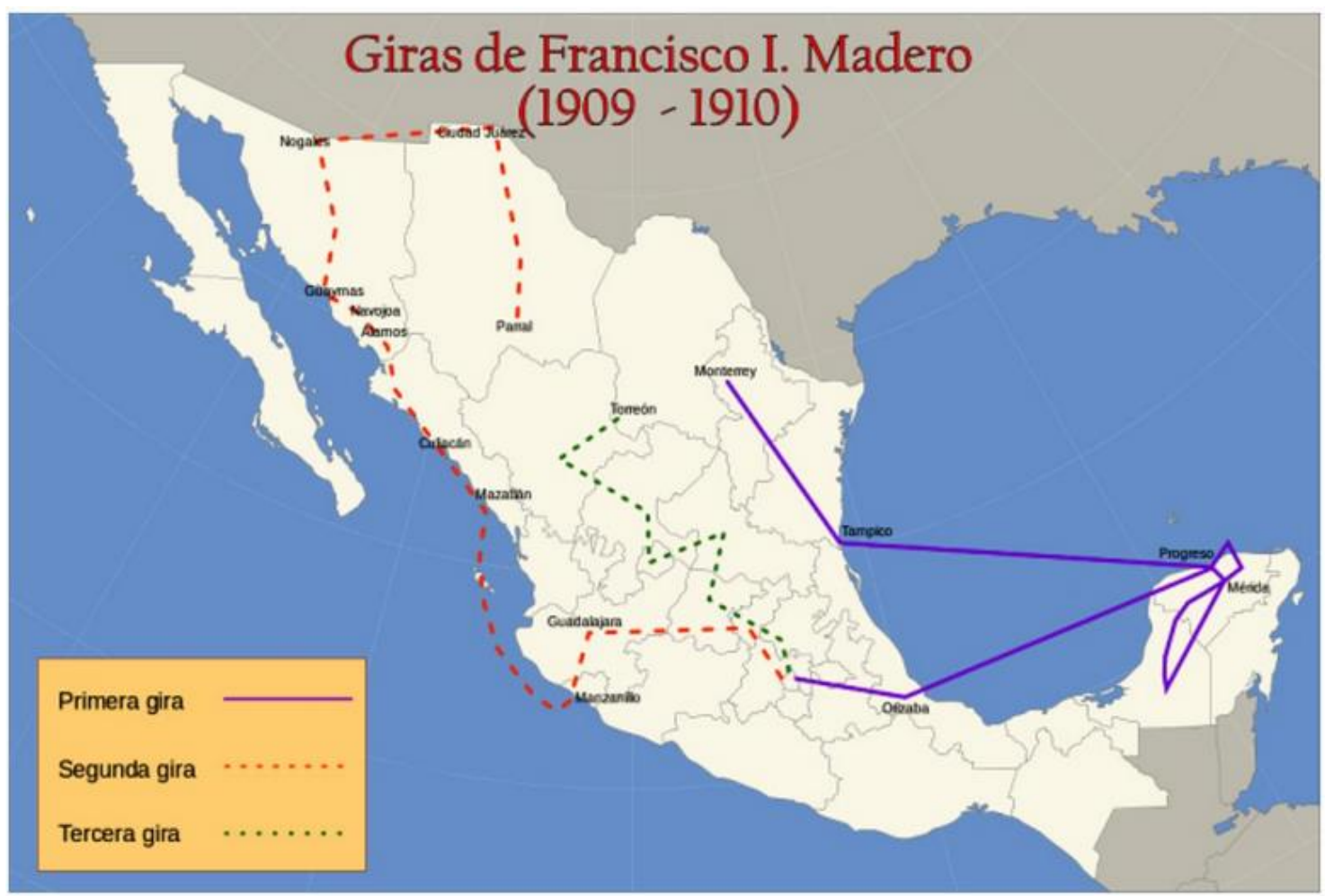

Apesar de não ser um grande orador, a presença de F. Madero fez emergir manifestações de descontentamento social com o regime porfirista em suas visitas a diferentes cidades mexicanas. Se em 1908 Porfírio Díaz estava mais preocupado com os conflitos internos de seu grupo - sobre quem ocuparia a função de vice-presidente em sua chapa - e, de alguma forma, desprezava os esforços de Madero, em 1910 o desprezo transformou-se em apreensão. E a apreensão transformou-se em repressão policial: em meio a suas viagens em campanha pelo país, F. Madero e Roque Estrada foram presos. O motivo alegado para a prisão foi uma frase proferida por Madero para apoiadores que os aguardavam no momento em que desciam de um trem em San Luís Potosí: “Que lo entiendan bien nuestros opresores; ahora el pueblo mexicano está dispuesto a morir por defender sus derechos; y no es que piense incendiar el território pátrio con una revolución, es que no le arredra el sacrifício."

\footnotetext{
${ }^{99}$ O mapa a seguir está disponível em: CARMONA, Doralicia. Memoria política de México. Guanajuato: Universidade de Guanajuato, 2014. <http://www.memoriapoliticademexico.org/Biografias/Im/19091910-Madero-giras 2.jpg > Consulta realizada em 31/102015.

${ }^{100}$ CAMÍN, Héctor Aguilar; MEYER, Lorenzo. A la sombra de la Revolución Mexicana. Ciudad de México: Aguilar, León y Cal Editores. $4^{\text {a }}$. Edição, 1990. P. 28.
} 
Por esse discurso, Madero é preso em 7 de junho de 1910. No dia 26 do mesmo mês foram realizadas primárias presidenciais e, em 10 de julho, as eleições secundárias ou definitivas. Durante todo o período eleitoral Madero permaneceu preso e as eleições nas quais era candidato aconteceram com a mesma prática de violência e fraude que as anteriores: Porfírio Díaz foi reeleito tendo Ramón Corral como vice-presidente ${ }^{101}$.

Em 22 de julho de 1910, 12 dias após as eleições presidenciais terem se encerrado, Francisco Madero e Roque Estrada são colocados em liberdade mediante fiança, sob a condição de que não deixassem a cidade de San Luís Potosí. O Comitê Eleitoral dos partidos Nacionalista Democrático e Nacional Antireeleccionista entregam ao presidente da Câmara dos Deputados mexicana um memorial de protesto, em que relatam os atentados e fraudes cometidos durante o processo eleitoral para a Presidência da República, e pleiteiam a nulidade das eleições. O Partido Antireeleicionista busca, dessa forma, por meio da via institucional, enfrentar as arbitrariedades que sofreu, sem sucesso.

No início de outubro de 1910, Madero foge de San Luís Potosí e sai do país contrariando a proibição estipulada na decisão que aceitou sua soltura sob fiança. Passa a viver a partir de então na cidade de San Antonio, no Texas. Roque Estrada encontraria com ele na mesma cidade dias depois. Antes da fuga, porém, Madero termina de escrever o Plan de San Luís Potosí ${ }^{102}$, que viria a ser impresso nos Estados Unidos e distribuído por correio.

\subsubsection{Plan de San Luís Potosí e a revolução com hora marcada}

Francisco Madero dá início ao Plano de San Luis Potosí com um texto que expõe sua versão resumida dos males que afetam o México do início do século XX. O diagnóstico é muito semelhante ao exposto em 1908, no livro "La sucesión presidencial en 1910", com uma relevante novidade: a própria disputa presidencial que travou com

\footnotetext{
${ }^{101}$ Importante lembrar que em 1910 a disputa mais intensa se dava em torno da figura do vice-presidente, que se tornaria o sucessor político natural de Díaz caso ele não conseguisse terminar o mandato, ou no próximo processo eleitoral.

${ }^{102}$ A íntegra do Plan de San Luís Potosí pode ser consultada aqui: CARMONA, Doralicia. Memoria política de México. Guanajuato: Universidade de Guanajuato, 2014. http://www.memoriapoliticademexico.org/Textos/6Revolucion/1910PSL.html Consulta realizada em $31 / 10 / 2015$.
} 
Porfírio Díaz. Tirania, governo autoritário, ditadura, opressão, totalitarismo fazem parte do repertório semântico usado por Madero para descrever o porfiriato. Para além dessas palavras, o Plan de San Luís Potosí afirma: "Pero esta situación violenta e ilegal no puede subsistir más." 103

Como medida prática inicial, Madero declara nulas as eleições ocorridas entre junho e julho de 1910 e se autoproclama presidente provisório, enquanto novas eleições legítimas não forem realizadas.

A relação do Plano - e do próprio Madero - com a legalidade produzida no período do porfiriato é bastante ambígua. Entre os objetivos e bandeiras do Partido Reeleicionista está a submissão do governo à Constituição e o retorno à legalidade material, assumindo ser essa a antítese do que o governo de Porfírio Díaz realiza. A fraude eleitoral, afirma o Plano no artigo $2^{\circ}$, fez com que o governo porfirista perdesse os últimos créditos de legalidade que poderia ter. Em seguida, em seu artigo $3^{\circ}$, dispõe o plano:

$3^{\circ}$ Para evitar hasta donde sea posible los trastornos inherentes a todo movimiento revolucionario, se declaran vigentes, a reserva de reformar oportunamente por los medios constitucionales aquellas que requieran reformas, todas las leyes promulgadas por la actual administración y sus reglamentos respectivos, a excepción de aquellas que manifiestamente se hallen en pugna con los principios proclamados en este Plan. Igualmente se exceptúan las leyes, fallos de tribunales y decretos que hayan sancionado las cuentas y manejos de fondos de todos los funcionarios de la administración porfirista en todos los ramos; pues tan pronto como la revolución triunfe, se iniciará la formación de comisiones de investigación para dictaminar acerca de las responsabilidades en que hayan podido incurrir los funcionarios de la Federación, de los Estados y de los Municipios.

En todo caso serán respetados los compromisos contraídos por la administración porfirista con gobiernos y corporaciones extranjeras antes del 20 del entrante.

\begin{abstract}
Abusando de la ley de terrenos baldíos, numerosos pequeños propietarios, en su mayoría indígenas, han sido despojados de sus terrenos, por acuerdo de la Secretaría de Fomento, o por fallos de los tribunales de la República. Siendo de toda justicia restituir a sus antiguos poseedores los terrenos de que se les despojó de un modo tan arbitrario, se declaran sujetas a revisión tales disposiciones y fallos y se les exigirá a los que los adquirieron de un modo tan inmoral, 0 a sus herederos, que los restituyan a sus
\end{abstract}

\footnotetext{
103 A íntegra do Plan de San Luís Potosí pode ser consultada aqui:

CARMONA, Doralicia. Memoria política de México. Guanajuato: Universidade de Guanajuato, 2014. http://www.memoriapoliticademexico.org/Textos/6Revolucion/1910PSL.html Consulta realizada em $31 / 10 / 2015$.
} 
primitivos propietarios, a quienes pagarán también una indemnización por los perjuicios sufridos. Sólo en caso de que esos terrenos havan pasado a tercera persona antes de la promulgación de este Plan, los antiguos propietarios recibirán indemnización de aquellos en cuyo beneficio se verificó el despojo.

O artigo terceiro apresenta como sua razão de existir evitar, na medida do possível, os transtornos derivados de movimentos revolucionários. Para fins de segurança jurídica e institucional, Madero decide manter vigentes e eficazes as normas produzidas pelo governo ilegítimo de Díaz. Também os compromissos assumidos internacionalmente até 20 de outubro de 1910 seriam preservados. O plano estabelece, no entanto, uma exceção à continuidade dos compromissos assumidos anteriormente: as terras que foram injustamente espoliadas de pequenos proprietários e comunidades rurais seriam restituídas.

Atribui-se ao texto do artigo terceiro a responsabilidade pela adesão das tropas lideradas por Emiliano Zapata e muitos outros camponeses ao movimento revolucionário impulsionado por Madero. A promessa feita no Plan de San Luís Potosí era contundente: os pequenos proprietários despojados de suas terras por meio da aplicação (abusiva) da lei de baldios teriam direito a tê-las de volta, sem que o Estado precisasse desapropriá-las ou pagar indenizações. É verdade que a lei de terrenos baldios mencionada não é a única fonte de arbitrariedades cometidas no campo, como se verá no segundo capítulo. Mas a expropriação realizada por meio desse instrumento é condenada pelo programa político de Madero, que promete a reversão da situação agrária injusta no momento em que conquistasse o poder.

$4^{\circ}$ Además de la Constitución y leyes vigentes, se declara Ley Suprema de la República el principio de NO REELECCIÓN del Presidente y Vicepresidente de la República, de los Gobernadores de los Estados y de los Presidentes Municipales, mientras se hagan las reformas constitucionales respectivas. ${ }^{105}$

\footnotetext{
104 A íntegra do Plan de San Luís Potosí pode ser consultada aqui: CARMONA, Doralicia. Memoria política de México. Guanajuato: Universidade de Guanajuato, 2014. http://www.memoriapoliticademexico.org/Textos/6Revolucion/1910PSL.html Consulta realizada em $31 / 10 / 2015$.

105 A íntegra do Plan de San Luís Potosí pode ser consultada aqui: CARMONA, Doralicia. Memoria política de México. Guanajuato: Universidade de Guanajuato, 2014. http://www.memoriapoliticademexico.org/Textos/6Revolucion/1910PSL.html Consulta realizada em $31 / 10 / 2015$.
} 
Além de reconhecer a legalidade nas normas elaboradas durante o porfiriato, Madero também eleva o princípio da não reeleição à "Ley Suprema de la República". O princípio de que os governantes não podem se reeleger nem se perpetuar em seus mandatos passaria a ser um princípio organizativo do exercício do poder no México, no caso de bem-sucedida a luta conclamada.

Para que essas e as outras propostas do plano - que conta com 11 artigos no total - possam ser concretizadas, Madero estipula no artigo $7^{\circ}$ a data de 20 de novembro de 1910, um domingo, às seis da tarde, para que os mexicanos peguem em armas e se insurjam contra o governo autoritário que os oprime. Trata-se da única revolução com data e hora marcadas da história ocidental. O plano se encerra, após mais uma carta que convoca os mexicanos a aderirem ao movimento revolucionário, nas data e hora estipuladas, com o lema: "Sufragio efectivo. No reelección".

No esperaban que llegara. El habito de la paz era más fuerte que la evidencia del cambio. El imparcial, primer diario industrial de México y símbolo el mísmo de la enorme transformación em modos y volúmenes que el país había registrado, garantizaba a sus lectores em 1909: 'Una revolución en México es imposible.' Karl Bunz, el ministro alemán, escribía a su gobierno el 17 de septiembre de ese mismo año: 'Considero, al igual que la prensa y la opinión pública, que una revolución general está fuera de toda posibilidad'. No se llevó outra idea sobre el futuro el industrial del acero norteamericano, Andrew Carnigie, después de su visita al país em 1910: 'En todos los rincones de la república reina una paz envidiable', a lo que añadió el poeta español Julio Sesto su propia certidumbre metodológica: 'Ninguna nube negra hay em el horizonte.'. ${ }^{106}$

O movimento revolucionário não era aguardado ou previsto no cenário político mexicano de 1910. E, tal como não era aguardado, não começou de uma vez, subitamente, tomando todo o país de assalto. Antes, foi tomando forma aos poucos, primeiro nos estados do norte do país, insurreições localizadas, contidas pelo exército, que, aos poucos, foram se multiplicando, multiplicando, obtendo algumas vitórias, até que o Exército do governo central (chamado de 'los federales') não conseguiu mais conter os grupos insurgentes.

Entre outubro e novembro de 1910, antes do dia 20, Madero e outras lideranças organizavam a sublevação no Texas, tendo recebido diversos correligionários de diferentes estados para discutir estratégias e ações. Muito embora o Plan de San Luis ${ }^{106}$ AGUILAR CAMÍN, Héctor; MEYER, Lorenzo. A la sombra de la Revolución Mexicana. Ciudad de
México: Aguilar, León y Cal Editores. $4^{\text {a }}$. Edição, 1990. P. 28. 
Potosí tenha sido enviado apenas para Maderistas e apoiadores do Partido Antireeleicionista, o governo de Porfírio Díaz tomou conhecimento e realizou ações preventivas para impedir o sucesso da revolução que vinha sendo planejada.

No dia 18 de novembro de 1910, dois dias antes da data prevista para a sublevação, na cidade de Puebla, no centro do México, alguns policiais foram fazer uma verificação na casa de Aquiles Serdán, líder maderista da região. Tinham notícia de que naquela casa estavam guardadas inúmeras munições e armas que seriam usadas em protestos contra o governo. Miguel Cabrera, chefe de polícia que liderava os policiais presentes à batida, foi morto pelo dono da casa no momento em que iniciava as tentativas de entrar na residência. A partir da queda do chefe de polícia, iniciou-se um grande conflito armado, que se encerrou apenas com a derrota completa dos insurgentes que estavam na casa e com a morte de Aquiles Serdán e inúmeros outros militantes. Homens e mulheres tentavam defender a propriedade dos batalhões de policiais que vieram combate-la, mas foram derrotados pelas forças oficiais. Dois dias antes do previsto, assim, teve início o conflito armado convocado para o dia 20 de novembro.

\begin{abstract}
Abraham González fue quien organizo los levantamentos armados em Chihuahua. El 20 de noviembre se levantó Pascual Orozco em San Isidro; José de la Luz Blanco, en San Tomás; Francisco Villa em San Andrés, muy cerca de la capital del Estado; y un día después Guillermo Baca se apoderó de la importante población de Parral, la que tuvo que abandonar al día siguiente por la superioridade de las fuerzas federales que marcharon a recuperar la plaza. Por menor importância em los Estados de Coahuila y Durango. ${ }^{107}$
\end{abstract}

As primeiras sublevações aconteceram no norte do país; não no estado natal de Madero - Coahuila - mas no vizinho Chihuahua, fronteiriço com os Estados Unidos da América. Francisco Madero, ao tomar conhecimento dos levantes armados que efetivamente ocorreram no dia 20 e continuaram nos dias seguintes de novembro, decidiu investir mais dinheiro no embate, fornecendo armamentos vindos dos EUA para os revolucionários. A luta na região norte do país se estendeu por alguns meses. No dia 14 de fevereiro de 1911, F. Madero volta ao território mexicano, entrando por meio da Ciudad Juárez. Em 6 de março lidera um combate na cidade de Casas Grandes, onde foi derrotado e quase capturado.

${ }^{107}$ SILVA HERZOG, Jesus. Breve Historia de la Revolución Mexicana - Los antecedentes y la Etapa Maderista. Fondo de Cultura Económica do México. 15ª . Reimpressão. Cidade do México, 1997. P. 178. 
Movimento independente, rapidamente sufocado pelas tropas federais, foi a tomada de duas cidades da Baixa Califórnia pelos irmãos Flores Magón e seus aliados, no final de janeiro de 1911. As cidades tomadas pelos magonistas foram Mexicali e Tijuana. Governistas e maderistas ficaram alarmados com a ação, pois as ideias dos irmãos Flores Magón eram muito mais radicais do que aquelas defendidas pelos políticos e revolucionários liderados por Madero. Ainda em novembro de 1910, Ricardo Flores Magón tentava desfazer a confusão entre seu partido e aquele liderado por Francisco Madero. Em artigo intitulado El Partido Liberal y el Antirreeleccionista, publicado no jornal Regeneración, ressalta o que considera ser a maior diferença entre as organizações políticas: "Este programa es bien distinto del Programa del Partido Antirreeleccionista que no pone ningún freno a la influencia del clero en los destinos del pueblo mexicano (...)"108. É verdade que ao longo do artigo Ricardo Flores Magón passa ainda pela necessidade de escolarização dos trabalhadores; da instituição de um salário mínimo que garanta a dignidade humana; da redução das jornadas de trabalho e da luta pelo fim da miséria no México. Todos esses pontos, enfatiza, estão ausentes do programa político elaborado por Madero e, junto com o mais importante - a complacência com o clero mexicano, causador, segundo ele, da maior parte dos males do país - fazem com que os programas dos dois partidos sejam completamente distintos. A análise de Ricardo Flores Magón era bastante lúcida em relação as ausências relacionadas aos direitos dos trabalhadores mexicanos. Porém, o programa do Partido Liberal, liderado por ele, ignorava um ponto ainda mais sensível da realidade do país: a questão agrária. E, em relação a esse ponto específico, Madero oferecia uma solução mais concreta e pela qual se podia lutar: o artigo terceiro prometia a reversão das espoliações de terras indígenas e de pequenos camponeses que haviam sido feitas pelo governo de Porfírio Díaz e seus representantes.

Assim, o início do levante revolucionário maderista, inspirado pelo Plan de San Luís Potosí, foi no Estado de Chihuahua, após a derrota de Aquilas Serdán em Puebla. E Francisco Villa estava entre os primeiros revolucionários. Saber por que os primeiros levantes aconteceram neste estado ganha importância quando associado à presença desse caudilho, que virá a ser um dos nomes mais associados à Revolução Mexicana.

\footnotetext{
108 A íntegra do artigo El Partido Liberal y el Antirreeleccionista, escrito por Ricardo Flores Magón e publicado no periódico Regeneración em 5 de novembro de 1910 pode ser encontrada aqui: http://www.memoriapoliticademexico.org/Textos/6Revolucion/1910PLA.html Consulta realizada em $02 / 11 / 2015$.
} 


\subsection{Francisco 'Pancho’ Villa e o início da Revolução Maderista: os levantamentos em Chihuahua.}

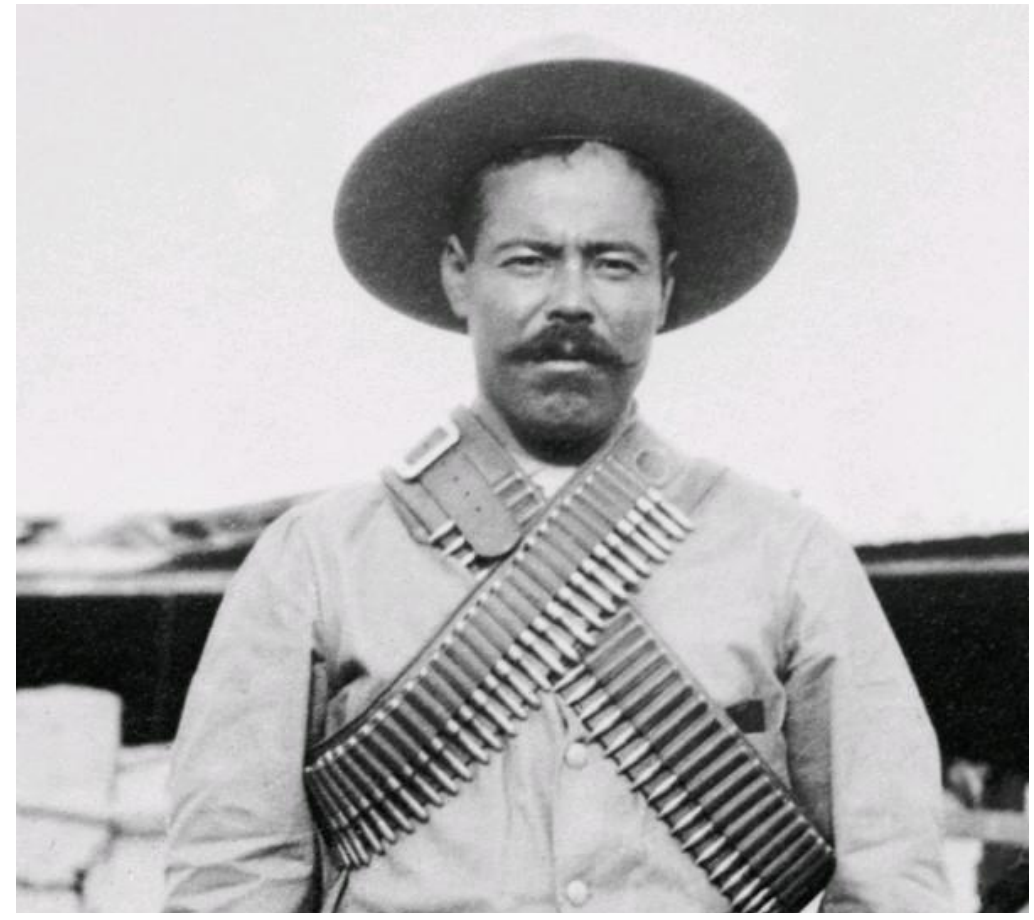

Francisco "Pancho" Villa

Francisco Villa, que talvez seja a personalidade mais controversa da Revolução Mexicana, nasceu em 5 de junho de 1878, em racho de la Coyotada, Estado de Durango. Chamava-se então Doroteo Arango. A mudança de nome e as muitas lendas associadas à sua figura têm relação com o início obscuro de sua vida: sua condição de foragido. Filho de uma família de agricultores que arrendavam terras, sua mãe ficou viúva ainda muito jovem, com cinco filhos pequenos sob sua responsabilidade. $\mathrm{O}$ primeiro fato controverso da vida de Villa envolve o enfrentamento do dono das terras onde a família vivia, que teria se envolvido - ou estuprado, a depender da versão - com sua irmã mais nova. Friedrich Katz publicou, no final dos anos 1990 o que é considerada a biografia mais completa de Pancho Villa, apelido que também dá nome ao livro. É nela em que há a análise detalhada de três diferentes lendas sobre sua juventude, incluindo uma baseada em uma espécie de autobiografia, ditada por Villa a um escritor. Katz considera lendas as versões para a juventude de Pancho Villa pois a análise dos poucos documentos de época que encontrou não sustenta a veracidade de nenhuma das três.

Um relato sobre a reunião (na qual Villa estava), em novembro de 1910, em que homens de Chihuahua decidiram responder ao chamado revolucionário de Francisco Madero é o documento base para Katz afirmar sua tese de que Villa não correspondia às lendas que criaram sobre ele. Para Katz, Villa não era nem um grande líder dos camponeses, uma espécie de Robin Hood, que tirava dos ricos para distribuir aos 
pobres, nem um matador irresponsável, pária da sociedade de Chihuahua, segundo as versões extremas acerca de sua juventude.

Antonio Ruiz relata, em 1912 - e a proximidade dos fatos aumenta a credibilidade do relato - que em um encontro convocado pelo Partido Antireeleicionista, em um povoado chamado La Cueva Pinta, diversos homens leram o Plan de San Luís Potosí e, entusiasmados com seu diagnóstico e suas promessas de reorganização da realidade política e social mexicana, teriam gritado " ¡Abajo el tirano! ¡Viva la libertad de los hombres! ¡Viva Francisco I. Madero!’. Decidiram, assim, aderir à nascente Revolução Maderista.

Nesse encontro relatado por Antonio Ruiz, os futuros revolucionários decidiram como seria sua própria organização para a luta. Elegeram dirigentes e chefes. Cástulo Herrera foi escolhido para coordenar os trabalhos de todas as companhias. Francisco Villa foi indicado para dirigir vinte e quatro homens, como chefe de uma das quatro companhias que atuariam naquela região. Além desse grupo, também em Chihuahua, Pascual Orozco liderava outras companhias. Dividia, assim, com Cástulo Herrera a posição de líder militar revolucionário mais importante da região, embora nenhum dos dois se notabilizasse por seu carisma.

Ainda sobre o encontro realizado em La Cueva Pinta, o registro histórico do ocorrido em 20 de novembro de 1910, no início das atividades revolucionárias, desmontaria, segundo Katz, as lendas que existiam sobre a vida de Villa até o início da Revolução. Afirma ele:

Así, Pancho Villa entró en la historia de la revolución mexicana como un jefe menor, al mando de veinticuatro hombres, pero también como alguien que había sido elegido para ese puesto por activistas revolucionarios serios. (...) Esa descripción contemporánea (fue escrita en noviembre de 1912, sólo dos años después del estallido de la revolución) pone en duda algunos de los principales aspectos de las tres leyendas sobre Villa: la leyenda negra, la leyenda épica y la leyenda blanca.

Si Villa hubiera sido en verdad el vulgar bandido y múltiple asesino que describe la leyenda negra, es difícil imaginar que una asamblea de ciudadanos responsables lo eligiera para un puesto directivo del movimiento revolucionario. El hecho de que ese puesto fuera de naturaleza subordinada - se hallaba bajo el mando de Cástulo Herrera y sólo encabezaba a veinticuatro hombres, que constituían una cuarta parte de los revolucionarios reunidos - indica que tampoco era el ídolo y reconocido cabecilla de miles de campesinos, azote del imperio de Terrazas. Esa versión también refuta la descripción que hace el propio Villa de sus actividades, su insistencia en que no 
dependía de nadie más que de González y Madero, y su pretensión de haber sido uno de los principales jefes desde el inicio de la revolución. ${ }^{109}$

As poucas informações concretas que se tem sobre o início da vida de Francisco Villa indicam que ele cumpriu um ano no exército por obrigação, em 1902: a "leva" foi obrigatória como punição para um delito de menor importância - furto de animais e pequenas mercadorias. Meses antes da reunião relatada por Antonio Ruiz, Pancho Villa foi levado à prisão para averiguação e solto no dia seguinte, sendo-lhe entregue sua pistola. Se fosse um bandido procurado, por quem as autoridades policiais estivessem dispostas a pagar altas somas em indenizações por sua prisão - como indica parte das lendas - não teria sido, como foi, liberado no dia seguinte. Apesar de os documentos compilados por Katz corroborarem a informação de que F. Villa realizava pequenos ilícitos em Durango, aparentemente em Chihuahua ele parece ter desenvolvido atividades legais ligadas à exploração da terra.

Se no início do levante revolucionário de Chihuahua - em 20 de novembro de 1910, tal como determinado pelo Plan de San Luís Potosí - Villa não era senão um chefe de uma pequena companhia, ao longo dos confrontos armados Cástulo Herrera, excelente articulador político (era líder de um sindicato local), não demonstrou a mesma habilidade militar. $\mathrm{O}$ respeito à sua liderança, assim, foi aos poucos se erodindo e Francisco Villa, com sua habilidade para planejar estratégias e coordenar combates armado, teve seu prestígio e respeito fortalecidos.

Em 29 de setembro de 1913, quase dois anos depois, nasce a Divisão Norte, desde o início sob os comandos de Pancho Villa. Em seu auge, a companhia chegou a contar com 30 mil homens em suas fileiras. O período em que exerceu essa liderança absoluta de suas tropas (e de quase toda região) estendeu-se até 21 de dezembro de 1915, quando seu exército começou a sofrer derrotas sucessivas. Segundo Katz, nesses vinte e sete meses, o villismo era uma alternativa real de organização para a sociedade mexicana.

Feito esse panorama inicial sobre Francisco Villa, cabe responder ao questionamento sobre por que a Revolução Mexicana teve início na região norte do país, já que as mazelas sociais ligadas aos problemas da concentração fundiária e à crise econômica estavam presentes em todo o território nacional. Villa, coadjuvante no início

${ }^{109}$ KATZ, Friedrich. Pancho Villa - Vol. 1. Trad. Paloma Villegas. México: Ediciones Era, 1998. 
do processo, estava em um ambiente não exatamente favorável à agricultura. As terras da região norte do México eram, em sua maioria, desérticas e não atraíram maior interesse até que lá foram descobertos minerais preciosos.

Após identificada a riqueza natural, a mineração passou a ser a principal atividade econômica da região. Simultaneamente, camponeses locais criavam animais para montaria e corte. As pastagens oferecidas aos animais, porém, ficavam em campos abertos, a grande maioria de titularidade do Estado mexicano. Ninguém era dono, ninguém limitava o acesso aos terrenos. No entanto, a política fundiária em relação aos terrenos públicos mudou a partir do fim do século XIX, causando conflitos na região e demandas por zonas de pastagens e água. Esse era, em linhas muito gerais, o peculiar contexto fundiário do norte do México. Para defender a região, para limitar a atuação de povos indígenas e para proteger a fronteira, foram criadas algumas colônias agrícolas no século XIX. Os camponeses foram armados e instruídos a defender o seu território. Creel e Terrazas, dois grandes proprietários de terras locais e ao mesmo tempo políticos da região, promoveram políticas que contrariavam os interesses dessas colunas.

Katz oferece uma resposta parcial a respeito do por quê a revolução teria começado em Chihuahua. Antes de responder especificamente ao "por que Chihuahua?", o autor formula hipóteses sobre as condições favoráveis para a revolução em todo o México.

Katz afirma que, para haver uma revolução, é preciso estar presentes alguns elementos sociais: (1) um descontentamente generalizado - social, político e econômico - em diversas classes e segmentos da população, ainda que por diferentes motivos; (2) também a presença de um processo de politização crescente é considerada um prérequisito revolucionário. Suas causas podem surgir em situações como as de uma guerra - quando os cidadãos são chamados a se sacrificarem em nome de questões coletivas, da vida política de seus países -, mas também em momentos em que regimes autoritários aumentam a liberdade política de seus cidadãos. Nessa segunda hipótese, Katz enquadra o México do início do século XX, que teria vivido a politização crescente a partir da entrevista de Díaz a Creelman e sua tolerância limitada à atuação política de Madero e do Partido Antireeleicionista. (3) Por fim, indica como requisito para o surgimento de levantes revolucionários a percepção por grande parte da população de que há uma ilegitimidade política no governo de fato. No México, essa percepção seria derivada da manipulação das eleições em meados de 1910. 
Nenhum desses três elementos explica por que o norte villista foi a vanguarda do processo mexicano, porém. Dirá Katz que o principal elemento é "la capacidad de lucha y la confianza en sí mismos que tenían sus habitantes". Os camponeses se instalaram no local também com o objetivo de controlar a atuação de índios apaches na região. O processo de ocupação do espaço foi marcado por muitos conflitos, nos quais os habitantes das colônias militares terminaram vitoriosos. Além disso, em um embate com forças governamentais em Tomóchic, também haviam derrotado tropas mais numerosas e bem armadas do que eles. Em paralelo, duas famílias - Creel e Terrazas concentravam muito poder econômico e político no local. Toda a população do território que não era ligada diretamente às duas famílias estava descontente com suas políticas. Por fim, a crise econômica internacional e a seca atingiram de maneira especial o estado, que dependia mais do que o resto do México do investimento norteamericano. Assim, uma particular concentração de poder, crise econômica e a confiança na própria capacidade de luta e vitória - aliadas aos outros elementos de contexto que aproximam o norte dos problemas do resto do México - parecem ser as causas para a convocação de Madero ter sido respondida especificamente naquela região.

O fato de o levante existir e ter início vitorioso em Chihuahua, por sua vez, demonstrou para o resto do país a falta de capacidade do exército de Porfírio Díaz em conter a insurreição. Esses elementos aparentemente foram responsáveis por estimular a organização e a ação revolucionárias no restante do país. Segundo Katz, pode-se afirmar

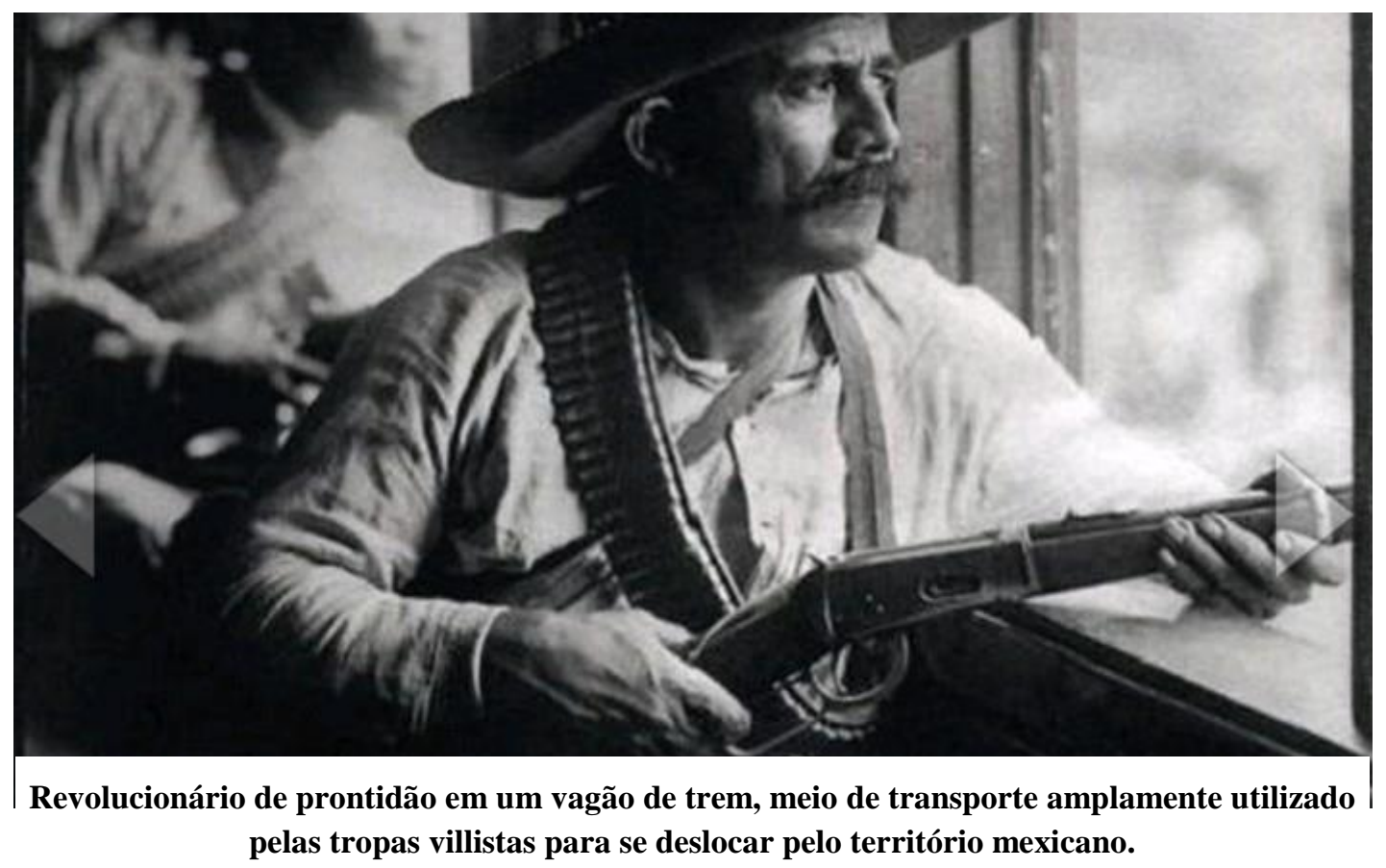


que Chihuahua cumpriu um papel de catalisador na Revolução Mexicana.

\subsection{Novos focos revolucionários, suspensão de garantias individuais, temor de invenção norte-americana e renúncia de Porfírio Díaz}

Se Francisco Villa entrou na Revolução Mexicana na exata data em que ela havia sido convocada por Madero, Emiliano Zapata e Pablo Torres Burgos passam a integrar a luta armada para a destituição do governo de Porfírio Díaz no Estado de Morelos, no centro-sul do país, apenas em março de 1911. Para que a adesão se consolidasse, Pablo Torres Burgos foi até San Antonio no Texas meses antes, discutir estratégias e trazer informações diretamente de Francisco Madero. No mesmo período, começam algumas sublevações de mesmo alinhamento político no Estado de Guerrero. Com tantos focos de insurreição, ainda que pequenos e limitados em seu alcance, o exército dos 'federales' passa a ser insuficiente. A força armada governista começa a sucumbir ante a pressão dos grupos revolucionários espalhados pelo país.

Nesse contexto, Porfírio Díaz edita a Ley de Suspensión de Garantías $^{110}$, datada de 16 de março de 1911. Essa lei suspende liberdades públicas e garantias individuais daqueles que cometem delitos nela especificados, em todo o México. Mais especificamente, suspende as proteções estipuladas nos artigos 13, 19, 20 e 21 da Constituição Mexicana de 1857, que dispõem sobre: a proibição de tribunais e procedimentos ad hoc (art.13); o tempo de prisões preventivas, para apurar a responsabilidade dos atos e colher provas, que não podem durar mais do que três dias (art.19); garantias ligadas ao processo penal, como o direito do réu conhecer o teor da acusação elaborada contra ele e o direito à ampla defesa (art.20) e sobre a exclusividade do Poder Judiciário para impor sanções penais, excluindo essa competência de qualquer órgão administrativo (art.21).

Para os delitos previstos no decreto ${ }^{111}$, é possível, segundo o artigo $3^{\circ}$, aplicar a pena de morte, tendo como único requisito para sua execução, no caso de flagrante

\footnotetext{
${ }^{110}$ MAGAÑA, Gildardo. Emiliano Zapata y el Agrarismo en México. Tomos I a V. Instituto Nacional de Estudios Históricos de la Revolución Mexicana. México, 1a ed. 1937. Edición facsimilar 1985. Tomo I. p. 117-119. Disponível em:

http://biblioteca.diputados.gob.mx/janium/bv/md/LXII/emiliano_zapata_agra_mex.pdf e também aqui: http://www.bibliotecas.tv/zapata/1911/z13mar11.html Consultas realizadas em 02/11/2015.

${ }^{111}$ Os delitos previstos na Lei, passíveis de suspensão de garantias e pena de morte, são:
} 
delito, o registro de uma ata elaborada pelo chefe da força policial ou do exército que realizou o flagrante (art. $4^{\circ}$ ). Nos casos em que não houver flagrante, haverá um julgamento sumário e verbal, com sete dias para apuração dos fatos e, no oitavo dia, expedição da sentença $\left(\operatorname{art.} 5^{\circ}\right)$. A suspensão de direitos e garantias e a possibilidade de aplicação da pena de morte de acordo com o rito do decreto tinham vigência limitada: deixariam de valer seis meses depois da publicação da norma, ou seja, no dia 16 de setembro de $1911\left(\right.$ art. $\left.7^{\circ}\right)$.

Em 18 de março, dois dias depois da publicação da Ley de Suspensión de Garantias, diversos estados do centro-sul do país (Guerrero, Michoacán, Tlaxcala, Campeche, Puebla e Distrito Federal) publicam o Plan Político-Social, em que desconhecem o Presidente e Vice-Presidente da República em função da suspensão das garantias constitucionais, que têm por objetivo, segundo o plano, "derramar a torrentes la sangre de los mexicanos dignos" $" 112$. As mais de dez mil pessoas representadas pelo documento, segundo a exposição de motivos inicial, além de desconhecerem Porfírio Díaz e Corral como governantes legítimos, afirmam ser Francisco Madero Presidente

Artículo $2^{\circ}$.- Quedan sujetos a las disposiciones de esta ley:

I.- Los salteadores de caminos, comprendiéndose entre ellos los que sin derecho detengan o descarrilen los trenes de las líneas férreas; los que quiten, destruyan o dañen los rieles, durmientes, clavos, tornillos, planchas que los sujetan, cambiavías, puentes, túneles, terraplenes o cualquiera otra parte de una vía férrea; los que pongan en ella obstáculos que puedan producir accidentes; los que separen, inutilicen o dañen las locomotoras, carros o vehículos del servicio; los que cambien las señales; los que disparen armas de fuego, lancen piedras $\mathrm{u}$ otros objetos sobre los trenes, o pongan explosivos destinados a destruirlos, y en general, los que ejecuten cualquier acto contra la seguridad o integridad de las vías férreas o contra su explotación.

II.- Los que sin derecho corten o interrumpan las comunicaciones, destruyendo o inutilizando los postes, alambres, aparatos o cualquiera parte o accesorio de una línea telegráfica, o de transmisión de energía eléctrica, o que ejecuten cualquier acto contrario a la seguridad e integridad de las instalaciones destinadas a producir esa energía, o que impidan su explotación.

III.- Los que bajo cualquiera forma cometan el delito de plagio, definido en el artículo 626 del Código Penal del Distrito Federal.

IV.- Los que cometan el delito de robo con violencia a las personas en despoblado, o mediante ataque a una población o finca rústica.

Artículo $3^{\circ}$.- Serán castigados con la pena de muerte los culpables de los hechos enumerados en las fracciones I y III del artículo anterior, resulte o no de ellos muerte o lesión, así como los culpables de los delitos enumerados en las fracciones II y IV del mismo artículo, siempre que sean ejecutados en camino público, sea o no de hierro y vayan precedidos, acompañados o seguidos del delito de homicidio con alevosía, premeditación o ventaja, o a traición, o del delito de incendio.

Los demás hechos comprendidos en el artículo $2^{\circ}$. de esta ley, serán castigados con la pena de cinco a doce años de prisión, según las circunstancias." Observação: A palavra "plágio" mencionada no art. $2^{\circ}$, III do decreto e prevista no art. 626 do Código Penal mexicano é usada aqui como sinônimo de sequestro.

A íntegra da Ley de Suspensión de Garantias está disponível aqui: Em: BIBLIOTECA GARAY. 500 años de México en documentos. México, 2011. http://www.bibliotecas.tv/zapata/1911/z13mar11.html Consulta realizada em 02/11/2015.

${ }^{112}$ A íntegra do Plan Político-Social, de 18 de março de 1911, pode ser encontrada aqui: BIBLIOTECA GARAY. 500 años de México en documentos. México, 2011.

http://www.bibliotecas.tv/zapata/1911/z18mar11.html Consulta realizada em 07/11/2015. 
Provisório, terem como lei suprema a Constituição de 1857 e, como lema, a expressão "¡Abajo la Dictadura! Voto Libre y No Reelección.”. Além das questões políticas, o plano trazia também normas sobre terra, jornada de trabalho e salário, possuindo assim uma parte social bastante extensa.

No mesmo mês de março, altos escalões do governo porfirista, governadores de diferentes estados do México e membros da família de Francisco Madero se encontram em Nova York para discutir a situação do México.

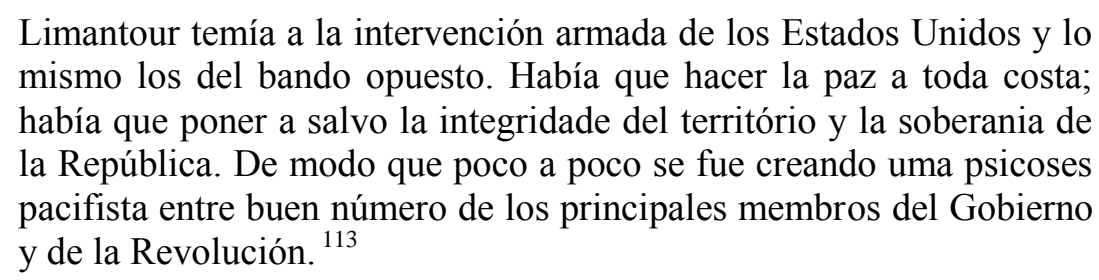

Os Estados Unidos da América já haviam invadido o México em 1847-48, o que resultou na perda de parcela significativa do território norte do país. Também em 1862 a França, aliada à Espanha e à Inglaterra, promoveu uma invasão estrangeira no México. Esses eventos históricos talvez expliquem a apreensão que alguns líderes políticos locais sentiam: o medo de que, em meio aos conflitos internos, o país se mostrasse frágil internacionalmente e sofresse mais uma violação de seu território.

Porfírio Díaz havia notificado a embaixada americana sobre o fato de o movimento revolucionário que ocorria no México ter uma base nos EUA, mais especificamente em San Antonio, no Texas. Notificado, o governo norte-americano enviou inúmeras tropas para a região da fronteira entre o México e os Estados Unidos, o que reforçou o sentimento de insegurança. Tal apreensão impulsionava os políticos para decisões que tivessem como resultado o reestabelecimento da paz, no momento em que as tropas federais já não estavam mais suportando o conflito distribuído por boa parte de seu território.

Em 24 de março de 1911, Porfírio Díaz muda alguns dos ministros que compunham seu gabinete presidencial. Seu objetivo era tentar avançar nas tratativas de paz sem ser necessário sair do governo. Tal mudança foi aconselhada por José Yvez Limantour, então Ministro das Finanças e um dos mais influentes personagens do grupo denominado "los Científicos", conjunto de políticos que realizavam o aconselhamento

${ }^{113}$ SILVA HERZOG, Jesus. Breve Historia de la Revolución Mexicana - Los antecedentes y la Etapa Maderista. Fondo de Cultura Económica do México. 15a. Reimpressão. Cidade do México, 1997. P. 182. 
do General Porfírio Díaz. Em $1^{\circ}$ de abril de 1911, Porfírio Díaz abre as sessões ordinárias do Congresso Mexicano com um discurso ${ }^{114}$ em que faz a análise da situação política mexicana naquele momento; informa sobre a proximidade das tropas estadunidenses e sobre a decisão de modificar seu ministério para renovar os quadros políticos - pois identifica essa como uma das aspirações da massa de revolucionários -, e anuncia a grande mudança: o fim da reeleição para todos os cargos do Poder Executivo e a mudança das regras eleitorais para tornar o sufrágio efetivo. Porfírio Díaz afirma que ao implementar tais transformações, com a ajuda do Congresso, tem o propósito de demonstrar "la firme intención de satisfacer las quejas fundadas en contra

${ }^{114}$ A íntegra do discurso proferido por Porfírio Díaz em $1^{\circ}$ de abril de 1911 pode ser encontrada aqui: BIBLIOTECA GARAY. 500 años de México en documentos. México, 2011. http://www.biblioteca.tv/artman2/publish/1911_214/Discurso_de Porfirio_D_az al abrir las sesiones_o r 531.shtml Consulta realizada em 04/11/2015. Lê-se no informe relatos da Revolução, segundo a perspectiva de Porfírio Dìaz: "Un grupo que en las últimas elecciones federales presentó candidatos á la presidencia y á la vicepresidencia de la República, sin haber alcanzado más que una escasa minoría de votos, no supo limitar su acción al legítimo ejercicio del sufragio popular que proclamaba, sino que pasadas las elecciones, recurrió á las armas, perturbando la paz de que gozaba el país hacía largos años.

Los jefes de ese grupo pretendieron organizar, mediante trabajos ejecutados tanto en territorio extranjero como en el mexicano, un movimiento revolucionario general que estallaría en fecha determinada.

Dicho movimiento revolucionario fué descubierto antes de iniciarse, y á poco acae cieron en Puebla los primeros sucesos, que costaron la vida á varios de los rebeldes y á algunos servidores del Gobierno local.

En la fecha señalada para el levantamiento general, se sublevaron en la región montañosa del Oeste de Chihuahua, varios grupos compuestos principalmente de campesinos, aprovechándose de las condiciones favorables de aquellos lugares para defenderse y ponerse fuera del alcance de las primeras tropas que se enviaron á perseguirlos.

Estas condiciones y la cooperación eficaz que recibieron los rebeldes en hombres y en elementos de guerra, de parte del extranjero, así como también de un grupo de mexicanos que desde hace años conspira no solamente contra el actual Gobierno sino contra todo orden social, explican fácilmente que la revuelta haya ido extendiéndose por casi todo el Estado de Chihuahua y por varios puntos de Sonora y de Durango, á pesar de los esfuerzos hechos para contenerla por el Gobierno Federal, por los de los Estados referidos.

Al mismo tiempo, desgraciadamente, han surgido no sólo en esos lugares, sino en algunos otros puntos del territorio nacional, numerosas gavillas sin color político, animadas únicamente por el espíritu de bandidaje, que comienza á desarrollarse de nuevo, sembrando entre los habitantes del país, mayor alarma quizá que la producida por los que iniciaron la revuelta.

En la Baja California se ha efectuado un movimiento de otro carácter, causado por bandas comunistas en las que figuran muchos filibusteros americanos, con el fantástico proyecto de formar una república socialista. Tan nefando propósito no podrá menos que provocar la más grande indignación en el país, y estoy seguro de que en caso necesario, el pueblo mexicano, siempre patriota y celoso de su autonomía, acudirá á la defensa del territorio nacional.

Para contener tales desórdenes no han bastado las fuerzas de seguridad pública, sino que ha sido preciso movilizar numerosas tropas federales, de las cuales la parte principal se ha dedicado á perseguir los núcleos revolucionarios y el resto se ha fraccionado en destacamentos para asegurar en cuanto es posible el orden público en todas las regiones del país.

Se complace el Ejecutivo en aprovechar esta ocasión para tributar un público homenaje á la lealtad y al valor del soldado mexicano, que sólo son comparables con la disciplina y la resignación con que sufre los rigores de todo género en la campaña. Sabe, además, el Gobierno, que cuenta con el heroísmo y la abnegación del Ejército para restablecer la paz y dar severas lecciones á los insensatos que la han perturbado." 
de algunas autoridades, especialmente de aquellas que están en más íntimo contacto con el pueblo."115.

Ou seja, Porfírio Díaz reconhece que há um problema e promete soluções políticas para apaziguá-lo. No entanto, isso não foi suficiente. Quer porque o problema já não pudesse ser resolvido por meio de uma decisão interna ao governo de Porfírio Díaz, quer porque a principal insatisfação popular, que teria motivado os insurgentes, não estivesse ligada diretamente às pautas da não-reeleição e do sufrágio efetivo, a promessa de Díaz não foi suficiente para diminuir os enfrentamentos armados que ocorriam em território mexicano.

Em 11 de abril, F. Madero começou a reunir as tropas que lutavam ao norte do país nos arredores de Ciudad Juárez, na fronteira com os EUA. Mais de três mil maderistas se reuniram e ameaçavam um ataque na região. Entre os dias 20 e 21 de abril, após Madero reivindicar o controle pacífico da cidade, o que the foi negado, iniciaram-se negociações de paz, tendo como representante do governo Francisco Carvajal; e como representantes dos revolucionários Francisco Vázquez Gómez, Francisco Madero pai e José Maria Pino Suárez. Para que as negociações ocorressem, foi celebrado um armistício, com prazo de cinco dias. Este prazo foi prorrogado por duas vezes, encerrando-se o terceiro período no dia 6 de maio de 1911.

No dia 7 de maio, o General Porfírio Díaz publica um manifesto à nação, em que afirma: "El Presidente de la República, que tiene la pena de dirigirse al pueblo, en estos solemnes momentos, se retirará, sí, del poder, pero como conviene a una Nación que se respeta (...)"116. Com esta frase sugere que não deixará a função de Presidente da República até o fim de seu mandato, ou então que o fará somente por motivos pessoais, mas não em razão da pressão revolucionária. Continua, no último parágrafo do manifesto: "El fracaso de las negociaciones de paz traerá consigo la recrudescencia de la actividad revolucionaria. El Gobierno, por su parte, redoblará sus esfuerzos contando con la lealtad de nuestro heroico ejército para sojuzgar la rebelión y

\footnotetext{
${ }^{115}$ A íntegra do discurso proferido por Porfírio Díaz em $1^{\circ}$ de abril de 1911 pode ser encontrada aqui: http://www.biblioteca.tv/artman2/publish/1911_214/Discurso_de_Porfirio_D_az_al_abrir_las_sesiones_o r 531.shtml Consulta realizada em 04/11/2015.

${ }^{116}$ A íntegra do Manifesto à Nação publicado por Porfírio Díaz em 07 de maio de 1911 está disponível aqui: CARMONA, Doralicia. Memoria política de México. Guanajuato: Universidade de Guanajuato, 2014. http://www.memoriapoliticademexico.org/Textos/6Revolucion/1911MAX.html Consulta realizada em 04/11/2015.
} 
someterla al orden (...)"117. Além da renúncia de Díaz, o manifesto promete reformas no sentido da não-reeleição de cargos do Poder Executivo e o sufrágio efetivo.

Se os revolucionários não aceitarem as condições do governo, o enfrentamento armado continuará e se intensificará, porque o governo de Porfírio Díaz está disposto a lutar, é o que se depreende do texto do Manifesto. Dadas essas declarações oficiais por parte do governo e não satisfeitas as reivindicações dos revolucionários - que incluíam, por pressão de Vázquez Gómez, a renúncia de Díaz - não havia outra alternativa para estes últimos senão lutar. E assim fizeram, enfrentando as forças governamentais de Ciudad Juárez já no dia seguinte, 8 de maio.

Depois de três dias de combate, em 10 de maio de 1911, os revolucionários tomam a cidade e, embora sem muita importância militar, a vitória tem enorme efeito simbólico. Ainda mais grupos insurgentes decidem integrar a luta maderista. Em Ciudad Juárez, Francisco Madero se auto-declara, cumprindo o disposto no Plan de San Luís Potosí, Presidente Provisório do México e nomeia seu gabinete de Ministros. Entre eles, Venustiano Carranza assume como Ministro da Guerra e Marinha. Os conflitos se intensificam.

Dada a efervecência revolucionária desses dias mexicanos e com a opinião pública favorável aos insurgentes, em 21 de maio de 1911 é firmado um convênio de paz, em que Díaz e Corral se comprometem a renunciar aos seus mandatos. Apenas em 25 de maio, porém, após um dia de titubeio e mais manifestações populares na Cidade do México, Porfírio Díaz renuncia efetivamente à Presidência do México, depois de mais de 30 anos de mandato. Sai da capital no mesmo dia, em um trem que seguiu em direção a Veracruz. Victoriano Huerta - que virá a ocupar o posto de Presidênte da República pouco tempo depois - é o responsável pela escolta do Presidente deposto. Em 27 de maio de 1911, Porfírio Díaz embarca em um navio rumo à Europa, já com 80 anos. Quatro anos depois, em 2 de julho de 1915, morre em Paris.

\footnotetext{
${ }^{117}$ A íntegra do Manifesto à Nação publicado por Porfírio Díaz em 07 de maio de 1911 está disponível aqui: http://www.memoriapoliticademexico.org/Textos/6Revolucion/1911MAX.html Consulta realizada em 04/11/2015.
} 


\subsubsection{Governo provisório de Francisco León de la Barra}

Para que o acordo de paz fosse firmado e a renúncia aceita, os revolucionários acordaram que Francisco Madero não seria presidente interino. Assumiu a função o Ministro das Relações Exteriores, Francisco León de la Barra, em 26 de maio. Madero era meramente um candidato a Presidência nas eleições que se realizariam dali a alguns meses. Mesmo assim, após as renúncias no fim de maio, realizou a viagem entre Ciudad Juárez e a Cidade do México como um verdadeiro herói revolucionário:

El viaje de Madero de Ciudad Juárez a la capital de la República fue una marcha triunfal; fue vitoreado em todo el trayecto com entusiasmo delirante. El 7 de junio llegó a México a las doce treinta de la tarde. Lo esperaban cien mil personas para aclamarlo. Las muestras espontâneas, enteramente espontâneas de adhesión y cariño que le tributo el pueblo en esa ocasión, no habían tenido paralelo en la história do México com caudillo alguno, excepción hecha quizá em la entrada de Iturbide al frente del Ejército Trigarante, al consumarse la Independencia política de México el 27 de septiembre de 1821; y después del 7 de junio de 1911 no ha sucedido nada semejante, si se excluye la que tuvo lugar en marzo de 1938 com motivo de la expropiación de los bienes de las empresas petroleras. ${ }^{118}$

O período de governo interino de Francisco León de la Barra foi conturbado. A imprensa, então totalmente livre, tornou-se bastante agressiva e crítica a Madero. Além disso, havia dois centros de poder. Embora ainda não fosse presidente, Madero instalou seu escritório no centro da Cidade do México e passou a interferir nos assuntos políticos do país. Um mês depois de ter chegado à cidade, em 9 de julho, Madero declara que o Partido Antirreeleicionista tinha sido extinto, em função de divergências com Francisco Vázquez Gómez, mais radical em suas propostas de transformação para o México.

Parte do Partido Antirreeleicionista, porém, não aceita a decisão de Madero, e decide manter a organização, dessa vez sob a liderança de Vázquez Gómez. Francisco Madero, por sua vez, funda o Partido Constitucional Progresista. Além desses dois, se reorganizam o Partido Nacional Democrático e o Partido Liberal. A liberdade de organização política vigora no México.

Fora da capital, permanecem alguns pequenos embates entre federales (agentes do exército mexicano, antes fiel a Díaz) e madeiristas. Em 12 de julho, acontece um

\footnotetext{
${ }^{118}$ SILVA HERZOG, Jesus. Breve Historia de la Revolución Mexicana - Los antecedentes y la Etapa Maderista. Fondo de Cultura Económica do México. 15a . Reimpressão. Cidade do México, 1997. P. 198.
} 
grande enfrentamento entre os dois grupos em Puebla. Como resultado, 80 madeiristas mortos, entre eles mulheres e crianças, e 20 federales. No dia 13 de julho de 1911, Madero chega à cidade - havia assumido compromissos antes do ocorrido - e, ao ser informado sobre a situação, defende os federales, muito embora o início do enfrentamento armado tenha sido aparentemente provocado por eles. Madero afirma na ocasião a necessidade de licenciamento das tropas revolucionárias. Essa e outras atitudes de Madero fazem com que vá, aos poucos, perdendo sua popularidade.

Irmão de Francisco Vázquez Gómez, Emílio Vázquez Gómez, que integrava pelos revolucionários o governo provisório de Francisco de la Barra, renuncia em 2 de agosto. Segundo as memórias de F. Vázquez Gómez, Madero teria dito a ele, na ocasião: "Ahora el Ministerio de Gobernación es una oficina decente, mientras que cuando estaba su hermano no había más que pelados"119. Pelados é uma gíria usada para caracterizar pessoas sem posses, pobres. A renúncia de Vázquez Gómes - e a falta de disposição de Madero em defendê-lo -, além de outras atitudes, foram minando a legitimidade de Madero também junto a alguns setores revolucionários. O governo provisório estava cada vez mais composto por profissionais antes ligados a Díaz.

Nesse contexto, começavam a ser prepararadas as eleições, que ocorreriam em $1^{\circ}$ e 15 de outubro de 1911 (primárias e secundárias). Nelas, Francisco Madero foi eleito quase por unanimidade para exercer a função de Presidente da República. José María Pino Suárez, em eleição mais disputada, foi eleito Vice-Presidente, pelo mesmo Partido Constitucional Progressista. Antes de relatar o início do governo de Francisco Madero, vale o relato de um encontro interessante, bastante simbólico de um dos desafios políticos que Madero teria que enfrentar como presidente. Em 18 de agosto de 1911, Madero e Zapata se encontraram em Cuautla. O objetivo do agora recém-empossado mandatário da nação era convencer o líder camponês a licenciar suas tropas.

\footnotetext{
119 Francisco Vázquez Gómez. Memórias políticas 1909-1913. Ciudad do México: 1933, Imprenta Mundial. P. 400.
} 


\subsection{Emiliano Zapata e a decisão por manter-se em armas}

Emiliano Zapata, mestiço metade índio, metade espanhol -, nasceu no Estado de Morelos, no sul do México, em 8 de agosto de 1879. Completou 32 anos em 1911, ano em que decide participar dos levantes revolucionários convocados por Francisco Madero. Antes disso, já colecionava uma série de feitos de resistência às injustiças praticadas pelo regime de Porfírio Díaz, sobretudo em relação à espoliação de terras sofridas pelas comunidades de seu Estado.

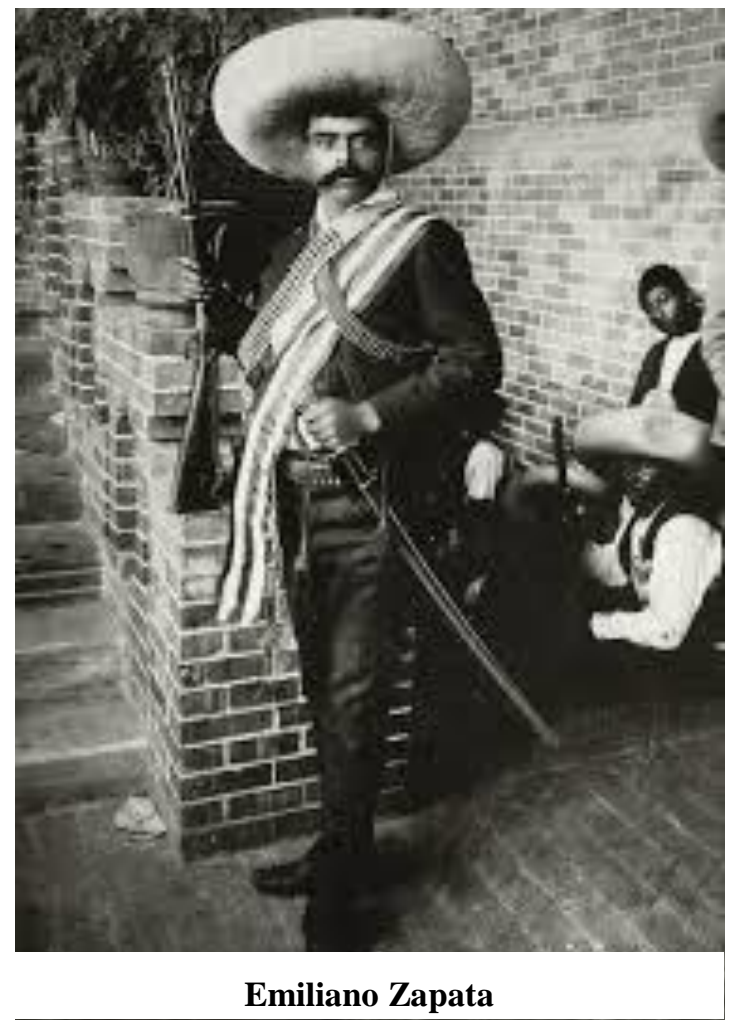

Alguns historiadores (entre eles John Womack Jr. e Gildardo Magaña) contam que já quando criança, ao ouvir seu pai e um amigo reclamarem das expropriações injustas de terras dos camponeses da região, perguntou por que eles não se juntavam todos e retomavam as terras roubadas pelos fazendeiros latifundiários. Ao receber a resposta de que isso não era possível, que os fazendeiros controlavam tudo, inclusive os mecanismos de controle, teria prometido retomar as terras espoliadas quando crescesse $^{120}$.

Em junho de 1897, Emiliano, então com 18 anos, foi preso em uma briga de rua. Depois de ser libertado na delegacia por seu irmão Eufemio, armado, tiveram que fugir os dois da cidade. Se estabeleceram no Estado de Puebla, onde trabalharam na fazenda de um conhecido de Frumencio Palacios - amigo da família que morava na região. Nesse período, Emiliano Zapata começou a trabalhar como amestrador de cavalos.

\footnotetext{
120 MAGAÑA, Gildardo. Emiliano Zapata y el Agrarismo en México (Selección). Biblioteca del Pensamiento Legislativo y Político Mexicano. 1ª Ed. Ciudad de México: 2014. P. 12-13.
} 
Voltando ao Estado de Morelos um ano depois, passou a cultivar as terras que tinha herdado de seus pais, falecidos pouco antes, e dedicou-se à criação de animais.

Por sua experiência na fazenda de Puebla e pela forma como tratava seus animais, Zapata passou a ser reconhecido por suas habilidades de amestrador de cavalos. Começou a ser chamado em grandes fazendas da Cidade do México e de Chietla, Estado de Puebla, para amestrar os animais mais valiosos dos fazendeiros. Conheceu, assim, a riqueza e a enorme desigualdade do México do início do século XX. Indignou-se com o fato de haver estábulos para cavalos mais confortáveis do que as casas de seus conterrâneos. Ao mesmo tempo, sempre manteve atividades em Anenecuilco que garantiam sua independência econômica, sem depender dos empregos ocasionais nas fazendas de terceiros. Nesse sentido, Zapata poderia ser caracterizado como a classe média rural mexicana: possuía um pedaço de terra e nunca trabalhou como "jornalero", ou seja, diarista em empregos rurais precários nas grandes fazendas de cana de açúcar da região. Não era rico, mas vivia uma vida relativamente confortável e independente.

Entre 1898 e 1909, Zapata foi participante ativo da vida política da região. Enquanto seu irmão Eufemio vendera sua parte no patrimônio herdado pelos pais e mudara-se para Veracruz para desenvolver atividades comerciais, Emiliano ficou em Anenecuilco e viveu as mudanças concentradoras promovidas pela política agrária de Porfírio Díaz ${ }^{121}$. Aos poucos o conflito agrário se intensificou na região, e se intensificaram também as ações de resistência. Zapata participava de protestos; organizava atos de resistência aos despojos de terra; compunha comitivas que iam fazer reuniões com o chefe do executivo local; esteve envolvido na campanha de um candidado a governador de oposição.

Em 1908, Zapata convocou os moradores de Anenecuilco e Villa de Ayala para defenderem, com armas, as terras que estavam sendo apropriadas pelos fazendeiros. Em razão dessa mobilização, foi punido com o alistamento obrigatório no Exército - por meio do instituto que era conhecido como "la leva". Aqui a visão de Gildardo Magaña, considerado sucessor de Zapata na organização da região, sobre o período de início de reconhecimento da liderança de Zapata:

\footnotetext{
${ }^{121}$ No capítulo 2 da presente tese é realizada uma retrospectiva histórica sobre as normas que organizaram a questão fundiária mexicana e como, especialmente no mandato de Porfírio Díaz, a concentração de terras nas mãos de poucos fazendeiros e as espoliações de comunidades indígenas e rurais se intensificou.
} 
Los hacendados de Morelos - lo repetiremos una vez más -, no satisfechos con las exageradas extensiones de sus propiedades, y apoyados por los gobernantes, hacendados también, y por los jueces venales, en cuyas manos la justicia era mercancía, valiéndose de chicanas, que constituían verdaderos actos delictuosos, consumaban el despojo de los ejidos de los pueblos que tenían la desgracia de colindar con sus feudos. Tocó su turno a Villa de Ayala y a Anenecuilco, y entonces, Emiliano Zapata, encabezando a los principales perjudicados, acudió primeramente a profesionales de México, para que defendieran los derechos de sus convecinos y, más tarde, cuando vio que la justicia se impartía al antojo de los hombres del poder, con- vocó a los moradores de Ayala y de Anenecuilco, para invitar los a defender, con las armas, las tierras de sus pueblos. Esta actitud enérgica, valiente y justa, alarmó e indignó a los hacendados y a su aliado, el gobernador de Morelos. La leva, el odioso sistema para cubrir las plazas vacantes en el Ejército, del que tanto abusó el régimen de Porfirio Díaz; la leva, implacable contra el débil y contra el desvalido, llevó a Zapata al cuartel del $9^{\circ}$ regimiento de caballería, que, en aquel enton ces (1908), comandaba el coronel Alfonso Pradillo y guarnecía la plaza de Cuernavaca. Zapata tuvo a su favor la influencia de hombres adinerados, entre los que se encontraba don Ignacio de la Torre y Mier, quien lo estimaba particularmente por su habilidad como charro, y, debido a esto, sólo permaneció en las filas federales algo más de seis meses. ${ }^{122}$

Porque tinha contatos com pessoas influentes da região, Zapata permaneceu no $9^{\circ}$ regimento da cavalaria apenas por pouco mais de seis meses. Esse episódio de tentativa de defesa da terra e outros mais faziam com que Zapata inspirasse admiração e respeito nas pessoas da região. Assim, em 1909, quando os quatro anciões que compunham o Conselho Regente de Anenecuilco convocaram uma reunião no povoado para dizer que queriam passar a organização da comunidade para outras pessoas mais jovens, o resultado da eleição realizada não foi uma surpresa. Zapata foi eleito por grande maioria de votos para ocupar o posto de Presidente do Conselho.

Womack Jr., historiador norte-americano que dedicou boa parte de seus estudos à organização zapatista surgida em Morelos no início do século XX, afirma que, para além de seus méritos pessoais e de liderança, Zapata carregava também a história de sua família na região. Seu avô materno, José Salazar, havia apoiado os combatentes da Guerra da Independência; dois irmãos de seu pai - Cristino e José Zapata - haviam participado da Guerra da Reforma e lutado contra a Intervenção Francesa ${ }^{123}$. Outro José Zapata (não se sabe bem o parentesco com Emiliano, mas provavelmente irmão de seu

\footnotetext{
122 MAGAÑA, Gildardo. Emiliano Zapata y el Agrarismo en México (Selección). Biblioteca del Pensamiento Legislativo y Político Mexicano. $1^{\text {a }}$. Ed. Ciudad de México: 2014. P. 14

${ }^{123}$ Um panorama bastante sucinto da história do México no século XIX pode ser encontrada no capítulo 2 da presente tese.
} 
avô), já mais velho, havia auxiliado as forças de resistência contra a Intervenção dos Franceses, colocando à disposição seus conhecimentos do terreno em que a batalha estava sendo travada. Em decorrência desse auxílio, ganhara prestígio e passara a participar da vida política da região, mantendo relações pessoais com Porfírio Díaz. Por meio do contato com Díaz, por sua vez, conseguira atuar para proteger as terras das comunidades da região contra a intervenção e apropriação das fazendas açucareiras, segundo ele uma "enfermedad maligna" "124. Assim, é possível dizer que o sobrenome Zapata era bem-quisto na região da Villa de Ayala, capital do distrito do qual Anenecuilco fazia parte.

Zapata fora eleito para presidir o Conselho Regente de Anenecuilco em 12 de setembro de 1909. Junto com ele foram indicados ainda um secretário, dois tesoureiros e um porta-voz para compor o órgão representativo e organizativo do povoado. Os nomeados eram, tal como Zapata, jovens que já atuavam como lideranças da região.

Ao final de 1908 havia morrido Manuel Alarcón, então governador de Morelos. Ao longo do Porfiriato, os governadores que atuavam nos estados passavam por um processo de eleição formal, já que a decisão efetiva sobre quem governaria era tomada por Porfírio Díaz. O eleito era sempre aquele indicado pelo então presidente. Às vezes a indicação do governo central era mais alinhada com as elites locais; outras vezes, tratava-se de uma escolha alheia aos interesses e reconhecimentos da região. Segundo Womack Jr., Alarcón contava com alguma legitimidade e sua morte abria a possibilidade de um conflito acirrado para decidir sua substituição, no início de 1909. Nas discussões locais, quatro nomes eram cogitados para suceder o governador recémfalecido: Luis Flores; Demetrio Salazar; Antonio Tovar e Augustín Aragón. Apesar disso, Díaz escolheu um quinto nome de fora do Estado: Pablo Escandón. A indicação causou enorme descontentamento na região. Zapata e outros moradores de Morelos uniram-se, então, em torno de uma candidatura de oposição: Patricio Leyva. Obviamente, a candidatura Leyvista foi derrotada, mas a atuação política de Zapata junto àqueles que a apoiaram teve como consequência a ampliação de seu círculo político na região. Sua liderança já não se limitava a Anenecuilco ou Ayala: Zapata passou a ser conhecido em todo o pequeno Estado.

\footnotetext{
${ }^{124}$ WOMACK JR, John. Zapata y la Revolución Mexicana. Secretaría de Educación Pública y Siglo XXI Editores. México, $1^{a}$ ed. 1969. Reimpresión 1985. P. 5-6.
} 
Essa pequena introdução à biografia de Emiliano Zapata talvez seja importante para entender a importância que ele assumiu ao longo dos embates revolucionários no México e por que foi escolhido como o paladino dos camponeses mexicanos. Como afirma Womack Jr., ele não buscou ativamente chamar a atenção para si, foram os próprios camponeses de Morelos que fizeram dele o seu chefe:

Zapata ocupa um lugar destacadíssimo em estas páginas no porque él mismo tratase de llamar la atención sobre sí, sino porque los campesinos de Morelos lo hicieron su jefe y constantemente acudieron a él para que los guiara, y porque otros campesinos de la Republica hicieron de él su paladín. A través de él, los campesinos se abrieron caminho en la Revolución mexicana. Si la suya no fu ela única clase de experiência revolucionaria, sí fue, creo yo, la que tuvo mayor significación. ${ }^{125}$

Em 1910, um ano após as disputas das eleições para governador no Estado de Morelos, as notícias sobre o Plan de San Luís Potosí e os primeiros levantes revolucionários demoraram a chegar. Só em dezembro Emiliano Zapata, Pablo Torres Burgos, Margarito Martínez, Catarino Perdomo e Gabriel Tepepa se reuniram para decidir se empreenderiam esforços para tomar parte no chamado maderista ou não. A decisão favorável à adesão esteve diretamente relacionada com o artigo $3^{\circ}$ do Plan de San Luís, que prometia a restituição das terras tomadas dos campesinos arbitrariamente:

Cierto que el artículo preinserto [3 $3^{\circ}$ Plan San Luís Potosí] distaba mucho de tocar el verdadero fondo del problema, ya que tan sólo se refería a remediar los abusos cometidos al amparo de la ley de terrenos baldíos, declarando sujetos a revisión las disposiciones y fallos relativos; pero fue un rayo de esperanza para quienes habían su frido el despojo de sus tierras, y nada más lógico ni más humano que el esclavizado pueblo morelense, al encontrar la oportunidad para reconquistar lo suyo, fuera a la lucha armada y respondiese al llamado de Madero, con el propósito de exigir justicia al triunfo de la causa popular, a cambio del sacrificio que significaba esa lucha. ${ }^{126}$

Tomada a decisão, Pablo Torres Burgos, que além de político era professor, foi até o Texas obter informações diretamente de Madero e decidir quais seriam as linhas estratégicas para o combate em Morelos. Em março de 1911, quando os enfrentamentos começaram efetivamente, Pablo Torres Burgos estava na liderança das tropas revolucionárias. Muito rapidamente, em um dos primeiros combates ainda em março,

\footnotetext{
${ }^{125}$ WOMACK Jr, John. Zapata y la Revolución Mexicana. Secretaría de Educación Pública y Siglo XXI Editores. México, $1^{\text {a }}$ ed. 1969. Reimpresión 1985. P. XII.

${ }_{126}$ MAGAÑA, Gildardo. Emiliano Zapata y el Agrarismo en México (Selección). Biblioteca del Pensamiento Legislativo y Político Mexicano. $1^{\text {a }}$. Ed. Ciudad de México: 2014. P. 17
} 
morreu. Os embates e tomadas de povoados continuaram na região, porém. Em abril Zapata já era reconhecido como líder do então exército madeirista de Morelos.

Em maio de 1911, a etapa maderista da Revolução Mexicana estava sendo decidida diplomaticamente no norte do país, nos arredores da Ciudad Juárez recém tomada. Em 25 de maio, Porfírio Díaz renunciava e Madero começava a pedir para os chefes revolucionários que licenciassem suas tropas, ou seja, para que desmobilizassem seus homens e não mantivessem a organização armada pronta para o ataque. Para os morelenses, porém, o confronto tinha pouco mais de dois meses. Assim, o pedido para que deixassem as armas não foi acatado. Aqueles que tinham se insurgido em razão do conflito agrário - e não por um especial desapreço à figura de Porfírio Díaz ou em relação ao instituto da reeleição - queriam mais do que a renúncia do então presidente para considerar que suas reivindicações haviam sido atendidas.

Após os pedidos não atendidos de Madero para que Zapata licenciasse suas tropas, um encontro entre eles foi agendado para 18 de agosto de 1911, na cidade de Cuautla, no Estado de Morelos. Madero foi até o território de Zapata para tentar negociar. Depois de uma breve discussão sobre a lealdade de outra liderança indicada por Madero para atuar na região, General Figueroa (em quem Zapata não confiava), o diálogo chegou ao ponto principal de divergência com os insurgentes:

- Como usted lo ordene, señor Madero - dijo Zapata-; pero el tiempo nos desengañará de quién es y cómo obra el general Figueroa. Lo que a nosotros nos interesa es que, desde luego, sean devueltas las tierras a los pueblos y que se cumplan las promesas que hizo la Revolución.

[Madero] - Todo eso se hará; pero en debido orden y dentro de la ley, porque son asuntos delicados que no pueden ni deben resolverse de una plumada y a la ligera. Tendrán que estudiarse, tramitarse y resolverse por las autoridades del Estado. Lo que conviene de pronto —agregó insistiendo el Jefe de la Revolución- es proceder al licenciamiento de las fuerzas revolucionarias, porque habiendo llegado al triunfo ya no hay razón de que sigamos sobre las armas.

(...)

-Es nuestro natural enemigo [el Ejercito Federal] —le dijo-; ¿o cree usted, señor Madero, que, por el hecho de que el pueblo derrocó al tirano, estos señores van a cambiar de manera de ser? Ya ve usted lo que está pasando con el nuevo gobernador, el señor Carreón, que está completamente a favor de los hacendados, y, si esto pasa ahora que estamos de triunfo y con las armas en la mano, ¿qué será cuando nos entreguemos a la voluntad de nuestros enemigos?

—No, general — repuso Madero—, la época en que se necesitaba de 
las armas ya pasó; ahora, la lucha la vamos a sostener en otro terreno. $\mathrm{Si}$ el actual gobernante de Morelos no garantiza los intereses revolucionarios del Estado, se pondrá uno que cumpla con su deber; pero debemos ser prudentes y no obrar con violencia, lo que nuestros enemigos y la opinión pública nos reprocharían. La Revolución necesita garantizar el orden, ser respetuosa con la propiedad.

-Mire, señor Madero; si yo, aprovechándome de que estoy armado, le quito su reloj y me lo guardo, y andando el tiempo nos llegamos a encontrar los dos armados y con igual fuerza, ¿tendría usted derecho a exigirme su devolución?

- ¡Cómo no, general, y hasta tendría derecho de pedirle una indemnización por el tiempo que usted lo usó indebidamente! -le contestó el Jefe de la Revolución.

- Pues eso justamente es lo que nos ha pasado en el estado de Morelos — replicó Zapata-, en donde unos cuantos hacendados se han apoderado por la fuerza de las tierras de los pueblos. Mis soldados, los campesinos armados y los pueblos todos, me exigen que le diga a usted, con todo respeto, que desean se proceda desde luego a la restitución de sus tierras. ${ }^{127}$

O encontro se encerrou com um convite feito por Emiliano Zapata para que Francisco Madero visitasse o Estado de Morelos e conhecesse pessoalmente as terras e as pessoas envolvidas nos conflitos da região. Francisco Madero respondeu aceitando o convite.

Dias depois do encontro amigável, Zapata concordou em, respeitadas algumas condições acordadas, licenciar suas tropas. Foi o que publicou no "Manifiesto al pueblo de Morelos" ${ }^{128}$ de 27 de agosto de 1911. No mesmo dia do manifesto, porém, um exército federal liderado por Huerta avançou sobre a cidade de Ayala, a pedido do presidente interino Francisco León de la Barra, desrespeitando o acordo firmado por Madero de retirada das tropas federais do Estado de Morelos. Tal decisão é considerada quase como um golpe contra Madero, já que desconsiderava seus esforços pacificadores na região. Com pouco confronto o exército tomou a região, já que os guerrilheiros zapatistas ainda não estavam prontos para uma luta aberta, e optaram quase sempre, naquele momento, por se retrair. No entanto, a decisão desastrada do presidente interino fez apenas acentuar a desconfiança e a hostilidade com relação ao exército federal. A

\footnotetext{
127 MAGAÑA, Gildardo. Emiliano Zapata y el Agrarismo en México (Selección). Biblioteca del Pensamiento Legislativo y Político Mexicano. $1^{a}$. Ed. Ciudad de México: 2014. P. 30-32.

${ }^{128}$ A íntegra do Manifesto elaborado por Emiliano Zapata em 27 de agosto de 1911 está disponível aqui: CARMONA, Doralicia. Memoria política de México. Guanajuato: Universidade de Guanajuato, 2014. http://www.memoriapoliticademexico.org/Textos/6Revolucion/1911APM.html Consulta realizada em 21/11/2015.
} 
tentativa de resolução amigável entre Madero e Zapata naufragou. Embora à moda das guerrilhas, o "Ejército Libertador" de Zapata continuou armado e atuante.

\subsection{A Presidência de Francisco Madero}

Francisco Madero assumiu a Presidência do México - logo depois das eleições de $1^{\text {o }}$ e 15 de outubro - em 6 de novembro de 1911. Alguns dias antes de sua posse, em 31 de outubro, revolucionários apoiadores de Emílio Vazquez Gómez, do agora dissidente Partido Antireeleicionista, proclamaram o Plan de Tacubaya ${ }^{129}$, em um povoado próximo à Cidade do México. O plano afirmava que as eleições realizadas naquele mês, as quais haviam elegido Madero, eram nulas. Reiteravam ainda os compromissos firmados no Plan de San Luís Potosí e acrescentavam a eles novas propostas, sobretudo em relação aos direitos dos trabalhadores mexicanos. Não fazia nem quinze dias que Madero havia sido eleito, um grupo já afirmava publicamente que ele teria traído a revolução que começou menos de um ano antes.

Passada a disputa eleitoral, esta foi a primeira de muitas manifestações públicas e planos que questionaram a legitimidade do governo de Francisco Madero. Entre os documentos e grupos que consideravam que Madero não estava sendo fiel aos ideais revolucionários defendidos por ele um ano antes, estavam o já mencionado (I) Plan de Tacubaya, de 31 de outubro de 1911; (II) o Plan de Ayala ${ }^{130}$, de 28 de novembro de 1911, elaborado pelos zapatistas ao sul do país e (III) o Plan de la Emplacadora, ou Plan Orozquista ${ }^{131}$, elaborado pelo líder do norte Pascual Orozco, em 25 de março de 1912. Também entre aqueles que defendiam a restauração de um regime político garantidor de privilégios, como era o de Porfírio Dìaz, havia organizações políticas e

\footnotetext{
${ }^{129}$ A íntegra do Plan de Tacubaya, de 31 de outubro de 1911, pode ser encontrada aqui: CARMONA, Doralicia. Memoria política de México. Guanajuato: Universidade de Guanajuato, 2014. http://www.memoriapoliticademexico.org/Textos/6Revolucion/1911PDT.html Consulta realizada em 21/11/2105.

${ }^{130}$ A íntegra do Plan de Ayala, publicado pelos zapatistas em 28 de novembro de 1911, pode ser consultada aqui: CARMONA, Doralicia. Memoria política de México. Guanajuato: Universidade de Guanajuato, 2014. http://www.memoriapoliticademexico.org/Textos/6Revolucion/1911PDA.html Consulta realizada em 21/11/2015.

${ }^{131}$ A íntegra do Manifesto redigido por Pascual Orozco em 8 de março de 1912 e a íntegra do Plan de la Emplacadora, também de Orozco, de 25 de março de 1912 podem ser consultados aqui: CARMONA, Doralicia. Memoria política de México. Guanajuato: Universidade de Guanajuato, 2014. http://www.memoriapoliticademexico.org/Textos/6Revolucion/1912-M-PO.html e http://www.memoriapoliticademexico.org/Textos/6Revolucion/1912MPO.html Consulta realizada em $21 / 11 / 2015$.
} 
planos públicos sendo elaborados. O general Bernardo Reyes, que já havia disputado o posto de vice-presidente de Porfírio Díaz, publica seu Plan de la Soledad ${ }^{132}$, que negava a legitimidade de Francisco Madero, em 16 de novembro de 1911. Além dele, Félix Díaz, sobrinho de Porfírio Díaz, se insurgiu contra o regime de Madero em 16 de outubro de $1912^{133}$, mas foi contido pelas tropas federais.

De fato, a popularidade de Madero já no início de seu mandato não era a mesma que possuía em meados de 1911, quando saiu vitorioso da Ciudad Juárez. O novo presidente era atacado e criticado pela imprensa, pelos revolucionários que participaram da luta pela destituição de Díaz e também por aqueles que queriam restaurar a ordem anterior. Muitos setores da sociedade mexicana criticavam-no, o que tornava sua situação política bastante delicada. Além disso, segundo analisa o historiador J. Herzog, o mesmo Madero que acabava de liderar uma insurreição vitoriosa contra o esclerosado porfiriato, embarcava agora na infeliz tentativa de construir um governo de conciliação com a ordem anterior. Ao compor seu gabinete, boa parte dos Ministros não tinham participado e nem sequer eram simpáticos à revolução realizada.

La verdad es que aquel Gobierno fue una prolongación del antiguo régimen y que tuvo que actuar bajo la presión de fuerzas antagónicas, lo cual hizo extremamente difícil su acción tanto política como adminsitrativa.(...)

Recuerdo que por aquellos días comenzó a decirse: Madero va a governar con sus enemigos contra sus amigos. ${ }^{134}$

Em meio a essa tentativa de conciliação de forças antagônicas, Madero realizou a principal bandeira política revolucionária: o fim da reeleição. Assim, um dos primeiros atos de Francisco Madero como presidente foi reformar os artigos da Constituição que autorizavam - ou eram silentes - a respeito da recondução de presidentes, vicepresidentes e governadores a postos anteriormente ocupados. A

\footnotetext{
132 A íntegra do Plan de la Soledad, publicado em 16 de novembro de Bernardo Reyes, pode ser encontrada aqui: CARMONA, Doralicia. Memoria política de México. Guanajuato: Universidade de Guanajuato, 2014. http://www.memoriapoliticademexico.org/Textos/6Revolucion/1911PBR.html Consulta realizada em 21/11/2015.

133 Antes de se insurgir, Félix Díaz publicou um manifesto em 16 de outubro, conhecido como Plan Felicista. A íntegra de seu documento está disponível aqui: BIBLIOTECA GARAY. 500 años de México en documentos. México, 2011. http://www.biblioteca.tv/artman2/publish/1912_213/Proclama_de_F_lix_D_az_o_Plan_Felicista_1843.sh tml Consulta realizada em 21/11/2015.

${ }^{\frac{1134}{13}}$ SILVA HERZOG, Jesus. Breve Historia de la Revolución Mexicana - Los antecedentes y la Etapa Maderista. Fondo de Cultura Económica do México. 15ª . Reimpressão. Cidade do México, 1997. P. 231.
} 
reforma estimulada por Madero e aprovada pelo Congresso foi publicada em 27 de novembro de 1911, vinte e um dias após ele assumir a presidência:

\section{Reforma do art. 78 e do art. 109 da Constituição Mexicana de 1857, em 27 de novembro de 1911}

Artículo 78. El Presidente y el Vicepresidente entrarán á ejercer sus encargos el $1^{\circ}$. de diciembre, durarán en él seis años y nunca podrán ser reelectos. El Presidente nunca podrá ser electo Vicepresidente. El Vicepresidente no podrá ser electo Presidente para el período inmediato. Tampoco podrá ser electo Presidente ni Vicepresidente el Secretario del Despacho encargado del Poder Ejecutivo al celebrarse las elecciones.

Artículo 109. Los Estados adoptarán para su régimen interior la forma de Gobierno republicano, representativo, popular. El período para el cargo de Gobernador no podrá exceder de seis años. Son aplicables á los Gobernadores de los Estados y á los funcionarios que los substituyan, las prohibiciones que para el Presidente, el Vicepresidente y el Presidente interino de la República establece respectivamente el artículo $78 .{ }^{135}$

A proibição de reeleição e de eleição como Vice-Presidente para aqueles que ocuparem uma vez a função de Presidente da República faz com que os seis anos de mandato sejam, de fato, os únicos de suas vidas para entrar na história. No que diz respeito à política local, regulada pelo artigo 109 da então Constituição de 1857, o novo texto afirma que devem existir governos republicanos, representativos e populares nos diferentes entes federativos do México. Também os governadores e vice-governadores não poderão ser reeleitos.

Já no fim de 1911, o governo de Madero passou por um teste de legitimidade. Bernardo Reyes que, durante o fim do porfiriato, tinha algum prestígio por ser militar próximo a Porfírio Díaz, tendo sido cotado para assumir como seu vice-presidente, vai até os Estados Unidos preparar um golpe armado. O governo norte-americano apreende armas, munições e prende alguns apoiadores de seu projeto. Desmantelada a organização incipiente nos Estados Unidos, Bernardo Reyes volta ao território mexicano e tenta, de lá, organizar a revolta. Publica um manifesto e tenta arregimentar partidários para sua luta. A organização é fracassada e rapidamente derrotada pelas tropas federais de F. Madero. Bernardo Reyes é preso, julgado e condenado à morte pelo episódio de rebelião. Madero poupa sua vida, mas o mantém na prisão.

\footnotetext{
${ }^{135}$ Íntegra do ato que sanciona as emendas constitucionais nos artigos 78 e 109 da Constituição Mexicana de 1857, assinado por Francisco Madero em 27 de novembro de 1911, está disponível aqui: MÉXICO. Secretaria de Gobernación: Unidade General de Asuntos Jurídicos. http://www.ordenjuridico.gob.mx/Constitucion/CH13.pdf Consulta realizada em 21/11/2015.
} 
Não só os que queriam restaurar a ordem anterior estavam insatisfeitos, porém. Madero parecia acreditar que, com a mudança constitucional promovida logo no início de seu mandato - que determinava a impossibilidade de reeleição e, pelo menos teoricamente, o sufrágio efetivo nas eleições estaduais -, estaria cumprindo dois dos ideais mais importantes do processo revolucionário. Contudo, os planos de seus correligionários, que não tinham dúvidas de que ele seria fiel à sua máxima da nãoreeleição, não parecem concordar com essa avaliação um tanto estreita dos princípios e motivos principais que haviam motivado a rebelião.

\section{Plan de Tacubaya, de 31 de outubro de 1911}

Madero, para engañar una vez más al pueblo, llama contrarrevolución a nuestra protesta, y sabe que miente: no combatimos contra la revolución, sino por ella, y continuamos la revolución que él hace fracasar: nuestra bandera es el Plan de San Luís, consagrado por la sangre de nuestros compatriotas, cuyo cumplimiento exigimos. La contra-revolución la ha hecho él, que se hace llamar leader de la revolución; él, que celebra festines sobre los cadáveres de Puebla; él, que ordena la aprehensión de los partidarios del Lic. Emilio Vázquez; él, que encarcela a los periodistas; él, que contrata empréstitos para comprar favoritos y para hacerse de tierras que explotar y de lacayos que dirigir; él, que promete distribuir terrenos y emplea el dinero del pueblo en dar a su hermano Gustavo para redimir las hipotecas de la familia y para tener a sueldo en Nueva Era a los ignominiosos calumniadores de oficio y a los probados enemigos de la revolución. (...)

I. Son y se declaran nulas las elecciones de $1^{\circ}$ y 15 de octubre y nulos todos los actos que de ellas se deriven. ${ }^{136}$

\section{Plan de Ayala, de 28 de novembro de 1911}

(...) teniendo en consideración: que el llamando Jefe de la revolución libertadora de México, Dn Francisco I. Madero, no llevó a felíz termino la revolución que gloriosamente incitó con el apoyo de Dios y del pueblo; puesto que dejó en pie la mayoría de poderes gubernativos y elementos corrompidos de opresión del gobierno dictatorial de Porfirio Díaz, que no son, ni pueden ser en manera alguna la legítima representación de la soberanía nacional,

(...) declaramos al susodicho Francisco I. Madero, inepto para realizar las promesas de la revolución de que fue autor, por haber traicionado los principios con los cuales burló la fe del pueblo, y pudo haber escalado el poder, incapaz para gobernante por no tener ningún respeto a la ley y a la justicia de los pueblos, y traidor a la Patria por estar a sangre y fuego humillando a los mexicanos que desean sus libertades, por complacer a los científicos, hacendados y caciques que

\footnotetext{
${ }^{136}$ A íntegra do Plan de Tacubaya, de 31 de outubro de 1911, pode ser encontrada aqui: CARMONA, Doralicia. Memoria política de México. Guanajuato: Universidade de Guanajuato, 2014. http://www.memoriapoliticademexico.org/Textos/6Revolucion/1911PDT.html Consulta realizada em $21 / 11 / 2105$.
} 
nos esclavizan, y desde hoy comenzamos a continuar la revolución principiada por él, hasta conseguir el derrocamiento de los poderes dictatoriales que existen.

$2^{\circ}$. Se desconoce como Jefe de la Revolución al C. Francisco I. Madero y como Presidente de la República por las razones que antes se expresan, procurando el derrumbamiento de éste funcionario.

$3^{\circ}$. Se reconoce como Jefe de la Revolución libertadora al ilustre general Pascual Orozco, segundo del caudillo Dn. Francisco I. Madero, y en caso de que no acepte este delicado puesto, se reconocerá como Jefe de la Revolución al C. general Emiliano Zapata. $^{137}$

\section{Manifesto de Pascual Orozco, de março de 1912}

El Gobierno de Francisco I. Madero traicionó a la revolución, traicionó al pueblo, traicionó a los que con abnegación y sacrificio lo elevaron y se vendió a los enemigos de ayer, a los que por todos los medios lo combatieron. Para esos enemigos, para los sicarios de la pasada tiranía, fueron los halagos y las concesiones y para los que lucharon, para los que derramaron su sangre y expusieron sus vidas por la libertad anhelada, para los humildes hijos del pueblo, fueron los desprecios y los abandonos. El Plan de San Luis Potosí, cuyas promesas enardecieron a los desheredados e hicieron soñar a tantas víctimas del despojo autoritario en una reivindicación efectiva y próxima; el Plan de San Luis Potosí que ofrecía solucionar el problema agrario en provecho del pueblo, distribuyendo tierras, castigando usurpaciones e impartiendo justicia a los expoliados por e! abuso del poder; ese plan famoso que fue la bandera de la rebelión en los días difíciles y terribles en la lucha, fue relegado al olvido tan pronto como Madero alcanzó la Presidencia; ${ }^{138}$

Os trechos dos três planos citados acima indicam que uma parte significativa dos combatentes revolucionários que haviam lutado por Madero ao norte, centro e sul do país estavam dispostos a continuar a revolução, agora contra ele, pouco tempo depois de sua subida à presidência. As razões do descontentamento estavam ligadas à composição do novo gabinete de ministros, ao afastamento de Vázquez Gómez (e a cisão do Partido Antireeleicionista), à forma com que o novo governo vinha lidando com os problemas agrários. Para os subscritores dos três planos revolucionários, não havia indícios de que

\footnotetext{
137 A íntegra do Plan de Ayala, publicado pelos zapatistas em 28 de novembro de 1911, pode ser consultada aqui: CARMONA, Doralicia. Memoria política de México. Guanajuato: Universidade de Guanajuato, 2014 http://www.memoriapoliticademexico.org/Textos/6Revolucion/1911PDA.html Consulta realizada em 21/11/2015.

${ }^{138}$ A íntegra do Manifesto redigido por Pascual Orozco em 8 de março de 1912 e a íntegra do Plan de la Emplacadora, também de Orozco, de 25 de março de 1912 podem ser consultados aqui: CARMONA, Doralicia. Memoria política de México. Guanajuato: Universidade de Guanajuato, 2014. http://www.memoriapoliticademexico.org/Textos/6Revolucion/1912-M-PO.html e http://www.memoriapoliticademexico.org/Textos/6Revolucion/1912MPO.html Consulta realizada em $21 / 11 / 2015$
} 
Madero mudaria sua forma de agir em breve, de que responderia em algum momento de seu mandato aos anseios dos revolucionários.

Entre os sinais que Madero dava de que não mudaria de orientação, estava a manutenção do exército de federales, antes fiel a Díaz, bem como a já mencionada composição de seu governo com Ministros porfiristas. Além disso, apesar de ter instaurado órgãos como a Comisión Nacional Agraria e a Comisión Agraria Ejecutiva para estudar a questão agrária e propor mudanças, havia muitos debates sobre quais os melhores caminhos e políticas a implementar, e quase todos passavam pela detenção privada da propriedade, sem a possibilidade de propriedades coletivas. Nesse contexto, Madero não mobilizou esforços para apresentar propostas e soluções efetivas para a questão fundiária no México. Queria sobretudo se estabilizar no poder por meio de um governo de coalizão, logo depois de um processo revolucionário. Por falta de análise política sobre o que o momento político do México demandava, perdeu legitimidade entre seus antigos apoiadores, entre aqueles que lutaram a seu lado. Os três manifestos de Tacubaya, de Ayala, de Orozco - são prova disso.

Dado esse cenário, não havia alternativa para Madero e seu exército de federales a não ser combater os insurgentes. Em Ayala, território de zapatistas, aldeias inteiras foram atacadas simplesmente por serem suspeitas de apoiar o exército de Zapata. E os confrontos no sul se estenderam até 1912. O mesmo ocorreu com Pascual Orozco, que se insurgiu em março de 1912 em Chihuahua. Além deles, em outubro de 1912, forças reacionárias lideradas por Félix Díaz, sobrinho de Porfírio, iniciaram um processo insurreicional contra o governo de Madero. Assim, entre novembro de 1911, quando assumiu a presidência, e novembro de 1912, Madero e as tropas governamentais já tinham recorrido inúmeras vezes à força para garantir sua permanência no poder.

Some-se a isso o fato de o presidente ter desagradado também interesses econômicos e internacionais. Em 3 de junho de 1912, editou um decreto no qual cria um imposto sobre a extração de petróleo no território mexicano, voltando-se contra a política ultraliberal de Porfírio Díaz no que tange à exploração de riquezas minerais. $\mathrm{O}$ decreto instituía um "Impuesto Especial del Timbre sobre el petróleo crudo de producción nacional, a razón de veinte centavos por tonelada, conforme al reglamento 
que expida el Ejecutivo." ${ }^{\prime 139}$. Diante de tantos inimigos, eis o balanço que J. Herzog faz do primeiro ano de governo maderista:

La renovación del Poder Legislativo y la elección de algunos gobernadores de los Estados, no siempre se ajustaron a la doctrina del sufragio efectivo. En ciertos casos se hizo sentir la presión del Gobierno central. Esto sumado a la incomprensión de los problemas económicos y sociales y a la actitud en ocasiones poco circunspecta del Presidente, fueron acumulando en el horizonte político vientos huracanados.

Manuel Calero escribió: 'Al terminar el primer año de su Gobierno, Madero era el Presidente más impopular que México ha tenido, sencillamente, porque ninguno había sido visto con tan poco respecto. 140

Ao sofrer um golpe realizado pelas forças do exército de federales que deveriam defender seu governo, em fevereiro de 1913, Francisco Madero tinha poucos aliados dispostos a defendê-lo.

\subsection{A Decena Trágica, o governo autoritário de Victoriano Huerta e a Revolução Constitucionalista}

Em 8 de fevereiro de 1913 a Cidade do México já não respirava tranquila. Entre os membros do exército, havia rumores de que seria realizado um golpe contra Francisco Madero. A informação se espalhou e deixou os habitantes da capital tensos.

O que era um rumor de fato aconteceu: sob a liderança militar do General Manuel Mandragón, parte do exército que estava na Cidade do México se sublevou. Entre 9 e 19 de fevereiro de 1913 houve inúmeros confrontos armados na cidade, com saldo de aproximadamente dois mil mortos e seis mil feridos. Esses dias da história mexicana ficaram conhecidos como Decena Trágica. Entre os mortos estava Bernardo Reyes, que fora libertado de sua prisão pelo exército em armas, no momento da insurreição. Bernardo Reyes e Félix Díaz, antigos opositores de Madero, participaram da organização política do golpe. Enquanto uma parte do exército se insurgia contra o

\footnotetext{
${ }^{139}$ Decreto de 3 de junho de 1912, assinado por Francisco Madero, sobre instituição de impostos, disponível aqui: CARMONA, Doralicia. Memoria política de México. Guanajuato: Universidade de Guanajuato, 2014. http://www.memoriapoliticademexico.org/Textos/6Revolucion/1912-PI-IEPC.html Consulta realizada em 22/11/2015.

${ }^{140}$ SILVA HERZOG, Jesus. Breve Historia de la Revolución Mexicana - Los antecedentes y la Etapa Maderista. Fondo de Cultura Económica do México. 15a. Reimpressão. Cidade do México, 1997. P. 278.
} 
governo de Madero, parte permaneceu fiel a ele, o que explica o grande número de mortos e feridos.

Con esto se iniciaba la famosa 'Decena Trágica', diez trágicos días que iban a conmover hasta sus cimientos a México, diez días de indecible sufrimiento para una población asombrada que no sabía por qué se luchaba, por qué se derramaba tanta sangre, por qué no se buscaba una pronta solución. ${ }^{141}$

Lauro Villar foi um dos comandantes que esteve à frente das tropas leais a Francisco Madero. Em meio aos combates do primeiro dia, foi ferido e, por isso, substituído por Victoriano Huerta. Estando à frente das tropas leais a Madero, Huerta era deliberadamente inefetivo em suas estratégias militares. O conflito se prolongou, mesmo com o exército leal ao presidente eleito tendo mais homens e mais estrutura. Mesmo com inúmeros indícios da deslealdade de Huerta, Madero manteve-o no comando. Até que, em 18 de fevereiro de 1913, Huerta trai explicitamente Madero e o que era combate materializa-se como golpe efetivo. Após um confronto armado em seu gabinete que, talvez, já tivesse como objetivo sua morte, Madero torna-se refém do general Aureliano Blanquet. O episódio contou com a participação do então embaixador norte-americano Henry Lane Wilson, o qual anuncia - sem consultar o país que representava - que os Estados Unidos poderiam intervir no conflito mexicano, caso o presidente Francisco Madero se recusasse a renunciar.

Em razão da traição de Huerta e da ausência de defesa militar de sua posição política, Francisco Madero e o vice-presidente Pino Suárez são presos, na intendência do palácio presidencial, em 18 de fevereiro de 1913. Na noite do mesmo dia, aqueles que haviam organizado política e militarmente o golpe se reunem na embaixada norteamericana para decidir os próximos passos. Firmam então o que ficou conhecido como Pacto de la Ciudadela ou ainda Pacto de la Embajada.

\section{Pacto de la Ciudadela o Embajada, de 18 de fevereiro de 1913 \\ PRIMERO. - Desde este momento se da por inexistente y desconocido el Poder Ejecutivo que funcionaba, comprometiéndose los elementos representados por los generales Díaz y Huerta a impedir por todos los medios cualquier intento para el restablecimiento de dicho Poder.}

SEGUNDO. - A la mayor brevedad se procurará solucionar en los mejores términos legales posibles, la situación existente y los señores

\footnotetext{
${ }^{141}$ GARFIAS, Luis. La Revolución Mexicana - compendio histórico político militar. $7^{\text {a }}$. reimpresión. Ciudad de México: Panorama Editorial, 2001. P. 83.
} 
generales Díaz y Huerta, pondrán todos sus empeños a efecto de que el segundo, asuma antes de setenta y dos horas la Presidencia Provisional de la República, con el siguiente gabinete (...)

TERCERO. - Entre tanto se soluciona y resuelve la situación legal, quedan encargados de todos los elementos y autoridades de todo género, cuyo ejercicio sea requerido para dar garantías, los señores generales Huerta y Díaz (Félix).

CUARTA. -El señor general Félix Díaz, declina el ofrecimiento de formar parte del gabinete provisional en caso de que asuma la presidencia provisional el señor general Huerta, para quedar en libertad de emprender sus trabajos en el sentido de sus compromisos con su partido en la próxima elección, propósito que desea expresar claramente y del que quedan bien entendidos los firmantes. ${ }^{142}$

Os grandes artífices do golpe são mencionados explicitamente no pacto firmado na embaixada americana: Victoriano Huerta e Félix Díaz, sobrinho de Porfírio Díaz. Quanto a Félix, deixa por escrito sua intenção de concorrer no processo eleitoral que supostamente ocorreria em seguida, o que está explícito no artigo quarto do pacto. $\mathrm{O}$ poder executivo, a presidência e vice-presidência da República exercidas por Francisco Madero e Pino Suárez, democraticamente eleitos, são consideradas inexistentes e desconhecidas.

Quanto à legalidade ou constitucionalidade da decisão que eles tornavam pública por meio do documento, afirmam que irão "resolver" a questão brevemente, "nos melhores parâmetros legais possíveis". Ou seja, os líderes reunidos naquele dia 18 assumem ter realizado um movimento ilegal e inconstitucional, mas prometem apresentar uma resolução formal para a questão tão logo seja possível. A legalidade dos atos é algo a se resolver depois de configurado o novo poder de fato. $\mathrm{O}$ desrespeito à ordem jurídica mexicana é assumida, sem meias palavras, no documento oficial elaborado por aqueles que realizam o golpe.

No dia seguinte, a solução formal para a situação fática foi encontrada: com a promessa de ter suas vidas poupadas, Francisco Madero e Pino Suárez assinaram as respectivas renúncias, que seriam apresentadas à Câmara dos Deputados. Com a renúncia, de acordo com norma da Constituição, o ministro das relações exteriores Pedro Lascuráin deveria assumir a presidência. Foi o que aconteceu por alguns minutos. Logo após assumir o posto, o ministro indicou Victoriano Huerta para a Secretaria de

${ }^{142}$ A íntegra do Pacto de la Ciudadela ou da Embajada, de 18 de fevereiro de 1913 pode ser encontrada aqui: CARMONA, Doralicia. Memoria Política de México. Guanajuato: Universidade de Guanajuato, 2014. http://www.memoriapoliticademexico.org/Textos/6Revolucion/1913PCE.html Consulta realizada em 23/11/2015. 
Governo e logo depois renunciou também, cedendo o cargo de presidente interino ao recém-empossado secretário.

O Embaixador cubano, Márquez Sterling, tentou salvar a vida de Francisco Madero e Pino Suárez, que estavam presos

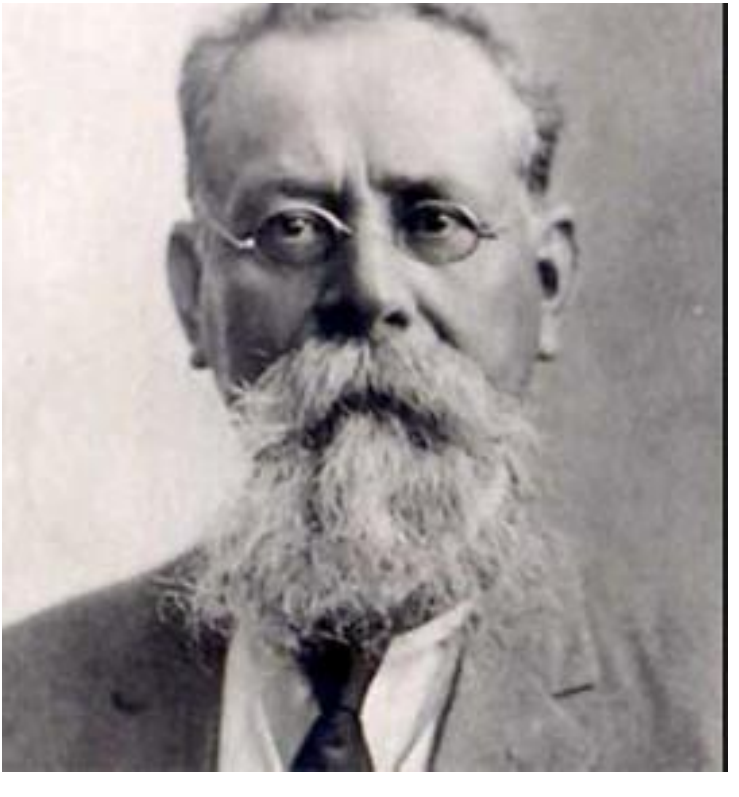

Venustiano Carranza no Palácio. Convocou um navio de guerra cubano para tirar os políticos do país. Seus esforços foram vãos, porém. Na noite de 22 de fevereiro de 1913 Madero e Pino Suárez, que já haviam assinado suas cartas de renúncia no dia 19 , foram mortos por membros do exército golpista. Dessa forma, em fevereiro de 1913, tem início o governo autoritário de Victoriano Huerta.

Venustiano Carranza, então governador do Estado de Coahuila, desconhece a Presidência de Victoriano

Huerta ainda no dia 19 de fevereiro de 1913, e se prepara para um enfrentamento militar da nova ordem federal, que considera ilegítima. A Casa del Obrero Mundial, fundada em setembro de 1912, publica também em fevereiro um posicionamento público contrário à deposição do Presidente Francisco Madero. Um dia após o assassinato dos dois políticos, Luis Manoel Rojas, deputado da Câmara dos Deputados mexicana, publica o texto "Yo Acuso", em que afirma ser o embaixador norte-americano Henry Lane Wilson o "responsable moral de la muerte de los señores Francisco I. Madero y José María Pino Suárez, que fueron electos por el pueblo" ${ }^{143}$.

Já em março de 1913, partidários de Venustiano Carranza, que também não reconhecem a legitimidade do Presidente Huerta, atacam Saltillo, a capital de Coahuila. Os revolucionários são, no entanto, derrotados e recuam até a fazenda de Guadalupe, onde será escrito e publicado o plano revolucionário que oferece as linhas básicas da organização militar dos insurgentes. Por esta pequena exposição dos primeiros dias de

\footnotetext{
143 A íntegra do texto "Yo Acuso", de Luis Manoel Rojas, de 23 de fevereiro de 1913, pode ser encontrada aqui: CARMONA, Doralicia. Memoria Política de México. Guanajuato: Universidade de Guanajuato, 2014. $\quad$ http://www.memoriapoliticademexico.org/Textos/6Revolucion/1913-YA-.html Consulta realizada em 23/11/2015.
} 
governo de Victoriano Huerta, fica claro que sua permanência no poder, que durou até julho de 1914, aproximadamente 17 meses, seria bastante conflituosa.

Em 4 de março de 1913, Zapata e o seu exército libertador do sul apresentam a sua versão do golpe sofrido por Madero: afirmam que, se Madero era ruim, o golpe engendrado por Victoriano Huerta e Félix Díaz nada mais quer do que reestabelecer o regime porfirista anterior. Ele viria instaurar, segundo o manifesto, "el triunfo de una dictadura sobre otra dictadura, que abofetea a la civilización con la aplicación de la ley fuga y el terror más escandaloso" ${ }^{\text {"144 }}$. Encerram o documento desconhecendo o governo de Huerta, contra quem se declaram em guerra, e afirmam, por fim, que "la Revolución no depondrá las armas (...) hasta recobrar las usurpaciones de tierras, montes y aguas del mismo y lograr por fin la solución del problema agrario que los enemigos del pueblo creen una utopía" ${ }^{145}$.

Carranza e um grupo de revolucionários já em confronto armado com o regime recém-instalado publicam, em 26 de março de 1913, o Plan de Guadalupe. Nele, além da presidência de Victoriano Huerta, também é recusada a legitimidade aos poderes legislativo e judiciário que compactuaram com o golpe. No mesmo documento são convocados para a luta revolucionários e descontentes com a reviravolta política sofrida por Madero. $\mathrm{O}$ artigo $4^{\circ}$ institui o Exército Constitucionalista e sua liderança: "Para la organización del ejército encargado de hacer cumplir nuestros propósitos, nombramos como Primer Jefe del Ejército que se denominará 'Constitucionalista', al ciudadano

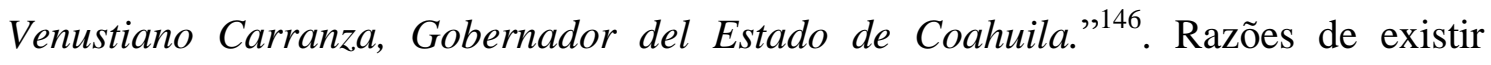
explicitadas, Exército Constitucionalista criado como entidade, Carranza indicado para a função de "Primer Jefe del Ejército Constitucionalista". Todas as bases para uma insurreição organizada contra o governo de Huerta garantidas por meio de um só documento, com pretensão de organizar a luta nacionalmente.

\footnotetext{
144 A íntegra do manifesto de Zapata, em 4 de março de 1913, pode ser encontrada aqui: CARMONA, Doralicia. Memoria Política de México. Guanajuato: Universidade de Guanajuato, 2014. http://www.memoriapoliticademexico.org/Textos/6Revolucion/1913-M-ZEDGH.html Consulta realizada em 23/11/2015.

${ }^{145}$ A íntegra do manifesto de Zapata, em 4 de março de 1913, pode ser encontrada aqui: CARMONA, Doralicia. Memoria Política de México. Guanajuato: Universidade de Guanajuato, 2014. http://www.memoriapoliticademexico.org/Textos/6Revolucion/1913-M-ZEDGH.html Consulta realizada em 23/11/2015.

${ }^{146}$ A íntegra do Plan de Guadalupe, de 26 de março de 1913, pode ser encontrada aqui: CARMONA, Doralicia. Memoria Política de México. Guanajuato: Universidade de Guanajuato, 2014. http://www.memoriapoliticademexico.org/Textos/6Revolucion/1913PGP.html Consulta realizada em 23/11/2015.
} 
Em 30 de maio de 1913, é publicada o documento Reformas al Plan de Ayala ${ }^{147}$, em que os zapatistas reforçam a participação na luta constra o governo despótico de Huerta, projetando no novo estadista as críticas feitas no original a Francisco Madero. Os objetivos da luta zapatista permanecem os estipulados no original Plan de Ayala, mas os revolucionários desconhecem o general Pascual Orozco, que havia sido indicado inicialmente como líder militar, por ter traído a causa revolucionária e aderido ao governo de Huerta. Nomeiam no novo documento Emiliano Zapata como "Jefe de la Revolución". É importante notar que, embora os zapatistas componham a luta contra Huerta, não se consideram submetidos a Carranza e nem declaram fazer parte do Exército Constitucionalista.

\section{Reformas al Plan de Ayala, de 30 de maio de 1913}

Son aplicables, en lo conducente, los conceptos contenidos en este artículo al usurpador del poder público, general Victoriano Huerta, cuya presencia en la Presidencia de la República acentúa cada día y más su carácter contrastable con todo lo que significa ley, la justicia, el derecho y la moral, hasta el grado de reputársele mucho, peor que Madero. ${ }^{148}$

O Plan de Ayala original, publicado em novembro de 1911, trazia ao final de seu texto o lema "Justicia y Ley". O artigo primeiro do novo documento, que apresenta reformas ao plano original, expõe publicamente que irá lutar contra o governo de Victoriano Huerta. Entre as motivações para a luta, o fato de o governo de Huerta representar o desrespeito "a tudo o que significa lei, justiça, direito e moral". Direito, lei, justiça e moral: conceitos agrupados talvez porque são referências normativas que, apesar de diferentes, orientam as condutas dos indivíduos para garantir a convivência em sociedade. Os zapatistas não parecem, nesse momento, estabelecer diferença entre os conceitos: Huerta desrespeita a todos, está em desacordo explícito com todos os códigos sociais. No entanto, os zapatistas escolheram a justiça e a lei como lema. Curioso pensar que a legalidade que defendem foi usada, no caso de Morelos, assim como inúmeros outros estados mexicanos, para tomar suas terras. Qual legalidade e qual

\footnotetext{
${ }^{147}$ Íntegra da Reforma al Plan de Ayala, de 30 de maio de 1913, pode ser encontrada aqui: CARMONA, Doralicia. Memoria Política de México. Guanajuato: Universidade de Guanajuato, 2014. http://www.memoriapoliticademexico.org/Textos/6Revolucion/1913RPA.html Consulta realizada em 23/11/2015.

${ }^{148}$ Íntegra da Reforma al Plan de Ayala, de 30 de maio de 1913, pode ser encontrada aqui: CARMONA, Doralicia. Memoria Política de México. Guanajuato: Universidade de Guanajuato, 2014. http://www.memoriapoliticademexico.org/Textos/6Revolucion/1913RPA.html Consulta realizada em $23 / 11 / 2015$.
} 
justiça defendem os zapatistas? ${ }^{149}$ Um dia antes da publicação do documento de Morelos, em 29 de maio, Francisco Villa se insurge contra Huerta em Chihuahua, sem documento que expusesse suas razões.

Após inúmeros conflitos armados espalhados pelo país e manifestações em protesto ao desaparecimento (e morte) do deputado Belisario Domínguez Palencia, que era crítico ao governo de Huerta, forças policiais dissolvem a Câmara dos Deputados mexicana, em outubro de 1913. Em apoio à Câmara, o Senado do país se autodissolve em seguida, deixando explícita a situação de concentração de poder no executivo e o autoritarismo de Huerta. No dia seguinte, três decretos do então presidente tentam justificar juridicamente o golpe.

No período do governo de Victoriano Huerta, o México viveu uma verdadeira guerra de decretos, uma disputa pela legalidade - e pela legitimidade que ela engendra. Carranza, que era auto-proclamado o Primer Jefe del Ejército Constitucionalista, utilizava habilmente a legalidade para arregimentar tropas e forças militares para seu projeto. No período em que se autoproclamou líder do movimento de resistência ao governo usurpador, expediu uma série de decretos que, para além de organizar a luta, indicavam a possibilidade de instalação de um poder estatal legítimo no futuro e prometiam recompensas para aqueles que se juntassem ao combate.

Assim, seis decretos foram publicados enquanto o conflito armado acontecia. $\mathrm{O}$ primeiro decreto, de 20 de abril de $1913^{150}$, reconhece as patentes de quem pertencia ao exército de los federales, mas não era fiel a Huerta. Também reconhecia as patentes de quem tinha participado do exército revolucionário maderista. A partir de uma norma simples, Carranza consegue arregimentar não apenas braços e pernas para o combate, mas estimula que altas patentes saiam das fileiras oficiais e integrem o exército revolucionário, sem ter que abrir mão de seus altos postos. $\mathrm{O}$ decreto estabelece ainda um prazo máximo para que esta transição seja feita: 30 dias a partir da publicação do ato normativo. Assim, Carranza estimula a traição rápida, caso contrário não seria reconhecida, daqueles que estavam no exército federal, pois ela não implicaria a perda de posto militar. Quatro dias depois, em 24 de abril, publica um decreto que apenas

\footnotetext{
${ }^{149}$ O capítulo dois, que tratará da regulamentação da terra no México do século XIX e também no início do XX, buscará responder a partir de mais informações esta interrogação.

${ }^{150}$ A íntegra do decreto n. 1 publicado por Venustiano Carranza, de 20 de abril de 1913, pode ser encontrada aqui: CARMONA, Doralicia. Memoria Política de México. Guanajuato: Universidade de Guanajuato, 2014. http://www.memoriapoliticademexico.org/Textos/6Revolucion/1913-D-VC-EC.html Consulta realizada em 23/11/2015.
} 
reafirma o que já estava no Plan de Guadalupe: nenhum dos atos dos três poderes da República deve ser considerado válido pelos revolucionários.

Dois dias mais tarde, em 26 de abril, como um legítimo governo paralelo, cria um papel moeda para financiar a própria atividade revolucionária. Em sua exposição de motivos, diz que um dos problemas que enfrenta o exército constitucionalista é "la adquisición de dinero para sostener los gastos de guerra y administración". Por isso, decide criar "la circulación de papel moneda, y se autoriza por de pronto una emisión por valor de cinco millones de pesos." ${ }^{151}$. Com cinco milhões de pesos em uma moeda própria, cujo lastro era a própria vitória futura da atividade revolucionária, Carranza passa a poder financiar seus empreendimentos revolucionários.

No quarto decreto, de 10 de maio de 1913, o Primer Jefe faz mais uma promessa, que se realizará se, e somente se, a luta constitucionalista for vitoriosa: autoriza aqueles que sofrerem danos com os enfrentamentos armados a cobrar indenizações do futuro Estado constitucional que se organizará. Em 14 de maio, Carranza reintroduz, no ordenamento jurídico mexicano paralelo que ele mesmo estava criando, uma lei de 1862, inicialmente sancionada por Benito Juárez. Na lei, são estabelecidas penas contra os "traidores da pátria"152, assim caracterizados todos aqueles que apoiam ou apoiaram deliberadamente o governo de Victoriano Huerta, sobretudo no momento do golpe realizado contra Madero. Na lei de 1862, duas são as penas possíveis: 8 anos de prisão ou pena de morte. Por fim, o decreto de 4 de julho de $1913^{153}$ organiza o Ejército Constitucionalista em sete áreas de atuação. Os corpos do Exército Constitucionalista foram divididos e caracterizados pelo nome da região em que atuam: Divisões Noroeste, Nordeste, Ocidente, Oriente, Centro, Sul e Sudeste. Mais uma vez, por meio da capacidade organizativa, Carranza se consolida como chefe do

\footnotetext{
${ }^{151}$ A íntegra do decreto 3, publicado por Venustiano Carranza, em 26 de abril de 1913, pode ser encontrada aqui: CARMONA, Doralicia. Memoria Política de México. Guanajuato: Universidade de Guanajuato, 2014. http://www.memoriapoliticademexico.org/Textos/6Revolucion/1913-DC-CDI.html Consulta realizada em 23/11/2015.

${ }^{152}$ A íntegra do decreto de 14 de maio de 1913, publicado por Venustiano Carranza, pode ser encontrada aqui: CARMONA, Doralicia. Memoria Política de México. Guanajuato: Universidade de Guanajuato, 2014. http://www.memoriapoliticademexico.org/Textos/6Revolucion/1913-D-VC-PVL.html Consulta realizada em 23/11/2015.

${ }^{153}$ A íntegra do decreto de 4 de julho de 1913, expedido por Venustiano Carranza, pode ser encontrada aqui: UNAM. Cidade do México: Instituto de Investigaciones Jurídicas. http://biblio.juridicas.unam.mx/libros/6/2883/13.pdf Consulta realizada em 23/11/2015.
} 
movimento insurgente contra o governo de Huerta. " $Y$ cada día el Ejército Federal era menos capaz de contener el torbelino de la Revolución" $" 154$.

A relação do Exército Constitucionalista com a defesa da legalidade é bastante intensa. No Plan de Guadalupe, lê-se que a traição de Huerta não foi contra Madero, mas sim contra as instituições constitucionais e a legalidade que ele havia jurado defender. Também os poderes judiciário e legislativo haviam compactuado com os procedimentos ilegais e inconstitucionais que haviam levado e reconhecido Huerta no poder $^{155}$. Constitucionalista se chamava o exército e seu líder organiza a luta por meio de decretos. Em nenhum momento os revolucionários mobilizados em torno do Plan de Guadalupe parecem questionar a força organizativa e simbólica da legalidade no processo. Pelo contrário, lutam em defesa da Constituição e da legalidade, ultrajadas, e utilizam decretos para organizar o enfrentamento.

Huerta, por sua vez, também pretende se legitimar pela forma jurídica, por meio da aparência de legalidade. Já no Pacto de la Embajada esse esforço estava explícito. Em 10 e 11 de outubro de 1913, expede três decretos para justificar a dissolução da Câmara dos Deputados mexicana. Afirma que a ordem constitucional é desrespeitada sempre que um dos poderes invade a esfera de atuação dos outros. Assim, quando o executivo exorbita de suas competências e invade a esfera de atuação dos demais poderes, a ordem constitucional é violada ${ }^{156}$. Segundo Huerta, porém, o poder legislativo era o principal vilão institucional no México de 1913. Em suas palavras, "[ $L a$ actual Legislatura de la Unión] rige los destinos de la República, ha llegado a convertirse en el peor enemigo del Ejecutivo, hostilizándolo en todos sus actos e invadiendo su jurisdicción". Huerta crescenta ainda que "[La Camara de Diputados]

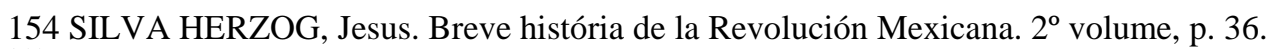

155 Lê-se na exposição de motivos do Plan de Guadalupe "Considerando que el general Victoriano Huerta, a quien el Presidente constitucional don Francisco I. Madero había confiado la defensa de las instituciones y legalidad de su Gobierno. (...) Considerando que los Poderes Legislativo y Judicial han reconocido y amparado en contra de las leyes y preceptos constitucionales al general Victoriano Huerta y sus ilegales y antipatrióticos procedimientos". Íntegra disponível aqui: CARMONA, Doralicia. Memoria política de México. Guanajuato: Universidade de Guanajuato, 2014.

http://www.memoriapoliticademexico.org/Textos/6Revolucion/1913PGP.html Consulta em 23/11/2015.

${ }^{156} \mathrm{Na}$ exposição de motivos dos decretos de Victoriano Huerta, de 10 e 11 de outubro de 1913, lê-se: "Considerando: que tanto se interrumpe el orden constitucional cuando el Poder Ejecutivo invade la esfera propia del Legislativo o el Judicial, como cuando es uno de éstos el que invade las atribuciones del Ejecutivo, y en el supuesto de que por fuerza de las circunstancias sea necesario interrumpir ese orden, debe ser siempre como suprema e ineludible medida de bien público, y esto sólo por el tiempo estrictamente indispensable para volver al régimen constitucional;". Íntegra do texto disponível aqui: BIBLIOTECA GARAY. 500 años de México en documentos.México, 2011. http://www.biblioteca.tv/artman2/publish/1913_212/Decretos_y_manifiesto_de_Victoriano_Huerta_que ord_1396.shtml Consulta realizada em 24/11/2015. 
atropella a los otros dos Poderes de la Unión e invade su esfera de acción propia y genuina" ${ }^{157}$, tudo para justificar a dissolução das duas casas do Poder Legislativo, que teria por função limitar sua atuação como chefe do poder executivo.

A justificativa do ato de dissolução, assim, é também a defesa da constitucionalidade, que estaria sendo desrespeitada pelos órgãos do poder legislativo. Para manter a aparência de legalidade, convoca ainda eleições para que fosse reestabelecido formalmente o poder legislativo e todas as suas funções no México, ainda no mês de outubro de 1913. Obviamente, a composição que surgiria desse processo eleitoral, fraudulento como costumava acontecer no país, seria muito mais favorável a Huerta do que o anterior.

Também no decreto Huerta informa as razões de assumir sozinho a tarefa de, segundo ele, pacificar o México. Câmara e Senado se recusaram a aceitar a indicação de um ministro de Estado indicado por ele, entre outras omissões e resistências políticas indevidas que o impediram, segundo os documentos, de efetivar os planos e reformas políticas necessárias ao México. Assim, seria justificável, constitucional, legal e legítima a dissolução das duas casas do poder legislativo, que não contribuíram para a harmonia entre os poderes. Após o manifesto de justificação para assumir o papel de chefe de um poder executivo autoritário e ilimitado institucionalmente, Huerta assina um último documento normativo em que retira o foro privilegiado de todos os membros do poder legislativo recém-dissolvido. Os deputados e senadores eleitos, ainda na vigência de seu mandato, não teriam direito ao julgamento realizado junto a tribunais superiores como previa a Constituição, mas deveriam ser julgados por juízes comuns caso cometessem delitos. Tal mudança de competência judicial era especialmente relevante no contexto em que, ao dissolver a Câmara, uma ordem de prisão de 110 deputados havia sido emitida. Qualquer que fosse o crime de que esses deputados haviam sido acusados, estavam, a partir do decreto, muito menos protegidos pela visibilidade que um processo junto a tribunais superiores poderia garantir. Possíveis arbitrariedades e punições sem o respeito ao devido processo legal foram menos controladas com processos espalhados e conduzidos por juízes de primeira instância.

\footnotetext{
157 Íntegra dos decretos de Victoriano Huerta, de 10 e 11 de outubro de 1913, disponível aqui: BIBLIOTECA GARAY. 500 años de México en documentos.México, 2011. http://www.biblioteca.tv/artman2/publish/1913 212/Decretos_y manifiesto_de Victoriano_Huerta que ord_1396.shtml Consulta realizada em 24/11/2015.
} 
Toda a narrativa de justificação desses atos arbitrários realizados por Huerta se dá por meio da invocação da legalidade. Assim como tantos outros usurpadores do poder e líderes autoritários, Huerta não abandonou o direito. Apesar de vilipendiá-lo, manteve-o como discurso justificador do seu exercício do poder.

A esta altura de 1913, Huerta já havia adiado as eleições presidenciais que prometera convocar em fevereiro, promessa realizada no momento em que Madero e Pino Suárez haviam sido destituídos. Tal adiamento começava a deixar descontentes antigos apoiadores e o governo dos Estados Unidos, que acompanhavam o desenrolar político mexicano de perto. Com a destituição dos membros do poder legislativo e novas eleições parlamentares convocadas para fim de outubro, a eleição presidencial é mais uma vez adiada. Além disso, reformas na lei eleitoral mudaram a forma de contagem dos votos, transferindo a competência para autoridades ligadas ao governo. Se as eleições mexicanas ocorridas no período do governo de Porfírio Díaz já não primavam pela lisura, a mudança legal escancarou os vícios e a falta de realidade dos resultados alcançados. Esse foi apenas mais um elemento a compor todos os traços que caracterizam o governo de Huerta como autoritário.

Em 2 de dezembro de 1913, o Presidente Wilson critica o governo de Victoriano Huerta, em mensagem direcionada ao Congresso dos Estados Unidos. Ao longo de todo esse ano de 1913, os conflitos armados continuam, com importantes vitórias para o Exército Constitucionalista. Para fazer frente aos embates armados e às baixas em seu exército de federales, Huerta passa a realizar amplamente o alistamento obrigatório de pessoas pobres. A confiabilidade e a lealdade do exército que defende seu governo diminui à medida em que aumenta o contingente de pessoas obrigadas a lutar.

Villa, Zapata, Pablo Gonzáles, Carranza, Lucio Blanco, Álvaro Obregón e outros líderes que lutam contra o governo de Huerta passam a impor derrotas importantes ao Exército Federal. Estados de Chihuahua, Sonora, Sinaloa; Ciudad Juárez, San Luís Potosí, Torreón, Iguala, Monterrey; esses são alguns dos estados e cidades tomados e ocupados pelo Exército Constitucionalista até o final de abril de 1914.

Em 9 abril de 1914, sete soldados e um ofical norte-americano são detidos no porto de Tampico, por engano. Foram libertados logo em seguida, liberação acompanhada de um pedido de desculpas. Mesmo assim, os Estados Unidos decidem reagir ao que consideraram uma grave ofensa à dignidade de seu país. Em 21 de abril, soldados norte-americanos promovem uma ofensiva no porto da cidade de Veracruz 
que, após uma breve resistência derrotada, sucumbe à intervenção estrangeira. Argentina, Chile e Brasil atuam como mediadores para evitar um confronto entre os países que, no mais, possuíam um poderio bélico bastante desigual. Inicialmente, as tentativas de conciliação entre os dois países, em reuniões realizadas no território canadense das cataratas do Niágara, não foram bem-sucedidas.

A instabilidade política, a intervenção estrangeira e as derrotas nos conflitos militares passaram a erodir rapidamente o prestígio de Huerta junto a seus apoiadores. Os triunfos do Exército Constitucionalista até abril se ampliaram em maio e junho. Em 12 de junho, o governo norte-americano impõe como condição para a solução do conflito gerado a partir da ocupação por suas forças armadas da cidade de Veracruz o afastamento de Victoriano Huerta e a convocação de eleições gerais ${ }^{158}$. Apesar desse "ultimato" norte-americano, Huerta resiste e só renuncia em 15 de julho de 1914. Em seu lugar, assume a Presidência provisória Francisco Carvajal, secretário de relações exteriores de Huerta. Era a tentativa de uma solução intermediária: Huerta deixa o poder, mas em seu lugar fica um membro de seu governo e não os caudilhos que lutavam contra ele. Em menos de um mês a solução se mostra inviável e Carvajal renuncia à Presidência. Álvaro Obregón e Lucio Blanco, líderes do Exército Constitucionalista, estavam com suas tropas às portas da Cidade do México para tomála militarmente.

Em 13 de agosto de 1914, data da renúncia de Carvajal, é assinado o Tratado de Teoloyucan, que estabelece que o exército dos federales deveria deixar a Cidade do México desarmado, em pequenos grupos e sem confronto com os constitucionalistas, portanto. Em 15 de agosto, o dirigente Álvaro Obregón entra na Cidade do México com suas tropas, invicto. Herzog descreve uma característica importante, relativa à estrutura social dos apoios às partes beligerantes, do período de lutas do Exército Constitucionalista contra o governo autoritário de Victoriano Huerta que, em meados de 1914, foi derrotado:

Y por estimarlo necesario y oportuno queremos repetir que apoyaron
al Gobierno de Huerta inmediatamente después del cuartelazo de la
Ciudadela, el ejército pretoriano del general Díaz, el Clero y la grande
y mediana burguesía nacional y extranjera. Con Carranza, Zapata y
los demás caudillos se fueron sumando individuos de la clase popular

${ }^{158}$ A cidade de Veracruz permaneceu efetivamente ocupada por forças norte-americanas entre abril e novembro de 1914. Os americanos só deixaram a região meses depois da renúncia de Victoriano Huerta. 
y unos quantos intelectuales pertenecientes a la clase media. ${ }^{159}$

Em 20 de agosto de 1914, Venustiano Carranza chega à capital do México como "Primer Jefe del Ejército Constitucionalista", encarregado do poder executivo da União, segundo ele. Carranza recusa o título de presidente provisório, uma afirmação estratégica do ponto de vista político, já que tinha intenção de participar das eleições para presidência que deveriam ocorrer em seguida. Se assumisse como presidente provisório, opositores poderiam objetar que se tratava de uma espécie de reeleição, proibida pela Constituição que eles lutaram para defender.

Consolidada a vitória sobre Huerta, não havia concordância política sobre a melhor forma de organizar o México politicamente, sobre os próximos passos institucionais a serem tomados ou mesmo sobre quais deveriam ser as pautas prioritárias imediatas após a instalação de um governo revolucionário. Arnaldo Córdova dirá que tanto Villa quanto Zapata tinham como foco primordial questões locais, e nunca se consolidaram como verdadeiras possibilidades de liderança para a reconstrução de um estado nacional, como era o México.

Su odio a los terratenientes no se tradujo en una acción programática coherente (...) y su localismo impedió que pudieran hacer frente al programa reformista de los constitucionalistas y luchar por la conquista del poder político, objetivo que, en el fondo, ni siquiera se llegaron a proponer y que cuando lo tuvieron a su alcance no supieron qué hacer con él. ${ }^{160}$

Tal afirmação é, porém, mais um objeto de disputa entre diferentes interpretações da história da Revolução. Fato é que, consolidada a vitória sobre Huerta, as divergências políticas e as tensões que envolveram a realização da Convenção de Aguascalientes entre outubro e novembro de 1914 expõem de forma exemplar as diferenças existentes entre os três grandes grupos que promoveram a resistência armada chamada genericamente de constitucionalista.

\footnotetext{
159 SILVA HERZOG, Jesús. Breve Historia de la Revolución Mexicana. Vol. 2 - La etapa constitucionalista y la lucha de facciones. $14^{\mathrm{a}}$. Reimpressão. Ciudad de México: Fondo de Cultura Económica do México, 1995. P. 97-98.

${ }^{160}$ CÓRDOVA, Arnaldo. La ideología de la Revolución Mexicana - la formación del nuevo régimen. $8^{\mathrm{a}}$ Edición. Ciudad del México: Ediciones Era, 1980. P. 25. A ideia é reforçada neste trecho:" [El Programa de la Convención] es el canto del cisne de los campesinos armados, el ultimo testimonio de la sapiencia politica de las masas populares, de su espíritu democrático; la confesión postrera y virtual de una equivocación que causó su ruina: el no haber sabido o no haber podido luchar por el poder político, aferrados a su única demanda, la tierra, y al temor y la desconfianza que habian heredado de los gobiernos." Arnaldo Córdova. La ideología de la Revolución Mexicana. P. 167-168.
} 


\subsection{A Convenção de Aguascalientes e a disputa entre as correntes revolucionárias vitoriosas}

Embora carrancistas, villistas e zapatistas lutassem contra Huerta, vencidos os embates e alcançada a renúncia, os revolucionários não possuíam um plano comum de ação política. Francisco Villa era reconhecido, pelo carrancista Plan de Guadalupe, como líder da Divisão Norte e primeiro chefe do Exército Constitucionalista no estado de Chihuahua, mas as relações entre ele e Carranza não eram as mais amigáveis. Ambos disputavam o protagonismo da Revolução. Zapata, por sua vez, não se submeteu à organização de Carranza, nem parecia preocupado com a proeminência nacional. Seu compromisso imediato era garantir a devolução de terras para os "pueblos"

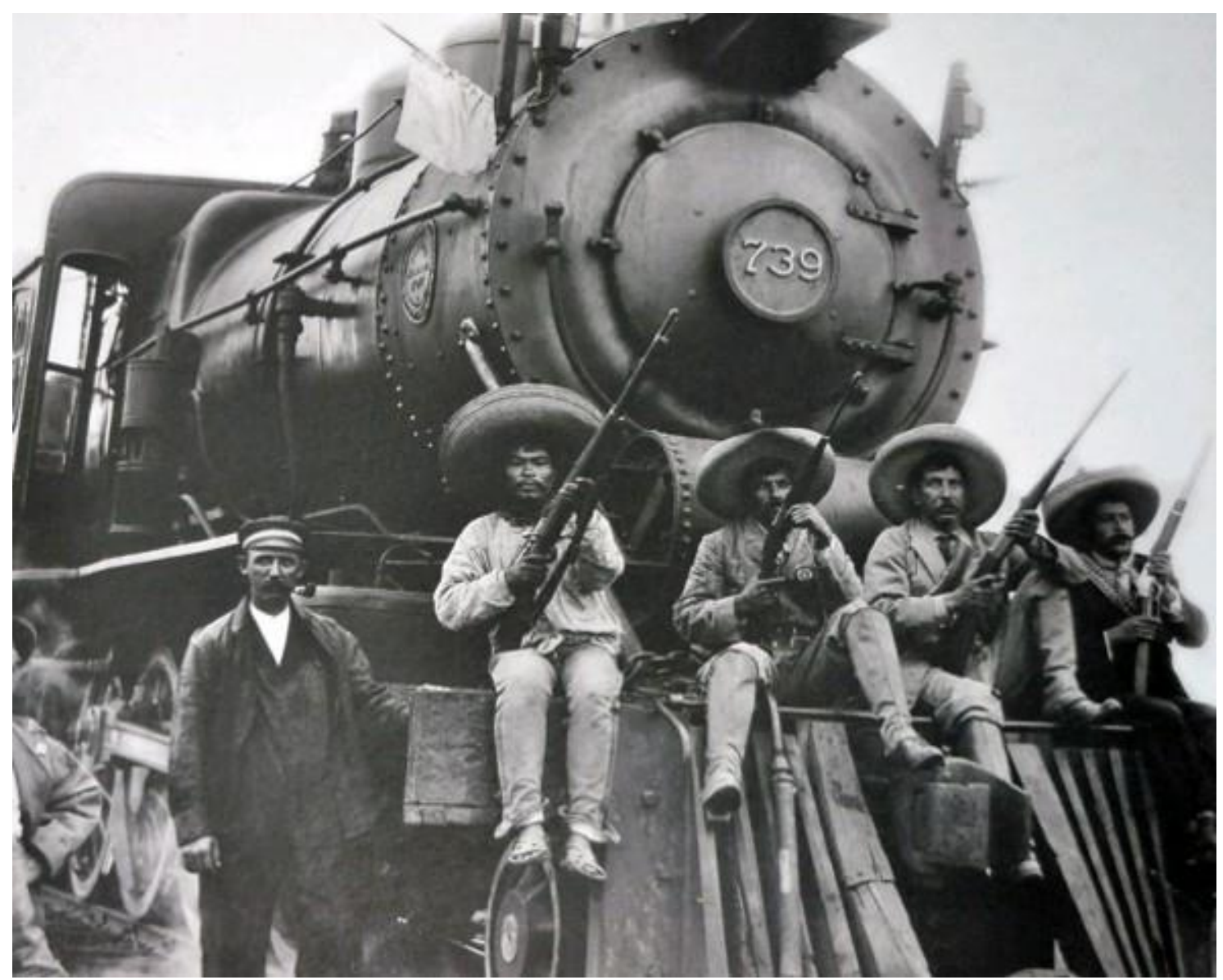

Revolucionários posam para foto em frente a locomotiva. Os trens foram usados como meio de transporte e base de ação durante a revolução.

injustamente espoliados e realizar a democracia local.

Entre julho e agosto de 1914, Pancho Villa competiu com Carranza para ser o primeiro a entrar na Cidade do México, após a vitória nacional, em diversas frentes, 
frente ao exército dos federales. Seu plano de chegar à capital logo depois da renúncia de Huerta foi obstruído por meio da ação deliberada de Carranza, que impediu que carregamentos de carvão chegassem às tropas de Villa. A Divisão Norte usava trens e locomotivas como meio de transporte. O Estado de Coahuila, origem política de Carranza, era o principal produtor de carvão do México e, por sua influência, o fluxo desse combustível para as locomotivas de Villa foi interrompido imediatamente após a vitória sobre Huerta.

Friedrich Katz afirma, ao falar sobre o período, que os Estados Unidos da América possuíam uma maneira bastante específica e eficaz de influir nos rumos dos embates mexicanos: eles escolhiam para quem suas armas e munições poderiam ser vendidas. Quando os combates começaram a virar a favor dos constitucionalistas, a política externa norte-americana passou a fortalecer alguns aliados e enfraquecer outros. Villa foi um dos boicotados neste processo. Sem insumos bélicos, não conseguiu levar as tropas sob seu comando para a Cidade do México logo após a derrota de Huerta.

Ainda durante as lutas contra o ditador, Carranza e Villa já tinham divergido algumas vezes. Em fevereiro de 1914, por exemplo, Carranza recebeu um telegrama de Villa. Nele, o relato de uma tentativa de assassinato que o caudilho do norte teria sofrido, realizada por um inglês. Villa narrava a Carranza sua versão dos fatos e a decisão de condenar o inglês à morte após um julgamento sumário feito por ele próprio e seus homens. Tal decisão gerou um conflito que extrapolou as fronteiras mexicanas e que afetou de forma negativa a imagem dos revolucionários internacionalmente. Nesse episódio a relação entre Villa e Carranza ficou estremecida. Carranza parecia acrecitar que decisão de tamanha importância e repercussão internacional deveria ter passado por ele, Primer Jefe do Exército Constitucionalista.

A essa primeira rusga, somaram-se outras. Talvez a mais importante delas: Villa tomou a cidade de Zacatecas no final de junho de 1914, sem que Carranza tivesse concordado com o ataque. A Divisão Norte venceu um exército de federales com mais de dez mil homens na ocasião. E, com a vitória da cidade estrategicamente relevante do ponto de vista militar, deixou o caminho das tropas da Divisão Norte livre até a Cidade do México. Carranza não desejava que Villa fosse o autor de mais essa vitória, às vésperas da derrocada de Huerta. A desobediência de Villa ao comando central, por outro lado, tinha como fundamento o poderio bélico que controlava. À época, ele dispunha de mais de trinta mil homens e mulheres sob seu vitorioso comando militar, o 
maior contingente revolucionário entre as divisões do Exército Constitucionalista. A Divisão Norte vivia seu auge, e Villa o auge de seu poder militar e político.

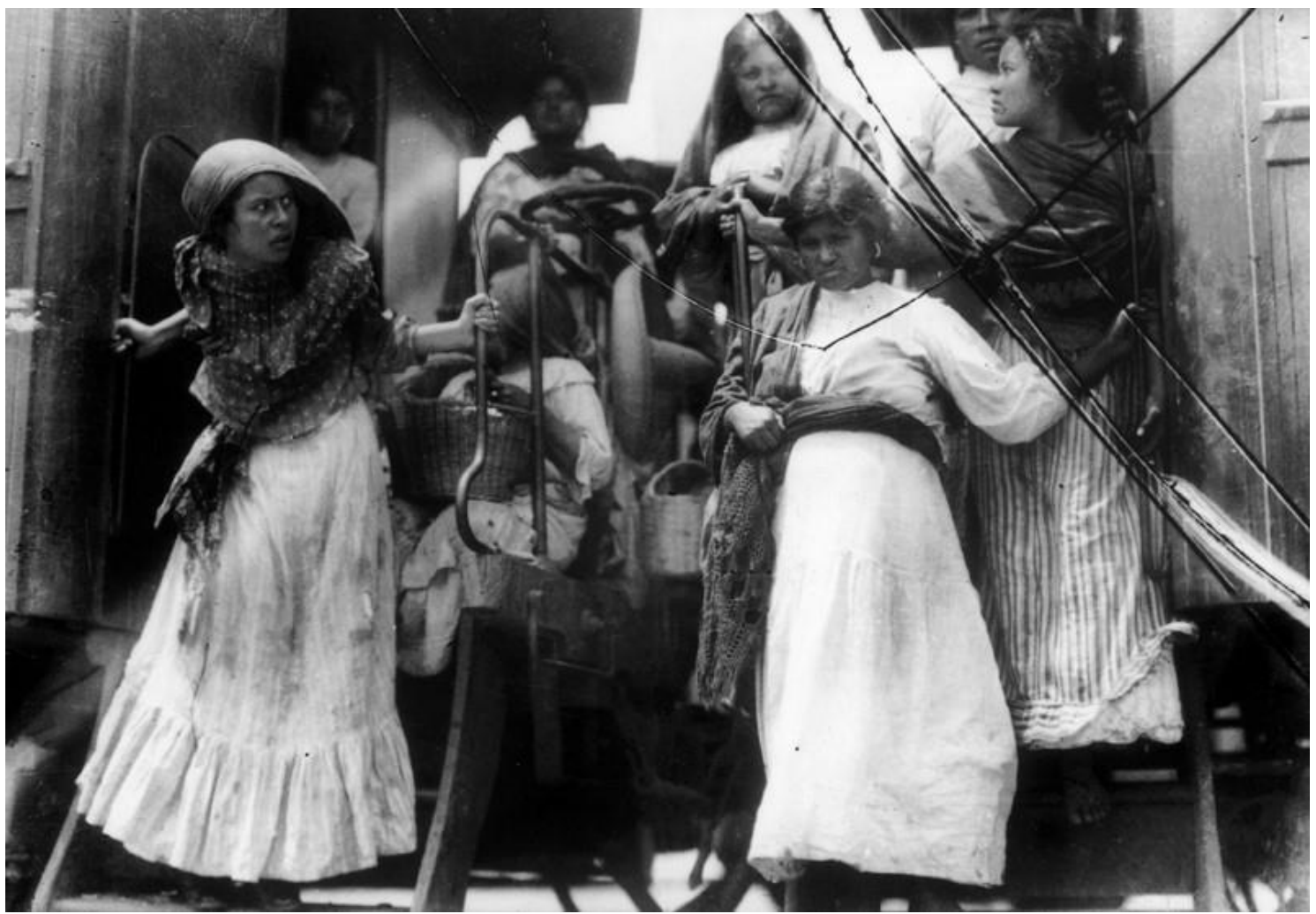

As mulheres tiveram um papel importante nos embates da Revolução Mexicana. Seja garantindo melhores condições na retaguarda, seja lutando em batalhões femininos, com baionetas em punho, elas participavam. Como Adelitas eram conhecidas as mulheres das forças revolucionárias; soldaderas as mulheres dos federales (membros do exército do Estado Mexicano).

Instalado o conflito, foram mobilizados negociadores para resolvê-lo. Entre os dias 4 e 8 de julho de 1914, pouco antes da renúncia de Huerta, após inúmeras reuniões e tentativas de conciliação, foi firmado o documento que ficou conhecido como Pacto de Torreón ${ }^{161}$, assinado por representantes da Divisão Norte e da Divisão Noroeste, os últimos em nome de Carranza. No pacto, os villistas reafirmam a liderança do Primer Jefe que, por sua vez, reafirma Pancho Villa como chefe da Divisão Norte. Entre as cláusulas acordadas no Pacto de Torreón - que possui uma extensa ata, em que se narram os acordos firmados dia a dia -, há algumas bastante elucidativas dos motivos de tensão entre as lideranças militares.

${ }^{161}$ A íntegra do Pacto de Torreón, firmado por representantes villistas e obregonistas em 8 de julho de 1914, pode ser encontrada aqui: BIBLIOTECA GARAY. 500 años de México en documentos.México, 2011.

http://www.biblioteca.tv/artman2/publish/1914 211/Pacto_de_Torre_n_Reformas_al_Plan_de_Guadalup e 227.shtml Consulta realizada em 30/11/2015. 
Ao lado da prioridade villista dada às reformas sociais, talvez a disputa entre o centralismo e o localismo fosse uma das principais divergências políticas entre Villa e Carranza. O Pacto de Torreón, em sua cláusula $7^{\mathrm{a}}$, estabelece que tão logo a Revolução seja vitoriosa devem ser convocadas eleições nos estados e cidades. Eleições locais que antecederiam as eleições presidenciais. Tal ordem de realização seria uma garantia da pouca influência do governo central nos assuntos locais, um dos objetivos villistas. Segundo Katz, essa era também uma forma de resolver provisoriamente os conflitos entre as diferentes correntes revolucionárias:

La solución política que Villa proponía para resolver los conflictos a corto plazo entre las facciones revolucionarias y para crear una nueva estructura política consistía en recrear el estado mexicano desde abajo. 'Él y la mayoría del partido constitucionalista sólo insisten en que se proceda de inmediato a la elección de funcionarios municipales, estatales y federales'. En posteriores declaraciones, Villa dejaría claro que las elecciones municipales y estatales debían preceder a las federales. Esto haría muy difícil para el gobierno central imponer sus candidatos, como había hecho en el pasado. ${ }^{162}$

Além disso, os villistas defendiam governos civis e não militares. Por isso, em uma das cláusulas do Pacto de Torreón, lê-se: "Ningún jefe constitucionalista figurará como candidato para Presidente o Vicepresidente de la República, en las elecciones de que trata la cláusula anterior." Um dos objetos da disputa, assim, era a possibilidade ou não de Carranza e outros líderes revolucionários ocuparem a presidência da República. A vedação que valia para Carranza, também impedia Villa e Zapata de pleitearem o posto.

É também no Pacto de Torreón que aparece pela primeira vez entre os villistas a proposta de realizar uma convenção de revolucionários, com competência para formular o programa do governo a ser criado depois da vitória. Segundo a proposta do Pacto de Torreón, a convenção seria composta por representantes eleitos, na proporção de um representante para cada mil homens que lutaram contra Huerta. Por ter tropas numerosas, os villistas seriam bem representados se essa regra fosse respeitada.

Por fim, na cláusula $8^{\mathrm{a}}$ afirma-se a necessidade de extinguir o exército de federales. A defesa do México deveria ser realizada pelo próprio exército constitucionalista, mesmo depois da destituição de Huerta. A revolução não poderia estar sujeita a mais uma traição, segundo o documento. Ainda mais importante do que

\footnotetext{
${ }^{162}$ KATZ, Friedrich. Pancho Villa - Vol. 1. Trad. Paloma Villegas. México: Ediciones Era, 1998.
} 
essa decisão, está também na cláusula $8^{\mathrm{a}}$ a defesa do regime democrático e a prioridade política conferida ao bem-estar dos operários e camponeses mexicanos, bem-estar que necessariamente passaria pela resolução do problema agrário do país:

\section{PACTO DE TORREÓN - 8 de julho de 1914}

Octava. Siendo la actual contienda una lucha de los desheredados contra los abusos de los poderosos, y comprendiendo que las causas de las desgracias que afligen al país emanan del pretorianismo, de la plutocracia y de la clerecía, las Divisiones del Norte y del Noreste se comprometen solemnemente a combatir hasta que desaparezca por completo el Ejército ex Federal, el que será substituido por el Ejército Constitucionalista; a implantar en nuestra nación el régimen democrático; a procurar el bienestar de los obreros; a emancipar económicamente a los campesinos, haciendo una distribución equitativa de las tierras o por otros medios que tiendan a la RESOLUCIÓN DEL PROBLEMA AGRARIO, y a corregir, castigar y exigir las debidas responsabilidades a los miembros del clero católico romano que material e intelectualmente hayan ayudado al usurpador Victoriano Huerta. ${ }^{163}$

O Pacto de Torreón, de 8 de julho, não foi capaz de apaziguar permanentemente os ânimos e eliminar os embates entre Carranza e Villa. Após a renúncia de Huerta em 15 de julho, Carranza continuou a promover boicotes militares contra as ações e movimentações da Divisão Norte. Assim, sem resistência do outro campo revolucionário, em 20 de agosto de 1914 Carranza entra na Cidade do México, consolidando seu protagonismo no delicado momento em que Huerta sai do poder e é preciso conduzir a transição.

Dias mais tarde, em 28 de agosto, Carranza envia alguns de seus apoiadores para tentar negociar com os zapatistas um acordo de paz e o licenciamento das tropas sob o comando do caudilho do sul. As divergências entre zapatistas e carrancistas também tinham um fundo ideológico claro. As desconfianças que Zapata nutria em relação a Francisco Madero se repetiam com Carranza. Após ter perdido muitos camponeses e revolucionários em confrontos armados na região, a população de Morelos não deixaria as armas até que o problema agrário local fosse resolvido. Em agosto de 1914, mês em que a vitória dos constitucionalistas sobre Huerta se consolida, Zapata publica o seguinte manifesto:

${ }^{163}$ A íntegra do Pacto de Torreón, firmado por representantes villistas e obregonistas em 8 de julho de 1914, pode ser encontrada aqui: BIBLIOTECA GARAY. 500 años de México en documentos.México, 2011.

http://www.biblioteca.tv/artman2/publish/1914_211/Pacto_de_Torre_n_Reformas_al_Plan_de_Guadalup e_227.shtml Consulta realizada em 30/11/2015. 


\section{Manifesto de Emiliano Zapata em Milta Alta, agosto de 1914}

El campesino tenía hambre, padecía miseria, sufría explotación, y si se levantó en armas fue para obtener el pan que la avidez del rico le negaba; para adueñarse de la tierra que el hacendado, egoísticamente guardaba para sí; para reivindicar su dignidad, que el negrero atropellaba inícuamente todos los días. Se lanzó a la revuelta no para conquistar ilusorios derechos políticos que no dan de comer, sino para procurar el pedazo de tierra que ha de proporcionarle alimento $y$ libertad, un hogar dichoso y un porvenir de independencia y engrandecimiento.(...)

El Plan de Ayala, que traduce y encarna los ideales del pueblo campesino da satisfacción a los dos términos del problema, pues a la vez que trata como se merecen a los jurados enemigos del pueblo, reduciéndolos a la impotencia y a la inocuidad por medio de la confiscación, establece en sus artículos $6^{\circ}$ y $7^{\circ}$ los dos grandes principios de la devolución de las tierras robadas (acto exigido, a la vez, por la justicia y la conveniencia). ${ }^{164}$

As tensões entre Villa, Zapata e Carranza estão presentes quando é convocada uma convenção para decidir os rumos da Revolução. A convenção, que de fato aconteceu entre outubro e novembro de 1914, não foi uma proposta de Carranza, e sim uma resposta às pressões que villistas e zapatistas promoveram com seus exércitos.

O primeiro movimento a antecipar a necessidade que as diferentes correntes revolucionárias teriam de um espaço para formular em conjunto um programa positivo de ação foi o zapatismo, muito antes do Pacto de Torreón. Nos artigos 12 e 13 do Plan de Ayala, de novembro de 1911, lê-se que "una vez triunfante la Revolución(...), una Junta de los principales Jefes revolucionarios de los diferentes Estados, nombrarán o designarán un Presidente interino de la República(...).”. O presidente interino dos revolucionários, assim, só poderia ser escolhido por meio de uma junta de chefes revolucionários. Não só a distribuição de terras, mas também a forma de eleição do presidente era uma questão relevante para os revolucionários de Morelos. É o que mais uma vez fica explícito em carta que Zapata escreve ao Presidente dos EUA Woodrow Wilson, em 23 de agosto de 1914:

El país está cansado de imposiciones, no tolera ya que se le impongan amos jefes; desea tomar parte en la designación de sus mandatarios; $y$ puesto que se trata del gobierno interino que ha de emanar de la Revolución y de dar garantías a ésta, es lógico y es justo que sean los

\footnotetext{
${ }^{164}$ Manifesto elaborado por Zapata e proclamado em Milta Alta, em agosto de 1914. A íntegra do Manifesto pode ser encontrada aqui: CARMONA, Doralicia. Memoria política de México. Guanajuato: Universidade de Guanajuato, 2014.

http://www.memoriapoliticademexico.org/Textos/6Revolucion/1914APM.html Consulta realizada em 25/11/2015.
} 
genuinos representantes de la Revolución, o sea los jefes del movimiento armado, quienes efectúen el nombramiento de Presidente Interino. Así lo dispone el artículo doce del Plan de Ayala, en contra de los deseos de D. Venustiano Carranza y de su círculo de políticos ambiciosos, los cuales pretenden que Carranza escale la Presidencia por sorpresa, o mejor dicho, por un golpe de audacia y de imposición. ${ }^{165}$

Os esforços e as tentativas de conciliação de Carranza com as duas outras correntes revolucionárias permanecem ao longo dos meses de setembro e outubro de 1914. Em 9 de setembro de 1914, Álvaro Obregón e Francisco Villa assinaram um documento endereçado a Carranza, com demandas específicas sobre como conduzir politicamente a reconstrução do país e consolidar no México um governo democrático. No documento, uma interessante reflexão sobre o papel da legalidade para a organização de uma sociedade pós-revolucionária.

La Revolución ha creado con el pueblo compromisos que debe cumplir; ella ha grabado sobre sus banderas la palabra CONSTITUCIONALISMO y bajo esta enseña se han perdido muchos intereses y muchas vidas. El pueblo mexicano ha comprado con su sangre el derecho de ser gobernado con la ley, a cuyo amparo sólo pueden existir la libertad dentro del orden y la justicia sin la tiranía (...)

Pero una vez consumado el triunfo, hay que estudiar y llevar adelante la resolución de las cuestiones sociales y económicas de la Revolución, (...). ${ }^{166}$

Somente a lei que limita o exercício do poder é capaz de garantir a liberdade e a proteção contra a tirania. Segundo o documento, o povo lutou também contra a arbitrariedade e por isso deve ser respeitado nesse anseio. Nos documentos villistas questões políticas e sociais não se opõe - como ocorre em algumas manifestações de Zapata -, mas se complementam. Os revolucionários têm direito a um governo que respeite o império da lei e que estabeleça como prioridade política resolver as questões sociais que motivaram a revolução: distribuição da terra e regulação do trabalho.

\footnotetext{
${ }^{165}$ A íntegra da carta de Emiliano Zapata a Woodrow Wilson, datada de 23 de agosto de 1914, pode ser consultada aqui: CARMONA, Doralicia. Memoria política de México. Guanajuato: Universidade de Guanajuato, 2014. http://www.memoriapoliticademexico.org/Textos/6Revolucion/1914-C-EZ-WW.html Consulta realizada em 30/11/2015.

${ }^{166}$ Documento elaborado por Álvaro Obregón e Francisco Villa, em 9 de setembro de 1914. A íntegra do documento pode ser encontrada aqui: CARMONA, Doralicia. Memoria política de México. Guanajuato: Universidade de Guanajuato, 2014.

http://www.memoriapoliticademexico.org/Textos/6Revolucion/1914MVC-AO-FV.html Consulta realizada em 30/11/2015.
} 
Depois de afirmada a importância da pauta social, o manifesto de Villa e Obregón segue com demandas de reorganização do sistema político mexicano, por meio de reformas constitucionais. Afirmam Villa e Obregón que, antes de ser realizada uma eleição presidencial, deveria ser modificada a Constituição para que a instituição da vice-presidência fosse extinta; para que o período de mandato presidencial fosse ampliado para seis anos a contar do momento da posse; para que a forma de indicação de membros da Suprema Corte de Justiça fosse alterada e, por fim, para que se incluísse a vedação da candidatura de chefes do exército nacional para cargos eletivos. Por fim, Villa e Obregón incluem no documento uma norma que tem destinatário certo:

Octava: No podrán ser electos para Presidente de la Republica, ni para Gobernadores de los Estados, los ciudadanos que hayan desempeñado estos cargos con carácter de provisionales, al triunfo de la Revolución, ni los que los desempeñen desde la fecha de la convocatoria hasta el momento de la elección. ${ }^{167}$

Álvaro Obregón havia sido enviado em uma missão diplomática e estratégica junto a Franciso Villa, para tentar evitar que o líder da Divisão Norte rompesse relações com o resto do exército constitucionalista. $\mathrm{O}$ documento assinado em conjunto era uma tentativa de realizar esse objetivo e impunha a Carranza a necessidade de abdicar de suas aspirações presidenciais. Carranza responde em seguida ao documento de Villa e Obregón, aceitando assumir como presidente interino, condição número um entre as reivindicações. Quanto aos outros pedidos, responde que não poderia tomar a decisão sozinho e estabelece a convenção de revolucionários, que deveria se reunir a partir do dia primeiro de outubro de 1914 na Cidade do México, como instância competente para decidir as questões políticas mais difíceis.

En general, cuestiones de tan profunda importancia, no pueden ser discutidas ni aprobadas por un reducido número de personas, ya que ellas deben trascender a la Nación entera, y son, por lo mismo de su soberana competencia. (...)

De las nueve proposiciones contenidas en el estudio a que me refiero, la primera debe considerarse como definitivamente aprobada; en la cuarta, es necesario la modificación en el sentido de que se convoque a elecciones de Ayuntamientos y Jueces Municipales, en aquellos lugares en que está establecida la elección popular para el caso, y en

\footnotetext{
${ }^{167}$ Documento elaborado por Álvaro Obregón e Francisco Villa, em 9 de setembro de 1914. A íntegra do documento pode ser encontrada aqui: CARMONA, Doralicia. Memoria política de México. Guanajuato: Universidade de Guanajuato, 2014.

http://www.memoriapoliticademexico.org/Textos/6Revolucion/1914MVC-AO-FV.html Consulta realizada em 30/11/2015.
} 
los demás, conforme a las leyes respectivas. Las demás proposiciones, de trascendentalísima importancia, no pueden considerarse objeto de discusión y aprobación entre tres o cuatro personas, sino que deben discutirse y aprobarse, en mi concepto, por una asamblea que pueda tener invívita la representación del país.(...)

Inspirado en este espíritu democrático-práctico, además, he creído de altísima conveniencia la convocación a una junta, en que deban discutirse y aprobarse, no solamente las proposiciones a que me refiero, sino todas aquellas de la trascendencia de ésta y de interés general. ${ }^{168}$

Inicialmente chamada de Gran Convención de Jefes militares con mando de fuerzas y gobernadores de los Estados, a composição da convenção recém-convocada era um problema para Villa. Carranza não concordara com o critério previsto no Pacto de Torreón, para que fosse eleito um representante a cada mil revolucionários. Ao invés disso, convidou a participar da convenção generais e governadores dos Estados, escolhidos por ele. Segundo Villa, essa forma de convite para a convenção traria distorções políticas importantes. Carranza, responsável pela convocação, praticamente tinha garantido sua maioria no órgão colegiado. Para Zapata, o problema da convenção convocada incluía a composição, mas dizia respeito sobretudo às competências que o órgão colegiado teria. No Plan de Ayala estava prevista a convenção para eleger um presidente interino e deliberar sobre o programa e prioridades do governo revolucionário. A convenção convocada por Carranza teria uma função majoritariamente consultiva, e não escolheria o presidente interino, porque este já teria sido determinado pelo Plan de Guadalupe, que não poderia ser questionado.

Assim, a resistência de villistas e zapatistas em aderir à assembleia revolucionária derivava de divergências sobre a própria concepção da convenção. Constitucionalistas, villistas e zapatistas divergiam nas respostas às perguntas fundamentais: qual é a composição legítima para este coletivo e quais são as funções que ele vai desempenhar no governo revolucionário? Por isso, a resposta procedimental de Carranza a Villa e Obregon, escrita em 13 de setembro de 1914, não agradou a Villa. Carranza diz que as grandes questões políticas levantadas pelos dois líderes revolucionários serão resolvidas em uma instância colegiada. Instância colegiada em

\footnotetext{
${ }^{168}$ Resposta de Venustiano Carranza, em 13 de setembro de 1914, ao documento enviado a ele por Álvaro Obregon e Francisco Villa, em 9 de setembro de 1914. A íntegra da resposta pode ser encontrada aqui: CARMONA, Doralicia. Memoria política de México. Guanajuato: Universidade de Guanajuato, 2014. http://www.memoriapoliticademexico.org/Textos/6Revolucion/1914RPC.html Consulta realizada em $30 / 11 / 2015$.
} 
que, tal como convocada por ele mesmo, a predominância de sua corrente política estava garantida.

Nesse contexto, em menos de dez dias Villa elaborou um manifesto público dirigido a todos os cidadãos mexicanos, expondo as razões que o levaram a romper com Carranza e convocando-os, uma vez mais, a se juntarem à Divisão Norte e empreender uma nova etapa do que descreve como luta pela liberdade e pela justiça social. Segundo seu texto deixa transparecer, os principais objetivos revolucionários que estariam em risco seriam exatamente as conquistas sociais desejadas, especialmente a reforma agrária. Villa alerta para o fato de Carranza ter maioria na convenção por ele convocada, e para os riscos que tal posição traz para a legitimidade das eleições que seriam organizadas durante a convenção. Afirma ainda que o fato de não reconhecer Venustiano Carranza não visa a satisfazer ambições pessoais de poder, suas ou de outros líderes da Divisão Norte. Segundo o documento, sua luta tem como objetivo a instalação de um governo civil, e não militar. Todos os chefes revolucionários - aqui ele reforça o que já previa o Pacto de Torreón - estariam impedidos de concorrer e assumir cargos eletivos. ${ }^{169}$

No mesmo dia em que publica seu manifesto de rompimento público com Carranza, Villa escreve a Emiliano Zapata. Na carta, o chama de "muy estimado compañero y fino amigo" ${ }^{\text {170 }}$. Repete para Zapata alguns dos argumentos presentes em seu manifesto e afirma ser Carranza o responsável pela desunião do movimento

\footnotetext{
${ }^{169}$ No Manifesto de 22 de setembro de 1914, em que Francisco Villa oficialmente rompe com o Exército Constitucionalista e com Venustiano Carranza, lê-se: "El señor Carranza se rehusó a aceptar la Convención sobre las bases propuestas en el pacto de Torreón y resolvió que al entrar a la capital de la República el Ejército Constitucionalista, convocaría a una Junta a los generales y a los gobernadores de los Estados para estudiar los problemas políticos y sociales de la Revolución. (...)

Este desconocimiento no encierra un acto de ambición de mi parte, ni de ninguno de los generales de la División del Norte, y solemnemente declaro con la debida autorización, que ni ellos ni yo aceptaremos los cargos de Presidente Interino ni Constitucional de la República, así como tampoco los de Vicepresidentes y Gobernadores, y que de acuerdo con los demás generales, jefes y oficiales del Ejército Constitucionalista que quieran coadyuvar con nosotros lucharemos por establecer un Gobierno Civil que garantice todos los derechos y todas las libertades de los ciudadanos.(...)

Conciudadanos, es muy doloroso para mí exigir del pueblo mexicano un nuevo sacrificio para que la Revolución pueda definitivamente realizar sus caros ideales, pero tengo la seguridad de que todo ciudadano honrado comprenderá que sin este último esfuerzo del pueblo, se derrumbaría toda la obra revolucionaria, porque habríamos derrocado una dictadura para substituirla por otra." A íntegra do Manifesto pode ser encontrada aqui: CARMONA, Doralicia. Memoria política de México. Guanajuato: Universidade de Guanajuato, 2014.

http://www.memoriapoliticademexico.org/Textos/6Revolucion/1914MFV.html Consulta realizada em $30 / 11 / 2015$

${ }^{170}$ A íntegra da carta de Francisco Villa para Emiliano Zapata, datada de 22 de setembro de 1914, pode ser encontrada aqui: CARMONA, Doralicia. Memoria política de México. Guanajuato: Universidade de Guanajuato, 2014. http://www.memoriapoliticademexico.org/Textos/6Revolucion/1914-C-FV-EZ.html Consulta realizada em 30/11/2015.
} 
revolucionário. Manifesta ainda seu desejo de tomar de assalto a Cidade do México. Pede, por fim, que Zapata também desconheça Carranza e o apoie militarmente na empreitada.

Ao final de setembro, as principais razões de divergência entre as três maiores correntes revolucionárias - zapatistas, villistas e constitucionalistas - estavam expostas e sobre a mesa. O xadrex diplomático, político e militar que foi jogado nos meses de outubro e novembro de 1914 tem, assim, razões políticas conhecidas.

A Gran Convención de Jefes militares con mando de fuerzas y gobernadores de los Estados estava convocada para começar no dia $1^{\circ}$ de outubro de 1914 e se reuniria na Cidade do México. Em 27 de setembro de 1914, chefes da Divisão Norte, Francisco Villa incluído, encaminham telegrama a Venustiano Carranza pedindo que ele ceda o poder a Fernando Iglesias Calderón. Carranza responde que apenas renunciaria perante a convenção de chefes revolucionários. Entre os chefes revolucionários havia um grupo que assumiu o objetivo de dirimir as divergências entre as diferentes correntes e efetivamente ser capaz de elaborar um programa de ação conjunto. Esse grupo queria, sobretudo, evitar que o conflito armado continuasse e se estendesse no tempo uma vez mais.

Estabilizar o país e conseguir um pacto em torno de novas instituições era um anseio de uma parte significativa entre aqueles que participaram militarmente da vitória sobre Huerta. Transformar o México em uma sociedade mais justa em relação a terras e direitos trabalhistas passava por interromper os conflitos armados e voltar à normalidade institucional. Como a Cidade do México estava tomada por tropas fiéis a Carranza, ainda no final de setembro surgiu a proposta de transferir a reunião dos líderes revolucionários para um local mais neutro. A cidade de Aguascalientes, cerca de 500 quilômetros a noroeste da capital, em uma região neutra militarmente, pareceu uma boa opção para a realização da convenção.

Entre os dias $1^{\circ}$ e 4 de outubro de 1914 , ocorreram as quatro primeiras sessões da convenção convocada por Carranza, sem a presença de nenhum representante villista ou zapatista. O espaço tinha início com uma clara ausência de legitimidade para deliberar sobre as ações de um governo revolucionário. No dia 2 de outubro, Venustiano Carranza apresentou sua proposta de renúncia como Primer Jefe del Ejército Constitucionalista, no exercício do poder executivo da União. A convenção não aceita sua renúncia. 
Com o objetivo de aumentar a legitimidade do espaço deliberativo, e aumentar as chances de Francisco Villa e Emiliano Zapata aderirem à Convenção, os representantes do exército constitucionalista reunidos na Cidade do México decidem transladar a reunião para a cidade de Aguascalientes no dia 6 de outubro de 1914. No dia 10 do mesmo mês, acontece a sessão inaugural daquela que ficou conhecida como Convenção de Aguascalientes, com sessões realizadas no Teatro Iturbide. O objetivo da realização da Convenção na cidade de Aguascalientes era exatamente a neutralidade militar. No entanto, no momento em que a reunião inaugural ocorria, tropas da Divisão Norte se aproximavam da cidade.

Em 14 de outubro de 1914, a sessão da Conveção decide um dos pontos de tensão em favor daqueles líderes revolucionários que ainda não haviam aderido. Afirmam que "Terminada la jura de esta bandera, (...) pasamos a declarar solemnemente instalada esta Convención y a declararla con mayor solemnidad aún: Soberana." ${ }^{171}$ Se a convenção seria consultiva ou deliberativa e, se deliberativa, quais seriam os limites de sua deliberação eram questões que villistas e zapatistas formularam para Carranza.

A modificação do local da reunião e a decisão pela soberania da convenção são duas alterações formais importantes em relação à proposta original de Carranza, feitas para tentar aproximar e incluir villistas e zapatistas na assembleia. Este objetivo de união também era consciente por parte dos convencionistas. Afirmam, na mesma ata em que declaram a convenção soberana, que "con este acto hemos logrado, o si no logrado, cuando menos hecho un esfuerzo sincero con ello, para unificar el país." ${ }^{172}$ As ações práticas dos convencionistas comprovam o esforço de unificação. Os efeitos foram rapidamente percebidos. Em 17 de outubro, Francisco Villa chega, sem tropas, à cidade de Aguascalientes. Comparece ao teatro em que as sessões da Convenção estão ocorrendo e assina sua bandeira - ato simbólico que significa a adesão ao espaço deliberativo. Cumpre, assim, todos os requisitos formais para participar efetivamente da Convenção.

\footnotetext{
171 A íntegra da ata da sessão de 14 de outubro de 1914 da Convenção de Aguascalientes pode ser consultada aqui: CARMONA, Doralicia. Memoria política de México. Guanajuato: Universidade de Guanajuato, 2014. http://www.memoriapoliticademexico.org/Textos/6Revolucion/1914-DCR-DS.html Consulta realizada em 01/12/2015.

172 A íntegra da ata da sessão de 14 de outubro de 1914 da Convenção de Aguascalientes pode ser consultada aqui: CARMONA, Doralicia. Memoria política de México. Guanajuato: Universidade de Guanajuato, 2014. http://www.memoriapoliticademexico.org/Textos/6Revolucion/1914-DCR-DS.html Consulta realizada em 01/12/2015.
} 
Com a presença pessoal de Francisco Villa na convenção, os convencionistas decidem elaborar um convite formal a Venustiano Carranza e a Emiliano Zapata para que, também eles, se reúnam em Aguascalientes. Em 18 de outubro, diferentes comissões de generais foram pessoalmente realizar o convite aos dois líderes, em nome da Convenção.

Como resposta ao convite, Zapata enviou um grande número de representantes, liderados por Antonio Diaz Soto y Gama, mas não foi pessoalmente. Os zapatistas chegaram a Aguascalientes em 24 de outubro e participaram da primeira sessão no dia 27.

Carranza, por sua vez, não aceitou o convite. Enviou uma carta para a Convenção de Aguascalientes em 23 de outubro de 1914, expondo suas razões. Nela afirma que não poderia comparecer como general, como outros tantos generais da convenção, porque teria que abrir mão do poder executivo da União que estava a exercer. Por outro lado, se comparecesse como Primer Jefe do Ejército no exercício do poder executivo, poderia inibir as tratativas para a resolução do problema que estavam enfrentando, sobretudo entre ele e o chefe da Divisão Norte. Nessa carta, Carranza acusa Francisco Villa de agir motivado por ambições pessoais, contra os interesses maiores do país. Carranza também se autodescreve como "hombre demasiado radical". Villa, segundo a interpretação expressa na carta, estaria a serviço de forças conservadoras da sociedade. Carranza afirma que ignora “cuáles sean las pretensiones del General Zapata; pero creo que no diferirán mucho de las del General Villa." ${ }^{173}$. Em um só documento, o Primer Jefe Carranza deslegitima as duas outras correntes revolucionárias que lutaram em conjunto pela destituição de Huerta.

Coloca, porém, seu cargo à disposição. Carranza afirma literalmente essa hipótese: "Si la Convención de Aguascalientes cree necesario que yo me retire del Poder (...)" ${ }^{174}$. Para que se reestabeleça a harmonia entre os elementos revolucionários; para que a revolução triunfe; para que sejam possíveis as reformas sociais e políticas de

\footnotetext{
${ }^{173}$ A íntegra da carta que Venustiano Carranza encaminha aos membros da Convenção de Aguascalientes pode ser acessada aqui: CARMONA, Doralicia. Memoria política de México. Guanajuato: Universidade de Guanajuato, 2014. http://www.memoriapoliticademexico.org/Textos/6Revolucion/1914MCA.html Consulta realizada em 02/12/2015.

${ }^{174}$ A íntegra da carta que Venustiano Carranza encaminha aos membros da Convenção de Aguascalientes pode ser acessada aqui: CARMONA, Doralicia. Memoria política de México. Guanajuato: Universidade de Guanajuato, 2014. http://www.memoriapoliticademexico.org/Textos/6Revolucion/1914MCA.html Consulta realizada em 02/12/2015.
} 
que o país precisa - ele não protestará. Abdicará de sua posição. Impõe, porém, três condições para que isso ocorra:

Primera.- Se establecerá un Gobierno preconstitucional apoyado por el Ejército Constitucionalista, que se encargue de realizar las reformas sociales y políticas que necesita el país antes de que se restablezca un Gobierno plenamente constitucional.

Segunda-El General Villa renunciará, no su candidatura a la Presidencia o Vicepresidencia de la República, que nadie le ha ofrecido, sino la jefatura militar de la División del Norte, retirándose, como yo, a la vida privada, y renunciando a toda pretensión de dominio político de él, saliendo de la República si la Convención acuerda que yo también deba expatriarme.

Tercera.- El General Zapata renunciará el mando de sus fuerzas y toda pretensión a puestos políticos, locales o federales, retirándose igualmente del país y entregando las fuerzas que ahora lo reconocen como jefe al Gobierno que la Convención constituya. ${ }^{175}$

Encerra o documento com uma ameaça. Afirma que, se não for possível a solução diplomática do impasse em que os vencedores da revolução estavam, não hesitaria em reunir novamente o exército constitucionalista e lutar. Diante dessa posição e do fato de Zapata também não participar pessoalmente da Conveção, Villa foi convidado a se retirar, mantendo apenas alguns generais como seus representantes.

Em 27 de outubro de 1914, os representantes zapatistas, recém-integrados à assembleia, apresentaram suas posições políticas na primeira sessão de que participaram. Paulino Martinez, jornalista liberal que participou dos levantes armados no México desde o governo de Porfírio Díaz, foi o porta-voz dos insurgentes do sul. Liberdades públicas e direitos sociais se mesclavam em seu discurso. Ao descrever os dois líderes, Villa e Zapata, como "titãs da homérica luta", afirma serem ambos mestiços e trazerem ambos nos rostos e nos corações as dores e as amarguras da raça indígena, humilhada, injustiçada, expulsa de sua terra e excluída das riquezas do México por quatro séculos. Descreve, em seguida, o Plan de Ayala, documento que organiza a luta zapatista e suas pretensões. O discurso é também uma justificativa sobre por que os zapatistas nunca integraram formalmente os quadros do exército constitucionalista, muito embora lutassem contra o mesmo golpista Victoriano Huerta. Os zapatistas lutam por terra, liberdade e justiça, e não por cadeiras presidenciais,

\footnotetext{
${ }^{175}$ A íntegra da carta que Venustiano Carranza encaminha aos membros da Convenção de Aguascalientes pode ser acessada aqui: CARMONA, Doralicia. Memoria política de México. Guanajuato: Universidade de Guanajuato, 2014. http://www.memoriapoliticademexico.org/Textos/6Revolucion/1914MCA.html Consulta realizada em 02/12/2015.
} 
explicou. Se Carranza acusa Villa e Zapata de agirem em nome de ambições pessoais de poder, os zapatistas têm a mesma visão sobre Carranza: seu objetivo, ao menos neste momento do conflito, são poder e riqueza. Paulilo afirma ainda em seu discurso ser um lamentável equívoco dos constitucionalistas acreditarem-se vitoriosos por terem entrado na capital da República, com o Plan de Guadalupe nas mãos e a certeza de que a sua proposta não discutida de governo provisório seria aceita. Uma instância de deliberação sobre como construir um governo revolucionário era necessária, segundo o Plan de Ayala, para dizer como seria a organização social depois da vitória armada.

Tal como a carta de Carranza, o discurso de Paulino Martínez deixa explícita a possibilidade de luta fratricida entre os movimentos revolucionários, o que gerava a apreensão de todos aqueles que tentavam sua conciliação em um programa comum. Afirma, antevendo o que ocorreria efetivamente: "Deploramos sinceramente que nuestros compañeros de hoy vayan a ser quizá mañana los enemigos a quienes se tenga que combatir; no queremos que continúe la lucha fratricida" ${ }^{176}$. Embora não queiram que a luta fratricida continue, Paulino afirma com todas as letras que os sulinos estavam dispostos a lutar em defesa da raça indígena expoliada por quatro séculos. Por fim, pede que os conferencistas reflitam sobre quais eram as posições políticas que motivavam as diferentes correntes revolucionárias neste momento de conflito. Para fundamentar sua percepção, invoca os próprios planos revolucionários que descrevem seus objetivos:

\begin{abstract}
Meditemos, señores compañeros, antes de que pueda reanudarse el combate. Examinemos detenidamente, sin pasión alguna, las banderas que enarbola cada campamento. El Ejército Constitucionalista enarbola el Plan de Guadalupe; el Ejército Libertador, el Plan de Ayala; aquél tiene por principal objeto -me atengo a lo escrito- elevar a un hombre al Poder, si se quiere, atropellando la autoridad del pueblo y los derechos indiscutibles de otros grupos revolucionarios; el Plan de Ayala tiene por principal objeto elevar los principios al rango de leyes, para redimir a una raza de la ignorancia y de la miseria, a fin de que los mexicanos tengan su propio hogar, abundante pan con qué alimentarse y escuelas libres donde poder abatir su ignorancia; y si esto es así, como los hechos lo demuestran, los campos están deslindados ya: luchadores de buena fe, ¡escoged! ${ }^{177}$
\end{abstract}

\footnotetext{
176 A íntegra do discurso de Paulino Martinez, proferido na Convenção de Aguascalientes, em 27 de outubro de 1914, pode ser encontrada aqui: CARMONA, Doralicia. Memoria política de México. Guanajuato: Universidade de Guanajuato, 2014.

http://www.memoriapoliticademexico.org/Textos/6Revolucion/1914-DDZ-CA.html Consulta realizada em 02/12/2015.

177 A íntegra do discurso de Paulino Martinez, proferido na Convenção de Aguascalientes, em 27 de outubro de 1914, pode ser encontrada aqui: CARMONA, Doralicia. Memoria política de México. Guanajuato: Universidade de Guanajuato, 2014.
} 
Os sete artigos do Plan de Guadalupe, de 1913, tinham como objetivo desconhecer o governo de Victoriano Huerta e os poderes que lhe deram suporte; organizar o exército constitucionalista e nomear Venustiano Carranza seu Primer Jefe. O mesmo plano dispunha que, consolidada a vitória, o então Primer Jefe se converteria em presidente provisório, responsável por convocar eleições presidenciais. Nem uma palavra sobre as mazelas sociais sofridas pelo México. O Plan de Ayala, além de reafirmar o que o Plan de San Luis Potosí já formulava, desconhecer os governos de Díaz, Madero e Huerta, traz em seus artigos $6^{\circ}, 7^{\circ}, 8^{\circ}$ e $9^{\circ}$ normas sobre a reorganização da terra de forma a reverter injustiças agrárias cometidas ao longo dos anos e ainda promover maior equidade nas atribuições de títulos de propriedade.

Em 6 de novembro de 1914, um primeiro documento oficial em nome da Convenção é divulgado. O objetivo da assembleia, segundo a declaração produzida, era unificar o movimento revolucionário e determinar "las bases y orientación del nuevo Gobierno de la República inspiradas en la opinión de la mayoría de sus ciudadanos armados" $" 178$. Ora, a maioria da assembleia soberana dos cidadãos armados mexicanos, reunida em Aguascalientes, decidiu ser primordial "hacer efectiva la paz en la República". Ao contrário das ameaças de luta das outras declarações, o manifesto coletivo chama a atenção para a importância da paz para a realização dos anseios de transformação social que animaram a revolução. Além das armas, afirma ter a opinião pública ao lado da convenção. E, também para afastar quaisquer suspeitas de ambições pessoais pelo poder e motivações mesquinhas, elege um presidente provisório: general Eulálio Gutiérrez.

Com este manifesto público a Convenção anuncia que o embate argumentativo teve um vencedor. Apesar de ser composta por políticos de posições bastante diferentes, a Convenção decidiu aceitar a renúncia de Carranza e indicar um novo presidente provisório. Isso significava que Carranza havia sido derrotado na instância coletiva que havia concordado em criar. Ele não se submeteu à decisão coletiva, no entanto. Sai da capital, mas se reestabelece em Veracruz, onde reorganiza o exército constitucionalista, com todos aqueles que ficaram descontentes com a decisão da Convenção.

http://www.memoriapoliticademexico.org/Textos/6Revolucion/1914-DDZ-CA.html Consulta realizada em $02 / 12 / 2015$.

${ }^{178}$ A íntegra do Manifesto da Convenção de Aguascalientes pode ser consultada aqui: CARMONA, Doralicia. Memoria política de México. Guanajuato: Universidade de Guanajuato, 2014. http://www.memoriapoliticademexico.org/Textos/6Revolucion/1914MAC.html Consulta realizada em $02 / 12 / 2015$. 
Eulálio Gutierrez havia sido o indicado pela Convenção para assumir a Presidência Provisória. As tarefas revolucionárias dessa instância coletiva, porém, não se esgotavam com a escolha do novo líder. Passado o primeiro embate, a Soberana Convención Revolucionária deveria se dedicar a elaborar princípios que orientariam a ação dos revolucionários no governo. Por isso, ela não se dissolveu formalmente. Continuou ativa até abril de 1916, quando publicou seu documento programático Programa de Reformas Político-Sociales de la Soberana Convención Revolucionária $^{179}$. Para que a elaboração de um plano de ação conjunto fosse possível, outras arestas - além da inicial sobre quem ocuparia a presidência até a eleição formal - precisariam ser aparadas pelos participantes do espaço deliberativo.

Felipe Ávila Espinosa propõe em seu livro Las corrientes revolucionarias y la Soberana Convención ${ }^{180}$ uma divisão para analisar as atividades da Convenção em quatro momentos distintos. Em primeiro lugar, Ávila identifica como uma unidade os quatro primeiros dias de encontro no início de outubro de 1914, ainda na Cidade do México. Essa primeira fase caracteriza-se pela predominância de constitucionalistas entre seus membros. Desde o momento em que é deslocada para Aguascalientes até a publicação do manifesto convencionista de 6 de novembro de 1914, a assembleia vive sua segunda fase. Nela, a mais crítica, os rumos e decisões da Convenção estão sob disputa das três principais correntes revolucionárias. Segundo Ávila, foi neste curto período, entre 10 de outubro e 6 de novembro de 1914, que a revolução teve a chance de formular uma proposta de conciliação capaz de evitar mais anos de luta armada.

A possibilidade não se realizou e, a partir de 6 de novembro, com a identificação clara dos vencedores e dos vencidos na Convenção, a assembleia passa a sua terceira etapa, compreendida entre novembro de 1914 e junho de 1915.

Perder a Convenção teve custos políticos para Carranza. Para além das tropas e generais ligados a Villa e a Zapata, em franca disputa pela liderança do processo, alguns generais próximos ao próprio Villa e que participaram do encontro foram convencidos

\footnotetext{
${ }^{179}$ A íntegra do Programa de Reformas Político-Sociales de la Soberana Convención Revolucionária, de 18 de abril de 1916. Em: CARMONA, Doralicia. Memoria política de México. Guanajuato: Universidade de Guanajuato, 2014. Disponível em:

<http://www.memoriapoliticademexico.org/Textos/6Revolucion/1916PRP.html> Consulta realizada em 27/12/2015.

${ }^{180}$ Felipe Arturo Ávila Espinosa. Las corrientes revolucionarias y la Soberana Convención. $1^{\mathrm{a}}$. ed. México, D.F.: Instituto Nacional de Estudios Históricos de las Revoluciones de México, 2014. 524 p. Disponível em: http://www.inehrm.gob.mx/work/models/inehrm/Resource/455/1/images/Las_corrientes_revolucionarias y_la_soberana_convencion_Felipe_Avila.pdf
} 
da importância de encontrar um ponto de convergência para a ação revolucionária, e que esse ponto de convergência só poderia ser construído em uma instância coletiva como era a Convenção. Ao reorganizar suas tropas a partir de Veracruz, Carranza inicialmente identificou algumas baixas entre seus aliados que, de constitucionalistas, tinham se tornado convencionistas.

Por fim, a quarta etapa configura-se quando as sucessivas derrotas da Divisão Norte, em meados de 1915, fazem com que o acordo entre os líderes do sul e do norte se dissolva. Ávila analisa que quando Álvaro Obregón vence as tropas de Villa, entre junho de 1915 e meados de 1916, simbolicamente é derrotada também a Convenção. Assim, em sua quarta fase a Convenção assume características predominantemente zapatistas.

Logo após o rompimento de Carranza com a Soberana Convenção de Aguascalientes, em novembro de 1914, os embates armados entre as tropas armadas carrancistas e convencionistas se intensificaram. Se estenderam até 1916 quando, praticamente derrotados, villistas e zapatistas tiveram que se contentar em sustentar uma guerrilha com muito menos pessoas, e táticas de enfrentamento menos abertas. $\mathrm{O}$ objetivo deste texto, porém, não é apresentar em minúcias os deslocamentos e as estratégias militares dos grupos revolucionários. O olhar se volta para os embates ideológicos e jurídicos que estiveram no pano de fundo da Revolução Mexicana expressos por meios de documentos de época, fontes primárias majoritariamente escritas em forma normativa. Seleciono, assim, algumas poucas informações e datas dos embates entre tropas e exércitos, apenas para apresentar o panorama do embate militar.

\subsection{Virada militar dos constitucionalistas liderados por Venustiano Carranza}

Em 24 de novembro de 1914, as tropas carrancistas saem, por decisão tática, da Cidade do México. Na mesma noite, zapatistas entram na capital. Em seguida, chegam os villistas e Eulálio Gutiérrez, dipostos a, em conjunto, fazer valer a decisão da Convenção de Aguascalientes, que havia nomeado Gutiérrez seu presidente provisório. As tropas de Villa e Zapata conferiam a base material para o seu efetivo exercício da presidência. Em 6 de dezembro de 1914, Francisco Villa e Emiliano Zapata pessoalmente entram triunfalmente na Cidade do México, data em que a famosa foto, 
onipresente nos retratos da Revolução Mexicana, retratando Zapata e Villa sentados nas cadeiras do Palácio Nacional, é tirada.

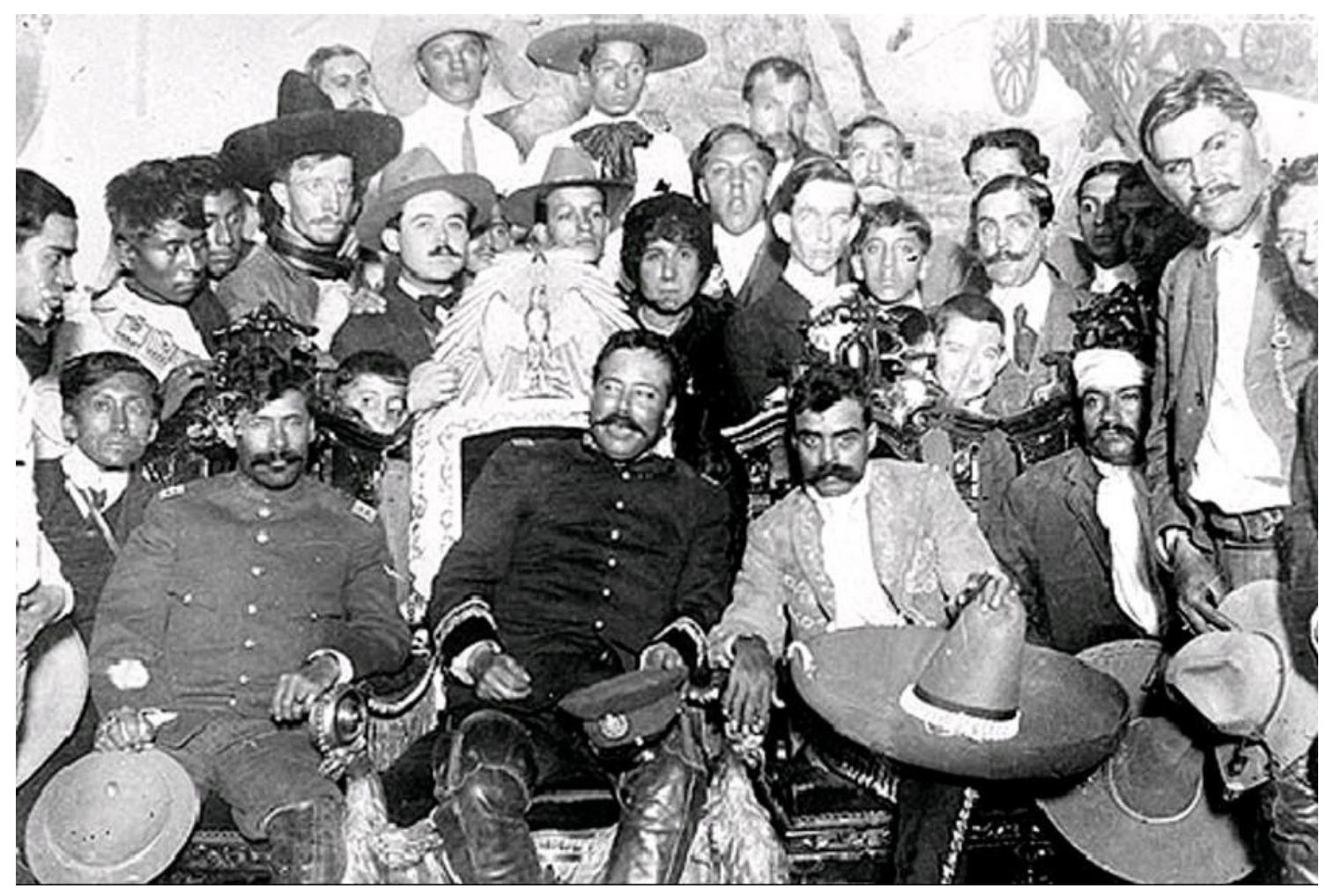

Francisco Villa e Emiliano Zapata (ao centro) chegam à Cidade do México e ao Palácio Nacional em dezembro de 1914

Desde o início da presença dos três líderes na cidade, porém, começam a surgir divergências entre Villa e Gutiérrez. Jesús Herzog afirma que entre dezembro e início de janeiro houve "en la capital varias autoridades de hecho, entre las cuales cabe mencionar la de Gutiérrez, la de Villa, la de Zapata y la de otros jefes militares."181

Simultaneamente, Carranza se instalava na cidade de Veracruz e, por meio de decretos, reorganizava as tropas e o estado paralelo que desejava consolidar. Em 6 de janeiro de 1915, como forma de responder às acusações convencionistas de que estaria na luta por ambições pessoais e mesquinhas, Carranza publica seu decreto que fica conhecido como "Ley agraria, que declara nulas todas las enajenaciones de tierras, aguas y montes pertenecientes a los pueblos" $" 182$.

181SILVA HERZOG, Jesús. Breve Historia de la Revolución Mexicana. Vol. 2 - La etapa constitucionalista y la lucha de facciones. $14^{\mathrm{a}}$. Reimpressão. Ciudad de México: Fondo de Cultura Económica do México, 1995. P. 163.

${ }^{182} \mathrm{O}$ conteúdo deste documento político-normativo, elaborado majoritariamente por Luis Cabrera, será analisado no capítulo 2. A íntegra da Ley Agraria, assinada por Venustiano Carranza em 6 de janeiro de 
Também em janeiro de 1915, Gutiérrez rompe com Villa, Zapata e Carranza. Após o rompimento, Gutierrrez planeja ações para se manter no poder. No entanto, ante o deslocamento de poderosas tropas villistas em direção à Cidade do México, dispostas a defender o acordo precário obtido na Convenção de Aguascalientes, Gutiérrez foge, sem enfrentar Villa. Em função da traição do presidente provisório eleito pela Soberana Convenção, um novo presidente é indicado: Roque González Garza. No mesmo mês, Álvaro Obregón, que já havia declarado lealdade a Carranza, reorganiza suas tropas e toma a cidade de Puebla.

Em janeiro de 1915 o México conflagrado vive uma peculiar configuração. Villa era o Chefe da Divisão Norte. Zapata, por sua vez, era conhecido como o caudilho do sul. Ambos estavam acostumados a lutar nos seus estados de origem e arredores Chihuahua e Morelos. Quando ocupam a Cidade do México e deslocam suas tropas para defender a capital, cedem aos constitucionalistas a periferia do país. À medida em que a necessidade de enfrentamento ficava mais clara, decidem voltar a seus territórios. Assim, em 28 de janeiro, Álvaro Obregón retoma a Cidade do México, sem combate. $\mathrm{Na}$ capital, recruta novos membros para compor suas tropas. Antevê a necessidade de enfrentar a temida Divisão Norte de Villa. Trabalhadores da Casa del Obrero Mundial declaram seu apoio - e alguns se juntam - ao exército constitucionalista, em fevereiro.

Em março de 1915, Obregón e seus combatentes saem da capital em busca de Villa e suas tropas. Zapatistas retomam a Cidade do México. A partir de então, muitas batalhas entre as tropas de Obregón e Villa se sucedem. Inicialmente, El Ébano e Querétaro são palcos dos confrontos. Entre abril e julho de 1915 há quatro grandes batalhas entre os dois generais. Duas delas ocorrem na cidade de Celaya. Uma terceira entre as cidades de Silao e León. O quarto grande enfrentamento, já em julho de 1915, ocorre nos arredores da cidade de Aguascalientes. Os villistas saem derrotados desses enfrentamentos, com consequente enfraquecimento de seu poderio militar.

Em meio aos confrontos armados, a disputa pelas regulamentações sociais permanece. Francisco Villa publica, em 24 de maio de 1915, na cidade de León, sua própria lei agrária. Obregón, meses antes, estabelece o salário mínimo nos estados que

1915, pode ser encontrada aqui: CARMONA, Doralicia. Memoria política de México. Guanajuato: Universidade de Guanajuato, 2014.

http://www.memoriapoliticademexico.org/Textos/6Revolucion/1915NET.html Consulta realizada em $02 / 12 / 2015$. 
estavam sob seu domínio. E determina que a norma tivesse seu âmbito de efetividade ampliado à medida em que novos estados fossem conquistados.

Após inúmeras vitórias militares, o governo dos Estados Unidos da América, por meio de seu Presidente Woodrow Wilson, reconhece em 19 de outubro de 1916 Venustiano Carranza e os constitucionalistas como o governo de fato do México. Esse reconhecimento em meio às batalhas gera em Villa um sentimento anti-americano profundo.

Em novembro de 1915 Villa sofre ainda uma nova derrota em Agua Prieta, Estado de Sonora. Ao final de 1915, as forças carrancistas dominavam quatro quintos do território Mexicano. A superioridade militar de suas tropas já estava mais do que evidente. Nesse contexto, Carranza sai em carreata pelo país e profere discursos em inúmeras cidades.

Em janeiro de 1916, generais villistas fuzilam dezessete passageiros de um trem. Entre os passageiros havia quinze norte-americanos, o que gera uma tensão internacional entre México e EUA. Em março, Villa participa pessoalmente de um assalto à cidade norte-americana de Columbus, juntamente com outros combatentes. Em razão da invasão do território dos Estados Unidos, as autoridades norte-americanas classificam a atitude como um crime de lesa pátria. Denunciado o crime, informam ao governo mexicano que soldados norte-americanos entrarão em território mexicano para capturar Villa, no início de março de 1916. Essa missão se encerra quase um ano depois, em fevereiro de 1917. As tropas norte-americanas voltam a seu território nacional, sem terem conseguido capturar Villa. Essa derrota simbólica de parte do exército norteamericano ajudou a construir as muitas lendas em torno de Pancho Villa.

Em 18 de abril de 1916, os convencionistas publicam o Programa de Reformas Político-Sociales, aprobado por la Soberana Convención Revolucionaria. Inúmeros historiadores consideram este documento o mais avançado na garantia de direitos sociais que a Revolução Mexicana produziu. No entanto, o programa surge em um momento em que as forças armadas convencionistas já estão bastante enfraquecidas. Suas propostas têm pouca efetividade prática, já que não havia força política e militar capaz de defendê-las e implementá-las.

Em 30 de julho de 1916, os operários e trabalhadores de diversos setores convocam uma greve geral na Cidade do México. Baixos salários, aumento do custo de 
vida e más condições de trabalho faziam parte das reclamações dos grevistas, e correspondentes reivindicações por mudanças. O aumento do custo de vida era também consequência dos intensos conflitos armados que diminuiam a produção de insumos alimentícios, diminuição também causada pela concentração fundiária.

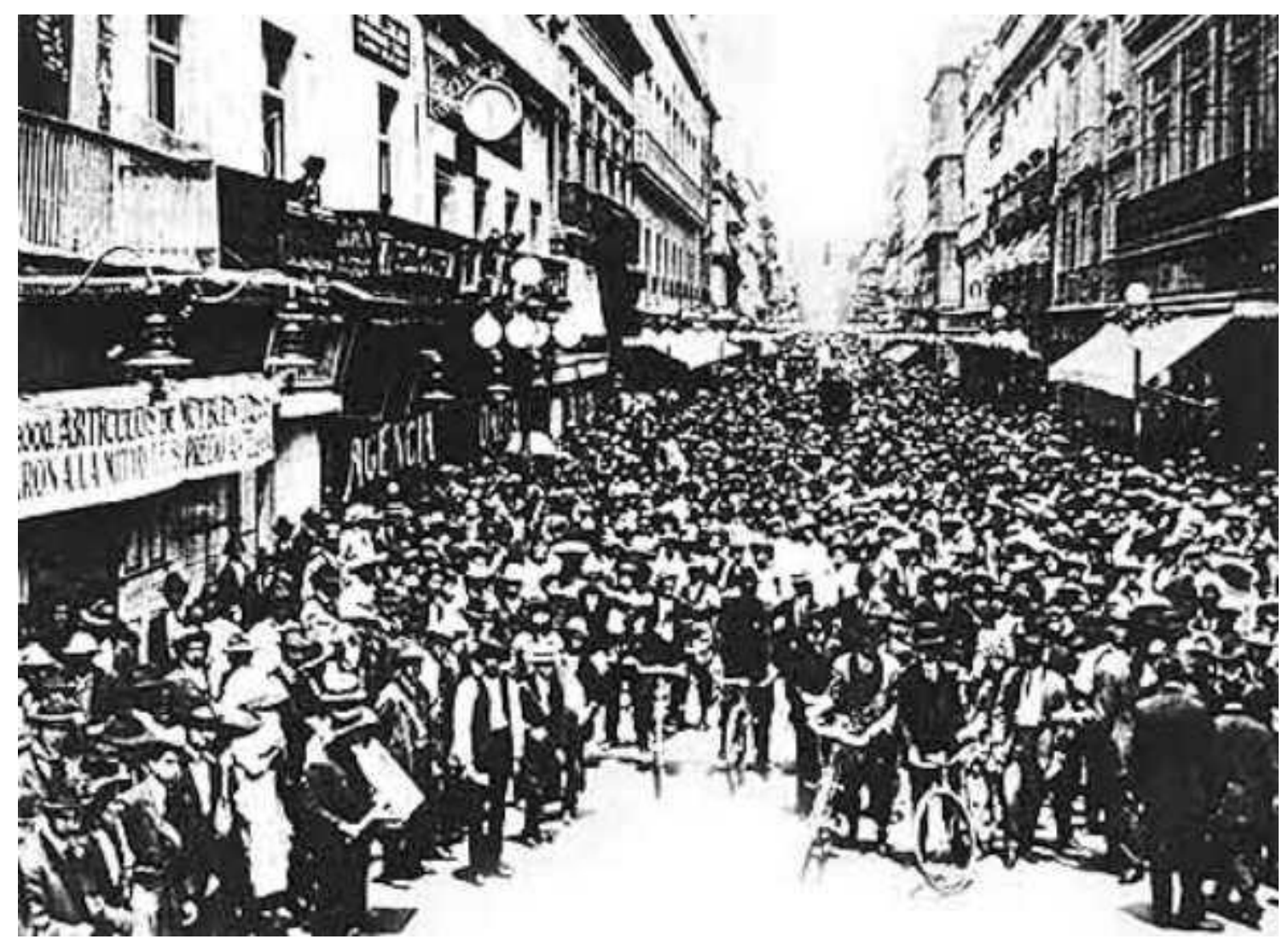

Trabalhadores em greve geral no final de julho de 1916, na Cidade do México.

No momento em que os setores responsáveis pela geração e transmissão de energia elétrica decidiram aderir, Carranza publica, em $1^{\circ}$ de agosto de 1916, um decreto que prevê que "Se castigará con la PENA DE MUERTE, además de a los trastornadores del orden público que señala la ley de 25 de enero de $1862^{\text {"183 todos }}$ aqueles que incitarem a suspensão dos trabalhos; que presidam as reuniões que têm a greve como pauta; que defenderem ou votarem a favor da greve nessas reuniões; que agirem contra a propriedade privada das empresas; que se engajem para impedir que

\footnotetext{
${ }^{183}$ A íntegra do decreto de Venustiano Carranza, em que são estabelecidas penas para os grevistas, publicado em $1^{\circ}$ de agosto de 1916, pode ser encontrada aqui: CARMONA, Doralicia. Memoria política de México. Guanajuato: Universidade de Guanajuato, 2014.

http://www.memoriapoliticademexico.org/Textos/6Revolucion/1916DCT.html Consulta realizada em $02 / 12 / 2015$.
} 
trabalhadores acessem seus postos de trabalho... A lista das hipóteses que podem ser penalizadas com a pena de morte continua, e é extensa. Carranza não tem nenhum constrangimento de agir com truculência e violência contra aqueles que tinham decidido lutar ao lado do exército constitucionalista um ano e meio antes.

No dia seguinte, em 2 de agosto de 1916, todos os serviços voltam a funcionar normalmente. A violência prometida pelo decreto de Carranza tinha sido eficaz para reprimir o movimento grevista. Os líderes que já haviam sido presos foram sendo libertados paulatinamente. Um dos últimos ficou preso até fevereiro de 1918. Além da greve geral reprimida de julho, outras foram as greves convocadas ao longo de 1916. Cresce a tensão entre Carranza e os trabalhadores.

Em 14 e 19 de setembro de 1916, Carranza expede dois decretos que convocam um Congresso Constituinte. A nova Constituição é aprovada e proclamada em 5 de fevereiro de 1917. Em $1^{\circ}$ de maio de 1917 Carranza toma posse como Presidente da República. Cumpre seu mandato até ser assassinado em 1920. O Congresso Constituinte e a Constituição dos Estados Unidos Mexicanos podem ser considerados marcos do fim da Revolução iniciada em 1910, apesar da persistência de alguns conflitos armados pelo país.

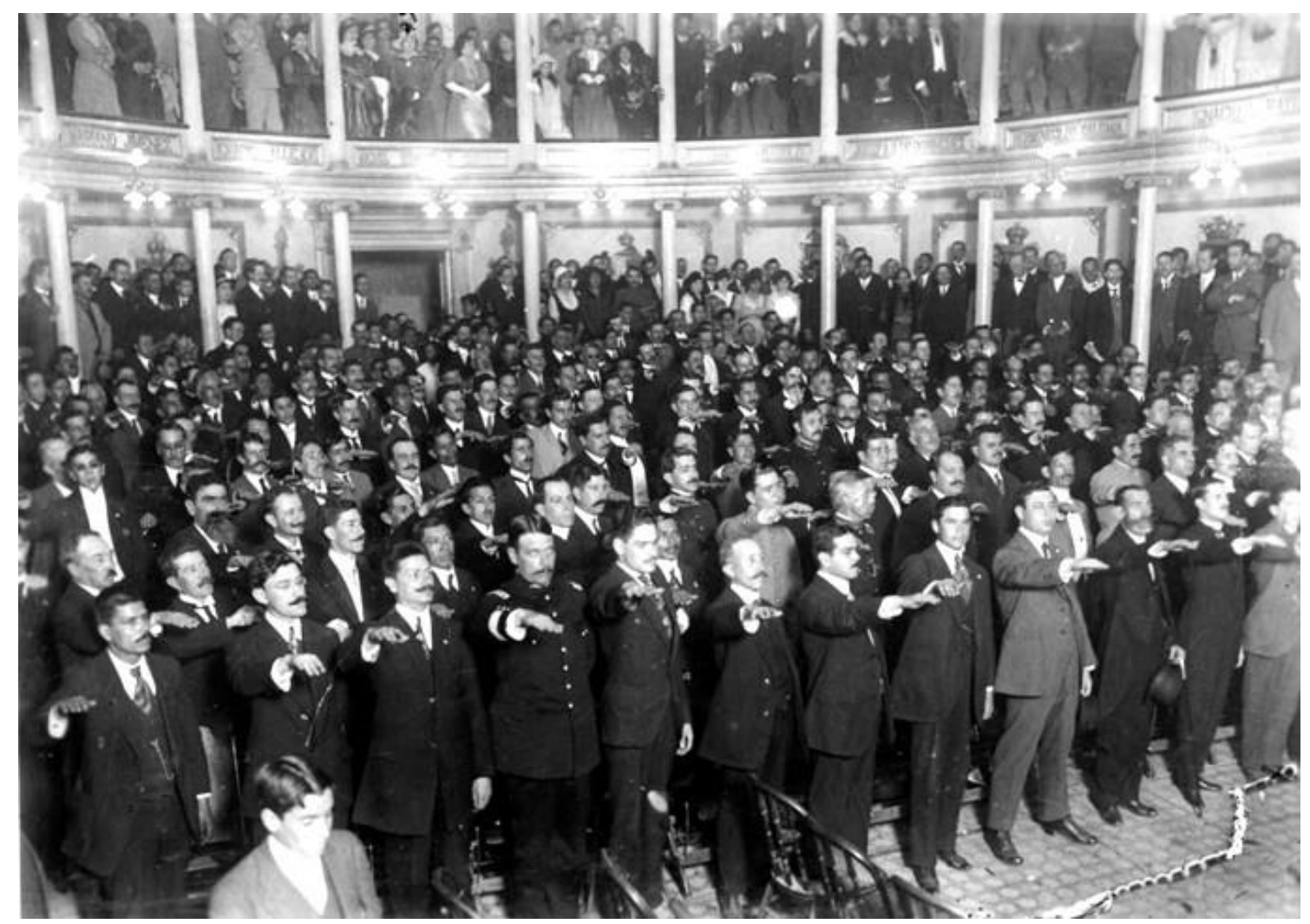

Deputados constituintes prestam juramento no início das sessões do Congresso Constituinte, em dezembro de 1916, Querétaro. 


\title{
1.11 Os anseios de transformação social corporificados: a Constituição Mexicana de 1917
}

\begin{abstract}
Aplazar las reformas era ponerlas en peligro. Las adiciones al Plan de Guadalupe fueron un programa concreto de revolución social. Dejarlas consignadas en un plan era una obra meramente literaria. Formular las leyes y decretos de tendencia social y expedirlas en un periodo preconstitucional, resultaba útil y fecunda propaganda de la revolución; pero no era una obra eficaz para consumarla. De ahí que el señor Carranza y sus colaboradores llegaran a la convicción de que era indispensable convocar a un congreso constituyente; en términos jurídicos: constituir a la revolución. ${ }^{184}$
\end{abstract}

O Exército Constitucionalista já tinha sob seu controle boa parte do território do México quando Venustiano Carranza tornou pública a decisão de convocar um Congresso Constituinte. Sua superioridade numérica - estima-se que em meados de 1916 o número de homens carrancistas passava de 150 mil - e sua presença distribuída por todas as regiões e estados mexicanos deixavam claro que, se os conflitos ainda não haviam se encerrado completamente, não era porque não se sabia quem era o vencedor. O que antes era uma guerra civil tinha se tornado uma guerrilha, sem que houvesse uma clara liderança com quem negociar um acordo de paz - ou mesmo disposta a aceitá-lo. Os conflitos permaneceram, mas já não ameaçavam Carranza e seu objetivo de reorganizar institucionalmente o México.

Em outubro de 1914, dois anos antes de ser convocada a Constituinte, Carranza recusou o convite para participar da Convenção de Aguascalientes e encaminhou suas condições para se afastar do exercício do poder executivo provisório. A primeira entre as condições afirmava ser necessário um governo provisório "preconstitucional" capaz de realizar reformas sociais e políticas antes de se reestabelecer o governo constitucional. ${ }^{185}$ Carranza não parecia confiar em um corpo colegiado, ou submetido às normas da Constituição, para realizar as reformas necessárias à reordenação do México.

\footnotetext{
${ }^{184}$ F. F. Palavicini. Historia de la Constitución de 1917, México, p. 49. Apud Arnaldo Córdova. La ideología de la Revolución Mexicana - la formación del nuevo régimen. $8^{\mathrm{a}}$ Edición. Ciudad del México: Ediciones Era, 1980, p. 217.

${ }^{185}$ A íntegra da carta que Venustiano Carranza encaminha aos membros da Convenção de Aguascalientes pode ser acessada aqui: CARMONA, Doralicia. Memoria política de México. Guanajuato: Universidade de Guanajuato, 2014. http://www.memoriapoliticademexico.org/Textos/6Revolucion/1914MCA.html Consulta realizada em 02/12/2015.
} 
Em 14 de setembro de 1916, no decreto em que convoca um Congresso Constituinte e eleições para seus deputados, Carranza reafirma a convicção de que uma instância colegiada, que respeitasse de alguma forma as etapas e a forma do processo legislativo, não seria necessária para realizar as reformas necessárias ao México. Afirma que, a exemplo dos líderes que deixaram ao país o legado liberal no século XIX, as mudanças no ordenamento jurídico "pueden ser expedidas y puestas en la práctica desde luego sin inconveniente alguno, como fueron promulgadas y ejecutadas inmediatamente las Leyes de Reforma" ${ }^{\prime 186}$. Essas leis da Reforma do meio do século XIX, muitas aprovadas sem processo legislativo, só entrariam na Constituição após anos de vigência efetiva na realidade mexicana. Carranza estava convencido de que poderia fazer o mesmo em 1916. Assim, mesmo convicto de que um Congresso Constituinte não seria estritamente necessário, Carranza convoca-o e afirma que sua decisão quer garantir que a legitimidade do processo de mudanças não seja questionada. Os "inimigos do governo constitucionalista", afirma, usam as mais diferentes estratégias e não poupam esforços para desestabilizar a conquista recém-alcançada. Assim, o Congresso Constituinte seria uma forma de prevenir um futuro ataque. E também de garantir a estabilidade institucional do Estado mexicano, que ficaria a salvo de qualquer questionamento posterior.

Mas quais seriam essas reformas tão necessárias à reorganização mexicana, segundo Carranza? Em seu longo texto de razões para convocar o Congresso Constituinte, o encarregado do poder executivo menciona inúmeras vezes a necessidade de se aperfeiçoarem as instituições políticas de forma a impedir o exercício da tirania. Organização e funcionamento dos três poderes políticos seriam objeto de reforma, já que a Constituição de 1857 seria "inadecuada para la satisfacción de las necesidades públicas y muy propicia para volver a entronizar otra tiranía" ${ }^{187}$. A inadequação da Constituição de 1857 está ligada diretamente à sua incapacidade de impedir o exercício

\footnotetext{
186 A íntegra do Decreto de Venustiano Carranza que convoca o Congresso Constituinte, em 14 de setembro de 1916, pode ser encontrada aqui: MÉXICO. Centenario de la Constitución Política de los Estados Unidos Mexicanos 1917. Cidade do México: Instituto Nacional de Estudios Históricos de las Revoluciones de México (INEHRM), 2015. http://www.constitucion1917.gob.mx/work/models/Constitucion1917/Resource/251/1/images/001.pdf Consulta realizada em 04/12/2015.

187 A íntegra do Decreto de Venustiano Carranza que convoca o Congresso Constituinte, em 14 de setembro de 1916, pode ser encontrada aqui: MÉXICO. Centenario de la Constitución Política de los Estados Unidos Mexicanos 1917. Cidade do México: Instituto Nacional de Estudios Históricos de las Revoluciones de México (INEHRM), 2015. http://www.constitucion1917.gob.mx/work/models/Constitucion1917/Resource/251/1/images/001.pdf Consulta realizada em 04/12/2015.
} 
arbitrário do poder. Inúmeras vezes ao longo do texto fica explícita o que parece ser a principal preocupação de Carranza: propor um novo desenho institucional capaz de impedir o autoritarismo. Curiosa proposição para aquele que supõe ser desnecessário o processo legislativo para realizar reformas, aquele que desejava realizar reformas constitucionais por meio de atos normativos unipessoais.

A Constituição Mexicana ganhou notoriedade internacional - e foi escolhida como objeto deste trabalho - por ser a primeira a incorporar direitos sociais em seu texto. Surpreendente perceber que, no ato de convocação do Congresso Constituinte responsável por sua formulação, a única menção às reformas sociais é uma singela afirmação: as reformas devem garantir instituições que "aseguren la situación económica de las clases proletarias" ${ }^{188}$. Note-se que não há previsão de normas garantidoras de direitos, mas sim instituições capazes de assegurá-los. Tanto o conteúdo do decreto convocador quanto a primeira versão do texto de Constituição encaminhado por Carranza ao Congresso Constituinte deixam claro que o crédito histórico pela incorporação de direitos sociais à Constituição, sobretudo aqueles relacionados à terra e ao trabalho, não deveriam ficar na sua conta ${ }^{189}$.

Que para salvar este escollo, quitando así a los enemigos del orden todo pretexto para seguir alterando la: paz pública y conspirando contra la autonomía de la nación y evitar a la vez el aplazamiento de las reformas políticas indispensables para obtener la concordia de todas las voluntades y la coordinación de todos los intereses, por una organización más adaptada a la actual situación del país y, por lo mismo, más conforme al origen, antecedentes y estado intelectual, moral y económico de nuestro pueblo, (...) Que planteado así el problema, desde luego se ve que el único medio de alcanzar los fines, es un Congreso Constituyente por cuyo conducto la nación entera exprese de manera indubitable su soberana voluntad, pues de este modo, a la vez que se discutirán y resolverán en la forma y vía más adecuadas todas las cuestiones que hace tiempo están

\footnotetext{
188 A íntegra do Decreto de Venustiano Carranza que convoca o Congresso Constituinte, em 14 de setembro de 1916, pode ser encontrada aqui: MÉXICO. Centenario de la Constitución Política de los Estados Unidos Mexicanos 1917. Cidade do México: Instituto Nacional de Estudios Históricos de las Revoluciones de México (INEHRM), 2015.

http://www.constitucion1917.gob.mx/work/models/Constitucion1917/Resource/251/1/images/001.pdf Consulta realizada em 04/12/2015.

189 "El proyecto de reformas de don Venustiano reproducía buen número de artículos de la Constitución de 1857 sin ninguna modificación, pero contenía cambios más o menos substanciales en varios de los más importantes. Sin embargo, esos cambios resultaron demasiado prudentes o tímidos para el ala izquierda del Congreso que incuestionablemente constituía la mayoría del mismo. Mención especial merecen los artículos $3^{\circ}, 27,28,123,130$. Fueron y son a nuestro juicio los de mayor significación de la nueva Carta Magna que debia regir y que rige en nuestro país desde hace algo más de diez lustros." Jesus Silva Herzog. Breve Historia de la Revolución Mexicana - La etapa constitucionalista y la lucha de facciones, p. 305.
} 
reclamando solución que satisfaga ampliamente las necesidades públicas, se obtendrá que el régimen legal se implante sobre bases sólidas en tiempo relativamente breve y en términos de tal manera legítimos que nadie se atreverá a impugnarlos. ${ }^{190}$

Carranza quer usar o Congresso Constituinte não para consolidar direitos sociais conquistados com as armas, constitucionalizando a lei agrária que editou em 6 de janeiro de 1915. Elaborar uma nova Constituição é tática de legitimação política para sua posição de vencedor da Revolução.

Segundo seu texto, as reformas que considera necessárias seriam realizadas por um Congresso considerado representante da soberania popular, por meio de um procedimento de deliberação coletiva. Seus 220 deputados constituintes ${ }^{191}$, escolhidos por meio de eleições diretas nos diferentes estados e territórios mexixanos, seriam, assim, a corporificação da soberania que conferiria legitimidade ao novo Estado Mexicano, construído após e a partir da Revolução.

Herzog afirma que a decisão pela convocação do Congresso Constituinte não era esperada pela sociedade Mexicana192. Córdova, por sua vez, afirma que “(...) seguramente ninguno de los caudillos campesinos se preguntó si el típico Estado liberal que contemplaba la Constitución [de 1857] podía ensamblar con su programa; quizá ni siquiera pensaron en ello". ${ }^{193}$

Uma carta de Emiliano Zapata ao então Presidente dos EUA, Woodrow Wilson, em 23 de agosto de 1914, parece contradizer a afirmação de Córdova. Se Zapata possuía ou não uma reflexão sobre a forma do Estado liberal, não é possível dizer. Em 1914, porém, o caudilho do sul já tecia críticas à Constituição de 1857.

\footnotetext{
${ }^{190}$ A íntegra do Decreto de Venustiano Carranza que convoca o Congresso Constituinte, em 14 de setembro de 1916, pode ser encontrada aqui: MÉXICO. Centenario de la Constitución Política de los Estados Unidos Mexicanos 1917. Cidade do México: Instituto Nacional de Estudios Históricos de las Revoluciones de México (INEHRM), 2015.

http://www.constitucion1917.gob.mx/work/models/Constitucion1917/Resource/251/1/images/001.pdf Consulta realizada em 04/12/2015.

${ }^{191}$ A lista completa dos deputados constituintes eleitos para o Congresso Constituinte de 1916 e 1917 pode ser encontrada aqui: MÉXICO. Centenario de la Constitución Política de los Estados Unidos Mexicanos 1917. Cidade do México: Instituto Nacional de Estudios Históricos de las Revoluciones de México (INEHRM), 2015.

http://www.constitucion1917.gob.mx/work/models/Constitucion1917/Resource/251/1/images/005.pdf Consulta realizada em 04/12/2015.

192 "El Señor Carranza, con sorpresa para la mayoría de la nación, convoco a un Congreso Constituyente por medio de dos decretos fechados el 14 y 19 de septiembre de 1916" SILVA HERZOG, Jesus. Breve Historia de la Revolución Mexicana - La etapa constitucionalista y la lucha de facciones, p. 303.

${ }^{193}$ CÓRDOVA, Arnaldo. La ideología de la Revolución Mexicana - la formación del nuevo régimen. $8^{\mathrm{a}}$ Edición. Ciudad del México: Ediciones Era, 1980, p. 151.
} 
(...) ya que la legislación no lo favorece y toda vez que la constitución vigente es más bien un estorbo que una defensa o una garantía para el pueblo trabajador, y sobre todo, para el pueblo campesino. ${ }^{194}$

Aparentemente a convocação do Congresso Constituinte não era esperada, ou, ao menos, não havia uma pressão popular que reivindicasse uma nova Constituição. Por outro lado, não se pode desconsiderar o fato de que havia no México de 1916 uma insatisfação generalizada com a ordem jurídica vigente. Apesar de defenderem a “justiça e a lei”, ou a ordem constitucional, há em diversos documentos revolucionário críticas veemente às leis que expropriaram terras de comunidades indígenas; aos juízes que elaboravam interpretações amplamente desfavoráveis às classes populares; a um específico modo de manejar a legalidade. Acreditavam que o direito e a justiça deveriam ser respeitados, acreditavam que o direito tinha que estar do lado deles. A vida prática e cotidiana dos campesinos, no entanto, não corroborava essa percepção. A crítica a algumas normas e às interpretações jurídicas realizadas nas vésperas da Revolução acabou por ser projetada também como crítica à Constituição de 1857, como indica a carta de Zapata. Assim, não se pode dizer que a decisão por um Congresso Constituinte foi obra individual de Carranza.

As eleições para deputados do Congresso Constituinte foram realizadas em 22 de outubro de 1916. Em 20 de novembro, os eleitos se apresentaram pela primeira vez no Teatro Iturbide, em Querétaro. Como o decreto convocador impedia que houvesse entre os eleitos funcionários públicos ou militares que tivessem sido hostis à causa constitucionalista, nem todos os deputados eleitos ${ }^{195}$ participaram efetivamente das deliberações. Após serem conferidas as documentações, como comprovação dos processos eleitorais, o Congresso efetivamente entrou em funcionamento em $1^{\circ}$ de dezembro de 1916 com 193 deputados.

Entre los 220 delegados -incluyendo los suplentes- había 62 abogados, 22 oficiales de alto rango, 19 agricultores, 18 profesores,

\footnotetext{
${ }^{194}$ A íntegra da carta de Emiliano Zapata ao Presidente dos EUA Woodrow Wilson, de 23 de agosto de 1914, pode ser encontrada aqui: CARMONA, Doralicia. Memoria política de México. Guanajuato: Universidade de Guanajuato, 2014. http://www.memoriapoliticademexico.org/Textos/6Revolucion/1914C-EZ-WW.html Consulta realizada em 04/12/2015.

${ }^{195}$ A lista completa dos deputados constituintes eleitos para o Congresso Constituinte de 1916 e 1917 pode ser encontrada aqui: MÉXICO. Centenario de la Constitución Política de los Estados Unidos Mexicanos 1917. Cidade do México: Instituto Nacional de Estudios Históricos de las Revoluciones de México (INEHRM), 2015.

http://www.constitucion1917.gob.mx/work/models/Constitucion1917/Resource/251/1/images/005.pdf Consulta realizada em 04/12/2015.
} 
16 ingenieros, 16 médicos, 14 periodistas, 7 contadores, 5 líderes sindicales, 4 mineros, 3 ferrocarrileros, 2 farmacéuticos, 1 actor y 31 representantes de otras profesiones, entre ellas artesanos, comerciantes y empleados. La gran mayoría provenía de zonas rurales, "tenía conceptos más bien provincianos" y pertenecía a la generación de ente 30 y 40 años. ${ }^{196}$

O Congresso Constituinte mexicano se reuniu ao longo de dois meses, entre $1^{\circ}$ de dezembro de 1916 e 5 de fevereiro de 1917, ultrapassando em poucos dias o prazo de dois meses estipulado na norma que o convocou. Foram realizadas 67 sessões e 179 votações. Em 117 delas, a questão foi resolvida por unanimidade. Em 62, portanto, a maioria decidiu a controvérsia. Para instalar as sessões de deliberação, o quórum mínimo era de 122 deputados. Na prática, houve oscilação entre 124 e 192 deputados presentes nas diferentes sessões deliberativas. Além disso, o Congresso contou com nove diferentes comissões temáticas ${ }^{197}$.

Huerta Cuevas, em sua obra "Ingeniería institucional y estabilidad política", destaca que, entre as divergências dos deputados constituintes, uma bastante presente referia-se à decisão de tornar o México um país politicamente mais centralizado ou mantê-lo descentralizado. Este embate emergiu em diversos momentos. No primeiro, discutiu-se o nome do país. Deveria ser mantido o nome Estados Unidos Mexicanos tal como na Constituição de 1857 - ou a nomenclatura República Federativa Mexicana seria a mais adequada? A segunda possibilidade, segundo os opositores da mudança nos debates no Congresso, induziria a uma maior centralização política. Outros afirmavam que o nome República Federativa tinha como único objetivo distanciar-se simbolicamente do país fronteiriço ao norte do México. Venceram aqueles que queriam manter Estados Unidos Mexicanos.

Nem todas as vitórias foram daqueles que defendiam a descentralização, porém. Em relação ao sistema penitenciário, por exemplo, os constituintes estabeleceram um regime de resposabilidades compartilhadas entre governo central e estados federados.

\footnotetext{
196 Declaração do deputado Jesús Romero Flores citada em Víctor E., Niemeyer, Revolución en Querétaro. El congreso constituyente mexicano de 1916-1917, Cámara de Diputados del Congreso de la Unión, 1993, p. 39. Apud Huerta Cuevas, Enrique, Ingeniería institucional y estabilidad política. El México revolucionario, 1908-1920, tesis de maestría, Puebla, Benemérita Universidad Autónoma de Puebla, Facultad de Derecho y Ciencias Sociales, 2013, pp. 75-98.

${ }^{197}$ Informações coletadas e organizadas por Enrique Huerta Cuevas. Ingeniería institucional y estabilidad política. El México revolucionario, 1908-1920. Tese de mestrado, Puebla, Benemérita Universidad Autónoma de Puebla, Facultad de Derecho y Ciencias Sociales, 2013, pp. 75-98. Disponível em: https://enriquehuertacuevas.wordpress.com/tag/el-congreso-constituyente-mexicano-de-1916-1917/ Consulta realizada em 04/12/2015.
} 
Os constituintes optaram também por incluir no texto constitucional o respeito à autonomia das gestões municipais, entre outras controvérsias que tinham como pano de fundo a tensão centralização versus descentralização.

Os direitos sociais, que conferem notoriedade à Constituição Mexicana de 1917, foram discutidos apenas em janeiro de 1917. As redações originais do artigo 123, que traz um extenso rol de direitos dos trabalhadores, e do artigo 27, sobre a terra ser propriedade da nação, que tem o direito de cedê-la em domínio a particulares. ${ }^{198}$, foram elaboradas por uma comissão chamada de "Comisión de Constitución y Reformas", da qual participavam os seguintes deputados: Pastor Rouaix, Victorio E. Góngora, Esteban Baca Calderón, Luis Manuel Rojas, Dionisio Zavala, Rafael de los Ríos, Silvestre Dorador e Jesús de la Torre. Embora Carranza não tivesse como projeto inicial a inclusão de direitos sociais em redações tão extensas, o que fica claro pelo exame do projeto original para a nova Constituição, Arnaldo Córdova afirma que seu resultado final poderia ter se revelado agradável ao caudilho que, em inúmeros momentos, mostrou-se favorável à instalação de um poder executivo forte. Córdova parece afirmar que a existência de direitos sociais fortalece, por si só, esse poder:

Carranza jamás se imaginó, ni dio trazas de comprenderlo después, el colosal poderío que se ponía a disposición del Estado, al convertir las reformas sociales en instituciones constitucionales. ${ }^{199}$

Além da terra e do trabalho, a Constituição de 1917 também regulamentava o direito à educação no artigo $3^{\circ}$, e instituía o procedimento chamado juício de amparo (art.107), por meio do qual se realizaria a defesa de direitos contra a arbitrariadade do exercício do poder. A aprovação e promulgação da Constitución de los Estados Unidos Mexicanos e de sua vasta regulamentação de direitos sociais, em 5 de fevereiro de 1917, marca a volta à normalidade institucional no México.

Embora nem todos os autores sejam unânimes sobre a data de término da Revolução Mexicana - alguns a estendem até muito tempo depois, na década de 30, governo de Cárdenas - neste trabalho adota-se a Constituição de 1917 como ponto final do processo revolucionário que teve início em 1910. Para além da opção ser justificável a partir do desenrolar do próprio processo revolucionário que tomou o México no início

\footnotetext{
${ }^{198}$ O conteúdo do artigo 27 será discutido no capítulo 2 e o artigo 123 será discutido no capítulo 3.

${ }^{199}$ CÓRDOVA, Arnaldo. La ideología de la Revolución Mexicana - la formación del nuevo régimen. $8^{\text {a }}$ Edición. Ciudad del México: Ediciones Era, 1980, p. 27.
} 
do século XX, soma-se ainda o fato de que, para o nosso estudo, a Constituição dos Estados Unidos Mexicanos de 1917 ser a corporificação jurídica de alguns dos anseios de transformação social que estiveram presentes desde antes de 1910, como será analisado nos próximos capítulos.

É forçoso reconhecer, porém, que o retorno à institucionalidade não estava completo em 5 de fevereiro, com a promulgação da nova Constituição. Em 6 de fevereiro de 1917, foram convocadas as eleições para deputados, senadores e presidente da República. Em 11 de março, as eleições foram realizadas e Venustiano Carranza foi eleito o primeiro presidente da nova ordem constitucional. Em 15 de abril, o novo Congresso mexicano foi instalado e, em $1^{\circ}$ de maio de 1917, Carranza tomou posse como Presidente da República. Carranza governará o México até o dia 21 de maio de 1920, data em que foi assassinado por questões políticas.

A morte de Carranza indica que a força dos conflitos vividos pelo México nestes pouco mais de seis anos de enfrentamennto armado não foram canalizados totalmente para as instituições criadas pela Constituição de 1917. Além do assassinato, diversos focos de conflito permaneceram existindo, em formato de guerrilha, em Morelos e Chihuahua ainda por muitos anos, mesmo após a morte de Emiliano Zapata, em abril de 1919, e de Francisco Villa, em julho de 1923.

No total, estima-se que o processo revolucionário tenha deixado o saldo de um milhão de mortos no México, entre aqueles que morreram em combate e outros que morreram pela fome e epidemias decorrentes dos conflitos. A Constituição aprovada em 1917 é considerada, por muitos, um dos mais importantes legados do processo revolucionário. Se um documento jurídico, sem a sua substancial efetivação, pode ser considerado tão importante, é questão que está em aberto. Do ponto de vista desse trabalho, que tem por objetivo investigar as relações que os movimentos estabelecem com a legalidade, ou com a forma jurídica, a corporificação de diversos anseios sociais em uma Constituição é, sem dúvida, fato digno de destaque. 


\title{
CAPítulo 2
}

\section{O Direito e A OrganizaÇÃo Fundiária MEXiCAna}

\begin{abstract}
El problema agrario en sus diversas modalidades es, en el fondo, la causa fundamental de la que derivan todos los males del país y de sus habitantes, y por esto se ha resuelto que las diversas soluciones de ese problema deben comenzar a ejecutarse y a realizarse lo mismo que los demás ideales de la revolución, en el momento mismo en que el triunfo se verifique, sin esperar más ni dilatar por motivo alguno la ejecución de las soluciones del problema agrario, que constituye el mejoramiento económico de los habitantes y el establecimiento definitivo del verdadero progreso. ${ }^{200}$ (Plan de Tacubaya, outubro de 1911)

(...) una vez más llegamos a la conclusión de que la historia de México es la historia de la lucha por la tenencia de la tierra.201
\end{abstract}

A historiografia sobre a Revolução Mexicana é praticamente unânime ao afirmar que problemas sociais relacionados à extrema concentração de terras no território do país estão entre as causas do movimento revolucionário. Jesús Herzog descreve provavelmente o ápice crítico da concentração fundiária do México, na passagem do século XIX para o século XX:

Sea de ello lo que fuere, lo cierto es que como resultado de las leyes de colonización, se organizaron en el país varias compañías denominadas deslindadoras. Estas compañías debían deslindar as tierras baldías y traer colonos extranjeros para que las trabajaran; y como compensación por los gastos que hicieran para conseguir esos propósitos, se les adjucaría la tercera parte de las tierras deslindadas.

\footnotetext{
${ }^{200}$ A íntegra do Plan de Tacubaya, de 31 de outubro de 1911, pode ser encontrada em: CARMONA, Doralicia. Memoria política de México. Guanajuato: Universidade de Guanajuato, 2014. http://www.memoriapoliticademexico.org/Textos/6Revolucion/1911PDT.html Consulta realizada em 21/11/2105.

201 MORA DONATTO, Cecilia. "Aspectos históricos-jurídicos del problema agrario en México. Segunda de dos partes: del México independiente al constituyente de 1917". In Revista de la Facultad de Derecho de la Universidad Nacional Autónoma de México (UNAM). Cidade do México, número 235, p. $183,2001$.
} 
De 1881 a 1889, las compañías de que se trata deslindaron 32.200.000 hectáreas. De esta cantidad se les adjudicaron de conformidad con la ley, es decir, sin pago alguno, 12.700.000 hectáreas; y se les vendieron a vil precio 14.800 .000 hectáreas más. Total: 27.500.000 hectáreas, o sea, algo más del 13\% de la superficie total de la nación. Empero, lo más impresionante estriba en señalar el hecho de que esas compañías hasta el año de 1889 estaban formadas únicamente por veintinueve personas, todas ellas acaudaladas y de gran valimiento en las altas esferas oficiales.

Todavía de 1890 a 1906, año en que fueron disueltas las compañías, deslindaron 16.800.000 hectáreas, quedándose con la mayor parte de las tierras los socios de tan lucrativo negocio, cuyo número había ascendido a cincuenta en los comienzos de este siglo. Por el camino de los deslindes, uno de los socios adquirió en Chihuahua 7.000.000 de hectáreas; otro, en Oaxaca, 2.000.000; dos socios en Durango, 2.000.000; y cuatro en Baja California, 11.500.000. De manera que ocho individuos se hicieron propietarios de 22.500 .000 hectáreas, hecho sin precedente en la historia de la propiedad territorial em el mundo. $^{202}$

Assim como outros historiadores, Herzog atribui parte da responsabilidade pela concentração de terras que experimentava o México no início do século XX a algumas políticas fomentadas pelos governos mexicanos por meio de documentos normativos, decretos e leis. Tais políticas tinham como objetivo declarado regular e garantir a ocupação da propriedade rural no país. Subsidiariamente, visavam reduzir o poder patrimonial da igreja e tornar a imensa área territorial mexicana mais produtiva, por meio da estratégia de importação de conhecimento e tecnologias de colonos europeus.

Nesse capítulo se reconstruirá a história da regulação jurídica sobre a propriedade rural no México. Ao organizar, descrever e analisar as normas presentes nos documentos históricos quer-se entender em que medida é possível atribuir-lhes responsabilidade pela brutal concentração fundiária existente no início do século XX.

A análise algo minuciosa de inúmeros documentos normativos que versaram sobre a organização da propriedade rural no século XIX se justifica para além do interesse sobre o processo de concentração de terras nas mãos de poucos proprietários experimentada pelo México, porém. Entender qual papel desempenhou o direito na espoliação vivida por pequenos camponeses, indígenas e mestiços mexicanos pode trazer elementos sobre o modo como os movimentos revolucionários que realizaram a

202 HERZOG, Jesús Silva. Breve historia de la revolución mexicana: los antecedentes y la etapa Maderista. 15 reimp. Cidade do México: Fondo de Cultura Económica do México., 1997, p. 18-19. 
revolução no campo, a partir de 1910, se relacionam com a legalidade, além de sobre quais anseios e expectativas estes projetam na forma jurídica.

Parte-se da hipótese de que reconstruir os passos jurídicos dados por diferentes sistemas políticos no século XIX contribuiria para esclarecer a perplexidade que causa, por exemplo, o lema adotado pelo Plan de Ayala - documento que orientou a luta zapatista a partir de 1911 - "Justicia y ley". Por que e em quais circunstâncias reivindicavam-se a justiça e a lei, quando tanto o Poder Judiciário quanto as normas editadas parecem sempre ter sido contrárias aos interesses dos signatários do plano?

A relação dos movimentos sociais com o direito, porém, parece ser ambígua. Explicitar a ambiguidade, por meio da análise dos documentos produzidos pelos próprios movimentos, também é objetivo deste capítulo. Ora conflito aberto com a legalidade que os oprimia; outras vezes aposta nos instrumentos jurídicos como meio eficiente para transformação - as diferentes relações com a legalidade devem estar relacionadas a diferentes experiências sociais e históricas vividas e sofridas por estes atores sociais e, portanto, com a história da regulação da propriedade rural no país.

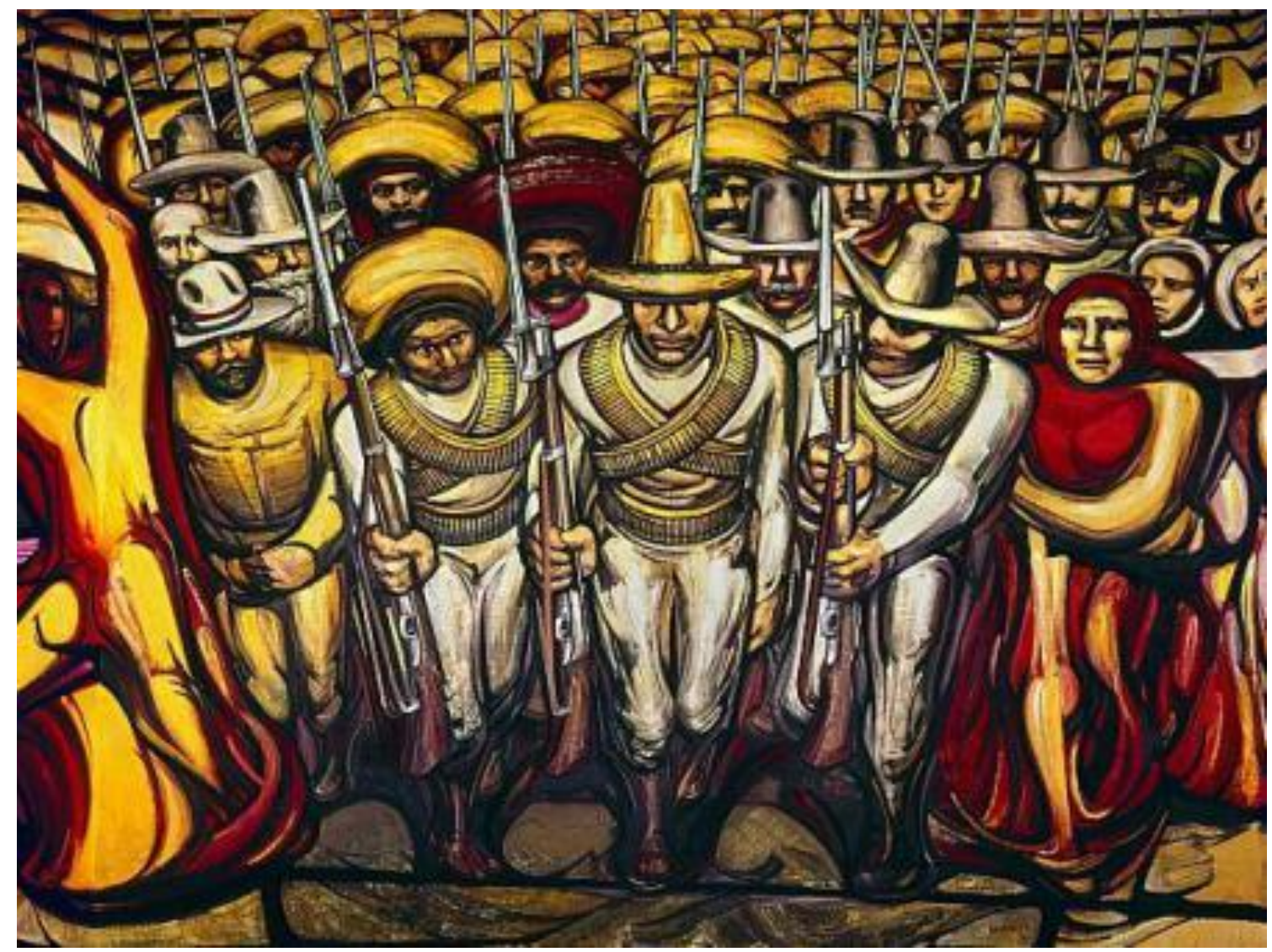

Detalhe do mural Del porfirismo a la Revolución (1957-1966), de David Alfaro Siqueiros. Museo Nacional de Historia del Castillo de Chapultepec 


\subsection{Antecedentes: México colonial}

Historiadores dedicados à fase pré-hispânica do México afirmam que a injusta distribuição de terras no país já existia antes mesmo da colonização espanhola ${ }^{203}$. Não se pode atribuir aos índios, porém, qualquer responsabilidade no cenário de concentração fundiária existente no início do século XX, momento em que eclode a Revolução ${ }^{204}$. Os traços indígenas na forma de organizar a posse da terra no México do início do século $\mathrm{XX}$, os pueblos, funcionavam sobretudo como resistência à existência dos latifúndios. Propriedades coletivas e ejidos faziam frente às grandes propriedades que foram progressivamente sendo criadas e ampliadas, principalmente a partir da segunda metade do século XIX.

Se os índios podem ser inocentados, o mesmo não se pode dizer da violenta colonização espanhola. No momento em que pisaram em solo mexicano, os espanhóis trabalharam para reorganizar a ocupação da terra. Sérgio Buarque de Holanda propõe uma bonita imagem para ilustrar as diferentes posturas entre o colonizador português e o espanhol. Afirma Holanda que os portugueses podem ser considerados semeadores, que lançam suas sementes ao vento e colhem-nas onde caírem. Já os espanhóis, ladrilhadores, ao inaugurarem suas cidades - muitas vezes destruindo cidades indígenas que antes ocupavam seu lugar - exercitavam o que Holanda chamou de "amor exasperado à uniformidade e à simetria" e "enérgica vontade construtora"205. A

\footnotetext{
${ }^{203}$ Cecilia Mora Donatto afirma que "La gran mayoría de los autores coincide en señalar que existía una injusta distribución de la tierra antes de la llegada de los españoles." MORA DONATTO, Cecilia. "Aspectos históricos-jurídicos del problema agrario en México. Primera de dos partes: del México independiente al constituyente de 1917". In Revista de la Facultad de Derecho de la Universidad Nacional Autónoma de México (UNAM). Cidade do México, número 229-234; p. 334, jan. dez. 2000.

204 Apesar da falta de dados e da imprecisão que acompanha necessariamente toda estimativa, estudos sobre o tamanho das populações andinas e mesoamericanas indicam a alta densidade populacional na região e, pós-invasão européia, decréscimo populacional acentuado. Em cálculos elaborados por Borah/Cook (apud ROMERO SOTELO; JÁUREGUI, 2003, p. 27), a população indígena anterior à colonização seria de aproximadamente 11 milhões e teria sido reduzida, no final do século XVI, a 2 milhões de habitantes. Também por esse motivo, os índios mexicanos não podem ser responsabilizados por quase nenhuma mazela existente após colonização, embora as populações tradicionais e mestiças tenham preservado traços, cultura e forma coletiva de possuir a terra. ROMERO SOTELO, María Eugenia; JÁUREGUI, Luis. México 1821-1867: Población y crecimiento económico. Cidade do México: Facultad de Economía / UNAM, 2003. P. 27.

${ }^{205}$ BUARQUE DE HOLANDA, Sérgio. Raízes do Brasil. 26 a ed. São Paulo: Companhia das Letras, 1995 , p. 117 e 109.
} 
organização da ocupação das cidades e do campo era estratégia da colonização espanhola para exercer o efetivo domínio sobre o território conquistado ${ }^{206}$.

São três as bulas editadas pelo Papa Alexandre VI, em maio de 1493, que autorizaram os espanhóis a ocupar legitimamente - do ponto de vista da normatização europeia do mundo - o território americano, incluindo o que hoje conhecemos como México. Nessa época a Espanha já estava em disputa com Portugal pelo domínio das terras recém-descobertas pelos europeus. No ano seguinte, em 1494, os reis dos dois reinos celebraram o Tratado de Tordesilhas, no qual eram redefinidos os limites de seus territórios nas terras ultramarinas. Para além da disputa e dos acordos firmados com Portugal sobre o domínio dos novos territórios, se reconhecia internacionalmente a instituição do direito de conquista ${ }^{207}$, também registrado no extenso documento normativo Las Siete Partidas - tentativa de uniformização das regras existentes no reino de Castella, escrito entre 1256 e 1265, no reinado de Alfonso X. Na Terceira Partida, Título XXVIII, lei 20, havia o preceito "Las cosas de los enemigos de la Fe, con quien non ha tregua, nin paz el Rey, quienquier que las gane, deven ser suyas",208.

Entre a colonização espanhola, no século XVI, e a independência mexicana, realizada entre 1810-1821, foram muitas as normas e os esforços para ocupar e organizar posses e propriedades dos territórios conquistados. Merece destaque o fato de que propriedades individuais foram constituídas pela coroa espanhola a soldados, funcionários e colonos que chegavam à "Nueva España", como estratégia para colonizar o território. Aqueles que recebiam as reales merceds, como eram chamadas, se comprometiam em contrapartida a construir casas, cultivar o solo e não vendê-lo no

\footnotetext{
${ }^{206}$ Tal amor pela geometria pode ser encontrado, inclusive, em um dos decretos do Século XIX, que será analisado a seguir. Trata-se da norma sancionada em 4 de janeiro de 1823 por Augustín Iturbide, no breve período em que foi imperador, pós-independência. Em seu artigo 13, lê-se "se procurará sin embargo que en la formacion de estas nuevas poblaciones se guarde, cuanto lo permita el terreno, la buena disposición y rectitud en las calles, dándolos dirección paralela do Sur a Norte, y de Oriente a Occidente". Íntegra do decreto pode ser consultada em: MAZA, Francisco de la. Código de colonización y terrenos baldios de la República Mexicana: años de 1451 a 1892. Cidade do México: Oficina Tip de la Secretaría de Fomento, 1893 ,p. 171 a 176.

${ }^{207}$ MORA DONATTO, Cecilia. "Aspectos históricos-jurídicos del problema agrario en México. Primera de dos partes: de la época prehispánica a la Independencia". In Revista de la Facultad de Derecho de la Universidad Nacional Autónoma de México (UNAM). Cidade do México, número 229-234; p. 343, jan. dez. 2000.

${ }^{208} \mathrm{O}$ texto integral da partida tercera de Las siete partidas del rey D. Alfonso el Sabio, escrito entre 1256 e 1265, pode ser encontrado em: Biblioteca Valenciana - Colección: BV Fondo antiguo - Ubicación: BV Biblioteca Nicolau Primitiu <http://bivaldi.gva.es/es/catalogo_imagenes/grupo.cmd?path=1010761> e $<$ http://bivaldi.gva.es/es/catalogo imagenes/grupo.cmd?path=1010762> p. 370. Consulta realizada em $17 / 12 / 2015$.
} 
prazo de quatro anos, tal como dispunha a Ley para Distribuición y Arreglo de la Propiedad, de agosto de 1523.

Além desse, outros instrumentos foram criados para repartir a terra. A estrutura de distribuição era semelhante, porém: a Coroa Espanhola, como detentora das terras conquistadas em seu nome e reconhecidas nas bulas papais e no Tratado de Tordesilhas, concedia terras àqueles que julgava capazes e merecedores de ocupar seu novo território, conferindo-lhes, inclusive, títulos de propriedade individual. Em largos quinhões e por meio da espoliação indígena, a terra era distribuída.

Apesar da proibição de venda das terras cedidas a indivíduos específicos, a concentração se realizava. Durante o período colonial, o México enfrentou uma concentração fundiária específica, a religiosa. Muitas terras se encontravam sob o domínio de manos muertas, como eram conhecidas as propriedades eclesiais, problema que o México independente teve que enfrentar. Quando o grande território da Nueva $E s p a \tilde{n} a^{209}$ ainda estava sob o domínio da coroa espanhola, houve um esforço em coibir a transmissão da propriedade rural para as mãos da Igreja Católica e seus monastérios, já que se acreditava que essas propriedades seriam menos ocupadas e menos produtivas. Em 1130, o Rei Alfonso VII havia instituído proibição de alienação de bens reais para monastérios e igrejas na Península Ibérica; em 1535, esta norma passou a valer também para a Nueva España ${ }^{210}$, sendo proibidas quaisquer vendas de propriedades rurais para corporações religiosas. Contra a determinação da coroa, porém, espanhóis colonizadores do atual território mexicano vendiam ou doavam seus bens para a Igreja, talvez para realizar seu sentimento religioso, ou simplesmente porque ser credor da Igreja, em uma relação de compra e venda, era mais seguro do que estabelecer tal contrato com outros

\footnotetext{
${ }^{209}$ No início do século XIX o território da Nueva España era muito maior do que o que hoje conhecemos como México. Timothy Anna afirma em seu texto sobre a independência mexicana: "En vísperas de la lucha por la independencia, el virreinato de Nueva España (México) comprendía una vasta área que se extendía desde el Caribe hasta el Pacífico y desde la frontera de Guatemala y Chiapas hasta las provincias internas del este y del oeste, incluyendo el territorio que más tarde se incorporó al suroeste de los Estados Unidos de Norteamérica. El virreinato, que en 1814 tenía una población de 6.122 .000 habitantes (en 1810 los Estados Unidos tenía 7.240.000), contenía más del tercio de la población total del imperio español de ultramar. Ciudad de México, la capital del virreinato, era la mayor ciudad tanto de América del Norte como del Sur; con sus 168.811 habitantes en 1811 era, después de Madrid, la segunda mayor ciudad del imperio". ANNA, Timothy. "La independencia de México y América Central". In BETHELL, Leslie (org.). Historia de America Latina. Vol. 5 - La independencia. Trad. Àngels Sòla. Barcelona: Editorial Crítica, 1991, p. 41.

${ }^{210}$ MORA DONATTO, Cecilia. "Aspectos históricos-jurídicos del problema agrario en México. Primera de dos partes: de la época prehispánica a la Independencia”. In Revista de la Facultad de Derecho de la Universidad Nacional Autónoma de México (UNAM). Cidade do México, número 229-234; p. 354, jan. dez. 2000.
} 
particulares. Cecilia Donatto descreve assim a situação da propriedade rural às vésperas da guerra pela independência:

No se puede precisar el valor de la propiedad eclesiástica en México durante la época colonial. Los únicos datos que se tienen son las apreciaciones hechas por Humboldt, que consideró que la propiedad eclesiástica en Puebla constituía las cuatro quintas partes de la propiedad territorial y el cálculo hecho por el obispo de Michoacán, Abad y Queipo, sobre los capitales hipotecarios destinados a obras pías y que, según él, ascendían a cuarenta y cuatro millones de pesos, en $1804 .^{211}$

O mal-estar social que levou à guerra de independência, porém, não estava ligado somente à posse da terra. Inúmeras formas de segregação estavam presentes na sociedade da Nueva España. Estima-se que 60\%da população era composta por índios. Mestiços, por sua vez, representavam $22 \%$ e brancos, apenas $18 \%{ }^{212}$. Mestiços e índios, que em sua maioria participavam efetivamente do cotidiano da sociedade colonial, ocupavam as piores posições sociais e, do ponto de vista do consumo, subsistiam. Os brancos, por sua vez, ocupavam todas as melhores posições sociais. Entre os 18\%, porém, havia uma divisão fundamental: brancos nascidos na Espanha possuíam um status maior do que aqueles nascidos em território mexicano, conhecidos como criollos. A elite adminsitrativa, ou seja, aqueles que efetivamente participavam da organização política do território, eram necessariamente os brancos espanhóis. Também os altos postos militares e religiosos eram ocupados por brancos nascidos na Europa. A população branca, nascida no México, por sua vez, era composta por fazendeiros, mineiros, comerciantes (que podiam fazer parte de uma elite econômica, mas não política), além de advogados e religiosos que ocupavam posições inferiores na administração política e na ordem religiosa.

\footnotetext{
${ }^{211}$ MORA DONATTO, Cecilia. "Aspectos históricos-jurídicos del problema agrario en México. Primera de dos partes: de la época prehispánica a la Independencia". In Revista de la Facultad de Derecho de la Universidad Nacional Autónoma de México (UNAM). Cidade do México, número 229-234; p. 343, jan. dez. 2000.

212 "Los indios constituían el 60 por 100 de la población, las castas el 22 por 100 y los blancos el 18. Por otro lado, entre los blancos también existían peligrosas diferencias: españoles nacidos en América (criollos) que alcanzaban el 17,8 por 100 de la población y los llamados europeos (conocidos en México como «gachupines») que sólo eran unos 15.000 , o sea el 0,2 por 100 de toda la población. El reducido grupo de peninsulares constituía la élite administrativa de la colonia debido a que ocupaban los cargos gubernamentales y militares más altos." ANNA, Timothy. "La independencia de México y América Central". In BETHELL, Leslie (org.). Historia de America Latina. Vol. 5 - La independencia. Trad. Àngels Sòla. Barcelona: Editorial Crítica, 1991, p. 43.
} 
A discriminação entre as parcelas da população branca se perpetuava: reiteradamente eram enviados novos homens espanhóis de confiança da coroa espanhola para ocupar os postos-chave da administração pública do vice-reinado. A elite econômica e a burguesia americanas passaram a identificar que seu status social - assim como sua capacidade de acumular riquezas e poder político - eram extremamente limitados por essa dinâmica. A insatisfação das classes médias e altas brancas criollas mexicanas, e, consequentemente, o nascente nacionalismo mexicano antiespanhol faziam parte do ímpeto social que levou à guerra da independência.

Os $82 \%$ da população mestiça e índia que estavam totalmente alijados das riquezas produzidas no país também compunham o cenário propício à insurreição do início do século XIX. Timothy Anna, porém, afirma que as classes baixas tiveram pouca influência nos rumos políticos pós-independência, apesar de Hidalgo e Morelos, dois heróis da luta independentista, defenderem ideais populares:

Las rebeliones que empezaron en 1810 tratarían de corregir algunos de estos abusos y al menos fueron una especie de respuesta de los indios y las castas a su opresión. Aunque los levantamientos de las clases más bajas en 1810 y después particularmente bajo la dirección de dos de los grandes héroes de la independencia, Miguel Hidalgo y José María Morelos fueron una característica particular de las luchas por la independencia mexicana, ni en México ni en ningún otro lugar de América Latina fueron las clases populares las que determinaron la llegada de la independencia ni la forma política que adoptaron los nuevos estados. Las insurrecciones de las clases bajas sirvieron para retrasar e incluso oscurecer la principal aspiración de la disidencia mexicana, expresada en el criollismo, es decir la voluntad de los criollos blancos, de las clases media y alta, y de las élites blancas ligadas a México por razón de residencia, propiedad o parentesco, si no por el nacimiento, de lograr el control de la economía y del Estado. ${ }^{213}$

Miguel Hidalgo y Costilla, branco criollo, era o padre responsável pela paróquia de uma pequena cidade chamada Dolores, no Estado de Guanajuato. Preocupado com a situação social dos índios e mestiços de sua paróquia, tornou-se um dos principais conspiradores e organizadores da luta pela independência, tornando-se aliado de um

${ }^{213}$ ANNA, Timothy. "La independencia de México y América Central". In BETHELL, Leslie (org.). Historia de America Latina. Vol. 5 - La independencia. Trad. Àngels Sòla. Barcelona: Editorial Crítica, 1991, p. 45. 
grupo que já se formava no Estado vizinho, de Querétaro ${ }^{214}$. A insurreição conhecida como "Grito de Dolores" começou em 16 de setembro de 1810, data que o México considera como de sua independência - muito embora as lutas tenham se estendido por longos anos. De qualquer modo, é fato que os três meses que se seguiram à insurreição de Hidalgo foram muito conflituosos e marcados por violência e perdas de vida.

José María Morelos, também padre, também criollo e também muito próximo dos índios e sensível à sua condição social, somou-se ao movimento armado pela independência ainda em seu início. Melhor líder militar do que Hidalgo, sustentou e liderou os enfrentamentos armados por longos anos. Assim como a Revolução Mexicana, a Guerra de Independência contou com a força da população pobre mexicana - majoritariamente composta por índios e mestiços - para ser vitoriosa, em 1821. Logo no início dos levantes, Miguel Hidalgo y Costilla determina a extinção da escravidão em território mexicano, em 29 de novembro de 1810, e a devolução das terras indígenas, em 5 de dezembro de 1810:

Desde el feliz momento en que la valerosa nación americana tomó las armas para sacudir el pesado yugo que por espacio de cerca de tres siglos la tenía oprimida, (...) sin perder de vista tan altos fines que anuncian la prosperidad de los americanos, trata de que estos comiencen a disfrutar del descanso y alivio en cuanto lo permitan la urgencia de la nación, por medio de las declaraciones siguientes, que deberán observarse como ley inviolable.

Que siendo contra los clamores de la naturaleza el vender a los hombres, quedan abolidas las leyes de la esclavitud, no sólo en cuanto al tráfico y comercio que se hacía de ellos sino también por lo relativo a las adquisiciones, de manera que conforme al plan del reciente gobierno pueden adquirir para sí, como unos individuos libres, al modo que se observa en las demás clases de la república; en cuya consecuencia, supuestas las declaraciones asentadas, deberán los amos, sean americanos o europeos, darles libertad dentro del término de diez días, so la pena de muerte que por inobservancia de este artículo se les aplicará.

Dado en la ciudad de Guadalajara, a 29 de noviembre de $1810 .^{215}$

\footnotetext{
${ }^{214}$ Ibid., p. 49.

215 Decreto de 29 de novembro de 1810, publicado por Miguel Hidalgo y Costilla. Disponível em CARMONA, Doralicia. Memoria Política de México. Guanajuato: Universidade de Guanajuato, 2014. http://www.memoriapoliticademexico.org/Textos/1Independencia/1810-MMH-ESC.html Consulta em $13 / 07 / 2015$
} 


\section{Don Miguel Hidalgo y Costilla, Generalísimo de América:}

Por el presente mando a los jueces y justicias del distrito de esta capital, que inmediatamente procedan a la recaudación de las rentas vencidas hasta el día, por los arrendatarios de las tierras pertenecientes a las comunidades de los naturales, para que enterándolas en la Caja Nacional, se entreguen a los referidos naturales las tierras para su cultivo, sin que para lo sucesivo puedan arrendarse, pues es mi voluntad que su goce sea únicamente de los naturales en sus respectivos pueblos.

Dado en mi cuartel general de Guadalajara, a 5 de diciembre de 1810.

Miguel Hidalgo, Generalísimo de América.

Por mandato de Su Alteza. Lic. Ignacio Rayon, Secretario. ${ }^{216}$ (grifo nosso)

O decreto de Hidalgo y Costilla que determina a entrega das terras de cultivo para os "naturales" também impede que tais terras sejam arrendadas ou alienadas a terceiros. Note-se que os destinatários da norma são os juízes e o sistema de justiça da capital (Guadalajara, proclamada capital por ele mesmo), já que o domínio sobre essa cidade era o único que conseguia garantir. Hidalgo y Costilla queria, dessa forma, prevenir a espoliação econômica dos índios, que deveriam ter garantida sua permanência na terra que utilizavam para cultivo e subsistência.

A resposta à participação camponesa na luta pela independência também se realiza por meio de outras determinações que visavam melhorar a situação no campo. Há um decreto, elaborado por José María Morelos em 17 de novembro de 1810, em que o foco principal, junto com a abolição da escravatura, é a extinção da diferença de tratamento entre diferentes estratos sociais dos cidadãos mexicanos. As chamadas “castas” no México foram extintas, pelo menos formalmente, por este:

Por el presente y a nombre de su excelencia, hago público y notorio a todos los moradores de esta América y establecimientos, del nuevo gobierno, por el cual, a excepción de los europeos, todos los demás habitantes no se nombrarán en calidad de indios, mulatos ni otras castas, sino todos generalmente americanos. Nadie pagará tributo, ni habrá esclavos en lo sucesivo, y todos los que los tengan serán

${ }^{216}$ Decreto de 5 de dezembro de 1810, publicado por Miguel Hidalgo y Costilla. Disponível em CARMONA, Doralicia. Memoria Política de México. Guanajuato: Universidade de Guanajuato, 2014. http://www.memoriapoliticademexico.org/Textos/1Independencia/1810DOD.html Consulta em $13 / 07 / 2015$. 
castigados. No hay cajas de comunidad y los indios percibirán los reales de sus tierras como suyas propias.

Noviembre 17, 1810. Cuartel general del Aguacatillo. José María Morelos. ${ }^{217}$

A insurreição de índios e mestiços durante o início do processo de independência mexicano, comprometida com avanços sociais, devolução de terras expropriadas aos nativos e melhorias nas condições de vida dos pobres, representada por Hidalgo e Morelos, porém, foi derrotada. Em seu lugar, surge um projeto conservador, criollo, com muito pouca empatia ou preocupação com indígenas e mestiços.

Ahora, en México, habían vencido quienes abogaban por las reformas moderadas y la monarquía constitucional. Estos objetivos eran conservadores si se los compara con los anhelos radicales de las revoluciones de Hidalgo y Morelos, pero no eran reaccionarios. México ya había rechazado el radicalismo de las revoluciones indias o mestizas. La élite y la burguesía observaban cómo las Cortes restauradas, aunque habían adoptado un programa de cambio radical en la política peninsular y en la estructura económica, aún no habían hecho nada para dar respuesta a las reivindicaciones de los americanos. $^{218}$

Apesar de derrotados em seus anseios políticos, os documentos produzidos por Hidalgo e Morelos em meio à guerra da independência - que, estima-se, ao final deixou seiscentas mil pessoas mortas ${ }^{219}$ - são prova de que a questão agrária já estava mais do que presente um século antes da eclosão da Revolução de 1910.

Apesar disso, o projeto do grupo conservador parecia querer manter o México independente tão parecido quanto possível com sua versão colonial: apesar da nova elite política e possibilidade de ascensão para os criollos, os conservadores desejavam manter a sociedade católica, desigual e segregada; do ponto de vista econômico, desejavam um país "extractivo, mercantilista y basado en nuevas normas neofeudales

\footnotetext{
217 Decreto de 17 de novembro de 1810, publicado por José María Morelos. Disponível em http://www.memoriapoliticademexico.org/Textos/1Independencia/1810HMS.html Consultado em 13/07/2015.

${ }^{218}$ ANNA, Timothy. "La independencia de México y América Central". In BETHELL, Leslie (org.). Historia de America Latina. Vol. 5 - La independencia. Trad. Àngels Sòla. Barcelona: Editorial Crítica, 1991, p. 67.

${ }^{219}$ Ibid., p. 73.
} 
de control de la mano de obra" ${ }^{220}$. Seu horizonte político incluía até a possibilidade de se conservar a monarquia como regime político - ao contrário dos ideais republicanos que circulavam entre os liberais -, o que de fato aconteceu.

\subsection{Antecedentes: México independente}

Sob a liderança de Agustín Iturbide e seu Plan de Ayala, de 24 de fevereiro de 1821, o México independente inaugurou sua vida livre da metrópole com um regime monárquico constitucional, e não uma república.

O Plan de Iguala define as linhas gerais do que deveria ser o Império Mexicano. Antes disso, porém, tece inúmeros elogios à ex-metrópole Espanha. Afirma que "Trescientos años hace que la América Septentrional esta bajo la tutela de la nación más católica y piadosa, heroica y magnánima. La España la educó y engrandeció, formando esas ciudades opulentas, esos pueblos hermosos, esas provincias y reinos dilatados $[\ldots]^{, 221}$. A falta de desejo de efetivamente romper com a Espanha também está no plano quando, apesar de declarar independência, declara que "Será su Emperador el Sr. D. Fernando VII', então rei espanhol.

No mesmo Plan de Ayala há a afirmação da confessionalidade católica do Império Mexicano, que seria intolerante a quaisquer outras formas de religiosidade. Agustín Iturbide fora sempre um militar defensor da coroa espanhola, chamado então de realista. Lutara contra a guerra de independência liderada por Hidalgo e Morelos. Sua figura à frente do Plan de Iguala, bem como a proposta de instauração de um império monárquico representam uma tentativa de conciliação entre os insurgentes liberais e os realistas religiosos, antes muito resistentes ao rompimento com a coroa espanhola. Essa proposta de conciliação foi forjada no momento em que o exército dos realistas já estava praticamente derrotado: o plano é de fevereiro de 1821. Em setembro de 1821, foi proclamada a independência do México e instaurada uma Regência Provisória com cinco membros, sendo Augustín Iturbide o chefe do Poder Executivo.

\footnotetext{
${ }^{220}$ Ibid., p. 45.

${ }^{221}$ Plan de Iguala, de 24 de fevereiro de 1821. Disponível em: CARMONA, Doralicia. Memoria Política de México. Guanajuato: Universidade de Guanajuato, 2014.

http://www.memoriapoliticademexico.org/Textos/1Independencia/1821PDI.html Consulta realizada em 29/12/2015.
} 
Em fevereiro de 1822 foi instalado o Congresso Constituinte, que tinha como objetivo elaborar uma constituição para o México independente. Perante o Congresso, os membros da Regência juraram reconhecer a soberania da nação mexicana representada no Congresso. Em 19 de maio do mesmo ano, quando ficou claro que a coroa espanhola não reconheceria a independência do México e, portanto, não indicaria ninguém de sua dinastia para ocupar a função de imperador que o Plan de Ayala lhes reservara, Augustín Iturbide foi proclamado imperador e coroado pelo Congresso Constituinte, que ainda não havia terminado seu trabalho de redação constitucional.

Em 31 de outubro de 1822, Iturbide dissolveu o Congresso sob a justificativa de que seu trabalho estaria se tornando utópico. Diversos grupos republicanos, já descontentes com a solução da monarquia constitucional, diante do fato de o então Imperador ter se voltado contra a própria possibilidade de elaboração da constituição que delimitaria os limites de sua ação, se uniram para lutar contra o então Imperador mexicano Augustín I.

Nicolás Bravo, Vicente Guerrero y Guadalupe Victoria se organizaram em torno do Plan de Veracruz, elaborado por António Lopez de Santa Anna, que exigia a reinstalação do Congresso Constituinte. Esses líderes encabeçaram a resistência armada, que levou à renúncia de Iturbide, em março de 1823. Antes de ser deposto, porém, em 4 de janeiro de 1823, o "primer Emperador constitucional de México" sancionou um decreto sobre colonização, o primeiro documento normativo que trata sobre terras no México independente.

A solução inicialmente conciliatória da monarquia constitucional indicava que todas as outras questões envolvidas na luta pela independência - entre elas a distribuição da terra - manteriam intactas suas características da Nueva España, ou seja, do período colonial. A derrocada do chamado Primeiro Império Mexicano, sob a liderança de Augustín Iturbide, fez com que o Congresso Constituinte, e a futura Constituição de outubro $1824^{222}$, se concentrassem em um problema político: a efetiva organização e pacificação dos Estados Unidos Mexicanos. Sob a justificativa de ser necessário primeiro resolver os problemas políticos do país para, em seguida, atender

\footnotetext{
${ }^{222}$ A íntegra da Constituição mexicana aprovada em outubro de 1824, que organiza forma de acesso e eleições para os três poderes, além de indicar a divisão entre união e estados, está disponível aqui: CARMONA, Doralicia. Memoria Política de México. Guanajuato: Universidade de Guanajuato, 2014. <http://www.memoriapoliticademexico.org/Textos/2ImpDictadura/1824CFEUM.html> Consulta realizada em 14/07/2015.
} 
aos sociais, a Constituinte ignorou a questão agrária. As lições de Miguel Hidalgo y Costilla e José María Morelos sobre os problemas sociais que assolavam o México - e a necessidade de seu enfrentamento pós-independência - foram esquecidas.

Estima-se que, no início do século XIX, a população do território mexicano de 6,5 milhões de pessoas ${ }^{223}$. Já o território do Estado recém-independente - as fronteiras estavam descritas na própria Constituição de 1824 - contava com cerca de 4 milhões de quilômetros quadrados ${ }^{224}$. Pode-se notar que, embora o México fosse um dos territórios mais populosos das Américas ${ }^{225}$, sua densidade populacional não era muito alta para o imenso território do país. A população existente, porém, se concentrava no Altiplano Central, que possuía terras em que a agricultura era mais fácil. Os territórios ao norte eram áridos e, ao sul, possuíam florestas tropicais, ambos pouco habitados.

A independência mexicana não foi reconhecida pela Espanha até 1936. Um dos desafios do país, nesse contexto, era exatamente garantir a ocupação efetiva de seu território, também como estratégia para fazer frente a possíveis invasões estrangeiras. Organizar e povoar todos os dezoito estados federados e três territórios que compunham o México do início do século XIX parecia ser um objetivo a ser alcançado por quem detivesse o poder político do novo país.

Assim, os governos que se seguiram à independência, no brevíssimo Império Constitucional e no início da República mexicana, tinham como preocupação principal, em relação à terra, ocupar e tornar produtivas partes de seu território que eram consideradas vazias, não cultivadas ou habitadas. Nem sempre, porém, as políticas respeitaram esse critério. Um dos principais problemas agrários do século XIX mexicano deveu-se à apropriação privada de terras que já tinham posse estabelecida. Além do objetivo de ocupar o território supostamente vazio, o Estado mexicano também

\footnotetext{
${ }^{223}$ No texto de María Eugenia Romero Sotelo e Luis Jáuregui os pesquisadores investigam as causas do lento crescimento populacional mexicano, principalmente ao longo do século XIX. Enfrentamentos armados e doenças são duas possíveis causas para o fenômeno, divergente de outros países latinoamericanos. Seja como for, Sotelo e Jáuregui confirmam em seu estudo que a baixa densidade populacional é um problema a ser enfrentado pelo México ao longo do século XIX, o que justifica, em certa medida, a ênfase normativa relativa ao objetivo da colonização. ROMERO SOTELO, María Eugenia; JÁUREGUI, Luis. México 1821-1867: Población y crecimiento económico. Cidade do México: Facultad de Economía / UNAM, 2003.

${ }^{224}$ MORA DONATTO, Cecilia. "Aspectos históricos-jurídicos del problema agrario en México. Primera de dos partes: de la época prehispánica a la Independencia". In Revista de la Facultad de Derecho de la Universidad Nacional Autónoma de México (UNAM). Cidade do México, número 229-234, p. 353, jan. dez. 2000.

${ }^{225}$ ANNA, Timothy. "La independencia de México y América Central". In BETHELL, Leslie (org.). Historia de America Latina. Vol. 5 - La independencia. Trad. Àngels Sòla. Barcelona: Editorial Crítica, 1991, p. 41.
} 
precisava de dinheiro para se consolidar. Tanto a venda de terras como a arrecadação de impostos com atividades produtivas pareciam boas estratégias. Os terrenos que seriam objeto da política de colonização eram chamados, como ficou cristalizado em diversos documentos normativos mexicanos, 'baldios ${ }^{226}$.

Incentivo à imigração de colonos estrangeiros; concessão de terras a soldados que lutaram na guerra de independência, a título de recompensa; demarcação e venda de terrenos; desamortização de terras das igrejas e das comunidades indígenas, entre outras estratégias, foram as principais formas de intervir na organização fundiária ao longo do século XIX. Entender como essas políticas se estruturaram juridicamente será objeto das seções seguintes.

\subsubsection{Decretos de colonização: o desafio de ocupar e controlar o território e a política de formação dos latifúndios}

\subsubsection{Decreto de 4 de janeiro de 1823: Iturbide privilegia os estrangeiros ${ }^{227}$}

Depois de dissolver o Congresso Constituinte, e antes de ser deposto, o então Imperador Augustín Iturbide expediu um decreto que tinha por objetivo regulamentar a colonização de terras no país. Este decreto teve eficácia bastante limitada, já que entre 4 de janeiro e 19 de março de 1823 não houve tempo para que produzisse efeitos, e sua validade é revogada no momento da renúncia do Imperador que o sancionou.

A análise do texto do documento normativo, porém, traz informações sobre os problemas que se queria enfrentar e as decisões políticas tomadas pelo breve Primeiro Império mexicano. O primeiro artigo do decreto afirma ser a religião católica a única do Império e acrescenta que a "libertad, propiedad y derechos civiles de todos os extrajeros que profesen la Religion Católica, Apostólica Romana" serão protegidos e respeitados pelo Estado.

\footnotetext{
${ }^{226}$ Muito embora o termo 'baldíos' pudesse ser traduzido para o português como terrenos baldios, decidi manter a terminologia da legislação mexicana para preservar a referência original e não haver desconforto com os textos .

227 A íntegra do Decreto de 4 de janeiro de 1823. pode ser consultada em: MAZA, Francisco de la. Código de colonización y terrenos baldios de la República Mexicana: años de 1451 a 1892 . Cidade do México: Oficina Tip. de la Secretaría de Fomento, 1893,p. 171 a 176. Disponível em: http://bdhrd.bne.es/viewer.vm?id=0000013888\&page $=1$ Consulta realizada em 27/07/2015.
} 
O fato de mencionar estrangeiros logo no primeiro artigo é indício de que um dos objetivos da colonização era trazer mais estrangeiros para o solo mexicano. Apenas no artigo 18 é mencionado que "Se atenderá con preferencia para la distribución de las tierras a los naturales del país, y principalmente á los militares del ejército trigarante, llevándose a efecto el decreto de 27 de marzo de 1821, y a los que hubieren servido en la primera época de la insurrecion".

Ora, o documento afirma literalmente ser prioridade a distribuição de terras para os mexicanos, mas, aparentemente apenas os militares seriam beneficiados pelo único dispositivo do decreto que trata explicitamente dos mexicanos. A grande maioria dos outros artigos tinha por objetivo estimular - e recompensar - a colonização realizada por estrangeiros. Assim é a previsão, no decreto, de prêmios em terras para empresários que trouxerem pelo menos duzentas famílias para realizar a colonização das terras mexicanas (arts. $2^{\circ}$ e 19). Do mesmo modo, se oferece a naturalização e cidadania para os estrangeiros que vierem se instalar no país (art. 27).

A tensão entre a realização de uma colonização por estrangeiros - católicos, no caso da primeira regulamentação - e a colonização por mexicanos está presente em muitos dos decretos e leis publicados no século XIX. Na grande maioria deles, como no caso do decreto de Augustín Iturbide, não há sequer menção às comunidades indígenas que povoavam parte do território mexicano. Em outros casos, tais pueblos são tratados como locais a serem civilizados - como é o caso do decreto de 8 de dezembro de 1846. Em sua exposição de motivos, afirma que perto de povoados "bárbaros" devem ser instaladas colônias militares - em que os camponeses teriam porte de armas - e garantida a presença de missões católicas como estratégia para que "La civilización irá así lenta, pero seguramente penetrando a las tribus salvajes". 228

Quer pela elaboração explícita da exposição de motivos do decreto de 1846, quer pela ausência no decreto de Augustín Iturbide, pode se supor que nem os índios (os "naturales", como a denominação de Miguel Hidalgo y Costilla) nem os criollos eram destinatários da política de colonização. Desejava-se beneficiar estrangeiros católicos majoritariamente europeus -, em primeiro lugar, e apenas militares mexicanos, em segundo.

\footnotetext{
${ }^{228}$ FIGUEROA ESQUER, Raúl (org.). Correspondencia diplomática de Salvador Bermúdez de Castro, ministro de España en México, Tomo V. (De enero de 1847 a julio de 1848). Cidade do México: ITAM Instituto Tecnológico Autónomo de México y Instituto Nacional de Estudios Históricos de las Revoluciones de México, 2013. p. 2194.
} 
Também em desacordo explícito com o que havia determinado Hidalgo y Costilla em meio à guerra pela independência, o decreto de Augustín Iturbide admite a escravidão no território mexicano, proibindo apenas a compra e venda em território nacional e declarando livres os filhos nascidos de escravos (art. 30). A norma representa um grande retrocesso em relação ao decreto de novembro de 1810, em que Hidalgo havia declarado que todos os antes considerados escravos deveriam ser reconhecidos desde aquele momento como indivíduos livres.

Afora os retrocessos e ausências em relação aos índios e escravos, Augustín Iturbide antecipa a possibilidade de haver empresas - o decreto fala em "empresarios" no artigo segundo - responsáveis por promover a colonização no México, delegando à iniciativa privada a possibilidade de organizar a ocupação da terra no território. Tal proposta voltará a aparecer nas normas de 1846 e, a partir de 1863, ganhará importantes impulsos legais e fáticos para se tornar efetiva.

Iturbide parece antecipar por meio de normas a prática que virá a vigorar na segunda metade do século XIX no México: a intermediação de pessoas físicas e jurídicas para estabelecer a relação entre Estado e colonos, com vistas a promover a ocupação da terra. Os intermediários, que promoveriam a colonização em nome do Estado, por sua vez, receberiam benefícios e seriam remunerados - muitas vezes com terras - para cumprir tal objetivo. Como em outras legislações posteriores, o decreto de 1823 prevê que os empresários que fossem bem-sucedidos em sua tarefa de ocupar e cultivar efetivamente a terra (art. 23) poderiam ter para si, sem que tivessem que pagar por isso, um terço das terras que tiverem contribuído para colonizar (art. 20). A fórmula de ceder um terço da terra colonizada, com algumas modificações, foi repetida em inúmeros documentos normativos posteriores.

O decreto segue com uma série de definições quanto às medidas e conceitos que deveriam balizar o registro de propriedades no México. No artigo $5^{\circ}$ estipula-se, por exemplo, que "supuesta la vara de medir de tres piés geométricos, uma línea recta de cinco mil varas hará una légua: un cuadrado que por lado tenga una legua, se llamará sítio, y esta será la unidad para contar (...); cinco sítios harán una hacienda.”. Ou seja, o decreto se dedica a criar definições e medidas capazes de estabelecer áreas de terrenos, úteis tanto para organizar a distribuição como para registrar os terrenos cedidos em propriedade. Os artigos $7^{\circ}, 8^{\circ}$ e 12 também se ocupam dessas definições. 
Outra tensão que percorrerá as diferentes regulamentações sobre a colonização diz respeito a deixar concentradas as decisões em uma autoridade do governo central ou, pelo contrário, delegá-las às autoridades locais, quer municipais, quer dos estados federados - que só seriam criados na Constituição de 1824. O decreto de janeiro de 1823 decide manter a decisão sobre a colonização com os "ayuntamientos" locais (art. $\left.4^{\circ}\right)$.

O decreto previa ainda que o governo era responsável por garantir "los médios de subvenir a su decente sustentación" paróquias católicas e párocos em número suficiente (art. 16), em locais em que houvesse concentração populacional. A norma tinha por objetivo garantir - com recursos estatais - a presença da religião católica, oficial, nos novos territórios que viessem a ser povoados.

Todas essas normas não tiveram quase nenhuma efetividade, uma vez que em março de 1823, dois meses após a publicação do decreto sobre colonização, Iturbide renuncia ao posto de Imperador. Sua importância, entretanto, reside no fato de servir de referência para o pensamento conservador mexicano que se organizou politicamente ao longo do século XIX.

\subsubsection{Decreto de 14 de outubro de 1823: tripartição dos baldíos da Província do Istmo}

Dias após a renúncia de Augustín Iturbide, ainda em março de 1823, foi reinstalado o Congresso Constituinte. Antes mesmo de terminar sua tarefa principal, a elaboração da Constituição ${ }^{229}$, a instância deliberativa considerou ser uma de suas obrigações editar um decreto em 14 de outubro de 1823 cujo objetivo principal era a criação da Província do Istmo, formada pelas jurisdições de Acayucan e Tehuantepec ${ }^{230}$.

Istmo é um termo usado para designar estreitas faixas de terra que, em geral, separam dois mares. No caso do México, a faixa de terra assim denominada - e

\footnotetext{
${ }^{229}$ Na verdade, o Congresso Constituinte reconvocado em março de 1823 foi responsável por reconhecer institucionalmente a renúncia de Iturbide; convocar um governo provisório e convocar um novo Congresso Constituinte, que tinha por objetivo único elaborar uma Constituição. No período de transição, antes da vigência da Constituição de 1824, o Congresso Constituinte inicial funcionou como um poder legislativo extraordinário. O segundo Congresso Constituinte foi instalado em 7 de novembro de 1823.

${ }^{230}$ A província é formada por dois estados (ou no território de pelo menos dois estados): Veracruz e Oaxaca.
} 
constituída como província - fica ao sul do país e abrange ao menos parte dos territórios de quatro estados: Oaxaca, Chiapas, Tabasco y Veracruz. Por ser um estreito que liga os oceanos Atlântico e Pacífico, a região era considerada estratégica para a defesa do país, o que justificaria a edição do decreto.

Mais importante do que a nova organização geográfica e política, porém, eram as informações que o decreto trazia acerca da estratégia para ocupar aquele território. Seu artigo sétimo determinava:

7. El terreno baldío que existe en esta provincia se dividirá en tres porciones. La primera la distribuirá el gobierno entre los militares que se retiren con una parte de sus sueldos, las personas que hayan hecho servicios a la patria, pensionistas y cesantes. Si aún restase algún terreno desocupado de esta primera porción, lo repartirá el mismo gobierno entre nacionales y extranjeros que se quieran establecer, siempre que tengan las calidades de buena conducta, industria, etc., prefiriendo a los casados. La segunda porción será beneficiada por el gobierno entre capitalistas nacionales y extranjeros que se establezcan en el país conforme a las leyes generales de colonización. La tercera se beneficiará o repartirá por la diputación provincial en provecho de sus habitantes que carezcan de propiedad, arreglándose en cuanto a cantidad de terreno que se conceda a un individuo a la base que asigna esta ley, y lo demás lo beneficiará para los ramos de fomento y educación de los vecinos de la provincia. ${ }^{231}$

Ora, de acordo com o Decreto citado acima, os "baldios" daquela região deveriam ser todos distribuídos, em partes iguais, para três grupos distintos. Os primeiros beneficiários seriam os militares, vinculados à carreira, aposentados ou desempregados; também aqueles que apenas tenham servido à pátria na época da luta pela independência, indicados no texto como aqueles que "hayan hecho servicios a la pátria". O segundo grupo a que deveriam ser distribuídos os "baldíos" são os capitalistas, nacionais ou estrangeiros que viessem se estabelecer no país atraídos pelas normas gerais de colonização, seriam editadas em agosto de 1824.

Por fim, o terceiro grupo beneficiado pelo decreto - e a quem corresponderia um terço das terras identificadas como "baldíos" - seriam os moradores da região que necessitassem de terras para cultivar.

\footnotetext{
${ }^{231}$ Íntegra do decreto de 14 de outubro de 1823 disponível em: BIBLIOTECA GARAY. 500 años de México en documentos. México, 2011.

$<$ http://www.biblioteca.tv/artman2/publish/1823 122/Decreto_Formaci_n_de_la_provincia_del_Itsmo_pr inter.shtml > Consulta realizada em 14/07/2015.
} 
O decreto também estabelece quem pode ocupar o cargo e quem tem competência para nomear a autoridade responsável por distribuir terras na região (art. $8^{\circ}$ ); os critérios de mérito que serão levados em conta para estabelecer a porção de terra a ser concedida aos militares (art. $9^{\circ}$ ); os impostos que serão pagos ao fundo da região, bem como a destinação dos fundos (diversos artigos); o tamanho da propriedade que pode ser conferida a um só indivíduo, podendo variar de acordo com o mérito no caso dos militares (art. 13), entre outras indicações práticas para realizar a ocupação dos terrenos naquela região.

Com validade restrita a uma pequena parte do território mexicano, o decreto deixa claro que a estratégia de ocupar terrenos está intimamente ligada ao anseio de defesa do território nacional. Isso explica que a política de colonização tenha tido início por uma região militarmente estratégica.

\subsubsection{Decreto de 18 de agosto de 1824: a República Mexicana apresenta suas normas para a colonização}

Em 18 de agosto de 1824, normas gerais sobre a colonização - que já haviam sido mencionadas no decreto de 1823 - foram, enfim, editadas pelo Congresso Constituinte do México, meses antes da promulgação da Constituição. O seu artigo primeiro indica quais são os principais destinatários da norma: "los extrangeros que vengan a establecer en su território". O decreto sobre colonização privilegia os estrangeiros, em detrimento dos habitantes locais, sejam eles indígenas, mestiços ou criollos. Também por isso, o artigo $4^{\circ}$ proíbe a colonização de territórios fronteiriços. Não só a ocupação de terra era o objetivo da norma. A agricultura de subsistência praticada pelos índios e mestiços não aumentava a arrecadação de impostos. Ao estimular a vinda de estrangeiros, desejava-se também aumentar a produtividade agrícola das terras mexicanas. Após diversos artigos que tratam do estrangeiro incluindo aquele que abre o documento normativo - o artigo $9^{\circ}$ afirma, sem convicção: “9. Deberá atenderse con preferencia en la distribución de tierra a los ciudadanos mexicanos, y no se hará distinción alguna entre ellos". O objetivo do decreto era colonizar terrenos que possuíssem essas características: 
2. Son objeto de esta ley aquellos terrenos de la nación, que no siendo de propiedad particular, ni pertenecientes a corporación alguna o pueblo, pueden ser colonizados.

3. Para este efecto, los congresos de los Estados formarán, a la mayor brevedad, las leyes o reglamentos de colonización de su respectiva demarcación, conformándose en todo á la acta constitutiva, constitución general y reglas establecidas en esta ley. ${ }^{232}$

Interessante notar que, para estarem aptos a participar do processo de colonização, os terrenos não poderiam ser de (1) propriedade particular; (2) pertencentes a corporações; (3) pertencentes a povoados (“pueblos”). Em relação a normas posteriores, a proteção do decreto de 1824 é bastante ampla, pois reconhece, além dos títulos de propriedade formalizados, também as propriedades de entidades coletivas corporações eras designações que se atribuíam tanto à pessoa jurídica da Igreja Católica quanto a comunidades indígenas formalmente constituídas e possuidoras de terrenos usufruídos coletivamente. Assim, propriedades coletivas de corporações (religiosas ou não) e "pueblos" (povoados de comunidades camponesas) eram protegidos pelo texto do decreto, que excluía de sua política terras já efetivamente ocupadas.

Por outro lado, o artigo terceiro delega aos estados regulamentar as normas gerais sobre colonização, o que, de alguma forma, distribui a competência para avaliar se uma terra pode ou não ser objeto de colonização. As decisões em casos de ocupação semelhante podiam ser díspares, apesar da proteção da norma nacional. Cada estado poderia estabelecer normas próprias para implementação das orientações gerais presentes no decreto de 1824. Na disputa entre decisão política centralizada e distribuição de poderes às entidades federadas, mais uma vez se fortalecem as lideranças locais.

Por fim, os artigos 12 e 13 tratam da extensão máxima que poderia ser cedida a título de propriedade individual para constituição de uma colônia - "No se permitirá (...)más de una legua cuadrada de cinco mil varas de tierra de regadío, cuatro de superficie de temporal, y seis superficies de abrevadero" (art. 12). Além disso, o decreto também estabelece a impossibilidade de transmitir a propriedade às "manos muertas" (Igreja Católica), seja por meio de venda, doação ou herança (art. 13).

\footnotetext{
${ }^{232}$ Íntegra do Decreto de 18 de agosto de 1824 disponível em: CARMONA, Doralicia. Memoria Política de México. Guanajuato: Universidade de Guanajuato, 2014. http://www.memoriapoliticademexico.org/Textos/2ImpDictadura/1824DGF.html Consultado em $14 / 07 / 2015$.
} 


\subsubsection{Decreto de 15 de setembro de 1829: uma vez mais a abolição da escravatura}

Após a promulgação da Constituição dos Estados Unidos Mexicanos, em 4 de outubro de 1824, foi nomeado presidente da República o general Guadalupe Victoria, que havia sido eleito em agosto, meses antes.

Guadalupe Victoria cumpriu seu mandato de presidente da recém-fundada República pelo período de quatro anos, tal como estabelecia a Constituição. Ele foi um dos poucos presidentes do século XIX, exceção de Benito Juárez e Porfírio Díaz, a cumprir seu mandato do início ao final. Como já mencionado no primeiro capítulo desta tese, o México viveu boa parte do século XIX em grande instabilidade política. Atribuise essa instabilidade à norma da Constituição de 1824 que, em seus artigos 85 e $86^{233}$ estabelece que seja vice-presidente aquele que ficar em segundo lugar nas eleições indiretas para presidência - realizadas de maneira indireta por meio de representantes eleitos nos diferentes estados. O segundo colocado em geral trata-se do opositor político mais forte do primeiro colocado, presidente eleito. Os vice-presidentes, assim, têm sempre interesse em destituir o presidente de seu cargo, dado que é seu opositor político e está apenas aguardando uma oportunidade para assumir a função.

O governo de Guadalupe Victória se encerraria em março de 1829. Em 1828 foram realizadas eleições - novamente indiretas. O candidato Manuel Gómez Pedraza teria alcançado maioria dos votos - 11 entre 36 votantes representantes dos estados mas fora acusado de fraude às eleições pelo próprio Poder Legislativo do país. O segundo colocado, Vicente Guerrero, do Partido Liberal, obteve 9 votos e foi quem tomou posse em abril de 1829. O terceiro colocado nas eleições, Anastasio Bustamante, do Partido Conservador, assumiu a vice-presidência. A grande disputa política do século XIX mexicano se estabelecia entre liberais e conservadores. Notável, assim, a situação de um presidente liberal estar acompanhado de um vice-presidente conservador. Esse quadro de disputa interna em um mesmo governo se repetiu diversas vezes até a

\footnotetext{
233 A íntegra da Constituição mexicana aprovada em outubro de 1824, está disponível em: CARMONA, Doralicia. Memoria Política de México. Guanajuato: Universidade de Guanajuato, 2014. http://www.memoriapoliticademexico.org/Textos/2ImpDictadura/1824CFEUM.html Consultado em $14 / 07 / 2015$
} 
promulgação da Constituição de 1857, que simplesmente extinguiu a figura do vicepresidente em seu texto original.

Ainda em 1829, quando Vicente Guerrero tomou posse, a Espanha tentaria reconquistar o território mexicano e, em decorrência do conflito armado que tal tentativa ocasionou, foram conferidos poderes extraordinários - previstos na Constituição - para o presidente Vicente Guerrero. Munido desses poderes extraordinários, tomou a decisão de abolir a escravidão, em decreto datado de 15 de setembro de 1829:

1. Queda abolida la exclavitud en la República.

2. Son por consiguiente libres los que hasta hoy se habian considerado como esclavos.

3. Cuando las circunstancias del erario lo permitan, se indemnizará á los propietarios de esclavos, en los términos que dispusieren las leyes.

Muito embora já em 1810 Hidalgo y Costilla tivesse decretado o fim da escravidão, por algum tempo o México ainda teria que se confrontar com esta prática, sobretudo no norte do país, onde a ocupação das terras estava sendo feita também por americanos ou imigrantes anglófonos. Em 1827 e em 1829 os Estados Unidos haviam feito ofertas para comprar uma parte do território mexicano: aquela que hoje corresponde ao Estado estadunidense do Texas. Nas duas ocasiões o governo mexicano se recusou a vender o território fronteiriço.

No entanto, como o decreto de colonização de agosto de 1824 delegava às entidades federadas organizar e regular a forma de implementação da norma em seus territórios, houve a concessão de diversas colônias a estrangeiros, em desacordo com o que previa o artigo $7^{\circ}$ da norma federal. A ocupação por falantes da língua inglesa que, além disso, ainda se recusavam a se naturalizar mexicanos e não se misturavam culturalmente, estabelecendo localidades em que só se falava inglês em pleno território mexicano - criara um problema para o governo da Cidade do México. O uso de escravos na agricultura local estava entre os grandes embates políticos gerados por essa forma de colonização e o decreto de Vicente Guerrero tinha por objetivo enfrentá-lo. Invasão espanhola pelo porto de Tampico entre julho e setembro de 1829 e proposta de compra e ocupação cultural de suas regiões fronteiriças do norte do país, somados a uma instabilidade política interna: o México realmente tinha de se preocupar em garantir a soberania sobre seu território. 


\subsubsection{Decreto de 6 de abril de $1^{233}{ }^{234}$ : a fronteira norte deve ser ocupada por mexicanos}

Respondendo a essa preocupação, em 6 de abril de 1830, já sob a presidência de Anastasio Bustamante - Vicente Guerrero havia sido destituído em algo que se assemelhou a um golpe de estado promovido pelo então vice-presidente -, fora editado um decreto que tinha por objetivo reorganizar a concessão de colônias a partir do governo central, principalmente nas terras ao norte do país, que faziam fronteira com o território dos Estados Unidos da América.

Entre as novas normas instituídas, constam: a competência do governo federal para fiscalizar as colônias concedidas (art. $3^{\circ}$ ); a proibição de estrangeiros ocuparem terras fronteiriças (enfatizada no art. 11) ${ }^{235}$; o impedimento da entrada de estrangeiros em território nacional sem passaporte (art. $9^{\circ}$ ); a criação de regras, presentes em diversos artigos, para controle da introdução do cultivo do algodão e para a instalação de tecelagens no México; e, por fim, a criação de um fundo federal - com contribuições advindas da agricultura, que estaria sendo fomentada -cuja utilização somente poderia se dar em caso de invasão espanhola (art.17). Para além das normas citadas acima, cabe destacar, no decreto de 1830, mais esses dois artigos:

7. Las familias mexicanas que voluntariamente quieran colonizar, serán auxiliadas para el viaje; mantenidas por un año, dándoles tierras y demás útiles de labor.

(...)

10. No se hará variación respecto de las colonias ya establecidas, ni respecto de los esclavos que halla en ellas; pero el gobierno general, ó el particular en cada Estado, cuidará bajo su más estrecha responsabilidad, del cumplimiento de las leyes de colonización, y de que no se introduzcan de nuevo esclavos.

\footnotetext{
234 A íntegra do Decreto de 6 de abril de 1830, chamada Ley de Colonización, em: CARMONA, Doralicia. Memoria Política de México. Guanajuato: Universidade de Guanajuato, 2014. http://www.memoriapoliticademexico.org/Textos/2ImpDictadura/1830-colo.html Consulta realizada em 12/01/2016.

${ }^{235}$ Antes do artigo $7^{\circ}$ do Decreto de 18 de agosto de 1824 , por exemplo, um importante colonizador americano recebeu, a título de colônia, significativa parcela de terras no norte do México, em março de 1823. Seu nome era: Stephen F. Austin e a permissão que o autorizava a colonizar a área concedida está disponível em: <http://www.memoriapoliticademexico.org/Textos/2ImpDictadura/1823SFA.html> Consultado em 15/07/2015.
} 
Ao contrário da norma de 1824, claramente direcionada aos estrangeiros, o decreto de 1830 garante às famílias mexicanas algum protagonismo no processo de colonização. Àquelas que quissesem se beneficiar das regras de distribuição de terras para fins de colonização, o documento previa a possibilidade de serem pagos os gastos com a viagem até o local a ser colonizado - a principal preocupação era ocupar com mexicanos as terras no norte do país -, além de incentivos que permitissem à família permanecer e cultivar a terra pelo prazo de um ano.

Por fim, o artigo $10^{\circ}$ do decreto de 1830 estabelecia uma nova norma sobre a escravidão - alinhada com o pensamento conservador personificado em Anastasio Bustamante, subscritor do documento. $\mathrm{O}$ artigo previa, em contradição com o que havia decretado um ano antes Vicente Guerrero, que não seriam afetadas as propriedades dos escravos já existentes, nem as colônias já estabelecidas na região; solicita, porém, máxima atenção dos administradores regionais para que fossem respeitadas as normas de colonização e a não introdução de novos escravos no país. O decreto representa um claro recuo em relação ao que já havia sido a voz oficial do Estado Mexicano em 1810 e 1829 no que tange à escravidão.

\subsubsection{Decreto de 27 de novembro de 1846: povoar o território para impedir a cobiça estrangeira e desenvolver o país}

Em 27 de novembro de 1846, José Mariano de Salas expediu decreto que cria a Dirección de Colonización, uma instituição vinculada ao Ministério das Relações Exteriores e Interiores - e, portanto, ao governo central do México - responsável por concentrar e organizar a venda de terrenos "baldios" pertencentes à nação. O decreto destaca, ainda, a importância de garantir aumento da arrecadação para o orçamento público em um contexto de aumento populacional. Antes das disposições objetivas, a exposição de motivos do decreto explicita as preocupações que levaram à sua edição:

Que autorizado en el Plan proclamado en la Ciudadela en 4 de agosto último, para dictar todas las medidas que exige la seguridad de la República, y considerando que una de las más necesarias y urgentes es la de promover la inmigración extranjera para poblar nuestros inmensos terrenos que hoy son el objeto de la codicia extranjera: que para esto es indispensable establecer la Dirección de Colonización anteriormente decretada, a fin de que se trabaje con celo 
y constancia en el rápido aumento de la población, de que dependerán grandes bienes: que las economías del erario son hoy más que nunca necesarias, y que las habrá en que la precitada Dirección se establezca en la oficina de la industria, cuya reunión no presenta, por otra parte, ningún inconveniente, he tenido a bien decretar lo que sigue. ${ }^{236}$

Ora, os imensos terrenos mexicanos eram objeto da cobiça estrangeira. Tanto é verdade o afirmado no decreto que, menos de um ano depois de promulgado, os Estados Unidos da América invadiram o México e, em virtude da ocupação, estima-se que o país tenha perdido quase metade de seu território inicial. A criação da Dirección de Colonización era uma tentativa de acelerar a ocupação das terras mexicanas, estimulando tal processo diretamente a partir do governo central. Quem assina a carta que expõe os motivos que levaram o governo central de José Mariano de Salas a expedir o segundo decreto - responsável por detalhar as competências da Dirección de Colonización recém-criada - é José María Lafragua, então ministro das Relações Exteriores e Interiores, publicada em 8 de dezembro de $1846^{237}$. Na carta, lê-se:

(...) y las principales reglas y principios bajo que debe procederse a la venta de terrenos baldíos de la federación, $y$ al establecimiento de nuevas poblaciones.

Tiempo hace que existe la persuasión de la necesidad de atender a este objeto que se ha considerado, con razón, como el fundamento del engrandecimiento y de la prosperidad de la República. Se han dado leyes, unas después de otras, relativas a este objeto, y se han ajustado contratos de fundaciones de colonias; pero sin efecto ni resultado. La única que se ha establecido y prosperado, es la que se rebeló en Texas, porque el pensamiento de ese establecimiento no fue de una empresa económica o mercantil, sino de usurpación de nuestro territorio, aprovechando el candor juvenil con que la República abría sin recelos sus brazos a todas las naciones extranjeras en los primeros días de su existencia independiente. Este hecho patentiza que las leyes de colonización eran inadecuadas para dar el resultado del

\footnotetext{
${ }^{236} \mathrm{Na}$ introdução deste trabalho já se chamou atenção para a relativa facilidade para se encontrar documentos normativos da história do México. A lista de fontes primárias na bibliografia deste trabalho também indica isso. O decreto de 27 de novembro de 1846, bem como sua regulamentação de 8 de dezembro de 1846, são a exceção que confirma a regra. Os textos originais foram difíceis de achar, encontrados apenas em uma coletânea de correspondências diplomáticas do Embaixador da Espanha no México Salvador Bermúdez de Castro. FIGUEROA ESQUER, Raúl (org.). Correspondencia Diplomática de Salvador Bermúdez de Castro, Ministro de España en México, Tomo V. (De enero de 1847 a julio de 1848). Cidade do México: ITAM - Instituto Tecnológico Autónomo de México y Instituto Nacional de Estudios Históricos de las Revoluciones de México, 2013, p. 2190.

${ }^{237}$ A carta e o decreto estão datados de 4 de dezembro de 1846. Assim, tanto o dia 4 de dezembro quanto o dia 8 de dezembro são datas usadas para identificar o decreto que ora se analisa. Neste trabalho, mantivemos a referência à data de publicação, dia 8, portanto.
} 
aumento de la población e insuficientes para precaver el mal de las usurpaciones. ${ }^{238}$

Importante notar que já não se falava - como, por exemplo, no artigo $9^{\circ}$ do decreto de 18 de agosto de 1824 , ou no artigo $7^{\circ}$ do decreto de 14 de outubro de $1823-$ em "distribuição" de terras ou que o governo "beneficiará" a determinados grupos. Passados mais de vinte anos - e havendo uma significativa transformação na demografia mexicana -, em 1846 o que se quer é organizar as vendas dos terrenos sem ocupação, por meio da Dirección de Colonización. Desejava-se, então, vender terrenos a quem estivesse interessado em ocupá-los. Assim, a política de colonização também era pensada como uma estratégia para arrecadar fundos para os cofres do Estado Mexicano.

Há, no início da carta de Lafragua, um diagnóstico sobre o efeito dos documentos normativos que já haviam sido editados sobre o assunto. Segundo ele, seriam todos não efetivos, porque, por um lado, não conseguiram atrair pessoas interessadas em cultivar a terra e, por outro, tampouco foram capazes de prevenir a ação de usurpadores oportunistas, interessados em representar interesses de outros países em território mexicano ou especular com as terras concedidas. Tratava-se, segundo Lafragua, da ingenuidade de uma República recém-constituída e ansiosa por ocupar e garantir a integridade de seu território.

(...) En él [decreto] se ha establecido extensamente lo relativo a la medida de los baldíos, porque el no haberse hecho esto antes, es sin duda la principal causa de que hasta aquí no haya habido empresas de colonización, ni venta de terrenos a extranjeros. Se habían ofrecido con liberalidad, pero sin expresar dónde estaban, ni su extensión $y$ circunstancias, $y$ esto no ha podido ni debido tener resultado. En lo de adelante, por las medidas, se verificará la existencia de los baldíos, y en los planos se expresará su situación y extensión, su temperatura, su fisonomía y calidad, las aguas que tenga, y los aprovechamientos que puedan sacarse de ellos. Planos semejantes levantados en los Estados Unidos del Norte, atraen compradores e inmigrantes, y por su falta nosotros no vemos solicitar los nuestros; porque no se busca ni apetece lo que no se conoce ni se sabe que exista, de una manera determinada, y sobre que se pueda calcular.

Se ha atribuido la indiferencia o la repugnancia de los extranjeros, para solicitar nuestros terrenos, a las revueltas interiores porque ha

\footnotetext{
${ }^{238}$ FIGUEROA ESQUER, Raúl (org.). Correspondencia Diplomática de Salvador Bermúdez de Castro, Ministro de España en México, Tomo V. (De enero de 1847 a julio de 1848). Op cit. p. 2191-2192.
} 
pasado la República; y esta causa ha podido en verdad tener alguna parte, en que no haya habido demandas de terrenos; pero no ha debido ser obstáculo a que hubiese muchos inmigrantes, debiendo éstos establecerse fuera del centro en que se han efectuado las perturbaciones, y más cuando éstas no han producido despojos de propiedades, ni en ellas se han visto violencias para hacer tomar las armas a los habitantes, dejando siempre tranquilos a los hombres pacíficos y laboriosos. ${ }^{239}$

Al fijar el precio de los terrenos, el gobierno ha querido también remover obstáculos a la inmigración. El de 10 reales por acre establecido anteriormente, alejaba toda solicitud de empresas. Este es el precio de los Estados Unidos; pero no debemos olvidar que cuesta mucho más el transporte a nuestros puertos, que a los de aquella nación; y que hay mayores dificultades y gastos que hacer para internarse en esta que en aquella República, donde por otra parte es todo fácil, dispuesto y conocido para los inmigrantes. Quizá deberían ser aún menores los precios establecidos. ${ }^{240}$

Lafragua chama a atenção para as possíveis causas que teriam levado ao fracasso das políticas elaboradas antes de 1846: (1) falta de informações sobre os terrenos que viriam a ser ocupados - "no se busca ni apetece lo que no se conoce ni se sabe que exista"; (2) desconfiança para investir em um país que viveu inúmeras "perturbações" e enfrentamentos armados, e (3) preço das terras alto em relação à infraestrutura logística de escoamento de produção do país. Em relação às inúmeras revoltas armadas que o México havia sofrido, o ministro faz questão de ressaltar que em nenhum momento foram realizados despojos de propriedades. Assim, a preocupação dos estrangeiros deveria ser tranquilizada.

O decreto de dezembro de 1846, segundo ele, tem como função reverter a falta de informações sobre esses dois pontos, tornando as terras mexicanas atraentes e garantindo segurança jurídica para aqueles que decidissem lá se instalar. O objetivo era abrir a "puerta a la inmigración extranjera que busque en los Estados Unidos Mexicanos un porvenir y una patria, y cerrándola a la astucia de los usurpadores." ${ }^{241}$ Até 1846, primeira metade do século XIX, não há indicações do que viria a ser a imensa

\footnotetext{
${ }^{239}$ FIGUEROA ESQUER, Raúl (org.). Correspondencia Diplomática de Salvador Bermúdez de Castro, Ministro de España en México, Tomo V. (De enero de 1847 a julio de 1848). Cidade do México: ITAM Instituto Tecnológico Autónomo de México y Instituto Nacional de Estudios Históricos de las Revoluciones de México, 2013, p. 2192-2193.

${ }^{240}$ Ibid., p. 2193.

${ }^{241}$ FIGUEROA ESQUER, Raúl (org.). Correspondencia Diplomática de Salvador Bermúdez de Castro, Ministro de España en México, Tomo V. (De enero de 1847 a julio de 1848). Cidade do México: ITAM Instituto Tecnológico Autónomo de México y Instituto Nacional de Estudios Históricos de las Revoluciones de México, 2013, p. 2192.
} 
concentração de terras nas mãos de poucos proprietários em território mexicano, ao menos não diretamente derivadas da política de colonização realizada pelo governo central. Aparentemente há um legítimo interesse em tornar produtivo o território.

A concentração existente, herança da época colonial, era de bens imóveis nas mãos da Igreja. Sobre este ponto, vale destacar o artigo 50 do decreto de 1846, ora em análise:

45. Se fundarán también colonias militares, compuestas de mexicanos o de extranjeros, o de unos y otros, en las costas y fronteras donde designe el gobierno, especialmente para impedir las irrupciones de los bárbaros, y en ellas se concederán a los colonos, gratis, los terrenos que asigne la Dirección de Colonización, con aprobación del gobierno. ${ }^{242}$

50. La misma Dirección procurará que en las colonias más próximas a las tribus salvajes se funden misiones, y propondrá al gobierno los medios de sostenerlas y aumentarlas y de fomentar las que ya existen. $^{243}$

Os índios, que compunham mais da metade da população mexicana no século XIX, praticamente não aparecem nos documentos normativos de então. Esses dois trechos do decreto de 1846 são bastante elucidativos quanto à visão que o governo central possuía dessa população. Às inúmeras instabilidades políticas - e seus respectivos conflitos armados -, à falta de informação e ao elevado preço das terras, pode-se se somar o motivo "terror de los bárbaros" ${ }^{244}$ para justificar a apreensão e a falta de estímulo que os estrangeiros sentiam quanto à possibilidade de migrar para o México. Segundo o texto oficial de Lafragua, a população indígena nativa era mais um empecilho à ocupação do território. A estratégia governamental para enfrentar o que era, então, considerado um problema consistia em instalar colônias militares e missões católicas em locais onde houvesse "tribos selvagens". Assim, acreditava-se, " $L a$ civilización irá así lenta, pero seguramente penetrando a las tribus salvajes."245 Aproximar a igreja dos selvagens era a estratégia civilizadora do governo mexicano, no

\footnotetext{
242 Ibid. p. 2202.

${ }^{243}$ Ibid., p. 2203.

${ }^{244}$ Ibid., p. 2194.

${ }^{245}$ FIGUEROA ESQUER, Raúl (org.). Correspondencia Diplomática de Salvador Bermúdez de Castro, Ministro de España en México, Tomo V. (De enero de 1847 a julio de 1848). Cidade do México: ITAM Instituto Tecnológico Autónomo de México y Instituto Nacional de Estudios Históricos de las Revoluciones de México, 2013, p. 2194.
} 
final da metade do século XIX. Em 10 anos, com a reforma, a relação entre governo mexicano e igreja católica iria se modificar radicalmente.

As colônias militares deveriam funcionar, segundo o decreto, como as colônias normais, mas com a peculiaridade de os colonos deverem se manter armados e municiados - armas e munições financiadas pelo governo -, sendo requisito serem cidadãos capazes de portar tais $\operatorname{armas}^{246}$. Em geral, deveriam ser povoadas principalmente pelos aposentados e os que ficaram impossibilitados de continuar no serviço militar (inválidos em serviço, em confronto), e ser estabelecidas nas regiões de fronteira (artigos 45-48).

O extenso decreto, que conta com 57 artigos, ainda contém uma definição de baldíos e a determinação de pertencerem à federação (art. $8^{\circ}$ ); do tamanho básico de um lote a ser concedido em colonização ${ }^{247}$ (art. 16) - além de inúmeras indicações para as atividades dos agrimensores; da obrigação imposta aos compradores de ocuparem seus lotes com pelo menos duas famílias, com cinco membros cada, obrigação a ser verificada dois anos após a data da compra (art. 29.) ${ }^{248 .}$ Por fim, o decreto também admite que haja empresários que promovam a colonização e distribuam as terras entre colonos (art. 39); que nas colônias não é permitida a escravidão (art. 35); e que todos aqueles que se estabelecessem no México com a intenção de povoá-lo seriam considerados cidadãos da República, o que já estava definido em decreto de 10 de setembro de 1846 (art. 41).

Lafragua chama a atenção, ao final da carta de motivos que abre o decreto, sobre a importância de contar com a colaboração dos governos estaduais para implementar as disposições do decreto e fazer efetiva a Dirección de Colonización ${ }^{249}$, deixando explícita

\footnotetext{
${ }^{246}$ Art 47. Las colonias militares tendrán las franquicias que las demás, y serán gobernadas como las que no lo son; pero estarán organizados todos los individuos que puedan llevar las armas, por compañías y cuerpos, siendo decuenta del gobierno el proveerlos de armamento, de municiones y de todo lo necesario para el servicio. Ibid., p. 2202.

${ }^{247} 16$. Cada cuadro de una milla cuadrada formará un lote de 5263351000 acres. El lote Núm. 16, quedará siempre sin venderse para los usos públicos a que el gobierno tenga a bien destinarlos. Ibid., p. 2197.

${ }^{248} 29$. Por regla general en todo contrato de venta, se obligará al comprador a poblar el terreno que adquiera, con dos familias por lo menos, de a cinco individuos cada una, por milla cuadrada en el término de dos años contados desde la fecha del remate o compra. Ibid., p. 2199.

249“Desea el Excelentísimo señor general encargado del Supremo Poder Ejecutivo, que los designios grandes que le han dado al guiar ese decreto, sean cumplidos, y esto dependerá en mucha parte de la cooperación de los gobiernos de los estados, de que se lisonjea S.E., que sabe por experiencia, cuánto debe esperarse de la consagración de V.E. a los objetos de que depende el bien de la nación." Raúl Figueroa Esquer (org.). Correspondencia Diplomática de Salvador Bermúdez de Castro, Ministro de España en México, Tomo V. (De enero de 1847 a julio de 1848). Cidade do México: ITAM - Instituto
} 
que a efetivação do plano de ocupação do território mexicano depende de um bom equilíbrio entre organização centralizada e efetivação no âmbito dos estados.

Interessante notar que os documentos normativos e exposição de motivos, ao menos até 1846, não indicam claramente que as estratégias de ocupação das zonas rurais mexicanas levarão à concentração de terras. Talvez apenas pela menção, no artigo 39, de empresários que promoveriam a colonização - primeira menção a empresas após o decreto de 4 de janeiro de 1823, expedido por Augustín I. Seja como for, o texto normativo estipula o tamanho do lote de terra que seria a unidade básica de colônias a serem formadas e a quantidade mínima de famílias (duas) que deveriam ocupá-lo. Nesse contexto, não parece haver muito espaço para a concentração. Além disso, a distribuição de terras, para militares licenciados ou inválidos em virtude dos confrontos e para colonos estrangeiros com baixo poder aquisitivo, não parece incentivar a concentração.

Ao investigar quais atos normativos possibilitaram a imensa concentração fundiária existente no início do século XX, não é boa estratégia - e por isso não é adotada neste trabalho - levar em conta os objetivos explicitamente expostos nos decretos que regulamentaram a propriedade. Concentrar terras nas mãos de poucos proprietários nunca foi objetivo em si de nenhuma norma, como se verá. Investiga-se, e a investigação seguirá pelos documentos normativos da segunda metade do século XIX, quais foram os mecanismos de apropriação de terras que tornaram possível a concentração. Até este ponto, 1846, as normas que tratam da colonização podem ter sido pouco efetivas, mas não concentradoras.

\subsubsection{Decreto de 16 de fevereiro de $1854^{250}$ : agentes para promoção da colonização são enviados à Europa}

Entre 1846 e 1854, data do documento normativo que será a seguir analisado, o México viveu inúmeras mudanças geográficas e políticas. Entre elas, os nove meses de invasão dos Estados Unidos da América - após o Texas decidir se unir ao país do norte e modificar o Rio que delimitava sua fronteira. A disputa pela área entre o rio Nueces e

Tecnológico Autónomo de México y Instituto Nacional de Estudios Históricos de las Revoluciones de México, 2013, p. 2194.

${ }^{250}$ A íntegra do Decreto de 16 de fevereiro de 1854, sobre colonização em: MAZA, Francisco de la. Código de colonización y terrenos baldíos de la República Mexicana: años de 1451 a 1892. Cidade do México: Oficina Tip. de la Secretaría de Fomento, 1893, p. 563. 
o rio Grande gerou um conflito que se estendeu sendo que, entre setembro de 1847 e junho de 1848 a Cidade do México ficou sob domínio norte-americano. O resultado de mais este embate violento foi a perda que o México teve de boa parte de seu território norte, reconhecido por meio do Tratado de Guadalupe Hidalgo.

Em 1833, Antonio López de Santa Anna candidatou-se à presidência da República pelo Partido Liberal, tendo sido eleito. Por razões de saúde, não assumiu o mandato, que foi exercido então pelo segundo candidato mais votado, também do Partido Liberal, Valentín Gomez Farías. Desde então, Santa Anna esteve presente em diversos momentos relevantes para a história do México, como na luta pela independência do Estado do Texas, como militar. Em 1848 e 1850 foram eleitos, respectivamente, José Joaquín de Herrera e Mariano Arista, ambos do Partido Liberal. Em abril de 1853, com o país enfrentando uma grande crise política e econômica, Mariano Arista foi deposto do cargo de presidente e Antonio López de Santa Anna, que já havia ocupado interinamente a presidência outras vezes, foi convidado pelos conservadores - então maioria no Congresso - a assumir o posto.

Santa Anna aceitou a presidência que, aos poucos, foi adquirindo feições ditatoriais. Uma das idiossincrasias que ilustram o movimento em direção ao autoritarismo foi o de ter modificado seu pronome de tratamento: em atos oficiais e situações em que estivesse exercendo o cargo de presidente deveria ser chamado por “Su Alteza Sereníssima”. É nesse contexto que elabora mais um decreto para colonização de terras mexicanas. O objetivo principal, em destaque no documento, é autorizar "el nombramiento de agentes de colonización en Europa.". Queria-se atrair colonos especificamente europeus ${ }^{251}$.

Para realizar esse objetivo, os dois primeiros artigos do decreto de 16 de fevereiro de $1854^{252}$ dispõem:

Art. 1 Con el objeto de hacer efectiva la colonización europea en el territorio de la República de un modo conveniente, el Ministerio de Fomento, Colonización, Industria y Comercio nombrará en Europa

\footnotetext{
${ }^{251}$ Chamando atenção para o aspecto racista das leis de colonização e da política de imigração mexicanas, Sanchez destaca que a análise racial de tais políticas tem ganhado relevância nas pesquisas históricas e sociais recentes feitas sobre o século XIX. SANCHEZ, Evelyne. Los proyectos de colonización en el segundo imperio y el fortalecimiento del Estado Mexicano. Cidade do México: El Colegio de México, A.C., 2013, p.690. <hal-00943702>

${ }^{252}$ A íntegra do Decreto de 16 de fevereiro de 1854 pode ser encontrado em: MAZA, Francisco de la. Código de colonización y terrenos baldíos de la República Mexicana: años de 1451 a 1892. Cidade do México: Oficina Tip. de la Secretaría de Fomento, 1893, p. 563.
} 
uno o más agentes que, con los conocimientos necesarios sobre la extensión, riqueza y demás circunstancias favorables de este país, promueva y dirija la emigración hacia él, demostrando las grandes ventajas que ofrece su suelo.

Art. 2 - Dichos agentes cuidarán de que la emigración se componga precisamente de personas que profesen la religión católica, apostólica, romana; que sean de buenas costumbres, y que tengan alguna profesión útil par a que pueda $\mathrm{n}$ desde luego dedicarse a la agricultura, la industria, las artes o el comercio.

O México teria, assim, funcionários na Europa cuja responsabilidade seria estimular que europeus emigrassem para o país, fornecendo-lhes detalhes e incentivos para se estabelecerem no país. O artigo segundo, por sua vez, indica qual é o perfil do europeu que se espera: católico e com o domínio de uma profissão de utilidade prática imediata, desenhando, assim, o perfil do cidadão que o México gostaria de atrair. O decreto também regulamenta a forma de aquisição da propriedade da terra para os colonos europeus que viessem a ali se instalar: deveriam pagar o valor integral do imóvel em cinco anos a partir da data inicial da posse, além de ocupar e cultivar a terra concedida nesse período (art. $10^{\circ}$ ). Também seria concedida imediata cidadania mexicana aos que se instalassem no país com intenção de permanecer (art. 12).

Como o decreto regulamenta especificamente a colonização europeia, sem nenhuma menção à possibilidade de colonização de terrenos por parte de mexicanos nativos, e como seu artigo 15 explicitamente revoga todas as "leyes, decretos y reglamentos" anteriores que tratem sobre colonização e terrenos baldios, fica explícita que a política de colonização de Santa Anna não poderia favorecer a ninguém que não os europeus. Além disso, com a revogação do artigo 15, ficava o México sem uma definição legal de "baldíos", pois o decreto apenas afirma, em seu artigo $8^{\circ}$, que o Ministério deveria executar, com a maior rapidez possível "la averiguación y deslinde do todos los terrenos baldios que existen en la República", sem afirmar o que pode ou não ser considerado um "baldio".

O século XIX mexicano foi um tanto quanto conturbado politicamente. A presença de Antonio López de Santa Anna no poder, a crescente concentração de 
poderes aliada à restrição de liberdades públicas, como a liberdade de imprensa (ver seção 1.1.5), motivou a organização de um movimento político de resistência, liderado pelos políticos Florencio Villareal, Juan Álvarez e Ignacio Comonfort. Com o objetivo explícito de destituir o presidente Santa Anna do poder e restaurar a garantia das liberdades públicas no território Mexicano, foi escrito o Plan de Ayutla, em março de 1854. Em torno desse plano, organizou-se uma força armada de resistência à presidência. Houve conflitos até agosto de 1855, quando Santa Anna decidiu renunciar. Em outubro de 1855, Juan Alvarez assumiu interinamente a presidência e, por motivos pessoais diversos, renunciou, deixandou presidência para Ignacio Comonfort.

Diversas leis de conflito aberto com a igreja católica foram editadas no período de presidência interina de Comonfort (Ley Juárez, de 1855, Ley Lerdo, de 1856 e Ley Iglesias, de 1857), que versavam principalmente sobre seus direitos patrimoniais (ver tópico 2.2.2). Em 5 de fevereiro de 1857, uma nova Constituição Mexicana foi promulgada, elaborada para satisfazer aos anseios liberais, que não encontravam ressonância afinada com a Constituição de 1824.

Em 1 de dezembro de 1857, Ignacio Comonfort foi eleito - já com os procedimentos previstos na nova Constituição aprovada no mesmo ano -, e, ao assumir a presidência, compôs um gabinete com ministros conservadores e liberais. Esta tentativa de realizar um governo de coalizão não foi bem-sucedida, visto que dias depois da eleição, os conservadores - liderados por Felix Zuloaga - organizaram o Plan de Tacubaya, em 17 de dezembro de 1857. Nele, desconheciam a validade da Constituição recém-promulgada, propunham a manutenção de Ignacio Comonfort na presidência e solicitavam a convocação de um Congresso Extraordinário para a elaboração de uma nova constituição. Benito Juárez, que ocupava então o posto de presidente do Supremo Tribunal, se manifestou de forma veemente contra a insurgência conservadora e contra os ataques à Constituição. A movimentação conservadora fracassou e, como Comonfort a havia apoiado, foi deposto. Dado que a Constituição de 1857 definia que, em casos de ausência, renúncia ou impedimento do presidente do país deveria assumir a função o presidente do Supremo Tribunal de Justiça, Benito Juárez assumiu o governo, observando a linha sucessória constitucional. Os conservadores, porém, não reconheceram a presidência de Juárez e nomearam Felix Zuloaga presidente.

Os dois centros de poder geraram um conflito armado conhecido como a Guerra dos Três Anos (1858-1861). Finda a guerra civil com a vitória dos liberais, em 15 de 
junho de 1861, Benito Juárez é eleito e mantém-se na presidência do país. No pano de fundo dos conflitos, estava a decisão forte do governo liberal de promover uma efetiva separação entre Estado e Igreja em território mexicano.

No início de 1862, com graves problemas econômicos, o México declara moratória perante países estrangeiros, e é invadido por Inglaterra, Espanha e França. As duas primeiras abandonam o território mexicano após renegociar o pagamento da dívida, já a França permanece e mantém uma ocupação de 1862 a1867. Nesse período, o presidente eleito Benito Juárez mantém um governo de resistência sediado em San Luis Potosí.

Jan de Vos faz um balanço sobre os documentos normativos que tinham por objetivo a colonização antes de 1863, data em que Benito Juárez promulgará sua própria regulamentação sobre a questão:

Las medidas legislativas de 1824 a 1830 , nunca fueran aplicadas. Las luchas civiles entre conservadores y liberales impidieron que entraran en vigencia. Otros proyectos posteriores, como el de Santa Anna en 1854 y el de Comonfort, de 1856, tampoco tuvieron mayor consecuencia. Fue necesario esperar el año de 1863 para que se volviera a emitir una ley a favor de la colonización. Esta ley, expedida por el Presidente Benito Juárez en la ciudad de San Luis Potosí, el 22 de julio de 1863, puede considerarse el primer intento serio, por parte del gobierno, para hacer efectiva su política colonizadora. ${ }^{253}$

O autor justifica sua afirmação com dados que coletou junto a instâncias oficiais do Estado do México; documentos oficiais da Secretaria de Fomento, responsável por centralizar a colonização; anuários estatísticos de pesquisas sobre a situação social do México no século XIX. De fato, a superfície adjudicada entre os anos de 1821 a 1857 é inferior ao que se praticou em apenas três anos de vigência (1863-1866) da norma que será analisada a seguir ${ }^{254}$ :

\footnotetext{
${ }^{253}$ VOS, Jan de. "Una legislación de graves consecuencias - el acaparamiento de tierras baldías en México, con el pretexto de colonización, 1821-1910". In Historia Mexicana: Revista del Centro de Estudios Históricos de el Colégio de México, Cidade do México, v. 34, n. 133, p. 77-78, out.-dez. 1984.

${ }^{254}$ Quadro extraído de VOS, Jan de. "Una legislación de graves consecuencias - el acaparamiento de tierras baldías en México, con el pretexto de colonización, 1821-1910”. In Historia Mexicana: Revista del Centro de Estudios Históricos de el Colégio de México, Cidade do México, v. 34, n. 133, p. 91, out.-dez. 1984.
} 
SUMA TOTAL DE TERRENOS ADJUDICADOS, 1821-1910

\begin{tabular}{|c|c|c|c|}
\hline Prindo & Tútulos expedidos & $\underline{\text { Superficie adjudicada }}$ & $\sigma$ \\
\hline $1821-1857$ & ? & 1054490 & 2.3 \\
\hline $1863-1866$ & $?$ & 1737465 & 4.0 \\
\hline $1867-1876$ & 880 & 1424097 & 3.3 \\
\hline $1877-1910$ & 42428 & 38774280 & 90.4 \\
\hline Total & & 42990332 & 100.00 \\
\hline
\end{tabular}

\subsubsection{Lei de 20 de julho de $1863^{255}$ : a primeira política de ocupação de terrenos “baldíos" efetiva e o necessário fincanciamento do Estado Mexicano}

É durante o conturbado período de ocupação francesa que Benito Juárez, em 20 de julho de 1863, diretamente de San Luís Potosí, promulga sua Ley sobre Ocupación y Enajenación de Terrenos Baldios ${ }^{256}$. Corrigindo os principais defeitos da norma promulgada por Santa Anna, o ato normativo assinado por Benito Juárez define já no primeiro artigo o que deve ser considerado "baldío"; também confere a possibilidade de todos os habitantes do México reivindicarem terrenos para realização de colônias agrícolas, não restringido essa faculdade a estrangeiros europeus, como fazia a norma de 1854.

Art. $1^{\circ}$ - Son baldíos, para los efectos de esta ley, todos los terrenos de la República que no hayan sido destinados a un uso público por la autoridad facultada para ello por la ley, ni cedidos por la misma á título oneroso o lucrativo, a individuo o corporación autorizada par a adquirirlos.

Art $2^{\circ}$ - Todo habitante de la República tiene derecho á denunciar hasta dos mil quinientas hectaras, y no más, de terreno baldío, con excepción do los naturales de las naciones limítrofes de la República

\footnotetext{
${ }^{255}$ Íntegra da Lei disponível em: MAZA, Francisco de la. Código de colonización y terrenos baldíos de la República Mexicana: años de 1451 a 1892. Cidade do México: Oficina Tip. de la Secretaría de Fomento, 1893, p. 729-735. http://bdh-rd.bne.es/viewer.vm?id=0000013888\&page=1

${ }^{256}$ Íntegra da Lei de 20 de julho de 1863 disponível em: MAZA, Francisco de la. Código de colonización y terrenos baldíos de la República Mexicana: años de 1451 a 1892. Cidade do México: Oficina Tip. de la Secretaría de Fomento, 1893, p. 729-735. http://bdh-rd.bne.es/viewer.vm?id=0000013888\&page=1
} 
$\mathrm{y}$ do los naturalizado $\mathrm{s}$ en ellas, quienes por ningún título pueden adquirir baldíos en los Estados que con ollas lindan.

Como nos documentos normativos que a precederam, não há indicações claras de que a lei sobre ocupação e alienação de terrenos "baldíos" editada por Benito Juárez possa promover a concentração de terras nas mãos de poucos proprietários. Antes, o contrário. Logo no segundo artigo, define-se um limite máximo de dois mil e quinhentos hectares que poderiam ser obtidos por meio dos mecanismos de compra estabelecidos na lei. Sobre a compra e a venda de baldíos, há que se considerar as necessidades orçamentárias para sustentar a precária situação do Estado Mexicano independente - invadido pelos franceses, tendo que promover esforços de guerra para reverter a ocupação ilegítima. Assim, um dos objetivos da lei era conseguir dinheiro para financiar o Estado e, naquele momento, a venda de terrenos baldíos pareceu uma boa estratégia.

Se aparentemente a lei é bastante ampla no que tange aos seus destinatários quaisquer habitantes do território -, ela restringe de forma considerável sua amplitude quando identificadas as minúcias de seus procedimentos. A demarcação - e regularização, como se verá a seguir - de títulos de propriedade prevista pela lei só é acessível àqueles que conseguem acionar o Poder Judiciário:

Art. 22 - Los gastos de medida, deslinde, posesión y cualesquiera otros que se causen, serán de cuenta del denunciante, sin perjuicio do que solo indemnice cuando haya, opositor que sea condenado en costas.

Além do acesso à justiça, os gastos com a demarcação (deslinde) das terras a serem identificadas como baldíos e posteriormente vendidas deveriam ser totalmente cobertos por aquele que promove a denúncia da existência daquela terra junto ao Poder Judiciário. Ora, embora todo habitante da República Mexicana pudesse, em tese, se beneficiar dos termos de obtenção de propriedades previstos na lei de 1863, poucos eram os que efetivamente tinham capacidade econômica para suportar os altos custos que o processo de denúncia implicava. Este aspecto torna-se mais grave quando observadas as outras normas da lei, pois por meio delas fica claro que o escopo do instrumento normativo não se restringia a garantir a ocupação de terrenos desocupados, sem atividade produtiva. A definição de baldío, presente no artigo primeiro, já transcrito acima, abarcava toda a propriedade que não estivesse regularizada com um título oficial. 
Assim, aquele que ocupasse um terreno desde tempos imemoriais - como era o caso de diversos povoados indígenas -, ou há tempo suficiente para se supor legítimo proprietário, estava ameaçado pela lei.

A posse permanente, pacífica e constante de um terreno não era suficiente para indicar que ele não era um baldío. Antes, o contrário. A própria lei possuía dispositivos para os casos de posse prolongada e amparada em justo título - caso em que o possuidor tivesse, além da posse do terreno, um título que o autorizava a permanecer naquele lugar. Para as situações de posse pacífica há dez anos e existência de justo título, a lei determinava um abatimento de metade do valor normalmente cobrado pelo Estado para a concessão do título de propriedade a terrenos semelhantes (art. $5^{\circ}$ ). A lei ainda previa outras hipóteses de descontos - menores, é verdade - no valor a ser cobrado pela terra. Casos em que houvesse apenas a posse por dez anos ou apenas o título e uma posse menor do que este período receberiam o abatimento de um quarto do preço (art. $6^{\circ}$ ).

Tais normas deixam explícito o que estava realmente em questão na lei aprovada por Benito Juárez, de forma muito mais clara do que os decretos que o antecederam: regularizar os títulos de propriedade no México. Mais do que ocupar terrenos desocupados ou improdutivos, a lei era um marco para conferir documentos oficiais para terrenos ocupados sem regularização. E, por meio do processo de regularização, obter dinheiro para o Estado.

Tais objetivos - compreensíveis para um liberal que quer estruturar e consolidar um Estado sobre um território - expressaram-se de uma forma que desconsidera características importantes de parcela significativa da população do país: os índios, os mestiços e os camponeses, praticamente todos relativamente pobres e analfabetos, incapazes de pleitear junto ao Poder Judiciário (art. 14), em três meses (tempo que os possuidores tinham para regularizar suas posses precárias) a concessão do título de propriedade para o terreno supostamente "baldio" que ocupavam (art. $\left.8^{\circ}\right)$.

Assim, se por um lado a lei se preocupa em limitar a quantidade máxima de hectares que cada habitante poderia obter por meio dos procedimentos legais - o que teria por objetivo limitar a concentração agrária; por outro, ela cria mecanismos demasiadamente onerosos do ponto de vista formal e econômico para a regularização das terras e a concessão do título de propriedade. Tais mecanismos, se não favorecem a concentração, deixam completamente desprotegidas as comunidades que ocupam e cultivam sem títulos oficiais os terrenos no país. 
O contexto de edição da lei de 1863 é tão diferente daquele conforme foram editadas as normas anteriores - ou ao menos assim era a percepção dos que a elaboraram - que ela prevê formas de solução de conflito entre os denunciantes da precariedade da posse, interessados nas terras, e os efetivos possuidores (artigos $17 \mathrm{e}$ 20). O sentido dessas normas contrapõe-se às anteriores por explicitar que o México não era mais um imenso território desocupado, mas um país em que poderia haver conflitos sobre a propriedade e a posse de certas terras.

A lei prevê, ainda, que os terrenos adjudicados deveriam manter-se ocupados por aqueles que tivessem obtido a posse pelo período de dez anos (art. 10 ${ }^{\circ}$ ). Determina também que ninguém pode impedir a denúncia de um terreno "irregular", cabendo apenas às autoridades públicas verificar a regularidade e a legalidade da denúncia realizada $\left(\operatorname{art} .9^{\circ}\right)$. Por fim, um juiz de primeira instância deveria acompanhar todo o processo de identificação, demarcação e estabelecimento de preço do terreno baldío, mas sua decisão só seria definitiva após a aprovação de um órgão do Poder Executivo o Ministério de Fomento (art. 18). Assim, dois poderes da República concorreriam e se controlariam na tarefa de regularizar a propriedade.

$\mathrm{Na}$ assinatura da lei, lê-se o lema "Dios y Libertad", lema curioso para alguém que, como Benito Juárez, esteve à frente das reformas, cujo principal objetivo era construir um estado laico, garantindo a separação entre Estado e Igreja.

Mais do que a menção à religião, o ponto mais delicado do decreto expedido por Benito Juárez é a absoluta ausência de proteção para aqueles que ocupavam e trabalhavam o solo mexicano sem títulos garantissem sua posse. Os mecanismos criados pelo decreto para a regularização de todas as propriedades excluíam qualquer possibilidade de reconhecimento desses possuidores, que também eram responsáveis por tornar as terras produtivas. Só em 1866, em um decreto promulgado durante o chamado Segundo Império Mexicano - neste período, havia dois centros de poder no México, como já se destacou - é que comunidades indígenas tiveram as terras que ocupavam reconhecidas como suas. As tentativas de fazer frente a latifúndios e à apropriação indevida de terras indígenas ou de camponeses antes da Revolução de 1910 serão objeto do item 2.2.3 deste capítulo. 


\subsubsection{Decreto de 31 de maio de 1875: as empresas colonizadoras realizam atividade antes reservada ao Estado e recebem um terço das terras ocupadas}

Ao continuar a análise das regulamentações que tinham por objetivo aumentar o percentual de ocupação do território mexicano e atrair colonos capazes de melhorar a produtividade das terras ocupadas, chegaremos ao decreto de 31 de maio de $1875^{257}$, assinado por Sebastián Lerdo de Tejada, que, por ser presidente da Suprema Corte de Justiça, sucedeu constitucionalmente Benito Juárez depois de sua morte, em 1872. O decreto introduz a possibilidade da contratação de empresas particulares para a realização da colonização. Em 1846, havia a menção a "empresários" que intermediariam as ações de colonização. Em 1854, previa-se um agente que, na Europa, incentivaria colonos a se instalarem no México. É apenas em 1875, porém, que a figura de uma empresa privada, cuja principal atividade será a de promover a colonização é mencionada normativamente. Tal menção vem acompanhada de uma autorização: o poder público poderá firmar contratos com as empresas colonizadoras para que essas realizem a colonização em seu lugar. Além disso, prêmios significativos estavam previstos para as empresas que realizassem essa atividade:

\section{DECRETO de 31 DE MAYO DE 1875}

Artículo $\mathrm{I}^{\circ}$. Se autoriza al Ejecutivo para que entretanto se expide la ley que definitivamente determine y arregle todo lo relativo a colonización, haga ésta efectiva por su acción directa y por medio de contratas con empresas particulares bajo las siguientes bases:

I. La de otorgar a las empresas: una subvención por familia establecida y otra menor por familia desembarcada, en algún puerto: anticipo con un rédito equitativo, hasta de un cincuenta por ciento de dicha subvención venta a largo plazo y módico precio pagadero en abonos anuales, de terrenos colonizables, previa medición, deslinde y avalúo: prima por familia inmigrante: exención de derechos de puerto a toda embarcación que transporte a la República diez o más familias de tal carácter: prima por familia de la raza indígena establecida en las colonias de inmigrantes: prima por familia mexicana establecida en las colonias de la frontera.

(...)

\footnotetext{
257 A íntegra do Decreto de 31 de maio de 1875, sobre empresas colonizadoras. Em: CARMONA, Doralicia. Memoria Política de México. Guanajuato: Universidade de Guanajuato, 2014. <http://www.memoriapoliticademexico.org/Textos/5RepDictadura/1875DCO.html> Consulta realizada em 22/07/2015.
} 
VI. La de que por habilitar un terreno baldío, con los requisitos que exige la fracción anterior, obtenga el que llene estos requisitos, la tercera parte de dicho terreno o de su valor, siempre que lo haga con la debida autorización.

(...)

Artículo $2^{\circ}$. Se autoriza igualmente al Ejecutivo para que en el próximo año fiscal pueda, al reglamentarla, disponer hasta, de la cantidad de 250,000 pesos para los gastos que exige esta ley, inclusive el de las comisiones explotadoras.

O curto decreto de 1875, com dois artigos apenas, tinha por principal objetivo autorizar a terceirização da atividade de colonização - antes realizada diretamente pelo Estado, por meio de seu governo central - para empresas privadas. O inciso dois do artigo primeiro exige que as empresas dêem garantias de que cumprirão os contratos firmados e de que os colonos disfrutarão dos diretos previstos na legislação sobre colonização. Um compromisso pequeno e vago, frente aos grandiosos benefícios previstos no decreto.

$\mathrm{O}$ inciso um do artigo primeiro estabelece que será paga uma subvenção à empresa por família estabelecida em solo mexicano. Além dela, há ainda outra subvenção, por família que tenha se deslocado até o território. O decreto também prevê prêmios e subvenções para cada uma das ações possíveis de uma empresa colonizadora.

Tais vantagens financeiras e pagamentos realizados pelo Estado para essas companhias privadas - que absorveram dele a atividade de organizar a ocupação do solo mexicano por meio do estabelecimento de colonos - não são o ponto nevrálgico do decreto. Poderia ser considerada uma remuneração para as atividades desenvolvidas pelas empresas, caso não se entendesse como estratégico que o próprio Estado organizasse a distribuição de seu território. O decreto, porém, contribui de forma decisiva para forjar a realidade de extrema concentração agrária experimentada pela República Mexicana no início do século $\mathrm{XX}$, ao ceder gratuitamente às empresas privadas responsáveis pela colonização um terço (1/3) dos terrenos baldíos em que atuassem para regularizar (art. $1^{\circ}$, VI). Ora, com esta fórmula prevista no decreto, quanto mais eficientes forem as empresas na colonização realizada, de maior quantidade de terras elas serão proprietárias, sem terem de pagar nada pelas terras que receberem. $\mathrm{O}$ artigo segundo do decreto estabelece o orçamento que o Estado Mexicano tinha 
disponível para tornar eficazes suas normas: 250 mil pesos a serem gastos no ano fiscal de 1876.

Soma-se a esta norma a regulamentação de 1863, que deixa completamente desprotegidos índios, comunidades indígenas e mestiças, além de pequenos camponeses que possuem terras sem títulos de propriedade, e o horizonte de tensão social no campo vivido no início do século XX já começa a se desenhar.

A sucessão política de Sebastián Lerdo de Tejada não foi tranquila. A Constituição de 1857 não previa a reeleição, o que Lerdo tentou modificar em 1876, para se tornar novamente candidato. Ironicamente, quem se voltou contra tal possibilidade foi Porfírio Díaz - que viria a propor a mudança constitucional poucos anos depois em benefício próprio. Mais uma vez o país se viu envolvido em uma guerra civil que se encerrou com eleições extraordinárias realizadas em 1877, nas quais Porfírio Díaz foi eleito, assumindo o mandato em 5 de maio do mesmo ano.

\subsubsection{Lei de 15 de dezembro de $1883^{258}$ : novamente um terço das terras para companhias deslindadoras - a concentração se aprofunda}

Em 15 de dezembro de 1883 fora editada uma nova lei sobre ocupação de terrenos baldíos. Tal lei vem a público em um breve intervalo formal do poder exercido por Porfírio Diaz. Apesar de ser Manuel González o presidente em exercício, eleito em 1880, a historiografia mexicana considera que o regime porfirista se estendeu de 1877 a 1910, tendo Manuel González ocupado o cargo apenas para manter as aparências de alternância e respeito à norma constitucional que proibia a reeleição. Seja como for, é Manuel González quem assina a "Ley sobre Terrenos Baldios, mandando Deslindar, Medir, Fraccionar y Valuar los Terrenos Baldíos o de Propiedad Nacional, para Obtener los Necesarios para el Establecimiento de Colonos", de 1883:

Articulo $1^{\circ}$. Con el fin de obtener los terrenos necesarios para el establecimiento de colonos, el Ejecutivo mandará deslindar, medir, fraccionar y valuar los terrenos baldíos o de propiedad nacional que hubiere en la República, nombrando al efecto las

\footnotetext{
${ }^{258}$ A íntegra da Lei de 15 de dezembro de 1883 pode ser encontrada em: CARMONA, Doralicia. Memoria política de México. Guanajuato: Universidade de Guanajuato, 2014. <http://www.memoriapoliticademexico.org/Textos/5RepDictadura/1883LTB.html > Consulta realizada em 22/07/2015.
} 
comisiones de ingenieros que considere necesarias, y determinando el sistema de operaciones que hubiere de seguirse.

Artículo $2^{\circ}$. Las fracciones no excederán en ningún caso a dos mil quinientas hectáreas, siendo ésta la mayor extensión que podrá adjudicarse a un solo individuo mayor de edad, y con capacidad legal para contratar.

Artículo $3^{\circ}$. Los terrenos deslindados, medidos, fraccionados y valuados, serán cedidos a los inmigrantes extranjeros y a los habitantes de la República que desearen establecerse en ellos como colonos, con las condiciones siguientes:

I. En venta, al precio del avalúo, hecho por los ingenieros y aprobado por la Secretaría de Fomento, en abonos pagaderos en diez años, comenzando desde el segundo año de establecido el colono.

II. En venta, haciéndose la exhibición del precio al contado, o en plazos menores que los de la fracción anterior.

III. A título gratuito, cuando lo solicitare el colono; pero en este caso la extensión no podrá exceder de cien hectáreas, ni obtendrá el título de propiedad sino cuando justifique que lo ha conservado en su poder y lo ha cultivado el todo o en una extensión que no baje de la décima parte, durante cinco años consecutivos.

Até o artigo 17 da lei de 1883, a regulamentação proposta dizia respeito às atividades que o poder público - por meio de comissões de engenheiros nomeadas, por exemplo - desenvolveria para promover a colonização de seu território. Do artigo 18 em diante, previa-se a delegação desta atividade para as companhias demarcadoras- ou "deslindadoras" $" 259$, como ficaram conhecidas.

Em seus primeiros artigos há normas interessantes. Mantém-se, por exemplo, o limite de dois mil e quinhentos hectares (art. $2^{\circ}$ ) estabelecido na lei de 1863, editada por Benito Juárez. A diferença daquela lei, que tratava de habitante que "denuncia um baldio" - e a ênfase estava no ato de denunciar a existência de um terreno daquele tipo -, nesta ressalta-se que o limite deve se impor para indivíduos maiores de idade. $\mathrm{Ou}$ seja, limita-se o tamanho das terras a serem possuídas por meio da lei de colonização a indivíduos, pessoas físicas. A ambiguidade da lei anterior - que poderia prejudicar empresas responsáveis por denunciar "baldíos", demarcá-los e promover sua colonização - fora eliminada. O limite não era obrigatório para elas.

\footnotetext{
${ }^{259}$ Embora a palavra deslindador exista na língua portuguesa, no Brasil, quando falamos em terras, é mais comum a utilização do verbo "demarcar". Assim, uma boa tradução em português para deslindar é demarcar.
} 
Além disso, se prevê a cessão de terrenos para nacionais e estrangeiros, a título oneroso ou gratuito. As condições para a ocupação dos terrenos cedidos gratuitamente eram mais limitadas - no máximo cem hectares poderiam ser cedidos -, mas a própria possibilidade deste tipo de ocupação revela preocupação com aqueles que não poderiam pagar para se tornarem proprietários de terras.

A lei segue com critérios - e procedimentos junto ao Estado - para que nacionais e estrangeiros possam ser admitidos como colonos. A verificação para a concessão da qualificação necessária se dá a partir de critérios muito pouco objetivos: “acrediten sus buenas costumbres, y la ocupación que han tenido antes de hacer su solicitud para ser admitidos como colonos" (art. $6^{\circ}$ ). No artigo 12, é a primeira vez que uma norma mexicana admite - ou prevê - que um colono possa querer se manter como estrangeiro; ou, o contrário, queira se naturalizar mexicano, tendo como condição abandonar sua nacionalidade de origem. Tal como em regulamentações anteriores, a lei estabelece as consequências punitivas para os casos em que a terra cedida a título de colônia for abandonada ou mantida improdutiva por seis meses ou um ano. Por fim, o artigo 17 estabelece quais são os possíveis auxílios que o Estado pode garantir aos colonos recém-estabelecidos para que consigam iniciar suas atividades: subvenções e financiamentos para a compra de maquinário para agricultura, gastos com transporte, sementes, materiais de construção para habitação, animais de corte e para o trabalho podem ser obtidos com o auxílio do Estado, segundo o decreto.

Do artigo 18 em diante, o tom muda e o Estado perde a centralidade da regulamentação. O Poder Executivo é que detém um único poder, o de "autorizar a compañías para la habilitación de terrenos baldíos con las condiciones de medición, deslinde, fraccionamiento en lotes, avalúo y descripción, y para el transporte de colonos y su establecimiento en los mismos terrenos" (art. 18). Nota-se que o artigo 18 associa à palavra habilitação cinco atividades: medir, demarcar, fracionar em lotes, avaliar e descrever. Todas essas atividades deveriam ser praticadas antes da vinda dos colonos.

O artigo 21 da lei de 1883, por sua vez, repete o mesmo dispositivo concentrador do decreto de 1875: confere às companhias "deslindadoras" um terço dos terrenos em que promoverem a demarcação. Essas companhias, com atividades diferentes daquelas mencionadas no artigo 24 e nos seguintes, que teriam por objetivo específico a 
colonização, deveriam promover a habilitação dos terrenos, deixando-os preparados para receber colonos.

Em cada processo de habilitação de terrenos para colonização, as companhias não poderiam receber mais do que mil e quinhentos hectares, como "pagamento" pelas atividades que desenvolveram. Note-se que não há um limite máximo de propriedade que elas possam manter em seu nome, apenas o terço das áreas específicas em que a companhia promoveu a colonização não pode ultrapassar mil e quinhentos hectares.

Ao final da lei, no artigo 25, são estabelecidos ainda uma série de isenções de impostos e prêmios aos quais as companhias fazem jus por realizarem a atividade econômica de colonização. A ideia é que a atividade pudesse ser desenvolvida por uma companhia privada especialmente criada para este objetivo. O artigo 24 da lei estabelece, assim, quais condições deveriam ser observadas para que tais companhias pudessem ser contratadas. Por fim, o artigo 31 revoga todos os atos normativos anteriores que tratassem de colonização.

Jan de Vos chama a atenção para as consequências da mudança legislativa de 1883 e as motivações das empresas que procuravam a Secretaria de Fomento para propor contratos de demarcação e colonização de terras no México:

Fueron muchos los empresarios que, a partir de 1884, se presentaron en la Secretaría de Fomento con el objeto de celebrar con el Gobierno Federal contratos de colonización o de deslinde. De hecho, en la primera década después de la promulgación de la ley, se firmaron más de 200 convenios, 145 de deslinde y 56 de colonización. Per aún entre las 56 compañías, dizque 'colonizadoras', había muchas que no estaban realmente dispuestas a 'hacer toda clase de sacrificios para atraer a extranjeros honrados y laboriosos... a nuestro privilegiado suelo', como lo pedía el gobierno desde $1877 .{ }^{260}$

Si comparamos el número de colonias particulares efectivamente establecidas - $44-$, con el número de contratos celebrados por el gobierno con personas y compañías particulares - 201 -, es obvio que la mayoría de los empresarios firmaron sus convenios sólo para poder hacer especulaciones con la tierra. ${ }^{261}$

\footnotetext{
${ }^{260}$ VOS, Jan de. "Una legislación de graves consecuencias - el acaparamiento de tierras baldías en México, con el pretexto de colonización, 1821-1910". In Historia Mexicana: Revista del Centro de Estudios Históricos de el Colégio de México, Cidade do México, v. 34, n. 133, p. 82, out.-dez. 1984. ${ }^{261}$. Ibid., p. 83.
} 
Diferentemente do que previa o Decreto de 1875, na norma de 1883 as empresas têm a possibilidade de escolher se querem realizar o convênio com o Estado Mexicano

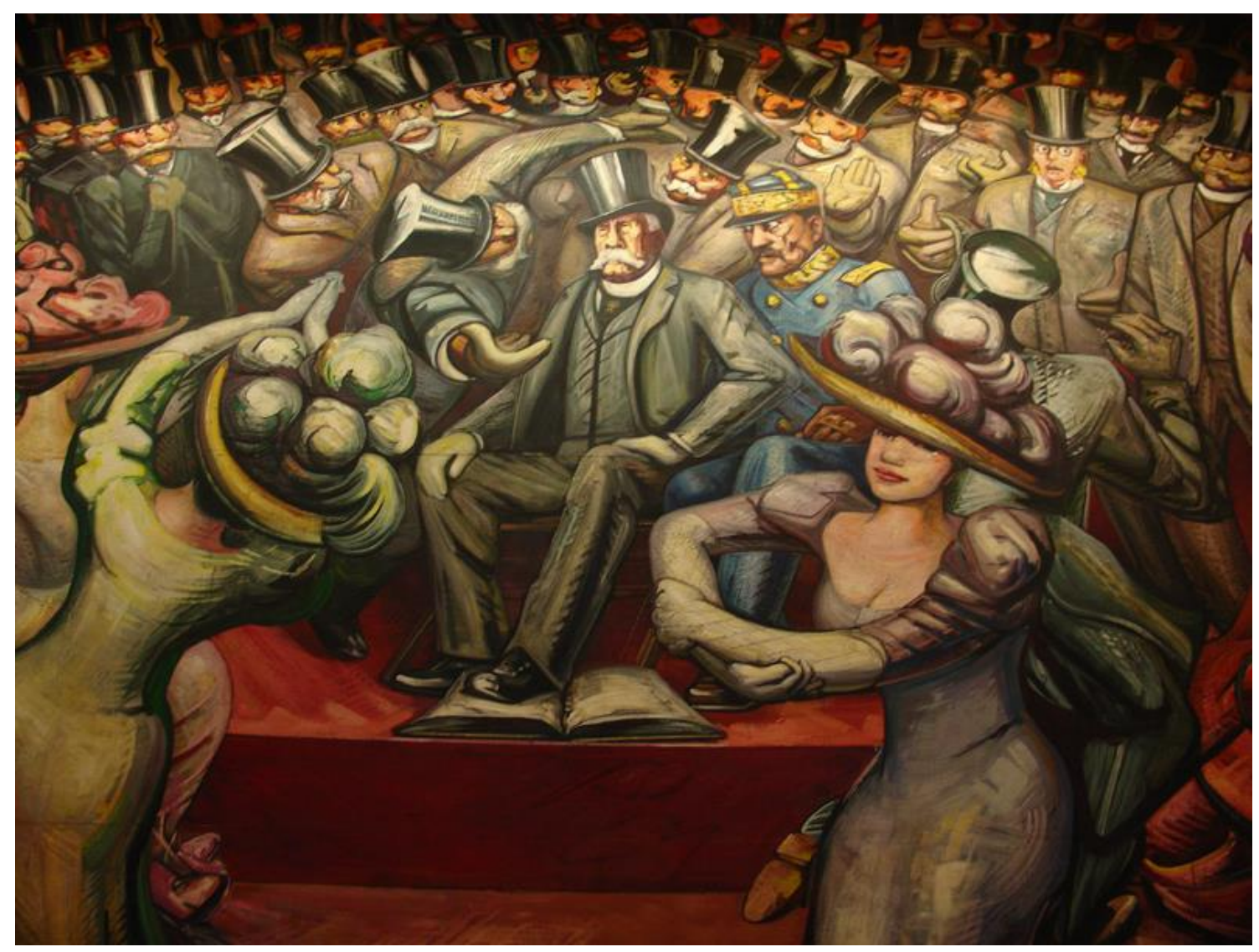

Detalhe do mural Del porfirismo a la Revolución (1957-1966), de David Alfaro Siqueiros. Ao centro, Porfírio Díaz pisa sobre a Constituição Mexicana de 1857. Museo Nacional de Historia del Castillo de Chapultepec

para realizar a colonização completa ou, por outro lado, apenas para demarcar o terreno e deixá-lo preparado para a ocupação. O "pagamento" com um terço das terras pode se realizar simplesmente em função da atividade de demarcação e essa simplificação dissociada da necessidade de encontrar pessoas e famílias interessadas a efetivamente colonizar o terreno - atraiu inúmeras empresas privadas. 


\subsubsection{Lei de 26 de março de 1894: “baldíos, demasías e excedencias" - a prevalência do título de propriedade sobre a posse efetiva}

Nesse contexto, Jesús Herzog chama a atenção sobre quanto a política promovida a partir da década de 80 do século XIX foi efetiva em seu objetivo, ao menos do ponto de vista da demarcação: "De 1881 a 1889, las compañías de que se trata deslindaron 32.200.000 hectáreas. De esta cantidad se les adjudicaron de conformidad con la ley, es decir, sin pago alguno, 12.700 .000 hectáreas; y se les vendieron a vil precio 14.800 .000 hectáreas más. ${ }^{262}$

O final do século XIX no México conheceu uma estabilidade política inédita autoritária, é verdade -, considerados os oitenta anos anteriores. Assim, é o mesmo Porfírio Díaz, no poder desde 1877, que em 26 de março de 1894 promulga a "Ley sobre ocupación y enajenación de terrenos baldios de los Estados Unidos Mexicanos" 263 , com o objetivo de complementar - e não revogar - a já "bem sucedida" lei de 1883.

Em seu primeiro artigo, a lei estabelece uma distinção entre os tipos de propriedade de terrenos existentes no território mexicano: (I) Baldíos; (II) Demasías; (III) Excedencias e (IV) Nacionales. Em seguida, no artigo 2º define baldio: "Son baldíos todos los terrenos de la República que no hayan sido destinados a un uso público, por la autoridad facultada para ello por la Ley, ni cedidos por la misma a título oneroso o lucrativo, a individuo o corporación autorizada para adquirirlos".

De acordo com a definição legal, ser ou não "baldio" - ou outra possibilidade prevista em lei - depende apenas e tão somente do reconhecimento que o poder central confere àquele terreno, sem nenhuma consideração sobre aspectos fáticos de sua ocupação. Um terreno que não possua título de propriedade, embora ocupado, é "baldío". A lei repete, assim, a mesma definição expressa em documentos normativos anteriores, conferindo um valor maior ao título do que à ocupação real.

\footnotetext{
262 SILVA HERZOG, Jesús. Breve historia de la Revolución Mexicana:los antecedentes y la etapa Maderista. $15^{\mathrm{a}}$ reimp. Cidade do México: Fondo de Cultura Económica do México, 1997, p. 18-19.

263 Íntegra da lei de 26 de março de 1894 disponível em: Instituto de Investigaciones Jurídicas, Universidad Nacional Autónoma de México. www.biblio.juridicas.unam.mx/libros/2/940/39.pdf Site consultado em 22/07/2015.
} 
As definições de "demasías" (art. 3) e "excedencias" (art. 4"), por sua vez, dizem respeito a proprietários de terras que têm a posse de extensões maiores do que as definidas no título de propriedade original. No caso da "demasía", os limites das propriedades foram um pouco alargados e, nas "excedencias", se tomou posse de um terreno vizinho. Por fim, “nacionales" (art. 5) são terrenos "baldios” que já foram identificados, medidos e demarcados, estando prontos para serem oferecidos a colonos e outros compradores.

Entre 1823, quando o primeiro decreto de colonização - que criava a Província do Istmo - e 1894, nesta lei promulgada por Porfírio Díaz, os problemas a serem resolvidos com as regulamentações mudaram. Se no início do século XIX a preocupação era a efetiva ocupação do território - por pessoas que reconhecessem a existência do Estado Mexicano -, no final do século a regularização dos títulos de propriedade válidos - muitas vezes contrários a ocupações e posses já existentes parecia ser o foco. Explicitamente, ao conceder propriedade para europeus e empresas espoliando comunidades indígenas, mestiças e campesinas - buscava-se aumentar a produtividade agrícola no campo. Implicitamente, as razões podem ter cunho racista, já que desprivilegiavam claramente os habitantes locais e originais do território mexicano. O objetivo era povoar o México com europeus, diminuindo os espaços de liberdade e cultivo dos nativos e mestiços. ${ }^{264}$

Nesse sentido, os artigos 42 e 43 conferiam descontos e prioridade para a compra de terrenos que estivessem sob a posse prolongada. Tal posse não garantia que, passado um ano, qualquer um pudesse oferecer denúncia e informar o poder central de que tal posse não era respaldada por nenhum título de propriedade. Passado um ano, mesmo que um terreno estivesse ocupado há vinte anos pela mesma família ou comunidade, qualquer habitante poderia realizar a denúncia de sua situação irregular e comprá-lo pelo preço estipulado nas tabelas oficiais, pagando o preço ao Estado e não aos possuidores anteriores.

A lei de 1894 também estabelece que ninguém pode se opor a uma propriedade reconhecida no Gran Registro de la Propiedad de la Republica (art. 48). Este registro é

\footnotetext{
${ }^{264}$ Sanchez chama a atenção para o aspecto racista das leis de colonização e da política de imigração mexicanas. Destaca que a análise racial de tais políticas tem ganhado relevância nas pesquisas históricas e sociais recentes feitas sobre o século XIX. SANCHEZ, Evelyne. "Los proyectos de colonización en el segundo imperio y el fortalecimiento del Estado Mexicano".Historia mexicana, Cidade do México, n. 250, p. 690, 2013. <hal-00943702> Consulta realizada em 12/01/2016.
} 
a fonte última de legitimidade da propriedade, pois estabelece que não se podia requerer nenhum documento adicional a quem possuísse um título registrado junto a essa instituição. Os artigos 63, 64 e 65, por sua vez, identificam quais títulos devem ser reconhecidos de forma subsidiária pelos agentes estatais.

Esses exemplos reforçam a tese de que a lei de 1894 inova ao valorizar - mais uma vez - o título de propriedade em detrimento da ocupação efetiva do solo. Se uma comunidade indígena, mestiça ou de camponeses tinha a posse de um terreno, sem título algum, vivia sobre um "baldio" que, por meio dos procedimentos da lei, poderia ser denunciado e adquirido - mediante contrato de compra e venda com o Estado - a qualquer momento.

Se essas mesmas comunidades tinham a posse de um terreno, respaldadas por um título de propriedade - e, com o aumento da população, aumentaram as áreas que ocupavam e cultivavam -, também as "demasias" e "excedencias" poderiam ser denunciadas. Todos os terrenos sem título regular de propriedade poderiam ser objeto de denúncia, por qualquer cidadão, desde que esses respeitassem os trâmites da lei:

\begin{abstract}
Artículo $6^{\circ}$. Todo habitante de la República, mayor de edad y con capacidad legal para contratar, tiene derecho, en los términos de la presente ley, para denunciar terrenos baldíos, demasías y excedencias en cualquier parte del territorio nacional, y sin limitación de extensión; excepto los naturales de las naciones limítrofes de la República y de los naturalizados en ellas, quienes por ningún título pueden adquirir baldíos en los Estados que con ellas linden.
\end{abstract}

A previsão de que "todo habitante" poderia denunciar terrenos "baldíos, demasías e excedencias" era limitada deliberadamente, entre outros, pelo artigo 27, que estabelece que toda denúncia de terrenos "baldios" deve ser publicada em periódico oficial da capital do estado, distrito ou território em que o terreno se encontre e que "Los gastos de esa publicación serán por cuenta del denunciante, así corno los de medición de terrenos y los de deslinde,[...]". Ora, se todos os habitantes do México - nacionais ou estrangeiros - podem denunciar um terreno, é certo que nem todos possuem capacidade econômica para arcar com os custos do processo de denúncia.

Voltando ao artigo $6^{\circ}$, todas as legislações anteriores limitavam o número de hectares máximo que um indivíduo poderia denunciar e, em consequência, o número de hectares máximo que poderia obter para si. A lei de 1894, ao contrário, faz questão de 
explicitar que o processo de denúncia não respeita qualquer limitação de extensão. Outro indício bastante evidente de mudança de curso no sentido - e objetivo - das normas sobre colonização fica explícito nos artigos seguintes:

Artículo $7^{\circ}$. Cesa la obligación hasta ahora impuesta, a los propietarios y poseedores de terrenos baldíos de tenerlos poblados, acotados y cultivados; y los individuos que no hubieren cumplido las obligaciones que a este respecto han impuesto las leyes anteriores a la presente, quedan exentos de toda pena, sin necesidad de declaración especial en cada caso y sin que la nación pueda en lo futuro sujetar a inquisición, revisión o composición los títulos ya expedidos, ni mucho menos reivindicar los terrenos que éstos amparen, por la falta de población, cultivo o acotamiento.

Artículo $8^{\circ}$. Cesa también la prohibición impuesta a las compañías deslindadoras de terrenos baldíos, por el artículo 21 de la ley de 15 de diciembre de 1883 o por cualquiera otra disposición legal, de enajenar las tierras que les hayan correspondido, por composición de gastos de deslinde, en lotes o fracciones que excedan de las mil quinientas hectáreas; y si alguna enajenación se hubiere hecho en lotes o fracciones de mayor extensión, no podrá ser invadida por este solo motivo, ni la nación podrá en ningún tiempo reivindicar los terrenos así enajenados, por sólo esta circunstancia.

Artículo $9^{\circ}$. Los terrenos baldíos, salvo el caso previsto en el artículo siguiente, sólo se enajenarán previo denuncio y mediante los trámites que establece esta ley, y a los precios que se fijen en la tarifa especial que el Ejecutivo Federal publicará y sancionará conforme el artículo 12.

Artículo 10. Las demasías y excedencias, así como los terrenos baldíos poseídos por particulares durante veinte años o más, sin título primordial, pero con título traslativo de dominio, emanado de particulares o de autoridad pública no autorizada para enajenar baldíos, se adquirirán también por denuncio, o por composición ajustada directamnte con la Secretaría de Fomento, conforme a las prevenciones de esta Ley.

Os proprietários - classe que, pela legislação mexicana, até então recebia terras mediante condições impostas para garantir os objetivos da nação que se formava - têm estabelecida, a partir do artigo $7^{\circ}$ da lei de 1894 , sua condição de supremos soberanos sobre os pedaços de solo que lhes pertencem, pois de acordo com os títulos oficiais não precisam mais mantê-los ocupados. 
A norma prevista na lei promulgada por Porfírio Díaz deixa explícita a mudança de espírito na legislação na medida em que a obrigação de manter as terras povoadas, delimitadas com cercas e produtivas se extingue. Basta ao proprietário ter o título em uma gaveta - e, quando perguntado, apresentá-lo - para garantir e comprovar que aquele pedaço de terra tem dono. Além da ausência de obrigação de ocupação, também não há limites para as vendas (alienações) que as companhias deslindadoras podem fazer a partir dos terrenos que receberam a título de compensação por seu trabalho demarcatório, tal como estava previsto na lei de 1883. Antes o tamanho máximo dos lotes que as companhias podiam vender era de mil e quinhentos hectares.

Note-se que essas novas vantagens, as obrigações que deixaram de ser impostas aos (futuros) proprietários e àqueles que promovem denúncias, não retiraram deles as que já tinham. A lei de 1894 não revoga a legislação anterior sobre "baldios" e isso significa que a atividade e os prêmios para as companhias deslindadoras continuavam autorizadas, incluindo seu direito de receber um terço das terras demarcadas a título de compensação pelo trabalho realizado, conforme previa o artigo 21 da lei de 1883, mencionado no artigo $8^{\circ}$. A nova lei de 1894, assim, deixa explícito seu objetivo logo no início: eliminar os entraves e limites da atuação das companhias deslindadoras e da obtenção de títulos de propriedade - porque não se trata mais de garantir a posse da propriedade, mas sim os títulos - por meio da ação estatal. Ela também elimina os parcos limites que havia na legislação quanto à concentração de terras em mãos de poucos proprietários.

Além do objetivo inicial, de eliminar entraves para a atuação das companhias deslindadoras, a lei de 1894 detalha os procedimentos para que a denúncia seja realizada junto à Secretaria de Fomento e a demarcação seja realizada (art. 24 e ss.). Ao Poder Judiciário cabia, ao contrário do que estava previsto na lei de 1863, promulgada por Benito Juárez, simplesmente dirimir casos de conflito (artigos 18, 20 e 50). Assim, títulos emitidos por agentes públicos não autorizados explicitamente pela lei são nulos de pleno direito (art. 71).

A lei estabelece, em seu art. 25, alguns impedimentos a serem verificados antes do início da tramitação do processo de denúncia, logo após a apresentação dos documentos pelo denunciante. Entre eles, a posse do terreno pela Fazenda Pública ou 
ser verificada a existência de colônias ou reduções indígenas ${ }^{265}$. Esta rápida menção a terras indígenas provavelmente não garantiu a preservação de seus territórios - até porque, nos artigos 67 a 69 da mesma lei são impostas restrições às propriedades comunais. Seja como for, seria - se aplicado fosse - um impedimento para a ação das companhias deslindadoras e outros latifundiários denunciantes de terras.

Também norma inédita na regulamentação da propriedade mexicana, o art. 14 da lei de 1894 faz a primeira menção à preservação de ruínas histórias. Dispõe que são inalienáveis, e propriedade da Federação, "los terrenos en que se encuentran ruinas monumentales, con la superficie que se declare necesaria para el cuidado conservación de éstas", além de praias, zonas marítimas e margens de rios.

Se nesse caso a propriedade da Nação Mexicana é preservada contra terceiros, o artigo 20 da mesma lei afirma que o direito de propriedade adquirido por meio dos procedimentos de adjudicação previstos na lei "confiere al adquirente la propiedad del terreno contra la Nación, y contra los particulares". Ou seja, a propriedade vem acompanhada de amplos poderes sobre aquele pedaço de terra, poderes que permitem que o proprietário se oponha inclusive à Nação. No art. 27 da Constituição de 1917, em espírito bastante diverso do art. 20 da lei de 1894, lê-se: "La propiedad de las tierras y aguas comprendidas dentro de los límites del territorio nacional, corresponde originariamente a la Nación (...). La Nación tendrá en todo tiempo el derecho de imponer a la propiedad privada las modalidades que dicte el interés público.”. Os movimentos revolucionários que impulsionaram a redação do artigo 27 da Constituição de 1917 serão objeto da seção 2.3 e seguintes do presente capítulo.

A lei de 1894 termina com a norma sobre a irresistibilidade do procedimento desencadeado por meio de uma denúncia, ao afirmar que ninguém poderia impedir os atos que se seguem à realização de uma denúncia - verificação da veracidade, demarcação, medição, adjudicação (art. 72). Caso o terreno não seja um “baldío”, o proprietário que sofrer o procedimento poderá ser indenizado pelo denunciante equivocado. Alerta, porém, que o simples fato de ter promovido a denúncia não dá direito à posse do terreno para o denunciante (art. 73).

\footnotetext{
265 A menção aos "ejidos" e às reduções indígenas aparece pela primeira vez - e é reconhecida - na Cédula Real de 10 de dezembro de 1573, emitida por Felipe II. "Los sítios en que han de se formar los pueblos y reducciones, tengan comodidad de agua, tierras y montes, entradas y salidas...”.
} 
Ao eliminar os entraves mais importantes à ação das companhias deslindadoras e aos denunciantes de terrenos "baldíos" - obrigação de ocupação; limites de tamanho - e ao privilegiar o título em detrimento da posse e da ocupação, a lei de 1894 favoreceu sobremaneira a concentração fundiária no México, como demonstra o quadro a seguir $^{266}$.

DISTRIBUCIÓN DE LA TIERRA ADJUUICADA, 1877-1910

\begin{tabular}{lcc}
\hline & Títulos \% & Superficie \% \\
\hline Ejidos & 72.52 & 1.51 \\
Colonias & 2.34 & 0.03 \\
Terrenos nacionales & 4.21 & 14.05 \\
Terrenos baldios & 17.67 & 25.53 \\
Compensación & 0.73 & 51.88 \\
\hline
\end{tabular}

FUENTE: Estadisticas Sociales del Porfinato, 1956, pp. 219-221, cuadro 86, Cfr. J. REVEL-MOUROZ, 1980, p. 156.

Jan de Vos destaca um dos interesses por trás da ostensiva eliminação de critérios e requisitos para realização da demarcação e deslinde de terras "las gruesas cantidades de dinero que dejaron al gobierno los deslindes. Las denuncias y las ventas de los terrenos baldíos, efectuadas de 1883 a 1893, dejaron em erário público la ingente suma de más de siete millones de pesos" ${ }^{267}$. Ora, se antes da lei de 1894 o processo de demarcação e cessão de terras já era extremamente rentável para o governo, o objetivo era exatamente ampliar estes benefícios.

O quadro acima, porém, mostra o fracasso da iniciativa - e ilustra as razões para a enorme tensão social vivida no campo. No período do porfiriato, entre 1877 e 1910, portanto, foram adjudicados aproximadamente 38.700 .000 hectares de terras, ou seja, foram demarcados e concedidos títulos de propriedade formais para toda essa superfície. Considerando que a superfície total do México, incluindo florestas, é de 195 milhões de hectares, a superfície adjudicada corresponde a aproximadamente 19,8\% do território do país.

\footnotetext{
${ }^{266} \mathrm{O}$ quadro a seguir foi retirado do texto de VOS, Jan de. "Una legislación de graves consecuencias - el acaparamiento de tierras baldías en México, con el pretexto de colonización, 1821-1910". In Historia Mexicana: Revista del Centro de Estudios Históricos de el Colégio de México, Cidade do México, v. 34, n. 133, p. 92, out.-dez. 1984.

${ }^{267}$ VOS, Jan de. "Una legislación de graves consecuencias - el acaparamiento de tierras baldías en México, con el pretexto de colonización, 1821-1910". In Historia Mexicana: Revista del Centro de Estudios Históricos de el Colégio de México, Cidade do México, v. 34, n. 133, p. 92, out.-dez. 1984.
} 
Entre as terras adjudicadas, por sua vez, apenas $0,03 \%$ da superfície foi transformado em colônia. A maior parte da superfície, 51,88\%, foi simplesmente cedida gratuitamente a particulares que realizaram os procedimentos de habilitação da terra medir, demarcar, fracionar em lotes, avaliar e descrever. Essa imensa superfície ficou concentrada nas mãos de poucos proprietários, o que pode ser verificado a partir da baixa porcentagem de títulos associados às terras: tratava-se de grandes propriedades abarcadas por poucos títulos.

No início do século XX, Porfírio Díaz decreta o fim dos contratos com as companhias deslindadoras, encerrando o ciclo que havia começado em meados do século XIX. As normas analisadas nesta seção - acompanhadas da política que efetivamente as implementaram, por meio dos contratos firmados com as companhias deslindadoras e colonizadoras - parecem ser uma das causas das inúmeras tensões sociais existentes na zona rural mexicana às vésperas da insurgência revolucionária de 1910.

\subsubsection{Características das políticas de colonização do século XIX mexicano: formalistas, racistas, concentradoras, cruéis ou equivocadas}

Abrimos o capítulo com a citação de Herzog268 sobre o ápice da concentração fundiária. González Roa, em El aspecto agrario de la Revolución mexicana também descreve a situação gerada após a política porfirista de demarcação de terrenos "baldíos”. Quando Porfírio Díaz decidiu interromper o processo de cessão de terras, o mal já estava feito:

Las adjudicaciones se hicieron por millones de hectáreas. En la Baja California se dieron más de 11,5 millones de hectáreas a 4 concesionarios; en Chihuahua, más de 14,5 millones de hectáreas a 7 concesionarios; solamente a uno se adjudicó solo la mitad; es decir, alrededor de 7 millones de hectáreas; en Chiapas, se adjudicaron a un concesionario poco más de 300000 hectáreas; en Puebla, se otorgaron a otro concesionario más de 76000 hectáreas; en Oaxaca, se adjudicaron a 4 concesionarios más de 3,2 millones de hectáreas, a uno solo se adjudicaron más de 720000 hectáreas; a un solo adjudicatario se entregaron poco menos de 5 millones de hectáreas en

268 HERZOG, Jesús Silva. Breve historia de la revolución mexicana: los antecedentes y la etapa Maderista. $15^{\mathrm{a}}$ reimp. Cidade do México: Fondo de Cultura Económica do México., 1997, p. 18-19. 
los Estados de Coahuila, Nuevo León, Tamaulipas y Chihuahua; en Durango, se entregaron a dos adjudicatarios casi 2 millones de hectáreas. En consecuencia, las extensiones de terrenos baldíos vinieron a formar enormes latifundios, quizás más grandes de los que existían anteriormente. ${ }^{269}$

Ao longo desta seção, realizou-se uma investigação sobre como os decretos e as leis sobre colonização disciplinam diversos temas relacionados à posse da terra. Entre os mais recorrentes, estão: (i) quem pode realizar a colonização? Há alguma preferência explícita na lei quanto aos seus destinatários, se estrangeiros ou nacionais? E quais são suas características mais valorizadas? (ii) Quem realiza os procedimentos para a garantia da ocupação e cultivo da terra, o próprio Estado ou empresas e empresários particulares? (iii) Quem, no Estado, organiza tal atividade, o governo central ou os governos locais, sejam eles estaduais ou municipais? (iv) Quando a demarcação e a colonização podem ser promovidas por particulares, quais as recompensas para aqueles que promovem a habilitação e demarcação da terras para realização de colônias? (v) Há, nas normas, requisitos formais para que a terra torne-se propriedade privada, como, por exemplo, mantê-la efetivamente ocupada e cultivada por algum intervalo de tempo? (vi) Há alguma norma que estabeleça o limite máximo de propriedades que uma pessoa, colono ou empresário, pode concentrar como propriedade sua? (vii) Alguma norma do documento aborda o problema da escravidão? Quais são as estratégias para extingui-la?

Parece que, em relação a várias dessas perguntas, a lei de 26 de março de 1894 pode ser considerada, juntamente com alguns artigos das leis de 1863 e 1883, uma das razões da concentração agrária no México do final do século XIX e início do XX. O objetivo de todas as onze normas analisadas nesta seção era, de alguma forma, transformar a ocupação e o registro da propriedade agrária no México. Nem todas possuíam a mesma capacidade de promover as mudanças que almejavam e tal incapacidade está relacionada à falta de controle sobre o poder do Estado e deste sobre o território. Assim, a instabilidade política do século XIX pode ser identificada como uma das razões para a falta de efetividade das normas antes do regime de Porfírio Díaz.

As políticas de colonização analisadas ao longo dessa seção tiveram por objetivo explícito a ocupação e povoamento do território do México recém-independente. Além

\footnotetext{
269 GONZÁLEZ ROA, Fernando. El aspecto agrario de la Revolución mexicana. Cidade do México: Departamento de Aprovisionamientos Generales, Dirección de Talleres Gráficos, 1919, p. 82. Disponível em: http://biblio.juridicas.unam.mx/libros/libro.htm?l=2885 (site consultado em 23/07/2015)
} 
dele, em parte da política praticada havia também o objetivo de obter receita para o Estado, que precisava de dinheiro para se estruturar e enfrentar a guerra contra invasores estrangeiros. Para além desses objetivos imediatos, é possível identificar algumas características comuns às normas que tinham por objetivo a colonização:

Formalistas: no embate entre o título de propriedade e a efetiva posse das terras, conferiam prioridade aos títulos em detrimento da posse efetiva. Assim, inúmeras normas conferem apenas vantagens temporárias, em prazos curtos contados em meses, para que os possuidores efetivos de terras pleiteassem o título de propriedade. Terras sem título oficial foram, em diversos documentos normativos, denominadas "baldios", ainda que produtivas e ocupadas, o que por si só explicita o conflito. Títulos eram preferidos à ocupação efetiva, ainda que o controle de sua validade, arquivos e forma de reconhecimento fossem precários e desorganizados, derivados de um Estado ainda em estabilização.

Um dos fundamentos iniciais das políticas de colonização e demarcação de terras no território mexicano era realizar o objetivo de ocupar e tornar produtivas terras vazias ou não utilizadas. Tal fundamento passa a ser absolutamente afastado e esquecido à medida que os documentos normativos se sucedem. O ápice desse movimento fica explícito no artigo $7^{\circ}$ da lei de 1894 , que elimina qualquer contra-parte de ocupação e cultivo efetivo da terra para que haja a concessão de título de propriedade às companhias deslindadoras.

Racistas: preferência por europeus, frequentemente em detrimento de mexicanos já residentes e, algumas vezes, com o objetivo explícito de diminuir os espaços físicos e culturais de indígenas.

Concentradoras: Ao longo da normatização, foram sendo desconstituídos e flexibilizados os mecanismos legais que impulsionavam pequenas e médias propriedades. Mesmo antes desse processo - realizado principalmente durante o governo de Porfírio Díaz -, porém, os prêmios e pagamentos realizados por meio da doação de terras a empresas e empresários que realizassem a demarcação e a colonização já favoreciam de forma indireta a concentração agrária e a especulação com tais bens imóveis.

Cruéis ou equivocadas: o fato de a Lei Lerdo de 1856 proibir que pessoas coletivas - por meio de pessoas jurídicas - possuíssem títulos de propriedade tinha, 
explicitamente, o objetivo de atingir os bens da Igreja Católica. Para além da Igreja, a referida norma impossibilitou que comunidades indígenas, que não reconheciam a propriedade privada e trabalhavam as terras coletivamente, fossem titulares oficiais de suas propriedades rurais.

Como, diante dessas características evidentemente contrárias aos interesses dos homens do campo, ainda assim, ao formular um de seus documentos orientadores - o Plan de Ayala - eles apostam na lei como forma de transformar a sua realidade? Por que, por outro lado, escolhem a forma do direito para escrever suas propostas e anseios? A pergunta e a perplexidade do início do capítulo permanecem.

\subsubsection{Desamortizações: propriedades coletivas indígenas e propriedades da Igreja Católica sob ataque}

A história do enfrentamento da propriedade eclesiástica no México do século XIX se mistura com o desmantelamento da propriedade comunal indígena, ambos promovidos por meio dos mesmos instrumentos jurídicos. Os dois objetivos estavam no horizonte dos liberais que implementaram suas políticas entre os anos de 1855 e 1876.

A historiografia mexicana frequentemente menciona os documentos normativos que disciplinam a desamortização entre as causas da concentração fundiária vivida no início do século XX. Responsabilizam, porém, sobretudo a interpretação que Porfírio Díaz deu ao instituto. Predomina a avaliação positiva do período denominado "Reforma", realizada pelos liberais ${ }^{270}$. O elogio dos políticos do período talvez seja compreensível, dado que eles enfrentaram bravamente sérias intempéries políticas entre as quais o conflito pelo fim da ditadura de Antonio López de Santa Anna (a derrubada de seu governo a partir da mobilização em torno do Plan de Ayutla, de 1 de março de 1854, é o marco inicial do período); as lutas com a Igreja Católica e suas propriedades; o enfrentamento de setores conservadores da sociedade mexicana, que tentaram implantar um segundo Império no México; a resistência contra a invasão francesa. Apesar de todos os obstáculos e enfrentamentos, os liberais do período da

\footnotetext{
${ }^{270}$ Benito Juárez foi homenageado com o nome de uma cidade - Ciudad Juárez - e elogiado em diversos documentos do início do século XX, entre eles o Programa do Partido Liberal, de 1906 e o Plan de Ayala, de 1911. Já na historiografia, os autores insistem em atribuir a responsabilidade pelas mazelas vividas pelo México a Porfírio Díaz, e a exaltar a boa política dos liberais que o antecederam.
} 
reforma - Juan Álvarez, Ignacio Comonfort, Benito Juárez e Miguel Lerdo de Tejada entre as lideranças - conseguiram manter sob domínio nacional o território mexicano.

Se honrosos foram os feitos em defesa da nação mexicana, principalmente frente à intervenção internacional, eles não eximem os liberais que governaram o México em meados do século XIX das consequências negativas das decisões políticas relativas à organização da terra. A desestruturação da propriedade coletiva indígena e a concentração de terras nas mãos de poucos proprietários se beneficiaram largamente da concepção individualista de propriedade defendida - e disseminada por meio de leis e ações concretas - pelos liberais. O primeiro instrumento utilizado nesse sentido foi a Ley Lerdo - de 25 de junho de 1856, que será analisada a seguir. Editada durante o mandato do presidente Ignacio Comonfort, recebeu o nome do ministro da Fazenda, Miguel Lerdo de Tejada, responsável por sua redação. Antes da Ley Lerdo, vale a pena apresentar brevemente outros momentos e temas marcantes do conflito - que caracterizou o período da Reforma - entre o governo mexicano e a Igreja Católica.

Uma parte significativa das terras produtivas do México no século XIX estava sob domínio da Igreja. Entre as consequências desse fato, segundo os liberais, estava a baixa produtividade das terras e o não recolhimento de impostos, já que as propriedades eclesiásticas gozavam de isenção. Além disso, em função da forma como chegavam a ser propriedade da Igreja - por meio de doações feitas em herança, por exemplo - ou por uma política da própria instituição religiosa, os bens da Igreja eram "amortizados" o que significa que não poderiam ser vendidos. Por estarem fora do mercado de compra e venda de propriedades produtivas, eram também designados bens de "manos muertas". Assim, as políticas de "desamortização" tinham por objetivo trazer para o comércio imóveis antes pertencentes à Igreja. ${ }^{271}$

O poder da Igreja, porém, não se resumia à concentração de terras. Ela controlava também o Tribunal Eclesiástico - instituição que exercia a função de Poder

\footnotetext{
271 "En contraposición con su misión espiritual, desde la época colonial la Iglesia católica devino en el principal propietario de tierras, que por añadidura se explotaban en forma por demás ineficiente. De conformidad con la tradición católica, los hacendados novohispanos y mexicanos tenían la costumbre de testar a favor de la Iglesia determinadas porciones de sus tierras, para el mantenimiento de conventos y órdenes monásticas, quizá con el propósito de hacerse perdonar los múltiples pecados cometidos, entre ellos el despojo de esas tierras a sus verdaderos propietarios, los indios. De ese modo, en el transcurso de casi 350 años la Iglesia acumuló enormes superficies, que ocasionalmente daba en arrendamiento, pero que en general no se atendían ni cultivaban, por lo cual se decía que estaban en manos muertas." MÉXICO. Secretaria de Desarrollo Agrario, Territorial y Urbano de México. Colonizar y desamortizar. Disponível em: <http://www.sedatu.gob.mx/sraweb/conoce-la-secretaria/historia/colonizar-ydesamortizar/> Consultado em 10 de agosto de 2015.
} 
Judiciário para questões que envolvessem a Igreja - e tinha influência política que garantia, por exemplo, a inexistência de liberdade religiosa no território mexicano.

Muitas foram as ações do Estado que contribuíram para este cenário de poder religioso. Algumas das normas sobre colonização - que determinam a existência de missões católicas ao lado de colônias militares (1846) ou o financiamento de paróquias e párocos em locais que possuam concentração populacional (1823), por exemplo - são indícios desse fato. Por outro lado, é verdade também que a coroa espanhola tentou evitar a concentração de bens imóveis nas mãos da Igreja, ainda no período do México Colonial, como já mencionado no item 2.1 deste capítulo. Antes de ser questão para o México independente, o problema das "manos muertas" tentou ser evitado e enfrentado pela então metrópole.

As instituições políticas mexicanas viviam, dessa forma, uma antiga tensão com a Igreja Católica. A aliança estratégica, porém, prevaleceu até meados do século XIX, quando houve um rompimento conflituoso. Sinais desse novo momento podem ser percebidos por meio de alguns documentos normativos da época.

Em 11 de janeiro de 1847, em meio à invasão norte-americana, o então presidente interino em exercício (na verdade, vice-presidente), do Partido Liberal, Valentín Gómez Farías, expediu um decreto que autorizava o governo mexicano a hipotecar ou vender bens de "manos muertas" (a expressão é usada no documento) ${ }^{272} \mathrm{e}$ obter até 15 milhões de pesos para financiar o exército que resistia à invasão estrangeira, principalmente armamentos de guerra ("prevenciones”). A autorização cessaria no momento em que a guerra contra os Estados Unidos da América acabasse (art. 11). Apesar da autorização, alguns bens não poderiam ser vendidos ou hipotecados. Entre eles, objetos sagrados e bens de uso direto e voltado ao benefício público hospitais, escolas, hospedagens, conventos entre outros (art. $2^{\circ}$ ).

Segundo as normas de 1847, as vendas de bens da Igreja de que trata o decreto deveriam ser realizadas à vista, sendo proibido aos funcionários públicos aceitar quaisquer títulos de crédito e o dinheiro deveria ser usado imediatamente para financiar

\footnotetext{
${ }^{272}$ A íntegra do decreto de 11 de janeiro de 1847 está disponível em: CARMONA, Doralicia. Memoria Política de México. Guanajuato: Universidade de Guanajuato, 2014.

<http://www.memoriapoliticademexico.org/Textos/2ImpDictadura/1841LAQ.html $>$ Consulta realizada em 12/01/2016.

O decreto tem início com o seguinte artigo: "Art 1. Se autoriza al gobierno para proporcionarse hasta quince millones de pesos á fin de continuar la guerra con los Estados-Unidos del Norte, hipotecando ó vendiendo en asta pública bienes de manos muertas, al efecto indicado."
} 
os esforços de guerra (art. $8^{\circ}$ ). Além disso, haveria prestação de contas do dinheiro arrecadado e de sua utilização para o Congresso (art. 13).

O decreto de Valentín Gómez Farías levou à Rebelión de los Polkos, que teve como consequência sua destituição do cargo e a retomada do poder por Antonio López de Santa-Anna, presidente que estava afastado para comandar tropas no norte do país. A rebelião - e a falta de efetividade do decreto de 1847 - diminuíram os recursos disponíveis para o embate com os EUA e, ao mesmo tempo, mostraram a força da Igreja para defender seus bens.

Menos de dez anos depois, tendo o México vivido uma ditadura comandada por Santa-Anna -iniciada em 1853 e encerrada pela Revolución de Ayutla, realizada em 1854 pelos liberais - outras normas enfrentaram o poder da Igreja, quer limitando sua propriedade, quer retirando-lhe capacidade de exercer o poder. O período, que tem início em 1854 e objetivos inicialmente organizados no Plan de Ayutla, publicado em $1^{\circ}$ de março desse mesmo ano, é conhecido na historiografia mexicana sob o nome de "Reforma", e tinha entre seus objetivos a separação entre Estado e Igreja.

O primeiro documento normativo que enfrenta os privilégios da Igreja no período da Reforma é a Ley de Administración de Justicia y Orgánica de los Tribunales de la Nación ${ }^{273}$, publicada em 23 de novembro de 1855, e também conhecida como Ley Juárez. Benito Juárez, que pouco depois, com a renúncia de Comonfort, viria a ser presidente do México, foi o idealizador do documento. À época da edição da lei, Juárez era ministro da Justiça do recente governo interino de Juan Álvarez, que havia assumido o posto no dia 4 de outubro de 1855.

Com seus 77 artigos, a longa lei de 1855 tinha por objetivo regulamentar toda a organização do Poder Judiciário no México. Competências dos órgãos julgadores territoriais, distritais, da Suprema Corte de Justiça e da Corte Marcial eram reguladas por meio do documento. Entre as modificações propostas pela reorganização, limitavase de maneira significativa o poder dos Tribunais Eclesiásticos existentes:

42. Se suprimen los tribunales especiales, con excepción de los eclesiásticos y militares. Los tribunales eclesiásticos cesarán de

\footnotetext{
${ }^{273} \mathrm{O}$ texto completo da Ley de Administración de Justicia y Orgánica de los Tribunales de la Nación, também conhecida como Ley Juárez, pode ser encontrado em: CARMONA, Doralicia. Memoria Política de México. Guanajuato: Universidade de Guanajuato, 2014. <http://www.memoriapoliticademexico.org/Textos/3Reforma/1855LEJ.html $>$. Consulta realizada em $12 / 08 / 2015$.
} 
conocer en los negocios civiles, y continuarán conociendo de los delitos comunes de los individuos de su fuero, miéntras se expide una ley que arregle ese punto. Los tribunales militares cesarán tambien de conocer de los negocios civiles, y conocerán tan solo de los delitos puramente militares ó mixtos de los individuos sujetos al fuero de guerra. Las disposiciones que comprende este artículo, son generales para toda la República, y los Estados no podrán variarlas o modificarlas. (...)

44. El fuero eclesiástico en los delitos comunes es renunciable. (...)

ARTí́CULOS TRANSITÓRIOS

$4^{\circ}$ Los tribunales militares pasarán igualmente á los jueces ordinarios respectivos, los negocios civiles y causas criminales sobre delitos comunes: lo mismo harán los tribunales eclesiásticos con los negocios civiles en que cesa su jurisdicción

Assim, o artigo 42 da Ley Juárez dispõe que os Tribunais Eclesiásticos não terão mais competência para questões ligadas à vida civil envolvendo a Igreja. Manterão, porém, a competência para julgar delitos, ou seja, mantém sua atribuição na esfera penal. Tal competência residual, porém, é limitada em seguida, pela norma do artigo 44: os indivíduos que seriam julgados pelos tribunais religiosos em delitos comuns - ou seja, previstos na legislação ordinária mexicana, e não nos códigos da Igreja - poderiam renunciar ao foro eclesiástico e se submeter aos órgãos julgadores ordinários. Mesmo a competência dos tribunais eclesiásticos na esfera penal, assim, fica bastante restringida pela lei. $\mathrm{O}$ artigo $4^{\circ}$ das disposições transitórias apenas reforça e explicita como deve ser operacionalizada a transferência de competência dos tribunais eclesiásticos para a Justiça comum.

A mudança tinha consequências de tal forma para a instituição religiosa que o então Arcebispo do México, Lázaro de La Garza, pede, em carta privada a Benito Juárez, que ele reconsidere sua decisão e suspenda a aplicação da Lei em relação aos três artigos que versam sobre os Tribunais Eclesiásticos.

Na carta, datada de 4 de dezembro de 1855, 11 dias após a publicação da lei, o arcebispo propõe que, antes de tornar válidas as normas indicadas, seja consultado o "Santísimo Padre el Romano Pontífice", ou seja, o Papa, como único caminho para que sejam evitados "el trastorno, las innumerables cuestiones y disgustos que los artículos protestados van a producir ${ }^{\text {,274 }}$. Afirma Lázaro, ainda em sua carta, que o procedimento

${ }^{274}$ Carta de Lázaro de La Garza para Benito Juárez, em 4 de dezembro de 1855, disponível em CARMONA, Doralicia. Memoria Política de México. Guanajuato: Universidade de Guanajuato, 2014. <http://www.memoriapoliticademexico.org/Textos/3Reforma/1855-LJ-R-V.html $>$, consulta realizada em $12 / 08 / 2015$. 
de consulta não ofende a dignidade da nação, apenas reafirma a boa relação e consideração que ela tem com a Santa Sé.

Em relação ao objeto de estudo do presente capítulo, retirar a competência civil dos tribunais eclesiásticos significava alijá-los das decisões que envolvessem conflitos relacionados à terra quando uma das partes envolvidas era a Igreja. A lei, assim, parece antecedente necessário às modificações que serão realizadas meses mais tarde, em 1856. A Ley Juárez foi a primeira a romper explicitamente com a Igreja Católica e afirmar o conflito aberto com a instituição.

Meses depois, a exemplo da proposta de 1847, outro documento normativo realiza expropriação de bens da Igreja em um contexto específico. Trata-se do decreto de 31 de março de $1856^{275}$ que, em seus "considerandos", justifica a existência do ato normativo: "Que el primer deber del gobierno es evitar a toda costa que la nación vuelva a sufrir los estragos de la guerra civil'. Acrescenta-se, então, a razão de atingir especificamente os bens da Igreja para cumprir este objetivo: “Que hay datos para creer que una parte considerable de los bienes eclesiásticos se ha invertido en fomentar la sublevación".

O México e Puebla haviam vivido conflitos armados decorrentes da revolução de Ayutla. O confronto deu-se entre aqueles que apoiavam a ditadura de Santa-Anna e os liberais, que defendiam a restauração das liberdades públicas. O embate havia terminado em 1855, com a renúncia de Santa-Anna e a nomeação do presidente interino Juan Álvarez. A hipótese do decreto de 1856, porém, é que os bens da Igreja haviam financiado os esforços militares antiliberais. Por esse motivo, estaria justificada sua expropriação, com o objetivo de indenizar a República pelos gastos que teve com a guerra civil, bem como os habitantes pelos prejuízos que sofreram com o conflito:

Art. 1. Los gobernadores de los estados de Puebla, Veracruz y el jefe político del territorio de Tlaxcala, intervendrán a nombre del gobierno nacional los bienes eclesiásticos de la diócesis de Puebla, sujetándose con respecto a esto a un decreto especial que arreglará esta intervención.

Art. 2. Con una parte de dichos bienes y sin desatender los objetos piadosos a que están dedicados, se indemnizará a la República de los gastos hechos para reprimir la reacción que en esta ciudad ha

\footnotetext{
${ }^{275}$ A íntegra do Decreto de 31 de março de 1856 está disponível em: CARMONA, Doralicia. Memoria Política de México. Guanajuato: Universidade de Guanajuato, 2014. $<$ http://www.memoriapoliticademexico.org/Textos/3Reforma/1856-D-BDO-IC.html $>$. Consulta realizada em 12/08/2015.
} 
terminado; se indemnizará igualmente a los habitantes de la misma ciudad de los perjuicios y menoscabos que han sufrido durante la guerra y que previamente justificarán, y se pensionará a las viudas, huérfanos y mutilados que han quedado reducidos a este estado por resultado de la misma guerra.

A autorização para intervir nos bens da Igreja a que os governadores de Puebla, Veracruz e Tlaxcala faziam jus só cessaria, de acordo como terceiro e último artigo da lei, quando "la paz y el orden público" estivessem consolidados. A avaliação da ocorrência desses dois requisitos, porém, dependeria do próprio governo.

\title{
2.2.2.1 Ley de desamortización de los bienes de las corporaciones civiles y eclesiásticas - Ley Lerdo, de 25 de junho de $1856^{276}$
}

A completa pacificação do território mexicano - tão distante de sua história do século XIX -, acompanhada da reconhecida ordem pública, não precisaram ser aguardadas e ansiadas pelos representantes religiosos que viviam na região: três meses depois da edição do decreto de 1856, a Ley Lerdo retirou seu caráter excepcional e transformou a exceção na regra. A partir de 25 de junho de 1856, todas as propriedades da Igreja poderiam ser desamortizadas, independentemente da situação social e política em que estivesse o país.

\begin{abstract}
Artículo 1.- Todas las fincas rústicas y urbanas que hoy tienen o administran como propietarios las corporaciones civiles o eclesiásticas de la República se adjudicarán en propiedad a los que las tienen arrendadas por el valor correspondiente a la renta que en la actualidad pagan, calculada como rédito al seis por ciento anual.
\end{abstract}

Artículo 5.- Tanto las urbanas como las rústicas que no estén arrendadas a la fecha de la publicación de esta ley, se adjudicarán al mejor postor en almoneda que se celebrará ante la primera autoridad política del Partido.

As propriedades rurais e urbanas administradas por corporações civis ou eclesiásticas, quer estivessem arrendadas a terceiros (art. $1^{\circ}$ ) ou não estivessem $\left(\operatorname{art.~} 5^{\circ}\right)$, deveriam ser vendidas e transformadas em propriedades de indivíduos. A motivação que levou à edição de tão radical lei está no único "considerando" que a precede: "uno de

\footnotetext{
${ }^{276}$ Ley de desamortización de los bienes de las corporaciones civiles y eclesiásticas - Ley Lerdo, de 25 de junho de 1856 e sua exposição de motivos. Íntegra do texto disponível em: BIBLIOTECA GARAY. 500 años de México en documentos. México, 2011. <http://www.biblioteca.tv/artman2/publish/1856_149/Ley_Lerdo_Ley_de_desamortizaci_n_de_bienes_d e la_i_247.shtml> Consulta realizada em 03/01/2016.
} 
los mayores obstáculos para la prosperidad y engrandecimiento de la Nación es la falta de movimiento o libre circulación de una gran parte de la propiedad raíz, base fundamental de la riqueza pública".

O objetivo da lei é, assim, transformar em propriedade privada, inteiramente disponível no mercado de compra e venda de bens imóveis, as terras antes pertencentes à Igreja Católica e às comunidades indígenas. É possível elaborar a hipótese de que esse objetivo, econômico, seja a razão que impulsionou todas as medidas - econômicas e simbólicas - adotadas pelos liberais para restringir o poder da Igreja Católica. Partia-se do pressuposto que a concentração de terras sob domínio religioso seria um entrave ao desenvolvimento do país.

Em uma primeira leitura, pode restar alguma dúvida sobre o que o legislador mexicano de 1856 teria querido dizer com "corporaciones civiles", expressão presente no artigo $1^{\circ}$ da lei. $\mathrm{O}$ artigo $8^{\circ}$, ao prever exceções para as regras gerais autorizadoras das desamortizações, não deixa margem para dúvida, porém:

\begin{abstract}
Artículo 8.- Sólo se exceptúan de la enajenación que queda prevenida, los edificios destinados inmediata y directamente al servicio u objeto del instituto de las corporaciones, aún cuando se arriende alguna parte no separada de ellos, como los conventos, palacios episcopales y municipales, colegios, hospitales, hospicios, mercados, casas de corrección y de beneficencia; como parte de cada uno de dichos edificios podrá comprenderse en esta excepción una casa que esté unida a ellos y la habiten por razón de oficio los que sirven al objeto de la institución, como las casas de los párrocos y de los capellanes de religiosas. De las propiedades pertenecientes a los ayuntamientos se exceptuarán también los edificios, ejidos y terrenos destinados exclusivamente al servicio público de las poblaciones a que pertenezcan.
\end{abstract}

Entre as propriedades pertencentes aos "ayuntamientos" (autoridades políticas representantes dos "pueblos" e das comunidades), não podem ser desamortizadas e reduzidas à propriedade individual aquelas pertencentes aos edifícios, "ejidos" e terrenos destinados exclusivamente ao serviço público, segundo a norma do art. $8^{\circ}$. Ora, no México são as comunidades indígenas e mestiças que possuíam “ejidos”. Se há uma exceção prevista para este tipo de propriedade coletiva, significa, sem qualquer dúvida, que entre as "corporaciones civiles" estão os "pueblos", as comunidades indígenas e mestiças rurais. Também nesse sentido, o artigo $3^{\circ}$ da lei fornecia uma definição de “corporaciones" propícia a incluir entre os objetos da desamortização as comunidades indígenas. Enquadram-se na definição legal de corporações, segundo o mencionado 
artigo "todo establecimiento o fundación que tenga el carácter de duración perpetua o indefinida".

Ainda que suas populações tenham sido bastante diminuídas no início do período colonial, em virtude dos confrontos e doenças provocados pela colonização, as comunidades indígenas eram presença marcante e identificável na sociedade mexicana de meados do século XIX. A específica forma com que os indígenas lidavam com a terra - coletiva, inalienável, não sujeita a sucessão hereditária ou avaliação monetária incomodava o pensamento liberal e individualista prevalecente entre os intelectuais que compunham parte das forças políticas do país.

Donald Fraser organiza, no artigo "La política de desamortización em las comunidades indígenas, 1856-1872" diversos discursos que surgem no mesmo contexto histórico da Ley Lerdo, e que deixam explícita a concepção liberal e as razões que levam ao enfrentamento da propriedade comunal indígena.

La Ley Lerdo parecía contener el proyecto de quebrantar el aislamiento de los índios, separándolos del 'cruel yugo de la comunidad', objetivo liberal que sostenían abiertamente por lo menos nueve diputados. ${ }^{277}$

Como se ha señalado, muchas personas - sobre todo liberales - creían que el gobierno indígena y la propiedad comunal contribuían al atraso y el aislamiento de los índios. ${ }^{278}$

Tal como se ha señalado en este artículo, la tesis más común es que la Ley Lerdo fue un ataque dirigido a la propiedad eclesiástica y que muy conocido artículo ocho era una rendija a través de la cual las comunidades escapaban a la desamortización. Sin embargo, es posible interpretar la ley como dirigida muy claramente contra las tierras de los pueblos, y hacerlo no sería tan ilógico en vista de las actitudes liberales hacia el problema y en vista de la legislación posterior. ${ }^{279}$

O artigo de Fraser é importante para refutar algumas interpretações históricas que identificam uma ruptura de sentido entre a política daqueles que promoveram a Reforma - Álvarez, Lerdo, Comonfort e Juárez - e o período governado por Porfírio Díaz. De acordo com os defensores da ruptura, os primeiros - liberais - não tinham por

\footnotetext{
${ }^{277}$ FRASER, Donald J. "La política de desamortización en las comunidades indígenas, 1856-1872". In Historia Mexicana. En el Centenario de la muerte de Benito Juárez. Cidade do México, vol. 21, n. 4, p. 630, abril-jun. 1972. Disponível em $<$ http://www.jstor.org/stable/25135316?seq=1\#page_scan tab_contents $>$. Consulta realizada em $11 / 08 / 2015$.

${ }^{278}$ Ibid., p. 629

${ }^{279}$ Ibid., p. 632.
} 
objetivo prejudicar comunidades indígenas. Já o porfiriato adotou como política sistemática o desmantelamento das propriedades comunais. Para esses mesmos historiadores, a inclusão de "corporações civis" entre os prejudicados pela lei que autoriza desamortizações funcionaria apenas como um disfarce, um amortecedor capaz de obscurecer o debate sobre a lei e dissimular seu alvo principal - a Igreja Católica. Assim, a real razão de existir da Ley Lerdo seria o enfrentamento das propriedades religiosas; as propriedades comunitárias indígenas, por outro lado, seriam protegidas pelas exceções do artigo $8^{\circ}$.

Fraser alega - e fundamenta sua afirmação em uma série de documentos de época - que não há evidências de que os liberais tivessem intenção de poupar as comunidades indígenas da desamortização. Antes, o contrário: para ele, os liberais consideravam nocivo e prejudicial o "cruel jugo da comunidade" sob o qual viviam e a partir do qual essas comunidades organizavam a posse da propriedade. A propriedade coletiva levava, ainda - segundo a opinião registrada em inúmeros documentos de época elaborados por liberais - a uma baixa produtividade, atraso e isolamento dos povoados indígenas. Assim, a falta de integração entre parcelas da população mexicana, era outro justificador da política de desamortização.

Como ministro da Fazenda, Miguel Lerdo de Tejada elaborou pareceres e decisões acerca de conflitos envolvendo a aplicação da lei, em muitos casos envolvendo comunidades indígenas. Já na exposição de motivos - carta que acompanhou a divulgação da lei de 25 de junho de 1856 - Lerdo dizia explicitamente que o que deveria ser enfrentado era a propriedade fora do mercado de compra e venda. Nada indica que o alvo central era a propriedade eclesiástica. Também a propriedade comunal não podia ser alienada. O livre mercado de bens imóveis estaria ligado, tal como descreve no início de sua carta, com o desenvolvimento das artes e da indústria:

Dos son los aspectos bajo los cuales debe considerarse la providencia que envuelve dicha ley para que pueda apreciarse debidamente: Primero, como una resolución que va a hacer desaparecer uno de los errores económicos que más han contribuido a mantener entre nosotros estacionaria la propiedad de impedir el desarrollo de las artes e industrias que de ella dependen: Segundo, como una medida indispensable para allanar el principal obstáculo que hasta hoy se ha presentado para el establecimiento de un sistema tributario, uniforme 
y arreglado a los principios de la ciencia, movilizando la propia raíz, que es la base natural de todo buen sistema de impuestos. ${ }^{280}$

Também as interpretações que ele oferece para resolver conflitos relacionados à aplicação da lei são todas no sentido da efetivação da desamortização, ou seja, da divisão da propriedade comunal em pequenas propriedades individuais que, após serem adjudicadas, estariam sob domínio completo de seus titulares, que poderiam vendê-las, mantê-las e transmiti-las em sucessão. Além disso, o artigo 28 da lei de junho de 1856 afirma que "los escribanos del Distrito enviarán directamente al Ministerio de Hacienda una noticia de todas las escrituras de adjudicación o remate otorgadas ante ellos". A forma como a lei foi aplicada e interpretada pelos diferentes agentes públicos nos estados mexicanos foram acompanhadas de perto pelo Ministério e, portanto, por Lerdo. Não há como pressupor a ignorância ou a discordância em relação às adjudicações que foram efetivamente realizadas em terras indígenas.

Parecería por el texto original de la ley y su reglamento, que las excepciones de ejidos y tierras empleadas en servicios públicos, quedaban estrictamente referidas, en su significación, al ejido y al fundo legal. Los otros tipos de tenencia de los pueblos - propios, montes, aguas y tierras de repartimiento - se destinaban definitivamente a la desamortización. (...) Antes que como una medida de amplia protección para las comunidades indígenas, el artículo ocho debe considerarse como una garantía limitada, en el contexto de una ley que puso todos los otros tipos de propiedad comunal en peligro. ${ }^{281}$

Fraser chama atenção para um fato importante: havia diversas formas de propriedade coletiva nas comunidades indígenas do México no século XIX. O artigo $8^{\circ}$ da Ley de desamortización de los bienes de las corporaciones civiles y eclesiásticas protege apenas e tão somente os ejidos e os edifícios e terrenos "destinados exclusivamente al servicio público de las poblaciones a que pertenezcan". A expressão "destinados exclusivamente ao serviço público" é ampla o suficiente para permitir diversas interpretações. E tais interpretações foram feitas, após a lei entrar em vigor, de

\footnotetext{
${ }^{280}$ Exposição de motivos, escrita pelo então Ministro da Fazenda Miguel Lerdo de Tejada, em 28 de junho de 1856, em carta que acompanhou a divulgação da Ley de desamortización de los bienes de las corporaciones civiles y eclesiásticas - Ley Lerdo, de 25 de junho de 1856. Íntegra do texto disponível em: BIBLIOTECA GARAY. 500 años de México en documentos. México, 2011. <http://www.biblioteca.tv/artman2/publish/1856_149/Ley_Lerdo_Ley_de_desamortizaci_n_de bienes_d e la i 247.shtml> Consulta realizada em 03/01/2016.

${ }^{281}$ FRASER, Donald J. "La política de desamortización en las comunidades indígenas, 1856-1872". In Historia Mexicana. En el Centenario de la muerte de Benito Juárez. Cidade do México, vol. 21, n. 4, p. 634, abril-jun. 1972.
} 
forma a restringir a propriedade comunal, Fraser nos mostra. Julgamos pertinente, aqui, realizar uma pequena apresentação dessas formas de possuir terras coletivamente.

Fundo legal: Expressão definida em diversas cédulas reais expedidas pela coroa espanhola no período do México colônia, que estipulavam que as áreas ocupadas com construções e habitações da comunidade indígena constituíam seu fundo legal. A área a ser demarcada e garantida para este fim era calculada, na maior parte das vezes, a partir do centro das construções da comunidade. Traçavam-se, então, duas retas de 500 ou 600 varas e, a partir delas, desenhava-se um quadrado com área de 1000 a 1200 varas quadradas. As normas coloniais também estabeleciam uma distância mínima entre os povoados indígenas e quaisquer assentamentos espanhóis.

"Ejidos": Terras sem demarcação, situadas no contorno externo imediato das comunidades, e que eram utilizadas coletivamente para pastoreio, colheita de frutos selvagens, extração de lenha e recreação. Ficam às margens do fundo legal - ou seja, para além do terreno em que há ocupação direta pelas habitações e construções da comunidade. São utilizadas por todos e de propriedade coletiva do povoado.

Terrenos de "repartimiento": Tipo de posse que mais se aproximava do ideal liberal de propriedade privada. Um indivíduo - em geral, uma família - era responsável pela posse de um pedaço de terra pertencente à comunidade. Essa posse individualizada dava direito à família de cultivar e de gozar privativamente dos frutos que a terra oferecia, sem necessidade de compartilhá-los. Diferentemente da propriedade privada, porém, os usufrutuários não tinham direito de dispor sobre a propriedade e de vendê-la, nem de aliená-la. Tampouco havia garantia de que os filhos do dono da terra a receberiam no momento de sua morte. As decisões fundamentais em momentos de mudança cabiam à comunidade e suas instâncias.

Águas, montes, entradas e saídas: Terrenos em que recursos naturais estavam disponíveis - água, vegetação que só nasce em encostas, campo para pastoreio - eram aproveitados coletivamente. Além disso, os caminhos de entrada e saída da comunidade também eram mantidos e usados como propriedades comunais. Muitas vezes esses elementos naturais também eram classificados como "ejidos".

“Própios": Terrenos cultivados pela comunidade para garantir insumos e financiamento para custear as atividades administrativas do "pueblo" ou da comunidade. 
Assim, a tese defendida por Donald Fraser diz respeito à vulnerabilidade que a Ley Lerdo gerou para muitas das terras ocupadas e utilizadas por comunidades indígenas, uma vez que a expressão "terrenos destinados exclusivamente ao serviço público" poderia ser interpretado restritivamente - e foi. Um dos principais bens coletivos afetados por processos de desamortização foram os terrenos de "repartimento", de boa qualidade para a agricultura, encravados em regiões centrais dos territórios das comunidades. A lógica de desamortização respeitou o objetivo de transformar a propriedade coletiva em propriedade privada. Se antes a terra já estava sob posse de indivíduos ou famílias, por que não formalizá-la com títulos efetivos de propriedade privada? A interpretação corrente foi nesse sentido. Porém, a lei estabelecia um prazo para que aqueles arrendatários ou possuidores efetivos da terra iniciassem o processo de desamortização e pleiteassem a titulação como legítimos proprietários: 3 meses (art. $9^{\circ}$ ). Dispõe o artigo $10^{\circ}$, logo em seguida: “Transcurridos los tres meses sin que haya formalizado la adjudicación el inquilino arrendatario, perderá su derecho a ella, subrogándose en su lugar con igual derecho al subarrendatario o cualquiera otra persona que en su defecto presente la denuncia entre la primera autoridad política".

E assim foi feito em muitas comunidades indígenas. Desamortizações realizadas por terceiros -que, muitas vezes, diziam aos índios "donos" das terras de "repartimiento" comunitárias sobre o quanto a lei era prejudicial, e os convenciam a não iniciar o processo de desamortização em nome próprio - passaram a corroer a propriedade comunal, transformando a comunidade, antes una, em uma colcha de retalhos. Dentro da própria comunidade, passou a haver proprietários-habitantes encravados, completamente alheios aos costumes que vigoravam naquele coletivo e que também não respeitavam suas instâncias decisórias. As duas formas distintas de conceber a propriedade - coletiva e individual -, convivendo lado a lado, geraram inúmeros conflitos ${ }^{282}$.

Depois do artigo $10^{\circ}$, a lei de 25 de junho de 1856 segue com uma série de normas que tentam prever e solucionar conflitos decorrentes da sucessão da titularidade do direito de propriedade que a lei desejava promover. Assim, o artigo 13 decide que as comunidades continuarão credoras das dívidas existentes antes da adjudicação em propriedade, em geral relacionadas ao arrendamento existente; se o novo proprietário

\footnotetext{
${ }^{282}$ FRASER, Donald J. "La política de desamortización en las comunidades indígenas, 1856-1872". In Historia Mexicana. En el Centenario de la muerte de Benito Juárez. Cidade do México, vol. 21, n. 4, p. 637-638, abril-jun. 1972.
} 
não é o arrendatário que possuía a terra antes, e essa possui dívidas, para receber o título de propriedade, o "denunciante" (é esta a terminologia usada) deverá saldá-las (art. 15), entre outras regras.

No artigo 21, é que se estabelece o vínculo entre o processo de adjudicação previsto pela lei - e sua consequência: a formalização da propriedade privada e todas as suas dimensões: "Artículo 21.- Los que por remate o adjudicación adquieran fincas rústicas o urbanas en virtud de esta ley, podrán en todo tiempo enajenarlas libremente y disponer de ellas como de una propiedad legalmente adquirida [...]". O artigo segue com uma exceção: devem permanecer com as corporações, antes proprietárias, o que definiu a lei como "censualistas por el capital y réditos". O objetivo aqui era conciliador em relação às corporações espoliadas (especialmente a Igreja), que manteriam - ao menos por algum período - a renda antes percebida. Nas palavras de Miguel Lerdo de Tejada, idealizador da norma:

Es también una circunstancia digna de notarse la de que al dictar el excelentísimo señor presidente esta medida, muy lejos de seguir las ideas que en otras épocas se han pretendido poner en planta con el mismo fin, expropiando absolutamente a las corporaciones poseedoras de esos bienes en provecho del gobierno, ha querido más bien asegurarles ahora la percepción de las mismas rentas que de ellas sacaban $[\ldots] .^{283}$ [grifo nosso]

Por outro lado, "nunca podrán volver en propiedad a las corporaciones", como determina o artigo 24. Uma vez constituída a propriedade privada de algum terreno antes pertencente a uma corporação civil ou eclesiástica - ele nunca poderá voltar a ser propriedade coletiva. Completa o artigo 25: "Desde ahora en adelante, ninguna corporación civil o eclesiástica, cualesquiera que sean su carácter, denominación u objeto, tendrá capacidad legal para adquirir en propiedad o administrar por sí bienes raíces, con la única excepción que expresa el Artículo 8 respecto de los edificios destinados inmediata y directamente al servicio u objeto de la institución.”. Não só aquelas propriedades que antes eram suas saíram do horizonte de possibilidades das corporações, como também elas perderam a própria capacidade civil de comprar e administrar seus bens imóveis, sendo as únicas exceções as estabelecidas no artigo $8^{\circ}$, já

\footnotetext{
${ }^{283}$ Exposição de motivos, escrita pelo então Ministro da Fazenda Miguel Lerdo de Tejada, em 28 de junho de 1856. Esta carta acompanhou a divulgação da Ley de desamortización de los bienes de las corporaciones civiles y eclesiásticas - Ley Lerdo, de 25 de junho de 1856. Íntegra do texto disponível em: BIBLIOTECA GARAY. 500 años de México en documentos. México, 2011. <http://www.biblioteca.tv/artman2/publish/1856 149/Ley_Lerdo_Ley de desamortizaci_n de bienes d e la_i_247.shtml $>$ Consulta realizada em 03/01/2016.
} 
transcrito acima. No caso de comunidades indígenas que, por exemplo, vivenciassem um aumento populacional, este impedimento era bastante severo. Para além das limitações presentes, ele impõe limites futuros que comprometem a própria existência da organização comunitária indígena tal como existia até então. $\mathrm{O}$ objetivo da lei de diminuir e desestimular a titularidade coletiva da propriedade, tal como era praticado pelas comunidades indígenas, foi, também por meio do artigo 25 , realizado.

Especificamente em relação ao enfrentamento com a Igreja, a Ley Lerdo repete a norma da Ley Juárez. O artigo 30 dispõe que juízes ordinários de primeira instância terão competência para solucionar controvérsias surgidas a partir da aplicação da lei. Os artigos 34 e 35 determinam que incide sobre todos os processos de adjudicação ou arremate disciplinados na lei o imposto da "alcabala", uma espécie de tributo sobre a transmissão da propriedade. O devedor do imposto é o novo proprietário - e de seu pagamento depende a formalização de sua nova posição. Com estes dispositivos finais, revela-se mais um interesse - para além do ideológico - na edição da Ley Lerdo. Tal como nos processos de adjudicação, analisados na seção anterior desse capítulo (sobre “baldios”), manipular, modificar e regularizar a propriedade fundiária no México significava também obter receitas para o Estado por meio de impostos, e garantir seu financiamento. $\mathrm{Na}$ exposição de motivos que acompanhou a divulgação da lei, escrita por Miguel Lerdo de Tejada em 28 de junho de 1856, este objetivo fica explícito:

Bajo el segundo punto de vista, independiente de los recursos que desde luego recibirá el erario nacional por el impuesto sobre las traslaciones de dominio que en virtud de esta ley deben verificarse, recursos que en el difícil período que hoy atraviesa la República pondrán al gobierno en actitud de cubrir las preferentes atenciones de la administración pública, sin ocurrir a los medios ruinosos que por desgracia, se han estado empleando de mucho tiempo a esta parte, se propone el excelentísimo señor presidente formar una base segura para el establecimiento de un sistema de impuestos, cuyos productos, sin cegar las fuentes de riqueza pública, basten a llenar las necesidades del gobierno y permitan a éste abolir de una vez para siempre todas esas gabelas que como una funesta herencia de la época colonial se conservan hasta el día entre nosotros, entorpeciendo el comercio con notable perjuicio de la agricultura, de las artes, de la industria y de toda la nación. ${ }^{284}$

\footnotetext{
${ }^{284}$ Exposição de motivos, escrita pelo então Ministro da Fazenda Miguel Lerdo de Tejada, em 28 de junho de 1856. Esta carta acompanhou a divulgação da Ley de desamortización de los bienes de las corporaciones civiles y eclesiásticas - Ley Lerdo, de 25 de junho de 1856. Íntegra do texto disponível em: BIBLIOTECA GARAY. 500 años de México en documentos. México, 2011.
} 
O então ministro da Fazenda tinha plena consciência de que a lei geraria imediatamente recursos derivados dos impostos sobre as transações de domínio, tal como previsto em seus artigos finais. Mas o incremento imediato nas receitas do Estado Mexicano - bem-vindo para enfrentar a turbulência política, ele faz questão de ressaltar, não era o único objetivo econômico, do ponto de vista do Estado, para a promulgação da lei. Esperava-se alcançar maior volume de impostos constantes por meio da propriedade privada desvinculada das corporações eclesiásticas e comunidades indígenas.

Em 5 de fevereiro de 1857, passados pouco mais de sete meses da publicação da Ley Lerdo, o México conheceu uma nova Constituição, feita pelos mais cultos intelectuais liberais da época. Nessa Constituição, liberal, elaborada no mesmo contexto da Reforma que conferia sentido às normas da Ley Lerdo, constava a norma que regulava a propriedade fundiária:

Artículo 27.- La propiedad de las personas no puede ser ocupada sin su consentimiento, sino por causa de utilidad pública y previa indemnización. La ley determinará la autoridad que deba hacer la expropiación, y los requisitos en que ésta haya de verificarse.

Ninguna corporación civil o eclesiástica, cualquiera que sea su carácter, denominación u objeto, tendrá capacidad legal para adquirir en propiedad o administrar por sí bienes raíces, con la única excepción de los edificios destinados inmediata y directamente al servicio u objeto de la institución.

A Constituição de 1857 repete a proibição que havia sido extensamente disciplinada na lei do ano anterior. Às corporações civis ou eclesiásticas não se reconhecia a capacidade legal de comprar ou administrar bens imóveis. A única exceção à regra prevista na constituição referia-se, novamente, aos edifícios destinados imediata e diretamente às atividades e objetivos da instituição. Duas são as interpretações possíveis para a exclusão do termo "ejidos" do texto constitucional: ou o constituinte não previa que os povoados (“pueblos") indígenas seriam diretamente afetados pela norma constitucional ou, por outro lado, eles diminuíram a sua proteção, frente ao artigo $8^{\circ}$ da Ley Lerdo. Há ainda uma terceira hipótese de que os constituintes acreditassem que a expressão "edifícios destinados inmediata y directamente al servicio u objeto de la institución" contemplassem a propriedade comunal sobre os ejidos. Quando os olhos

<http://www.biblioteca.tv/artman2/publish/1856_149/Ley_Lerdo_Ley_de_desamortizaci_n_de_bienes_d e la i 247.shtml> Consulta realizada em 03/01/2016. 
do presente se voltam para o passado, porém, e observam a política implementada - e a forma como os órgãos do Poder Judiciário interpretaram tais normas - fica clara que a terceira hipótese é muito ingênua para merecer crédito.

Para defender a tese de que houve uma decisão deliberada de reduzir ainda mais a proteção às terras indígenas, em benefício de propriedades individuais, Donald Fraser cita um discurso proferido por donos de propriedades rurais durante o Congresso Constituinte, discurso que tinha por objetivo influenciar a redação do próprio artigo 27:

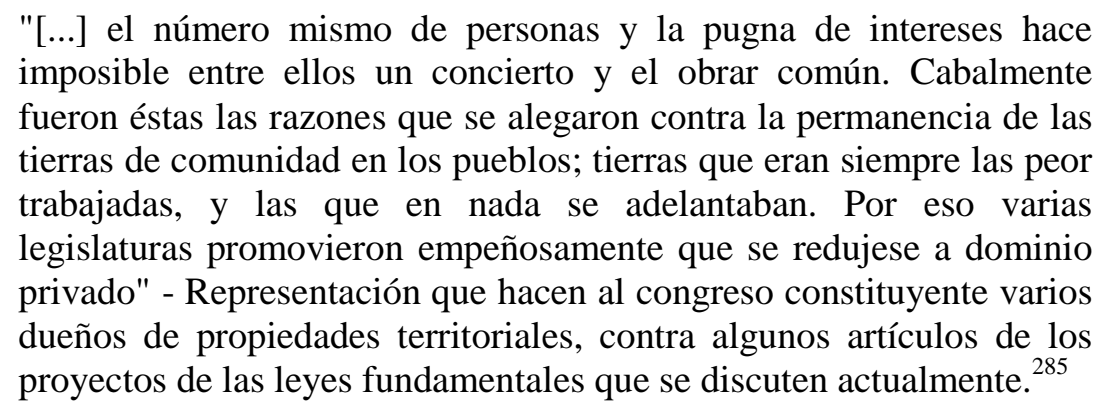

Baixa produtividade, isolamento de povoados indígenas, falta de integração nacional, incapacidade de objetividade no trabalho e decisão em função do número de pessoas que tem ingerência sobre a terra, necessidade de trabalho comum, entre outros argumentos, são invocados contra a própria existência da propriedade coletiva. Talvez seus reflexos econômicos - ser inalienável, não sujeita à sucessão hereditária ou avaliação monetária - incomodassem ainda mais. Some-se a esses motivos, o fato de os pueblos reivindicarem autonomia política: capacidade de decidir de forma independente sobre questões de seu território e comunidade.

O fato é que as discussões no Congresso Constituinte caminharam no sentido da diminuição gradual da propriedade comunal - prevendo-se inclusive sua extinção. E parece ser este o motivo da diminuição da proteção, em relação à que era oferecida pela Ley Lerdo, e a exclusão do termo "ejidos" do texto constitucional. Os apelos dos deputados constituintes Ponciano Arriaga, Isidoro Olivera e José Maria Castillo Velasco não foram ouvidos.

\footnotetext{
285 "Representación que hacen al congreso constituyente varios dueños de propiedades territoriales, contra algunos artículos de los proyectos de las leyes fundamentales que se discuten actualmente". México, 1856, p. 12. Apud FRASER, Donald J. "La política de desamortización en las comunidades indígenas, 1856-1872". In Historia Mexicana. En el Centenario de la muerte de Benito Juárez. Cidade do México, vol. 21, n. 4, p. 630, abril-jun. 1972.
} 
Sob o longo governo liberal de Benito Juárez - que teve início em situações adversas, em 1858, e só se encerrou em julho de 1872, com sua morte - as políticas de desamortização de propriedades coletivas sob titularidade de corporações civis e comunidades indígenas continuaram. É verdade que, entre 1858 e 1867, o país viveu diversos conflitos armados que impediram a ampla efetividade de políticas realizadas pelo governo central. O sentido da política, porém, que iria ter maior realização e amplitude durante o porfiriato, teve início com os liberais. A análise dos instrumentos normativos aqui realizada e também das decisões jurisprudenciais organizadas por Donald Fraser fundamentam a conclusão.

Parece desprenderse de las disposiciones citadas, que el gobierno Juárez, con muy leves vacilaciones, siguió estrechamente las medidas jurídicas de Lerdo que ordenaban la división de todas las propiedades comunales, con excepción de las que pudieran caer claramente en lo previsto por el artículo octavo. Incluso en los casos en que fueron permitidos los ejidos, se hizo énfasis en que debían ser utilizados únicamente para el servicio público. La forma de la legislación final es muy significativa porque revela que la política atribuida con frecuencia al régimen de Díaz hacia 1889 o 1890, en realidad fue iniciada mucho antes, y que existe una continuidad en la política de desamortización de las comunidades indígenas durante toda la época que va de 1856 a $1911 .{ }^{286}$

\subsubsection{Ley de Nacionalización de los Bienes del Clero Regular y Secular, de 12 de julho de 1859, e outras leis da Reforma}

$\mathrm{O}$ artigo 27 da Constituição e a Ley de desamortización de los bienes de las corporaciones civiles y eclesiásticas, Ley Lerdo, de 1856, foram os dois documentos normativos com maior impacto sobre a propriedade comunal indígena. Essas normas geraram, porém, um conflito aberto diretamente com a Igreja - já que suas propriedades também eram objeto prioritário das normas sobre desamortização. Entre 1857 e 1860, o México viveu a chamada Guerra da Reforma, contra as decisões que o Estado Mexicano impunha sobre a propriedade eclesiástica. Entre as partes envolvidas, as mais visíveis

\footnotetext{
${ }^{286}$ FRASER, Donald J. "La política de desamortización en las comunidades indígenas, 1856-1872". In Historia Mexicana. En el Centenario de la muerte de Benito Juárez. Cidade do México, vol. 21, n. 4, p. 652, abril-jun. 1972.
} 
eram Igreja e Estado Liberal, talvez porque as duas contassem com relativa igualdade de força e armas. A espoliação comunitária indígena praticamente não foi combatida ${ }^{287}$.

A lei de nacionalização dos bens do clero e o decreto que a regulamenta, ambos de julho de 1859, foram publicados já sob a presidência de Benito Juárez, que sucedeu Comonfort no posto em 1858. Nos três primeiros anos de seu mandato teve que enfrentar o conflito armado inicialmente organizado por Félix Zuloaga, Manuel Silíceo, José María Revilla, Mariano Navarro e José Bazque que, apoiados pelo exército e o pelo clero, se insurgiram contra a política liberal, contra a Constituição de 1857 e seus representantes. Tais objetivos foram formalizados no Plan de Tacubaya, de 17 de dezembro de 1857.

Comonfort se comprometeu com o plano e, portanto, conspirou contra a Constituição que deveria orientar seus atos como presidente. Benito Juárez, então presidente da Suprema Corte de Justiça, era o sucessor de Comonfort na Presidência da República, segundo norma constitucional. Chegou a ser preso pelos insurgentes, mas foi libertado. Dispôs-se, então, a assumir a função de presidente constitucional e organizar uma ofensiva contra aqueles que queriam desconhecer a Constituição de 1857. Primeiro na cidade de Guanajuato e, em seguida, transladando-se para várias cidades mexicanas, o governo de Benito Juárez viveu longos períodos de turbulência.

Assim, em meio ao conflito armado que os liberais travavam contra a Igreja que se encerrou apenas no final de 1860 - o discurso se acirrou. Enquanto a Ley Lerdo preservava parte dos rendimentos dos terrenos desamortizados para as corporações que eram suas titulares, a Ley de Nacionalización de los Bienes del Clero Regular y Secular, de 12 de julho de 1859, adota um tom - e normas - bem menos conciliadoras. Publicada já sob a presidência do que viria a ser um dos heróis nacionais, Benito Juárez, a própria lei, em seus "considerandos" iniciais, justifica sua existência. O tom do texto é a medida para auferir o enorme embate ideológico envolvido no conflito armado:

Que el motivo principal de la actual guerra promovida por el clero es conseguir sustraerse de la dependencia a la autoridad civil; (...)

Que cuando quiso el soberano, poniendo en vigor los mandatos mismos del clero, sobre observaciones parroquiales, quitar a éste la odiosidad que le ocasionaba el modo de recaudar parte de sus

\footnotetext{
${ }^{287} \mathrm{Na}$ verdade, a próxima seção deste capítulo trata de alguns movimentos em defesa de terras indígenas e pequenas propriedades, que tinham como objetivo a reversão das políticas de colonização e desamortização. No entanto, o conflito que percorreu o país em todo o seu território foi, de fato, entre a Igreja e o Estado.
} 
emolumentos, el clero prefirió aparentar que se dejaría perecer antes de sujetarse a ninguna ley; (...)

Que si en otras veces podía dudarse por alguno que el clero ha sido una de las rémoras constantes para establecer la paz pública, hoy todos reconocen que está en abierta rebelión contra el soberano;

Que dilapidando el clero los caudales que los fieles le habían confiado para objetos piadosos, los invierte en la destrucción general, sosteniendo y ensangrentando cada día más la lucha fratricida que promovió en desconocimiento de la autoridad legítima, y negando que la República pueda constituirse como mejor crea que a ella convenga;

Que habiendo sido inútiles hasta ahora los esfuerzos de toda especie por terminar una guerra que va arruinando la República, el dejar por más tiempo en manos de sus jurados enemigos los recursos de que tan gravemente abusan sería volverse cómplices, y

Que es imprescindible deber poner en ejecución todas las medidas que salven la situación y la sociedad, he tenido a bien decretar lo siguiente: ${ }^{288}$

Ora, a lei que nacionaliza os bens do clero é uma lei de exceção. Não se trata, como era o caso da Ley Lerdo, de melhorar - de acordo com a perspectiva ideológica liberal - a organização fundiária mexicana, garantindo a livre circulação de bens imóveis, antes amortizados. Na lei de julho de 1859, o objetivo explícito era diminuir o poder econômico da Igreja Católica no país, já que esse poder estava servindo para financiar uma longa guerra civil.

Nos "considerandos" há ainda a afirmação de que a Igreja desconhecia o poder da autoridade civil legítima para regular a vida em sociedade, e que o clero teria preferido perecer a se submeter à lei. O conflito clássico entre autoridade espiritual e autoridade secular - presente pelo menos desde a tragédia grega Antígona, de Sófocles, escrita quatrocentos anos antes de Cristo - encontra sua versão mexicana em meados do século XIX. Entre as razões, diversas de ordem econômica: concentração fundiária nas mãos da Igreja, baixa arrecadação de impostos relacionados a esses bens imóveis, discordância da forma como a Igreja arrecadava seus emolumentos, utilização dos bens e doações recebidos para fazer frente aos poderes do Estado constituído.

${ }^{288}$ A íntegra da Ley de Nacionalización de los Bienes del Clero Regular y Secular, de 12 de julho de 1859, está disponível aquí: CARMONA, Doralicia. Memoria Política de México. Guanajuato: Universidade de Guanajuato, 2014.

$<$ http://www.memoriapoliticademexico.org/Textos/3Reforma/1859LNB.html $>$. Consulta realizada em 17/08/2015. 
Em 1859, assim, decide-se atacar a fonte de recursos daqueles que chamam de "jurados inimigos", como estratégia para por fim à "sangrenta luta fratricida" e "salvar a situação da sociedade". Dispõe o artigo $1^{\circ}$ da lei "Entran al dominio de la nación todos los bienes que el clero secular y regular ha estado administrando con diversos títulos, sea cual fuere la clase de predios, derechos y acciones en que consistan, el nombre y aplicación que hayan tenido".

Todos os bens do clero são nacionalizados por meio da norma, independentemente do uso a que se destinavam. Hospedarias, escolas, casas de caridade, hospitais: todos os edifícios antes pertencentes ao clero foram por esse ato nacionalizados. Em relação à Ley Lerdo, que preservava os imóveis utilizados diretamente nas atividades da corporação - preservados por meio do já analisado artigo $8^{\circ}-$, o enfrentamento fica muito mais profundo.

$\mathrm{O}$ artigo $3^{\circ}$ da lei de 1859 , por sua vez, avança na almejada separação entre Estado e Igreja: "Habrá perfecta independencia entre los negocios del Estado y los negocios puramente eclesiásticos. El gobierno se limitará a proteger con su autoridad el culto público de la religión católica, así como el de cualquier otra."

O fim dos tribunais eclesiásticos, determinado pela Ley Juárez de 1855; a desamortização de bens da Igreja e sua completa nacionalização - impostas respectivamente pelas leis de 1856 (Ley Lerdo) e 1859 (Ley de Nacionalización) - já davam indícios dos objetivos que os liberais queriam alcançar com as chamadas leis da Reforma. A completa independência entre os negócios do Estado e da Igreja, prevista no art. $3^{\circ}$ da lei de 1859 , fora se consolidando a golpes jurídicos e de espada. Para além do conflito armado, leis foram responsáveis por restringir os poderes da Igreja Católica, que estava acostumada a interferir nos negócios e decisões políticas do país. A presença e a movimentação política da instituição religiosa em diversos momentos da história do país - raiz de males que queriam ser evitados - ficam evidentes em trecho de circular do Ministério da Justiça, então dirigido por Manuel F. Ruiz, em que são expostas as outras razões motivadoras da Ley de Nacionalización de los Bienes del Clero Regular y Secular:

En 1833, en 1836, en 1842, en 1847, el clero y siempre el clero, aparece insurreccionando al país, atentando de diversas maneras contra la autoridad, oprimiendo al pueblo y derramando su sangre en los combates fratricidas que arteramente preparaba. (...) 
En 1856 combinó la más formidable de las revoluciones que hasta entónces habia preparado, y V. E. no olvidará que en los campos de Ocotlan y en las calles de la ciudad de Puebla se derramó á torrentes la sangre de nuestros hermanos lanzados al combate por los ministros del Dios de la paz. ${ }^{289}$

Ainda em 23 de julho de 1859, dias depois da Lei de Nacionalização, foi publicada a Lei do Matrimônio Civil, em que se retirou da autoridade religiosa o monopólio para efetivar casamentos, que passaram a ser considerados contratos civis. Para validar frente ao Estado Mexicano os casamentos que haviam sido realizados junto à autoridade religiosa, a Ley Orgánica del Registro Civil o Ley sobre el Estado Civil de las Personas, de 28 de julho de 1859, institui o procedimento para registro de todas as mudanças no estado civil dos cidadãos mexicanos. Nascimentos, adoções, reconhecimento, matrimônios e falecimentos passaram a ser registrados junto aos “juizes do estado civil”, autoridades criadas especificamente para esse fim.

Entre as mais relevantes leis da Reforma está ainda a Ley sobre Libertad de Cultos $^{290}$, de 4 de dezembro de 1860, publicada já quase no final do enfrentamento armado entre Estado e Igreja. A Constituição de 1857, embora liberal, não havia estabelecido a liberdade religiosa no México, constrangida que estava por inúmeras vozes e forças políticas contrárias. O artigo primeiro da lei que institui a liberdade de cultos no México impõe como únicos limites aos cultos religiosos - "católico y de los demás que se establezcan en el país" - os direitos de terceiros e a ordem pública. Reafirma também a independência entre o Estado e as práticas e crenças religiosas dos cidadãos que vivem sobre seu território. No artigo 24 , a lei pró́be que todos os funcionários públicos, militares incluídos, assistam a atos religiosos em caráter oficial. Além dessas normas, outros decretos versaram sobre o fim da intervenção do clero em cemitérios, o não reconhecimento de alguns feriados religiosos e a secularização de hospitais e casas de beneficência antes administrados por entidades eclesiásticas. Além disso, a própria Ley de Nacionalización determinava o fim de todas as ordens religiosas (art. $5^{\circ}$ ), tornando os sacerdotes católicos “reducidos al clero secular" (art. $7^{\circ}$ ).

\footnotetext{
${ }^{289}$ Trecho de circular do Ministerio da Justiça, em que são expostas as razões que motivaram a Ley de Nacionalización de los Bienes del Clero Regular y Secular. Documento disponível em: CARMONA, Doralicia. Memoria Política de México. Guanajuato: Universidade de Guanajuato, 2014. <http://www.memoriapoliticademexico.org/Textos/3Reforma/1859RMD.html > Consulta realizada em $18 / 08 / 2015$.

${ }^{290}$ A íntegra da Ley sobre Libertad de Cultos, de 4 de dezembro de 1860, pode ser encontrada em: CARMONA, Doralicia. Memoria Política de México. Guanajuato: Universidade de Guanajuato, 2014. <http://www.memoriapoliticademexico.org/Textos/3Reforma/1860LLC.html>. Consulta realizada em 18 de agosto de 2015.
} 
Para voltar às razões econômicas que motivavam a limitação do poder da Igreja no período da Reforma, a Ley de Nacionalización de los Bienes del Clero Regular y Secular, de 1859, trazia em seu texto ainda algumas normas sobre a terra que merecem destaque. $\mathrm{O}$ artigo $4^{\circ}$ garantia aos ministros religiosos a capacidade de estipular "indenizações" para os serviços religiosos que realizassem, além da possibilidade de receber oferendas. Determina, no entanto, que "Ni las ofrendas ni las indemnizaciones podrán hacerse en bienes raíces", isto é, bens imóveis não poderiam voltar às mãos da Igreja por meio de doações realizadas por terceiros, nem mesmo a título de pagamento por serviços religiosos realizados.

O artigo 22 da Ley de Nacionalización determina que serão nulas e sem nenhum efeito as tentativas de alienação - venda - de bens que são objeto do processo de nacionalização previsto no artigo $1^{\circ}$. O eventual comprador teria que devolver o terreno ou o objeto comprado ou entregar o valor correspondente para o poder público. Além disso, são previstas sanções para o escrivão que autorizar o contrato. No artigo 23, atribui-se a pecha de conspiradores a todos que se oponham ou criem obstáculos ao cumprimento da lei.

No dia seguinte à publicação da Lei de Nacionalização dos Bens do Clero - em 13 de julho de 1859 , portanto - foi expedido um decreto ${ }^{291}$ que disciplinava sua implementação imediata. O objetivo declarado, ao contrário dos bélicos considerados fixados na lei do dia anterior, estava ligado diretamente ao objetivo de uma melhor organização fundiária: "Que con el objeto de que la enajenacion de los bienes de que habla la ley de 12 del actual, contribuya eficazmente á la subdivision de la propiedad territorial y ceda en beneficio general de la nacion, que es el gran fin de la reforma que ella envuelve [...]."

A distribuição e venda dos bens do clero que fossem nacionalizados, de acordo com o objetivo geral estipulado, deveriam contribuir para a constituição de propriedades menores, subdivididas, o que traria benefícios para a nação. $\mathrm{O}$ artigo $5^{\circ}$ do decreto repete a orientação para a divisão da propriedade nacionalizada. Os artigos seguintes (artigos $6^{\circ}$ a $10^{\circ}$ ), porém, estipulam um procedimento para a venda: o leilão público,

\footnotetext{
${ }^{291}$ A íntegra do decreto de 13 de julho de 1859, que regulamenta a Lei de Nacionalização dos Bens do Clero, está disponível em: CARMONA, Doralicia. Memoria Política de México. Guanajuato: Universidade de Guanajuato, 2014 <http://www.memoriapoliticademexico.org/Textos/3Reforma/1859RLN.html> Consulta realizada em $18 / 08 / 2015$.
} 
respeitado o maior preço oferecido. Tal procedimento em nada contribuiu para a efetiva diminuição da propriedade fundiária. Por fim, de forma semelhante ao que a lei de 1875 faria, recompensando as companhias deslindadoras pela denúncia de terrenos sem título de propriedade, o decreto que regulamenta a lei de nacionalização oferece, em seu artigo 28, uma recompensa para pessoas que denunciarem bens eclesiásticos ainda não desamortizados ou nacionalizados.

A política de enfrentamento da Igreja Católica e das propriedades coletivas indígenas - por meio das políticas de desamortização e de expropriação de seus bens imóveis - não teve, do ponto de vista da reorganização social do país, o efeito esperado pelos liberais. Katz elabora um balanço da situação social e fundiária no país em 1867, mais de uma década após a publicação da Ley Lerdo e oito anos da Lei de Nacionalização dos Bens do Clero.

Quando o presidente liberal Benito Juárez retornou à Cidade do México, em julho de 1867, depois da guerra contra os franceses, que se seguira a três anos de guerra civil entre os liberais e os conservadores, o entusiasmo da vitória militar quase não disfarçava a frustração dos liberais diante do fracasso de muitos dos objetivos que haviam estabelecido doze anos antes. Com efeito, a execução de Maximiliano e, portanto, a derrota de Napoleão III afastara por muito tempo a ameaça de uma intervenção europeia, e a sobrevivência do México como nação independente parecia assegurada. A Igreja perdera a maior parte de sua influência política e econômica sobre o país; e os golpes que ela tantas vezes inspirara eram coisa do passado. $\mathrm{O}$ antigo exército dos conservadores, tão propenso à indisciplina e à revolta, fora dissolvido para sempre. O governo regional achava-se firmemente nas mãos dos liberais. O número das grandes propriedades comunais diminuíra consideravelmente. Mas esses desdobramentos não produziram os resultados esperados. A desapropriação da terra da Igreja não deu origem a uma classe de pequenos agricultores, porque a terra foi vendida em leilão pelo maior lance e sua maior parte foi parar nas mãos dos ricos fazendeiros locais. Para grande pesar dos liberais mais radicais, isso apenas aumentou a força econômica e a coesão política de uma classe já dominante de hacendados ricos. O novo exército dos liberais não foi uma garantia de estabilidade maior do que fora a antiga instituição dos conservadores. Era apenas uma frouxa aglomeração de soldados, do corpo regular do exército e de guerrilheiros, sendo cada unidade chefiada por um comandante local diferente com diferentes graus de lealdade ao governo central. Era grande demais para as necessidades de uma época de paz; e mais, a simples dispensa dos veteranos das duas guerras sem uma recompensa adequada por seu longo serviço ameaçava desencadear novas revoltas. Apesar do novo sentimento de patriotismo que a vitória contra os franceses e o surgimento de um novo líder genuinamente popular como Juárez haviam despertado, o país estava mais distante da integração do que jamais estivera. Durante os anos de guerra, diversas províncias desenvolveram uma 
existência quase autônoma, com vida social, econômica e política totalmente isolada do restante do México. O parcelamento das terras comunais aumentara muito pouco os quadros da classe média. Algumas das melhores terras tinham sido perdidas para os ricos fazendeiros. Os poucos camponeses que adquiriram um pedaço de terra próprio foram chamados los riquitos por seus irmãos menos afortunados. No final, formaram um grupo muito mais parecido com os kulaks russos ou com os coqs du village franceses. ${ }^{292}$ [grifo nosso]

Ao longo desta seção ficou evidente que as políticas do período da Reforma no México não se voltavam apenas contra o imobilismo imobiliário eclesiástico. Também a forma de propriedade coletiva das comunidades indígenas incomodava a estrutura individualizada de sociedade defendida pelos liberais. As políticas implementadas, porém, não contribuíram com a criação de pequenas propriedades e de uma classe média local, como talvez fosse esperado - e estava descrito como objetivo em documentos oficiais da época. Antes, o contrário: propriedades comunais passaram a fazer parte de grandes fazendas; poucos arrendatários de terras eclesiásticas se tornaram efetivamente seus donos; e a Igreja teve seu poder político bastante diminuído, mas em seu lugar uma nova força conservadora havia se organizado, os fazendeiros.

Com a morte de Benito Juárez, Sebastián Lerdo de Tejada assume a presidência, já que é o sucessor constitucionalmente indicado - ocupava então o posto de presidente da Suprema Corte de Justiça. Sebastián Tejada governa até novembro de 1876, quando é sucedido por Porfírio Díaz, no ano que marca o início do chamado porfiriato, encerrado pela Revolução Mexicana em 1910.

Foi durante o governo de Porfírio Díaz que as políticas fundiárias implementadas pelo Estado Mexicano centralizado geraram efetivamente a imensa concentração de terras vivida no início do século XX. Tal política, porém, seguia orientação semelhante àquela iniciada pelos liberais.

$\mathrm{Na}$ seção anterior deste capítulo, sobre as políticas de colonização, foi a Ley sobre ocupación y enajenación de terrenos baldios de los Estados Unidos Mexicanos $^{293}$, de 26 de março de 1894, que levou ao extremo a política de conferir

\footnotetext{
${ }^{292}$ KATZ, Friedrich. "O México: a República Restaurada e o Porfiriato, 1867-1910”. In BETHELL, Leslie (org.) História da América Latina vol. V: de 1870 a 1930. Trad. Geraldo Gerson de Souza. São Paulo: Edusp, 2008,.p. 24-25.

${ }^{293}$ Íntegra da Ley sobre ocupación y enajenación de terrenos baldios de los Estados Unidos Mexicanos de 26 de março de 1894. Em: Instituto de Investigaciones Jurídicas, Universidad Nacional Autónoma de México. <www.biblio.juridicas.unam.mx/libros/2/940/39.pdf> Consulta realizada em 22/07/2015.
} 
títulos de propriedade a empresas deslindadoras e fazendeiros que promovessem a denúncia de terrenos não protegidos por títulos, então denominados "baldíos". Nessa mesma lei de 1894, Porfírio Díaz reitera a incapacidade jurídica das comunidades e corporações civis - note-se que aqui desaparece a menção às corporações eclesiásticas de possuir bens imóveis. Afirma, em seguida, que as autoridades públicas não pouparão esforços para promover o fracionamento das terras comunais e sua adjudicação a vizinhos. Mais radical que todas as normas anteriores, porém, é a previsão de que os "ejidos" e os "excedentes" dos fundos legais devem ser fracionados:

Artículo 67. Subsisten la prohibición e incapacidad jurídica que tienen las comunidades y corporaciones civiles para poseer bienes raíces; y los Gobiernos de los Estados, auxiliados por las autoridades federales, continuarán el señalamiento, fraccionamiento en lotes y adjudicación entre los vecinos de los pueblos, de los terrenos que formen los ejidos y de los excedentes del fundo legal, cuando no se hubieren hecho esas operaciones; sujetándose para el señalamiento a los límites fijados en las concesiones otorgadas a los pueblos, ya por el Gobierno español en la época colonial, ya por los Gobiernos de los Estados en la época en que pudieron disponer de los baldíos. En caso de que en la concesión no se hubiere fijado ni la extensión ni los límites de dichos terrenos, se asignará a cada población una legua cuadrada, conforme a las disposiciones antiguas, siempre que haya terrenos baldíos en los que pueda hacerse el señalamiento, porque no ha de invadirse la propiedad particular, ni ha de tomarse de los baldíos mayor cantidad de terreno que la que exprese la concesión.

Artículo 68. Si algún pueblo estuviera poseyendo, a títulos de ejidos, excedencias o demasías, podrá ser admitido a composición, en los mismos términos que los particulares.

Artículo 69. Para solicitar las composiciones que expresa eI artículo que precede, así como para defender de denuncios ilegales los ejidos, terrenos y montes de los pueblos, y para gestionar su repartición o fraccionamiento entre los individuos que a ello tengan derecho, se confiere personalidad jurídica a los Ayuntamientos, Asambleas o Corporaciones Municipales de la República, sea cual fuere la denominación con que sean designados por las leyes locales.

$\mathrm{O}$ artigo 67 da Ley sobre ocupación y enajenación de terrenos baldios de los Estados Unidos Mexicanos ${ }^{294}$, publicada por Porfírio Díaz, praticamente limita a uma légua quadrada - antes reconhecida como fundo legal - a terra que pode manter-se sob titularidade das comunidades indígenas, em regime de propriedade coletiva. Apesar de reconhecer a personalidade jurídica a "ayuntamientos, asambleas e corporaciones

\footnotetext{
${ }^{294}$ Íntegra da Ley sobre ocupación y enajenación de terrenos baldios de los Estados Unidos Mexicanos de 26 de março de 1894. Em: Instituto de Investigaciones Jurídicas, Universidad Nacional Autónoma de México. <www.biblio.juridicas.unam.mx/libros/2/940/39.pdf> Consulta realizada em 22/07/2015.
} 
municipales”, e apesar de o artigo 69 afirmar que o objetivo de reconhecer tal personalidade jurídica é exatamente a proteção das comunidades contra denúncias ilegais de "ejidos", terrenos e montes dos povoados, a interpretação global das normas da lei sugerem - como foi na prática - enormes perdas patrimoniais para tais comunidades.

Ao contrário do artigo $8^{\circ}$ da Ley Lerdo, que protegia os "ejidos", os fundos legais e os terrenos destinados exclusivamente ao serviço público, sem mencionar exatamente como seriam interpretados tais conceitos - e deixando uma margem razoável de verificação empírica para preencher de conteúdo a expressão "terrenos destinados ao serviço público", a lei de 1894 era formalista. Os limites para a atividade de fracionamento que deveria ser levada a cabo pelas autoridades públicas seriam os títulos outorgados pela coroa espanhola e pelos governos do México independente. Nenhuma consideração acerca da posse e ocupação efetiva de terrenos por parte de comunidades indígenas seria considerada legítima para requerer seus títulos de propriedade. Os "pueblos" que tivessem posse de algum terreno "baldio" deveriam promover sua denúncia e realizar o procedimento previsto na lei exatamente como os particulares, em três meses, sem nenhuma vantagem prévia.

Evidentemente, tais normas formalistas, que valorizavam - e respeitavam - as propriedades apenas quando elas podiam ser comprovadas por meio de documentos, prejudicavam sobremaneira as comunidades indígenas. Além disso, o período de estabilidade política possibilitou a implementação efetiva das leis durante o porfiriato. Ao final do século XIX, a demanda por terras no México enfrentava uma valorização, potencializada pela nova presença de linhas férreas capazes de distribuir e transportar os produtos cultivados para os centros consumidores do próprio país e para os portos, a partir dos quais poderiam ser exportados. Além disso, no final do século XIX o mercado internacional viveu um aumento do preço de produtos agrícolas. As terras cultiváveis mexicanas observaram, assim, uma valorização expressiva. ${ }^{295}$

Esse dado histórico é fundamental para a análise das legislações sobre a terra de 1883 e 1894, promovidas por Porfírio Díaz e já analisadas em suas linhas gerais. Diversas forças econômicas pressionavam seu governo para a apropriação privada de terras, cada vez mais valorizadas. Assim, também a expansão ferroviária é elemento que

\footnotetext{
${ }^{295}$ COATSWORTH, John H. "Indispensable railroads in a backward economy: the case of Mexico". Journal of Economic History, 1979, n. 39, 4, p. 939-960.
} 
compõe, juntamente com o marco legal, as razões da concentração e da luta pelo reconhecimento da propriedade das terras mexicanas no final do século XIX.

\subsubsection{Enfrentamento da espoliação indígena e defesa da pequena propriedade no século XIX: a luta perdida}

$\mathrm{Na}$ luta pela independência mexicana, Hidalgo e Costilla e José María Morelos já prenunciavam o pensamento - aliado a uma luta concreta - em defesa da distribuição de terras e da ampliação de direitos sociais no México. Os decretos que dispõem sobre o fim da escravidão, o fim do regime de castas e a garantia da propriedade da terra aos naturais, já examinados neste capítulo, são prova desse fato.

Em âmbito regional, muitos foram os atores e pensadores que seguiram esta linha de reflexão e ação. As lutas yaquis no norte do país e os diversos conflitos em Sierra Gorda - cujos documentos serão analisados nesta seção - comprovam que a reflexão sobre a necessidade de se distribuir terras, bem como as críticas às condições de vida dos trabalhadores mexicanos, ocorriam em todo o território.

Em 1856, durante os debates que levaram à elaboração da Constituição de 1857, cabe destacar o pensamento de alguns políticos que desejavam impulsionar a própria Constituição a reconhecer direitos sociais, a regular a propriedade fundiária e também o direito do trabalho. Ponciano Arriaga, Isidoro Olvera e José Maria Castillo Velasco, em debates sobre os problemas da concentração de terras nas mãos de poucos proprietários; Ignacio Ramirez, que chamava atenção para a falta de direitos que assolava os trabalhadores mexicanos, apesar de derrotados, cumpriram importante papel de alerta durante os debates constituintes. Em 23 de junho de 1856, Ponciano Arriaga proferiu discurso que se tornaria referência para os estudiosos da questão agrária mexicana:

Mientras que pocos individuos están en posesión de inmensos e incultos terrenos, que podrían dar subsistencia para muchos millones de hombres, un pueblo numeroso, crecida mayoría de ciudadanos, gime en la más horrenda pobreza, sin propiedad, sin hogar, sin industria ni trabajo. Ese pueblo no puede ser libre ni republicano, y mucho menos venturoso, por más que cien constituciones y millares de leyes proclamen derechos abstractos, teorías bellíssimas, pero impracticables, en consecuencial del absurdo sistema económico. Poseedores de tierras hay en la República Mexicana, que, en fincas de campo o haciendas rústicas, ocupan (...) una superficie de tierra 
mayor que la que tienen nuestros Estados soberanos, y aún más dilatada que la que alcanzan alguna o algunas naciones de Europa. ${ }^{296}$

Se proclaman las ideas y olvidan las cosas (...) No divagamos en la discusión de derechos y ponemos aparte los hechos positivos. La Constitución debiera ser la ley de la tierra; pero no se constituye ni se examina el estado de la tierra. ${ }^{297}$

Liberdades e republicanismo não conseguem produzir seus bons efeitos quando a população que os recebe está faminta, pobre e desempregada; expulsa da terra que possuía e cultivava desde tempos imemoriais. De que adianta discutir e garantir a liberdade de ensino, de trabalho, de manifestação de ideias, de associação e de residência - todas aprovadas pelos constituintes de 1857 - se boa parte do povo mexicano sofre sem as condições mínimas de subsistência?

Segundo Arriaga, liberdades públicas e direitos sociais - entre eles o direito à terra - deveriam, necessariamente, caminhar pari passu. Ao discutir as normas que deveriam estar presentes na Constituição, este imperativo deveria se fazer sentir: os constituintes deveriam introduzir normas capazes de reverter a situação de imensa concentração agrária vivida pelo país. No mesmo sentido, Ignacio Ramirez chama a atenção para a importância dos direitos dos trabalhadores no México. Os artigos 27 e 123 da Constituição de 1917 são legatários da revolução que os antecedeu, mas também dos constituintes que, desde a elaboração da Constituição, chamavam a atenção para a importância de se garantir direitos constitucionais que tivessem por objetivo transformar a realidade social mexicana.

Os esforços de Arriaga e seus companheiros, porém, não foram suficientes para reverter um problema que teve início na Constituição de 1857. Em seu artigo 27, que garante e protege a propriedade privada individual, lê-se:

Ninguna corporacion civil o eclesiástica, cualquiera que sea su carácter, denominacion o objeto, tendrá capacidad legal para adquirir en propiedad o administrar por sí bienes raíces, con la única excepcion de

\footnotetext{
${ }^{296}$ CARBÓ, Margarita. "La Reforma y la Intervención: El campo en llamas". In Historia de la cuestión agraria mexicana: La tierra y el poder, 1800-1910. Cidade do México: Siglo XXI/Centro de Estudios Históricos del Agrarismo en México, P. 127. Também em: Voto de Ponciano Arriaga em 23 de junho de 1856. Em CARMONA, Doralicia. Memoria Política de México. México: Universidade de Guanajuato, 2014. 〈http://www.memoriapoliticademexico.org/Textos/3Reforma/1856PA-VPart.html> Consulta realizada em 12/01/2016.

${ }^{297}$ Voto de Ponciano Arriaga em 23 de junho de 1856. Em CARMONA, Doralicia. Memoria Política de México. México: Universidade de Guanajuato, 2014.

$<$ http://www.memoriapoliticademexico.org/Textos/3Reforma/1856PA-VPart.html $>$ Consulta realizada em 12/01/2016.
} 
los edificios destinados inmediata y directamente al servicio o objeto de la institucion. ${ }^{298}$

Essa norma, que repete e constitucionaliza dispositivo já presente em outras normas, foi um dos grandes empecilhos para que as comunidades indígenas e de camponeses pudessem manter seus bens de uso comum, as propriedades dos "pueblos", entre eles os "ejidos", que eram cultivados e mantidos coletivamente. O reconhecimento formal dessas propriedades, assim, deveria ser dado à pessoa coletiva que representasse seus verdadeiros donos. Quando a Constituição reforça a proibição de que qualquer corporação civil possa adquirir ou administrar propriedade, isso afeta diretamente as comunidades indígenas, além das instituições eclesiásticas. Este problema é enfrentado, por exemplo, no Plan de Sierra Gorda, de 1879, e em outros planos da Revolução Mexicana, sobretudo naqueles idealizados por Luis Cabrera.

\subsubsection{Legislação agrária do Segundo Império - Lei de 18 de dezembro de 1865 e Decreto de 16 de setembro de 1866}

No início de 1864, em meio à ocupação francesa do México que havia começado em 1862, representantes das forças conservadoras da sociedade mexicana foram até a Europa convencer os franceses a enviar um novo imperador para seu território e pacificar o país. Por circunstâncias políticas européias - Napoleão III desejava melhorar suas relações com o império austríaco - Maximiliano, um membro da família real austríaca dos Habsburgos, foi o escolhido para assumir o Trono de Moctezuma em solo Mexicano. Maximiliano havia imposto como condição para aceitar o título a concordância da população mexicana; após sua reivindicação, eleições foram forjadas no país.

Os conservadores mexicanos viam na ocupação francesa e no reestabelecimento do Império no México a possibilidade de se insurgir contra o movimento da Reforma, liderado então por Benito Juárez, que realizava um amplo enfrentamento da Igreja Católica. Assim, em 10 de abril de 1864, Maximiliano e Napoleão III estabeleceram

\footnotetext{
${ }^{298}$ Constitución Política de la República Mexicana de 1857, promulgada em 5 de fevereiro de 1857. Cidade do México: Instituto de Investigaciones Jurídicas. $<$ http://www.juridicas.unam.mx/infjur/leg/conshist/pdf/1857.pdf $>$ Consulta realizada em 11/01/2016.
} 
uma cooperação militar, formalizada por meio do Tratado de Miramar ${ }^{299}$, para instaurar o Império em solo mexicano. As tropas francesas permaneceriam no México, financiadas pelo governo que Maximiliano se dispôs a organizar. Em junho de 1864, Ferdinand Maximiliano de Habsburgo, segundo imperador do México independente, trouxe sua mulher, Amalia Carlota de Bélgica, e sua corte para a Cidade do México. Residiu no Palácio Nacional por quatro anos, período que durou seu Império, cujo fim se deu após a retirada do exército francês do solo mexicano e sua derrota militar. Maximiliano foi fuzilado em 19 de junho de 1867.

Durante seu governo - sempre em conflito com o governo de Benito Juárez, que mantinha um centro de poder paralelo sediado em San Luís Potosí -, Maximiliano aprovou dois diferentes documentos normativos sobre a organização da terra, um em 1865 e outro em 1866. Diferentemente de toda a história legislativa mexicana precedente, com exceção dos decretos de Hidalgo y Costilla e José Maria Morelos, Maximiliano realizou um "indigenismo legislativo". Ambos os documentos tem início com normas originais quanto aos seus destinatários.

$\mathrm{Na}$ "Ley para Dirimir Conflictos sobre Tierras y Aguas", de 18 de dezembro de 1865, o objetivo principal é exposto logo no primeiro artigo: “Art. $1^{o}$. Todo pueblo que tenga que demandar la propiedad o posesión de tierras o aguas a otro pueblo o propietario particular, presentará a la Prefectura política superior del Departamento una exposición de su pretensión, [...]".

Já no "Decreto sobre Fundo Legal y Ejidos", de 16 de setembro de 1866, lê-se: “Art. $1^{\circ}$ - Los pueblos que carezcan de fundo legal y ejido tendrán derecho a obtenerlos siempre que reúnan las circunstancias designadas en los dos artículos siguientes.”.

Ambas as normas se dirigem aos "pueblos", povoados indígenas reconhecidos como entidades coletivas. Sua representação nas demandas de que tratam as normas, regulamenta o artigo 13 do decreto de 1866, será feita por meio de "alcaldes o comisarios municipales". Acompanhando atentamente a análise e as características das normas agrárias do México no século XIX - fossem elas sobre colonização, demarcação de terras ou desamortização dos bens da Igreja -, é possível ter a dimensão da ruptura que os dois documentos do Imperador Maximiliano provocam desde seu início.

${ }^{299}$ Tratado de Miramar, de 10 de abril de 1867, em: BIBLIOTECA GARAY. 500 años de México en documentos. México, 2011.

<http://www.biblioteca.tv/artman2/publish/1864_161/El_Tratado_de_Miramar_1388.shtml $>$ Consulta realizada em 03/01/2016. 
Para além de reconhecer a capacidade das pessoas coletivas de possuírem terras, atribuía-se aos "pueblos" a possibilidade de atuar junto aos órgãos públicos para pleitear mais propriedades, nos casos em que as terras da comunidade fossem ou estivessem ficando escassas, ou para dirimir conflitos relativos à posse e propriedade frente a outros "pueblos" ou a proprietários particulares. Dessa forma, as normas conferem direitos e capacidades a entidades coletivas indígenas.

Para que não restassem dúvidas quanto a seus propósitos, Maximiliano publicou o "Decreto sobre Fundo Legal y Ejidos", de 1866, em edição bilíngue: espanhol e náhuatl, língua indígena bastante difundida no território ${ }^{300}$. Apreciados estes aspectos gerais sobre a normatização agrária promovida por Maximiliano, passemos à análise dos dois documentos separadamente:

A “Ley para Dirimir Conflictos sobre Tierras y Aguas", de 18 de dezembro de 1865, tinha por objetivo criar procedimentos para a resolução dos conflitos relacionados à terra, quer entre dois diferentes “pueblos", quer entre "pueblos" e particulares. Assim, sempre que uma controvérsia a respeito da posse ou propriedade de terras envolvesse um "pueblo" - como promotor da reclamação ou reclamado -, deveriam ser respeitados os procedimentos estabelecidos na lei.

Propriedade ou posse são tratadas de forma igual no artigo que abre a lei. Assim, pode-se demandar o direito legítimo a qualquer uma das duas. Para tanto, basta apresentar, por escrito, uma exposição dos motivos que levam ao pedido, acompanhada de documentos que o fundamentem. Os documentos devem ser apresentados em "copias de ellos en papel común”, ou seja, não precisam ser apresentados os títulos originais, ou documentos lavrados por algum poder público.

Para quem já lidou com poderes públicos excessivamente formalistas e burocráticos, presentes em boa parte dos estados modernos, fica clara a intenção de simplificar o acesso ao procedimento de resolução de controvérsias.

O mesmo intuito simplificador - ou alternativo à outra forma mais frequente de resolver controvérsias agrárias - têm os artigos $3^{\circ}$ e $4^{\circ}$ da lei de 1865 . Seu objetivo

\footnotetext{
${ }^{300}$ Uma cópia da edição original bilíngue do "Decreto sobre Fundo Legal y Ejidos", de 16 de setembro de 1866, pode ser consultada Em: LIBRARIES DIGITAL COLLECTIONS of University of Texas at Santo Antonio. Santo Antonio: University of Texas at Santo Antonio, 2011.

<http://digital.utsa.edu/cdm/ref/collection/p15125coll6/id/1398>. Consultado em 12/01/2016.
} 
parece ser obrigar que todas as controvérsias sobre terras que tenham "pueblos" em um dos pólos da disputa fossem discutidas em âmbito administrativo não judicial.

É a "prefectura política superior del departamento" a responsável por receber e processar os pedidos relativos a conflitos entre possuidores e proprietários de terra, tal como está estabelecido no artigo primeiro. $\mathrm{O}$ artigo segundo estabelece o procedimento de notificação e direito de defesa e resposta daquele proprietário ou "pueblo" que foi demandado. Tal como em um procedimento administrativo ou judicial tradicional, há, aqui, partes em conflito. Se uma parte gera uma demanda, expõe suas razões, formula seus pedidos e apresenta suas provas, a outra deve ter o direito de contrapor suas próprias razões, provas e pedidos. $\mathrm{O}$ artigo segundo, assim, garante o princípio do contraditório no processo administrativo que o Imperador queria ver implementado.

Nos artigos terceiro e quarto, porém, estão os elementos que tornam o procedimento administrativo obrigatório. Para aqueles que não apresentarem sua defesa em ambito administrativo "se considerará que renuncian todo derecho a las tierras o aguas en cuestión, y sin ser oídos en juicio y previo pedimento del agente del Ministerio Público"(art. $3^{\circ}$ ), ou seja, a ausência de manifestação junto à prefeitura política implica renúncia de direito. $\mathrm{O}$ artigo segue afirmando que a própria entidade administrativa, sem interferência do Poder Judiciário, tomará as providências para garantir ao autor do pedido os direitos que pleiteou.

$\mathrm{O}$ artigo quarto, por sua vez, estabelece que "Los documentos que no se presenten con las exposiciones a que se refieren los artículos precedentes, no podrán ya hacerse valer en caso de juicio; y si entonces se presentaren no podrán los jueces y tribunales apoyar en ellos sus sentencias". Ou seja, se os demandados nas controvérsias em âmbito administrativo não apresentarem suas provas e documentos à prefeitura política, perderão definitivamente o direito de usarem tais documentos como prova em outros âmbitos, notadamente junto ao Poder Judiciário. Uma vez que as provas e os documentos só são legitimados para figurar em juízo depois de terem passado pelo crivo e análise da instância administrativa, torna-se forçoso adotá-la como primeira instância para a solução de controvérsias sobre terra.

Há, assim, uma intenção clara de retirar do Poder Judiciário a primazia na solução de conflitos sobre terras que envolvessem "pueblos". A provável motivação que impele a aprovação dessas normas é o caráter conservador e anti-indigenista do Poder Judiciário, sobretudo em questões agrárias. Esta percepção é reforçada pelo 
último artigo do documento normativo, que abre a possibilidade de recurso ao Poder Judiciário para discutir a posse momentânea, por meio de "interdictos posesorios", mas deixa claro que esta é a única exceção. A posse e a propriedade definitivas, em caso de conflitos previstos na lei, devem ser discutidas em primeiro lugar em âmbito administrativo: "pero en ningún caso se intentará el juicio plenario sobre posesión o propiedad, sin llenar previamente los requisitos prevenidos por esta ley" (art. 10).

Porém, salvo em conflitos entre dois pueblos, o "consejo departamental", órgão administrativo responsável por decidir, não tem a última palavra no conflito. Ele encerra sua participação com um parecer sobre quem teria o "mejor derecho", concedendo, além disso, licença (autorização) para que se leve o embate para o Poder Judiciário, caso seu parecer não consiga satisfazer as duas partes em disputa. Assim, o inciso 2 do artigo sexto estabelece que "Otorgarán licencia a los pueblos para demandar a particulares, si del examen de los documentos resultare que hay justicia para ello; o la denegarán en caso contrario. Al conceder las licencias nombrarán abogados defensores de notoria probidad, los cuales, así como los demás curiales, cobrarán derechos sencillos a los pueblos."

$\mathrm{O}$ inciso 3 do mesmo artigo praticamente repete o texto do artigo anterior, com uma grande diferença: no lugar de "hay justicia para ello" utiliza "tienen mejor derecho que el de los particulares". Nestas duas simples expressões, usadas alternativamente para afirmar a garantia de um pueblo ao pedaço de terra que está pleiteando, se revela uma concepção bastante rara na história legislativa mexicana. Há aqueles que têm direito - reconhecido por meio de documentos e títulos de propriedade - sobre a terra e há os pedidos de terra que se reconhecem como justos, ainda que lhes faltem os títulos comprobatórios. Nos dois casos, as autoridades públicas devem julgar favoravelmente aos "pueblos". Estas duas expressões, com as mesmas consequências institucionais, revelam uma concepção muito pouco formalista ligada ao direito de propriedade. Tal concepção teria mais sucesso junto ao Poder Judiciário, avaliavam os formuladores da lei, caso viesse registrada e assinada por um agente público da prefeitura política, ou seja, de um órgão oficial do poder estatal.

O último inciso do artigo sexto prevê que, enquanto a decisão judicial definitiva não for expedida, a posse da terra deverá ficar com aquele a quem a autoridade administrativa reconhecer o direito. Os artigos subsequentes tratam da possibilidade de recurso administrativo ao "Ministério de Gobernación", tanto promovido por 
particulares quanto, principalmente, em casos em que estão envolvidos dois "pueblos", a quem a lei veda o acesso ao Poder Judiciário (art. $\left.6^{\circ}, \mathrm{I}\right)$.

O “Decreto sobre Fundo Legal y Ejidos", de 16 de setembro de 1866, estabelece uma série de condições para que um pueblo possa reivindicar mais terras para uso coletivo, a ser atribuídas de acordo com dois títulos: fundo legal e "ejidos". O artigo dois dispõe que povoados com mais de 400 habitantes e uma escola primária faz jus ao fundo legal, tal como previsto em lei.

A legislação do México independente, porém, não faz referência ao conceito de fundo legal. Por isso, deve-se buscar a definição no direito colonial: as cédulas reais da coroa espanhola. Em diversas delas - de 1549, 1560, 1578 e 1687, por exemplo - há definição sobre o que é o fundo legal. Trata-se de uma porção de terra a ser possuída por povoados indígenas - que poderiam usá-la para habitação e cultivo -, em área calculada a partir da construção central de seus povoados. Eram demarcados terrenos com $500 \mathrm{ou}$ 600 varas de largura, na mesma estrutura de organização das cidades espanholas: quadriculado do terreno. Além disso, as cédulas reais também estabeleciam uma distância mínima entre os povoados indígenas e qualquer assentamento espanhol - 1100 varas. Para que não se imagine uma benevolência da coroa espanhola com os povos indígenas, é importante esclarecer que estes benefícios eram usados para retirar indígenas de suas terras. Assim, essas condições só valiam para os índios que tivessem disponibilidade para abandonar suas terras e se deslocar até os territórios nos quais os colonizadores queriam concentrá-los: Yucatán y a ilha de Cozumel, ambos no extremo sul do país.

Seja como for, a definição de fundo legal medido em aproximadamente 600 varas, a partir da concentração de habitações do povoado, era a terra em que os índios podiam habitar e cultivar seus alimentos. No caso da norma ora em análise, as únicas condições para a obtenção da demarcação do fundo legal era a população de 400 habitantes e a existência de uma escola primária (art. $2^{\circ}$ ). O espírito da demarcação de fundo legal era, portanto, bastante diferente daquele que motivara as normas coloniais sobre o tema.

$\mathrm{O}$ artigo terceiro do decreto de Maximiliano I amplia ainda as proteções às comunidades indígenas: "art. $3^{\circ}$. Los pueblos cuyo censo exceda de dos mil habitantes, tendrán derecho a que se les conceda, además del fundo legal, un espacio de terreno 
bastante y productivo para ejido y tierras de labor, que Nos señalaremos en cada caso particular, en vista de las necesidades de los solicitantes."

Para além do fundo legal, considerado como um espaço mínimo garantido à existência do um povoado indígena, no caso de comunidades populosas, com mais de dois mil habitantes, se prevê um terreno extra, cujo objetivo é garantir terras cultiváveis e pastagens para a pecuária. O tamanho a ser concedido para cada "pueblo" a título de “ejido" não seria pré-determinado, sendo decidido - de acordo com o texto da norma pela figura do Imperador em pessoa.

O decreto de 1866 segue prevendo a possibilidade de haver "pueblos" que não completem o número mínimo de habitantes previsto em suas normas; nesse caso, confere a possibilidade de haver agrupamento de "pueblos" indígenas para que possam ser beneficiados. No caso de agrupamento, e de um "pueblo" abandonar suas terras e ir para perto de outro povoado, prevê-se uma indenização pelas terras abandonadas (art. $\left.4^{\mathrm{o}}\right)$.

Os artigos $8^{\circ}$ e $9^{\circ}$ tratam das formas de se obter terrenos e fundos legais a serem adjudicados aos "pueblos". Duas são as hipóteses: que sejam identificados nas proximidades "baldios o realengos improductivos, si los hubiere; y en su falta, de los que adquiera por compra o mediante otros convenios que arregle con los dueños de los que se necesiten" (art. $8^{\circ}$ ). Em caso de ausência de terrenos disponíveis, e caso haja proprietários particulares que não queiram negociar a compra e venda, a lei prevê a possibilidade de expropriação (art. $9^{\circ}$ ), ou seja, a tomada obrigatória do terreno mediante indenização. Mesmo contra a vontade dos proprietários privados, podem ser obtidos terrenos que serão concedidos aos "pueblos" pra fins de "ejido" ou fundo legal.

Os artigos 11 e 17 revogam explicitamente as disposições da "Ley para Dirimir Conflictos sobre Tierras y Aguas", de 18 de dezembro de 1865, acima analisada. Retornam diretamente para os juízes e tribunais ordinários a competência para julgar conflitos de terras entre "pueblos" e entre estes e proprietários privados. Aparentemente descontente com a nova etapa criada, o decreto de 1866 parece mais preocupado em fazer com que os prazos para resolução de conflitos sejam respeitados do que com quem os processa. No artigo 11 se lê que os juízes e outros órgãos competentes devem julgar ações que envolvam pueblos em "la mayor brevedad posible". O decreto mantém seu anti-formalismo ao dispor, também no artigo 11 que "no se perjudique el derecho de los litigantes por falta de prueba". 


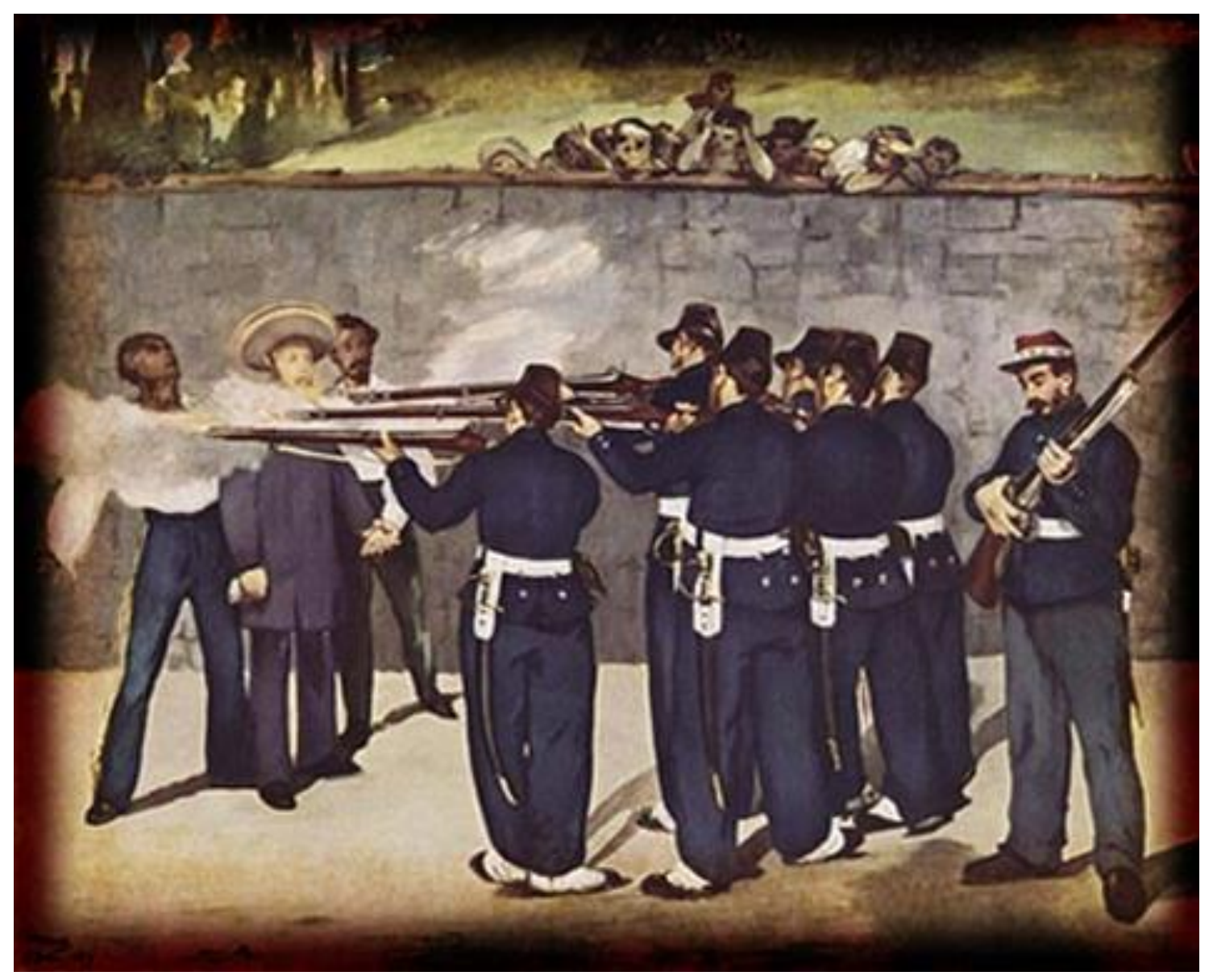

Fuzilamento do Imperador Maximiliano do México. Édouard Manet, 1868-1869

Os artigos 12, 13 e 14 tratam da legitimidade para representar os "pueblos" perante autoridade pública, ao passo que o artigo 16, contempla as penalidades impostas a autoridades públicas que tentarem cobrar taxas ou pagamentos em função dos procedimentos e competências previstos na lei. Desse artigo depreende-se que todo o processo de solicitação de novas terras, bem como de resolução de conflitos agrários, deveria ser feito gratuitamente para as comunidades indígenas - que, inclusive, teriam advogados nomeados para os representarem gratuitamente em juízo (art. $6^{\circ}$, II e III da lei de 1865).

Conteúdo e forma do "Decreto sobre Fundo Legal y Ejidos", de 1866, publicado em edição bilíngue, espanhol e náhuatl, como já mencionado - corroboram para a percepção de que as normas expedidas por Maximiliano I representavam um "indigenismo legislativo". Como teve um breve mandato - governou entre maio de 1864 e junho de 1867 - e, mesmo assim, sem controle sobre todo o território do 
México, já que Benito Juárez se firmava como presidente legítimo simultaneamente, os efeitos das normas que publicou foram bastante limitados.

O comemorado fim do Segundo Império deveu-se a uma série de motivos. O exército francês não conseguiu subjugar o país, mas propagou um enfrentamento militar longo - os republicanos liberais não abdicaram da luta e da pretensão de reestabelecer a ordem Constitucional de 1857 nem por um instante. Nesse contexto, Napoleão III desistiu da empreitada, também após sofrer pressão americana. Por outro lado, os conservadores antiliberais e a Igreja, que apoiaram a restituição da monarquia e a coroação de Maximiliano I, não estavam satisfeitos com seu governo, pois, como indicam as normas sobre regulação da terra, tinha tendências progressistas. Sem apoio do exército francês e sem sustentação interna - para além do conteúdo de suas normas, os liberais identificavam-no como símbolo da sujeição do México a forças estrangeiras e retrógradas - Maximiliano foi deposto e fuzilado, a mando de Benito Juárez, desde então herói da pátria.

É a partir da década de 1870, com a ascensão de Porfírio Díaz ao poder, que as demarcações e cessões de títulos de propriedade a pessoas jurídicas privadas se faz de forma mais intensa, conforme já analisado no item sobre colonizações deste capítulo. $\mathrm{O}$ processo de habilitação de terras para serem "colonizadas" - na verdade, registradas com título de propriedade -, vem acompanhado do início da criação de uma extensa malha ferroviária, tornando possível a exploração econômica das terras que, por atos formais do governo, passavam a ter donos, embora fossem poucos donos para muitas terras.

É em função de todas as mudanças promovidas pela violenta política de organização fundiária, que a resistência ao processo de espoliação se intensifica também na década de 1870 .

Dois diferentes movimentos de enfrentamento à concentração agrária e outras violações de direitos surgem na mesma região do país: Sierra Gorda. No início deste capítulo já se chamou a atenção para o fato de a população mexicana se concentrar no Altiplano Central, que possuía terras mais favoráveis à agricultura. É justamente nele, 
mais especificamente nos Estados de Querétaro e Guanajuato, que os movimentos de resistência promovem sua luta. Além desta coincidência, outros são os elementos que podem levar à confusão entre ambos: os dois movimentos se organizam em torno de planos denominados "Plan Socialista", ambos publicados em 1879.

O primeiro movimento a ser analisado surge a partir de uma organização indígena. O "Plan Socialista Proclamado por los Representantes de los Pueblos de los Estados de Querétaro y Guanajuato" ${ }^{301}$, nome completo do plano por eles elaborado, foi publicado nos primeiros dias de junho de 1879, no periódico El Socialista, que circulava então na Cidade do México. Tal documento também ficou conhecido por Plan de la Barranca, em referência à cidade em que foi elaborado e aprovado.

"Los pueblos" que estão no título do documento são as muitas comunidades indígenas que assinam o manifesto: San Bartolomé Rincón, San Miguel de los Naranjos, Santa Catarina de Cuevas, Real de la Luz e muitas outras compõe os trinta e seis povoados representados no documento. Talvez chame a atenção o fato de os nomes indicados não serem indígenas.

Mirtha Urbina Villagómez, pesquisadora mexicana, relembra que a origem e identidade indígena desta organização já foram questionadas por alguns historiadores a ausências de nomes índios em seus "pueblos" seria uma evidência. Mirtha, porém, recusa de forma veemente a possibilidade de a dúvida ser sequer formulada, ao afirmar o princípio da auto-definição para questões ligadas à identidade étnica. A autora defende que afirmação subjetiva dos próprios atores quanto à sua identidade - que se dá também a partir dos objetivos políticos que querem alcançar - deve ser o elemento decisivo para a definição. Ele deve prevalecer frente a outros critérios, como origem, características étnicas, reconhecimento e pertencimento cultural:

Frente a ello, nosotros optamos por reconocer a nuestros actores como indígenas. Gilberto Giménez precisa cómo la identidad "supone por definición, el punto de vista subjetivo de los actores sociales sobre su unidad y sus fronteras simbólicas, sobre su relativa persistencia en el tiempo y sobre su ubicación en el 'mundo', es decir, en el espacio social". Al respecto, pues, nos preguntamos: ¿Cuál era esa ubicación en el "espacio social" de nuestros protagonistas? ¿Cómo construían su persistencia en el tiempo? Sus actores no se

\footnotetext{
${ }^{301}$ A íntegra do "Plan Socialista proclamado por los representantes de los pueblos de los estados de Querpetaro y Guanajuato" pode ser consultada aqui: http://anarquiamx.blogspot.com.br/2011/12/plansocialista-de-la-sierra-gorda-1879.html Site consultado em 29/07/2015.
} 
afirmaban como "campesinos", sino como indígenas; no como otomíes sino como "chichimecas"; no como caseríos de rancherías de haciendas, sino como pueblos de indios; no como habitantes de Querétaro y Guanajuato, sino de la Gran Chichimeca; no como ciudadanos de un Estado, sino hijos de una República de Indios; no como parte de una Nación Federada, sino de una Nación Indiana. Nuestro planteamiento es que lo que cuenta es su voluntad como pueblo que se reconoce a sí mismo, y esta voluntad mediante la cual deciden su propia identidad es un acto político. Además, consideramos que ser indígena no se puede reducir a un asunto étnico, ya que la identidad no es ni una "substancia esencial" ni una estructura fija, sino un proceso permanente de estructuración/desestructuración. Desde este punto de vista, los grupos en lucha creaban o recreaban su identidad a partir de un autorreconocimiento colectivo como sujetos indígenas en lucha, es decir, de una voluntad política colectiva, de resistencia compartida, en cuya base estaba un umbral de esperanzas/desesperanzas compartidas. Es decir, ser indígena habla de una identidad política. Por todo ello, hemos de entender a nuestro sujeto como un sujeto político colectivo. $^{302}$

\subsubsection{Plan Socialista Proclamado por los Representantes de los Pueblos de los Estados de Querétaro y Guanajuato ${ }^{303}$ ou Plan de La Barranca, de $1^{\circ}$ de junho de 1879}

A percepção de Mirtha Urbina é reforçada quando analisado o texto do Plan de La Barranca. Antes de passar à sua parte expositiva, o documento normativo apresenta sua razão de existir em uma série de "considerandos". Aliás, cabe aqui chamar a atenção para um elemento comum a diversos planos políticos que orientaram mobilizações e insurreições no México a partir do século XIX: boa parte deles elege a linguagem jurídica como forma de expressar seus anseios de transformação social. $\mathrm{O}$ Plan de La Barranca é o primeiro de uma série que iremos analisar neste capítulo e, como tantos outros, obedece a essa tendência.

\footnotetext{
${ }^{302}$ URBINA VILLAGÓMEZ, Mirtha Leonela. "Reconstrucción de una memoria negada: la lucha agraria de las comunidades indígenas en el Bajío y la Sierra Gorda (1876-1884)". In CARR, David Charles Wright; FERRO VIDAL, Luis Enrique; CONTRERAS SOTO, Ricardo (coord.). La memoria histórica de los pueblos subordinados. Málaga: Eumed.net (Universidad de Málaga/Fundación Universitaria Andaluza Inca Garcilaso), 2012,p. 151-152.

${ }^{303}$ A íntegra do "Plan Socialista proclamado por los representantes de los pueblos de los estados de Querpetaro y Guanajuato" pode ser consultada aqui: http://anarquiamx.blogspot.com.br/2011/12/plansocialista-de-la-sierra-gorda-1879.html Site consultado em 29/07/2015.
} 
Assim, o Plan de La Barranca começa com uma espécie de exposição de motivos, nos quais as razões que levaram à organização política e luta são expostas. É a escravidão de indígenas que é rechaçada no segundo considerando: "Que no obstante estar abolida la esclavitud por nuestras leyes, ella es un hecho en el suelo mexicano, puesto que los hacendados compran y por corto precio, no solo el trabajo, sino la persona misma de los desgraciados indígenas que los sirven, y a quienes hacen legar las deudas que contraen a sus hijos [...].”. Também o alistamento compulsório especificamente de índios para o exército, promovido por meio da força, é repudiado no terceiro considerando. A ausência de garantia de educação aos índios -um meio de formá-los como ativos reivindicadores de direitos - é reclamada no quarto considerando e, por fim, a oposição ao despojo de terras indígenas é o foco do documento e do movimento no oitavo considerando.

Ora, o documento de 1879 não deixa dúvidas quanto à identidade indígena da organização política formalizada pelo "Plan Socialista Proclamado por los Representantes de los Pueblos de los Estados de Querétaro y Guanajuato". A partir dessa identidade, porém, os índios organizados se declaram socialistas.

A organização de 1879 teve início, segundo pesquisa de Mirtha Urbina Villagómez, em 1876, quando grupos indígenas se reuniram para lutar contra o que consideravam espoliação espanhola de suas terras. Apesar do fim do colonialismo espanhol e da sangrenta luta pela independência, as comunidades da região afirmavam haver uma continuidade na prática de apropriação ilegítima de suas terras, sua água e seus bosques. Identificavam a gestão realizada pelos Estados Unidos Mexicanos, por meio de normas e políticas de colonização e demarcação, com aquela realizada pelos espanhóis, fundamentada no direito de conquista que um povo com superioridade de armas tem sobre o outro. Afirmavam, assim, que o direito à propriedade pertencia aos habitantes originais, naturais da terra. Esta percepção por parte das comunidades indígenas é especialmente interessante quando se relembram características das políticas de colonização formuladas e implementadas pelos governos do México independente: muitas delas tinham por destinatários os europeus. Seu objetivo parecia ser ocupar o território com brancos e, com este processo, "desindianizar" o país. Este objetivo fica claro, apenas para mencionar um exemplo, na exposição de motivos do decreto de 1846, já analisado neste trabalho. (p. ) 
Para além dos bens naturais, a organização política em formação também pleiteava autonomia decisória dos municípios e pueblos. Na disputa entre governo e decisões centralizadas, em contraposição a um estado federado que reconhece autonomia decisória para seus entes, a organização indígena compunha a força pródescentralização. Além disso, reivindicavam seu reconhecimento como pessoas jurídicas coletivas, capazes de ser titulares de propriedades fundiárias. Tanto a lei 25 de junho de 1856, quanto a Constituição de 1857 eram entraves jurídicos específicos para este objetivo.

Em 1877, boa parte dessas reivindicações já estava formalizada no documento denominado Defensa del Derecho Territorial Patrio Elevado por el Pueblo Mexicano al Congreso General de la Nación, em que se reivindicava a "reconquista" da propriedade territorial pelos cidadãos habitantes (originais) da República por meio de novas leis agrárias aprovadas. O interlocutor do documento de 1877 era o Congresso da Nação, ou seja, o Poder Legislativo central, e a reivindicação era para que fossem criadas novas leis agrárias que reconhecessem o direito dos habitantes mexicanos originais. Nesse momento da organização política dos indígenas de Sierra Gorda, denominado por historiadores de "Guerra da Conquista", não havia ainda o uso da palavra socialismo. Seus pedidos referiam-se à devolução das terras ocupadas. Boa parte dos povoados indígenas participantes, já em 1877, haviam sido "fagocitados" por grandes fazendas. Isso significa que, naquele momento, outras pessoas possuíam os títulos de propriedade sobre terras que antes eram suas. $\mathrm{E}$ os indígenas sofriam as consequências dessa apropriação por terceiros.

Villagómez relata que, entre as estratégias iniciais de Los Pueblos, figurava a de apresentar reclamações junto ao Poder Judiciário, pleiteando a reversão da situação que consideravam injusta. Não obstante seus esforços de permanecer em diálogo com as instituições estatais - poderes Legislativo e Judiciário -,na etapa "Guerra da Conquista" a organização indígena foi desarticulada por meio da prisão de vários de seus líderes. Pouco tempo depois, ela se reorganizou, incorporando na nova etapa novas regiões, novas comunidades e um grande objetivo - a implantação do socialismo no México.

Se até 1877 a luta se concentrava contra a apropriação violenta das terras indígenas, em 1879 ela ressurge com uma crítica mais profunda à própria organização estatal que permitiu tais despojos. Assim, no primeiro considerando do Plan de La Barranca, lê-se "que los gobiernos constituidos hasta hoy, no son sino la rémora para 
la felicidad del país y la amenaza constante de los derechos inviolables de la vida, de la libertad y de la propiedad,[...]". Ora, são os governos os responsáveis por impedir ou adiar (rêmora) a felicidade dos povos. O problema, assim, não são mais alguns atos pontuais dos governos, mas os próprios governos possuírem características a ser transformadas.

A crítica da própria organização política da sociedade está, dessa forma, configurada. O que o documento quer dizer com ser um "Plan Socialista", porém, já não é tão claro. Muito embora o sétimo considerando trate das imensas fazendas improdutivas como um problema a ser resolvido, não se questiona a propriedade em si, que só é mencionada no primeiro considerando, como bem que sofre a ameaça dos governos. O artigo $8^{\circ}$, já da parte normativa do plano, afirma que será eleito um congresso agrário em cada capital dos estados federados, para que "éste devuelva a los indígenas los terrenos que les hayan usurpado.”.

Não está claro, de acordo com este dispositivo, se trata-se de posse ou propriedade formal e se ela deve ser exercida individual ou coletivamente: deseja-se que ela esteja em domínio indígena, isso é fato. Não há, assim, - apesar do socialista no nome - clareza sobre qual o regime de propriedade a sociedade almejada realizará, muito embora o artigo primeiro afirme: "Se desconoce la autoridad de todo gobierno constituido en las formas conocidas hasta hoy, y las que de él emanen, reconociendo solo el municipal o socialista."

O socialismo defendido aparentemente também não acabaria com o trabalho assalariado. O sexto considerando chama a atenção para as más condições enfrentadas pelos trabalhadores - rurais e industriais - no país: "Que son muy cortos los salarios y jornales que se ven obligados a recibir los industriales, obreros y labradores; produciendo esto la decadencia del comercio, la miseria del proletario, y en una palabra, el malestar de nuestra sociedad". A parte propositiva do plano, porém, nada traz sobre o fim da propriedade privada dos meios de produção ou da reorganização social do emprego. Talvez tal afirmação fosse desnecessária, uma vez que os índios já possuem uma forma alternativa de organizar o trabalho na terra, que não passa pelo pagamento de salários.

O socialismo indígena e municipalista defendido no plano, assim, não traz com profundidade reflexões sobre uma forma positiva de reorganizar a sociedade. Antes, quer organizar a luta para vencer os males que os atormentam. Assim, dispõe sobre a 
criação de um exército revolucionário, sob a denominação de "Falanges Populares" (art. $3^{\circ}$ ). O documento segue explicitando as formas de adesão ao exército revolucionário e os benefícios que os engajados terão quando vencida a revolução, como, por exemplo, se tornarem credores de terrenos não cultivados $\left(\operatorname{art.~} 6^{\circ}\right.$ ); o o pagamento de uma pensão vitalícia para as famílias daqueles que sucumbirem durante os enfrentamentos armados $\left(\right.$ art. $\left.9^{\circ}\right)$ e, de soldados e servidores fiéis do exército das Falanges Populares receberem prêmios por honra ao mérito militar (art. 13).

Para que a luta tivesse organicidade, havia um diretório socialista central, com competência - de acordo com o plano - de reconhecer os líderes das forças revolucionárias (art. 11). Tal diretório, segundo Mirtha Urbina, faz parte de uma organização maior: a Confederación Mexicana Socialista, uma das organizações responsáveis por promover o encontro entre a organização indígena e o ideário do socialismo. A autora faz uma análise sobre os resultados dessa mistura:

En este encuentro con el socialismo, la lucha indígena se radicalizó, transitando de un programa anticolonialista, hacia uno anticapitalista y antiimperialista. No obstante, aunque hizo suyo el programa internacionalista de los grupos socialistas y anarquistas europeos, esto sólo puede ser entendido en términos generales, pues en lo concreto se dio un proceso resignificaciones dio paso al surgimiento de algo nuevo. Es decir, esta otra historia revela cómo nuestros actores resignificaron al socialismo europeo a partir de sus propias formas culturales y políticas y de su experiencia de lucha, dando paso a un socialismo anticlerical pero cristiano - que no debe ser confundido con el evangélico, sino en el sentido de que reivindica los principios igualitarios y humanistas pregonados por Cristo, "el primer socialista y libertador"-. Esta postura empatará con la profunda religiosidad popular de las comunidades indígenas, religiosidad irreductible igualmente ante la religiosidad oficial.

Este socialismo puede ser entendido también como un socialismo indiano, pues estará permeado por la cosmovisión, la base histórica, cultural y política indígena. Sus más radicales demandas - el municipio libre, la comuna territorial y la República socialista prefiguran los programas e idearios de la Revolución Mexicana, particularmente de los movimientos populares del magonismo, el villismo y, por sobre todo, del zapatismo. El concepto específico de "municipio libre" no puede ser entendido en la acepción carrancista de "supresión de las odiosas prefecturas", sino en el del poder del "común" o del pueblo, de la asamblea. Es decir, un "quinto poder" o contrapoder popular que desde abajo reclama el derecho a la autonomía y autodeterminación o a sus propias formas de autogobierno. Por su parte, el de la "comuna territorial" apela no sólo 
a un derecho al territorio y sus recursos en tanto comunidades originarias, sino a un derecho natural otorgado por Dios, al hombre como ser genérico. Este derecho se opone al derecho positivo, el establecido por los hombres en las leyes, es decir propiamente el derecho impuesto por el Estado capitalista. De ahí que en algunos discursos aparezca, como reclamo, la tierra como "de ningún particular". Y la "República Socialista" retoma como modelo la experiencia y principios legados por la Comuna de París de 1871, suponía la refundación social con base en la socialización y colectivización de la tierra y los medios de producción, por la construcción de autonomías y por ampliar el constreñido concepto de democracia liberal, por hacer efectiva la soberanía popular y construir una democracia desde abajo, social y política. ${ }^{304}$

O penúltimo artigo do Plan de La Barranca (art. 12) dispõe que, quando ocupada a capital da República - e este parece ser um dos objetivos centrais da organização, pois só assim será possível implementar o governo socialista - serão convocadas eleições para governos municipais. Os governos municipais, por sua vez, convocarão as eleições para o Congresso Agrário e para as demais autoridades que "unidas formarán la Constitución Socialista". O uso do termo "constituição", aqui, não é totalmente claro. Tampouco o plano entra em detalhes sobre a forma de organizar o exercício do poder pós-revolução planejada. É inequívoco, porém, seu desejo de ver as instituições transformadas, de tomar e exercer o poder. E esse é um traço distintivo deste plano revolucionário indígena.

\subsubsection{Plan Socialista de Sierra Gorda, de 15 de julho de $1879^{305}$}

Diferentemente do Plan de La Barranca, o Plan Socialista de La Sierra Gorda, tem uma concepção clara sobre a propriedade privada,apresentada como requisito para o exercício de outros direitos: " $5^{\circ}$ La libertad, la igualdad, la fraternidad, la ilustración, la prosperidad, son imposibles sin la propiedad".

\footnotetext{
${ }^{304}$ URBINA VILLAGÓMEZ, Mirtha Leonela. "Reconstrucción de una memoria negada: La lucha agraria de las comunidades indígenas en el Bajío y la Sierra Gorda (1876-1884)". In CARR, David Charles Wright; FERRO VIDAL, Luis Enrique; CONTRERAS SOTO, Ricardo (coord.). La memoria histórica de los pueblos subordinados. Málaga: Eumed.net (Universidad de Málaga/Fundación Universitaria Andaluza Inca Garcilaso), 2012, p. 165-166.

${ }^{305}$ A íntegra do Plan Socialista de Sierra Gorda, de 15 de julho de 1879, está disponível em: CARMONA, Doralicia. Memoria Política de México. Guanajuato: Universidade de Guanajuato, 2014. <http://www.memoriapoliticademexico.org/Textos/5RepDictadura/1879-PS-SG.html >, site consultado em 30/07/2015.
} 
Os atores que o Plan de Sierra Gorda teve em torno de si também foram diferentes. Miguel Negrete, um militar que atuou nas guerras contra as ocupações francesa e americana, e já havia ocupado o posto de ministro da Defesa, liderou a insurreição de camponeses rebeldes entre 1879 e 1884. Entre as motivações políticas para a sublevação, estava o não cumprimento dos acordos firmados no Plan de Tuxtepec que, anos antes - em 1876 - levou Porfírio Díaz ao poder.

Junto a ele estavam membros do diretório socialista mexicano - Salomon Morales, Diego Hernández e Luis Luna - sendo responsáveis inclusive pela elaboração do plano. Essas lideranças, urbanas, vinculadas ao diretório socialista, mobilizaram uma insurreição camponesa. Juan Santiago foi responsável por realizar a intermediação entre os camponeses e os demais líderes. ${ }^{306}$

As queixas dos camponeses locais estavam diretamente relacionadas à reorganização do campo que a política porfirista vinha promovendo de forma mais efetiva do que os seus predecessores: as terras estavam sendo apropriadas por terceiros e, somado a isso, as condições de trabalho propostas pelos novos proprietários - que passavam a ser patrões daqueles que viviam sobre suas terras - eram muito ruins.

O Plan Socialista de Sierra Gorda, de julho de 1879, também reproduz a estrutura de uma norma jurídica. Começa com "considerandos", que expõem o contexto e os motivos que levaram os signatários a escrever e a unir esforços - e armas - em torno do plano. Após a exposição de motivos, o plano se subdivide em três partes: um projeto de lei agrária, uma reforma política e uma lei eleitoral. Mark Saad Saka afirma que as demandas por reorganização política foram incorporadas ao movimento por influência do diretório socialista com sede na Cidade do México.

A reforma política, analisada em conjunto com o projeto de lei eleitoral, parece querer simplesmente desconstituir as instituições existentes, para implementar algo parecido com uma República Conselhista. A expressão "no hay" está no início de cinco entre os onze artigos relativos à reforma política. Junta-se a eles um sexto artigo que começa com o verbo “cesan". Ora, caso o plano fosse implementado, todas essas funções, instituições e órgãos seriam substituídos pelo próprio conselho municipal ou por seus membros: chefes políticos vinculados a diferentes partidos (art. $2^{\circ}$ ); agentes

\footnotetext{
${ }^{306}$ O relato detalhado das insurreições lideradas por Negrete em Sierra Gorda entre 1879 e 1884 está organizado em SAKA, Mark Saad.For God and revolution: priest, peasant, and agrarian socialism in the Mexican Huasteca. Albuquerque: University of New Mexico Press, 2013, p.186.
} 
municipais (art. $3^{\circ}$ ); secretaria de educação primária (art. $4^{\circ}$ ); tribunais de justiça (art. $5^{\circ}$ ); oficinas de registro civil e, por fim, poder legislativo estadual, cujas funções seriam assumidas pelos conselhos municipais das capitais dos estados, que teriam jurisdição sobre todo o território (art. $9^{\circ}$ ). Cada município - comunidade que deve observar um tamanho rígido, entre mil e cinco mil pessoas (art. $1^{\circ}$ ) - possuiria um conselho e este seria a instituição central na forma de organização política proposta pelos insurgentes.

A reforma política elaborada pelo Plan Socialista de Sierra Gorda parece querer simplificar muito a estrutura política do país. Além da reestruturação política, também integra o plano um projeto de lei eleitoral em que há definições sobre as eleições a serem realizadas para identificar os membros dos conselhos - em âmbito municipal (art. $3^{\circ}$ ), estadual (art. $4^{\circ}$ ) e nacional (art. $5^{\circ}$ ). Participam das eleições todos os membros do território que será objeto de atuação do respectivo conselho. Se município, todos os munícipes; se estado, todos os residentes no estado e, em relação ao conselho nacional, são eleitores todos os habitantes do país.

Os presidentes - municipais, estaduais e nacional -, que teriam por missão exercer o equivalente ao Poder Executivo nos territórios sob sua jurisdição, seriam eleitos indiretamente, pelos membros de seus respectivos conselhos (art. $7^{\circ}$ ). Os auxiliares dos presidentes e suas forças de defesa - a polícia - seriam escolhidos diretamente pelos presidentes.

Esta estrutura fundamental é ainda complementada por outras normas, entre elas aquela que impede a reeleição de quaisquer dos presidentes (art. $9^{\circ}$ ), que teriam mandatos anuais (art. $10^{\circ}$ ). Muito embora o projeto de lei eleitoral afirme que "Cada pueblo elegirá sus autoridades con absoluta independencia de las autoridades superiores" (art. $\left.1^{\circ}\right)$ e que "Las poblaciones eligen sus consejos; los consejos eligen sus presidentes; los presidentes eligen sus regidores y policías" (art. $7^{\circ}$ ), os eleitores não parecem ser todos os membros de "las poblaciones". Logo em seguida, no artigo 80, que define a instalação inicial do conselho, afirma-se que devem ser convocados os "jefes de família". Esses, por sua vez, escolherão entre dez e vinte pessoas respeitadas na comunidade, com experiência no governo, para formar o conselho permanente.

Ora, o artigo oitavo do projeto de lei eleitoral do Plan de Sierra Gorda coloca em xeque a ideia de que o plano tinha por objetivo implementar uma república conselhista democrática. Não fica claro se outros, que não os chefes de família, poderiam participar da eleição e da escolha dos membros do conselho. 
Independentemente de quem forem seus eleitores, porém, a alternância de poder fica restrita ao presidente do município, com mandato anual, pois o conselho é permanente. Os ex-presidentes, que exerceram seu mandato por um ano, passariam a compor o conselho (art. 11) e os conselheiros só perderiam seus cargos por impedimentos pessoais ou com a morte ( $\operatorname{art.} 9^{\circ}$ ). Quanto a forma de realização de eleições, o artigo 17 dispõe que "Todas las elecciones se hacen en asamblea pública y por escrutinio directo y secreto".

O Plan de Sierra Gorda propõe um rompimento completo com separação de poderes, elaborando uma proposta de república conselhista, com traços democráticos. $\mathrm{O}$ conselho seria um órgão múltiplo, que concentraria as funções legislativa e jurisdicional. Declaram ser a favor de uma "república democrática social" ao fim do plano e têm como lema "Tierra. Industria. Educación. Armas.", muito diferente do "Justiça e Lei” propagado pelos zapatistas.

Especificamente no que tange à propriedade fundiária, já foi dito que o plano afirma ser requisito possuí-la para o exercício de outros direitos, como igualdade, fraternidade e liberdade. Além disso, no diagnóstico proposto pelo plano, afirma-se que o fato de a população local ter sido espoliada de terras que antes possuía levou esses mexicanos a viverem em "estado salvaje", dispersos em desertos (considerando $7^{\circ}$ ). Entre os responsáveis, estão a lei de desamortização e a lei de repartimento, a usurpação e a conquista "bárbara y feroz", que despojou a nação de seu solo (considerando $9^{\circ}$ ), levando "el monopolismo del suelo al último extremo, hundiendo a los pueblos em la más desesperante miseria" (considerando $8^{\circ}$ ). Assim, o plano tem por objetivo primeiro "destruir la conquista y restablecer la patria, la nación proclama y plantea la ley agraria". Entre as três partes do documento - reorganização política, projeto de lei eleitoral e projeto de lei agrária - os problemas relacionados à terra parecem ser os mais importantes.

O artigo primeiro do projeto de lei agrária presente no Plan Socialista de Sierra Gorda dispõe, como fará de forma semelhante o artigo 27 da Constituição de 1917, em que "La nación declara ser suyo el territorio que habita". Ora, todo o território do país pertence à nação. E segue com o artigo segundo "Todo hijo de la nación tiene derecho de poseer y recibe en propiedad particular, el terreno que puede o quiere cultivar". 
Todos os mexicanos teriam direito à terra, desde que seu objetivo, ao possuí-la, fosse cultivá-la. Mexicanos natos e estrangeiros naturalizados são considerados pelo plano filhos da nação (art. $3^{\circ}$ ).

A insurreição armada que se organizou em torno do plano tinha por objetivo, em um primeiro momento, tornar públicas fazendas de grandes proprietários. Esse objetivo transparece ao garantirem, no projeto de lei agrária, o respeito a algumas partes desses imóveis. $\mathrm{O}$ artigo $5^{\circ}$, assim, garante que os proprietários mantenham a propriedade sobre suas casas de campo, fábricas, minas, cabeças de gado e propriedades urbanas. $\mathrm{O}$ artigo $6^{\circ}$, porém, declara públicas todas as benfeitorias feitas pelos fazendeiros que podem ser úteis para a coletividade - bicas de água, cercas, templos e casas não utilizadas.

Atento à situação dos trabalhadores do campo, o projeto de lei extingue as dívidas que os camponeses tivvessem com os fazendeiros para quem trabalhavam (art. $7^{\circ}$ ) e propõe a distribuição imediata das casas em que esses trabalhadores residiam e das terras que cultivavam (art. $8^{\circ}$ ).

$\mathrm{O}$ artigo $10^{\circ}$ protege as mulheres e os filhos ao instituir o que no direito brasileiro chama-se outorga uxória. A norma torna impossível vender um imóvel sem o consentimento familiar. $\mathrm{O}$ artigo 13 reintroduz a possibilidade de os povoados (pueblos) - comunidades com cem ou mais habitantes (art. 11) - serem proprietários de terras comuns, de acordo com sua necessidade social. Tais terrenos, por sua vez, seriam inalienáveis (art. 17).

Os conselhos municipais seriam os órgãos responsáveis por organizar a demarcação dos terrenos (art. 15) e, apenas os terrenos sem cultivo, "sobrantes", poderiam ser distribuídos para os estrangeiros imigrantes (art. 18), que deveriam ser, preferencialmente, das "razas americanas y asiática" (art. 19). Por fim, dispõe que os frutos cultivados no solo comum do povoado deveriam ser gratuitos para seus habitantes (art. 22) e que por meio da implementação da lei agrária é que se restabeleceria a pátria (art. 23).

O Plan Socialista de Sierra Gorda é um documento político bastante avançado, sobretudo por propor uma reorganização da sociedade mexicana que passava tanto por novas instituições e forma de organização política quanto por diferentes relações com a terra e com a propriedade privada. Em torno desse documento, sustentou-se um 
importante movimento de resistência à política agrária do porfiriato no Estado de Querétaro, no centro do país.

Muito embora normativamente elaborado, o Plan de Sierra Gorda nunca foi implementado, dado que seus defensores são derrotados em 1884, um ano após a edição da Ley Terrenos Baldíos, assinada por Manuel González, que intensificou a política de identificar todos os terrenos sem título de propriedade formal como "baldíos", mesmo que estivessem ocupados por "pueblos" ou comunidades indígenas, demarcá-los e entregá-los às mãos de particulares. Os líderes, urbanos e camponeses, da insurreição armada foram presos e mortos no longo embate travado com os "federales" entre 1879 e 1884 .

\subsection{A demanda pela terra nos primeiros documentos dos movimentos revolucionários mexicanos}

Destacam-se os esforços do poder público para promover a ocupação do território e para incentivar ondas imigratórias e garantir a formação de colônias; realização de desamortizações e nacionalização de bens da Igreja Católica - e, efeito colateral - também de terras comunitárias indígenas; contratação de companhias privadas, pagas com terras pelo poder público, para demarcar terras desocupadas, reparti-las e vendê-las.

Como já dito no início do capítulo, a maior parte das políticas do século XIX geraram extrema concentração de terras e não favoreceram os "naturales" do México, como dizia Hidalgo. Pelo contrário: prejudicaram sobretudo pacíficos índios, mestiços e camponeses que possuíam com a terra uma relação que não era de propriedade privada, mas de usufruto comum comunitário. As terras espoliadas foram apropriadas por grandes fazendeiros para realizar plantações que visavam a exportação: monoculturas de cana de açúcar, agave para fabricação de sisal, café, tabaco, algodão e criação bovina. Essas produções ocuparam áreas antes destinadas a produções de consumo interno, principalmente de milho, feijão, trigo e arroz, entre outros.

Havia uma enorme tensão social nas áreas rurais mexicanas, já indicadas pelos levantes de Querétaro, que formulavam claramente suas demandas agrárias. Desde 1876, no Estado de Sonora, na fronteira norte do país, os índios yaquis rejeitavam 
violentamente que suas terras fossem expropriadas para serem cedidas, entre outros, à norte-americana Richardson Company. O conflito se prolongou por quase todo o período do porfiriato. Também colonos militares de Chihuahua pegaram em armas, oferecendo indícios de seu descontentamento de 1891 a 1893, que culminariam com o fato de ser este o primeiro Estado a se insurgir, em novembro de 1910. Assim, o início o século XX no México é marcado pelos inúmeros descontentamentos acumulados nas regiões rurais de todo o território mexicano e também pelo desgaste e "envelhecimento" do regime político de Porfírio Díaz. É nesse contexto de esgarçamento político, econômico e social acumulados, já apresentados em linhas gerais no primeiro capítulo, que surgem as organizações revolucionárias com objetivo de transformar a realidade (também agrária) mexicana.

\subsubsection{Programa do Partido Liberal Mexicano de $1^{\circ}$ de Julho de $1906^{307}$ : a aposta na dicotomia propriedade produtiva $x$ propriedade improdutiva}

Em meio a um diagnóstico tão preciso sobre as condições sociais, políticas e econômicas do início do século XX mexicano, os fundadores do Partido Liberal Mexicano cometem um erro de avaliação: apostam ser o trabalhador urbano a força motriz para promover as mudanças da sociedade que almejavam.

Em relação à concentração fundiária, o Programa do Partido Liberal afirma que uma distribuição de terras mais justa geraria um maior desenvolvimento nacional. Apesar de citar, ao final de um parágrafo de sua exposição de motivos, que " $L a$ restitución de ejidos a los pueblos que han sido despojados de ellos es clara justicia", nem a palavra "ejido", nem as injustiças que foram cometidas contra comunidades campesinas mexicanas aparecem em outros trechos do documento.

Ao invés disso, o Programa disserta sobre as vantagens para o desenvolvimento econômico do país se as terras fossem mais bem distribuídas. As injustiças cometidas não são tema, mas sim as vantagens que uma nova organização fundiária poderia gerar. A partir desse ponto de vista, concluem os liberais que o problema do México são

\footnotetext{
${ }^{307}$ Programa del Partido Liberal Mexicano, publicado em $1^{\text {o }}$ de julho de 1906. Íntegra disponível em: MEXICO. Cidade do México: Secretaria de Gobernación: Unidade General de Asuntos Jurídicos. http://www.ordenjuridico.gob.mx/Constitucion/CH6.pdf Consulta realizada em 23/09/2015.
} 
apenas os monopólios improdutivos, que deveriam ser combatidos, pois subtraem o potencial produtivo do país. Por outro lado, as propriedades forjadas violentamente, desde que em uso para o engrandecimento e enriquecimento nacional, deveriam ser mantidas. O que está em questão, então é a "obligación del terrateniente de hacer productivos todos sus terrenos, so pena de perderIos.". Também coerente com essa visão, afirmam que "No se les van a quitar las tierras que les producen beneficios, las que cultivan, aprovechan en pastos para ganado, etc., sino sólo las tierras improductivas, las que ellos mismos dejan abandonadas y que, de hecho, no les reportan ningún beneficio".

Além disso, afirmam que todos os mexicanos que desejem um pedaço de terra para cultivar deverão ter acesso a ele, sem privilégios ou exclusivismos. Não há no texto do Programa do Partido Liberal Mexicano nenhuma menção à restituição ou restauração de propriedades que existiam antes, ou mesmo propriedades coletivas, usufruídas por comunidades inteiras. A distribuição de terrenos improdutivos pelo Estado se daria unicamente a partir de critérios e perspectiva individual: os quinhões seriam distribuídos a indivíduos dispostos a cultivá-los, estabelecendo-se um máximo de tamanho que poderia ser concedido a cada um deles. Coerente com essa concepção de reforma agrária, os liberais prevêem a criação de um banco agrícola responsável por garantir crédito para os pequenos produtores iniciarem e financiarem a baixos juros suas atividades agrícolas.

Na parte dispositiva do plano, são quatro os artigos que tratam da questão da terra no México:

34. Los dueños de tierras están obligados a hacer productivas todas las que posean; cualquier extensión de terreno que el poseedor deje improductiva la recobrará el Estado y la empleará conforme a los artículos siguientes.

35. A los mexicanos residentes en el extranjero que lo soliciten los repatriará el Gobierno pagándoles los gastos de viaje y les proporcionará tierras para su cultivo.

36. El Estado dará tierras a quien quiera que lo solicite, sin más condición que dedicarlas a la producción agrícola, y no venderlas. Se fijará la extensión máxima de terreno que el Estado pueda ceder a una persona.

37. Para que este beneficio no sólo aproveche a los pocos que tengan elementos para el cultivo de las tierras, sino también a los pobres que carezcan de estos elementos, el Estado creará ofomentará un Banco 
Agrícola que hará a los agricultores pobres préstamos con poco rédito y redimibles a plazos.

Note-se que não há entre as normas propostas nenhuma menção a "ejidos", propriedades coletivas ou expropriações injustas. Reforça-se apenas a dicotomia produtiva $\mathrm{x}$ improdutiva, sem menção às injustiças que desrespeitaram terras anteriormente produtivas e tornaram semi-escravos camponeses que antes eram produtores autônomos. Também a forma de distribuição parte de uma concepção individualista de uso e fruto da terra, diferente daquela praticada por inúmeras comunidades mexicanas.

Muito sagazes em quase todos os outros aspectos da vida social e política mexicanas, em relação à terra os urbanos liberais deixam a desejar. Como dito no primeiro capítulo, talvez a concepção agrária exposta neste importante documento político, bem como a aposta nos operários e trabalhadores urbanos como força revolucionária, tenham sido as causas do fracasso da tentativa de organização política do Partido Liberal Mexicano no início do século.

\subsubsection{Programa del Partido Antireeleccionista ${ }^{308}$, Plan de San Luís Potosi ${ }^{309}$ (1910) e a justa promessa de restituir terras expropriadas}

O Programa do Partido Antireeleicionista foi aprovado em sua assembleia de 15 de abril de 1915. Francisco Madero e Francisco Vázquez Gómez concorreriam respectivamente à presidência e à vice-presidência do país contra Porfírio Díaz, que havia afirmado para uma revista norte-americana em 1908 que o país estaria preparado para uma disputa democrática. Muito embora no documento de diagnóstico de Francisco Madero "La Sucesión Presidencial en 1910" o político tivesse afirmado desejar um programa o mais enxuto possível, dado que quanto menos propostas

\footnotetext{
${ }^{308}$ A íntegra do Programa do Partido Antireelecionista, aprovado em Convenção do Partido em 15 de abril de 1910, pode ser encontrada em: BIBLIOTECA GARAY. 500 años de México en documentos. México, 2011. <http://www.biblioteca.tv/artman2/publish/1910_215/Programa_pol tico_aprobado_en_la_Convenci_n del Gr_1466.shtml> Consulta realizada em 16/12/2015.

${ }^{309}$ A íntegra do Plan de San Luís Potosí de 5 de outubro de 1910, pode ser consultada em: CARMONA, Doralicia. Memoria política de México. Guanajuato: Universidade de Guanajuato, 2014. http://www.memoriapoliticademexico.org/Textos/6Revolucion/1910PSL.html Consulta realizada em $31 / 10 / 2015$.
} 
positivas, mais concordâncias o programa angariaria, o documento efetivamente produzido em 1910 foi além do lema "elecciones libres y no-reeleccion".

Vázquez Gómez teria contribuído para que o Programa do Partido Reeleicionista aprovado também incluísse alguns princípios orientadores em temas que passavam por direitos dos trabalhadores, organização política e fundiária. No que tange à terra, o Programa dispunha:

VIII - Fomentar la grande y muy especialmente la pequeña Agricultura y la irrigación, a la cual se destinará una parte de los fondos públicos.

En cuanto a la Minería, la Industria y el Comercio, se les concederán todas las franquicias que aseguren su desarrollo y prosperidad.

Clausulas adicionales

IV.-Leyes que favorezcan la creación y subsistencia de la pequeña propiedad agraria.

O Estado Mexicano deveria, caso o Partido Antireeleicionista fosse eleito, fomentar financeiramente especialmente as pequenas propriedades agrícolas. Mas também as grandes propriedades, as indústrias, as mineradoras e o comércio. Assim, grandes e pequenos proprietários deveriam se satisfazer e identificar com o programa que tinha o objetivo de ser conciliador. Nenhuma menção é feita ao processo de demarcação e distribuição de terra praticado pelo governo de Porfírio Díaz. Os antirreeleicionistas indicam apenas que mudariam o sentido da política, privilegiando a formação de novas pequenas propriedades. As já criadas permaneceriam intocadas, segundo o texto.

Após serem perseguidos, presos, impedidos de concorrer às eleições em que eram candidatos, Madero e Vázquez Gómez mudaram o discurso em relação à questão agrária no Plan de San Luís Potosí, no conhecido artigo $3^{\circ}$, provável corresponsável pela empreitada armada maderista ter obtido tantos adeptos e por ter sido bem-sucedida. Assim formulava o texto de 5 de outubro de 1910:

$3^{\circ}$ Para evitar hasta donde sea posible los trastornos inherentes a todo movimiento revolucionario, se declaran vigentes, a reserva de reformar oportunamente por los medios constitucionales aquellas que requieran reformas, todas las leyes promulgadas por la actual administración y sus reglamentos respectivos, a excepción de aquellas que manifiestamente se hallen en pugna con los principios 
proclamados en este Plan. Igualmente se exceptúan las leyes, fallos de tribunales y decretos que hayan sancionado las cuentas y manejos de fondos de todos los funcionarios de la administración porfirista en todos los ramos; pues tan pronto como la revolución triunfe, se iniciará la formación de comisiones de investigación para dictaminar acerca de las responsabilidades en que hayan podido incurrir los funcionarios de la Federación, de los Estados y de los Municipios.

En todo caso serán respetados los compromisos contraídos por la administración porfirista con gobiernos y corporaciones extranjeras antes del 20 del entrante.

Abusando de la ley de terrenos baldíos, numerosos pequeños propietarios, en su mayoría indígenas, han sido despojados de sus terrenos, por acuerdo de la Secretaría de Fomento, o por fallos de los tribunales de la República. Siendo de toda justicia restituir a sus antiguos poseedores los terrenos de que se les despojó de un modo tan arbitrario, se declaran sujetas a revisión tales disposiciones y fallos y se les exigirá a los que los adquirieron de un modo tan inmoral, o a sus herederos, que los restituyan a sus primitivos propietarios, a quienes pagarán también una indemnización por los perjuicios sufridos. Sólo en caso de que esos terrenos hayan pasado a tercera persona antes de la promulgación de este Plan, los antiguos propietarios recibirán indemnización de aquellos en cuyo beneficio se verificó el despojo.

$\mathrm{O}$ artigo $3^{\circ}$ do Plan de San Luís Potosí é, na verdade, um artigo de precaução e de manutenção da ordem jurídica. Prevê que continuem vigentes todas as leis e atos normativos do Estado Mexicano, antes sob a liderança de Porfírio Díaz, até que a revolução vitoriosa instale um novo governo e passe a revisar a legislação herdada. Uma vez que o plano tenha sido explícito na continuidade do ordenamento jurídico vigente antes da revolução com hora marcada, se preocupou também em estabelecer uma exceção para essa continuidade legitimada pelo plano revolucionário: os excessos promovidos por meio da lei de terrenos "baldíos" com a conivência de órgãos públicos como a Secretaría de Fomento e representantes do Poder Judiciário. Legislativo, Executivo e Judiciário concorreram, segundo o diagnóstico de Madero, para que os indígenas e camponeses tenham sido injustamente despojados de suas terras. E contra esses despojos injustos a revolução promete se insurgir: todas as terras nessas condições devem ser restituídas a seus antigos proprietários.

Essa é a nobre promessa que Francisco Madero faz a todos os mexicanos que sofreram os processos de expropriação de terras promovidos principalmente por Porfírio 
Díaz. E é em nome dessa promessa que os mexicanos pegam em armas a partir de novembro de 1910.

\subsubsection{Plan Político-Social ${ }^{310}$, de 18 de março de 1911: proteção dos índios, dos arrendatários, devolução de terras e moradia}

Muitos mexicanos aderiram à luta maderista contra o regime autoritário e permeado de injustiças sociais de Porfírio Díaz. Nem todos eles, porém, aderiram integralmente ao Plan de San Luís Potosí. Líderes revolucionários do centro-sul do México, mais especificamente dos estados de Guerrero, Michoacán, Tlaxcala, Campeche, Puebla e Distrito Federal, decidiram formular em nome e documento próprios as razões por que lutavam.

O Plan Político-Social de 18 de março de 1911 reconhece Francisco Madero como chefe da revolução e reafirma o lema do Plan de San Luís, "voto libre y no reelección". Mais enfático e direto do que o documento maderista em relação à terra, no Plan Político-Social lê-se:

VIII.- Se protegerá en todo sentido, a la raza indígena, procurando, por todos los medios, su dignificación y su prosperidad;

IX.- Todas las propiedades que han sido usurpadas para darlas a los favorecidos por la actual administración, serán devueltas a sus antiguos y legítimos dueños;

Os índios devem ser especialmente protegidos na nova sociedade que os dez mil revolucionários supostamente representados pelo plano de 1911 desejavam criar. E especialmente para eles deverá ser útil a norma de restituição de todas as propriedades que foram usurpadas pela administração porfirista. Além dessas duas normas, o plano prevê, ainda, que deveriam ser revistos e padronizados os valores de arrendamento das propriedades urbanas.Também afirma que o Estado deverá se responsabilizar por construir moradias baratas, que possam ser financiadas em longos prazos, para as classes trabalhadoras (art. 13).

\footnotetext{
${ }^{310}$ A íntegra do Plan Político-Social, de 18 de março de 1911, pode ser encontrada em: BIBLIOTECA GARAY. 500 años de México en documentos. México, 2011. http://www.bibliotecas.tv/zapata/1911/z18mar11.html Consulta realizada em 07/11/2015.
} 
Por fim, os revolucionários do centro-sul do país almejam que todos os proprietários que mantivessem suas terras improdutivas deveriam obrigatoriamente cedê-las a quem estivesse disposto a cultivá-las, sendo fixo o valor que deveria ser pago nesses casos: $6 \%$ anuais sobre o valor fiscal do terreno cedido (art. 14). Essa era uma proteção contra contratos de parceria, por exemplo, que exigiam metade de tudo o que a terra fosse capaz de produzir (chamados de medieros, ver seção 3.2). Ainda, o artigo 15 do plano afirma a abolição de quaisquer monopólios - agrários ou industriais - em território mexicano.

\subsubsection{Plan de Tacubaya $^{311}$ de 31 de outubro de 1911: o problema agrário como objeto único da revolução}

Em 1910, Francisco I. Madero, Emílio e Francisco Vázquez Gómez estavam do mesmo lado da luta contra Porfírio Díaz. Francisco Vázquez Gómez foi inclusive o candidato à vice-presidência de Madero nas eleições que ocorreriam em junho e julho de 1910. Após a renúncia de Porfírio Díaz e ainda durante o governo interino de Francisco León de la Barra, porém, em julho de 1911, os irmãos Vázquez Gómez e Madero passam a ter atritos e se distanciam politicamente, gerando um racha no Partido Antirreeleicionista. Assim, Francisco Madero concorre às eleições como candidato do Partido Constitucional Progressista, vencendo com larga margem.

As divergências políticas entre o grupo político dos irmãos Vázquez Gómez e Francisco Madero diziam respeito sobretudo à forma como o presidente eleito decidira conduzir a questão agrária, uma vez no governo. Seu curto mandato tentou realizar uma coalizão com parte do governo porfirista e, antes de tomar quaisquer medidas em relação ao problema agrário, decidiu constituir uma Comissão ligada ao Poder Legislativo para estudar as possíveis intervenções.

Essa decisão por adiar qualquer ação prática em relação às terras das comunidades de camponeses, majoritariamente indígenas e mestiços, somada a um progressivo afastamento das classes populares, foram as principais causas do afastamento dos grupos. Quando Madero fora eleito com larga margem de votos, nos

\footnotetext{
${ }^{311}$ A íntegra do Plan de Tacubaya, de 31 de outubro de 1911, pode ser encontrada em: CARMONA, Doralicia. Memoria política de México. Guanajuato: Universidade de Guanajuato, 2014. http://www.memoriapoliticademexico.org/Textos/6Revolucion/1911PDT.html Consulta realizada em $21 / 11 / 2105$.
} 
turnos $1^{\circ}$ e 15 de outubro, o grupo político que havia protagonizado a divisão do Partido Antirreeleicionista lançou o Plan de Tacubaya, reconvocando os mexicanos para a luta.

Mexicanos: si os llamamos nuevamente al combate no es con el sólo fin de quitar a un hombre de la silla presidencial para poner otro, sino para llevar a su término los ideales u objeto único de la revolución:

Resolver de una vez y para siempre nuestro problema agrario e impartir la Justicia por igual a todos los hombres, respetando y haciendo respetar la Ley, cuyo respeto debe ser el fundamento de la paz. Tacubaya, octubre 31 de 1911.

O plano recusa qualquer interpretação personalista: seu propósito não é simplesmente fazer uma troca de quem ocupará o posto de presidente da República. Seus mentores afirmam estarem mais preocupados com a realização do que consideram ser o único objetivo da revolução: resolver o problema agrário do país, em nome da lei.

Muito embora o chamamento do Plan de Tacubaya não tenha tido como efeito a insurreição armada no país, desconhecer politicamente Madero foi importante para que zapatistas, orozquistas e outros descontentes com a falta de solução imediata proposta por Francisco Madero se manifestarem. O Plan de Tacubaya, de 31 de outubro de 1911, foi rapidamente secundado e reiterado pelo Plan de Ayala, de 25 de novembro do mesmo ano, elaborado pelos zapatistas; pelo Plan de Santa Rosa, de 3 de fevereiro de 1912; e pelo Plan de la Empacadora, de 25 de março de 1912, de Pascual Orozco. Grupos políticos organizados do centro, sul e norte do país manifestaram assim sua insatisfação com a decisão de Madero de adiar indefinidamente a implementação de ações práticas para a resolução do problema das terras no México.

No texto do Plan de Tacubaya fica clara a posição política de considerar inadmissível adiar ou postergar a solução em nome de uma reflexão científica do problema como propôs Madero. Os sofrimentos eram urgentes e atuais; sendo assim, demandavam uma intervenção imediata, que não poderia ser postergada no tempo. Essa era a principal insatisfação quanto à conduta de Madero:

El problema agrario en sus diversas modalidades es, en el fondo, la causa fundamental de la que derivan todos los males del país y de sus habitantes, y por esto se ha resuelto que las diversas soluciones de ese problema deben comenzar a ejecutarse y a realizarse lo mismo que los demás ideales de la revolución, en el momento mismo en que el triunfo se verifique, sin esperar más ni dilatar por motivo alguno la ejecución de las soluciones del problema agrario, que constituye el 
mejoramiento económico de los habitantes y el establecimiento definitivo del verdadero progreso. ${ }^{312}$

Segundo os signatários do Plan de Tacubaya, tão logo a revolução fosse vitoriosa dever-se-ia perseguir a resolução da justa distribuição de terras no México. Considerando que a renúncia de Porfírio Díaz tinha ocorrido em 25 de maio de 1911; que o governo provisório de Francisco León de la Barra já tinha sido uma proposta de conciliação, em que os revolucionários haviam cedido e adiado o início de sua atuação sobre o país; e que, uma vez eleito, Francisco Madero não havia dado nenhum sinal de ter a intenção de efetivar uma solução prática rápida, já que sua única decisão nesse sentido fora constituir uma Comissão Agrária para estudar o assunto, os adeptos do Plan de Tacubaya decidiram que a única solução era o desconhecimento da presidência de Madero e a convocação dos mexicanos para, novamente, tomarem as armas em defesa de seus direitos.

\subsubsection{Plan de Ayala $^{313}$, de 28 de novembro de 1911: os zapatistas e a dupla solução para a concentração fundiária mexicana}

Enquanto os dissidentes do Partido Antirreeleicionista simplesmente afirmavam a urgência de medidas concretas para enfrentar a questão agrária do país, os zapatistas elaboravam, um mês mais tarde, propostas concretas para avançar no sentido da solução. Também descontentes com as decisões políticas que Francisco Madero vinha tomando como líder da revolução vitoriosa - as rusgas entre Madero e os zapatistas começaram antes de sua eleição, no momento em que Madero tentou pedir que Zapata licenciasse suas tropas (ver seção 1.6) -, o Plan de Ayala desconhece a liderança do então presidente e, em seu lugar, nomeia Pascual Orozco ou, alternativamente, Emiliano Zapata para cumprirem a função de liderar o movimento revolucionário até a vitória.

\footnotetext{
312 A íntegra do Plan de Tacubaya, de 31 de outubro de 1911, pode ser encontrada em: CARMONA, Doralicia. Memoria política de México. Guanajuato: Universidade de Guanajuato, 2014. http://www.memoriapoliticademexico.org/Textos/6Revolucion/1911PDT.html Consulta realizada em 21/11/2105

313 A íntegra do Plan de Ayala, publicado pelos zapatistas em 25 de novembro de 1911, pode ser consultada em: CARMONA, Doralicia. Memoria política de México. Guanajuato: Universidade de Guanajuato, 2014. http://www.memoriapoliticademexico.org/Textos/6Revolucion/1911PDA.html Consulta realizada em 21/11/2015.
} 


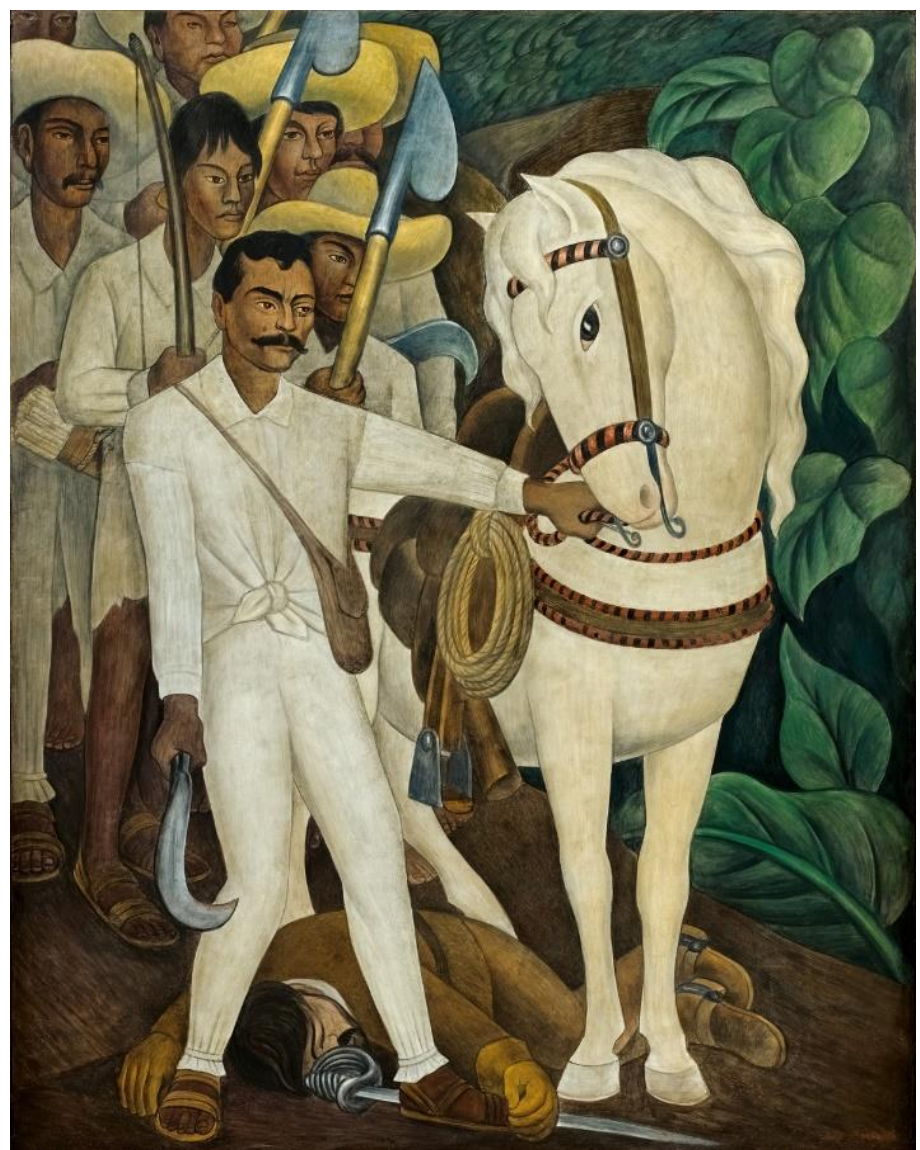

El líder campesino Zapata, 1931, Diego Rivera. Reprodução: www.moma.org

A exposição de motivos do Plan de Ayala é dedicada às razões políticas que levaram ao rompimento com Madero. Assim, nos textos dos próprios artigos que devem orientar a ação estão tanto o diagnóstico quanto as soluções possíveis para a concentração fundiária mexicana:

$6^{\circ}$. Como parte adicional del Plan que invocamos hacemos constar, que los terrenos, montes, y aguas que hayan usurpado los hacendados, científicos o caciques a la sombra de la tiranía y de la justicia penal entrarán en posesión de estos bienes inmuebles desde luego los pueblos o ciudadanos que tengan sus títulos correspondientes a esas propiedades, de las cuales han sido despojados, por la mala fe de nuestros opresores, manteniendo a todo trance con las armas en la mano la mencionada posesión, y los usurpadores que se consideren con derecho a ellos, lo deducirán ante tribunales especiales que se establezcan al triunfo de la Revolución.

$7^{\circ}$. En virtud de que la inmensa mayoría de los pueblos y ciudadanos mexicanos, no son más dueños que del terreno que pisan. Sufriendo los horrores de la miseria sin poder mejorar su condición social ni poder dedicarse a la industria o a la agricultura por estar 
monopolizados en unas cuantas manos las tierras, montes y aguas, por esta causa se expropiarán previa indemnización de la tercera parte de esos monopolios a los poderosos propietarios de ellos, a fin de que los pueblos y ciudadanos de México obtengan ejidos, colonias, fundos legales para pueblos o campos de sembradura o de labor, y se mejore en todo y para todo la falta de prosperidad y bienestar de los mexicanos.

$8^{\circ}$. Los hacendados, científicos, o caciques que se opongan directa o indirectamente al presente Plan, se nacionalizarán sus bienes y las dos terceras partes que a ellos les correspondan, se destinarán para indemnizaciones de guerra, pensiones de viudas y huérfanos de las víctimas que sucumban en la lucha del presente Plan.

$9^{\circ}$. Para ajustar los procedimientos respecto a los bienes antes mencionados, se aplicarán leyes de desamortización y nacionalización según convenga; pues de norma y ejemplo pueden servir las puestas en vigor por el inmortal Juárez, a los bienes eclesiásticos que escarmentaron a los déspotas y conservadores, que en todo tiempo han pretendido imponernos el yugo ignominioso de la presión y del retroceso.

Montes, águas e terras foram usurpadas por fazendeiros, científicos e, em geral, protegidos pelo regime político de Porfírio Díaz. O Plan de Ayala parte de uma constatação interessante: as grandes propriedades foram efetivamente constituídas, seria difícil voltar atrás. Depois de anos e anos de política demarcadora e distribuidora de terras, já não é tão fácil - como o texto do Plan de San Luís de Potosí parece supor ser identificar quais dessas terras foram conseguidas de forma legítima e quais não foram.

Mais eficaz do que tentar iniciar um processo de reconstituição de um passado que não voltará, o Plan de Ayala é o primeiro documento a propor uma reforma agrária partindo da organização fundiária mexicana de 1911.

Partindo desse diagnóstico, a solução se divide em duas partes. No art. $6^{\circ} \mathrm{o}$ plano prevê que aqueles "pueblos" (povoados), comunidades indígenas, que tenham títulos de propriedade concedidos no momento da colônia, ou mesmo em algum momento do México independente, devem tomar esses documentos e pleitear as terras que foram ilegalmente apropriadas por terceiros frente a tribunais especiais revolucionários ad hoc, ou seja, criados pela revolução especialmente para esse fim. As comunidades de camponeses e indígenas que estejam protegidas por títulos e documentos que comprovem seu direito a um quinhão de terra terão seus direitos respeitados por esse procedimento. 
A segunda solução proposta pelo Plan de Ayala, por sua vez, visa a responder a todas as comunidades e camponeses que não têm em mãos documentos de propriedade para fazer frente às grandes fazendas que se formaram sobre as terras que costumavam considerar suas. Para essa segunda situação, o Plan de Ayala propõe - seguindo um critério presente em muitos documentos normativos do século XIX - que um terço das terras dos grandes latifúndios mexicanos seja expropriada e distribuída a comunidades e pequenos proprietários. Nelas podem ser constituídas tanto propriedades coletivas "ejidos, fundos legales" - quanto pequenas propriedades individuais - colônias, campos de semeio e trabalho $\left(\operatorname{art} .7^{\circ}\right)$.

Ora, a dupla solução do Plan de Ayala é bastante interessante porque diagnostica que o problema agrário mexicano não se resolverá apenas promovendo a reconstituição de uma situação idílica vivida pelo México na metade do século XIX. Uma completa reorganização fundiária, que devolva terrenos injustamente tomados, sim, mas que também promova a pequena propriedade em locais que não necessariamente fossem antes ocupados pelas comunidades que cresceram, pois em uma sociedade que demanda maior produção de alimentos e gêneros agrícolas, seria necessária para reverter a concentração.

Os artigos $6^{\circ}$ e $7^{\circ}$ do Plan de Ayala respondem a esses dois problemas, próximos porque têm em comum a terra como bem apropriado e concentrado, mas diferentes. $\mathrm{O}$ plano segue com a determinação da pena para todos aqueles fazendeiros que se opuserem à sua realização: se 0 artigo $6^{\circ}$ prevê que dois terços das terras dos fazendeiros permaneceriam como sua propriedade, para aqueles que resistirem às medidas não restará nada: toda a terra será nacionalizada e distribuída àqueles que dela necessitem.

Por fim, os signatários do Plan de Ayala demonstram saber bem a história da regulação jurídica fundiária do México: invocam como fundamento para suas ações as leis de nacionalização e desamortização dos bens da Igreja (e das corporações civis) editadas por Benito Juárez em 1856 e 1859 (art. 9º). As leis, que iniciaram o processo que em muito prejudicou as comunidades indígenas - pois insurgiam-se contra qualquer propriedade coletiva e não só a religiosa - são invocadas aqui para reverter este mesmo processo. Os zapatistas pareciam saber que Benito Juárez, apesar de liberal e defensor de políticas que incentivavam o exercício individual do direito de propriedade, era um herói nacional. Invocar suas leis contra todo o aparato normativo criado por Porfírio 
Díaz (mais prejudicial e, principalmente, mais efetivo contra as comunidades indígenas) era, de alguma forma, um inteligente recurso simbólico. Mais do que fazer um elogio das normas liberais sobre terras - contraditórias com o objetivo de constituir "ejidos" e "fundos legales" para as comunidades, como estava previsto no artigo $7^{\circ}$ do Plan de Ayala - era trazer o próprio Benito Juárez e seu capital simbólico para lutar ao seu lado no embate ideológico que se travou ao longo da revolução.

O Plan de Ayala se encerra com a afirmação de que Madero teria traído a Revolução Mexicana e, a exemplo do Plan de Tacubaya, que os signatários "no somos personalistas, somos partidarios de los principios y no de los hombres". Pede, então, que o povo mexicano apoie a causa com suas armas, assinando com o lema "Justicia y ley.".

\subsubsection{Plan de Santa Rosa ${ }^{314}$, de 3 de fevereiro de 1912: o Estado como dono exclusivo das terras}

No Estado de Chihuahua, no momento e lugar em que o importante caudilho Francisco Villa continuava apoiando Francisco Madero em sua empreitada política, surge um grupo descontente com as decisões do recém-empossado governo. A exemplo dos signatários do Plan de Tacubaya e do Plan de Ayala, também os insurgentes do Plan de Santa Rosa acreditavam que Madero tinha traído a revolução que iniciara. Assim, abrem o documento afirmando que desejam o "triunfo definitivo del Plan de San Luís Potosî".

Em seu primeiro artigo, afirma o lema "Tierra y Justicia". O artigo $2^{\circ}$ traz uma formulação inusual para o momento histórico mexicano, afirmando que todo o território nacional deverá ser expropriado e declarado de utilidade pública. Com algumas poucas exceções (propriedades urbanas, cascos de fazendas, fábricas e terrenos de vias férreas), todas as terras do México seriam do Estado Mexicano "para siempre"315. O governo

\footnotetext{
${ }^{314}$ A íntegra do Plan de Santa Rosa, de 3 de fevereiro de 1912, pode ser encontrada em CARMONA, Doralicia. Memoria política de México. Guanajuato: Universidade de Guanajuato, 2014: http://www.memoriapoliticademexico.org/Textos/6Revolucion/1912-PSR.html Consulta realizada em $16 / 12 / 2015$.

${ }^{315}$ Lê-se no artigo $2^{\circ}$ do Plan de Santa Rosa: “2. Se decretará, por causa de utilidad pública previas las formalidades legales, la expropiación del Territorio Nacional, exceptuándose la superficie ocupada por las fincas urbanas, los edificios que constituyen lo que generalmente se llama cascos de haciendas, fábricas y
} 
teria então a responsabilidade de ceder as terras de sua propriedade a arrendatários que tivessem intenção de cultivá-las pessoalmente. Apesar da nacionalização e extinção da propriedade privada de todas as terras do território mexicano, a proposta do Plan de Santa Rosa parte de uma concepção individual do usufruto da terra: os terrenos deveriam ser cedidos a pessoas, que juntamente com suas famílias seriam responsáveis por cultivá-los. Não haveria, assim, cessão para formas coletivas de usufruto da terra. Dias após a publicação do documento, um esclarecimento firmado pelos mesmos autores do Plan de Santa Rosa veio a público: dizia respeito exatamente à forma de arrendamento proposta pelo artigo $2^{\circ}$. No texto visando a eliminar as dúvidas lia-se que “'La posesión de los arrendatarios que hagan uso de los terrenos agrícolas de la propiedad nacionalizada pasará de padres a hijos a todas las generaciones venideras". Apesar de precária e sem título de propriedade, a posse dos terrenos que pertenceriam à nação passariam, segundo a proposta formulada, hereditariamente, permanecendo na família.

Em 3 de fevereiro de 1912, o plano foi publicado. O pequeno impacto militar alcançado pelo grupo que se organizou em torno do documento, porém, fez com que nem ele, nem aqueles que o defendiam obtivessem reconhecimento histórico. Vale dizer que esse é um dos planos menos mencionados do processo revolucionário, apesar de sua intrigante proposta de reorganização agrária.

ranchos y los terrenos de las vías férreas. El Gobierno será para siempre dueño exclusivo de las tierras y las rentará únicamente a todos los que las soliciten en la proporción en que puedan cultivarlas personalmente y con los miembros de su familia, los terrenos pastales serán igualmente rentados a los particulares, procurando que su distribución corresponda a los fines de equidad que persigue el inciso anterior." em CARMONA, Doralicia. Memoria política de México. Guanajuato: Universidade de Guanajuato, 2014: $\quad$ http://www.memoriapoliticademexico.org/Textos/6Revolucion/1912-PSR.html Consulta realizada em 16/12/2015. 


\subsubsection{Plan de la Empacadora e Manifesto de Pascual Orozco ${ }^{316}$, de 8 e 25 de março de 1912: deslegitimados pela história}

Pascual Orozco foi importante líder militar da campanha maderista, tendo atuado na região norte do país, sobretudo no Estado de Chihuahua. A exemplo do grupo político ligado aos irmãos Vázquez Gómez e dos zapatistas, Pascual Orozco demonstrou insatisfação com as decisões políticas de Francisco Madero. Além disso, antes da publicação de seus documentos de março, já no artigo $3^{\circ}$ do Plan de Ayala, os zapatistas nomeiam-no como seu líder revolucionário e, apenas caso ele não aceitasse a incumbência, Emiliano Zapata deveria assumir.

Em março de 1912, Pascual Orozco rompe definitivamente com Francisco Madero. No primeiro documento que publica, em 8 de março, tece inúmeras considerações sobre por que Francisco Madero não havia cumprido as promessas formuladas no Plan de San Luís Potosí, e, como consequência, por que não deveria mais ser digno de confiança política:

El Plan de San Luis Potosí, cuyas promesas enardecieron a los desheredados e hicieron soñar a tantas víctimas del despojo autoritario en una reivindicación efectiva y próxima; el Plan de San Luis Potosí que ofrecía solucionar el problema agrario en provecho del pueblo, distribuyendo tierras, castigando usurpaciones e impartiendo justicia a los expoliados por el abuso del poder; ese plan famoso que fue la bandera de la rebelión en los días difíciles y terribles en la lucha, fue relegado al olvido tan pronto como Madero alcanzó la Presidencia; los grandes expoliadores del pueblo en la dictadura porfiriana, los Terrazas, los Creel, los Iñigo Noriega, conquistaron fácilmente el favor del nuevo Gobierno, y los humildes, aunque heroicos defensores de la libertad, los que elevaron con su esfuerzo y su sacrificio esta nueva administración, tan pronto corrompida y desquiciada, quedaron en la misma situación de miserables y oprimidos, sin ver realizada la distribución de las tierras ni verificado el castigo de las usurpaciones.

\footnotetext{
${ }^{316}$ A íntegra do Manifesto redigido por Pascual Orozco em 8 de março de 1912 e a íntegra do Plan de la Empacadora, também de Orozco, de 25 de março de 1912 podem ser consultados em: CARMONA, Doralicia. Memoria política de México. Guanajuato: Universidade de Guanajuato, 2014. http://www.memoriapoliticademexico.org/Textos/6Revolucion/1912-M-PO.html e http://www.memoriapoliticademexico.org/Textos/6Revolucion/1912MPO.html Consulta realizada em 21/11/2015.
} 
Além das denúncias sobre a falta de compromisso de Madero em relação à sua promessa pública feita em outubro de 1910, Orozco acusa o então presidente de uma série de outros abusos de poder e submissões a interesses privados e estrangeiros. Os documentos de Orozco talvez corporifiquem a crítica mais virulenta dirigida a Madero. Entre as críticas formuladas, uma das principais é exatamente sua falta de compromisso e empenho para resolver a questão agrária mexicana.

Se o manifesto publicado no dia 8 de março apresentava um diagnóstico sobre a situação do México naquele início de 1912, bem como as razões de rompimento de Orozco com Madero, o Plan de la Empacadora, de 25 de março do mesmo ano, apresenta as propostas capazes de agregar adeptos para o combate que o general pretendia iniciar. Entre essas propostas, algumas diziam diretamente respeito à situação fundiária mexicana:

Art. 35 - Siendo el problema agrario en la República el que exige más atinada y violenta solución, la Revolución garantiza que desde luego se procederá a resolverlo, bajo las bases generales siguientes;

I. Reconocimiento de la propiedad a los poseedores pacíficos por más de veinte años.

II. Revalidación y perfeccionamiento de todos los títulos legales.

III. Reivindicación de los terrenos arrebatados por despojo.

IV. Repartición de todas las tierras baldías y nacionalizadas en toda la República.

V. Expropiación por causa de utilidad pública, previo avalúo, a los grandes terratenientes que no cultiven habitualmente toda su propiedad; y las tierras así expropiadas se repartirán para fomentar la agricultura intensiva.

VI. A fin de no gravar el Erario, ni echar mano de las reservas del Tesoro, ni mucho menos aumentar con empréstitos en el extranjero la deuda exterior de la Nación, el Gobierno hará una emisión especial de bonos agrícolas para pagar con ellos los terrenos expropiados, y pagará a los tenedores el interés del 4 por ciento anual hasta su amortización. Esta se hará cada 10 años con el producto del pago de las mismas tierras repartidas con el que se formará un fondo especial destinado a dicha amortización.

VII. Se dictará una Ley Orgánica Reglamentaria sobre la materia.

A primeira norma determina que deveria ser conferido título de propriedade à posse pacífica por mais de vinte anos. Seu potencial impacto positivo reside no fato de 
regularizar o título de terras ocupadas por comunidades ou possuidores há muito tempo. Sua efetividade, porém, depende de quais formas forem admitidas para provar a existência da posse pacífica e do órgão competente para decidir sobre a existência ou não da condição de titulação: muitos documentos indicam que o Poder Judiciário mexicano não era muito confiável para a proteção dos desfavorecidos economicamente.

Seja como for, o documento de Orozco é o primeiro a propor a solução de reconhecer a propriedade àqueles que detém a posse pacífica prolongada, como muitos ordenamentos jurídicos posteriores vieram a consolidar por meio do instituto jurídico do usucapião. Associado ao reconhecimento dos terrenos ainda em posse de pessoas e comunidades, Orozco propõe que nos terrenos em que houve despojos injustificáveis, realize-se a reivindicação, ou seja, o retorno da posse - e posteriormente também o reconhecimento do título de propriedade - a seus antigos e legítimos possuidores.

Tal como no Plan de Ayala, o Plan de la Empacadora não se restringe a uma volta ao passado. Para a questão agrária propõe que, além da restituição de terra àquelas comunidades e pessoas que foram despojadas, propõe também a repartição de latifúndios que, quando não fossem produtivos em toda sua extensão, deveriam ser expropriados, além de propor o fracionamento de terrenos "baldios" e terras nacionalizadas.

Última inovação do Plan de Pascual Orozco, foi a forma de pagamento para os grandes detentores de terras que fossem expropriados: ao invés do pagamento à vista, a criação de "bonos agrícolas", ou títulos de dívidas agrária do Estado Mexicano. Esse pagamento do montante principal postergado permitiria que expropriações fossem feitas em quantidade maior do que a que o orçamento do Estado teria à disposição para pagamento à vista.

Seja em relação ao reconhecimento formal, por meio de título de propriedade da posse prolongada e pacífica; seja em relação ao pagamento das expropriações com "bonos agrícolas", as propostas de Orozco para a melhor distribuição de terras no México são interessantes: enfrentam o problema dos despojos feitos injustamente e também da extrema concentração fundiária promovida por diversas políticas.

Aquele que havia sido indicado pelo Exército Libertador do Sul zapatista para liderá-los, e que possuía propostas interessantes para o problema agrário mexicano, 
escolheu seu lado na história em fevereiro de 1913: na Decena Trágica participou do golpe militar contra Madero.

Em manifesto de 4 de março de $1913^{317}$, Zapata afirma que Victoriano Huerta era um usurpador do poder, que havia agido de maneira vil com a intenção de tomar o poder do presidente eleito. Se Madero havia traído a causa revolucionária e merecia ser destituído, Huerta estava em uma posição ainda pior segundo os zapatistas: não havia nenhum indício de que faria avançar qualquer solução razoável da questão agrária e, somado a isso, baseava seu exercício do poder não no voto popular, mas em um golpe de estado ilegítimo. Meses mais tarde, em 30 de maio do mesmo 1913, os zapatistas desconstituíam Pascual Orozco do posto que o Plan de Ayala original havia lhe atribuído e nomeavam Emiliano Zapata como chefe do Ejército Libertador del Sur ${ }^{318}$. A participação no golpe de Victoriano Huerta durante a Decena Trágica tirou de Pascual Orozco qualquer legitimidade como formulador consequente de políticas sociais.

\subsection{Presidência de Francisco Madero: resposta insatisfatória para o principal problema mexicano - o Relatório da Comissão Nacional Agrária ${ }^{319}$, de 7 de fevereiro de 1912}

Os irmãos Vázquez Gómez, os zapatistas, os signatários do Plan de Santa Rosa e Pascual Orozco estavam corretos em seus diagnósticos: Madero não considerava prioritário o avanço no sentido da distribuição mais justa das terras mexicanas. Ao menos no início do mandato, concentrava-se nas tentativas de estabilização política do país.

Francisco León de la Barra, em sua presidência interina, organizou em setembro de 1911 uma Comisión Nacional Agraria ${ }^{320}$, que teria por objetivo estudar e propor

\footnotetext{
${ }^{317}$ Manifesto de Emiliano Zapata, de 4 de março de 1913. Em CARMONA, Doralicia. Memoria política de México. Guanajuato: Universidade de Guanajuato, 2014.

<http://www.memoriapoliticademexico.org/Textos/6Revolucion/1913-M-ZEDGH.html> Consulta realizada em 23/11/2015.

318 Reformas ao Plan de Ayala, de 30 de maio de 1913. Em: MÉXICO. Secretaria de Gobernación: Unidade General de Asuntos Jurídicos. http://www.ordenjuridico.gob.mx/Constitucion/CH9.pdf Consulta realizada em 12/01/2016.

${ }^{319}$ A íntegra do relatório da Comisión Nacional Agraria, de 7 de fevereiro de 1912, está em: CARMONA, Doralicia. Memoria política de México. Guanajuato: Universidade de Guanajuato, 2014. http://www.memoriapoliticademexico.org/Textos/6Revolucion/1912-PD-CNA.html Consulta realizada em 02/01/2016.
} 
soluções para o problema agrário mexicano. Ao assumir a presidência em novembro de 1911, Francisco Madero reiterou a importância dos estudos que estavam sendo feitos pela comissão, decidindo esperar até que os primeiros resultados fossem apresentados para tomar decisões a respeito das terras. A existência da comissão postergou qualquer intervenção política relacionada ao tema, contrariando o diagnóstico de parte daqueles que lutaram a seu lado para a destituição de Porfírio Díaz, que consideravam o problema urgente e demandante de ações imediatas, tão logo a revolução fosse vitoriosa.

Constituída a Comissão Nacional Agrária, ela produziu seu primeiro relatório em 7 de fevereiro de 1912. Seu texto final e os problemas que ele se propõe a enfrentar aproximam-no mais dos documentos normativos do século XIX, que tratavam da colonização e das companhias responsáveis por demarcar e fracionar as terras, do que uma resposta para o país que se insurgiu contra as arbitrariedades e injustiças realizadas no campo.

As propostas do documento se concentram em alguns eixos: forma de realização do fracionamento e demarcação de terrenos "baldios" (fracionamento que poderia ser realizado por meio de empresas contratadas, segundo a proposta); formas de promoção da irrigação em áreas nas quais a agricultura era difícil em virtude da aridez da região; formas de venda dos terrenos fracionados para nacionais e estrangeiros (o texto mantém uma preocupação com o estímulo à vinda de estrangeiros para o país); estímulos à implantação de colônias. Não há qualquer menção aos "ejidos". às propriedades coletivas e à reversão de despojos injustos. O texto e suas propostas não fazem

\footnotetext{
${ }^{320}$ É o próprio Francisco Madero, em seu primeiro informe à XXV Legislatura do Congresso Nacional Mexicano que reconhece ter sido Francisco León de la Barra o responsável por organizar a Comissão Nacional Agrária, em setembro de 1911. Segundo o texto de Madero, essas eram as funções previstas para a Comissão: "En el Mensaje de 16 de septiembre próximo pasado[1911], el ciudadano Presidente interino anunció al Congreso la organización de una comisión especial que propondría los medios más adecuados para llevar a cabo el riego, fraccionamiento y colonización de tierras. La Comisión debidamente organizada con el nombre de Comisión Nacional Agraria, integrada por personal de notoria competencia y animado de alto espíritu de civismo, ha terminado la primera serie de sus labores relacionadas con el problema de la pequeña propiedad y ha propuesto las medidas de mayor urgencia para la solución de este importante asunto. Merecen especial mención, entre esos trabajos, el programa y dictamen de la Comisión sobre conservación y fomento de bosques, reglamentación del uso de las aguas, colonización, etc., de 7 de febrero próximo pasado. Actualmente estudia la Comisión, en sus detalles, diversas proposiciones hechas al Gobierno para adquirir grandes predios rústicos, propios para el cultivo, en donde pueden establecerse agricultores en pequeño, mediante adecuado fraccionamiento." Informe de Madero à XXV Legislatura do Congresso Nacional Mexicano de $1^{\circ}$ de abril de 1912. disponível em: BIBLIOTECA GARAY. 500 años de México en documentos. México, 2011. $<$ http://www.biblioteca.tv/artman2/publish/1912 213/Informe_de_Francisco_I_Madero_pronunciado_ant e la 99.shtml> Consulta realizada em 02/01/2015.
} 
referência à promessa realizada no Plan de San Luís Potosí. O intuito do documento parece ser, tal como no período pós-independência, ocupar e organizar um território sobre o qual não há disputa por terras e que demanda aumento populacional para a garantia da soberania nacional.

Criar pequenas propriedades que, depois de fracionadas e demarcadas, seriam vendidas pelo governo a mexicanos e estrangeiros parece ser o grande objetivo da Comisión Nacional Agraria. Lê-se ao longo do documento:

La experiencia confirma que la colonización artificial expondría a graves fracasos, y la inducción demuestra que es preferible procurar que la inmigración venga por los caminos naturales.

(...) conviene que el Gobierno emprenda desde luego las obras ya estudiadas, en vía de estudio, o que se presenten como factibles, sin perjuicio de que se haga un estudio completo de los recursos naturales que el país ofrece, para formar el plan definitivo de otras, el que se desarrollará a medida que lo permitan los elementos disponibles, respetando, en todos casos, los derechos adquiridos. (...)

El Gobierno deberá preferentemente dedicar los fondos de que puede disponer, al mejoramiento de los terrenos nacionales y a la adquisición y mejora de los terrenos de propiedad particular, susceptibles de riego y cultivo, que pueda adquirir a un precio que no exceda de veinticinco pesos (\$25.00) por hectárea.(...)

Concluidas las obras necesarias para el éxito del fraccionamiento, los lotes no deberán ser cedidos gratuitamente, sino enajenados a los labradores que dispongan de un pequeño capital, ó que por su moralidad y aptitudes se lo puedan proporcionar, para la compra de animales de trabajo, herramientas y, en general, de todos los recursos indispensables para que puedan desde luego dedicarse a la explotación del lote que adquieran.

Em fevereiro de 1912, enquanto o país saía de uma insurreição armada que tinha por fundamento um mal-estar social no campo, soam absolutamente anacrônicas as preocupações da Comisión Nacional Agrária com incentivos à vinda de estrangeiros, a compra de terrenos baratos como prioridade para a realização dessa redistribuição de terras e a exigência de que os terrenos fracionados sejam vendidos para indivíduos. A solução proposta passa longe de enfrentar o problema dos despojos das propriedades comunitárias dos "pueblos" mexicanos, usufruídas coletivamente. Nesse sentido, é ainda mais grave - e contraditória com a afirmação do art. $3^{\circ}$ do Plan de San Luís Potosí - a menção sobre o respeito aos direitos adquiridos. Deveriam ser respeitados os 
direitos adquiridos ilegitimamente, por sobre títulos de posse e propriedade detidos pelos "pueblos"? Deveriam ser respeitados os direitos adquiridos quando o Plan de San Luís Potosí, que levou Madero à presidência, afirmava ser "de toda justicia restituir a sus antiguos poseedores los terrenos de que se les despojó de un modo tan arbitrario" ${ }^{321}$ ?

Segundo a Comisión Nacional Agraria, o governo poderia celebrar, ainda, contratos com empresas privadas ${ }^{322}$ que realizassem o fracionamento dos terrenos em seu nome. Como forma de pagamento para os serviços prestados por essas empresas privadas, a comissão sugere ser possível "La cesión gratuita de los terrenos nacionales de que el Gobierno puede disponer".

As propostas da comissão apresentadas em 7 de fevereiro de 1912 parecem variações sobre os mesmos objetivos e formas praticados ao longo do século XIX, acrescidos de uma intensa preocupação com formas de valorizar por meio de técnicas avançadas de irrigação e tornar cultiváveis terrenos onde, antes, a agricultura se mostrava inviável. Desconsideram, portanto, as enormes mudanças sociais vividas pelo México desde o final do século XIX com a intensificação da política de Díaz e, sobretudo, pelo processo revolucionário que havia apresentado suas próprias propostas de reorganização fundiária.

Francisco Madero, por sua vez, edita o primeiro documento normativo de seu governo sobre terras dias depois, em 24 de fevereiro de 1912, seguindo as orientações da Comissão Nacional Agrária, com algumas modificações. Quer promover demarcação e fracionamento de terrenos "baldíos" ou nacionais. É também o artigo $3^{\circ}$ do documento de Madero que afirma "Al verificarse los deslindes, se tendrá especial cuidado de respetar las propiedades legítimamente adquiridas o poseídas" ${ }^{\text {323 }}$. Para

\footnotetext{
321 A íntegra do Plan de San Luís Potosí, de 5 de outubro de 1910, pode ser consultada em: http://www.memoriapoliticademexico.org/Textos/6Revolucion/1910PSL.html Consulta realizada em 31/10/2015.

322 "El Gobierno podrá celebrar contratos para fraccionamiento de terrenos con particulares nacionales y extranjeros, ó con sociedades nacionales. Estos contratos se sujetarán a las siguientes bases: $1^{\mathrm{a}}$ Los particulares ó Compañías acreditarán, a satisfacción del Gobierno, que tienen la capacidad financiera necesaria para realizar los trabajos que traten de llevar a cabo, ó que pueden procurarse por medio de préstamos, con ó sin emisión de bonos hipotecarios, las sumas de dinero indispensables para el mismo objeto." A íntegra do relatório da Comisión Nacional Agraria, de 7 de fevereiro de 1912, em: http://www.memoriapoliticademexico.org/Textos/6Revolucion/1912-PD-CNA.html Consulta realizada em 02/01/2016.

${ }^{323}$ A íntegra do Decreto de 24 de fevereiro de 1912, para el deslinde de tierras, sancionado por Francisco Madero. Em: CARMONA, Doralicia. Memoria Política de México. México: Universidade de
} 
todos os efeitos, as propriedades constituídas e as posses de fato deveriam ser respeitadas no novo processo de demarcação, fracionamento e venda dos terrenos que Madero visava impulsionar.

O artigo $7^{\circ}$ do decreto de Madero estipula 200 hectares como o tamanho máximo dos terrenos que seriam vendidos. Além disso, afirma que tais terrenos só poderão ser vendidos a mexicanos, e estalece um preço por hectare em cada um dos estados mexicanos. Ao contrário do documento da Comissão Nacional Agrária, o decreto de Madero não ignora a questão dos "ejidos":

Art. 15. A los indígenas de los pueblos que carezcan de ejidos y se hallen en las inmediaciones de los terrenos a que aluden los artículos $6^{\circ}$ y $7^{\circ}$, se les proporcionarán los lotes que necesiten para su subsistencia y la de sus familias.

Art. 16. El Gobierno podrá destinar también parte de los terrenos ya mencionados, a objetos de colonización o a otros fines de interés público, conforme a las leyes respectivas. ${ }^{324}$

Para além de vender pequenas propriedades a mexicanos interessados, os terrenos nacionais ou "baldios" de que trata o decreto também poderiam ser cedidos a "pueblos"ou destinados a outras utilidades públicas que o governo julgasse conveniente. $\mathrm{O}$ decreto de Madero elege como destinatários das pequenas propriedades os próprios mexicanos, não havendo - ao contrário do documento da Comisión Nacional Agraria - nenhuma menção a estrangeiros. Além disso, prevê que as terras podem ser cedidas - e não vendidas - em forma de "ejidos". No mais, estabelece os procedimentos de demarcação, fracionamento das terras de que trata, as condições e os valores para a venda, os créditos agrícolas que seriam concedidos, as possibilidades e os valores para o arrendamento das terras cedidas. Um pouco mais alinhado com as demandas da realidade mexicana de 1912, ainda assim o decreto de Madero não respondeu às demandas das comunidades camponesas.

No informe de $1^{\text {o }}$ de abril de 1912, Francisco Madero afirma que os zapatistas de Morelos não tinham razão em relação a algumas de suas demandas por terras. Dado que

Guanajuato, 2014. http://www.memoriapoliticademexico.org/Textos/6Revolucion/1912DDT.html Consulta realizada em 02/01/2016.

${ }^{324}$ A íntegra do Decreto de 24 de fevereiro de 1912, para el deslinde de tierras, sancionado por Francisco Madero. Em: CARMONA, Doralicia. Memoria Política de México. México: Universidade de Guanajuato, 2014. http://www.memoriapoliticademexico.org/Textos/6Revolucion/1912DDT.html Consulta realizada em 02/01/2016. 
Madero considera que as queixas dos morelenses não eram legítimas, e que eles escolheram o caminho da violência para lutar por elas, "ha sido necesario combatir por la fuerza de las armas, ya que los medios de persuasión [...] no alcanzaron el resultado apetecido" ${ }^{325}$. Depois de elogiar os trabalhos da Comissão Nacional Agrária, afirma ser seu principal objetivo para a reorganização fundiária mexicana: "Si de los distintos trabajos antes relacionados se obtiene, corno es de esperarse, el resultado que busca el Ejecutivo, pronto aumentará en gran escala el número de las pequeñas propiedades ${ }^{\sharp 26}$. Transformar o México em um país de pequenas propriedades individuais, e não reparar as injustiças históricas praticadas principalmente contra as propriedades coletivas dos “pueblos”, era a principal ambição de Madero.

Não obstante, talvez por estar insatisfeito com a composição da Comisión Nacional Agraria, em abril de 1912 o então presidente decide criar uma Comisión Agraria Ejecutiva. Seu objetivo era, nas palavras do próprio Francisco Madero, no informe ao Congresso Nacional de 16 de setembro de 1912: "poner en práctica las conclusiones de la Comisión Nacional Agraria; indicando las resoluciones que convengan, e indicar las medidas que juzgue oportunas y que tiendan a facilitar los propósitos del Gobierno para la más pronta y eficaz resolución del problema agrario de la Nación" ${ }^{327}$. Comissão Nacional Agraria e Comissão Agrária Executiva tinham, em alguma medida, competências que se sobrepunham.

Foi a Comisión Nacional Agraria, porém, que em abril do mesmo ano de 1912 formulou uma proposta de reconstituição da propriedade coletiva dos "pueblos" mexicanos, os "ejidos" "328. A proposição exposta em um relatório, porém, só se tornou

${ }^{325}$ Informe de Madero à XXV Legislatura do Congresso Nacional Mexicano de $1^{\circ}$ de abril de 1912.disponível em: BIBLIOTECA GARAY. 500 años de México en documentos. México, 2011. $<$ http://www.biblioteca.tv/artman2/publish/1912_213/Informe_de_Francisco_I_Madero_pronunciado_ant e_la_99.shtml> Consulta realizada em 02/01/2015.

326 Informe de Francisco Madero ao Congreso Mexicano, em $1^{\circ}$ de abril de 1912, disponível em: BIBLIOTECA GARAY. 500 años de México en documentos. México, 2011. $<$ http://www.biblioteca.tv/artman2/publish/1912_213/Informe_de_Francisco_I_Madero_pronunciado_ant e la_99.shtml> Consulta realizada em 02/01/2015.

327 Informe de Francisco Madero ao Congreso Mexicano, em 16 de setembro de 1912, disponível em: CARMONA, Doralicia. Memoria política de México. Guanajuato: Universidade de Guanajuato, 2014 < http://www.memoriapoliticademexico.org/Textos/6Revolucion/1912-FM-C.html >. Consulta realizada em 02/01/2016.

${ }^{328}$ Lê-se no documento da Comisión Nacional Agraria, de abril de 1912: "'La reconstitución de los ejidos bajo la forma comunal, con su carácter de inalienable, además de las razones que en su apoyo se acaban de señalar, subsana ciertas dificultades que conviene tomar en cuenta, por que son muy importantes. (...)en quinto lugar en la gran masa de población que solicita tierras, la mayoría de los componentes carece de aptitudes para ser propietarios y cumplir compromisos personales, mientras que sí cumplirá los que contraiga colectivamente, y la explotación de terrenos comunales se hará en una forma tal, que sólo disfruten de ellos los que sean trabajadores, los que cultiven y utilicen debidamente las parcelas que les 
pública em novembro do mesmo ano, não tendo sido colocada em prática ou transformada em qualquer ato normativo pelo governo ${ }^{329}$. Os efeitos práticos positivos que poderiam advir da adoção das recomendações do relatório não foram percebidos simplesmente porque não foram implementados.

Luís Cabrera, em discurso que será analisado na seção 2.4.2, afirma ter ido ao governo de Francisco Madero expor sua opinião sobre a importância da ação estatal de reconstituição dos "ejidos" para que diminuísse o mal-estar e a tensão no campo mexicano. Afirma Cabrera: "no dejé de procurar auscultar la opinión del Poder Ejecutivo acerca de la buena disposición en que estuviese para emprender estas reformas; y debo aclarar con franqueza que no encontré esa buena disposición de parte del Ejecutivo" ${ }^{330}$. Talvez por isso o relatório da Comisión Nacional Agraria, no mesmo sentido do projeto de lei de Luis Cabrera, tenha ficado em segredo e sem efeitos ao longo de 1912, único ano completo em que Francisco Madero esteve à frente da presidência da República. Já no início de fevereiro, ele não teria mais o Estado para colocar em prática suas próprias convicções sobre a melhor forma de organizar a propriedade da terra no México.

correspondan". Em discurso de Luís Cabrera de 3 de dezembro de 1912, frente à XXV Legislatura do Congresso Nacional. CARMONA, Doralicia. Memoria Política de México. México: Universidade de Guanajuato, 2014. <http://www.memoriapoliticademexico.org/Textos/6Revolucion/1912REP.html>. Consulta realizada em 02/01/2015.

${ }^{329}$ Tanto a existência do relatório da Comisión Nacional Agraria de abril de 1912 quanto o fato de ela só ter sido divulgada em novembro são fatos citados por Luis Cabrera, deputado, em discurso que expõe seu projeto de lei sobre ejidos, realizado em 3 de dezembro de 1912. "Desde el mes de abril a acá, el Secretario de Fomento había recibido iniciativas de la Comisión Agraria en el sentido de la reconstitución de los ejidos y de la resurrección o restablecimiento de la propiedad comunal. La Secretaría de Fomento no había creído conveniente, sin embargo, tomar en cuenta estas medidas, y hasta la fecha no ha recibido esta Cámara de Diputados ninguna iniciativa de esa Secretaría que muestre siquiera que estaba dispuesta a acometer las cuestiones agrarias." A íntegra do discurso de Luís Cabrera em 3 de dezembro de 1912, para a XXV Legislatura do Congresso Nacional está em: CARMONA, Doralicia. Memoria Política de México. México: Universidade de Guanajuato, 2014.

$<$ http://www.memoriapoliticademexico.org/Textos/6Revolucion/1912REP.html $>$. Consulta realizada em $02 / 01 / 2015$

${ }^{330}$ A íntegra do discurso de Luís Cabrera em 3 de dezembro de 1912, para a XXV Legislatura do Congresso Nacional está em: CARMONA, Doralicia. Memoria política de México. Guanajuato: Universidade de Guanajuato, 2014.

$<$ http://www.memoriapoliticademexico.org/Textos/6Revolucion/1912REP.html $>$. Consulta realizada em $02 / 01 / 2015$. 


\subsubsection{Projeto de reforma constitucional de Juan Sarabia, de 24 de outubro de $1912^{331}$ : a relativa legalidade dos despojos agrários injustos}

Juan Sarabia, membro fundador do Partido Liberal Mexicano, era deputado sensível aos problemas agrários de seu país. $\mathrm{Na}$ exposição de motivos de sua proposta de alteração constitucional, afirma em dois momentos distintos que "hay una cuestión fundamental, la agraria, como causa de la revolución de 1910" e também que "El problema fundamental que la revolución de 1910 tiene todavía por resolver, es indudablemente el de la cuestión agraria".

Revolução Mexicana e mal-estar social entre os camponeses mexicanos estavam intrínsecamente ligados, segundo seu texto. Juan Sarabia propõe então um diagnóstico e um projeto normativo para a reversão do cenário nefasto causador da revolução. Segundo o deputado, três seriam as causas para as tensões no campo, duas delas legislativas. Identifica um problema na legislação sobre terrenos "baldios" mexicana, mais especificamente na lei de 20 de julho de 1863; um problema na lei da reforma que proíbe corporações civis de serem titulares de títulos de propriedade (Ley Lerdo, de 25 de junho de 1856) e, por fim, um problema fático: a forma como a ditadura de Porfírio Díaz interpretou os dispositivos normativos e realizou expoliações sem qualquer preocupação com as condições de vida dos camponeses.

Liberal, Juan Sarabia afirma ser um admirador das políticas da Reforma - e de seus promotores, Sebastián Lerdo de Tejada e Benito Juárez entre eles. Apesar disso, não se exime de criticar algumas características da legislação produzida pelos liberais da metade do século XIX. Segundo ele, a lei sobre colonização de terrenos "baldíos", de 1863, sofre do mesmo defeito da lei elaborada por Porfírio Díaz em 1894: privilegia os títulos formais que comprovariam a propriedade da terra em detrimento de situações de posse prolongada. Em defesa dos liberais, porém, afirma que a lei de 1863 foi feita em uma circunstância política excepcional: com o país atacado por exércitos estrangeiros, o Estado precisava de dinheiro para financiar seu esforço militar de defesa. O que era excepcional em 1863 tornou-se norma amplamente utilizada, com efeitos

\footnotetext{
331 Íntegra da proposta de reforma constitucional e discurso apresentado à XXVI Legislatura do Congreso Nacional Mexicano em 24 de outubro de 1912 está em: BIBLIOTECA GARAY. 500 años de México en documentos. México, 2011. <http://www.biblioteca.tv/artman2/publish/1912_213/Proyecto_sobre_Cuesti_n_Agraria_presentado_a_la _XX_103_printer.shtml> Consulta realizada em 04/01/2016.
} 
verdadeiramente nefastos. Juan Sarabia descreve de maneira sensata o confronto entre posse pacífica prolongada de comunidades e indivíduos e a necessidade - imposta pela lei - de apresentação de títulos formais de propriedade. Sem eles, as terras ocupadas por longos períodos, em posse pacífica, eram declaradas "baldios", demarcadas e revendidas a terceiros:

\begin{abstract}
Había muchas comunidades, sobre todo de indígenas o personas particulares, que venían poseyendo de tiempo atrás de una manera pacífica, reconocida por todo el público, esos terrenos, y a nadie se le había ocurrido poner en duda la legitimidad de esa propiedad en el pueblo donde ella se tenía; todos los vecinos reconocían que Fulano de tal era propietario de tal o cual parcela de terreno, porque desde tiempo inmemorial habían venido viendo que esa familia poseía dicho terreno y que se pasaba de padre a hijo en herencia perfectamente natural y legítima; y sin embargo, con este articulo de ley de baldíos, se presentaba un favorito del general Díaz y decía: «Denuncio el terreno de Fulano»; se le exigían a aquel desventurado los títulos primordiales, no los tenía, y no bastaba la fama pública, no bastaba la posesión -no digo de decenas de años que marca la ley, sino de centenares de años-, para que se le respetara a aquel desgraciado su propiedad, sino que se le arrojaba de ella, y el favorito venía y se quedaba con la propiedad que era del pobre ciudadano independiente que carecía de amparo en el Gobierno.
\end{abstract}

Se adiciona la Constitución con los siguientes artículos de materia agraria:

O erro inicial promovido pela lei de 1863, ao considerar como "baldios" todos os terrenos que não possuíssem títulos de propriedade, se propagou e difundiu com a prática porfirista de implementar e aplicar a regra a todo o território mexicano. Segundo Sarabia, soma-se ao equívoco dessa norma outro documento normativo produzido pela Reforma: a Ley Lerdo, que em 25 de junho de 1856 proibia que qualquer corporação civil tivesse ou administrasse propriedades. Sarabia afirma, no entanto, a correção da decisão dos liberais em proibir propriedades da Igreja Católica. Repudia, porém, sua projeção e validade também para os "pueblos" e comunidades agrárias indígenas e mestiças. A norma restritiva foi repetida no artigo 27 da Constituição de 1857, de forma a limitar ainda mais os bens que excepcionalmente os "pueblos" poderiam manter para suas atividades essenciais (apenas poderiam manter e adminsitrar edifícios usados diretamente para os serviços e objetivos da instituição). Encerrou-se, por meio da lei, 
uma prática de manutenção de propriedades coletivas detidas e administradas pelos "pueblos", 332 .

Legislação liberal com concepções e propostas equivocadas para reorganização fundiária, segundo Sarabia, se somaram a uma prática autoritária, patrimonialista e nãorepublicana do governo de Porfírio Díaz, que usou esses instrumentos para favorecer e enriquecer aqueles que estavam próximos ao poder. Esse é o diagnóstico de Juan Sarabia para o que considera ser a principal causa da Revolução Mexicana. Dado o cenário, parecia-lhe natural que os injustiçados ficassem ao lado daquele que se insurgiu contra o governo que promoveu as injustiças.

Talvez o mais interessante do diagnóstico de Sarabia seja ele chamar atenção para o fato de que esses processos tenham sido fundamentados em normas das leis que cita. Ou seja, embora nefastos e equivocados, os processos tiveram fundamento legal ou ao menos uma aparência de legalidade - já que defendiam que a lei de 1863 deveria ter sido usada apenas no momento excepcional que o Estado Mexicano vivia até 1867. Afirma, por exemplo, que os descontentes "habiendo perdido su propiedad, habiendo sido despojados en una forma más o menos hábil, más o menos legal”; e que, embora haja "ciertas apariencias de legalidad en esas ventas, el hecho es que ese pueblo no tiene tierras, que actualmente ese pueblo está sufriendo hambre porque no tiene tierras".

\footnotetext{
332 Juan Sarabia expõe as consequências da decisão de impedir que corporações civis mantivessem propriedades coletivas: "De allí resulta que muchos pueblos de indígenas de la República que habían estado acostumbrados a la posesión, en comunidad, de los ejidos de su pueblo, por virtud de las Leyes de Reforma tuvieron que verlos fraccionados, y entonces la propiedad que era común y que había producido buenos efectos para el cultivo de la tierra en esa forma, pasó a ser propiedad privada y dio resultados malísimos, porque el estado de cultura, el cambio repentino de una forma de propiedad a otra forma, o lo que ustedes quieran, no permitió a aquellos indígenas, no permitió a aquellas comunidades administrar sus bienes cuando la propiedad estaba fraccionada lo mismo que cuando la propiedad estaba en común, y resultó que por especiales defectos, por incultura para esa clase de administración o por facilidad para vender rápidamente y tener en sus manos una cantidad de dinero que nunca habían tenido, se vieron tentados a ir vendiendo sus terrenos a agentes más hábiles que trataban de apoderarse de ellos, o simplemente no siendo más fuerte el individuo que la comunidad, los individuos aislados estaban expuestos a ser víctimas de los atropellos de la comunidad misma; de donde resulta que así fue como muchos de esos propietarios, una vez fraccionada la propiedad que antes se tenía en común, o bien vendieron por engaños, con ciertas apariencias de legalidad de que se aprovechaban los más hábiles que ellos, o bien sencillamente fueron brutalmente despojados por vecinos poderosos que se apoderaban de sus terrenos." Íntegra da proposta de reforma constitucional e discurso apresentado à XXVI Legislatura do Congreso Nacional Mexicano em 24 de outubro de 1912 está em: BIBLIOTECA GARAY. 500 años de México en documentos. México, 2011. $<$ http://www.biblioteca.tv/artman2/publish/1912_213/Proyecto_sobre_Cuesti_n_Agraria_presentado_a_la

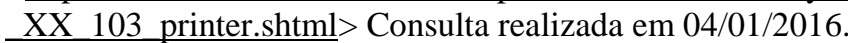


Apesar da aparência de legalidade ou certa legalidade com que os atos de despojo se revestiram, Sarabia destaca o fato de, ao fim e ao cabo, os camponeses estarem passando fome porque não têm terras para cultivar. Legal ou não, a situação de pobreza deve ser revertida pela ação estatal, e a proposta de Sarabia é que ela tenha início exatamente com uma mudança constitucional. Seu projeto é redigido de forma interessante: no artigo $\mathrm{I}^{\mathbf{0}}$ expõe todos as mudanças substanciais que deseja promover na Constituição eno artigo II $^{\circ}$, propõe em quais artigos constitucionais deve haver mudanças para que as propostas do artigo $\mathrm{I}^{\mathrm{o}}$ se efetivem. Limita-se aqui a analisar as propostas substanciais do artigo primeiro, assim:

\section{ARTICULO I ${ }^{\circ}$}

Artículo $1^{\circ}$ Se establecen tribunales federales de Equidad que, juzgando como jurados civiles, decidan, en breve plazo, previa práctica de diligencias relativas solamente a las pruebas de la posesión y al despojo, respecto de las restituciones a los pueblos, agrupaciones indígenas o pequeños propietarios, de las tierras, aguas o montes de que hubieren sido despojados por medio de violencia, física o moral, o en virtud de contratos con apariencia legal.

Artículo $2^{\circ}$ Quedan comprendidos en el caso del artículo anterior, los casos de despojo, verificados con pretexto de la venta de baldíos, en perjuicio de municipios o de pequeños propietarios que hayan estado amparados por la prescripción consignada en las leyes de baldíos.

El Tribunal de Equidad tendrá derecho de decretar indemnizaciones, a costa del Erario y a favor de los terceros poseedores de buena fe.

Artículo $3^{\circ}$ Las resoluciones que dicte este Tribunal, serán ejecutadas desde luego y podrán ser recurridas ante la Suprema Corte de Justicia de la Nación en Tribunal Pleno.

Artículo $4^{\circ}$ Se declara de utilidad pública la expropiación de los siguientes bienes raíces:

I. Tierras, aguas o montes cercanos a los pueblos, con objeto de dotar de ejidos a los que de ellos carezcan, en cantidad proporcional a su población;

II. Tierras, aguas o montes necesarios para la creación de nuevos pueblos, que se formen por la colonización;

\section{Los latifundios, en la parte excedente del máximum legal, y}

IV. Tierras no cultivadas. La ley determinará la alternabilidad mínima para el cultivo de cada clase de tierra.

Artículo $5^{\circ}$ La base para la expropiación a que se refiere el artículo anterior, será el valor fiscal de la manifestación que haga el propietario en obedecimiento de la ley reglamentaria y dentro del 
plazo que ella fije; y sólo en el caso de manifestación notoriamente exagerada, se acudirá al juicio pericial.

Artículo $6^{\circ} \mathrm{El}$ precio de la expropiación será pagado por el Erario Federal, a largos plazos y mediante abonos, en cada uno de los cuales se incluirá la pensión de amortización del capital y el rédito causado por éste. El Erario Federal a su vez se reembolsará de estos pagos cobrando dichos abonos a los adquirientes de los predios expropiados, por medio de la facultad económico-coactiva.

Artículo $7^{\circ}$ Los ayuntamientos de los pueblos tendrán derechos por esta vez, de optar por la repartición proporcional, entre los vecinos, de los bienes raíces que tengan, que se les restituyan o adquieran en virtud de la expropiación, o de decidir que esos bienes se posean en común. En el primer caso, podrán también imponer a los beneficiados en el reparto, la prohibición de enajenar o gravar sus predios antes de cierto tiempo.

\section{ARTIGO II $^{\circ}$}

(...)

Adición al artículo 27. Los municipios podrán poseer y administrar sus ejidos. La Federación podrá poseer y administrar los bienes inmuebles procedentes de la expropiación agraria.

A proposta de Juan Sarabia envolve a criação de uma instância do Poder Judiciário - que ele chamou de Tribunal Federal de Equidade - com competência especial para decidir sobre questões agrárias. Nesses Tribunais, seriam privilegiadas as comprovações e reivindicações sobre a posse prolongada e pacífica da terra em detrimento dos títulos. Seu objetivo claro é reverter as políticas realizadas anteriormente, que adotavam critério oposto (opção pelo título em detrimento da posse). Para além da reversão de despojos injustos de terras, o artigo $4^{\circ}$ prevê formas de constituir novas terras comunais por meio de expropriações, garantindo áreas estrategicamente importantes para as comunidades (montes, águas e terras necessárias aos "pueblos", cuja necessidade deveria ser aferida de acordo com a população local). Além disso, o projeto prevê a expropriação de todas as terras de latifúndios que excedam o máximo legal, que ainda estava por ser definido. Também as terras não cultivadas, improdutivas, deveriam ser expropriadas.

O projeto de Juan Sarabia buscava, ao mesmo tempo, reverter as injustiças históricas cometidas e, mesmo sem a verificação de uma injustiça patente - ou comprovável - e a garantia de terras capazes de promover bem-estar a "pueblos" e 
comunidades que as demandem. Além desse objetivo, também no artigo $4^{\circ}$ está subentendida a intenção de promover a pequena propriedade, já que as fazendas teriam um tamanho máximo e as propriedades improdutivas estariam sujeitas à expropriação. $\mathrm{O}$ artigo $6^{\circ}$, por sua vez, identifica a fonte de recursos financeiros necessários para realizar as expropriações necessárias: os cofres federais. A política, assim, seria de alguma forma centralizada, já que o dinheiro viria do governo da União.

Por fim, tão importante quanto a criação de um tribunal especial junto ao Poder Judiciário é a reforma que o projeto propõe no artigo 27: autorizaria-se que os municípios (ou "pueblos") pudessem possuir ou administrar seus próprios bens. Essa proposta, que reverte a decisão da Reforma, está alinhada com as demandas zapatistas e de outras comunidades indígenas e mestiças por autonomia decisória e política local. Podendo possuir e administrar seus próprios bens imóveis, essa autonomia estaria garantida a elas.

A proposta de Juan Sarabia, que por se tratar de reforma constitucional demandaria um quórum de dois terços para sua aprovação, segundo o artigo 127 da Constituição de 1857, não obteve sucesso. Assim, pouco depois de um mês, Luís Cabrera apresentou projeto de lei em sentido semelhante. Tal projeto, por se limitar a uma mudança legislativa, não demandava quórum qualificado para aprovação.

\subsubsection{Projeto de lei de Luís Cabrera ${ }^{333}$ : a crítica às "soluções ingênuas" do problema agrário mexicano e as diferentes formas de organização da apropriação da terra: individual e coletiva}

Luis Cabrera era deputado da XXV Legislatura do Congreso mexicano em 3 de dezembro 1912. Segundo ele, eleito pelos "pueblos" de Milpa Alta, de Tlálpan y de San Angel, todos na serra de Ajusco, Estado do México, estava notoriamente envolvido com a questão agrária. Sua experiência como professor em uma escola rural, em uma fazenda produtora de "pulque, 334 no Estado de Tlaxcala, em 1895, aproximou-o dos

\footnotetext{
${ }^{333}$ A íntegra do discurso e do Projeto de Lei Agrária de Luís Cabrera, apresentados em 3 de dezembro de 1912 para a XXV Legislatura do Congreso Mexicano, em: CARMONA, Doralicia. Memoria política de México. Guanajuato: Universidade de Guanajuato, 2014.

<http://www.memoriapoliticademexico.org/Textos/6Revolucion/1912REP.html > . Consulta realizada em $02 / 01 / 2015$

${ }^{334}$ Bebida alcoólica fermentada branca e opaca, feita com agave e típica do altiplano central do México.
} 
camponeses e peões e, a partir deles, do problema fundiário mexicano. Desde então, tornou-se um militante em defesa das propriedades coletivas dos "pueblos", sobretudo na forma de "ejidos".

Os cinco artigos do projeto de lei que apresentou aos deputados em dezembro de 1912 são fundamentados por um extenso diagnóstico sobre a situação agrária mexicana, que Luis Cabrera expõe em discurso feito ao Congreso. Nesse discurso defende a pertinência, a necessidade e a urgência da aprovação de seu projeto. Antes dos motivos, os próprios artigos são eloquentes:

Artículo $1^{\circ}$ - Se declara de utilidad pública nacional la reconstitución y dotación de ejidos para los pueblos.

Artículo $2^{\circ}$ - Se faculta al Ejecutivo de la Unión para que de acuerdo con las leyes vigentes en la materia proceda a expropiar los terrenos necesarios para reconstituir los ejidos de los pueblos que los hayan perdido, para dotar de ellos a las poblaciones que lo necesitaren, o para aumentar la extensión de los existentes.

Artículo $3^{\circ}$ - Las expropiaciones se efectuarán por el Gobierno Federal, de acuerdo con los Gobiernos de los Estados, de acuerdo con los Ayuntamientos de los pueblos de cuyos ejidos se trate, para resolver sobre la necesidad de reconstitución o dotación, y sobre la extensión, identificación y localización de los ejidos. La reconstitución de ejidos se hará, hasta donde sea posible, en los terrenos que hubiesen constituido anteriormente dichos ejidos.

Artículo $4^{\circ}$ - Mientras no se reforme la Constitución para dar personalidad a los pueblos para el manejo de sus ejidos, mientras no se expidan las leyes que determinen la condición jurídica de los ejidos reconstituidos o formados de acuerdo con la presente ley, la propiedad de éstos permanecerá en manos del Gobierno Federal, y la posesión y usufructo quedarán en manos de los pueblos, bajo la vigilancia y administración de sus respectivos Ayuntamientos, sometidos de preferencia a las reglas y costumbres anteriormente en vigor para el manejo de los ejidos de los pueblos.

Artículo $5^{\circ}$ - Las expropiaciones quedarán a cargo de la Secretaría de Fomento. Una ley reglamentaria determinará la manera de efectuarlas y los medios financieros de llevarse a cabo, así como la condición jurídica de los ejidos formados. ${ }^{335}$

\footnotetext{
${ }^{335}$ A íntegra do discurso e do Projeto de Lei Agrária de Luís Cabrera, apresentados em 3 de dezembro de 1912 para a XXV Legislatura do Congreso Mexicano, em: CARMONA, Doralicia. Memoria política de México. Guanajuato: Universidade de Guanajuato, 2014.

$<$ http://www.memoriapoliticademexico.org/Textos/6Revolucion/1912REP.html $>$. Consulta realizada em $02 / 01 / 2015$.
} 
O objetivo inicial da lei encontra-se no primeiro artigo: uma das propostas para fazer avançar o problema da apropriação de terras no México seria, segundo Luis Cabrera, reconstituir e realizar dotações de "ejidos" para os "pueblos". As duas possibilidades previstas já no primeiro artigo mostram a amplitude de situações que o projeto quer alcançar: tanto reconstituir "ejidos" existentes anteriormente quanto criar novos, para que os "pueblos" que eventualmente não possuíssem "ejidos" passassem a contar com essa especial forma coletiva de propriedade. O segundo artigo prevê ainda a ampliação de áreas já existentes de "ejidos".

Para que seja possível reconstituir e criar novas propriedades "ejidales", o governo deverá expropriar terras que naquele momento sejam propriedade privada de fazendeiros ou indivíduos $\left(\operatorname{art} .2^{\circ}\right)$. A necessidade de terra para formar "ejidos" seria constatada após uma consulta aos diferentes estados mexicanos, assim como aos “ayuntamientos", menor unidade administrativa no México, responsável pela adminsitração local dos municípios e "pueblos" (art. $3^{\circ}$ ).

O projeto de Cabrera prevê ainda a necessidade de uma mudança constitucional que reconhecesse aos "pueblos" sua personalidade jurídica para que, assim, pudessem ser titulares em nome próprio dos terrenos "ejidos". Enquanto a reforma constitucional não fosse implementada, a posse e o usufruto estariam nas mãos do "pueblo" e a propriedade formal detida pelo governo federal. Os "ayuntamientos", por sua vez, seriam também responsáveis pela vigilância e administração desses "ejidos", dando-se, porém, preferência aos costumes que as próprias comunidades praticavam quando possuíam propriedades coletivas $\left(\operatorname{art.} 4^{\circ}\right)$.

Por fim, o artigo $5^{\circ}$ do projeto prevê que o órgão competente para realizar as desapropriações seja a Secretaría de Fomento e que outra lei defina dotações orçamentárias necessárias para a realização das expropriações, bem como seus procedimentos.

A autonomia política reivindicada por diversos "pueblos" não está em contradição com a proposta de Cabrera. Tanto é verdade que, no âmbito da competência do projeto de lei, defende que haja uma reforma constitucional para garantir aos "pueblos" personalidade jurídica e, portanto, total autonomia para gerir e administrar suas terras de uso comum. A única exceção, não explícita no texto, porém, é a condição de serem os "ejidos" terras inalienáveis, ou seja, amortizadas, fora do mercado de compra e venda. 
Cabrera inicia a exposição de motivos sobre a importância da aprovação do projeto de lei afirmando que não se deve esperar de um homem - ou de apenas um projeto de lei - a solução para o problema agrário mexicano. Afinal, segundo ele "hay muchos problemas agrarios, muchas cuestiones agrarias, y se necesitan, para su resolución, muchas leyes agrarias" ${ }^{336}$. Não se pode considerar seu projeto uma panaceia para todos os males econômicos mexicanos, portanto.

Apesar de acreditar que não exista uma solução única e que múltiplas propostas possam se somar para a solução do problema, Luís Cabrera critica iniciativas vindas do que considerava serem diagnósticos superficiais da realidade mexicana. Afirma que algumas propostas - provavelmente fazendo referência aos primeiros documentos da Comisión Nacional Agraria e ao decreto de Francisco Madero editado em fevereiro de 1912 - se fundamentavam na ideia vaga de que a população mexicana precisava de terras. Essa necessidade não era, segundo ele, preenchida de elementos e características concretas. Acreditava-se que era preciso dar terras e forjar a pequena propriedade, mas não se sabia exatamente a quem essas terras deveriam ser concedidas, onde e em que forma de propriedade.

Para Cabrera, propor a criação de pequenas propriedades privadas e detidas individualmentes que, para serem compradas, demandariam a realização de dívidas por meio de linhas de crédito e a baixos juros; que, para serem cultivadas, deveriam recorrer a linhas de créditos agrícolas para compra de maquinários e sementes; que teriam o benefício da isenção de impostos para suas produções; e que seriam vendidas a partir de um cadastro de interessados representava um idealismo muito distante da realidade mexicana.

Os indígenas, acostumados a cultivar a terra sem maiores formalidades, não enfrentariam a maratona institucional proposta por Madero para serem pequenos proprietários individuais, como o decreto parecia querer incentivar. Não estavam imbuídos da ideologia empreendedora, como um pequeno empresário cujo negócio é cultivar a terra. Antes, suas plantações eram parte de sua forma de existir e subsistir. Desejavam plantar e colher o suficiente para comer, se alimentar, trocar, e não para

\footnotetext{
${ }^{336}$ A íntegra do discurso de Luís Cabrera em 3 de dezembro de 1912, para a XXV Legislatura do Congresso Nacional em: CARMONA, Doralicia. Memoria política de México. Guanajuato: Universidade de Guanajuato, 2014.

<http://www.memoriapoliticademexico.org/Textos/6Revolucion/1912REP.html >. Consulta realizada em $02 / 01 / 2015$.
} 
pagar dívidas que assumidas junto ao governo para poder comprar sementes, cultivar a terra e pagar as parcelas do financiamento para a compra do terreno.

A lógica de apropriação privada da terra era muito conflitante com toda a experiência de apropriação coletiva e informal vivida pelas comunidades agrárias indígenas e mestiças - mexicanas. Alguns historiadores acusam Cabrera de possuir um olhar idealista para a realidade dos "pueblos" no século XIX, antes mesmo da edição da Ley Lerdo, que em 1856 começou a mudar por força de lei a forma de apropriação coletiva das terras dos povoados.

Emílio Kourín ${ }^{337}$ afirma que nas "tierras de repartimiento”, verdadeiras propriedades agrícolas (já que os "ejidos" eram usados como pasto e local de extração de madeira e colheita de frutos selvagens, sem plantações e semeaduras produzidas pela intervenção humana) havia sim uma divisão familiar dos terrenos, com limites estabelecidos sobre quem poderia plantar em que lugar, e os frutos daquela terra cultivada também eram restritos a uma só família. Pode-se responder, no entanto, que embora as "tierras de repartimiento" fossem usufruídas de forma privada, havia um controle coletivo, centralizado nos órgãos deliberativos dos "pueblos" que definiam os tamanhos, a possibilidade ou não desse terreno respeitar a sucessão hereditária e a necessidade de se constituir mais um lote, dividindo-se lotes anteriores, se uma nova família surgisse e demandasse terra fértil. $O$ fato de o usufruto ser, de alguma forma, privado mesmo antes da Ley Lerdo não muda o fato de que sua organização era feita predominantemente por uma instância coletiva: a autoridade ou o órgão decisório dos "pueblos".

O relatório da Comisión Nacional Agraria, de abril de 1912 - mas que só se tornou público ao final do mesmo ano - apresenta diagnóstico muito semelhante ao de Luis Cabrera quanto à inadequação da proposta de criação de pequenas propriedades privadas para as comunidades índias e mestiças.

(...) en quinto lugar en la gran masa de población que solicita tierras, la mayoría de los componentes carece de aptitudes para ser propietarios y cumplir compromisos personales, mientras que sí cumplirá los que contraiga colectivamente, y la explotación de terrenos comunales se hará en una forma tal, que sólo disfruten de ellos los que sean trabajadores, los que cultiven y utilicen debidamente las parcelas que les correspondan.

337 KOURÍ, Emilio. "La invención del ejido". Revista Nexos. jan. 2015. Disponível em: < http://www.nexos.com.mx/?p=23778 > Consulta realizada em 04/01/2016. 
Los medios a que se tiene que acudir para lograr la reconstitución de los ejidos, tienen que variar de acuerdo con las circunstancias especiales de la localidad de que se trata ${ }^{338}$.

Segundo o documento, a maior parte da população que demanda terras no México não tem a "atitude" necessária para ser pequeno proprietário e se comprometer com compromissos econômicos de produtividade, sendo capaz de gerar rendimentos para si e excedentes para o pagamento de dívidas contraídas no momento da constituição da propriedade. Essa postura, atitude lógica de cultivo da terra não estaria presente no campo mexicano.

Ao menos em Luís Cabrera essa constatação não vem acompanhada de nenhum juízo de valor negativo. Simplesmente decorre da observação das características dos camponeses mexicanos. Conclui que "Era necesario dar tierras, no a los individuos, sino a los grupos sociales" ${ }^{339}$. O documento de Cabrera faz uma defesa da propriedade coletiva frente à propriedade individual. Não porque a forma coletiva de apropriação da terra fosse intrinsecamente melhor de acordo com parâmetros morais ou de acordo com uma futura sociedade almejada; simplesmente porque era a forma mais adequada de responder aos milhares de mexicanos que demandavam terra para garantir a própria sobrevivência. Sua divergência com Francisco Madero, assim, não residia em uma consideração abstrata sobre a melhor forma de organizar a apropriação da terra; mas dizia respeito ao diagnóstico da realidade agrária mexicana e quais as melhores medidas para enfrentá-la e melhorá-la ${ }^{340}$.

O diagnóstico de Cabrera parte de uma análise sobre o século XIX mexicano, em que as fazendas (haciendas) disputavam permanentemente espaço com os

\footnotetext{
${ }^{338}$ Parte da proposta de abril da Comisión Nacional Agraria citada em discurso de Luís Cabrera de 3 de dezembro de 1912, frente à XXV Legislatura do Congresso Nacional. CARMONA, Doralicia. Memoria política de México. Guanajuato: Universidade de Guanajuato, 2014 $<$ http://www.memoriapoliticademexico.org/Textos/6Revolucion/1912REP.html >. Consulta realizada em $02 / 01 / 2015$.

${ }^{339}$ Parte da proposta de abril da Comisión Nacional Agraria citada em discurso de Luís Cabrera de 3 de dezembro de 1912, frente à XXV Legislatura do Congresso Nacional. CARMONA, Doralicia. Memoria política de México. Guanajuato: Universidade de Guanajuato, 2014.

<http://www.memoriapoliticademexico.org/Textos/6Revolucion/1912REP.html >. Consulta realizada em $02 / 01 / 2015$.

${ }^{340}$ Manuel Scorza fornece uma impressionante forma artística para o conflito de concepções e modos de organizar o uso da terra em seu romance Bom dia para os defuntos. Apesar de partir da realidade peruana - e não mexicana - o conflito entre os personagens se dá em termos muito semelhantes à discussão mexicana do início do século XX. SCORZA, Manuel. Bom dia para os defuntos. Trad. Hamílcar de Garcia. Rio de Janeiro: Civilização Brasileira, 1978.
} 
“pueblos". Se o polo economicamente mais fraco - os "pueblos" - resistia com alguma galhardia, isso se devia ao fato de possuírem formas de propriedade coletiva por meio das quais conseguiam se organizar frente às grandes propriedades. Essas propriedades coletivas, por sua vez, assumiam diferentes títulos - "tierras de repartimiento; ejidos; propios", cada uma cumprindo uma função específica (ver seção 2.2.2.1) - mas todos eles colaboravam para fortalecer o ente coletivo que eram os "pueblos".

Foram as leis da Reforma, sobretudo a Ley Lerdo, de 25 de junho de 1856, as responsáveis por diminuir as propriedades coletivas, que seriam depois quase liquidadas. Cabrera afirma que, após o processo de desconhecimento jurídico e formal das propriedades coletivas, os territórios dos "pueblos" passaram a ficar restritos aos locais de moradia dos habitantes, sobretudo da região do altiplano central mexicano. Isso significa que esses camponeses não tinham mais bosques para retirar a lenha que servia de combustível para cozimento e aquecimento no inverno, não tinham mais matas de onde retirar frutas nativas, não tinham mais onde levar seus animais para pastarem e não tinham mais propriedades para cultivar. A consequência era que sua única forma de sobrevivência passou a ser a venda da força de trabalho, em condições que chegavam até a escravidão moderna, porque a liberdade se perdia em dívidas com os fazendeiros e com as "tiendas de raya" (ver Capítulo 3). Nesse contexto, Cabrera defende que a constituição de "ejidos" é uma forma de melhorar as condições de trabalho dos camponeses e de complemento salarial para os peões:

En la actualidad, ahora que el Gobierno carece o no quiere emplear los medios de represión antiguos, el jornalero es el enemigo natural del hacendado, principalmente en el sur de Puebla, en Morelos, en el Estado de México, bajo la forma del zapatismo; pero esta insurrección tiene principalmente una causa económica. La población rural necesita complementar su salario: si tuviese ejidos, la mitad del año trabajaría como jornalero, y la otra mitad del año aplicaría sus energías a esquilmarlos por su cuenta. No teniéndolos, se ve obligada a vivir seis meses del jornal, y los otros seis meses toma el rifle y es zapatista. $^{341}$

\footnotetext{
341 A íntegra do discurso de Luís Cabrera em 3 de dezembro de 1912, para a XXV Legislatura do Congresso Nacional está em: CARMONA, Doralicia. Memoria política de México. Guanajuato: Universidade de Guanajuato, 2014.

<http://www.memoriapoliticademexico.org/Textos/6Revolucion/1912REP.html >. Consulta realizada em $02 / 01 / 2015$.
} 
Os "ejidos", na proposta de Cabrera, não seriam a fonte de uma existência econômica autônoma, mas o complemento de uma vida assalariada, que, no mais, não demanda mão de obra constantemente ao longo do ano. Sobre a forma de constituição dessas propriedades "ejidales", defende que todo o processo seja feito por meio de expropriações - propriedades privadas desapropriadas e indenizadas pelo poder público. Afirma que o processo de reivindicação de devolução de terras tomadas injusta ou ilegalmente teria inúmeras desvantagens: é muito mais conflituoso, não oferece contrapartida para os atuais proprietários, tende a desfavorecer os pequenos proprietários e não atingir os grandes latifundiários (ele cita exemplos concretos), não responde aos anseios dos "pueblos" que não tinham "ejidos" na história recente ou que não possuíam títulos para comprová-los, depende da intervenção do Poder Judiciário. Apesar de o projeto de lei prever os dois processos - reivindicações e expropriações claramente Cabrera prefere o segundo.

Por fim, o deputado chama a atenção para o fato de nem todo "pueblo" de 1912 precisar ou demandar "ejidos". Como exemplo, cita as regiões de maior industrialização, nas quais supostamente os empregos e salários permitiriam uma vida digna, ou, por outro lado, onde não existem terras e terrenos capazes de servir ao propósito, nem tempo disponível para o cultivo da terra, sendo mais efetiva a reivindicação por melhores condições de trabalho. Por isso, justifica a existência do artigo $3^{\circ}$ de seu projeto de lei e a necessidade de se consultar e fazer participar as instâncias locais para decidir onde e em que tamanhos e locais far-se-ia necessária a constituição de "ejidos".

Muito embora o projeto de lei de Luís Cabrera não tenha sido aprovado - já que passados apenas dois meses de sua apresentação para o plenário do Congreso, o México vivia novamente uma grande turbulência institucional, com o golpe de estado realizado por Huerta e sofrido por Madero - sua concepção e formulação tiveram enorme impacto na história mexicana dos anos que se seguiram. Venustiano Carranza, prestes a se consolidar como vencedor da luta entre os movimentos revolucionários no início de 1915, transformou em decreto as normas sobre "ejidos" que deveriam ser garantidas aos "pueblos" formuladas pelo próprio Cabrera. O diagnóstico e as propostas de 1915 muito se assemelham a seu projeto e sua exposição de motivos do final de 1912. 
2.5. Os documentos revolucionários pós-Madero: a disputa de concepções agrárias entre as correntes revolucionárias

\subsubsection{Ley Agraria de Venustiano Carranza, Decreto de 6 de janeiro de $1915^{342}$}

No início de novembro de 1914, a Soberana Convención Revolucionaria de Aguascalientes publica seu primeiro documento oficial. Nele, implicitamente aceita a renúncia de Venustiano Carranza à função de encarregado do Poder Executivo da União e, entre outras medidas e decisões, indica como presidente provisório Eulálio Gutiérrez.

Carranza, porém, não aceita a decisão da Convenção. Imediatamente passa a organizar as tropas fiéis a ele, se desloca à cidade de Veracruz e se prepara para o embate com as outras forças revolucionárias que, a partir da decisão da Convenção, passam a se auto-denominar convencionistas. Entre os convencionistas, estavam Villa e Zapata (ver seção 1.9).

Em meio aos conflitos que já se iniciavam entre as correntes revolucionárias, Venustiano Carranza decide publicar o Decreto de 6 de janeiro de 1915, elaborado por Luís Cabrera. Nos considerandos que expõem as razões do documento normativo, Carranza afirma que havia uma situação de mal-estar e desconforto no campo mexicano e que uma importante causa desse mal-estar foram os despojos e alienações das terras que antes eram detidas coletivamente pelos "pueblos". Afirma, ainda, que essa situação havia empurrado o camponês mexicano para o trabalho nas fazendas em condições de miséria, que se assemelhavam à escravidão de fato; e que, diante desse diagnóstico, ficaria evidente a necessidade de devolver aos "pueblos" os terrenos que lhes haviam sido tomados injustamente, por um lado, e, para aqueles que não teriam como provar a existência histórica desses terrenos, a necessidade de conformar novas áreas destinadas ao usufruto coletivo da terra.

Ora, o parágrafo acima deixa clara a proximidade de diagnóstico entre o projeto de Luís Cabrera, de 1912, e a de Carranza, em 1915. Uma análise, porém, os distancia. No documento assinado por Carranza, tal como no de Cabrera, a Ley Lerdo, de 25 de junho de 1856 é citada. Em Cabrera, porém, suas normas são as principais responsáveis

\footnotetext{
${ }^{342}$ A íntegra do Decreto de Venustiano Carranza, de 6 de janeiro de 1915, está em: MÉXICO. Secretaria de Gobernación: Unidade General de Asuntos Jurídicos. < http://www.ordenjuridico.gob.mx/Constitucion/CH15.pdf $>$ Consulta realizada em 03/01/2015.
} 
por diminuir e praticamente extinguir a propriedade coletiva dos "pueblos" mexicanos. Dizia Cabrera em 1912:

La situación de los pueblos frente a las haciendas, era notoriamente privilegiada hasta antes de la ley de desamortización de 1856. (...)

Las leyes de desamortización de 1856, acabando con los ejidos, no dejaron como elementos de vida para los habitantes de los pueblos, que antiguamente podían subsistir durante todo el año por medio del esquilmo y cultivo de los ejidos, más que la condición de los esclavos, de siervos de las fincas.

Já Carranza deseja, com sua lei de 1915, declarar nulas as ações feitas "en contravencióna lo dispuesto en la Ley de 25 de junio de 1856 y demás leyes y disposiciones relativas;" (art. $\left.1^{\circ}, \mathrm{I}\right)$. Ou seja, segundo a visão carrancista, a lei de 1856 era razoável em seus dispositivos, e a má interpretação ou má aplicação de suas normas levou às injustiças relacionadas às propriedades coletivas mexicanas. Essa visão é confirmada pelo texto que está na exposição de motivos:

a pretexto de cumplir con la Ley de 25 de junio de 1856 y demás disposiciones que ordenaron el fraccionamiento y reducción a propiedad privada de aquellas tierras entre los vecinos del pueblo a que pertenecían, quedaron en poder de unos cuantos especuladores.

Se as ações que levaram as terras às mãos dos especuladores foram feitas "a pretexto de cumprir" a lei de 1856, isso significa que, de fato, elas não cumpriam suas normas. E, portanto, justifica-se a importante norma da primeira fração do primeiro artigo da lei de Carranza: devem ser declaradas nulas as alienações feitas "em contravenção" ao disposto na Ley Lerdo. Entende-se, a contrário senso, que aquelas alienações feitas de acordo com as normas da lei de 1856 devem ser mantidas. Ocorre que, como Luis Cabrera analisava em 1912 e como este trabalho interpreta em sua seção 2.2.2.1, a Ley Lerdo já trazia em seu bojo normas amplamente contrárias às propriedades coletivas e, cumprida à risca, reduziria amplamente as propriedades coletivas. Seu artigo $8^{\circ}$ afirmava que só não seriam alienados e divididos em propriedades individuais os "edificios, ejidos y terrenos destinados exclusivamente al servicio público de las poblaciones a que pertenezcan"343.

\footnotetext{
${ }^{343}$ Ley de desamortización de los bienes de las corporaciones civiles y eclesiásticas - Ley Lerdo, de 25 de junho de 1856 e sua exposição de motivos. Íntegra do texto disponível em: BIBLIOTECA GARAY. 500 años de México en documentos. México, 2011.
} 
As interpretações para o texto podem ser múltiplas, mas seu sentido é claro: quer-se manter como exceção a preservação de propriedades coletivas. O uso da palavra "exclusivamente" corrobora essa interpretação. A regra, então, seria o fracionamento da propriedade em porções a serem usufruídas e detidas privativamente. Entre os problemas para a aplicação do decreto proposto por Carranza estava no fato de o significado que em 1856 se atribuía ao termo "ejido" ser diferente do significado de Luís Cabrera em 1912. Para Cabrera "ejido" era o conceito que engloba todos os tipos e formas de apropriação de propriedades coletivas dos "pueblos".

Em 1856, pelo contrário: "ejido" era apenas uma das variadas formas de propriedade comunal. Outros tipos de propriedade comunal eramprevistas na legislação do séculoXIX: os fundos legais (local em que as construções, moradias e, quando houvesse, o pequeno comércio se estabelece); os terrenos de "repartimiento" (terrenos agriculturáveis, demarcados e, em geral, usufruídos por famílias. Esse é o tipo de posse que mais se assemelha à propriedade privada. $\mathrm{O}$ usufruto da terra pela família, porém, não lhe dava o direito de vendê-la ou mesmo de transmiti-la a seus herdeiros; essas decisões cabiam à comunidade) e, por fim, a definição estrita de "ejidos" (contorno externo imediato às áreas habitadas dos "pueblos"; área usada para pastoreio, coleita de frutos selvagens, extração de lenha e recreação). Qual legalidade Carranza quereria protegera? Apenas aquela que protegia os ejidos na definição de 1856 ou a uma reavaliação seria feita a partir da definição do século XX de ejidos?

o fato é que a lei de 1856 só protege os “ejidos” em seu sentido estrito. Todas as terras de "repartimiento", que eram comunais, foram dividas legalmente, já que não estavam sob a proteção do artigo $8^{\circ}$. Luís Cabrera tinha claro o diagnóstico: os liberais da década de 50 do século XIX possuíam uma visão bastante crítica às propriedades coletivas e queriam reduzi-las a seu mínimo. A lei de Carranza de 1915, por outro lado, deixa margem para dúvidas interpretativas. Seu texto poderia ser usado para tornar pouco efetivas as anulações que supostamente desejava promover.

A manipulação da interpretação do sentido das normas de uma lei de 1856, assim, pode ter sido uma estratégia para parecer benéfico aos povoados e comunidades indígenas e, na realidade, não efetivamente alcançar os resultados que se aparenta

<http://www.biblioteca.tv/artman2/publish/1856_149/Ley_Lerdo_Ley_de_desamortizaci_n_de_bienes_d e la i 247.shtml> Consulta realizada em 03/01/2016. 
desejar. O texto do decreto de Carranza de 6 de janeiro de 1915 segue, afirmando querer reverter as "ilegalidades" e "contravenções" realizadas:

Artículo $1^{\circ}$ Se declaran nulas:

1. Todas las enajenaciones de tierras, aguas y montes pertenecientes a los pueblos, rancherías, congregaciones o comunidades, hechas por los jefes políticos, gobernadores de los Estados o cualquiera otra autoridad local, en contravención a lo dispuesto en la Ley de 25 de junio de 1856 y demás leyes y disposiciones relativas;

II. Todas las concesiones, composiciones o ventas de tierras, aguas y montes, hechas por la Secretaría de Fomento, Hacienda o cualquiera otra autoridad federal, desde el primero de diciembre de 1876, hasta la fecha, con las cuales se hayan invadido y ocupado ilegalmente los ejidos, terrenos de repartimiento o de cualquiera otra clase, pertenecientes a los pueblos, rancherías, congregaciones o comunidades, $\mathrm{y}$

III. Todas las diligencias de apeo o deslinde, practicadas durante el periodo de tiempo a que se refiere la fracción anterior, por compañías, jueces u otras autoridades, de los Estados o de la Federación, con las cuales se hayan invadido y ocupado, ilegalmente, tierras, aguas y montes de los ejidos, terrenos de repartimiento o de cualquiera otra clase, pertenecientes a los pueblos, rancherías, congregaciones o comunidades.

O propósito deste capítulo é exatamente demonstrar como as políticas mexicanas de concentração fundiária se fundaram em documentos normativos que legitimavam a ação dos poderosos de plantão. Curiosa a ênfase do documento de Carranza de reversão dos atos feitos ilegalmente. Claro que muitas ações dos poderes públicos contrariavam títulos de propriedade. No caso da Reforma realizada pelos liberais do século XIX, porém, retirava-se a personalidade jurídica dos “pueblos" e, não só por meio da Ley Lerdo, mas também por intermédio do artigo 27 da Constituição de 1857, se proibiam as propriedades coletivas no México. A Constituição de 1857, aliás, vai além dos dispositivos da lei editada um ano antes. Em seu texto admite propriedades de corporações civis ou eclesiásticas em apenas uma "única excepción: los edificios destinados inmediata y directamente al servicio u objeto de la institución".

De acordo com o direito constitucional vigente no México em 1915, assim, os "pueblos" não poderiam possuir nenhuma propriedade coletiva, salvo os edifícios utilizados diretamente para suas atividades. Dessa forma, a situação que Carranza aparenta querer reverter, não apenas tinha fundamento legal como também 
constitucional. As terras coletivas detidas pelos "pueblos" e as existentes depois de 1857 deveriam ser, segundo o comando da própria Constituição Mexicana, fracionadas e transformadas em propriedade individual.

Tanto Juan Sarabia quanto Luís Cabrera sabiam desse fato. Em 1912, ambos acrescentaram em suas exposições de motivos análises sobre leis aprovadas pela Reforma e por Porfírio Díaz que legitimavam e legalizavam os despojos injustos realizados pelo poder público. Já se chamou a atenção para esse fato na análise da reflexão de Sarabia, que entendia serem as ações de destituição das propriedades comunais derivadas de posse pacífica e prolongada como "mais ou menos legais" ou "revestidas de uma aparência de legalidade". Também Luis Cabrera mencionou o fato em sua exposição de motivos de 1912.

Nesse contexto, o que teria levado Carranza a incluir a expressão "en contravención" exatamente no primeiro artigo de sua lei, dedicado a supostamente reverter as injustiças cometidas contra as comunidades camponesas mexicanas, a partir de uma análise tão falaciosa do passado legal mexicano? Pode-se cogitar que seu objetivo fosse parecer ser favorável a uma nova forma de organização fundiária quando, na verdade, não tinha intenção de realizá-la na prática.

O único artigo transitório da lei também indica algo semelhante. Segundo a norma, a lei de 6 de janeiro de 1915 seria válida desde o momento de sua publicação até que "no concluya la actual guerra civil". Por que limitar a validade e eficácia desta norma à existência da guerra civil? Por que o fim da guerra civil levaria, necessariamente, ao fim da aplicação do ato normativo de 6 de janeiro de 1915 ?

A interpretação benevolente, que não parece ser muito alinhada ao espírito carrancista, já que Carranza se julgava capaz de fazer em nome próprio as mudanças constitucionais necessárias à nova ordem pós-revolucionária (ver seção 1.11), seria imaginar que, finda a guerra civil entre os movimentos revolucionários, uma instância de deliberação coletiva - tal como um congresso constituinte - fosse ser convocada para deliberar sobre as importantes questões sociais do México. Nesse contexto, não faria sentido manter a vigência de uma norma como a editada por Carranza.

Outra forma de interpretar a norma transitória da lei de 1915, é afirmar que Carranza só precisava da legitimidade que uma lei agrária lhe garantiria no confronto com os outros movimentos revolucionários enquanto durasse o conflito. Finda a guerra, 
estabelecida a sua própria vitória, ele não precisaria manter uma lei com a qual, no mais, talvez não concordasse inteiramente. Nessa segunda interpretação, Luís Cabrera e seu texto normativo foram usados para que Carranza tivesse mais legitimidade - e, portanto, mais adeptos - no embate militar que empreendia contra zapatistas, villistas e convencionistas.

Entre o primeiro e o último artigos já analisados do decreto carrancista, porém, há outras normas. $\mathrm{O}$ artigo $2^{\circ}$ dispõe exatamente sobre os casos em que o fracionamento da terra tenha sido feito de forma "legítima", sem nenhum vício. Nesses casos, para que haja reversão ao status quo ante, ou seja, para que sejam reinstituídas as propriedades coletivas, dois terços dos moradores deverão solicitar a reversão. $\mathrm{O}$ artigo $3^{\circ}$, por sua vez, trata das comunidades campesinas que precisem de "ejidos" e que não consigam realizar suas restituições porque não têm os títulos, porque não se pode mais identificálos ou porque eles tenham sido legalmente alienados. Nesses casos, prevê a norma que o governo nacional exproprie os terrenos ao redor do "pueblo" e constitua novos "ejidos".

Os artigos $4^{\circ}, 5^{\circ}, 6^{\circ}, 7^{\circ}, 8^{\circ}, 9^{\circ}$ e $10^{\circ}$ dispõem sobre as instâncias e os procedimentos que devem ser observados para a realização das reconstituições e novas dotações de "ejidos" para os "pueblos". Três seriam as instâncias por meio das quais os pedidos de reinvindicação e instituição de " ejidos"tramitariam: "comités particulares ejecutivos; comisión local agraria e Comisión Nacional Agraria”. Cada estado federado deverá ter uma comissão local agrária e quantos comitês executivos forem necessários. Por óbvio, a Comissão Nacional é única, e tem competência sobre todo o território mexicano.

Apesar de as solicitações deverem ser encaminhadas para os governadores dos estados ou chefes militares no exercício do Poder Executivo local (art. 6º), que deveriam tomar as decisões sobre a solicitação a partir dos pareceres da comissão local agraria $\left(\operatorname{art} .7^{\circ}\right.$ ), suas decisões deveriam já ser implementadas e executadas pelo comitê particular executivo (art. $8^{\circ}$ ), mas a decisão final, aquela que efetivamente confere o título de propriedade formal ao "pueblo" só pode ser dado pela Comissão Nacional Agrária (art. $9^{\circ}$ ). Ou seja, muito embora a lei preveja uma série de procedimentos e instâncias locais e estaduais, a decisão final e definitiva é do órgão nacional, muito possivelmente controlado politicamente por Carranza. $\mathrm{O}$ artigo $10^{\circ}$ prevê que podem 
recorrer ao Poder Judiciário, no prazo de um ano, indivíduos - ou "pueblos" - que se sintam prejudicados pelas decisões tomadas pelas instâncias definidas na lei.

$\mathrm{O}$ artigo 11 afirma que deve haver uma lei em que se defina qual deve ser a condição e a forma de uso dos terrenos adjudicados aos "pueblos" a título de "ejido". Esse artigo entra em confronto direto com a permanente demanda zapatista por autonomia local. Se o governo definiria, por meio de uma lei, quais seriam as possíveis formas de organização e utilização das terras comunais, essa autonomia e liberdade das comunidades restaria muito limitada. Por fim, o artigo 12 determina que os chefes dos poderes executivos em exercício no Estado deveriam, desde a publicação da lei, nomear as comissões locais agrárias e os comites particulares executivos. Jesús Herzog também analisa o decreto de 6 de janeiro de 1915:

Es seguro que al conocerse la ley se plantearon numerosas interrogaciones, puesto que no dice nada sobre no pocos aspectos de indiscutible importancia, tales como la forma de pago de las indemnizaciones, previo o mediante, y procedimientos para el avalúo de los terrenos, etc. En el artículo $3^{\circ}$ se habla de expropriar en los casos de dotaciones, por cuenta del gobierno nacional; y en el artículo $10^{\circ}$ se dice que cuando un propietario obtenga sentencia favorable de los tribunales en caso de restitución, sólo tendrá derecho a recibir la indemnización correspondiente de parte del tesoro público. A nuestro juicio la vaguedad de la ley en ciertos puntos pudo haber sido intencional, con el objeto de no plantear desde luego problemas de dificil solución. Había que dar el primer paso, sobre todo por razones políticas; había que atraer al constitucionalismo la masa campesina del centro y del norte del país para combatir con éxito contra la División del Norte comandada por el general Francisco Villa; había que tener a la mano una ley agraria frente al plan de Ayala, con el proposito bien claro de quitar al general Zapata el monopolio del ideal agrarista. ${ }^{344}$

Herzog chama a atenção para as inúmeras arestas não aparadas na proposta de regulamentação de Carranza: ausência de clareza sobre o modo e o momento de pagamento de indenizações no caso de expropriações, forma e instância competente para avaliar qual seria o montante, entre outras ausências. Mais importante do que chamar atenção para a vagueza e falta de detalhamento e precisão nas normas carrancistas, é a percepção de que a lei tinha uma função política: arregimentar

\footnotetext{
${ }^{344}$ SILVA HERZOG, Jesús. Trayectoria ideológica de la Revolución Mexicana y otros ensayos. $1^{\mathrm{a}}$ reimp. Cidade do México: Fondo de Cultura Econômica, 1994, p. 78.
} 
apoiadores capazes de lutar contra a Divisão Norte, liderada por Francisco Villa, por um lado. Por outro, retirar dos zapatistas o monopólio simbólico de serem os únicos que defendem com armas e formulam programas com propostas de reorganização fundiária. O historiador chega a cogitar que a vagueza e falta de precisão normativa tenham sido intencionais, e que a lei tenha sido um passo no embate simbólico, sem grandes preocupações com a sua efetividade prática.

Ao contrário do que ocorreu com os direitos dos trabalhadores rurais e urbanos, que passaram a ser protegidos por inúmeras normas e decretos estaduais, editadas pelos líderes militares constitucionalistas no exercício do Poder Executivo dos estados que passavam a dominar, a partir de agosto e setembro de 1914, no caso da regulação da terra, Carranza reservou a regulamentação para si, para o Governo Central.

Não há como saber exatamente a intencionalidade dessa decisão mas, de alguma forma, ela parece simbolicamente acertada para os fins de legitimação que Carranza visava a alcançar. Não há "se" na história, mas parece ter sido uma decisão inteligente politicamente promover regulações diversas e díspares no tocante à proteção ao trabalhador e, ao mesmo tempo, centralizada no caso da questão fundiária. É de se notar que seus dois opositores diretos - Villa e Zapata - tivessem uma relação muito próxima com a terra, afinal, eram camponeses. Os trabalhadores organizados, majoritariamente urbanos, não estavam envolvidos diretamente com o processo de embate entre as correntes revolucionárias. Talvez essa diferença de posição - embate, por um lado; grupo a ser conquistado, por outro - justifique a decisão pela pulverização de normas, no caso dos direitos dos trabalhadores, e a centralização, no caso da proposta de reorganização fundiária.

Seja como for, essa decisão pela centralização - que ficou clara a partir de setembro de 1914, sobretudo quando comparada às normas estaduais regulamentadoras do trabalho - já parecia ter sido tomada logo depois de 6 de agosto de 1913. Neste dia, Lucio Blanco, general carrancista que atuava no norte do país, nos Estados de Nuevo León e Tamaulipas, juntamente com outros oficiais decidiu realizar a primeira repartição de terras. $\mathrm{O}$ documento expõe as razões para o ato:

[La comisión nombrada para estudiar el reparto de tierras] se les enteró detalladamente de todos los proyectos, planes, proclamas y demás labores que dicha comisión ha propuesto para la realización práctica, segura e inmediata de la distribución de terrenos, tanto a la 
clase desheredada del país, como a los soldados constitucionalistas que han sabido defender, a riesgo de su vida, la legalidad y la justicia de la causa del pueblo; y habiendo quedado todos plenamente satisfechos de la eficacia y viabilidad de los referidos trabajos, los aprobaron por unanimidad y resolvieron, compenetrados de la importancia y del espíritu de justicia que encierra este magno esfuerzo de la revolución, defenderlo con su espada ${ }^{345}$

Os oficiais constitucionalistas reunidos no dia 6 de agosto de 1913, na cidade de Matamoros, julgaram ser a distribuição imediata de terras pertencentes a um fazendeiro contrarrevolucionário medida prática, segura, que respeita a legalidade, a justiça, além de ter plena eficácia e viabilidade. Por serem dessa opinião, expressa no documento de época, realizaram imediatamente a distribuição entre os camponeses pobres e carentes de terras e os soldados que haviam lutado ao lado dos constitucionalistas e tinham a intenção de tornarem-se agricultores. Adolfo Gilly conta que Carranza, ao saber da decisão de seus subordinados, reagiu mal:

El conflicto de Carranza con ese sector [de oficiales con tendencia nacionalista, jacobina y aun socilizante] fue constante, aunque no siempre abierto, porque estaba subordinado al conflito aún más profundo con el villismo dentro de sus propias filas; y fuera de ellas, a los conflictos abiertos con el gobierno y con el zapatismo. Una de sus primeras manifestaciones públicas se produjo después de la toma de la ciudad fronteriza de Matamoros, Tamaulipas, por las tropas del general Lucio Blanco, cuyo jefe de estado mayor era el entonces mayor Múgica. Blanco tomó Matamoros el 4 de junio de 1913 y luego de afirmar su dominio sobre la zona, resolvió junto con Múgica que era necesario comenzar a aplicar los principios de la revolución y hacer el primer reparto de tierras. En consecuencia Múgica, como iniciador y promotor de la medida, realizó la expropiación de una hacienda de un general contrarrevolucionario y en agosto de 1913, en acto público, se efectuó el reparto entre los campesinos.

La reacción de Carranza fue violenta. Ordenó a Lucio Blanco suspender toda nueva medida de reparto de tierras, lo relevó de su mando trasladándolo a otra región y nombró en su lugar al general Pablo González, futuro masacrador de campesinos y organizador del

\footnotetext{
${ }^{345}$ A íntegra do documento que notifica a repartição de terras por Lucio Blanco, em 6 de agosto de 1913, em: BIBLIOTECA GARAY. 500 años de México en documentos.México, 2011. <http://www.biblioteca.tv/artman2/publish/1913 212/Revoluci_n_y_R_gimen_Constitucionalista_Docu mento 424_Primer_reparto_de tierras_realizado_por_la_Revoluci_n_Acta_suscrita_por_el_general_Luc io_Blanco_comandante de las fuerzas constitucionalistas de los_Estados_de_Nuevo_Le_n_y_Tamauli pas_printer.shtml> Consulta realizada em 03/01/2016.
} 
asesinato de Zapata, que por su incapacidad militar fue conocido como 'el general que nunca ganó una batalla'.

Carranza ordenou que Lucio Blanco revertesse a decisão de 6 de agosto e, em seguida, destituiu-o do controle das tropas da região. Tudo indica - embora haja quem questione essa interpretação - que a remoção de Lucio Blanco e suas tropas de Nuevo León e Tamaulipas tenha sido uma represália carrancista contra a independência de Lucio Blanco ao tomar frente neste tema simbólica e estrategicamente importante. Após a edição de sua lei agrária, em 6 de janeiro de 1915, porém, Salvador Alvarado, no Estado de Yucatán, promulgou um decreto em 9 de dezembro de 1915, que tinha por objetivo regulamentar a lei de Carranza (ver seção 2.5.4), sem consequências negativas para o autor da regulamentação.

Vaga ou precisa, centralizadora, comprometida com a efetiva constituição de novos "ejidos" ou apenas preocupada com a legitimação simbólica e política que ela poderia the trazer; o fato é que apesar de todos os problemas de seu texto e de sua concepção, a lei agrária de Carranza, publicada em todos os lugares sob o domínio do exército constitucionalista-carrancista, parece ter contribuído de forma decisiva para a nova leva de adesões ao movimento por ele liderado. Parece ter cumprido, assim, sua missão simbólica de auxiliar Carranza no projeto de ter todo o país sob seu domínio.

\subsubsection{Ley Agraria de Francisco Villa, de 24 de maio de 1915: a primazia da pequena propriedade individual}

Francisco Villa foi o líder revolucionário que menos documentos produziu ao longo dos embates. Excelente estrategista militar, apoiava ou recusava apoio a grupos e programas políticos, sem ter elaborado o seu próprio programa.

No entanto, em dezembro de 1913, enquanto vivia o auge de seu poder militar e era reconhecido pelos constitucionalistas como governador em exercício do Estado de Chihuahua, publica um decreto que determina "la confiscación de bienes pertenecientes a los malos mexicanos que han comerciado con la vida humana, y que son los

\footnotetext{
${ }^{346}$ GILLY, Adolfo. La revolución interrumpida. $1^{\text {a }}$ ed. digital. Cidade do México: Ediciones Era, 2013, p. 128.
} 
inmediatos causantes del derramamiento de nuestra sangre"347. Os "maus mexicanos", segundo a definição de sua exposição de motivos, além de terem feito comércio com a vida humana, são os causadores do derramamento de sangue gerado pela revolução e de seu prolongamento no tempo. Os maus mexicanos, segundo Villa, enriqueceram injustamente às custas do Estado, por meio de fraudes, enganos e uso da força. $\mathrm{O}$ confisco de seus bens seria, assim, uma forma de render "cuentas ante la vindicta pública". Francisco Villa afirma ser essa uma medida de justiça também porque, com o dinheiro disponível, os "maus mexicano" comprariam traidores e assassinos. Esses maus mexicanos são identificados e nomeados nos três artigos do curto decreto:

Primero.-Son confiscables y se confiscan, en bien de la salud pública y a fin de garantizar las pensiones a viudas y huérfanos causados por la defensa que contra los explotadores de la administración ha hecho el pueblo mexicano, y para cubrir también las responsabilidades que por sus procedimientos les resultan en los juicios que a su tiempo harán conocer los Juzgados especiales que a título de restitución de bienes mal habidos se establecerán en las regiones convenientes, fijando la cuantía de esas responsabilidades destinándolos íntegros para esos fines, los bienes muebles e inmuebles y documentaciones de todas clases pertenecientes a los individuos Terrazas (Luis) e hijos, hermanos Creel, hermanos Falomir, José María Sánchez, hermanos Cuilty, hermanos Luján, J. Francisco Molinar y todos los familiares de ellos y demás cómplices que con ellos se hubieren mezclado en los negocios sucios y en las fraudulentas combinaciones que en otros tiempos llamaron políticas.

Segundo.- Una ley reglamentaria que se dictará al triunfo de nuestra causa, determinará lo relativo a la equitativa distribución de esos bienes, pensionando primeramente a las viudas y huérfanos cuyos miembros hayan defendido la causa de la justicia desde 1910; en seguida se tendrán en cuenta los defensores de nuestra causa para el reparto módico de esos terrenos; se cubrirán al erario los fraudes cometidos por los individuos citados, por la falta de pago de contribuciones en los muchos años que tal cosa hicieron, y se restituirán también, a los legítimos y primitivos dueños, las propiedades que, valiéndose del poder les fueron arrebatadas por esos individuos, haciéndose así plena justicia a tanta víctima de la usurpación.

${ }^{347}$ Decreto de Francisco Villa, datado de 21 de dezembro de 1913, válido para o Estado de Chihuahua. Em CARMONA, Doralicia. Memoria política de México. Guanajuato: Universidade de Guanajuato, 2014. 〈http://www.memoriapoliticademexico.org/Textos/6Revolucion/1913-D-FV.html> Consulta realizada em 05/01/2016. 
Tercero.- Todos los bienes confiscados serán administrados por el Banco del Estado, quien llevará cuenta minuciosa, correctamente documentada, de ingresos y egresos que hubiere por tal motivo. ${ }^{348}$

Luis Terrazas, irmãos Creel, irmãos Falomir, José María Sánchez, irmãos Cuilty, irmãos Luján e J. Francisco Molinar, bem como suas famílias, eram os "maus mexicanos" de que Francisco Villa falava abstratamente na exposição de motivos de seu documento normativo. Nesta lista, os maiores proprietários do Estado de Chihuahua. Segundo o texto da norma, são confiscáveis e se confiscam efetivamente todos os bens móveis e imóveis, assim como títulos de crédito, dessas famílias.

No artigo segundo, o documento dispõe que, apenas após o triunfo da luta constitucionalista, haveria uma lei que determinaria a distribuição dos bens confiscados. Entre seus destinatários, estariam os órfãos e as viúvas daqueles que lutaram na revolução desde 1910, seguidos dos próprios revolucionários sobreviventes, que receberiam uma parte do "reparto módico" dos terrenos. Além disso, os terrenos confiscados também seriam utilizados para devolver fundos ao patrimônio público, que havia sido reduzido por meio de fraudes e para "restitución de bienes mal habidos". Enquanto a repartição entre os participantes da revolução não ocorresse, os bens seriam administrados pelo Banco do Estado.

O curto decreto villista do fim de 1913 pune os grandes proprietários de seu estado, não apenas por serem grandes "terratenientes", mas também porque enriqueceram e concentraram terras por meio de fraudes e às custas do Estado. Além disso, não tem o objetivo generoso de conceder terras a todos que precisem, ou aos "pueblos" eventualmente despojados pelos grandes fazendeiros, por meio de fraudes. Outro critério é utilizado por Villa ao prometer que, quando seu movimento fosse vitorioso, receberiam terras aqueles que tiverem lutado e, caso não tenham sobrevivido, suas viúvas e seus órfãos. Esse parecia ser um incentivo para que mais habitantes de Chihuahua se engajassem nas lutas e no exército liderados por Villa, pois somente por meio do engajamento no movimento, após a vitória, obteriam terras. Subjacente a essa

\footnotetext{
${ }^{348}$ Decreto de Francisco Villa, datado de 21 de dezembro de 1913, válido para o Estado de Chihuahua. Em CARMONA, Doralicia. Memoria política de México. Guanajuato: Universidade de Guanajuato, 2014. 〈http://www.memoriapoliticademexico.org/Textos/6Revolucion/1913-D-FV.html> Consulta realizada em 05/01/2016.
} 
tática de arregimentação de novos combatentes, pode haver também uma noção de que, para conseguir a terra, deve-se lutar por ela, merecer conquistá-la ${ }^{349}$.

O decreto de dezembro de 1913 desejava confiscar terras de famílias específicas e conceder terras para aqueles que lutassem na Divisão Norte. Não havia, assim, nenhuma pretensão de transformar seus critérios em base para uma ação nacional. Em setembro de 1914, ainda antes do início da Soberana Convención Revolucionaria, Francisco Villa rompe com Venustiano Carranza. Suas divergências diziam respeito à forma e à composição da convenção que decidiria os rumos do movimento revolucionário. Ao publicar a sua Ley Agraria de 24 de maio de 1915, Francisco Villa está em enfrentamento pelo controle político - e a reorganização fundiária - em todo o país. Deixa, assim, de ser governador militar de um Estado ou região e passa a apresentar suas propostas para resolver o problema do México. Antes das propostas, o “caudillo" apresenta seu diagnóstico:

Que siendo la tierra en nuestro país la fuente, casi la única de la riqueza, la gran desigualdad en la distribución de la propiedad territorial ha producido la consecuencia de dejar a la gran mayoría de los mexicanos, a la clase jornalera, sujeta a la dependencia de la minoría de los terratenientes, dependencia que impide a aquella clase el libre ejercicio de sus derechos civiles y políticos. ${ }^{350}$

Terra é a principal fonte de riquezas no início do século XX, segundo Villa. A desigualdade em sua distribuição, portanto, gera uma desigualdade na apropriação das próprias riquezas para a população. O desequilíbrio econômico, por sua vez, tem efeitos tanto nas más condições de vida dos trabalhadores, quanto na vida política da sociedade. Aqueles que sofrem com carências materiais não são capazes de exercer de forma plena

\footnotetext{
${ }^{349}$ Nesse sentido, Friedrich Katz, em entrevista, afirma: "Hay ese decreto famoso de diciembre de 1913, donde se expropian todas las tierras de la oligarquía mexicana, de Terrazas, Creel y de las grandes familias de Chihuahua, y donde se dice que al triunfar la revolución se van a devolver las tierras tomadas o quitadas a los pueblos; que una parte del producto de las haciendas se va a destinara la ayuda de las viudas y huérfanos de los soldados $\mathrm{y}$, además, que todos los soldados que están dentro del ejército villista van a obtener tierras. Esto ya es un cambio comparado con el agrarismo de Villa de 1911, pero aquí, también hay aspectos interesantes y diferentes de otras regiones. Básicamente, Villa propone tierras para dos grupos: los que han perdido la tierra y los soldados del ejército. En mi opinión, esto sigue la antigua tradición de los colonos militares de Chihuahua y está marcada por la idea atávica de que hay que merecer la tierra, y hay que luchar para que uno obtenga la tierra. Es un poco la tradición de las colonias militares del siglo XVIII.". NEXOS. Volvámos con Pancho Villa: Una entrevista con Friedrich Katz. Revista Nexos, 1.11.1986. Em < http://www.nexos.com.mx/?p=4687> Consulta realizada em 05/01/2016.

${ }^{350}$ Ley Agraria de Francisco Villa, publicada em 24 de maio de 1915. Em BIBLIOTECA GARAY. 500 años de México en documentos. Cidade do México, 2011.

$<$ http://www.biblioteca.tv/artman2/publish/1915_210/Ley_Agraria_del_General_Francisco_Villa_211.sht $\underline{\mathrm{ml}}>$ Consulta realizada em 05/01/2016.
} 
seus direitos políticos e suas liberdades públicas. E sofrem arbitrariedades cometidas por aqueles que detém poder econômico e, por isso, proteções institucionais.

A concentração de terras também gera prejuízos para o país: grandes áreas não cultivadas ou subaproveitadas por seus donos não seriam capazes de gerir todo o imenso território de que dispõem. A baixa produtividade da terra, somada à prioridade a gêneros agrícolas voltados à exportação, geram - ainda segundo Villa - uma produção insuficiente até para satisfazer as necessidades básicas de consumo alimentício da população. Diante desse cenário, propõe Villa:

Que por estas consideraciones ha venido a ser una apremiante necesidad nacional el reducir las grandes propiedades territoriales a límites justos, distribuyendo equitativamente las excedencias. (...)

Que la Ley Federal no debe sin embargo contener más que los principios generales en los que se funda la reforma agraria dejando que los Estados, en uso de su soberanía, acomoden esas bases a sus necesidades locales; porque la variedad de los suelos y de las condiciones agronómicas de cada región requieren diversas aplicaciones particulares de aquellas bases; porque las obras de reparto de tierras y de las demás que demanda el desarrollo de la agricultura serían de difícil y dilatada ejecución si dependieran de un centro para toda la extensión del territorio nacional; y porque las cargas consiguientes a la realización del reparto de tierras deben, en justicia, reportarlas los directamente beneficiados y quedan mejor repartidos haciéndolas recaer sobre cada región beneficiada. ${ }^{351}$

Nesses dois parágrafos é explicitada uma das características distintivas da proposta villista para reorganização fundiária: construir um território de pequenas propriedades por meio da intervenção dos diferentes estados. Para Villa, só as unidades políticas dos estados federados - governadores, legislativos regionais - poderiam realizar uma reforma agrária que respondesse às necessidades locais, à variedade de solos, às condições agronômicas das diversas regiões. Nos casos em que expropriações fossem necessárias, seriam também os estados federados os responsáveis por arcar com os custos da desapropriação. A proposta que Villa apresenta em 24 de maio de 1915, embora tenha pretensões de estimular em todo o território mexicano à instituição de pequenas propriedades privadas, garantiria a cada um dos estados mexicanos uma ampla

\footnotetext{
${ }^{351}$ Ley Agraria de Francisco Villa, publicada em 24 de maio de 1915. Em BIBLIOTECA GARAY. 500 años de México en documentos. Cidade do México, 2011.

<http://www.biblioteca.tv/artman2/publish/1915_210/Ley_Agraria_del_General_Francisco_Villa_211.sht $\underline{\mathrm{ml}}>$ Consulta realizada em 05/01/2016.
} 
margem para decisão sobre a forma de realizar esse objetivo. É a partir da garantia das autonomias locais que a "ley agraria" villista deve ser interpretada. Seu objetivo é tão somente definir princípios gerais, que devem orientar a realização da reestruturação fundiária e deixar sob a responsabilidade de cada estado e região definir os detalhes das mudanças que seriam efetivadas em seu território.

Assim, o artigo $1^{\circ}$ da lei afirma ser "incompatible con la paz y la prosperidad de la República la existencia de las grandes propiedades territoriales" ${ }^{352}$. São os estados, no entanto, os responsáveis por definir qual seria a superfície máxima de terra que poderia ser possuída por um mesmo dono em cada território. Superfície total do estado, disponibilidade de água, qualidade da terra, densidade populacional, extensão do território já cultivado: todos esses seriam elementos a serem observados, de acordo com a lei villista, para definir o tamanho máximo das propriedades privadas a serem instituídas $\left(\operatorname{art.} 2^{\circ}\right)$. Aquelas que ultrapassassem o limite estabelecido deveriam ser consideradas de utilidade pública, expropriadas mediante indenização a ser paga pelos estados e fracionadas (art. $3^{\circ}$ ). A indenização deve ser paga antes que as terras sejam ocupadas ou possam ser utilizadas por terceiros (art. 11). Para definir o valor a ser pago, devem ser nomeados dois peritos, um representante do Estado que fará a expropriação e um representante do proprietário que terá sua terra desapropriada. Em caso de controvérsia entre os peritos, um terceiro será convocado. Se ainda assim não houver concordância, o valor final deve ser fixado a partir da soma dos três valores indicados pelos peritos, dividida por três (art. $8^{\circ}$ ).

Artículo 4o. Se expropiarán también los terrenos circundantes de los "pueblos" de indígenas en la extensión necesaria para repartirlos en pequeños lotes entre los habitantes de los mismos "pueblos" que estén en aptitud de adquirir aquéllos, según las disposiciones de las leyes locales. ${ }^{353}$

Francisco Villa define clara posição no embate sobre a possibilidade de coexistência de propriedades coletivas e individuais. Sua preferência pela organização

\footnotetext{
${ }^{352}$ Ley Agraria de Francisco Villa, publicada em 24 de maio de 1915. Em BIBLIOTECA GARAY. 500 años de México en documentos. Cidade do México, 2011.

<http://www.biblioteca.tv/artman2/publish/1915_210/Ley_Agraria_del_General_Francisco_Villa_211.sht ml> Consulta realizada em 05/01/2016.

${ }^{\overline{353}}$ Ley Agraria de Francisco Villa, publicada em 24 de maio de 1915. Em BIBLIOTECA GARAY. 500 años de México en documentos. Cidade do México, 2011.

<http://www.biblioteca.tv/artman2/publish/1915 210/Ley_Agraria_del_General_Francisco_Villa_211.sht $\underline{\mathrm{ml}}>$ Consulta realizada em 05/01/2016.
} 
individual da propriedade é clara. Nesse sentido, o artigo $4^{\circ}$ de sua lei prevê que terrenos situados ao redor dos "pueblos" indígenas fossem expropriados. Os moradores desses "pueblos", porém, deveriam estar aptos a adquiri-los para que a expropriação se justifique. Assim, se trataria de uma transação de compra e venda, onerosa, feita a indivíduos ou famílias que, residindo nos “pueblos", possuiriam pequenos lotes para usufruto individual. Em nenhum momento a ley agraria villista prevê a restauração, a instauração de propriedades coletivas. O artigo 13 indica que os terrenos antes pertencentes aos "pueblos" que tivessem sido nacionalizados e permanecessem como propriedade do governo federal deveriam ser fracionados, tal como as demais terras expropriadas. Há uma única menção à possibilidade de existência de propriedade coletiva na fração VI do art. 12, que prevê o gozo comum de bosques e pastagens necessários. Em sua concepção, a apropriação da terra se realiza quase exclusivamente de forma individual ou familiar.

No caso das fazendas expropriadas em função de sua área estar acima dos limites permitidos pelos estados, o art. 12 estabelece que elas deveriam ser fracionadas, demarcadas e vendidas a preço de custo. As frações (incisos) do artigo 12 estabelecem, ainda, as normas a ser observadas pelos estados nesse processo de adjudicação de propriedades aos interessados: as adjudicações devem ser feitas sempre por meio da compra e venda, não podendo ser cedidas gratuitamente (fração I). Apesar disso, o estado federado poderia oferecer aos compradores um financiamento com prazos e condições de pagamento favoráveis. A porção de terra a ser vendida não pode ultrapassar a metade da área máxima que uma propriedade pode possuir no Estado. As propriedades vendidas pelo processo, assim, terão sempre como limite a metade da área máxima permitida às propriedades nos estados (fração IV). Impõe-se, também, a quem comprasse terras por meio dos procedimentos previstos na lei a obrigação de cultivar a terra. Se essa obrigação não fosse cumprida, injustificadamente, durante dois anos, seria considerada nula a venda antes realizada (fração III).

A lei segue com a regulação das formas de parceria para cultivo da terra (art. 14); regulação da utilização de águas fluviais (art. 15); reavaliação fiscal dos valores dos terrenos para fins de cobrança de impostos (art.16); determinação de inalienabilidade dos imóveis familiares, que só poderiam ser transmitidos por herança (art. 17); autorização para existência de propriedades com áreas maiores do que os limites estabelecidos para empresas agrícolas mexicanas (art. 18.); previsão de legislação 
regulamentadora sobre créditos agrícolas, colonização e infraestrutura de ferrovias e rodovias responsáveis pelo escoamento da produção (art. 19). Por fim, se declaram nulas todas as alienações que, decididas pelos estados, contrariem os princípios básicos afirmados na lei villista (art. 20).

O enfraquecimento militar da poderosa e temida Divisão Norte, que em 1915 sofreu derrotas importantes para a tropa liderada por Álvaro Obregon, impediu as propostas de reorganização fundiária, que afirmavam a primazia da pequena propriedade individual, de serem testadas e aplicadas, mesmo no norte do país. O projeto que se opunha à manutenção e ao aprofundamento das propriedades coletivas no território mexicano foi derrotado simbólica e militarmente.

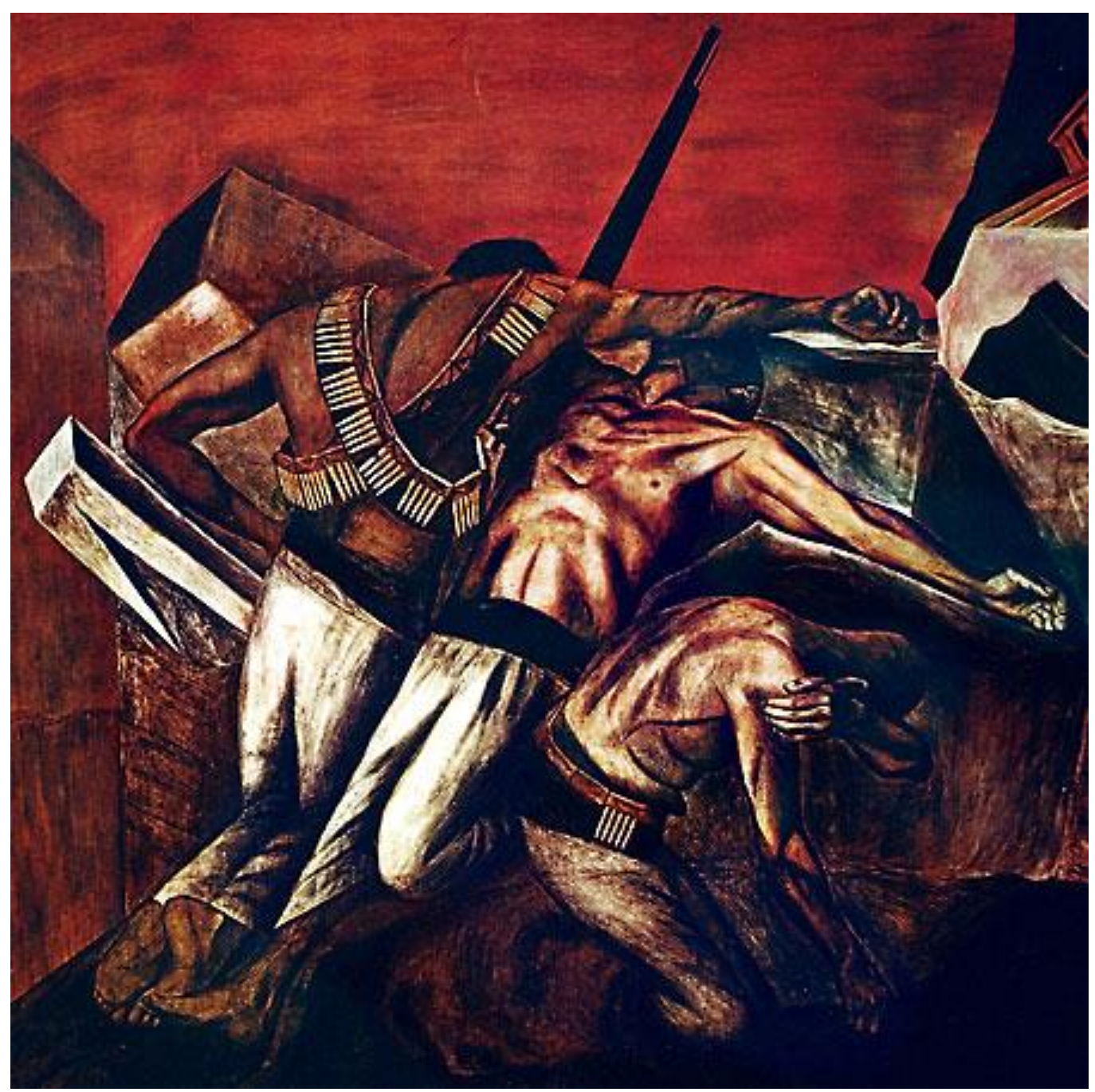

La Trinchera (1926-1927). José Clemente Orozco 


\subsubsection{Ley Agraria zapatista-convencionista de 26 de outubro de 1915: a defesa da autonomia política dos "pueblos" e comunidades, e a convivência pacífica entre propriedade coletiva e pequena propriedade individual}

Quando os zapatistas publicaram, em nome da Soberana Convención Revolucionária, sua proposta de regulamentação da realidade agrária mexicana, Francisco Villa e Venustiano Carranza já haviam apresentados suas "armas" no embate de projetos para reorganização fundiária do país. Talvez os zapatistas tenham se sentido confortáveis para serem os últimos a apresentar propostas detalhadas de resolução do problema agrário porque o Plan de Ayala, de novembro de 1911, já era referência obrigatória para quem desejasse discutir os caminhos para reverter a situação da concentração de terras no México. Ou talvez tenha sido mais demorado e trabalhoso produzir um documento coletivamente, conciliando interesses, pois mesmo que a Soberana Convención Revolucionária tenha se tornado cada vez mais homogênea do ponto de vista ideológico (e mais próxima do zapatismo), ela ainda era uma instância coletiva.

Antes desse grupo editar uma lei que, segundo o próprio texto, visa a "regulamentar debidamente los principios consignados en dicho Plan [de Ayala]"354, outros documentos contribuíram para forjar a posição do Ejército Libertador del Sur e dos convencionistas sobre o tema. Um desses documentos se trata de uma carta assinada por Emiliano Zapata e endereçada ao então presidente americano Woodrow Wilson. Ela serve como uma exposição de motivos detalhada dos projetos que foram publicados algum tempo depois. Datada de 23 de agosto de 1914, a carta foi motivada pela visita dos americanos Charles Jenkinson e Thomas W. Reilly ao Estado de Morelos e tinha por objetivo desfazer equívocos sobre a personalidade e os propósitos do movimento zapatista, "villanamente calumniados por la prensa venal y corrompida de la Ciudad de México" ${ }^{355}$.

Segundo a carta, que claramente tinha por objetivo estabelecer boas relações com o presidente norte-americano, o movimento zapatista assumia "el formal

\footnotetext{
${ }^{354}$ Ley Agraria zapatista-convencionista, de 26 de outubro de 1915, em: BIBLIOTECA GARAY. 500 años de México en documentos. Cidade do México, 2011. <http://www.bibliotecas.tv/zapata/1915/z22oct15.htm> Consulta realizada em 04/01/2016.

355 Carta de Emiliano Zapata a Woodrow Wilson, de 23 de agosto de 1914. Em BIBLIOTECA GARAY. 500 años de México en documentos. Cidade do México, 2011. <http://www.bibliotecas.tv/zapata/1914/z23ago14.html > Consulta realizada em 04/01/2016.
} 
compromiso de dar plenas garantías antes y después del triunfo, a las vidas e intereses legítimos de nacionales y extranjeros, y así me complazco en hacerlo a usted presente 356 . Antes de assumir esse compromisso, porém, Zapata expõe ao destinatário de sua carta as razões que, segundo ele, levaram o México à revolução, bem como os objetivos de seu grupo com a luta:

Unos cuantos centenares de grandes propietarios han monopolizado toda la tierra laborable de la República; de año en año han ido acrecentando sus dominios, para lo cual han tenido que despojar a los pueblos de sus ejidos o campos comunales, y a los pequeños propietarios de sus modestas heredades. Hay ciudades en el Estado de Morelos, como la de Cuautla; que carecen hasta do terreno necesario para tirar sus basuras, y con mucha mayor razón, del terreno indispensable para él ensanche de la población. Y es que los hacendados, de despojo en despojo, hoy con un pretexto, mañana con otro, han ido absorbiendo todas las propiedades que legítimamente pertenecen y desde tiempo inmemorial han pertenecido a los pueblos de indígenas, y de cuyo cultivo éstos últimos sacaban el sustento para sí y para sus familias. 357

Toda a terra agriculturável no México estava nas mãos de poucos proprietários. As propriedades coletivas dos "pueblos" haviam sido usurpadas e, em 1914, algumas comunidades não tinham terrenos públicos sequer para jogar seus lixos, quando mais para garantir o uso comum das crescentes populações locais. Posse legítima, aqui, é contraposta à "legislación por los ricos y para favorecer a los ricos". O direito foi usado para promover esse processo, corroborado pela "cumplicidad de los tribunales" ${ }^{358}$. Tal como outros analistas da situação agrária mexicana, Zapata chama a atenção para os efeitos das destituições de terras realizadas: a vida dos camponeses mexicanos se tornou miserável e sofrível, pois, dada a ausência de terras para cultivar com independência, tiveram de se submeter a empregos nas grandes fazendas, em péssimas condições de trabalho e recebendo salários baixíssimos. Sua vulnerabilidade social transcendia, segundo a análise de Zapata, as relações laborais: os fazendeiros cometiam as maiores arbitrariedades contra os camponeses e suas famílias - prisão, restrição de liberdade, castigo físico, violência sexual -, sem que esses tivessem caminhos institucionais para se proteger. Ainda na carta "Esta situación insoportable

\footnotetext{
356 Ibid.

357 Ibid.

${ }^{358}$ Carta de Emiliano Zapata a Woodrow Wilson, de 23 de agosto de 1914. Em BIBLIOTECA GARAY. 500 años de México en documentos. Cidade do México, 2011. <http://www.bibliotecas.tv/zapata/1914/z23ago14.html > Consulta realizada em 04/01/2016.
} 
originó la Revolución de 1910 que tendía principal y directamente a destruir ese régimen feudal y a combatir el monopolio de las tierras" 359.

Zapata relata que, vencidos os primeiros combates, os revolucionários se apressaram em iniciar a repartição de terras, injustamente concentradas ao longo da história mexicana. Algumas repartições foram realizadas nos Estados de Morelos, Guerrero, Puebla, Tamaulipas, Nuevo León, Chihuahua, Sonora, Durango, Zacatecas e San Luis Potosí. E no momento em que Victoriano Huerta foi vencido definitivamente, Zapata afirmou que "Esta convección [de Aguascalientes] de los jefes revolucionarlos de todo el país es la única que puede elegir con acierto el Presidente Interino" 360.

Assim é exposto o diagnóstico zapatista sobre o contexto que levou à Revolução Mexicana. Zapata reafirma que tanto os princípios do Plan de Ayala, como as deliberações da Convención Soberana Revolucionaria de Aguascalientes são capazes de oferecer os parâmetros adequados para resolver a situação insuportável que havia levado o país às armas.

Dias depois, em 8 de setembro de 1914, Emiliano Zapata publica um documento normativo cujo objetivo é punir os "enemigos de la Revolución" 361 , que com suas ações estariam atrasando o triunfo completo da revolução. Em 5 de abril de 1914, outro decreto de Zapata havia autorizado a pena de morte para todos aqueles que "no hayan depuesto las armas o que no hayan cesado de ayudar al mal Gobierno ilegal"362. Já nesse decreto, os bens daqueles que tivessem sofrido a pena de morte seriam nacionalizados. Em setembro, o objetivo é regulamentar o procedimento de nacionalização e para quais fins os bens nacionalizados poderiam ser usados.

$\mathrm{O}$ artigo $4^{\circ}$ do decreto de setembro estipula que todos os bens nacionalizados fossem cedidos aos "pueblos" que não tivessem terras para cultivar ou, alternativamente, se destinassem à proteção dos órfãos e viúvas ${ }^{363}$. Mais interessante do

\footnotetext{
359 Ibid.

${ }^{360}$ Ibid.

${ }^{361}$ Decreto de Emiliano Zapata, que declara a nacionalização dos bens dos inimigos da revolução, de 8 de setembro de 1914. Em CARMONA, Doralicia. Memoria política de México. Guanajuato: Universidade de Guanajuato, 2014. 〈http://www.memoriapoliticademexico.org/Textos/6Revolucion/1914DecEZ.html> Consulta realizada em 04/01/2016.

${ }^{362}$ Decreto de Emiliano Zapata em 5 de abril de 1914. Em BIBLIOTECA GARAY. 500 años de México en documentos. Cidade do México, 2011. < http://www.bibliotecas.tv/zapata/1914/z05abr14.htm> Consulta realizada em 04/01/2016.

363 “Artículo IV. Las propiedades rústicas nacionalizadas pasarán a poder de los "pueblos” que no tengan tierras que cultivar y carezcan de otros elementos de labranza, o se destinarán a la protección de huérfanos y viudas de aquellos que han sucumbido en la lucha que se sostiene por el triunfo de los ideales
} 
que para quem poderiam ser cedidos os bens nacionalizados, é a forma como os "pueblos" poderiam decidir, eles mesmos, como organizar a utilização das terras obtidas:

Artículo VI. Los terrenos, montes y aguas nacionalizados a los enemigos de la causa que se defiende serán distribuidos en comunidad para los pueblos que lo pretendan y en fraccionamiento para los que así lo deseen. ${ }^{364}$

"En comunidad" significa que as terras seriam apropriadas e usufruídas coletivamente. Por outro lado, "en fraccionamento" quer dizer que cada quinhão de terra seria demarcado e atribuído a indivíduos ou famílias específicas. A decisão sobre se as terras seriam dadas para usufruto coletivo ou individualizado seria dos "pueblos". Cada um deles escolheria se pretenderia usar a terra de forma coletiva ou, por outro lado, se gostaria de vê-la fracionada entre os seus habitantes. De acordo com o projeto, porém, não haveria a mesma liberdade quanto ao poder de dispor da propriedade adjudicada. Os artigos $7^{\circ}$ e $8^{\circ}$ estabelecem que as propriedades que tenham sido reconhecidas por meio do procedimento do decreto "no podrán ser vendidos ni enajenados en ninguna forma" e, além disso, no caso de fracionamento do terreno, "sólo podrán cambiar de poseedores por transmisión legítima de padres a hijos" 365.

Em setembro de 1914, assim, os zapatistas propõem uma regulamentação sobre o procedimento e a finalidade de bens imóveis dos inimigos da revolução que deveriam ser nacionalizados, sem direito à indenização. Essa norma, em forma de princípio, já estava no artigo $8^{\circ}$ do Plan de Ayala. No artigo $7^{\circ}$ do plano, os zapatistas indicavam que todas as grandes propriedades deveriam ser expropriadas em um terço de sua extensão para que seus terrenos fossem oferecidos aos "pueblos" ou, alternativamente, nelas fossem constituídas pequenas propriedades. O artigo $8^{\circ}$, por sua vez, afirma que deveriam ser expropriadas em sua totalidade somente as propriedades pertencentes

invocados en el Plan de Ayala." Decreto de Emiliano Zapata em 5 de abril de 1914. Em BIBLIOTECA GARAY. 500 años de México en documentos. Cidade do México, 2011.

<http://www.bibliotecas.tv/zapata/1914/z05abr14.htm> Consulta realizada em 04/01/2016.

${ }^{364}$ Decreto de Emiliano Zapata em 5 de abril de 1914. Em BIBLIOTECA GARAY. 500 años de México en documentos. Cidade do México, 2011. 〈http://www.bibliotecas.tv/zapata/1914/z05abr14.htm> Consulta realizada em 04/01/2016.

${ }^{365}$ Decreto de Emiliano Zapata em 5 de abril de 1914. Em BIBLIOTECA GARAY. 500 años de México en documentos. Cidade do México, 2011. 〈http://www.bibliotecas.tv/zapata/1914/z05abr14.htm> Consulta realizada em 04/01/2016. 
àqueles que se opusessem à implementação do Plan de Ayala, bem como aos antigos apoiadores "científicos” do governo de Porfírio Díaz.

Com a Ley Agraria de 26 de outubro de 1915, os zapatistas-convencionistas propõem um novo patamar de intervenção na organização fundiária mexicana. Essa radicalidade na proposta de transformação pode ser percebida pelo texto de seu artigo $4^{\circ}$, que determina:

Art. $4^{\circ}$. (...) serán expropiadas por causa de utilidad pública y mediante la correspondiente indemnización, todas las tierras del país, con la sola excepción de los terrenos pertenecientes a los pueblos, rancherías y comunidades, y de aquellos predios que, por no exceder del máximum que fija esta ley deben permanecer en poder de sus actuales propietarios. ${ }^{366}$

Segundo a proposta zapatista, a regra seria a expropriação. A manutenção da propriedade, tendo como referência os títulos existentes naquele momento histórico, seria a exceção. Todas as terras do país deveriam ser expropriadas mediante indenização, a ser definida conforme o censo fiscal de 1914 (art. $7^{\circ}$ ). A indenização, por sua vez, poderia ser paga por meio do dinheiro arrecadado com a venda dos terrenos urbanos e dos rendimentos gerados pelas fábricas nacionalizadas, ambos confiscados sem indenização, como forma de sanção aos inimigos da revolução (art. 27).

As propriedades coletivas dos "pueblos", "rancherías" e comunidades poderiam ser mantidas. Além delas, também todas as pequenas propriedades que não ultrapassem os limites de tamanho estabelecidos no $\operatorname{artigo} 5^{\circ}$ da lei. Segundo a proposta zapatista, ou a propriedade se realizava como de pequeno porte, ou simplesmente não poderia existir. Entre as variantes apresentadas, a proposta zapatista de intervenção e mudança na forma de apropriação do território mexicano é a mais profunda e radical. Se fosse aplicada, não subsistiria nenhuma propriedade de mais de 100 hectares em regiões quentes, irrigadas e férteis. $\mathrm{O}$ artigo $5^{\circ}$ da lei estabelece várias combinações entre clima, qualidade do solo e disponibilidade de água para caracterizar os diferentes tipos de terra do país. O clima quente, com terra de boa qualidade e irrigado foi o considerado o mais nobre, justificando, assim, a definição de propriedades de tamanho bastante reduzido (100 hectares). Em terrenos para pastos pobres, por outro lado, podem ser mantidas

\footnotetext{
${ }^{366}$ Ley Agraria elaborada pelos zapatistas, em nome da Soberana Convención Revolucionaria, publicada em 26 de outubro de 1915. Em BIBLIOTECA GARAY. 500 años de México en documentos. México, 2011. <http://www.bibliotecas.tv/zapata/1915/z26oct15.htm> Consulta realizada em 04/01/2016.
} 
propriedades de até mil hectares. Nas regiões áridas e baldias dos estados do norte do país (Chihuahua e Coahuila, por exemplo), permite-se manter propriedades de até mil e quinhentos hectares. Nenhuma propriedade que extrapolasse os limites territoriais definidos no artigo $5^{\circ}$ deveria ser admitida.

Além da expropriação de quaisquer áreas concentradas em uma só propriedade, a lei também previa que fossem restituídas às comunidades ou "pueblos" suas terras, águas e montes que estivessem protegidos por títulos anteriores a 1856 (art. $\left.1^{\circ}\right) . \mathrm{O}$ artigo

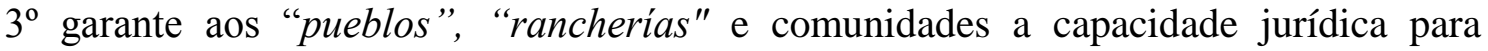
possuir propriedades, usufruí-las coletivamente e administrá-las da forma como considerarem conveniente.

$\mathrm{O}$ artigo $6^{\circ}$ apresenta uma longa lista de elementos para identificar quem pode ser considerado "enemigo de la revolución", que, nessa condição, deverá ter todos seus bens nacionalizados. Entre eles, os apoiadores de Porfírio Díaz chamados "científicos" (fração a); os governadores e funcionários do Estado que, aproveitando-se de seu cargo, enriqueceram e adquiriram propriedades fundiárias por meios fraudulentos (fração b e c); os autores e cúmplices do Quartelaço da Ciudadela, durante a Decena Trágica (fração d); todas as pessoas que desempenharam papéis políticos de confiança durante o regime de Huerta (fração e); membros do alto clero que financiaram e fizeram propaganda política de Huerta (fração f); os que ajudaram os governos dos inimigos da revolução; os que financiaram, mantiveram periódicos e promoveram a divisão entre as correntes revolucionárias; enfim, todos o que foram cúmplices de governos contrários à causa revolucionária (frações g e final).

Comissões estaduais deveriam então ser formadas (art. $7^{\circ}$ ) para identificar as pessoas que se enquadram nas descrições do artigo $6^{\circ}$. A decisão pelo confisco das propriedades, porém, poderiam ser revisadas pelos tribunais especiais de terras (art. $9^{\circ}$, previstos também no art. $6^{\circ}$ do Plan de Ayala). Tanto as terras expropriadas mediante indenização quanto as terras confiscadas dos inimigos da revolução se dividirão em lotes a serem cedidos - gratuitamente - áqueles que solicitarem. Os lotes devem ter o tamanho suficiente para suprir as necessidades de uma família e, claro, não devem ultrapassar em nenhuma hipótese os limites do art. $5^{\circ}$ (art. 10 $)$. Os bens imóveis cedidos a comunidades ou indivíduos, por sua vez, não poderiam ser alienados (vendidos) ou servir de garantia para empréstimos. Todos os contratos que desrespeitassem essa regra seriam nulos (art. 14). Somente por herança se transmitiria a 
propriedade dos terrenos cedidos pelo estado (art. 15). Além disso, aqueles que recebessem essas propriedades se comprometeriam, também, a cultivar a área recebida. $\mathrm{O}$ desrespeito injustificado à regra de manutenção da propriedade produtiva por dois anos levaria à perda da propriedade (art. 26).

Um órgão central, chamado Ministerio de Agricultura y Colonización, seria o responsável por organizar a implementação da lei, incluindo instituir um banco agrícola encarregado de realizar empréstimos para possibilitar a produção de agricultores de pequenas propriedades e regulamentar o uso das águas. A lei trata ainda da possibilidade da instalação de cooperativas (art. 28), da possibilidade de reavaliação dos valores das propriedades para fins de cobrança de impostos (art. 31) e declara nacionais todas as águas utilizáveis para irrigação (art. 32).

Nos artigos provisórios, a lei zapatista-convencionista decide obrigar todos os municípios a, imediatamente, aplicar a lei, garantindo desde logo a posse das terras mencionadas aos "pueblos" e pequenos agricultores. Além do lema clássico do zapatismo convencionista, "Reforma, Libertad, Justicia y Ley", o documento declara "que la presente Ley forma parte de las fundamentales de la República, siendo, por tanto, su observancia general y quedando derogadas todas aquellas leyes [...] que de cualquier manera se opongan a ella" ${ }^{367}$.

Em sua exposição dos motivos que levaram à edição da lei, o texto do documento normativo fala em "derecho natural" ou "derecho indiscutible" que todo homem teria sobre a terra necessária para sua própria subsistência e também na necessária constituição de um estado social. Segundo a lei zapatista-convencionista, esse estado social teria por responsabilidade tanto reconstituir a propriedade coletiva $\left(\operatorname{artigos} 1^{\circ}, 2^{\circ}\right.$ e $3^{\circ}$ ), garantindo inclusive aos "pueblos” a decisão sobre a melhor forma de administrar seus bens, como também o dever de promover as pequenas propriedades individuais ou familiares, por meio de expropriações. Mais importante do que ser coletiva, a propriedade precisa ser inalienável, fora do comércio, para permanecer como meio de subsistência para aquelas famílias a quem tiver sido adjudicada.

Além dessa específica proposta de lei agrária zapatista-convencionista, a Soberana Convención Revolucionaria publicou ainda um documento chamado

\footnotetext{
${ }^{367}$ Ley Agraria elaborada pelos zapatistas, em nome da Soberana Convención Revolucionaria, publicada em 26 de outubro de 1915. Em BIBLIOTECA GARAY. 500 años de México en documentos. Cidade do México, 2011. <http://www.bibliotecas.tv/zapata/1915/z26oct15.htm> Consulta realizada em 04/01/2016.
} 
Programa de Reformas Político-Sociales, em 18 de abril de 1916, momentos antes de ser derrotada militarmente e, consequentemente, poder apresentar-se como um projeto alternativo possível para o México. Com apenas cinco artigos sobre o tema, afirma que “Nada más grande, ni más trascendental para la Revolución, que la cuestión agraria, base y finalidad suprema del movimiento libertador, [... ." 368 . Mesmo assim, diagnostica que o objetivo de transformar a realidade agrária mexicana foi traído duas vezes, uma por Francisco Madero e a segunda por Venustiano Carranza político que, segundo os convencionistas, "después de repetidos alardes de radicalismo, de pureza y de intransigencia, ha degenerado en una forma absurda de la reacción, en un pacto oprobioso e increíble con los grandes poseedores de tierras." 369

A lei carrancista de 6 de janeiro de 1915 não convenceu seus opositores das boas intenções de Carranza para a transformação da realidade concentradoras de terras no México. Mais de um ano depois, afirmam ser ele um aliado dos grandes possuidores de terras. Partindo desse diagnóstico, a Soberana Convención Revolucionaria apresenta suas próprias propostas de transformação:

\section{CUESTIÓN AGRARIA}

La Revolución se propone realizar las siguientes reformas:

Art. 1. Destruir el latifundismo, crear la pequeña propiedad y proporcionar a cada mexicano que lo solicite la extensión de terreno que sea bastante para subvenir a sus necesidades y a las de su familia, en el concepto de que se dará la preferencia a los campesinos.

Art. 2. Devolver a los pueblos los ejidos y las aguas de que han sido despojados, y dotar de ellos a las poblaciones que, necesitándolos, no los tengan o los posean en cantidad insuficiente para sus necesidades.

\section{Art. 3. Fomentar la agricultura, fundando bancos agrícolas que} provean de fondos a los agricultores en pequeño, e invirtiendo en trabajos de irrigación, plantío de bosques, vías de comunicación y en cualquiera otra clase de obras de mejoramiento agrícola todas las sumas necesarias, a fin de que nuestro suelo produzca las riquezas de que es capaz.

\footnotetext{
${ }^{368}$ A íntegra do Programa de Reformas Político-Sociales de la Soberana Convención Revolucionária, de 18 de abril de 1916, em: CARMONA, Doralicia. Memoria política de México. Guanajuato: Universidade de Guanajuato, 2014. Disponível em:

<http://www.memoriapoliticademexico.org/Textos/6Revolucion/1916PRP.html > Consulta realizada em 27/12/2015.

${ }^{369}$ A íntegra do Programa de Reformas Político-Sociales de la Soberana Convención Revolucionária, de 18 de abril de 1916, em: CARMONA, Doralicia. Memoria política de México. Guanajuato: Universidade de Guanajuato, 2014. Disponível em:

<http://www.memoriapoliticademexico.org/Textos/6Revolucion/1916PRP.html > Consulta realizada em $27 / 12 / 2015$.
} 
Art. 4. Fomentar el establecimiento de escuelas regionales de agricultura y de estaciones agrícolas de experimentación para la enseñanza y aplicación de los mejores métodos de cultivo.

\begin{abstract}
Art. 5. Facultar al Gobierno federal para expropiar bienes raíces, sobre la base del valor actualmente manifestado al Fisco por los propietarios respectivos, y una vez consumada la reforma agraria, adoptar como base para la expropiación, el valor fiscal que resulte de la última manifestación que hayan hecho los interesados. En uno y en otro caso se concederá acción popular para denunciar las propiedades mal valorizadas. ${ }^{370}$
\end{abstract}

Os primeiros dois artigos do Programa de Reformas Político-Sociales convencionista mostram a maturidade da discussão sobre as necessidades de reorganização fundiária mexicana: o primeiro afirma que se deve fomentar a pequena propriedade e destruir os latifúndios. Para isso, todos os mexicanos que quisessem se dedicar à agricultura, deveriam ter acesso a um pedaço de terra capaz de proporcionar uma vida digna a sua família. Assim, a pequena propriedade privada seria incentivada. No segundo artigo, quer-se reconstituir as propriedades coletivas dos "pueblos" que foram despojadas, além de instituir novas áreas com a mesma destinação, nos locais e comunidades em que forem necessárias. Pequena propriedade privada e propriedades coletivas, com ênfase nas reparações de injustiças cometidas no passado, convivem, nesta proposta, sem tensão ou disputa entre os modelos.

Avançada também é a concepção de que o Estado deve fomentar a pequena agricultura com bancos e créditos agrícolas, melhorar a infraestrutura para a circulação de mercadorias, promover a irrigação, garantir a existência de escolas de agricultura e financiar a pesquisa sobre novas técnicas e experimentações. Na sucinta versão convencionista, o Estado assumiria o papel de promotor de políticas de incentivo à agricultura e ao pequeno proprietário, com o objetivo de proporcionar o aumento da produtividade no campo.

Por fim, nas expropriações de bens imóveis que seriam necessárias à instituição de novas pequenas propriedades e "ejidos", o valor a ser pago aos proprietários seria aquele declarado ao fisco para fins de cobrança de impostos. O objetivo é não admitir que os proprietários declarem baixos valores venais quando lhes interessa - ou seja, quando se trata de pagar impostos proporcionais ao valor da propriedade - e, ao mesmo tempo, negar o valor declarado e exigir mais, o "valor de mercado", quando o poder ${ }^{370}$ Ibid. 
público desapropria a área para fins de utilidade pública ( constituição de pequenas propriedades e propriedades coletivas para os "pueblos"). A fixação do valor indenizatório em casos de expropriação como sendo o valor venal declarado visa não admitir que os grandes proprietários se beneficiem de diferentes avaliações sobre o valor de um mesmo imóvel. Essa discussão se perpetua em casos de desapropriações feitas pelos órgãos públicos e se recoloca contemporaneamente, parecendo a solução proposta pelos convencionistas razoável e de acordo com critérios de justiça.

As propostas zapatistas-convencionistas para reorganização fundiária mexicana, entre os anos de 1914 e 1916, parecem querer conciliar autonomia para os "pueblos", comunidades e "rancherías" nas decisões sobre como organizar suas terras com a proibição de venda dos terrenos adjudicados, visto que os bens imóveis não seriam objeto de comércio. Além disso, elas defendem uma reorganização de terras que conciliasse diferentes formas de uso efetivo da propriedade: propriedades coletivas convivendo com pequenas propriedades individuais, harmonicamente. Além disso, segundo as propostas, deveriam ser estabelecidos limites rígidos para os tamanhos máximos das propriedades.

Muito embora derrotadas, as correntes revolucionárias convencionistas - tanto o grupo villista, quanto os zapatistas - influenciaram a formulação final da Constituição de 1917 e são, talvez, o pensamento mais maduro produzido no início do século XX.

\subsubsection{Decreto regulamentador da Ley agraria carrancista no Estado de Yucatán,} de 3 de dezembro de 1915: Salvador Alvarado e o controle estatal rígido das propriedades coletivas

Salvador Alvarado chega ao Estado de Yucatán - situado na península de mesmo nome, no golfo do México - em março de 1915. General do exército constitucionalista, viveu e atuou no norte do país a maior parte de sua vida. Foi designado por Carranza para ocupar, dominar militarmente e governar Yucatán por ser um homem de confiança: neste Estado estava a produção de sisal do país, uma das atividades econômicas mais lucrativas naquele início de século $\mathrm{XX}$, de modo que o dinheiro arrecadado por meio de impostos na região seria importante para $o$ financiamento do exército constitucionalista. Em seu governo estadual, que tem como 
marco inicial sua chegada e se prolongou até fevereiro de 1918 , editou 753 decretos ${ }^{371}$. Entre eles, um decreto que detalhava a forma de aplicação da Ley agraria carrancista de 6 de janeiro de 1915.

Formulado em 3 de dezembro de 1915 e publicado dias mais tarde, o decreto regulamentador de Alvarado possuiu 88 artigos, 3 normas transitórias e uma longa exposição de motivos inicial. Antítese das propostas zapatistas que visavam a garantir a autonomia dos "pueblos" e comunidades para definir as formas como utilizariam as terras distribuídas, o documento normativo de Salvador Alvarado possui regulamentação detalhada sobre os possíveis usos e controles que o Estado pode ter sobre a posse da terra adjudicada. Essa decisão fica clara desde a exposição de motivos:

Que conforme a dicho decreto se establecerán de nuevo los ejidos, o lo que en espíritu significa "tierras para el pueblo"; y que al mismo tiempo se deben dar tierras al pueblo, se debe asegurar el incremento de la producción, lo cual no sucedería si los ejidos estuvieran en cultivo, y se entregaran a la comunidad sin ninguna restricción, o reglamentación, que traería indudablemente una devastación inmediata de lo existente;

Que el Gobierno del Estado no solamente tiene interés platónico de distribuir tierras al pueblo, sino es un objeto que las tierras distribuidas se pongan realmente en activa producción; ${ }^{372}$

As terras para o povo seriam concedidas desde que o povo se comprometesse a aumentar a produtividade do Estado, assim, todos os "ejidos" deveriam ser cultivados. O Estado, responsável por garantir o direito à terra, seria - de acordo com a concepção de Alvarado - também responsável por controlar o uso dessa benesse. Seria omisso se não impusesse nenhuma restrição. Alvarado afirma acreditar que, se não houvesse regulamentação, deixados à própria sorte, os “pueblos” gerariam uma devastação das produções existentes. Ou o Estado realiza sua tutela e os orienta quanto ao uso da terra, ou uma catástrofe produtiva se ocorreria, de acordo com essa concepção.

${ }^{371}$ CORTINA QUIJANO, Aurora. Los congresos feministas de Yucatán en 1916 y su influencia en la legislación local y federal. Cidade do México: Instituto de Investigaciones Jurídicas, Universidad Nacional Autónoma de México, 1986, p. 164.

372 ALVARADO, Salvador. "Decreto regulamentador da ley agraria carrancista no Estado de Yucatán, de 3 de dezembro de 1915".. In Centenario de la Constitución Política de los Estados Unidos Mexicanos 1917. Cidade do México: Instituto Nacional de Estudios Históricos de las Revoluciones de México (INEHRM), 2015. 〈http://constitucion1917.gob.mx/es/Constitucion1917/Ley_Agraria_>. Consulta realizada em 05/01/2016. 
Apesar de afirmar em seu primeiro considerando que "nadie es propietario exclusivo de la tierra, como nadie lo es de la luz ni del aire" ${ }^{373}$, o Estado, segundo sua concepção, seria o responsável por garantir seu bom uso, ao menos nas propriedades coletivas instituídas por ele. Águas e bosques, por sua vez, seriam considerados de utilidade pública, não sendo possível transformá-los em propriedade privada, e sua utilização também seria fiscalizada pelo Estado.

Artículo 11. Conforme al Decreto de 6 de enero de 1915, los ejidos se entregarán a las comunidades, las cuales, al convertirse en Municipios Libre, administrarán con toda libertad dichas tierras, mientras se distribuyan conforme a este Reglamento. (...)

Artículo 41. Se pierde el lote cultivado:

1.- Cuando no se cumpla con lo ordenado en este Reglamento respecto a la conservación de 25 a 30 hojas en cada mata de henequén, conforme al artículo 59.

11.- Cuando se deje de pagar la amortización de cultivo por dos trimestres consecutivos.

11l.- Cuando el descuido sea tan manifiesto en el cultivo del lote, que haya peligro de que se pierda la plantación.

IV.- Cuando se vendiese el henequén que produzca el lote, a otra persona que no sea la Comisión Reguladora del Mercado de Henequén, en los términos que indica el artículo 60.

V.- Cuando se deje de pagar por un año la contribución de $2 \frac{1}{2} 2$ por ciento a que se refiere el artículo 48.

VI.- En los demás casos expresamente determinados por este Reglamento.

No texto da exposição de motivos, Alvarado deixa clara sua intenção de controlar a forma e a produtividade das terras que seriam adjudicadas como "ejidos". Ao longo dos artigos do decreto, porém, surge uma contradição. A norma presente no artigo 11 afirma que os municípios administrariam com total autonomia as terras que recebessem. $\mathrm{O}$ artigo 41, porém, lista uma série de situações que levariam à perda das propriedades instituídas como "ejidos". Entre essas situações de perda da propriedade, figuram o desrespeito à necessária conservação da plantação do “henequén”, planta responsável pela produção do sisal; a ausência de pagamento de impostos criados pela lei, explicados em outros artigos do decreto, como a amortização de cultivo (art. 48); a renda predial e o imposto territorial (art. 52); a identificação de "descuidos" no cultivo ${ }^{373}$ Ibid. . 
do lote passíveis de levar à perda da plantação; quando o "henequén" produzido for vendido a outra pessoa ou instituição que não a Comisión Reguladora del Mercado de Henequén. Ora, onde está a completa liberdade dos municípios para administrar suas terras, quando a porcentagem do solo que deve receber plantações de "henequén" e o comprador necessário desse produto agrícola são determinados pelo documento normativo?

Muito embora o decreto regulamentador de Salvador Alvarado pareça ter a intenção de realizar efetivamente a adjudicação de terras aos "pueblos" do estado que governa - na exposição de motivos define-se inclusive que a primeira distribuição de terras deve ser feita entre a data de publicação do decreto (9 de dezembro de 1915) até o dia 28 de fevereiro de 1916, fixando uma periodicidade semestral para as distribuições subsequentes -, a forma como o decreto propõe a cessão dessas propriedades limita gravemente qualquer autonomia ou liberdade dos "pueblos" para decidir a forma como os terrenos serão usados depois de adjudicados.

Nesse mesmo sentido - mas com previsão que semelhante a de muitas propostas de reorganização fundiária do período - proíbe-se, no artigo 75 do decreto, que as terras distribuídas pelo governo sejam objeto de contratos de compra e venda, hipotecas ou arrendamentos. $\mathrm{O}$ documento normativo segue, ainda, com disposições sobre as formas de fomento de que o estado disporá para ajudar os pequenos agricultores e as sociedades cooperativas, normas sobre o crédito agrícola, e a liberdade concedida aos novos proprietários para escolher quem seriam seus herdeiros entre ascendentes e descendentes diretos (art. 84).

A norma regulamentadora de Salvador Alvarado para o Estado de Yucatán, no mesmo 1915, ano de edição da lei de Carranza, antecipa uma tendência que marcaria a reforma agrária mexicana efetivamente realizada por Cárdenas em 1934: estimular a criação de novas propriedades coletivas, impondo como contrapartida, porém, inúmeras obrigações, que seriam controladas por um aparato burocrático estatal. Estímulo às propriedades coletivas e aumento do controle estatal sobre elas são, assim, as duas características marcantes desse documento normativo estadual.

\subsection{A regulamentação da terra no artigo 27 da Constituição Mexicana de 1917}


Às três e meia da madrugada do dia 30 de janeiro de 1917, o artigo 27 do então projeto de Constituição para os Estados Unidos Mexicanos foi aprovado pelo Congresso Constituinte, por unanimidade entre os 150 deputados votantes. A única exceção ao consenso forjado em torno das normas propostas estava na fração II que, repetindo o espírito da Constituição de 1857, proíbe as "igrejas" - católicas ou de outras religiões de serem proprietárias, possuidoras ou administradoras de bens imóveis. As exceções admitidas na norma proibitiva são os templos onde ocorrem os cultos: apesar de serem propriedades da nação, podem ser administrados pelas religiões. Essa fração do artigo 27 recebeu 88 votos favoráveis e 66 votos contrários.

Os debates e as divergências entre os deputados constituintes, porém, não se limitaram àquela que se manifestou pelo voto. A longa fração VII - que entre outros temas dispõe sobre a forma de reconstituição das propriedades comunais dos "pueblos", "rancherías" e comunidades - também mereceu acalorados posicionamentos na tribuna.

No início de dezembro de 1916, Carranza apresentou um projeto com redação bastante tímida para o artigo $27^{374}$. Constatada a insuficiência da proposta -que era identificada em quase todas as formulações iniciais elaboradas pelo "primer jefe" -, dezessete deputados constituintes formaram uma comissão responsável por elaborar uma nova proposta de redação para o artigo 27. Composta por Pastor Rouaix, Francisco Múgica, Alberto Román, Luis G. Monzón, Enrique Recio y Enrique Colunga, entre outros, a comissão, instalada em 13 de janeiro, levou dez dias para elaborar a redação inicial. No dia 25 de janeiro, a proposta foi aprovada na comissão e encaminhada ao plenário do Congreso Constituyente ${ }^{375}$.

\footnotetext{
${ }^{374}$ A proposta inicial de Carranza para o artigo 27 da Constituição começava com a seguinte redação: "La propiedad privada no puede ocuparse para uso público, sin previa indemnización. La necesidad o utilidad de la ocupación deberá ser declarada por la autoridad administrativa correspondiente; pero la expropiación se hará por la autoridad judicial, en el caso de que haya desacuerdo sobre sus condiciones entre los interesados". O texto integral do Projeto de Constituição encaminhado por Venustiano Carranza ao Congresso Constituyente, em 6 de dezembro de 1916, em: MÉXICO. Diário de los debates del Congreso Constituyente, 6 de diciembre de 1916. Centenario de la Constitución Política de los Estados Unidos Mexicanos 1917. Cidade do México, Instituto Nacional de Estudios Históricos de las Revoluciones de México (INEHRM), 2015, p. 345.

〈http://www.constitucion1917.gob.mx/work/models/Constitucion1917/Resource/251/1/images/016.pdf> Consulta realizada em 28/12/2015.

375 Detalhes da tramitação e dos debates do Congreso Constituyente relacionados ao artigo 27 da Constituição em: MÉXICO. Diário de los debates del Congreso Constituyente. Debates Notables. Articulo 27 Constitucional. Centenario de la Constitución Política de los Estados Unidos Mexicanos 1917. Cidade do México, Instituto Nacional de Estudios Históricos de las Revoluciones de México (INEHRM), 2015. 〈http://constitucion1917.gob.mx/work/models/Constitucion1917/Resource/251/1/images/020.pdf> Consulta realizada em 06/01/2016. Também em HUERTA CUEVAS, Enrique. Ingeniería institucional y
} 
Ao contrário do artigo presente no esboço carrancista que começava com " $\mathrm{La}$ propiedad privada no puede ocuparse para uso público, sin previa indemnización" $376 \mathrm{e}$ tinha a propriedade privada como protagonista do artigo, o texto aprovado - em sua concepção geral válido até hoje - inverte as prioridades. Não é a propriedade privada que deve ser protegida contra o uso público, o qual só poderia ser admitido mediante indenização dos proprietários que tivessem seu direito atingido. Antes, a nação mexicana era a titular plena de todo o seu território. E, como titular plena, realizou e realizará concessões algo precárias aos indivíduos que queiram usufruir a sua terra. É a nação quem constitui e reconhece a propriedade privada, uma decorrência do fato de a terra ser da nação mexicana a prioridade do interesse e da utilidade públicos frente aos interesses privados. O domínio permitido aos particulares pela nação mexicana não autoriza que, mudadas as circunstâncias, ele venha a atrapalhar o interesse público.

O debate sobre o status jurídico da propriedade privada estava já nos contratualistas do século XVIII. O reconhecimento do direito de propriedade como um direito natural, sagrado, inviolável do homem - digno de especial proteção contra as ações e intervenções do Estado, portanto - estava no artigo 17 da Declaração dos Direitos do Homem e do Cidadão francesa, em $1789^{377}$. É essa concepção liberal que Carranza repete no texto de seu projeto de Constituição. Os constituintes de Querétaro, por outro lado, rompem com essa visão ao afirmar ser a nação a titular máxima de seu território. Qualquer apropriação individual dele, por consequência, só é admitida com sua autorização. O território, a terra, o direito de propriedade não existem antes da ideia de que existe uma nação mexicana, responsável pela totalidade daquele território. Por

estabilidad política. El México revolucionario, 1908-1920. 2013, p. 75-98. Dissertação (Mestrado), Benemérita Universidad Autónoma de Puebla, Facultad de Derecho y Ciencias Sociales. Puebla,. <https://enriquehuertacuevas.wordpress.com/tag/el-congreso-constituyente-mexicano-de-1916-1917/> Consulta realizada em 04/12/2015.

${ }^{376} \mathrm{O}$ texto integral do Projeto de Constituição encaminhado por Venustiano Carranza ao Congresso Constituyente, em 6 de dezembro de 1916, em: DIÁRIO de los debates del Congreso Constituyente, 6 de diciembre de 1916. Centenario de la Constitución Política de los Estados Unidos Mexicanos 1917. Cidade do México, Instituto Nacional de Estudios Históricos de las Revoluciones de México (INEHRM), 2015 , p. 345. <http://www.constitucion1917.gob.mx/work/models/Constitucion1917/Resource/251/1/images/016.pdf > Consulta realizada em 28/12/2015.

377 O texto do artigo $17^{\circ}$ da Declaração dos Direitos do Homem e do Cidadão de 1789: "Como a propriedade é um direito inviolável e sagrado, ninguém dela pode ser privado, a não ser quando a necessidade pública legalmente comprovada o exigir e sob condição de justa e prévia indenização." Biblioteca Virtual de Direitos Humanos da $<$ http://www.direitoshumanos.usp.br/index.php/Documentos-anteriores-\%C3\%A0cria\%C3\%A7\%C3\%A3o-da-Sociedade-das-Na\%C3\%A7\%C3\%B5es-at\%C3\%A9-1919/declaracao-dedireitos-do-homem-e-do-cidadao-1789.html > Consulta realizada em 06/01/2016. 
isso, essa nação têm especiais poderes para regular o exercício do direito sobre a terra que ela cede.

Pouco mais de dois anos após a aprovação da Constituição Mexicana, em 31 de julho de 1919 a Alemanha promulgava sua Constituição de Weimar, primeira constituição republicana daquele país, elaborada também em um contexto de insurreição social. Constituição Mexicana e Constituição de Weimar são reconhecidas como as primeiras duas constituições a trazerem em seu bojo direitos sociais. Ambas ganharam notoriedade também pelas propostas de regulação do direito de propriedade. O texto do artigo 153 da Constituição alemã, porém, mantém a propriedade como protagonista, muito embora limitada pelo interesse público: "A propriedade é garantida pela Constituição. Seu conteúdo e seus limites serão fixados em lei. [...] A propriedade acarreta obrigações. Seu uso deve servir igualmente ao bem-estar da coletividade" ${ }^{378}$. A formulação original da Constituição Mexicana é muito mais surpreendente, por romper com noções muito fundamentais de que a propriedade seria um direito humano nato, cabendo o Estado não constituí-lo, mas reconhecê-lo e respeitá-lo. No texto original:

Art. 27 - La propiedad de las tierras y aguas comprendidas dentro de los límites del territorio nacional, corresponde originariamente a la Nación, la cual ha tenido y tiene el derecho de transmitir el dominio de ellas a los particulares, constituyendo la propiedad privada.

Esta no podrá ser expropiada sino por causa de utilidad pública y mediante indemnización.

La Nación tendrá en todo tiempo el derecho de imponer a la propiedad privada las modalidades que dicte el interés público, así como el de regular el aprovechamiento de los elementos naturales susceptibles de apropiación, para hacer una distribución equitativa de la riqueza pública y para cuidar de su conservación. Con este objeto se dictarán las medidas necesarias para el fraccionamiento de los latifundios; para el desarrollo de la pequeña propiedad; para la creación de nuevos centros de población agrícola con las tierras y aguas que les sean indispensables; para el fomento de la agricultura y para evitar la destrucción de los elementos naturales y los daños que la propiedad pueda sufrir en perjuicio de la sociedad. ${ }^{379}$

\footnotetext{
378 Tradução de MALUF, Carlos Alberto Dabus. Limitações ao direito de propriedade. 2a. ed., São Paulo: Revista dos Tribunais, 2005, p. 69. No original alemão: "Das Eigentum wird von der Verfassung gewährleistet. Sein Inhalt und seine Schranken ergeben sich aus den Gesetzen. (...) Eigentum verpflichtet. Sein Gebrauch soll zugleich Dienst sein für das Gemeine Beste.”

${ }^{379}$ Texto original da CONSTITUICIÓN Política de los Estados Unidos Mexicanos, de 5 de fevereiro de 1917. In Centenario de la Constitución Política de los Estados Unidos Mexicanos 1917. Cidade do
} 
Segundo o artigo 27 da Constituição promulgada em 5 de fevereiro de 1917, a propriedade do território mexicano é originalmente da nação mexicana. É a nação quem tem direito de transmitir o domínio de suas terras a particulares. A esse processo de transmissão de domínio dá-se o nome de propriedade privada. Segundo essa interpretação, o caput do artigo 27 propõe uma nova definição para o conceito de propriedade privada, diferente do praticado pelo constitucionalismo existente até então.

Essa propriedade, porém, não pode ser expropriada, salvo em casos nos quais haja reconhecida utilidade pública e mediante indenização -embora as formas de indenização previstas, porém, não protegessem demasiadamente o proprietário, como se verá a seguir. Para além dos casos de expropriação, a propriedade também pode sofrer limitações necessárias à realização do interesse público. Para além da afirmação genérica, o texto ainda acrescenta alguns exemplos de situações em que a propriedade pode ser limitada - o que não diminui a força do conceito genérico de "interesse público", autorizador das intervenções. Entre os exemplos, estão: necessidade de conservação, restrição do uso dos bens naturais presentes nas propriedades (água e riquezas minerais, especialmente) e distribuição equitativa de riqueza. Novamente, segundo a formulação da norma, é a nação que tem o direito de impor restrições para atender ao interesse público, e não o direito à propriedade privada ser limitado pelas restrições motivadas pelo interesse público.

Na prática, essa concepção autoriza, por exemplo, a divisão em pequenas propriedades de latifúndios existentes no país. Em paralelo com a constituição de novas pequenas propriedades, também povoados agrícolas podem ser criados, sendo-lhes garantidas terras e águas de uso comum. Riquezas minerais dos mais diversos tipos, bem como as águas - marítimas, fluviais, de lagos, de nascentes, águas explicitadas em suas mais diferentes fontes citadas no texto do artigo 27 - são também propriedade da nação mexicana e, portanto, sujeitas a regulações especiais. O domínio da nação sobre as águas e riquezas minerais é inalienável e imprescritível. Sua exploração, assim, tem como requisito a existência de uma concessão pública.

$\mathrm{O}$ artigo constitucional segue com normas sobre a "capacidad para adquirir el dominio de las tierras y aguas de la Nación" ${ }^{380}$, ou seja, disposições sobre quem pode -

México, Instituto Nacional de Estudios Históricos de las Revoluciones de México (INEHRM), 2015. $<$ http://www.juridicas.unam.mx/infjur/leg/conshist/pdf/1917.pdf > Consulta realizada em 06/01/2016.

${ }^{380}$ Texto original da CONSTITUICIÓN Política de los Estados Unidos Mexicanos, de 5 de fevereiro de 1917. In Centenario de la Constitución Política de los Estados Unidos Mexicanos 1917. Cidade do 
e, principalmente, quem não pode - ser titular de direitos sobre bens imóveis. Nota-se neste trecho do documento normativo uma preocupação com o vocabulário. Ao invés de usar "propriedade", fala-se em adquirir "dominio" sobre a terra, que é da nação. A primeira fração numerada desse trecho do artigo afirma que só os mexicanos por nascimento ou por naturalização (e as sociedades mexicanas) estão aptos a adquirir o domínio sobre as terras do território mexicano. Frente às inúmeras normas do século XIX sobre colonização que privilegiavam deliberadamente estrangeiros, essa é uma mudança radical de sentido. Os estrangeiros que desejarem possuir terras no México deverão declarar "ante la Secretaría de Relaciones en considerarse como nacionales respecto de dichos bienes y en no invocar, por lo mismo, la protección de sus Gobiernos, por lo que se refiere a aquéllos" ${ }^{381}$. Caso essa declaração não seja efetuada, o domínio será devolvido à nação, sem indenização. Nas áreas que, em linha reta, estiverem a cem quilômetros das fronteiras e a cinquenta quilômetros das praias não pode haver propriedade de estrangeiros.

Sobre a fração II do artigo 27 já afirmaou que foi o único trecho do texto constitucional que recebeu votos contrários à sua aprovação. Na norma, afirma-se a incapacidade absoluta das associações religiosas, "cualquiera que sea su credo", para adquirir, possuir e administrar nem bens imóveis, nem investimentos financeiros sobre esse tipo de patrimônio. Todos os bens que estivessem nessa situação no momento da promulgação da constituição deveriam se tornar imediatamente domínio da nação. A constituição estabelece, ainda, um procedimento para que as propriedades irregulares possam ser denunciadas por quaisquer pessoas. Também os templos em que se realizam os cultos são de propriedade da nação, e somente a alguns o governo federal daria autorização para permanecerem realizando sua função religiosa. Por fim, a fração II determina que:

Los obispados, casas curales, seminarios, asilos o colegios de asociaciones religiosas, conventos o cualquier otro edificio que hubiere sido construido o destinado a la administración, propaganda o enseñanza de un culto religioso, pasarán desde luego, de pleno derecho, al dominio directo de la Nación, para destinarse

\footnotetext{
México, Instituto Nacional de Estudios Históricos de las Revoluciones de México (INEHRM), 2015. $<$ http://www.juridicas.unam.mx/infjur/leg/conshist/pdf/1917.pdf > Consulta realizada em 06/01/2016.

${ }^{381}$ Texto original da CONSTITUICIÓN política de los Estados Unidos Mexicanos, de 5 de fevereiro de 1917. In Centenario de la Constitución Política de los Estados Unidos Mexicanos 1917. Cidade do México, Instituto Nacional de Estudios Históricos de las Revoluciones de México (INEHRM), 2015. $<$ http://www.juridicas.unam.mx/infjur/leg/conshist/pdf/1917.pdf $>$ Consulta realizada em 06/01/2016.
} 
exclusivamente a los servicios públicos de la Federación o de los Estados en sus respectivas jurisdicciones. ${ }^{382}$

Isso significa que a maior parte dos imóveis destinados a serviços religiosos seria transformada em prédios públicos. Antigos colégios religiosos, por exemplo, poderiam ser transformados em colégios públicos com ensino laico (art. $3^{\circ}$ da Constituição). Não surpreende que tenha havido divergências entre os deputados constituintes sobre este trecho do artigo 27, pois ele representa uma intervenção ainda mais profunda do que a realizada em 1856, 1857 e 1859 sobre os bens da Igreja Católica.

Na fração VII do artigo 27 está a seguinte norma:

VII - Fuera de las corporaciones a que se refieren las fracciones III, IV, V y VI, ninguna otra corporación civil podrá tener en propiedad o administrar por sí, bienes raíces o capitales impuestos sobre ellos, con la única excepción de los edificios destinados inmediata y directamente al objeto de la institución. ${ }^{383}$

As frações III, IV, V e VI, por sua vez, estabelecem regimes especiais para a relação que alguns tipos específicos de pessoas jurídicas estabelecerão com os domínios de bens imóveis. As pessoas jurídicas mencionadas especificamente no texto constitucional são instituições de beneficência, associações mutualistas, instituições de investigação e ensino, sociedades comerciais por ações, bancos, e instituições financeiras, revertendo, por fima injustiça histórica forjada pelo texto da Constituição de 1857, "condueñazgos, rancherías, pueblos, congregaciones, tribus y demás corporaciones de población que de hecho o por derecho guarden el estado comunal", que recebem a autorização para possuir propriedades coletivas na fração VI.

A regra do direito constitucional mexicano, de acordo com o caput da fração VII do artigo 27, é que as pessoas jurídicas não podem possuir ou administrar bens imóveis. A única exceção feita a essa regra diz respeito aos domínios diretamente utilizados para realizar os objetivos da instituição. Também na exceção da fraçãoVII a capacidade reconhecida aos entes públicos - Estados, Distrito Federal, Territórios e Municípios -

\footnotetext{
${ }^{382}$ Ibid.

383 Texto original da Constituición Política de los Estados Unidos Mexicanos, de 5 de fevereiro de 1917. In MÉXICO. Centenario de la Constitución Política de los Estados Unidos Mexicanos 1917. Cidade do México, Instituto Nacional de Estudios Históricos de las Revoluciones de México (INEHRM), 2015. $<$ http://www.juridicas.unam.mx/infjur/leg/conshist/pdf/1917.pdf $>$ Consulta realizada em 06/01/2016.
} 
para adquirir e manter bens necessários aos seus serviços. Evitar a especulação por meio de aquisição e manutenção de bens imóveis parece ser um dos objetivos dessa restrição constitucional quanto à capacidade civil de pessoas jurídicas.

Está também prevista na fração VII a orientação de que, sempre que for verificada a utilidade pública, a União e os Estados poderão ocupar as propriedades privadas mediante indenização. Sobre o valor a ser pago pelas indenizações, o texto constitucional dispõe:

El precio que se fijará como indemnización a la cosa expropiada, se basará en la cantidad que como valor fiscal de ella figure, en las oficinas catastrales o recaudadoras, ya sea que este valor haya sido manifestado por el propietario o simplemente aceptado por él de un modo tácito, por haber pagado sus contribuciones con esta base, aumentándolo con un diez por ciento. ${ }^{384}$

A determinação de que o valor a ser pago como indenização será fixado de acordo com o valor da terra declarado ao fisco tem inspiração em norma presente no artigo $5^{\circ}$ do Programa de Reformas Político-Sociales de la Soberana Convención Revolucionária $^{385}$. Seu objetivo, mais explícito no texto constitucional, é evitar que o proprietário - que se beneficia da declaração de que sua terra vale pouco, pois assim paga menos impostos - não ganhe em todas as circunstâncias. Quando suas terras forem objeto de desapropriação, o Estado usará o mesmo critério para pagar sua indenização, acrescido de $10 \%$. A norma afirma, ainda, que controvérsias sobre o valor das benfeitorias realizadas na propriedade após a declaração ao fisco - e só essas estarão em discussão - deverão ser decididas por meio de peritos e decisões judiciais. O texto constitucional segue com a previsão de outras formas de mudança na titularidade do domínio sobre as terras:

\footnotetext{
${ }^{384}$ Texto original da CONSTITUICIÓN Política de los Estados Unidos Mexicanos, de 5 de fevereiro de 1917. In Centenario de la Constitución Política de los Estados Unidos Mexicanos 1917. Cidade do México, Instituto Nacional de Estudios Históricos de las Revoluciones de México (INEHRM), 2015. <http://www.juridicas.unam.mx/infjur/leg/conshist/pdf/1917.pdf> Consulta realizada em 06/01/2016.

385 "Art. 5. Facultar al Gobierno federal para expropiar bienes raíces, sobre la base del valor actualmente manifestado al Fisco por los propietarios respectivos, y una vez consumada la reforma agraria, adoptar como base para la expropiación, el valor fiscal que resulte de la última manifestación que hayan hecho los interesados. En uno y en otro caso se concederá acción popular para denunciar las propiedades mal valorizadas." A íntegra do Programa de Reformas Político-Sociales de la Soberana Convención Revolucionária, de 18 de abril de 1916, em: CARMONA, Doralicia. Memoria política de México. Guanajuato: Universidade de Guanajuato, 2014. Disponível em:

<http://www.memoriapoliticademexico.org/Textos/6Revolucion/1916PRP.html > Consulta realizada em $27 / 12 / 2015$.
} 
Se declaran nulas todas las diligencias, disposiciones, resoluciones y operaciones de deslinde, concesión, composición, sentencia, transacción, enajenación o remate que hayan privado total o parcialmente de sus tierras, bosques y aguas, a los condueñazgos, rancherías, pueblos, congregaciones, tribus y demás corporaciones de población, que existan todavía, desde la ley de 25 de junio de 1856; y del mismo modo serán nulas todas las disposiciones, resoluciones y operaciones que tengan lugar en lo sucesivo y produzcan iguales efectos. En consecuencia, todas las tierras, bosques y aguas de que hayan sido privadas las corporaciones referidas, serán restituidas a éstas con arreglo al Decreto de 6 de enero de 1915, que continuará en vigor como ley constitucional. ${ }^{386}$

Tal como na análise da exposição de motivos que antecede o projeto da lei agrária de Luis Cabrera, em 1912, e da Ley Agraria zapatista-convencionista, de 1915, na Constituição a Ley Lerdo, de 25 de junho de 1856, é considerada um marco para o início das espoliações das propriedades coletivas dos "pueblos", "rancherías", comunidades mexicanos. Curiosamente, o artigo 27 da Constituição transforma em "ley constitucional' o decreto carrancista de 6 de janeiro de 1915, que tem diagnóstico e propostas diferentes. Segundo o decreto, foram ações ilegais - e não fundamentadas na lei de 1856 - que teriam gerado a espoliação das terras comunitárias dos camponeses mexicanos. Seja como for, a Constituição declara todas as ações de despojo de terras nulas, determinando que os domínios voltem aos seus titulares originais.

A Constituição afirma ainda que, nas situações em que a simples restituição não seja possível, por qual motivo for, novas terras devem ser adjudicadas "sin que en ningún caso deje de asignársele las que necesitare" ${ }^{387}$. Assim, verificada a necessidade que um "pueblo" ou comunidade agrícola de qualquer natureza tenha por terras coletivas, essas lhes deverão ser asseguradas. A norma prevê ainda uma única exceção para a restituição de terras transferidas desde 1856: casos em que foi realizada a distribuição ("repartimiento") "cuando su superficie no exced a de cincuenta hectáreas" para titulares que estão na posse da terra há mais de dez anos. Verificados os dois critérios (tamanho máximo e posse de mais de dez anos), a titularidade dos domínios será mantida. Em casos de propriedades maiores com posse prolongada, o excesso de terras possuídas deve ser devolvido às comunidades e indenizado o

\footnotetext{
${ }^{386}$ Texto original da Constituición Política de los Estados Unidos Mexicanos, de 5 de fevereiro de 1917. In MÉXICO. Centenario de la Constitución Política de los Estados Unidos Mexicanos 1917. Cidade do México, Instituto Nacional de Estudios Históricos de las Revoluciones de México (INEHRM), 2015. $<$ http://www.juridicas.unam.mx/infjur/leg/conshist/pdf/1917.pdf > Consulta realizada em 06/01/2016. ${ }^{387}$ Ibid.
} 
proprietário. Por fim, a norma resolve, em seu texto, uma controvérsia sempre presente nos textos constitucionais que incluem direitos sociais. Afirma que "Todas las leyes de restitución que por virtud de este precepto se decreten, serán de inmediata ejecución por la autoridad administrativa.". Isso significa que as normas da constituição são autoaplicáveis, não demandam regulamentação posterior para produzirem efeitos. $\mathrm{O}$ texto se encerra com a determinação para que sejam inalienáveis todas as propriedades restituídas ou constituídas pelo procedimento desse parágrafo constitucional.

A fração VII e o próprio artigo 27 se encerram com mais uma hipótese de limitação ao domínio privado sobre suas propriedades. A norma disciplina os procedimentos para "llevar a cabo el fraccionamiento de las grandes propiedades" 388. Tal como na Ley Agraria villista, determina a Constituição que são os estados federados os responsáveis por decidir quais são as extensões máximas permitidas às propriedades em seus territórios (art. 27, VII, a). Após definida a área máxima que apenas um dono pode concentrar, o excedente possuído pelo indivíduo deveria ser fracionado pelo próprio proprietário, responsável por vender suas terras até se enquadrar no limite legal. Prazos máximos e forma das vendas deverão ser definidas também em legislações estaduais (VII, b). Caso o proprietário não realize a divisão de sua propriedade e a venda no prazo definido pela lei, os governos locais serão os responsáveis por expropriar as terras que excedam o limite máximo (VII, c). No caso de ocorrer essa expropriação, as propriedades desapropriadas deverão ser indenizadas com a constituição de títulos da dívida pública agrária (“bonos da deuda”), por meio amortizações anuais, em prazo não inferior a vinte anos e juros de, no máximo, $5 \%$ ao ano. Durante esse período, a terra expropriada será inalienável. Por fim, os estados deverão elaborar leis que protejam a propriedade familiar.

A Constituição de 1917 determinou que a instituição e a reconstituição de propriedades comunais das comunidades camponesas mexicanas ("condueñazgos, rancherías, pueblos, congregaciones, tribus y demás corporaciones de población, que existan todavía") seriam "de inmediata ejecución por la autoridad administrativa" ${ }^{389}$. Totalmente diferente é seu empenho em fracionar as grandes propriedades e transformálas em pequenas. A reforma agrária de pequenos proprietários individuais dependeria,

${ }^{388}$ Texto original da CONSTITUICIÓN Política de los Estados Unidos Mexicanos, de 5 de fevereiro de 1917. In Centenario de la Constitución Política de los Estados Unidos Mexicanos 1917. Cidade do México, Instituto Nacional de Estudios Históricos de las Revoluciones de México (INEHRM), 2015. $<$ http://www.juridicas.unam.mx/infjur/leg/conshist/pdf/1917.pdf > Consulta realizada em 06/01/2016. ${ }^{389}$ Ibid. 
segundo a Constituição, de uma série de decisões políticas e administrativas que deveriam ser realizadas por cada um dos estados mexicanos.

A própria definição do que é uma pequena propriedade foi delegada aos estados, que, além de defini-la, estabeleceriam um prazo para que os próprios proprietários se adequassem. Passado esse prazo, os estados promoveriam desapropriações a serem pagas com títulos da dívida agrária estadual que, depois de demarcadas, gerariam pequenas propriedades. Nesse caminho, há espaço para omissões legislativas, omissões administrativas e critérios desfavoráveis à pequena propriedade. Todo o esforço para tornar imediatamente aplicável a restituição e a instituição de novos "ejidos" 390 não se repetiu quanto à promoção das pequenas propriedades, cuja instituição ficara a cargo dos estados.

Seja como for, o texto do artigo 27 da Constituição Mexicana de 1917 surpreende pela formulação e pelas profundas transformações na organização fundiária que a autoriza e possibilita, todas elas devendo ser impulsionadas pelo Estado mexicano. Inovadora é, sobretudo, a inversão dos titulares de direitos ligados à terra. $\mathrm{Na}$ concepção liberal clássica, indivíduos titulares do direito de propriedade se protegem contra a ação estatal. Na formulação mexicana, é a nação que tem direitos plenos sobre seu territórios, e cede domínios, limitados e precários, aos particulares.

As discussões em diferentes documentos e momentos históricos que esse capítulo apresenta indica que tal formulação só poderia surgir em um contexto de extrema tensão e embates - armados inclusive - relacionados à legítima apropriação desse bem social. Aliado ao problema social permanentemente presente, existia um rico debate de concepções sobre como enfrentá-lo e resolvê-lo. O artigo 27 da Constituição Mexicana de 1917 é fruto de sua época. É claro que, assim como nos enfrentamentos armados, também nas ideias consolidadas no texto da constituição há vencedores e derrotados. Talvez surpreendente seja o fato de que Carranza, vitorioso nas armas, não prevaleceu totalmente nas formulações constitucionais, embora haja uma menção honrosa à lei de 6 de janeiro de 1915, elevada a norma constitucional.

Por fim, somente a certeza de que a história e os embates mexicanos sobre a terra têm muito a ensinar sobre organização e distribuição de riquezas fundiárias. Sobretudo para o Brasil.

\footnotetext{
390 Embora a palavra não esteja no texto, o conceito amplo de propriedade coletiva, usufruída
} coletivamente pelas comunidades está. 


\section{ANEXO DO CAPÍTULO 2}

\section{CONSTITUCIÓN POLÍTICA DE LOS ESTADOS UNIDOS MEXICANOS ${ }^{391}$}

Art. 27 - La propiedad de las tierras y aguas comprendidas dentro de los límites del territorio nacional, corresponde originariamente a la Nación, la cual ha tenido y tiene el derecho de transmitir el dominio de ellas a los particulares, constituyendo la propiedad privada.

Esta no podrá ser expropiada sino por causa de utilidad pública y mediante indemnización.

La Nación tendrá en todo tiempo el derecho de imponer a la propiedad privada las modalidades que dicte el interés público, así como el de regular el aprovechamiento de los elementos naturales susceptibles de apropiación, para hacer una distribución equitativa de la riqueza pública y para cuidar de su conservación. Con este objeto se dictarán las medidas necesarias para el fraccionamiento de los latifundios; para el desarrollo de la pequeña propiedad; para la creación de nuevos centros de población agrícola con las tierras y aguas que les sean indispensables; para el fomento de la agricultura y para evitar la destrucción de los elementos naturales y los daños que la propiedad pueda sufrir en perjuicio de la sociedad. Los pueblos, rancherías y comunidades que carezcan de tierras y aguas, o no las tengan en cantidad suficiente para las necesidades de su población, tendrán derecho a que se les dote de ellas, tomándolas de las propiedades inmediatas, respetando siempre la pequeña propiedad. Por tanto, se confirman las dotaciones de terrenos que se hayan hecho hasta ahora de conformidad con el Decreto de 6 de enero de 1915. La adquisición de las propiedades particulares necesarias para conseguir los objetos antes expresados, se considerará de utilidad pública.

Corresponde a la Nación el dominio directo de todos los minerales o substancias que en vetas, mantos, masas o yacimientos, constituyan depósitos cuya naturaleza sea distinta de los componentes de los terrenos, tales como los minerales de los que se extraigan metales y metaloides utilizados en la industria; los yacimientos de piedras preciosas, de sal de gema y las salinas formadas directamente por las aguas marinas. Los productos derivados de la descomposición de las rocas, cuando su explotación necesite trabajos subterráneos; los fosfatos susceptibles de ser utilizados como fertilizantes; los combustibles minerales sólidos; el petróleo y todos los carburos de hidrógeno sólidos, líquidos o gaseosos.

Son también propiedad de la Nación las aguas de los mares territoriales en la ex tensión y términos que fija el Derecho Internacional; las de las lagunas y esteros de las playas; las de los lagos inferiores de formación natural, que estén ligados directamente a corrientes constantes; las de los ríos principales o arroyos afluentes desd e el punto en que brota la primera agua permanente hasta su desembocadura, ya sea que corran al mar o que crucen dos o más Estados; las de las corrientes intermitentes que atraviesen

\footnotetext{
${ }^{391}$ Texto original da Constituición Política de los Estados Unidos Mexicanos, de 5 de fevereiro de 1917. Em Centenario de la Constitución Política de los Estados Unidos Mexicanos 1917. México, Instituto Nacional de Estudios Históricos de las Revoluciones de México (INEHRM), 2015. < http://www.juridicas.unam.mx/infjur/leg/conshist/pdf/1917.pdf $>$ Consulta realizada em 06/01/2016.
} 
dos o más Estados en su rama principal; las aguas de los ríos, arroyos o barrancos, cuando sirvan de límite al territorio nacional o al de los Estados; las aguas que se extraigan de las minas; y los cauces, lechos o riberas de los lagos y corrientes anteriores en la extensión que fije la ley. Cualquiera otra corriente de agua no incluida en la enumeración anterior, se considerará como parte integrante de la propiedad privada que atraviese; pero el aprovechamiento de las aguas, cuando su curso pase de una finca a otra, se considerará como de utilidad pública y quedará sujeta a las disposiciones que dicten los Estados.

En los casos a que se refieren los dos párrafos anteriores, el dominio de la Nación es inalienable e imprescriptible, y sólo podrán hacerse concesiones por el Gobierno Federal a los particulares o sociedades civiles o comerciales constituidas conforme a las leyes mexicanas, con la condición de que se establezcan trabajos regulares para la explotación de los elementos de que se trata, y se cumplan con los requisitos que prevengan las leyes.

La capacidad para adquirir el dominio de las tierras y aguas de la Nación, se regirá por las siguientes prescripciones:

I. - Sólo los mexicanos por nacimiento o por naturalización y las sociedades mexicanas, tienen derecho para adquirir el dominio de las tierras, aguas y sus accesiones, o para obtener concesiones de explotación de minas, aguas o combustibles minerales en la República Mexicana. El Estado podrá conceder el mismo derecho a los extranjeros siempre que convengan ante la Secretaría de Relaciones en considerarse como nacionales respecto de dichos bienes y en no invocar, por lo mismo, la protección de sus Gobiernos, por lo que se refiere a aquéllos; bajo la pena, en caso de faltar al convenio, de perder en beneficio de la Nación, los bienes que hubieren adquirido en virtud del mismo. En una faja de cien kilómetros a lo largo de las fronteras y de cincuenta en las playas, por ningún motivo podrán los extranjeros adquirir el dominio directo sobre tierras y aguas.

II. - Las asociaciones religiosas denominadas iglesias, cualquiera que sea su credo, no podrán en ningún caso tener capacidad para adquirir, poseer o administrar bienes raíces, ni capitales impuestos sobre ellos; los que tuvieren actualmente, por sí o por interpósita persona entrarán al dominio de la Nación, concediéndose acción popular para denunciar los bienes que se hallaren en tal caso. La prueba de presunciones será bastante para declarar fundada la denuncia. Los templos destinados al culto público son de la propiedad de la Nación, representada por el Gobierno Federal, quien determinará los que deben continuar destinados a su objeto. Los obispados, casas curales, seminarios, asilos o colegios de asociaciones religiosas, conventos o cualquier otro edificio que hubiere sido construido o destinado a la administración, propaganda o enseñanza de un culto religioso, pasarán desde luego, de pleno derecho, al dominio directo de la Nación, para destinarse exclusivamente a los servicios públicos de la Federación o de los Estados en sus respectivas jurisdicciones. Los templos que en lo sucesivo se erigieren para el culto público, serán propiedad de la Nación.

III. - Las instituciones de beneficencia, pública o privada, que tengan por objeto el auxilio de los necesitados, la investigación científica, la difusión de la enseñanza, la ayuda recíproca de los asociados o cualquier otro objeto lícito, no podrán adquirir, tener y administrar capitales impuestos sobre bienes raíces, siempre que los plazos de imposición no excedan de diez años. En ningún caso, las instituciones de esta índole, 
podrán estar bajo el patronato, dirección, administración, cargo o vigilancia de corporaciones o instituciones religiosas, ni de ministros de los cultos o de sus asimilados, aunque éstos o aquéllos no estuvieren en ejercicio.

IV. - Las sociedades comerciales, por acciones, no podrán adquirir, poseer o administrar fincas rústicas. Las sociedades de esta clase que se constituyeren para explotar cualquiera industria fabril, minera, petrolera o para algún otro fin que no sea agrícola, podrán adquirir, poseer o administrar terrenos únicamente en la extensión que sea estrictamente necesaria para los establecimientos o servicios de los objetos indicados, y que el Ejecutivo de la Unión, o de los Estados, fijará en cada caso.

V. - Los Bancos debidamente autorizados, conforme a las leyes de instituciones de crédito, podrán tener capitales impuestos sobre propiedades urbanas y rústicas de acuerdo con las prescripciones de dichas leyes pero no podrán tener en propiedad o en administración, más bienes raíces que los enteramente necesarios para su objeto directo.

VI. - Los condueñazgos, rancherías, pueblos, congregaciones, tribus y demás corporaciones de población que de hecho o por derecho guarden el estado comunal, tendrán capacidad para disfrutar en común las tierras, bosques y aguas que les pertenezcan o que se les haya restituído o restituyeren, conforme a la ley de 6 de enero de 1915; entre tanto la ley determina la manera de hacer el repartimiento únicamente de las tierras.

VII. - Fuera de las corporaciones a que se refieren las fracciones III, IV, V y VI, ninguna otra corporación civil podrá tener en propiedad o administrar por sí, bienes raíces o capitales impuestos sobre ellos, con la única excepción de los edificios destinados inmediata y directamente al objeto de la institución. Los Estados, el Distrito Federal y los Territorios, lo mismo que los Municipios de toda la República, tendrán plena capacidad para adquirir y poseer todos los bienes raíces necesarios para los servicios públicos.

Las leyes de la Federación y de los Estados en sus respectivas jurisdicciones, determinarán los casos en que sea de utilidad pública, la ocupación de la propiedad privada; y de acuerdo con dichas leyes la autoridad administrativa, hará la declaración correspondiente. El precio que se fijará como indemnización a la cosa expropiada, se basará en la cantidad que como valor fiscal de ella figure, en las oficinas catastrales o recaudadoras, ya sea que este valor haya sido manifestado por el propietario o simplemente aceptado por él de un modo tácito, por haber pagado sus contribuciones con esta base, aumentándolo con un diez por ciento. El exceso de valor que haya tenido la propiedad particular por las mejoras que se le hubieren hecho con posterioridad a la fecha de la asignación del valor fiscal, será lo único que deberá quedar sujeto a juicio pericial, y a resolución judicial. Esto mismo se observará cuando se trate de objetos cuyo valor no esté fijado en las oficinas rentísticas.

Se declaran nulas todas las diligencias, disposiciones, resoluciones y operaciones de deslinde, concesión, composición, sentencia, transacción, enajenación o remate que hayan privado total o parcialmente de sus tierras, bosques y aguas, a los condueñazgos, rancherías, pueblos, congregaciones, tribus y demás corporaciones de población, que 
existan todavía, desde la ley de 25 de junio de 1856; y del mismo modo serán nulas todas las disposiciones, resoluciones y operaciones que tengan lugar en lo sucesivo y produzcan iguales efectos. En consecuencia, todas las tierras, bosques y aguas de que hayan sido privadas las corporaciones referidas, serán restituidas a éstas con arreglo al Decreto de 6 de enero de 1915, que continuará en vigor como ley constitucional. En el caso de que, con arreglo a dicho Decreto, no procediere, por vía de restitución, la adjudicación de tierras que hubiere solicitado alguna de las corporaciones mencionadas, se le dejarán aquéllas en calidad de dotación sin que en ningún caso deje de asignársele las que necesitare. Se exceptúan de la nulidad antes referida, únicamente las tierras que hubieren sido tituladas en los repartimientos hechos a virtud de la citada ley de 25 de junio de 1856 o poseídas en nombre propio a título de dominio por más de diez años, cuando su superficie no exced a de cincuenta hectáreas. El exceso sobre esa superficie deberá ser vuelto a la comunidad, indemnizando su valor al propietario. Todas las leyes de restitución que por virtud de este precepto se decreten, serán de inmediata ejecución por la autoridad administrativa. Sólo los miembros de la comunidad tendrán derecho a los terrenos de repartimiento y serán inalienables los derechos sobre los mismos terrenos mientras permanezcan indivisos, así como los de propiedad, cuando se haya hecho el fraccionamiento.

El ejercicio de las acciones que correspondan a la Nación, por virtud de las disposiciones del presente artículo se hará efectivo por el procedimiento judicial; pero dentro de este procedimiento y por orden de los Tribunales correspondientes, que se dictará en el plazo máximo de un mes, las autoridades administrativas procederán desde luego a la ocupación, administración, remate o venta de las tierras y aguas de que se trate, y todas sus accesiones, sin que en ningún caso pueda revocarse lo hecho por las mismas autoridades antes de que se dicte sentencia ejecutoriada.

Durante el próximo periodo constitucional, el Congreso de la Unión y las Legislaturas de los Estados, en sus respectivas jurisdicciones, expedirán leyes para llevar a cabo el fraccionamiento de las grandes propiedades, conforme a las bases siguientes:

(a). - En cada Estado y Territorio se fijará la extensión máxima de tierra de que puede ser dueño un sólo individuo o sociedad legalmente constituída.

(b). - El excedente de la extensión fijada deberá ser fraccionado por el propietario en el plazo que señalen las leyes locales; y las fracciones serán puestas a la venta en las condiciones que aprueben los gobiernos de acuerdo con las mismas leyes.

(c). - Si el propietario se negare a hacer el fraccion amiento, se llevará éste a cabo por el Gobierno local, mediante la expropiación.

(d). - El valor de las fracciones será pagado por anualidades que amorticen capital y réditos en un plazo no menor de veinte años, durante el cual el adquiriente no podrá enajenar aquéllas. El tipo del interés no excederá del cinco por ciento anual.

(e). - El propietario estará obligado a recibir Bonos de una deuda especial para garantizar el pago de la propiedad expropiada. Con este objeto el Congreso de la Unión expedirá una ley facultando a los Estados para crear su deuda agraria. 
(f). - Las leyes locales organizarán el patrimonio de familia, determinando los bienes que deben constituirlo, sobre la base de que será inalienable, no estará sujeto a embargo ni a gravamen ninguno. Se declaran revisables todos los contratos y concesiones hechos por los Gobiernos anteriores desde el año de 1876, que hayan traído por consecuencia el acaparamiento de tierras, aguas y riquezas naturales de la Nación, por una sola persona o sociedad, y se le faculta al Ejecutivo de la Unión, para declararlos nulos, cuando impliquen perjuicios graves para el interés público. 


\section{CAPítulo 3}

\section{A RegulamentaÇão JuRídica das RelaÇões de Trabalho NO MÉXICO REVOLUCIONÁRIO}

\subsection{O trabalho no México do início do século XX: assalariado e livre?}

Gastón Garcia Cantú, em seu livro O socialismo en México descreve uma das dificuldades do incipiente trabalho assalariado no México do fim do século XIX: os operários eram obrigados a trabalhar 14 horas por dia no inverno e 15 horas no verão. Nos períodos em que não havia luz natural, velas eram utilizadas para iluminar o ambiente de trabalho. Por esse motivo, os períodos de trabalho noturno ficaram conhecidos como "veladas". Aqueles que trabalhassem um período menor do que as 14 ou 15 horas - segundo os empregadores, correspondentes à jornada de trabalho completa - eram descontados em seus salários: recebiam apenas três quartos do valor tradicionalmente pago por dia de trabalho ${ }^{392}$.

Ao analisar as atividades da Compañía Industrial de Orizaba S.A. (CIDOSA) e da Compañía Industrial Veracruzana S.A. (CIVSA), duas grandes indústrias têxteis do México no início do século XX, a historiadora Aurora Gómez-Galvarriato chama atenção para as mudanças da jornada de trabalho no período. No início de 1907, os trabalhadores das duas companhias cumpriam uma jornada de 12 horas de trabalho. Em junho de 1907, para a CIDOSA, e em agosto de 1910, para a CIVSA, a jornada foi reduzida em uma hora, após algumas greves. Após essa primeira mudança, de 12 para 11 horas de trabalho, outras se sucederam. Em 1912, a queda foi de 11 para 10 horas diárias trabalhadas; em 1915, de 10 para 9 horas. Por fim, em 1917, com a Constituição

\footnotetext{
392 "El 4o. de los abusos, era el de obligar a los obreros a admitir que el día se componía de 14 horas en invierno y 15 en verano, 'de modo que al obrero que no vele o trabaje con luz artificial, sólo se le pagaran tres cuartos de jornal, contados desde las 5 y $1 / 4$ de la mañana hasta a las $63 / 4$ de la tarde en verano; o de las 6 de la mañana a las 6 de la tarde en invierno; es decir, de 14 a 15 horas de trabajo material para 'hombres, niños, cuya constitución y alimentos distan mucho de ser sólidos...'. González pedía una ley que aboliera las veladas así como la reglamentación de las horas de trabajo. [obreros de Tlalpan, 11 de mayo de 1873 - Francisco de P. Gonzáles].” GARCÍA CANTÚ, Gastón. El socialismo en México. $4^{\mathrm{a}}$ reed.. Cidade do México: Ediciones Era, 1986, p. 30.
} 
dos Estados Unidos Mexicanos, a jornada máxima de trabalho em todo o México passou a ser de 8 horas ${ }^{393}$.

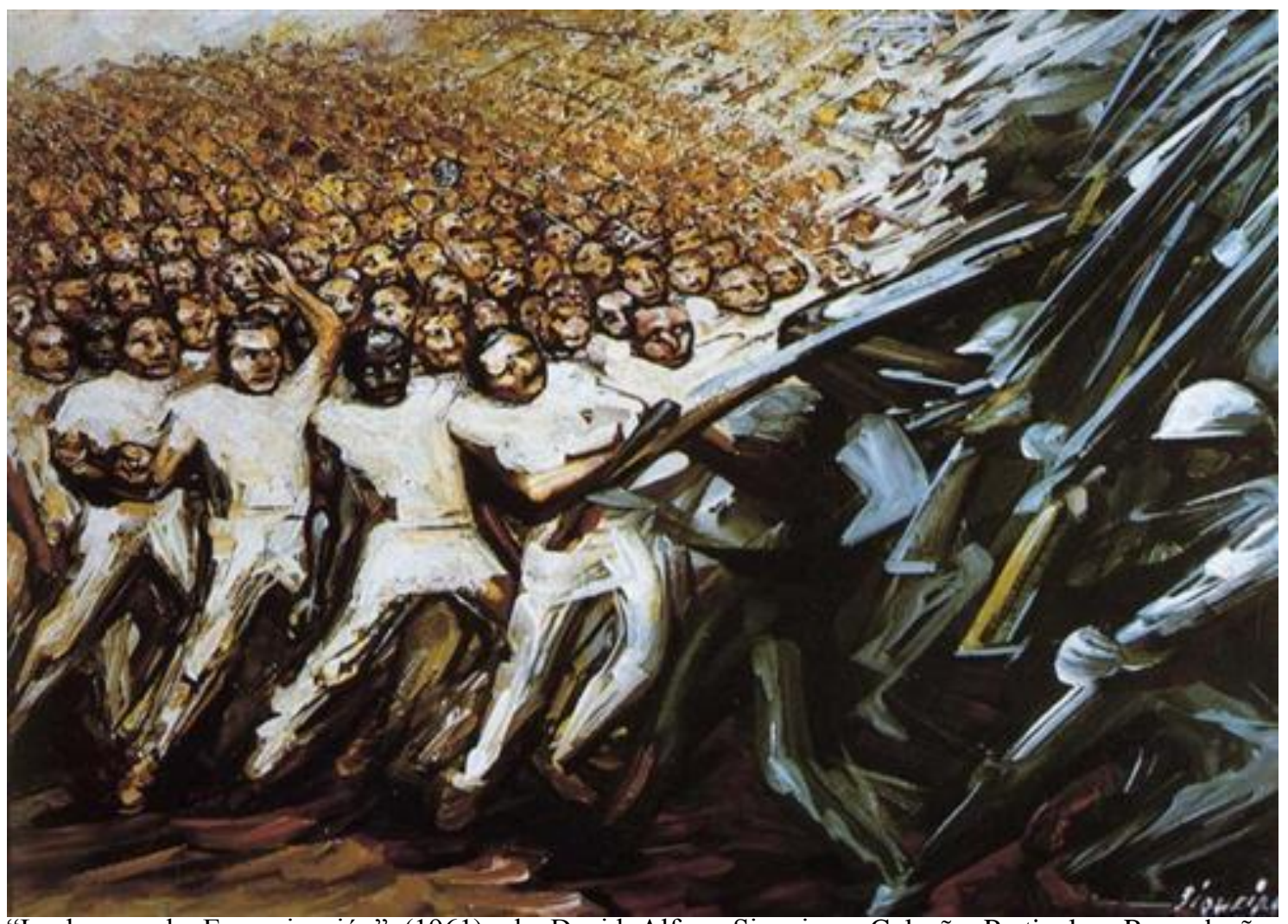

"Lucha por la Emancipación" (1961), de David Alfaro Siqueiros. Coleção Particular. Reprodução: Wikiart

Em dez anos, os trabalhadores dessas duas indústrias têxteis passaram de 12 para 8 horas de trabalho diário. Se consideradas as horas trabalhadas por dia no final do século XIX, pode-se dizer que, em vinte anos, a jornada de trabalho no México foi reduzida quase pela metade. Impossível ignorar que essas mudanças ocorreram em um México imerso em uma revolução popular. Se não causa direta de todos os acordos muitas vezes firmados no âmbito das indústrias, a Revolução Mexicana - e suas muitas reivindicações, expressas por meio de inúmeros documentos revolucionários contribuíram para a criação de um marco regulatório para as relações de trabalho no México, antes inexistente.

${ }^{393}$ GÓMEZ-GALVARRIATO, Aurora. "Measuring the impact of institutional change in capital-labor relations in the Mexican textile industry, 1900-1930". In BORTZ, Jeffrey; HABER, Stephen. The Mexican economy, 1870-1930: essays on the economic history of institutions, revolution, and growth. Califórnia: Stanford University Press, 2002, p. 292. 
As condições de trabalho da CIDOSA e da CIVSAtratam do trabalhador industrial e urbano, ainda muito pouco representativo no México do início do século XX. Jean Meyer, em seu livro La revolución mexicana 1910-1940, descreve que o México vivia no início do século um período de grandes taxas de crescimento industrial (média de 12\% ao ano). Mesmo com a urbanização acelerada que esse ciclo engendra, em 1910 70\% da população da população é rural e vive da agricultura. Da população de quinze milhões de mexicanos, estima-se que onze milhões viviam no campo. No ano em que tem início a fase maderista da Revolução, estima-se que houvesse no México 195 mil operários - majoritariamente do setor têxtil e de mineração - e 500 mil artesãos, número bastante pequeno quando comparado ao contingente de trabalhadores no campo $^{394}$.

Mexico's revolution radically transformed the labor regime. In 1910, there existed no body of law that was specifically a labor code. There were no minimum wage or maximum hour regulations. There were no collective contracts. Unions existed but only on the margins of law and power. There were no government labor offices or labor courts. (...)

Pre-revolutionary Mexico lacked a formal labor relations system to mediate conflicting interests. Revolutionary Mexico invented one, although many scholars have seen it as a political rather then economic institution. ${ }^{395}$

The violence of the revolution changed factory operations as workers not only organized unions, but also attacked and sometimes killed recalcitrant bosses without great fear of retribution. Unions, worker violence, and the incapacity of the state to support beleaguered owners changed factories. ${ }^{396}$

Jeffrey Bortz defende a ideia de que a regulamentação das relações de trabalho deve ser compreendida como uma limitação (legítima) da propriedade privada.

\footnotetext{
394 "En 1910 hay 195,000 obreros y 500,000 artesanos. De quince millones de mejicanos, once viven en el campo. Los campesinos mejicanos constituyen el 62\% de la población activa de 1910. En 1910 el $40 \%$ de las comunidades consiguieron sobrevivir a la ofensiva de los "cercados". Se trata sobre todo de las regiones montañosas y aisladas del sur indio. A costa de una resistencia encarnizada las comunidades de Morelos conservaron sus tierras en un 60\%. A ello se suman 600,000 pequeños propietarios, un cuarto de los cuales posee menos de una hectárea, el $60 \%$ menos de 5 y el $90 \%$ menos de 50 hectáreas". MEYER, Jean, La revolución mexicana 1910-1940. Barcelona: Dopesa, 1973, p. 17-18.

${ }^{395}$ BORTZ, Jeffrey L.. "The legal and contratual limits to private property rights in Mexican industry during the revolution". In BORTZ, Jeffrey; HABER, Stephen. The Mexican economy, 1870-1930: essays on the economic history of institutions, revolution, and growth. Califórnia: Stanford University Press, 2002, p. 256-257.

${ }^{396}$ BORTZ, Jeffrey L. "The legal and contratual limits to private property rights in Mexican industry during the revolution". In BORTZ, Jeffrey; HABER, Stephen. The Mexican economy, 1870-1930: essays on the economic history of institutions, revolution, and growth. Califórnia: Stanford University Press, 2002, p. 269.
} 
Descreve que antes da Revolução os empresários tinham liberdade quase absoluta para administrar e disciplinar as atividades que ocorriam em sua propriedade privada. Contratavam, despediam, estipulavam as normas e aplicavam as sanções aosempregados ${ }^{397}$ que trabalhassem - e, em muitos casos da área rural, morassem - em suas propriedades. Após a revolução, todas essas atividades foram limitadas e regulamentadas pelo Estado. Salário mínimo, jornada máxima de trabalho, descanso semanal remunerado, regras de convivência no ambiente laboral foram estabelecidas nacionalmente em documentos produzidos e reivindicados pelos revolucionários.

Apesar de a Constituição de 1857 garantir que todos os escravos que pisassem em solo mexicano tornariam-se automaticamente livres, sujeitos de direito e estariam sob a proteção da lei $\left(\operatorname{art.~} 2^{\circ}\right)^{398}$; apesar de incluir entre as liberdades públicas fundamentais a afirmação de que "Todo hombre es libre para abrazar la profesion, industria ó trabajo que le acomode" $\left(\operatorname{art} .4^{\circ}\right)^{399}$; apesar de proibir que no território mexicano haja trabalhos forçados, sem pagamento de retribuição ou sem consentimento do trabalhador $\left(\operatorname{art} .5^{\circ}\right)^{400}$, e apesar de proibir quaisquer distinções entre trabalhadores mexicanos e estrangeiros (art. 32) ${ }^{401}$, foi a Revolução Mexicana a responsável pelo

\footnotetext{
397 "Before the revolution, the liberal ideal of unfettered property rights determined factory relationships. After the revolution, factory relationships were mediated by layers of new organizations, each with measured of power and influence. Meanwhile, a complex set of rules ensured that workers could dominate only if they controlled their unions, not easy in the political environment of post-revolutionary Mexico. In 1910, private property rights for industrialists allowed owners to run the factories as they wished. By 1921, constitutional and state law restricted the rights of owners to hire, fire, or discipline workers, and to even write work rules. These were new limits to private property in Mexican industry." Jeffrey L. BORT, "The legal and contratual limits to private property rights in Mexican industry during the revolution", p. 273.

398 “2. En la República todos nacen libres. Los esclavos que pisen el territorio nacional, recobran, por ese solo hecho, su libertad, y tienen derecho á la proteccion de las leyes." Constitución Política de la República Mexicana de 1857, promulgada em 5 de fevereiro de 1857. Cidade do México: Instituto de Investigaciones Jurídicas. <http://www.juridicas.unam.mx/infjur/leg/conshist/pdf/1857.pdf> Consulta realizada em 11/01/2016.

399 “4. Todo hombre es libre para abrazar la profesión, industria o trabajo que le acomode, siendo útil y honesto, y para aprovecharse de sus productos. Ni uno ni otro se le podrá impedir sino por sentencia judicial cuando ataque los derechos de tercero, o por resolución gubernativa, dictada en los términos que marque la ley, cuando ofenda los de la sociedad." Constitución Política de la República Mexicana de 1857, promulgada em 5 de fevereiro de 1857. Cidade do México: Instituto de Investigaciones Jurídicas. <http://www.juridicas.unam.mx/infjur/leg/conshist/pdf/1857.pdf> Consulta realizada em 11/01/2016.

400 “5. Nadie puede ser obligado á prestar trabajos personales, sin la justa retribución y sin su pleno consentimiento. La ley no puede autorizar ningun contrato que tenga por objeto la pérdida o el irrevocable sacrificio de la libertad del hombre, ya sea por causa de trabajo, de educación o de voto religioso. Tampoco puede autorizar convenios en que el hombre pacte su proscripción o destierro." Constitución Política de la República Mexicana de 1857, promulgada em 5 de fevereiro de 1857. Cidade do México: Instituto de Investigaciones Jurídicas. <http://www.juridicas.unam.mx/infjur/leg/conshist/pdf/1857.pdf> Consulta realizada em 11/01/2016.

401 “32. Los mexicanos serán preferidos á los extranjeros, en igualdad de circunstancias, para todos los empleos, cargos o comisiones de nombramiento de las autoridades, en que no sea indispensable la calidad de ciudadanos. Se expedirán leyes para mejorar la condicion de los mexicanos laboriosos, premiando á
} 
impulso social capaz de criar normas que efetivamente regulassem as relações de trabalho no México. O país saiu de uma situação de anomia, em 1910, para uma das mais extensas legislações trabalhistas existentes no mundo naquele momento histórico. Assim, os embates, as lutas e mesmo a violência dos dez anos que separam a prática da jornada de trabalho de 12 horas nas fábricas de Orizaba e a regra nacional de, no máximo, 8 horas de trabalho incluída na Constituição de 1917 não devem ser esquecidos ao tentarmos entender essa profunda transformação do direito do trabalho e do ordenamento jurídico no México do início do século XX.

Iniciamos esse capítulo discutindo os efeitos da Revolução: seu desenrolar teve impacto, notável ao final, nos direitos garantidos aos trabalhadores. Interessa saber se as condições de trabalho no México do início do século XX podem ser incluídas entre as causas do mal-estar social que levou à insurreição. As muitas expropriações de terras de índios, mestiços e campesinos geraram uma sensação de enorme injustiça nos campos mexicanos. A tensão relacionada à terra gerava também efeitos concretos no mundo do trabalho. Campesinos desalojados, retirados de suas atividades cotidianas tinham poucas alternativas: ou se submetiam ao regime proposto pelo novo proprietário das terras que antes eram suas ou tinham de procurar trabalho em outros lugares.

Ficar era, muitas vezes, insuportável. Ao sair, nem sempre havia a garantia de conseguir um novo trabalho. Com a expulsão dos pequenos agricultores do campo mexicano, gerou-se um enorme contingente de reserva nas crescentes cidades mexicanas. O processo de apropriação privada das terras aumentou a população, muitas vezes desempregada, nas cidades. Formou-se um exército de reserva, uma massa de trabalhadores potenciais, cuja substituição rápida e fácil possibilitava impor baixos salários e más condições de trabalho. Ao mesmo tempo, o processo de expulsão das suas antigas propriedades também tornou precárias as relações no campo: contratos de parceria, de arrendamento, trabalho com baixíssima remuneração diária, obrigação de consumir o salário nas lojas dos patrões, que cobravam preços abusivos, dívidas que se somavam e que, na prática, acabava com a liberdade do empregado de decidir sair de seu posto de trabalho, aproximando sua condição à de um escravo.

los que se distingan en cualquier ciencia o arte, estimulando al trabajo y fundando colegios y escuelas prácticas de artes y oficios." Constitución Política de la República Mexicana de 1857, promulgada em 5 de fevereiro de 1857. Cidade do México: Instituto de Investigaciones Jurídicas. <http://www.juridicas.unam.mx/infjur/leg/conshist/pdf/1857.pdf> Consulta realizada em 11/01/2016. 
Os problemas relacionados à terra estavam refletidos no mundo do trabalho. Além deles, as tensões típicas de um país em que há uma industrialização nascente e que, sem qualquer regulação, vive os abusos daqueles que detêm os meios de produção, o monopólio do poder de decisão e toda a vontade de lucrar e de extrair a máxima produtividade dos insumos de que dispõem, inclusive a força de trabalho.

Chamar de trabalho assalariado relações baseadas na submissão absoluta, com práticas que incluem até penas físicas para faltas funcionais, sem recebimento de salário e sem liberdade para interromper as atividades em função de enormes dívidas contraídas nas lojas dos patrões ou em razão de altas multas impostas por pequenas faltas, também estipuladas e aplicadas pelos patrões, é, no mínimo, um eufemismo. Grande parte das relações reais de trabalho do México no início do século XX não poderiam ser caracterizadas como típicas relações de trabalho assalariado e livre. Antes, a relação de exploração máxima, em que todos os benefícios estavam do lado dos empregadores, em detrimento da saúde e qualidade de vida dos empregados, se aproximava de um regime semifeudal $^{402}$, se não claramente escravocrata, de trabalho. Sendo assim, não se pode deixar de incluir essa realidade entre as motivações da insatisfação popular que levaram à Revolução, junta e intrinsecamente relacionadas às tensões agrárias vividas pelo México de 1910.

\subsection{Trabalho rural: peonaje, aparceria, arrendamiento, mediería}

O campo mexicano não era, ao longo do século XIX, um bom ambiente de trabalho. Friedrich Katz descreve como Benito Juárez, considerado herói nacional, presidente responsável pela luta contra a invasão francesa e por grande parte das reformas liberais realizadas no México, esteve às voltas com o problema das condições de trabalho no campo. Apesar de o deputado Julio Zarate apresentar um projeto de lei que tentava impedir, ou ao menos tornar ilegais, as maiores arbitrariedades realizadas por fazendeiros contra seus empregados, e apesar de Benito Juárez ter apoiado o projeto, nada de concreto foi feito ou aprovado.

\footnotetext{
402 "Bajo las condiciones semifeudales del país, los obreros lograron luchar y organizarse. No hay duda que sus esperanzas y proposiciones, en 1876, anteceden al artículo 123 de la Constitución de 1917”. GARCÍA CANTÚ, Gastón . El socialismo en México. $4^{\mathrm{a}}$ reedição. Cidade do México: Ediciones Era, 1986, p. 205.
} 
Juárez também não fez mais do que um fraco esforço para impedir os piores excessos da servidão por dívida (peonaje) e, associado intimamente a ela, o poder arbitrário do fazendeiro sobre os seus peões. Em 1868, um congressista liberal, Julio Zarate, apresentou uma proposta que proibia os hacendados de instalar cárceres privados, de ministrar castigos corporais ou de transferir as dívidas dos pais para os filhos. O Congresso rejeitou-a, sob a alegação de que não tinha jurisdição para decidir sobre essa questão, que era um caso de competência exclusiva do Judiciário local. Juárez apoiou a proposta de Zarate e tentou intevir, mas as limitadas medidas que decretou no tocante à servidão por dívidas nunca foram implementadas ${ }^{403}$.

Ao longo do porfiriato e, consequentemente, de forma muito aguda no início do século $\mathrm{XX}$, as práticas descritas por Katz tornaram-se socialmente insuportáveis. Não tanto porque as penas físicas ou a servidão por dívidas - que caracterizava a chamada peonaje - tenham se tornado mais cruéis. Seus mecanismos e formas já eram bastante duros e violentos na época de Benito Juárez, cujo liberalismo não alcançou as relações de trabalho. O fato de tais práticas se tornarem motivo de insatisfação generalizada está diretamente relacionado com o aumento de seu alcance, ou seja, com o aumento do número de mexicanos submetidos a elas. Camponeses que antes organizavam o próprio trabalho, a própria terra e a própria atividade produtiva - muitas vezes de forma coletiva - tiveram suas terras expropriadas. Segundo Katz, em La servidumbre agraria en México en la época porfiriana, ao final do governo de Porfírio Díaz, 95\% das aldeias comunais tinham perdido suas terras ${ }^{404}$. Assim, a população que antes vivia nessas aldeias comunais precisou encontrar novas formas de garantir a própria sobrevivência.

Como o Estado mexicano havia reconhecido a propriedade privada de outra pessoa naquelas que antes eram terras desses camponeses, eles quase automaticamente passaram a ser empregados dos novos proprietários, em diferentes modalidades. O número de peões, arrendatários e parceiros aumentou significativamente nos trinta anos de governo Porfírio Díaz.

Para Juan Felipe Leal, em Origen y evolución de hacienda en México: siglos $X V I$ al XX, a peonaje está ligada ao próprio conceito mexicano de hacienda, estando presente como traço distintivo desse tipo de organização de atividade econômica nos quatro séculos que toma por objeto de análise:

\footnotetext{
${ }^{403}$ KATZ, Friedrich. "O México: a república restaurada e o porfiriato, 1867-1910". In BETHELL, Leslie (org.). História da América Latina vol. V: de 1870 a 1930. São Paulo: Edusp, 2008, p. 32.

${ }^{404}$ KATZ, Friedrich. La servidumbre agraria en México en la época porfiriana. $9^{\mathrm{a}}$ reimp. Cidade do México: Ediciones Era, 2004, p. 13.
} 
La hacienda novohipanica-mexicana exhibió una matriz básica, constante y característica a lo largo de cuatro siglos, que puede describirse de la siguiente manera: se trataba de una propiedad rústica que cumplía con un conjunto específico de actividades econômicas (...), y que se fundaba en el peonaje por deudas para el desempeño de sus funciones. Este último era, sin duda, el rasgo más distintivo del sistema hacendista. Dicho de otro modo: sin trabajadores residentes y endeudados no había hacienda en el sentido clásico del término. ${ }^{405}$

Nesse sentido, os trabalhadores que moravam nas fazendas mexicanas não estabeleciam com os fazendeiros uma relação de trabalho livre. Quando o vínculo se consolidava, geralmente em condições iniciais já desfavoráveis para os trabalhadores, ele tendia a se perpetuar principalmente por meio de dívidas que impediam o seu rompimento. As dívidas tinham diferentes origens: poderiam ser geradas por meio de pagamentos adiantados e empréstimos ${ }^{406}$, por compras realizadas a preços abusivos nas tiendas de rayas (armazéns) dos donos das fazendas, ou ainda quando os camponeses cometiam alguma falta cuja penalidade era o pagamento de uma multa, em valores que por vezes ultrapassavam o que recebiam ao longo de um ano de trabalho. Seja qual fosse sua origem, as dívidas dos peões tinham o mesmo efeito: tornar impossível a desvinculação da propriedade em que trabalhavam e, consequentemente submetê-los a condições cada vez mais desfavoráveis e degradantes de trabalho. Katz informa que, no período do porfiriato, entre 1876 e 1910, o poder aquisitivo do jornal, valor diário pago pelos fazendeiros aos peões, caiu muito ${ }^{407}$.

Por surpreendente que possa parecer, a prática de manter trabalhadores eternamente vinculados a um contrato de trabalho por meio de dívidas, aparentemennte

${ }^{405}$ LEAL Y FERNANDÉZ, Juan Felipe . "Fuentes, métodos y enfoques en el estudio de la hacienda en México". In JARQUÍN, María Teresa (org.). Origen y evolución de hacienda en México: siglos XVI al XX. Memorias del simposio realizado del 27 al 30 de septiembre de $1989.1^{a}$ ed.. Toluca: Instituto Nacional de Antropología y Historia, 1990, p. 43.

406 "Em 1901, dizia um observador: um dos meios legais de prender os criados à fazenda consiste num pagamento adiantado: nessa condição significa que um trabalhador que deixa a hacienda pode ser trazido de volta à força pela polícia. Geralmente, esses pagamentos adiantados são feitos quando um jovem nascido na fazenda atinge a idade de 18 ou 20 anos e se casa. Então, seu patrão lhe dá cem a cento e cinquenta, algumas vezes até duzentos pesos, para construir uma casa e ambas as partes concordam tacitamente que essa soma e outras quantias que possam ser adiantadas em data posterior em caso de acidente ou de doença nunca serão pagas. É o preço pelo qual o jovem yucateco vende sua liberdade". Nas páginas seguintes do mesmo texto, Katz descreve mais uma estratégia para consolidar a servidão por dívida: a realização de pagamentos anuais. Narra ainda uma cena relatada por estrangeiros no início do século XX, em que capatazes armados acompanhavam o trabalho dos peões ao longo de todo o dia e, à noite, os trabalhadores ficavam presos em um galpão, deixando explícito que o trabalho não respeitava a liberdade de decidir dos trabalhadores." KATZ, Friedrich. "O México: a república restaurada e o porfiriato, 1867-1910”. In BETHELL, Leslie (org.) História da América Latina vol. V: de 1870 a 1930. Trad. Geraldo Gerson de Souza. São Paulo: Edusp, 2008., p. 76-77.

${ }^{407}$ KATZ, Friedrich. La servidumbre agraria en México en la época porfiriana. $9^{\mathrm{a}}$ reimp. Cidade do México: Ediciones Era, 2004,p. 13. 
contrária a qualquer legalidade, ganhou um possível respaldo jurídico por meio de uma modificação na Constituição Mexicana de 1857. O artigo $5^{\circ}$ original da Constituição dispunha que "Nadie puede ser obligado á prestar trabajos personales, sin la justa retribución y sin su pleno consentimiento. La ley no puede autorizar ningun contrato que tenga por objeto la pérdida o el irrevocable sacrifício de la libertad del hombre, ya sea por causa de trabajo [...]”. Em 10 de junho de 1898, porém, Porfírio Díaz introduziu algumas exceções no texto do referido artigo constitucional. A primeira frase da norma ficou muito mais longa: "Nadie puede ser obligado á prestar trabajos personales, sin la justa retribución y sin su pleno consentimiento, salvo el trabalho impuesto como pena por la autoridad judicial. En cuanto á los servicios públicos [...] ${ }^{, 408}$. O que até 1898 era uma prática violadora do ordenamento jurídico mexicano passou a ser admissível pela constituição, sempre que autorizada por uma ordem judicial, após a emenda constitucional de Díaz.

$\mathrm{Na}$ típica hacienda mexicana, os peões trabalhavam as melhores terras como empregados dos fazendeiros-proprietários. As terras de menor valor produtivo - com irrigação e acesso difíceis, em terrenos íngrimes, menos férteis - eram geralmente cedidas temporariamente a título de arrendamento ou parceria. Os fazendeiros eram estimulados a deixar que camponeses cultivassem partes de suas propriedades para aumentar sua produtividade total, já que, por inconvenientes vários, eles não teriam interesse em utilizá-las diretamente. Além disso, ter arrendatários ou parceiros em suas próprias terras era garantir força de trabalho quando, nas épocas de colheita e plantio, ela fosse necessária aos seus cultivos principais. A garantia de mão de obra sazonal quando fosse necessária, sem custos de transação, aliada à possibilidade de explorar de forma mais completa as terras de suas propriedades eram dois estímulos desse tipo de relação. Juan Felipe Leal afirma que a proporção que cada uma das partes da hacienda ocupava do total - quanto de exploração direta pelo proprietário e quanto de exploração mediante arrendamento e outras formas de cessão - variava de acordo com o contexto econômico pelo qual passava o país assim como as demandas de produção. Quanto mais o mercado estava aquecido e os preços de venda de produtos agrícolas alto, uma maior

\footnotetext{
408 FLORES, Imer B.. "La constitución de 1857 y sus reformas: a 150 años de su promulgación". In VALADÉS, Diego; CARBONELL, Miguel (coord). El proceso constituyente mexicano: a 150 años de la constitución de 1857 y 90 de la constitución de 1917. Cidade do México: Instituto de Investigaciones Jurídicas de la Universidad Nacional Autónoma de México, 2007, p. 304-305.
} 
parcela da propriedade era explorada diretamente pelo fazendeiro; em épocas de retração, a parte arrendada tendia a crescer.

A definição pelo contrato de parceria ou de arrendamento também se dava a partir dos interesses do proprietário de terras. Caso houvesse expectativa de uma boa produtividade no terreno cedido, o contrato mais vantajoso era o de parceria, em que uma parte do produzido naquele pedaço de terra deveria ser entregue ao seu proprietário. Em locais em que a produtividade não era tão grande - ou a produção envolvia algum risco - estabelecia-se o arrendamento, com o pagamento mensal, semestral ou anual de um valor pré-combinado e invariável. Os contratos de arrendamento tinham ainda a vantagem de, quando não cumpridos, transformar o que antes eram arrendatários em peões endividados. Além de aparcería, arrendamiento em seus termos originais em espanhol - um contrato frequente era o de mediería, um subtipo de parceria. A peculiaridade desse tipo de contrato é a porcentagem que os medieros deveriam pagar para os proprietários: exatos 50\%do que fossem capazes de produzir. Mesmo a porcentagem que dava o nome desse tipo de contrato foi modificada, mais uma vez em detrimento dos interesses dos camponeses, como descreve Friedrich Katz ao analisar as mudanças nesse tipo de contrato de utilização de terras:

Quando a produção de safras para o mercado se tornou cada vez mais lucrativa, muitos hacendados começaram a substituir os acordos de parceria, preferindo contratar trabalhadores que cultivassem a terra das fazendas para eles. A parceria não foi de modo nenhum abolida, mas os parceiros foram empurrados aos poucos para terras marginais, mais sujeitas às oscilações do tempo. Em outros casos, os acordos de parceria foram substituídos por outros arranjos ainda mais desfavoráveis aos camponeses. A evolução dos padrões de meação numa fazenda perto de Celaya, no Estado de Guanajuato, ilustra com mais clareza como as haciendas fizeram essa substituição. Até a última parte do século XIX havia nessa hacienda dois tipos de meeiros: os medieros al rajar e os medieros al quinto. Os primeiros forneciam seus próprios implementos agrícolas e os bois e recebiam 50 por cento da colheita. Os segundos usavam os equipamentos e os animais da fazenda e, em troca, pagavam aos costumeiros 50 por centos de suas safras, mais um quinto do restante em pagamento pelo uso das máquinas e dos animais. (...) No começo do século XX, somente alguns colonos privilegiados ainda trabalhavam suas terras numa base de meias. Todos os outros haviam tornado-se medieros al quinto. ${ }^{409}$

\footnotetext{
${ }^{409}$ KATZ, Friedrich. "O México: a república restaurada e o porfiriato, 1867-1910". In BETHELL, Leslie (org.). História da América Latina vol. V: de 1870 a 1930. Trad. Geraldo Gerson de Souza. São Paulo: Edusp, 2008, p. 75-76.
} 
O que era $50 \%$ na mediería, tornou-se $60 \%$. A maior parte do que os camponeses eram capazes de produzir era destinada aos proprietários da terra. Se a vida daqueles que moravam nas fazendas como arrendatários ou parceiros, servindo como mão de obra sazonal, não era fácil, a situação daqueles que se submetiam ao regime de peonaje era ainda pior. Além dos baixos salários, muitas vezes pagos em forma de vales que só poderiam ser usados nas tiendas de raya, armazéns instalados nas fazendas e administrados pelos proprietários e seus capatazes; além das dívidas que mantinham os trabalhadores vinculados a seus locais de trabalho, também as estruturas do Estado mexicano reforçavam as condições precárias de trabalho. Se um camponês fugia da fazenda para a qual supostamente devia, o aparato repressor do Estado - seus policiais e o ejército de federales - poderia ser acionado para que o devedor fosse trazido de volta a seu lugar de trabalho e obrigado a ceder o único bem que dispunha para pagá-la: sua força de trabalho. As dívidas eram um mecanismo que tornavam o trabalho do camponês quase gratuito para os fazendeiros.

Embora o Código Penal de 1872 proibisse- e coibisse com multa - o pagamento de jornales com meios de pagamento que não moeda corrente; embora o mesmo Código Penal disciplinasse como crime o cárcere privado, não há, segundo García Cantú, registros na história pré-revolucionária de quaisquer processos judiciais em que essas regras tenham sido aplicadas contra os fazendeiros empregadores ${ }^{410}$. Não obstante a falta de sanção, a prática era frequente. Para além dos baixos salários, os fazendeiros costumavam punir seus subordinados com períodos de restrição da liberdade de ir e vir, verdadeiros cárceres ou tlaxpiqueras, como eram conhecidas as instalações para esse fim nas haciendas. A complacência que o sistema de justiça praticava com os fazendeiros não se verificava para com os camponeses: qualquer início de sublevação ou insurreição contida era punida com multas altas, além de entre 8 e 3 meses de prisão.

\footnotetext{
410 "Si el Código Penal de 1872, que estuvo vigente hasta el presente siglo (XX), estipulaba que los hacendados que pagaran los jornales con 'tarjas, o planchuelas de metal o de otra materia', pagarían una multa igual a la cantidad a que ascediera la última semana de raya, también disponía que la mitad de esa multa la pagaran los jornaleros. No hay, al menos en las noticias publicadas en esa época, hecho alguno que probara la aplicación de esa ley. Tampoco hubo castigo para los hacendados o industriales que encerraban a campesinos y obreros en tlaxpiqueras o cárceles, a pesar de las frecuentes denuncias públicas al respecto. El artículo 355 de dicho Código era igualmente contrario a los trabajadores: los 'amos' podrían exigir de ellos lo que, a su juicio, no fuere cumplido exactamente. El artículo 925 imponía de 8 días a tres meses de arresto y multa de 25 a 500 pesos - cantidad ésta que jamás ganaría un campesino ni un obrero durante toda su vida - 'o una sola de estas dos penas, a los que formen tumulto o motín o empleen de cualquier modo la violencia física o moral, con el objeto de hacer que suban o bajen los salarios o jornales de los operarios, o de impedir el libre ejercicio de la industria o trabajo". GARCÍA CANTÚ, Gastón . El socialismo em México. 4ª reed.. Cidade do México: Ediciones Era, 1986, p. 31-32.
} 
Para manter os camponeses submissos e presos às suas condições de trabalho, desde 1853 havia uma lei que proibia a vagancia, ou, em português, a vagabundagem. Multas podiam ser aplicadas a todos aqueles que "no tienen oficio, profesión, hacienda, renta, sueldo, ocupación o medio lícito con que vivir" ${ }^{\text {"411 }}$. Além de ser penalizados pela falta de um meio lícito de sobrevivência, a norma previa que eles também eram candidatos naturais a serem convocados pela leva, obrigação de se alistar no exército mexicano.

Quer se considere a autorização para trabalhos forçados por meio de ordem judicial, quer sejam analisadas as normas que criminalizam a vagancia e as tentativas de resistência organizada ao poder dos fazendeiros, fica evidente que o ordenamento jurídico e as instituições judiciais colaboravam para a manutenção do modo explorador e degradante em que o trabalho rural estava organizado.

Esta conivência institucional contra os trabalhadores não era exclusividade do campo, porém. Também nas cidades as instituições protegiam os proprietários em detrimento dos trabalhadores das fábricas. Realidade comum aos trabalhadores urbanos e rurais foi a significativa queda no padrão de vida no início do século XX. Para além da diminuição (algumas vezes nominal) dos jornales, já que a mão de obra tinha se tornado mais abundante em função das expulsões dos camponeses de suas próprias terras, o custo de vida tinha subido significativamente. Entre os itens de primeira necessidade, o preço dos alimentos aumentou, já que a produção nas haciendas, algumas recémcriadas, passara a se voltar para o mercado externo ao invés dos bens de consumo dos mexicanos. Se a violência institucional e a diminuição progressiva do poder de compra dos salários recebidos pelos trabalhadores urbanos e rurais os aproximava, outros elementos tornavam os dois contextos de trabaho bastante diferentes. A principal delas talvez seja a concentração populacional em um mesmo território. As regiões industriais, como o vale de Orizaba que era sede de inúmeras indústrias têxteis, chegavam abrigar mais de sete mil trabalhadores, vizinhos. Essa organização territorial tinha impacto nos vínculos de solidariedade e na possibilidade de organização coletiva para a defesa de direitos.

\footnotetext{
411 A íntegra do decreto que proíba a vagancia, de 20 de agosto de 1853 , pode ser encontrada em CARMONA, Doralicia. Memoria Política de México. Guanajuato: Universidade de Guanajuato, 2014. http://www.memoriapoliticademexico.org/Textos/2ImpDictadura/1853LCV.html Consulta realizada em $\underline{10 / 12 / 2015}$.
} 


\subsection{Trabalho urbano: mineração, petroleiras e indústria têxtil}

Apesar de o número de trabalhadores industriais ter crescido muito ao logo do porfiriato (só entre 1895 e 1900 o número passou de 692.697 para $803.294^{412}$ ), quando comparado ao total da população mexicana - de 15 milhões de pessoas -, o operariado industrial ainda representava uma porcentagem pequena da população economicamente ativa. As cidades que abrigavam esses trabalhadores industriais eram pólos de um dos três principais setores: mineração, petroleiras e indústria têxtil. A duas primeiras situavam-se em áreas em que havia reservas minerais disponíveis. Era quase possível enumerar as cidades em que havia intenso trabalho industrial, como Cananea, Rio Blanco, Santa Teresa e Cidade do México, entre outras.

Embora muito menos representativos do que o contigente rural, os trabalhadores das indústrias desempenharam um papel importante ao longo da Revolução Mexicana. Antes da sublevação de 1910, as greves organizadas em Rio Blanco e Cananea - e as respectivas respostas violentas por parte do governo de Porfírio Díaz - contribuíram para deixar cada vez mais explícito para a opinião pública o caráter autoritário do governo. Antes dessa intervenção, era de alguma forma cômodo para Porfírio Díaz responsabilizar proprietários particulares, governantes e juízes distribuídos em diferentes estados pelas mazelas sofridas diretamente pela população.

Uma mudança legislativa ou a demarcação e apropriação de terras não têm tanto impacto imagético e simbólico quanto uma ação de extrema violência de um exército armado contra sua própria população: trabalhadores que se manifestavam por melhores condições de trabalho. Antes de apresentar as duas grandes greves reprimidas - sinais de que havia, também entre os trabalhadores industriais, um grande mal-estar social - vale a pena revisar quais eram as condições de trabalho dos operários urbanos.

Cada cidade, região ou ramo de produção industrial possuía especificidades em suas relações de trabalho, segundo Katz. Em todas elas, porém, ocorriam abusos relacionados a um controle disciplinar demasiadamente estrito, em diferentes modalidades. Para além de sanções graves - como perda do emprego devido a mínimos atrasos e repressão a qualquer tentativa de organização de trabalhadores para reivindicar direitos -, também a forma de receber salários era um problema em algumas fábricas da

${ }^{412}$ KATZ, Friedrich. "O México: a república restaurada e o porfiriato, 1867-1910”. In BETHELL, Leslie (org.). História da América Latina vol. V: de 1870 a 1930. Trad. Geraldo Gerson de Souza. São Paulo: Edusp, 2008, p. 82. 
indústria têxtil. Tal como acontecia com trabalhadores rurais mexicanos, obrigados a comprar nas tiendas de raya das haciendas, algumas indústrias também realizavam pagamentos por meio de vales que só podiam ser usados em lojas da própria companhia, onde os preços eram mais altos do que os praticados pelo comércio local. Some-se a esses problemas a ausência completa de quaisquer instituições de seguridade social para o trabalhador, visto que nas fábricas mexicanas do início do século XX não havia mecanismos de proteção à saúde. Em caso de acidentes de trabalho ou incapacidade laboral, os trabalhadores simplesmente deixavam de trabalhar e receber seus salários, com exceção de algumas indústrias petroleiras, que cobravam uma contraparte rígida para seus parcos benefícios: disciplina militar ${ }^{413}$.

Muito embora houvesse inúmeras precariedades nas condições de trabalho industrial, Katz chama a atenção para o fato de só começarem a surgir manifestações de descontentamento de trabalhadores urbanos - greves, atos e paralisações - após a virada do século. O autor elabora a hipótese de que, quando comparadas ao trabalho no campo, as condições da fábrica pareciam menos ruins. Por isso, embora sujeitos a inúmeras arbitrariedades daqueles que controlavam as fábricas, os trabalhadores não se organizavam para reivindicar mais direitos trabalhistas. A lembrança do campo fazia com que se contentassem com uma situação ruim, estimulados ainda pelo fato de a vagabundagem ser crime e compelidos pela necessidade de vender sua força de trabalho para subsistir.

A calmaria nas instalações das fábricas não durou eternamente, porém. Em 1900 e 1903 ocorrem algumas greves nas indústrias têxteis do Estado de Puebla. No mesmo

\footnotetext{
413 "Suas condições de vida variaram enormemente. Na região petrolífera, as empresas forneceram moradia, construíram escolas e instalaram até mesmo um serviço médico rudimentar. Em troca, exigiam obediência inquestionável. Nas vilas das empresas de petróleo os prefeitos faziam parte da folha de pagamento das companhias, e estas também criavam e controlavam as forças de polícia. Sindicatos e greves eram proibidos. Nas fábricas têxteis, as condições podiam ser muito mais duras. Na indústria têxtil de Santa Teresa y Contreras, na capital, os trabalhadores não recebiam em dinheiro mas em vales, que só podiam resgatar no armazém da companhia. Os trabalhadores se queixaram muito de uma sobretaxa de 18 por cento que fora aplicada sobre todos os produtos vendidos nesse armazém. Na fábrica Hercules Textile, em Querétaro, os trabalhadores manifestaram reclamações idênticas, mas denunciaram sobretudo o sistema arbitrário de castigo praticado pela companhia: quem chegasse um minuto depois do horário de início do trabalho, 5 horas da manhã, podia ser demitido imediatamente. Não havia provisões para seguro médico, de acidente ou de incapacidade. Não obstante, até a virada do século, foram raras as greves e outros movimentos de protesto por parte dos trabalhadores industriais. Não somente os padrões de vida estavam subindo, como também as condições de trabalho, por difíceis que fossem, ainda eram melhores do que as vigentes nas haciendas, de onde muitos trabalhadores tinham vindo (...)". KATZ, Friedrich. "O México: a república restaurada e o porfiriato, 1867-1910. In BETHELL, Leslie (org.) História da América Latina vol. V: de 1870 a 1930. Trad. Geraldo Gerson de Souza. São Paulo: Edusp, 2008, p. 8283.
} 
período, os trabalhadores das ferrovias também fizeram algumas paralisações, motivadas sobretudo pelos privilégios que os trabalhadores estrangeiros recebiam frente aos mexicanos. É em uma mineradora estadunidense na cidade de Cananea que a organização dos operários ganha maiores proporções: dez mil mineiros se declararam em greve em $1^{\text {o }}$ de junho de 1906.

\subsubsection{A greve de Cananea}

A Cananea Consolidated Cooper Company era uma companhia norte-americana que empregava milhares de mineiros na extração de cobre na região da cidade de Cananea, Estado de Sonora, situado a noroeste do território mexicano e fronteiriço com o território dos Estados Unidos. Os trabalhadores da Cananea Co. suportavam, tal como a esmagadora maioria dos trabalhadores mexicanos, longas e extenuantes jornadas de trabalho dentro das minas.

Em 1899 o primeiro clube liberal foi criado na cidade de San Luís Potosí. A partir dele, outros clubes liberais foram fundados em diferentes estados do México. Entre eles o Club Liberal de Cananea, organizado inicialmente por Esteban Baca Calderón, Manuel M. Dieguez e Lázaro Gutiérrez de Lara, leitores do jornal Regeneración $^{414}$. É o clube liberal, em atividades clandestinas, que estimula a organização dos mineiros na cidade. Desde abril de 1906, os trabalhadores passaram a cogitar e a organizar uma greve para reivindicar melhores condições de trabalho. Dias antes da greve efetivamente ter começado, alguns trabalhadores da mina Oversight, uma das minas exploradas em Cananea, foram informados de que seus contratos de trabalho deixariam de ser diretos com a Cananea Co., e passariam ao controle de outras companhias mineradoras menores, com atividades na região. Essa terceirização de mão de obra nas minas significava, para os trabalhadores, maiores jornadas de trabalho e condições ainda mais precárias de trabalho ${ }^{415}$.

\footnotetext{
${ }^{414}$ Narra-se brevemente história dos clubs liberales no início do século XX e a fundação do Partido Liberal Mexicano no capítulo 1 desta tese.

${ }^{415}$ Sentença do Ministro Seráfico Robles, secretário do Supremo Tribunal de Justiça do Estado de Sonora, no processo que estabeleceu penas para os grevistas e que descreve o início dos conflitos, em 10 de agosto de 1908, pode ser acessada na íntegra em: Revista Relaciones 118, Primavera de 2009, vol. XXX. http://www.revistarelaciones.com/files/revistas/118/pdf/documento.pdf Consulta realizada em 12/12/2015.
} 
Tal como nas ferrovias, uma das reclamações dizia respeito ao tratamento desigual conferido a trabalhadores mexicanos e norte-americanos. Para além de conseguirem ocupar cargos mais altos, os norte-americanos também recebiam maiores salários ao desempenhar as mesmas funções. Além disso, a Cananea Co. tinha como prática pagar parte dos salários em vales, a ser utilizados na tienda de raya (armazém) da companhia, que cobrava preços abusivos por seus produtos. Somem-se esses dois motivos às condições precárias de segurança e trabalho dentro das minas de cobre, além da inexistência de um salário mínimo estabelecido ou de limite de horas para a jornada de trabalho.

Em torno do Club Liberal de Cananea, dois mil mineiros decidem começar a

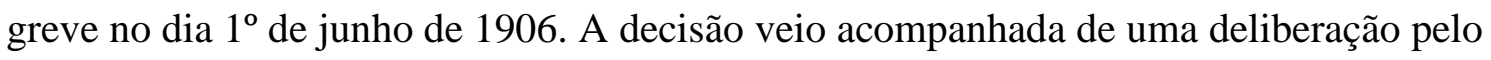
caráter pacífico da manifestação. O primeiro ato da greve foi apresentar ao presidente da companhia - William Greene - suas reivindicações. O documento produzido pelos mineiros trazia reivindicações sobre as condições de trabalho e também um protesto contra o tratamento desigual conferido a mexicanos e trabalhadores de outras nacionalidades:

$1^{\circ}$ Queda el pueblo obrero declarado en huelga.

$2^{\circ}$ El pueblo obrero se obliga a trabajar sobre las condiciones siguientes:

I. La destitución del empleo del mayordomo Luis (Nivel 19).

II. El mínimum sueldo del obrero será cinco pesos diarios con ocho horas de trabajo.

III. En todos los trabajos de la Cananea Consolidated Copper Co., se ocupará el $75 \%$ de mexicanos y el $25 \%$ de extranjeros, teniendo los primeros las mismas aptitudes que los segundos.

IV. Poner hombres al cuidado de las jaulas que tengan nobles sentimientos para evitar toda clase de irritación.

V. Todo mexicano en los trabajos de esta negociación tendrá derecho a ascenso según lo permitan sus aptitudes.

Obreros mexicanos: Un gobierno electo por el pueblo para que lo guíe y satisfaga sus necesidades en lo que cabe: Eso no tiene México.

(...)

Execración sin igual que un mexicano valga menos que un yankee, que un negro o un chino, en el mismo suelo mexicano. Esto se debe [p. 19] al pésimo gobierno que da las ventajas a los aventureros con menoscabo de los verdaderos dueños de esta desafortunada 
tierra ${ }^{416}$ As reivindicações incluíam características pessoais ("ter nobres sentimentos") daqueles que organizavam o cotidiano das minas, salário mínimo de 5 pesos diários para uma jornada máxima de 8 horas de trabalho e não discriminação em detrimento de outras nacionalidades. Mas o documento tratava também de como o governo autoritário de Porfírio Díaz era incapaz de defender direitos e interesses dos operários. Essa associação explícita entre o cotidiano sofrido dos trabalhadores de Cananea e o governo central do México vem à tona por influência do Club Liberal e da organização que criou o Partido Liberal Mexicano um mês mais tarde. $\mathrm{O}$ documento afirma que o México não tem um governo eleito que queira satisfazer os anseios e os direitos de seu povo. A acusação a Porfírio Díaz é ser submisso e só agir para favorecer as empresas estrangeiras, em detrimento da defesa dos direitos dos cidadãos que deveria representar.

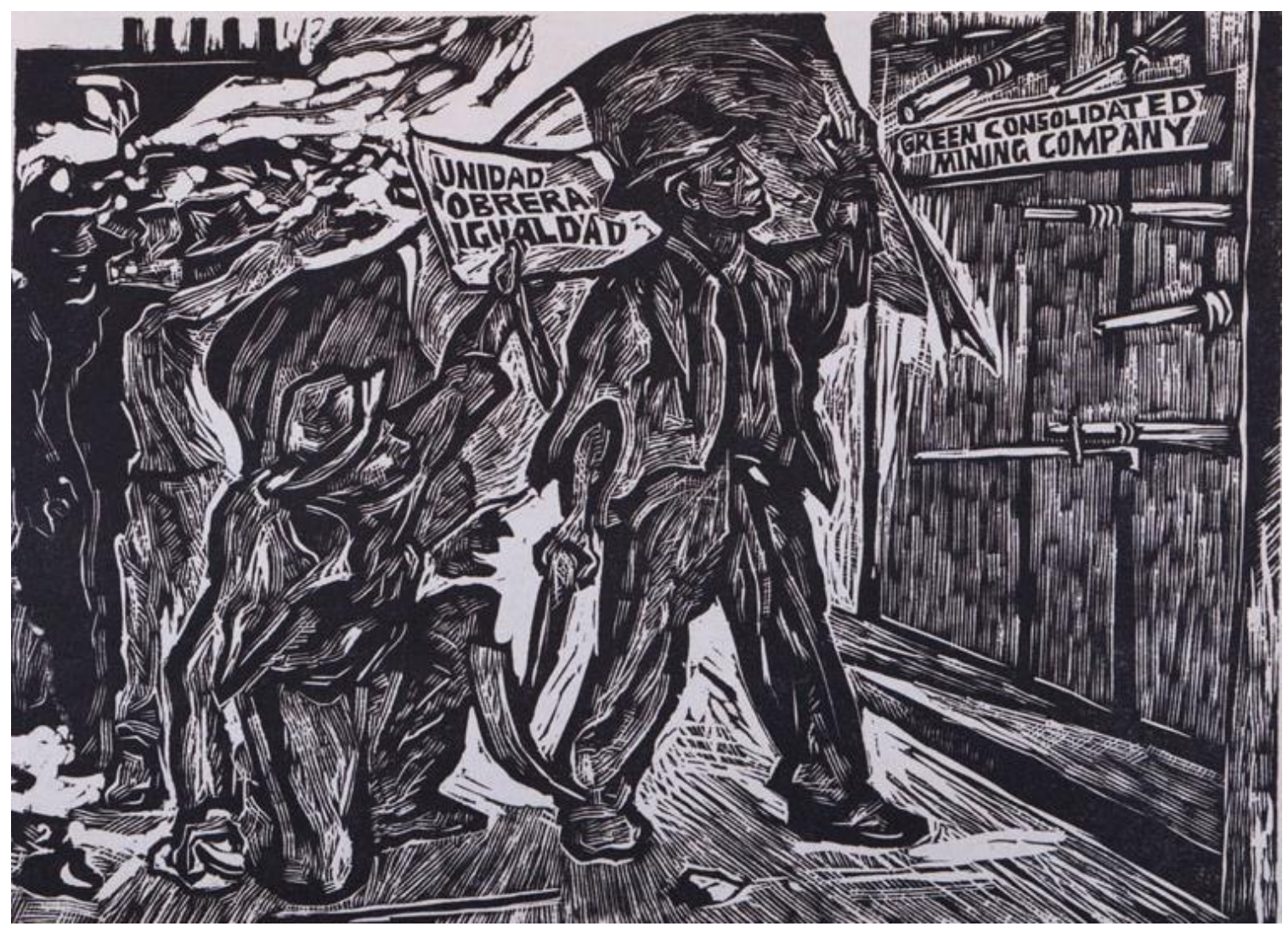

“La huelga de Cananea” (A greve de Cananea). Pablo O’Higgins. Reprodução: Museo de Arte Carrillo Gil

\footnotetext{
${ }^{416}$ A íntegra do documento de reivindicações dos mineiros de Cananea, publicado em $1^{\circ}$ de junho de 1906, pode ser encontrada em CARMONA, Doralicia. Memoria política de México. Guanajuato: Universidade de Guanajuato, 2014:

http://www.memoriapoliticademexico.org/Textos/5RepDictadura/1906-HC-MFR.html realizada em 12/12/2015.

Consulta
} 
Essas são as demandas que os trabalhadores reunidos em frente à mina Oversight apresentam ao presidente da Cananea Co. para expor as razões que os levaram a entrar em greve. No encontro, Greene nega todos os pedidos formulados. Afirma que os mineiros da Cananea eram os trabalhadores mais bem pagos do México e que as jornadas de trabalho de doze horas eram proporcionais aos salários recebidos ${ }^{417}$.

Ante essa primeira negativa à tentativa de negociação de novas condições de trabalho, os grevistas seguiram até outras minas para convencer seus colegas a também parar e a adesão à greve foi crescendo. Em uma madereira da fábrica, porém, o trabalho continuava. Os mineiros em greve seguiram na direção dela para estimular que outros operários também aderissem à greve. Ao chegar à madereira, os grevistas foram recebidos com jatos de água por trabalhadores norte-americanos, dispostos a defender a companhia. Diante do jato de água e da constatação de estrangeiros na defesa do local, os mineiros em greve decidiram reagir e, segundo relato do jornal Regeneración ${ }^{418}$, pegaram pedras no chão para atirar naqueles que atiravam água. Nesse momento em que o conflito se intensificou, entre pedras e águas, os americanos passaram a atirar com armas de fogo (rifles) contra os mineiros em greve, deixando muitos feridos e, naquele momento, dois mortos. Os relatos do episódio divergem sobre a existência ou não de armas de fogo em posse dos mineiros. Seja como for, os trabalhadores foram os mortos e feridos, não havendo nenhum norte-americano morto ou ferido com arma de fogo neste enfrentamento.

A polícia mexicana foi enfim chamada para resolver o conflito, afinal americanos haviam atirado, matado e ferido cidadãos mexicanos no território da cidade. Os homens que haviam atirado, porém, estavam dentro do prédio da madereira da companhia. Os representantes da polícia mexicana disseram que não poderiam fazer nada, já que os agressores estavam dentro do prédio, e eles não tinham nem autorização para entrar, nem mandado de prisão para detê-los. Ante a recusa de atuação policial, os grevistas decidiram colocar fogo no prédio da madereira, para obrigar todos a sair do

\footnotetext{
${ }^{417}$ Sentença do Ministro Seráfico Robles, secretario do Supremo Tribunal de Justiça do Estado de Sonora, no processo que estabeleceu penas para os grevistas e que descreve o início dos conflitos, em 10 de agosto de 1908, pode ser acessada na íntegra em:

http://www.revistarelaciones.com/files/revistas/118/pdf/documento.pdf Consulta realizada em $12 / 12 / 2015$

${ }^{418}$ Relato completo dos conflitos ocorridos a partir do início da greve em Cananea, em $1^{\circ} \mathrm{de}$ julho de 1906, pode ser encontrado no n. 11, $3^{\mathrm{a}}$ época do jornal Regeneración. O facsímile da edição impressa pode ser consultado em: http://archivomagon.net/wp-content/uploads/e3n11.pdf Consulta realizada em $11 / 12 / 2015$.
} 
local. Quando saíram correndo das chamas, quatro seguranças norte-americanos foram mortos a pedradas.

Passado o tumulto, já com a dispersão de alguns grevistas, um carro com representantes da companhia - o jornal Regeneración afirma que Greene entre eles passa pelos trabalhadores atirando, ferindo e matando mais alguns operários. A partir desse momento, em diversos pontos da cidade havia estrangeiros matando e ferindo mexicanos, além de alguns conflitos entre funcionários norte-americanos, defensores da companhia e grevistas ou trabalhadores indignados com o desenrolar dos acontecimentos.

Os grevistas, então, se dirigiram ao Palacio Municipal, sede do Poder Executivo do Ayuntamiento no México, para pedir que as autoridades interviessem no conflito que já deixava muitos mortos. Isidoro Castañedo, responsável local, respondeu o pedido com mais violência contra os trabalhadores. A polícia de Cananea também passou a combater e a perseguir os grevistas. O jornal Regeneración descreve assim o papel da lei e das instituições para o desenlace do conflito:

\begin{abstract}
Sí, esta es la ley que nos imponen los traidores que nos gobernan, y la prueba tenemos en que después de los disturbius en Cananea, los yanquis que provocaron el desorden, que agredieron a los mexicanos, que asesinaran cobardemente á nuestros compatriotas desarmados, están enteramente libres, riéndose de la impunidad en que han quedado sus hazañas de criminales, mientras que las víctimas de su salvajismo, los mexicanos ultrajados y agredidos, los deudos delos que cayeron bajo las balas del extranjero, fueron fusilados ó están presos, en número excesivo, esperando que la justicia (?) los castigue por el enorme delito de haber defendido su vida contra los asesinos yanquis. ${ }^{419}$
\end{abstract}

Definitivamente nem a lei, nem as instituições do Estado mexicano estavam ao lado dos trabalhadores. O jornal Regeneración foi um dos poucos a repudiar publicamente os atos violentos realizados contra os trabalhadores de Cananea no calor dos acontecimentos. A imprensa do país há muito era reprimida. Se o Regeneración conseguia circular devia-se unicamente ao fato de ser produzido nos Estados Unidos, no

\footnotetext{
${ }^{419}$ Relato completo dos conflitos ocorridos a partir do início da greve em Cananea, em $1^{\circ} \mathrm{de}$ julho de 1906, pode ser encontrado no n. 11, $3^{\text {a }}$ época do jornal Regeneración. O facsímile da edição impressa pode ser consultado em: http://archivomagon.net/wp-content/uploads/e3n11.pdf Consulta realizada em $11 / 12 / 2015$.
} 
Texas. Antes de seus editores e redadores terem se deslocado para lá, foram presos e seu jornal retirado de circulação.

Apesar disso, também Francisco Madero, em seu livro Sucesión presidencial 1910, de 1908, repudia os atos do poder público em resposta ao conflito de Cananea. Descreve ironicamente os pedidos que o Estado mexicano faz a seus operários “ ¡Está bien que mueran de hambre; pero que se mueran en orden, en silencio, sin protestar, sin intentar organizarse para la defensa de sus derechos!". Além disso, critica o governo que "tantos privilegios concede á la compañía explotadora" e ao mesmo tempo "está completamente desarmado, para proteger en casos como el que nos ocupa, los intereses del obrero mexicano?" 420.

Em 2 de junho de 1906, o governador de Sonora, Rafael Izábal, aparece na cidade acompanhado de membros do exército americano e, depois, segue de carro com o Presidente da Cananea Co., Greene. Para além da violação da soberania nacional em função da entrada de forças armadas norte-americanas em território mexicano, a atitude de Izábal solapava qualquer esperança dos moradores de Cananea de terem algum direito protegido pelos poderes públicos nacionais. No segundo dia de conflitos, mexicanos continuaram sendo mortos, por funcionários fiéis à Cananea Co. e, depois da adesão do governo, também fuzilados por forças oficiais mexicanas. Dizia o Regeneración ao relatar os fatos "Ser mexicano era bastante razón para morir" ${ }^{421}$. Os relatos desses primeiros dias de junho de 1906 afirmam que houve 23 mexicanos mortos e mais de 50 feridos $^{422}$, e ante a constatação clara de que não havia uma guerra a ser ganha, já que os trabalhadores de Cananea estavam desarmados, sendo mortos sem combate, Izábal pediu aos membros do exército norte-americano que voltassem aos Estados Unidos. O pedido de Izábal foi atendido, já que eles haviam entrado no país a seu pedido e recebendo sua autorização.

\footnotetext{
${ }^{420}$ MADERO, Francisco. "La sucesión presidencial em 1910". Biblioteca del Político, INEP-AC. Coahuila, 1908. In CARMONA, Doralicia. Memoria política de México. Guanajuato:Universidade de Guanajuato, 2014. http://www.memoriapoliticademexico.org/Textos/6Revolucion/1910LSP.pdf Consulta realizada em 26/10/2015, p. 9.

${ }^{421}$ Relato completo dos conflitos ocorridos a partir do início da greve em Cananea, em $1^{\circ} \mathrm{de}$ julho de

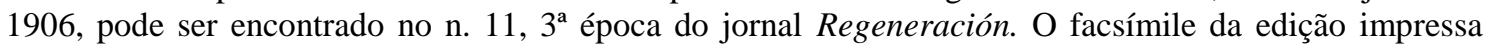
pode ser consultado em: http://archivomagon.net/wp-content/uploads/e3n11.pdf Consulta realizada em $11 / 12 / 2015$

${ }^{422}$ Sentença do Ministro Seráfico Robles, secretário do Supremo Tribunal de Justiça do Estado de Sonora, no processo que estabeleceu penas para os grevistas e que descreve o início dos conflitos, em 10 de agosto de 1908, pode ser acessada na íntegra em:

http://www.revistarelaciones.com/files/revistas/118/pdf/documento.pdf Consulta realizada em $12 / 12 / 2015$.
} 
Ya en nuestro número anterior hicimos las consideraciones relativas á la invasión de nuestro territorio por fuerzas yanquis, y manifestamos que el Código Penal castiga á Izábal con doce años de prisión y multa de $\$ 1000$ á $\$ 3000$; esto no porque creamos que el traidor sea castigado, sino para que sepan nuestros lectores con toda claridad cómo burla la Dictadura las leyes más severas y precisas. ${ }^{423}$

Tema frequente no periódico Regeneración, a interpretação ora rigorosa ora complacente dos dispositivos legais aparece duas vezes aqui. Uma vez para chamar atenção para a falta de punição para os seguranças da companhia Cananea, outra para informar que o convite que o governador de Sonora fez para as tropas estrangeiras entrarem no território mexicano era um crime com pena e multa altas. Nas duas ocasiões, o sistema de justiça não reagiu às agressões ao ordenamento jurídico. Já para os grevistas, o rigor era máximo: prisões e fuzilamentos foram aplicados pelas autoridades de plantão no mesmo episódio. A justiça seletiva era mais uma das arbitrariedades com a qual os mexicanos estavam obrigados a conviver. E ela também gerava mal-estar social. Não à toa, o episódio de Cananea é considerado um antecedente do levante revolucionário que tomaria o país quatro anos depois.

\subsubsection{A greve de Tlaxcala e Puebla e os conflitos em Río Blanco}

Os Estados mexicanos de Puebla e Tlaxcala concentram a industrialização mais antiga do país. Puebla, em que a produção artesanal de tecidos existia mesmo antes da independência, sediou em 1835 a primeira fábrica de tecelagem. Em 1877 já existiam 21 fábricas sediadas na capital do Estado. Diferentemente de Cananea, no Estado de Sonora ao noroeste do país, longe da Cidade do México, os Estados de Puebla e Tlaxcala - relativamente também Veracruz - ficam próximos da capital. Conflitos naquela região, assim, eram mais sensíveis para o governo central.

Já a região do vale de Orizaba, em que está a cidade de Río Blanco, Estado de Veracruz, fica próxima à fronteira com Puebla. Do ponto de vista industrial, Río Blanco se beneficiava da passagem de linhas férreas que ligavam a região ao porto de Veracruz - responsável por trazer matéria-prima para a produção de tecidos. Também era

\footnotetext{
${ }^{423}$ Relato completo dos conflitos ocorridos a partir do início da greve em Cananea, em $1^{\circ} \mathrm{de}$ julho de 1906, pode ser encontrado no n. 11, 3ª época do jornal Regeneración. O facsímile da edição impressa pode ser consultado aqui: http://archivomagon.net/wp-content/uploads/e3n11.pdf Consulta realizada em $11 / 12 / 2015$.
} 
vantagem a proximidade com regiões populosas do México, como o altiplano central e a própria Cidade do México, principais centros consumidores. Além disso, os governos de Veracruz concediam isenção de impostos nos cinco primeiros anos de funcionamento das fábricas na região. O clima úmido e o rio que dá nome à cidade favoreciam, por fim, a produção industrial de tecidos, empreendida principalmente por franceses.

As fábricas em Orizaba, porém, eram muito mais recentes do que as de Puebla e Tlaxcala. A industrialização começou a surgir ao final do século, juntamente com uma usina de produção de energia elétrica da região. A companhia Río Blanco, especializada em branqueamento e estamparia de tecidos, foi fundada em 1892. Tornou-se, ao longo do tempo, a maior fábrica da região. No início de 1907, quando os conflitos que aqui serão relatados aconteceram, contava com dois mil e quinhentos trabalhadores em suas instalações. O total de trabalhadores da região de Orizaba se aproximada de seis mil. Por ser fruto de uma industrialização mais tardia, as dimensões e a tecnologia utilizadas nas fábricas de Orizaba eram muito diferentes daquelas existentes em Puebla.

Visto que a região era relativamente despovoada antes da chegada das fábricas, a maioria dos trabalhadores imigraram de outros lugares do México para lá. Puebla, Oaxaca, Tlaxcala e Cidade do México eram os Estados que com maior frequencia forneceram trabalhadores para Orizaba. Esses trabalhadores vinham de cidades em que já havia a presença de indústrias, como Puebla, e também de regiões rurais ${ }^{424}$.

La vecindad adquiere una realidad más marcada. Las casas están próximas. Los hombres trabajan en el mismo sítio. Los niños comparten los juegos en las calles, algunos concurren a la única escuela del lugar que es sustenida por la empresa, y el día de mañana - ya más grandes - se incorporarán a las fábricas o a la mina ripitiendo historias parecidas a las de sus progenitores. Los domingos las familias participan en similares actividades recreativas generadas, muchas veces, por la misma comunidad local. Es decir, no solo se reducen las relaciones entre personas hacia el 'afuera' sino se da una intensidad de la vida social hacia 'adentro' con un alto grado de concurrencia de los habitantes en las reunioones colectivas propias del pueblo. ${ }^{425}$

\footnotetext{
${ }^{424}$ GARCÍA, Bernardo. "Migraciones internas a Orizaba y formación de la clase obrera en el porfiriato". In NOVELO, Victoria (org.). Historia y cultura obrera. Cidade do México: Instituto Mora; Centro de Investigaciones y Investigaciones en Antropología Social La Casa Chata, 1999. p. 108, 119.

${ }^{425}$ LUPANO, Maria Marta. Cuando la ficción se convierte en realidad. Las huelgas de Cananea y Río Blanco, en México, en clave de historia urbana. Buenos Aires: Instituto de Arte Americano e Investigaciones Estatísticas, 2015, p. 6.
} 
Se Bernardo García investiga como a diversidade de origens migratórias dos trabalhadores de Orizaba teve influência em sua forma de organização política, Maria Lupano chama a atenção para o fato de esta população recém-chegada viver em uma mesma cidade industrial, ou "company-town", como ela denomina. O fato de conviverem e terem cotidianos tão próximos e parecidos, faz com que surja identidade, solidariedade e lealdade entre as pessoas que vivem naquele território. Entre os imigrantes havia trabalhadores para quem Orizaba já era a segunda experiência de trabalho em fábricas. E, junto com a experiência, a lembrança da organização operária por melhores condições de trabalho, muito presente em Puebla e principalmente em Tlaxcala.

Nesse contexto, em abril de 1906, Manuel Avila, José Rumbia e José Neyra fundam o Gran Círculo de Obreros Libres, em Río Blanco. Ao longo dos meses que se seguiram, o Gran Círculo criou um periódico chamado La Revolución Social, conseguiu fundar subsedes em outras indústrias do vale do Orizaba e aumentou sua influência entre os trabalhadores. Nesse mesmo período, foi fundado oficialmente o Partido Liberal Mexicano, com quem o Gran Círculo de Obreros Libres mantinha contato estreito. É fato que essa movimentação não passou despercebida pelas autoridades das fábricas e do Estado mexicano na região. Alternado táticas de repressão e cooptação, as autoridades mantiveram contato próximo com uma das lideranças dos trabalhadores: José Morales, que concorreu a um cargo diretivo da organização. Mesmo derrotado, houve grande pressão para que ele se mantivesse à frente do movimento.

Para completar as informações sobre o contexto em que surgiram os confrontos de 1906-1907 na região, é importante dizer que as indústrias de Puebla e Tlaxcala sofreram com a concorrência das fábricas de Orizaba. Com máquinas mais antigas e posição menos favorável no território, o custo de sua produção estava alto em relação às suas concorrentes. Em crise, a solução encontrada foi implementar um controle maior sobre as atividades dos trabalhadores, tendo por objetivo, talvez, aumentar a produtividade da força de trabalho.

Assim, em 2 dezembro de 1906, os industriais da região publicaram um reglamento que valeria para todos os trabalhadores das indústrias de Puebla e Tlaxcala. Bernardo García descreve assim as condições de trabalho nessas fábricas têxteis:

Todos los que ingresaban a la fábrica quedaban bajo el estricto control y disciplina impuestos por el capitalista y sus representantes. 
Los trabajadores no tenían recurso legal alguno frente a ellos; debían aceptar los castigos y multas, que les imponían profusammente, no sólo por 'mal trabajo' sino lo mismo por rotura de canillas, lanzaderas, catarinas, pasatramas o cualquier otra de las piezas renovables de la maquinaria que acaban por deteriorarse o destruirse con el uso, que por una serie de conductas o actos considerados como irregulares por la compañía. Tenían también que soportar el trato arbitrario de algunos de los empleados, que habían convertido el principio de autoridad imprescindible en la organización del trabajo en autoritarismo, y que aun a veces pasaban de los procedimientos de la boca a las manos.

A tal régimen estaban expuestos los obreros por largas horsa; el trabajo lo iniciaban diariamente a las seis de la mañana para salir hasta las ocho de la noche, y en ocasiones extendían la jornada hasta media noche. ${ }^{426}$

Descontentes com a perspectiva de terem condições de trabalho ainda mais severas e desfavoráveis do que as que já enfrentavam, os operários da região decidiram entrar em greve em 4 de dezembro de 1906 e em greve permaneceram por alguns dias, sem que as fábricas da região concordassem em anular os efeitos do novo reglamento. Constatado o impasse, os trabalhadores sugeriram aos industriais que todos recorressem à mediação de Porfírio Díaz. Os industriais não aceitaram a sugestão e, ao invés disso, em 24 de dezembro promoveram o fechamento de suas próprias fábricas, impedindo os trabalhadores de entrar e trabalhar (lockout).

O que era um conflito restrito a Puebla e Tlaxcala se expandiu. Também as indústrias de Veracruz, Jalisco, Querétaro e Cidade do México fecharam suas portas. Estima-se que trinta mil trabalhadores tenham sido impossibilitados de entrar em seus locais de trabalho neste dia $^{427}$. Na região de Orizaba, assim como em outros estados, o lockout se estendeu e se manteve em solidariedade aos industriais de Puebla e Tlaxcala. Assim, trabalhadores de Río Blanco, que muito pouco haviam feito em solidariedade aos grevistas de Puebla, viram-se impedidos de trabalhar e, sem trabalhar, deixaram de

\footnotetext{
${ }^{426}$ GARCÍA DÍAZ, Bernardo. "Apuntes sobre la Huelga de Río Blanco". In Anuario II del Centro de Estudios Históricos de la Universidad Veracruzana, Vera Cruz, 1979, p. 188-189. Também em documento de 2013, em que a Câmara dos Deputados mexicana faz uma homenagem aos grevistas de Cananea e Río Blanco, há um resumo das condições de vida que suportavam: "los trabajadores eran sometidos a jornadas de trabajo de hasta 14 horas y media, recibían un salario miserable (menos las multas que con diversos pretextos se les imponían), y se explotaba a mujeres y niños". A exposição de motivos que justifica a inscrição em homenagem aos grevistas de Cananea e Río Blanco na Câmara dos Deputados mexicana, de 5 de junho de 2013, pode ser acessada em: http://sil.gobernacion.gob.mx/Archivos/Documentos/2013/06/asun_2985062_20130605_1370543867.pdf Consulta realizada em 13/12/2015.

${ }^{427}$ Fonte de muitas das informações utilizadas nesta seção: GARCÍA DÍAZ, Bernardo. "Apuntes sobre la Huelga de Río Blanco". In Anuario II del Centro de Estudios Históricos de la Universidad Veracruzana, Vera Cruz: Universidade Veracruzana, 1979, p. 183-207.
} 
receber seus salários semanais, como era costume à época. As fábricas permaneceram fechadas até o início de janeiro, quando as partes concordaram em pedir que Porfírio Díaz atuasse para resolver o conflito na região.

Numa sexta-feira, 4 de janeiro de 1907, Porfírio Díaz publica um decreto propondo uma solução para a situação. $\mathrm{O}$ artigo primeiro do decreto afirma que as fábricas deveriam ser reabertas no dia 7 de janeiro, segunda-feira, e que os trabalhadores que voltassem ao trabalho teriam que se submeter aos regulamentos existentes à época do fechamento das fábricas. Apesar de reafirmar a validade das normas anteriores à greve e ao lockout, o decreto de Porfírio Díaz segue com uma série de normas sobre as condições de trabalho na região. As normas pré-existentes que continuariam valendo seriam aquelas que não estivessem em conflito direto com o decreto do então Presidente do México.

Artículo primero. El lunes 7 de enero de 1907 se abrirán todas las fábricas que actualmente están cerradas, en los Estados de Puebla. Veracruz, Jalisco, Querétaro y Tlaxcala, y en el Distrito Federal; y todos los obreros entrarán a trabajar en ellas, sujetos a los reglamentos vigentes al tiempo de clausurarse, o que sus propietarios hayan dictado posteriormente, y a las costumbres establecidas.

Artículo segundo. Los industriales dueños de dichas fábricas, por medio de los representantes que se hallan en esta capital, ofrecen al señor Presidente de la República continuar haciendo el estudio que han emprendido desde antes de la huelga actual de los obreros, con objeto de uniformar las tarifas de todas las fábricas, sobre las bases siguientes:

I. Los obreros que trabajen en las máquinas de preparación, hilados o tejidos, en una fábrica, recibirán salarios iguales a los que perciben los trabajadores de su clase, en las demás fábricas de una región o Distrito fabril, en donde las condiciones de vida y de trabajo sean idénticas.

$[\ldots]$

Artículo tercero. Se establecerá en las fábricas el sistema de dar a cada obrero una libreta con las contraseñas necesarias para su autenticidad, y en la cual se anotarán los datos que se consideren necesarios, respecto a la buena conducta, laboriosidad y aptitudes del operario.

$[\ldots]$

Artículo cuarto. Ofrecen los señores industriales al señor Presidente de la República, ocuparse desde luego en estudiar los reglamentos de las fábricas, para introducir en ellos las reformas y modificaciones que estimen convenientes, tanto para garantizar los intereses y la buena marcha de sus establecimientos, como para mejorar, hasta 
donde sea posible, la situación de los obreros. Especialmente introducirán las mejoras siguientes:

I. Las multas que se establezcan por falta de cumplimiento de los obreros y por otras que se expresarán en los reglamentos, se destinarán íntegras a un fondo para auxiliar a las viudas y huérfanos de los obreros.

II. No se harán descuentos a los obreros para pago de médicos, para fiestas religiosas o profanas, ni para otros fines. Cada fábrica pagará un médico por iguala para que lo ocupen los obreros que lo deseen.

III. Solamente se cobrarán a los obreros las lanzaderas, canillas y otros materiales de las fábricas que se destruyan por su culpa; pero no los que se rompan o concluyan por el uso a que están destinados. Esto se determinará por el Administrador tomando en consideración los informes de los maestros.

IV. Los obreros podrán recibir en sus habitaciones a las personas que estimen convenientes, quedando a cargo de la autoridad dictar los reglamentos que sean necesarios para la conservación del orden, de la moral y de la higiene, y la manera de hacerlos cumplir.

V. Cuando un obrero sea separado de una fábrica por causa que no constituya delito o falta de los que castigan las leyes o están previstos en los reglamentos de las fábricas, tendrá un plazo de seis días para desocupar la casa que esté ocupando, contándose ese plazo desde que se pague su raya. Cuando su separación se verifique por causa que amerite castigo impuesto por la ley, o porque en los registros de los obreros que se acostumbran a las entradas y salidas de las fábricas, se descubra que lleva armas o cerillos, o que cometa cualquiera otra de las infracciones que motivan esos registros, deberá desocupar la casa en el mismo día en que se le pague su raya.

$[\ldots]$

Artículo séptimo. No se admitirán niños menores de siete años, en las fábricas para trabajar, y mayores de esa edad sólo se admitirán con el consentimiento de sus padres, y en todo caso no se les dará trabajo sino una parte del día, para que tengan tiempo de concurrir a las escuelas hasta que terminen su instrucción primaria elemental.

Artículo octavo. Los obreros deberán aceptar que los Jefes políticos respectivos nombren personas que se encarguen de la dirección de los periódicos que publiquen, con el objeto de que en ellos no se deslicen injurias para nadie, ni se publiquen doctrinas subversivas que extravían a los mismos obreros. Estos podrán escribir en dichos periódicos, dentro de esos límites, todo lo que gusten, con el objeto de levantar el nivel de las clases trabajadoras, y de inspirarles hábitos de honorabilidad, de orden y de ahorro. ${ }^{428}$

\footnotetext{
${ }^{428}$ A íntegra do Decreto de 4 de janeiro de 1907, editado por Porfírio Díaz, que ficou conhecido como Reglamento de Trabajo del Centro Industrial Mexicano pode ser encontrada em CARMONA, Doralicia. Memoria política de México. Guanajuato: Universidade de Guanajuato, 2014: <http://www.memoriapoliticademexico.org/Textos/5RepDictadura/1907LPD.html> Consulta realizada em $12 / 12 / 2015$.
} 
As normas estabelecidas por Porfírio Díaz no decreto de 4 de janeiro de 1907 são prova histórica das condições de trabalho a que os trabalhadores tinham que se submeter. $\mathrm{O}$ artigo $2^{\circ}$, que tem o claro objetivo de satisfazer as demandas dos trabalhadores, estabelece que os industriais devem estudar formas de garantir que os trabalhadores da tecelagem recebam salários iguais aos de outros trabalhadores que desempenhem a mesma função em outras indústrias, desde que os custos e as condições de vida e de trabalho nas indústrias padronizadas sejam idênticos.

O artigo oferece a possibilidade de padronização salarial, mas a obrigação para seus destinatários é vaga: devem continuar a desenvolver estudos para garantir igualdade em circunstâncias idênticas. Há muitas formas interpretativas de os empregadores se esquivarem da obrigação que lhes é imposta pela norma. O artigo segundo segue com a intenção de tornar iguais os salários para outros tipos de trabalhadores da indústria têxtil, e estabelece normas que tornam ainda menos vinculante a obrigação inscrita no inciso I. Por exemplo, o inciso IV garante a possibilidade de os industriais pagarem prêmios por mérito para aqueles que trabalharem mais e melhor. Na prática esse inciso autoriza a manutenção da prática de diferenças salarias.

Se o artigo segundo em tese respondia a uma reivindicação dos trabalhadores, os seguintes são em sua maioria em defesa dos industriais. $\mathrm{O}$ artigo terceiro institui a prática de distribuir para cada trabalhador uma libreta, uma espécie de carteira de trabalho, cujo objetivo é realizar anotações relacionadas à conduta dos trabalhadores. Assim, seria anotada na libreta cada falta cometida, cada atraso, cada descumprimento de ordem, cada organização para reivindicar melhores condições de trabalho que desrespeitem a estrita forma de realizar reclamações, em suma, todas as ações que, segundo os patrões, estivessem relacionadas à "buena conducta, laboriosidad y aptitudes del operario" seriam anotadas em seu caderno pessoal de registros. Essa libreta, por sua vez, acompanharia o trabalhador de um emprego a outro. Assim, ao contratar um empregado, os administradores da fábrica poderiam ver seu histórico. Desnecessário dizer que a criação deste instrumento de registros pessoal, ligado a supostos descumprimentos de boa conduta do trabalhador, seria usado contra ele, como mais um instrumento de punição, ameaça e controle nas plantas das fábricas.

$\mathrm{O}$ artigo quarto diz respeito às melhorias nos regulamentos das fábricas que os industriais devem procurar fazer. Ou seja, as melhorias previstas na norma de Díaz não 
são compulsórias, mas sim orientações. A partir das sugestões feitas, é possível imaginar as condições de trabalho existentes antes. Ao invés de extinguir a existência ou limitar o valor - das multas que eram frequentemente aplicadas aos trabalhadores, por quaisquer faltas, grandes ou pequenas, que cometessem ou não cometessem, Porfírio Díaz destina as multas a um fundo que deve auxiliar viúvas e órfãos de trabalhadores que possivelmente morreram também em função de suas precárias condições de trabalho e acesso a serviços de saúde.

Os industriais devem também, segundo o decreto de Díaz, mudar seus regulamentos para que os trabalhadores não sejam descontados em seus salários para pagar médico oferecido pela fábrica e para a organização de festas e outros eventos pela indústria. Pela norma, sabe-se que essa era uma prática nas fábricas têxteis mexicanas. Outra, explicada no inciso seguinte, dizia respeito à cobrança por qualquer peça que se quebrasse, independentemente de a peça ter se quebrado pelo desgaste natural do tempo de uso ou por alguma conduta errada dos trabalhadores. Sabe-se, assim, que era prática compartilhar com os operários os custos de produção dos tecidos, uma vez que as peças que tinham de ser repostas em virtude de seu desgaste eram descontadas de seus salários. Porfírio Díaz recomenda que apenas as peças quebradas por dolo ou culpa dos empregados sejam cobradas deles.

Pede-se também que as indústrias autorizem que seus funcionários recebam visitas em suas casas, no inciso IV, conduta que antes lhes era proibida. A autorização deve ser concedida, no entanto, desde que se conserve a "orden, la moral y la higiene", na avaliação dos responsáveis por manter a ordem nas cidades industriais, claro. $\mathrm{O}$ inciso V, por fim, estabelece um prazo de seis dias para que os trabalhadores desocupem a casa em que moram, alugada pela fábrica, em caso de demissão sem justa causa. A norma ainda prevê para os casos em que o operário cometeu alguma falta que tenha levado à demissão, o dever de desocupação de sua casa no mesmo dia da demissão e recebimento do último salário.

Os incisos do artigo quarto deixam claro que, mesmo nas normas que parecem favorecer aos trabalhadores, há uma brecha para o seu descumprimento ou ainda expressões que sugerem uma interpretação desfavorável aos empregados, sempre em benefício dos industriais.

$\mathrm{O}$ artigo quinto, por sua vez, estabelece a forma pela qual os trabalhadores devem levar suas reclamações ao conhecimento dos encarregados da administração da 
fábrica. $\mathrm{O}$ artigo estabelece, in verbis "Los obreros que tengan alguna reclamación o solicitud que hacer, la presentarán personalmente, por escrito que firmarán ellos mismos, al Administrador, quien deberá comunicarles la resolución que se dicte a más tarde en el término de quince días. ${ }^{429}$.

Associado ao artigo quinto está o nono, que proíbe a realização de greves. Argumenta que as greves já não seriam necessárias, já que a "cláusula 5 a. se establece la forma de que hagan conocer sus quejas y sus solicitudes, con el fin de satisfacer-las hasta donde sea justa" ${ }^{430}$. Interessante notar que quem deverá estabelecer até que ponto e em que medida as reivindicações dos trabalhadores são justas é o próprio empregador. A norma de Porfírio Díaz estabelece como juiz das queixas dos trabalhadores a parte contrária, interessada.

$\mathrm{O}$ artigo sétimo proíbe que crianças com menos de sete anos trabalhem nas fábricas - e as que tiverem mais de sete devem ter autorização de seus pais e um período reservado aos estudos. Seja como for, crianças de sete anos já podiam trabalhar nas fábricas. E, pela necessidade da norma proibitiva, possivelmente a prática era de que crianças menores também trabalhassem. Por fim, o artigo oitavo dispõe que os operários deviam "aceptar que los Jefes políticos respectivos nombren personas que se encarguen de la dirección de los periódicos que publiquen, con el objeto de que en ellos no se deslicen injurias para nadie ${ }^{\text {"431 }}$. Além de todas as obrigações que o cotidiano das fábricas lhes impõem, também a liberdade de se expressar era tolhida: os jornais e periódicos produzidos pelos trabalhadores deveriam ter um diretor indicado pelos chefes políticos das cidades industriais, chefe político muitas vezes ligado ou indicado diretamente pela indústria.

Esse foi o laudo arbitral proposto por Díaz para solucionar o impasse entre trabalhadores e empregadores nas indústrias têxteis do centro do país. Em Puebla, no Teatro Guerrero onde os trabalhadores se reuniram para tomar conhecimento e discutir a

\footnotetext{
${ }^{429}$ A íntegra do Decreto de 4 de janeiro de 1907, editado por Porfírio Díaz, que ficou conhecido como Reglamento de Trabajo del Centro Industrial Mexicano pode ser encontrada em CARMONA, Doralicia. Memoria politica de México. Guanajuato: Universidade de Guanajuato, 2014:

<http://www.memoriapoliticademexico.org/Textos/5RepDictadura/1907LPD.html> Consulta realizada em 12/12/2015.

430 Ibid.

${ }^{431}$ A íntegra do Decreto de 4 de janeiro de 1907, editado por Porfírio Díaz, que ficou conhecido como Reglamento de Trabajo del Centro Industrial Mexicano pode ser encontrada em CARMONA, Doralicia. Memoria política de México. Guanajuato: Universidade de Guanajuato, 2014:

<http://www.memoriapoliticademexico.org/Textos/5RepDictadura/1907LPD.html> Consulta realizada em $12 / 12 / 2015$.
} 
proposta de Díaz, apenas a minoria dos trabalhadores foi contrária às normas do documento. Quando essa voz minoritária se expressou, o orador responsável por apresentar o documento argumentou que os trabalhadores haviam se comprometido a cumprir o que quer que fosse decidido por Díaz. Diante desse argumento, a posição que já era minoritária, se enfraqueceu mais. Os trabalhadores decidiram voltar pacificamente às fábricas em 7 de janeiro de 1907. Em Río Blanco, a situação foi diferente. Bernardo García descreve a reação dos trabalhadores após a leitura das normas do decreto, no dia 6 de janeiro:

\begin{abstract}
Al término de la lectura se hizo un silencio que parecía ser de aprobación. Pero poco a poco, comenzaron a escucharse rumores de descontento y entre todos ellos se alzó una voz gritando: 'que no se aceptaba el reglamento, que primero mártires que esclavos.' Este grito anonimo retrató el estado de ánimo en el 'Gorostiza'. José Morales en vano hubiera tratado de colocar un discurso apaciguador: por el contrario, perdió el control de la sesión y ésta terminó en una confusión, ciertamente el laudo les daba concesiones a los obreros, pero no obstante, les escamoteaba la posibilidad de hacer huelgas y junto a ello dotaba de amplios poderes al Jefe Político y a los empleados de las compañías, para que por medio de las libretas, calificaran lo mismo la conducta cotidiana en el interior de la fábrica, que su actividad sindicalista. Incluso aquello que parecía un favorable transación entre ambas partes, como el artículo que no prohibía las multas que se imponían a los obreros, pero sí hacía que éstas fueran a un fondo para las viudas y huérfanos de obreros. Para muchos de ellos era una conquista conseguida y aun superada semanas atrás gracias a las huelgas. Incluso, no atacaba el problema de las tiendas de raya. No, el laudo no era aceptable. Perjudicaba particularmente al grupo disidente a Morales. Por eso Rafael Moreno y Manuel Juárez fueron los que encabezaron la protesta contra este intento del gobierno de poner coto a la creciente militancia de los obreros. ${ }^{432}$
\end{abstract}

O encontro em Gorostiza no dia 6 de janeiro não deliberou por uma greve no dia seguinte. No entanto, no dia 7 de janeiro de 1907, no horário de início de atividades nas fábricas de Orizaba, às 5 horas da manhã, inúmeros trabalhadores começaram a se manifestar na porta da fábrica Río Blanco. Tentavam desestimular os trabalhadores a entrar lá, argumentando que não era justo se submeter a um regulamento tão desfavorável como tinha proposto Díaz. Argumentavam que não fazia sentido eles, que haviam ficado sem salário em função de 12 dias do lockout que não haviam provocado, ${ }^{432}$ GARCÍA DÍAZ, Bernardo. “Apuntes sobre la Huelga de Río Blanco”. In Anuario II del Centro de
Estudios Históricos de la Universidad Veracruzana, Vera Cruz: Universidade Veracruzana, 1979, p. 196. 
se submeterem, com o decreto de Díaz, a algumas condições piores do que as existentes antes.

A manifestação-greve sem organização cresceu e ganhou adeptos. À frente do processo, estavam os trabalhadores das tecelagens, a mais valorizada atividade em uma indústria têxtil. Em determinado momento da manifestação dos trabalhadores, os responsáveis pela Río Blanco decidiram fechar os portões da fábrica. O que começou como um protesto antes do horário de abertura da fábrica Río Blanco se transformou em inúmeros conflitos violentos sucessivos, com muitos mortos.

Em um primeiro momento, os trabalhadores seguiram em direção à tienda de raya de Victor Garcín, que ficava a poucos metros do portão da entrada da Río Blanco. Enquanto jogavam pedras e tentavam forçar a entrada no armazém, um funcionário de Garcín atirou sobre os trabalhadores, ferindo vários e matando um deles. Revoltados com a violência, os trabalhadores invadiram e saquearam o armazém. Policiais e rurales $^{433}$ tentaram conter os operários, sem sucesso. Só saíram da tienda de raya quando todos os seus víveres já tinham se esgotado e ela estava em chamas.

Houve um conflito entre um funcionário da empresa Río Blanco e um operário que havia entrado e trabalhava dentro da fábrica. Essa informação chegou até os trabalhadores que se manifestavam. A história que se contava e recontava ganhou contornos mais dramáticos. $\mathrm{O}$ boato inverídico afirmava que estavam agredindo e matando operários dentro da fábrica. Cheios de pedras os manifestantes voltaram à porta da fábrica e começaram a apedrejá-la. Foram dispersados com a chegada do $13^{\circ}$ Batalhão do Exército de Orizaba. Seguiram então para a vila de Nogales, na qual saquearam a casa de penhor de Lauro Machorro e em seguida a casa de penhor de Rafael Mateos. Seguiram, por fim, ao centro comercial em frente à fábrica de San Lorenzo. Depois de realizarem seu saque, colocaram fogo no centro comercial e as chamas se espalharam para as casas vizinhas.

Novamente houve um enfrentamento com as tropas do $13^{\circ}$ Batalhão de Orizaba, responsável por dispersar a multidão e por matar seis pessoas, deixando também vários feridos. Simultaneamente, um outro grupo de trabalhadores que havia ficado na porta da Fábrica Río Blanco foi pego em uma emboscada preparada pelo exército na cidade de Nogales. Um pouco mais tarde, os grupos se reagruparam na vila fabril de Santa Rosa.

\footnotetext{
${ }^{433}$ Membros da polícia rural, montada a cavalo, e cujo objetivo principal era proteger diligências e caravanas em trânsito de saques; atuante em todo o território mexicano.
} 
Além de libertar pessoas que estavam presas - também tinham adotado esse procedimento em Nogales -, saquearam o centro comercial e colocaram fogo nos imóveis. Diante do caos social configurado, altos funcionários das empresas mandaram suas famílias embora em trens que partiam pela região sob agressões verbais mútuas.

Nesse clima de "beligerancia en ascenso" ${ }^{434}$, como descreve Bernardo García, o $13^{\text {a }}$ Batalhão, com tropas reforçadas, dispara contra os trabalhadores. Seis deles são mortos, vários ficam feridos e os trabalhadores não voltam a se reunir. Todos os conflitos ocorreram entre seis da manhã e duas da tarde, quando o exército dispersa os manifestantes que estavam em Santa Rosa.

Na madrugada entre o dia 7 e o dia 8 de janeiro de 1907, duas companhias do $24^{\circ}$ Batalhão do Exército de Orizaba chega à cidade de Río Blanco e promovem o terror noturno. Os militares entram nas casas, revistam, encontram e levam para prestar esclarecimentos os feridos, levam detidas pessoas supostamente envolvidas com as manifestações, confiscam bens que supõem terem sido objeto do saqueio. A repressão em resposta às ações da manhã anterior fora dura.

No dia seguinte, chegam à cidade mais duzentos e cinquenta homens entre policiais e rurales, deslocados para atuar na região. Manuel Juárez, Rafael Troncoso, Rafael Moreno, líderes do levante e participantes do Gran Círculo del Obrero Libre, foram executados nos dias seguintes. Ao final de janeiro, em função dos levantes do dia 7, permaneciam presas duzentas e vinte cinco pessoas, incluindo mulheres que também lideraram os atos, entre elas Margarita Martínez, Filomena Pliego, Lucrecia Toriz.

De los 7.083 obreros que laboraban en las fábricas textiles hasta antes del paro, el día 9 sólo regresaron al trabajo 5.512. Los otros 1571 huyeron de la región, fueron consignados, estaban heridos o muertos. Hoy a más de 50 años, es difícil precisar el número de muertos, la opinión más autorizada sobre estos acontecimientos ha afirmado que probablemente fueron entre 50 y 70 los victimados. ${ }^{435}$

Bernardo García descreve uma situação trágica após a insurreição: mais de $20 \%$ dos trabalhadores que viviam no vale de Orizaba não voltaram aos seus postos de

\footnotetext{
${ }^{434}$ GARCÍA DÍAZ, Bernardo. “Apuntes sobre la Huelga de Río Blanco”. In Anuario II del Centro de Estudios Históricos de la Universidad Veracruzana. Vera Cruz: Universidade Veracruzana, 1979, p. 202.

${ }^{435}$ GARCÍA DÍAZ, Bernardo. "Apuntes sobre la Huelga de Río Blanco". In Anuario II del Centro de Estudios Históricos de la Universidad Veracruzana, Vera Cruz: Universidade Veracruzana, 1979, p. 204205.
} 
trabalho no dia 9 de janeiro de 1907. García apresenta algumas razões para essas ausências: muitos trabalhadores foram mortos ou estavam feridos e incapacitados, outros foram presos, outros ainda fugiram da região. Apesar de afirmar ser difícil precisar o número de mortos naqueles dois dias, estima que tenham sido 50 ou 70 mortos. Em junho de 2013, a Câmara dos Deputados Mexicana aprovou uma homenagem aos grevistas de Cananea e Río Blanco. Um dos poderes do mexicano, corresponsável por muitas dessas mortes, afirma que houve no período entre 400 e 800 vítimas dos confrontos no vale de Orizaba:

El resultado de la Huelga de Río Blanco fueron entre 400 y 800 obreros asesinados, mientras que cientos fueron detenidos (algunos fueron fusilados, otros llevados a Valle Nacional en Oaxaca o a inhóspitas tierras de Quintana Roo donde pronto encontrarían la muerte sometidos a trabajos forzados) incluida una docena de mujeres. El sacrificio de estos trabajadores, al lado de sus familias y su comunidad, merecen que se les rinda un homenaje. ${ }^{436}$

Independentemente de quantos tenham sido os mortos, o fato é que os conflitos em Río Blanco foram reprimidos violentamente, mesmo depois de encerradas as ações diretas dos trabalhadores. Ao longo do dia 7 de janeiro, estima-se que não houve mais de 20 mortos. Os outros foram vítimas da repressão posterior.

Para além da enorme violência usada para reprimir a manifestação dos trabalhadores descontentes, o evento do vale de Orizaba é simbólico das condições de trabalho insuportáveis a que eram submetidos os trabalhadores. No caso das indústrias têxteis, essas condições foram legitimadas, legalizadas por meio da proposta de regulamento publicada por Porfírio Díaz.

Simultaneamente a suas regulações de demarcação e concessão de terras, também as regras trabalhistas publicadas no dia 4 de janeiro de 1907 visavam, acima de tudo, prejudicar os trabalhadores. O governo de Porfírio Díaz é prolífero em produzir normas jurídicas contra a maior parte da população que deveria governar. Seu autoritarismo e os privilégios que confere às parcelas da população que detém poder,

\footnotetext{
${ }^{436}$ A exposição de motivos que justifica a inscrição em homenagem aos grevistas de Cananea e Río Blanco na Câmara dos Deputados mexicana, de 5 de junho de 2013, pode ser acessada em: http://sil.gobernacion.gob.mx/Archivos/Documentos/2013/06/asun_2985062_20130605_1370543867.pdf Consulta realizada em 13/12/2015.
} 
bens e cultura não se efetiva apenas em ações, mas também por meio de atos normativos.

Para enfrentar essa situação, também as propostas de transformação da realidade eram elaboradas respeitando a gramática normativa. Nas seções a seguir, serão analisadas as proposas de regulação jurídica das relações de trabalho elaboradas algumas implementadas - pelos movimentos revolucionários.

Las peticiones de justicia se contestan con consignaciones al Ejército; las protestas se ahogan en sangre; la palabra es detenida en los labios por la manaza de los gendarmes. La vida no sonrie al mexicano, ese desposado con la muerte y con la injusticia... ${ }^{437}$

\subsection{As propostas de regulação das relações de trabalho nos documentos revolucionários}

\subsubsection{Programa do Partido Liberal Mexicano (1906)}

O Partido Liberal Mexicano foi uma organização política fundada a partir da experiência dos clubes liberais e seus periódicos, organizados na virada do século XIX para o XX, já apresentados no primeiro capítulo. Sua fundação praticamente simultânea às greves de Cananea e Río Blanco, em $1^{\text {o }}$ de julho de 1906, não é fruto do acaso. As greves foram gestadas por militantes próximos aos círculos liberais, que liam os jornais produzidos por eles e participavam da organização política que tinha pretensões de ser nacional e popular. Os representantes do liberalismo social tomaram como objetivo político para si organizar a classe trabalhadora. Isso explica o alinhamento ideológico entre o Programa do Partido Liberal Mexicano e as reinvindicações da greve de Cananea e das manifestações de Orizaba.

Com as principais lideranças nos Estados Unidos, o partido recém-fundado buscava organizar a classe trabalhadora industrial e se fortalecer. As organizações das greves de Cananea, Puebla e Tlaxcala e as duras repressões sofridas pelos trabalhadores em Cananea e Río Blanco marcam, ao mesmo tempo, o auge e o declínio da capacidade do Partido Liberal Mexicano recém-fundado de participar definitivamente da política

437 Periódico Revolución. Ano 1, Número 1. $1^{\circ}$ de junho de 1907. Facsímile disponível em: http://archivomagon.net/wp-content/uploads/rev_n1.pdf Consulta realizada em 14/12/2015. 
mexicana. A aposta na organização dos trabalhadores urbanos - e um relativo afastamento das questões do campo - são possíveis explicações para a relevância limitada do Partido Liberal no desenrolar político do início do século XX no México.

O texto de seu programa, porém, foi o primeiro a organizar as principais questões e problemas enfrentados pelos trabalhadores naquele período, propondo soluções normativas. Além de afirmar a possibilidade de regulação e estabelecer parâmetros para as relações entre capital e trabalho, o fato de suas propostas serem reivindicadas por um partido indica que haveria um caminho político para elas se tornarem efetivas. A conjunção entre as propostas de regulação das relações de trabalho e a forma de organização política para implementá-las faz com que esse documento seja tão importante. Sua influência é reconhecida em diferentes momentos da história política do México relacionada às questões trabalhistas, sendo que suas ressonâncias se fazem sentir até mesmo no texto da Constituição de 1917.

Além do trabalho, o autoritarismo do governo de Porfírio Díaz e seu descolamento dos interesses populares são também temas centrais do texto do Programa. É o governo sem compromisso com os direitos do povo responsável por uma situação em que "el trabajador mexicano nada gana; desempeñando rudas y prolongadas labores, apenas obtiene lo muy estrictamente preciso para no morir de hambre." ${ }^{438}$. Receber o mínimo apenas suficiente para não morrer de fome, estar permanentemente endividado, ter um cotidiano que esgota e não deixa tempo livre nem mesmo para um mínimo de descanso e entretenimento são as condições gerais de trabalho no México. As propostas do Partido Liberal para reverter esse cenário são "una labor máxima de ocho horas y un salario mínimo de un peso" ${ }^{\$ 339}$.

No texto em que expõem os motivos dessa proposta, antes da parte propriamente normativa do plano, os membros do partido defendem que o salário mínimo de um peso diário está longe de ser o ideal para garantir as condições de vida digna que merecem os trabalhadores - um mês antes, os trabalhadores de Cananaea reivindicavam o salário diário de cinco pesos. Mesmo assim, os liberais afirmam que essas duas propostas são o mínimo necessário para uma vida relativamente digna e que, com a jornada laboral

\footnotetext{
${ }^{438}$ Programa del Partido Liberal Mexicano, publicado em $1^{\text {o }}$ de julho de 1906. Íntegra em: MEXICO, Secretaria de Gobernación: Unidade General de Asuntos Jurídicos. $<$ http://www.ordenjuridico.gob.mx/Constitucion/CH6.pdf $>$ Consulta realizada em 23/09/2015.

${ }^{439}$ Programa del Partido Liberal Mexicano, publicado em $1^{\circ}$ de julho de 1906. Íntegra em: MEXICO, Secretaria de Gobernación: Unidade General de Asuntos Jurídicos. $<$ http://www.ordenjuridico.gob.mx/Constitucion/CH6.pdf $>$ Consulta realizada em 23/09/2015.
} 
reduzida para no máximo oito horas, os trabalhadores terão mais tempo para se organizar politicamente e para reivindicar melhores condições de trabalho. Embora a organização política, em sindicatos, dos trabalhadores seja explicitamente mencionada na exposição de motivos inicial do Programa do Partido Liberal Mexicano, na parte normativa de suas propostas não há nenhuma menção sobre o direito de greve ou o direito à organização sindicalista. Considerando que o Programa foi lançado em uma edição do jornal Regeneración em que a manchete principal relatava os confrontos em Cananea, não incluir o direito à organização política e a possibilidade de manifestação por meio da interrupção do trabalho configura-se como uma ausência notável.

O Programa também propõe uma regulamentação específica para o trabalho doméstico, dado que nas atividades especiais os limites de horas trabalhadas são mais difíceis de estabelecer. Em que pesem as especificidades do trabalho em casas de família, tanto a jornada máxima de trabalho quanto o salário mínimo deveriam ser garantidos de forma equivalente aos dos demais trabalhadores. A regulamentação específica, assim, teria como objetivo aproximar os direitos reconhecidos a todos os trabalhadores também para os trabalhadores domésticos ${ }^{440}$.

Para além da diferenciação por tipo de trabalho, o texto que apresenta as decisões políticas do programa também chama a atenção para o significado do salário mínimo de um peso em um país grande e permeado por desigualdades dos mais diversos tipos. Segundo o documento, em todas as regiões do México o mínimo que uma pessoa deve receber para viver com dignidade é um peso diário. Em nenhum local seria possível sobreviver com menos do que esse valor. Se isso é verdade, o mesmo não se pode dizer sobre ser esse valor suficiente em todas as regiões do México. O programa chama a atenção para o fato de em alguns lugares o custo de vida ser mais alto e de, em alguns casos, os trabalhadores da região já receberem um peso diário. Nessas

\footnotetext{
${ }^{440}$ Norma do programa: "22.- Reglamentación del servicio doméstico y del trabajo á domicilio." Texto da exposição de motivos sobre o tema: "La reglamentación del servicio doméstico y del trabajo á domicilio se hace necesaria, pues á labores tan especiales como éstas es difícil aplicarles el término general del máximum de trabajo y el mínimum de salario que resulta sencillo para las demás labores. Indudablemente, deberá procurarse que los afectados por esta reglamentación obtengan garantías equivalentes á las de los demás trabajadores.[...]". Programa del Partido Liberal Mexicano, publicado em $1^{\circ}$ de julho de 1906. Íntegra disponível em: MEXICO, Secretaria de Gobernación: Unidade General de Asuntos Jurídicos. http://www.ordenjuridico.gob.mx/Constitucion/CH6.pdf Consulta realizada em $15 / 12 / 2015$
} 
circunstâncias, seria necessário o estabelecimento de um salário mínimo mais alto do que o genericamente estipulado ${ }^{441}$.

Para além de salário mínimo nacional - com adaptações nos casos em que garantir o mínimo já não seja um benefício para o trabalhador - e a jornada de oito horas diárias, que deve beneficiar a todos indistintamente, o Programa do Partido Liberal Mexicano ainda apresenta uma série de direitos que, segundo os autores, "son de necesidad y justicia patentes":

Los demás puntos que se proponen para la legislación sobre el trabajo son de necesidad y justicia patentes. La higiene en fábricas, talleres, alojamientos y otros lugares en que dependientes y obreros deben estar por largo tiempo; las garantías á la vida del trabajador; la prohibición del trabajo infantil; el descanso dominical; la indemnización por accidentes y la pensión á obreros que han agotado sus energías en el trabajo; la prohibición de multas y descuentos; la obligación de pagar con dinero efectivo; la anulación de la deuda de los jornaleros; las medidas para evitar abusos en el trabajo á destajo y las de protección á los medieros; todo esto lo reclaman de tal manera las tristes condiciones del trabajo en nuestra Patria, que su conveniencia no necesita demostrarse con ninguna consideración. ${ }^{442}$

À lista de direitos básicos e condições mínimas que deveriam estar presentes nas relações de trabalho no México, a exposição de motivos acrescenta que garantir tais direitos aos trabalhadores trará benefícios para o desenvolvimento da indústria e produção mexicanas. Com maiores salários e melhores condições de trabalho, os

\footnotetext{
${ }^{441}$ Norma presente no Programa "21.- Establecer un máximum de ocho horas de trabajo y un salario mínimo en la proporción siguiente: \$1.00 para la generalidad del país, en que el promedio de los salarios es inferior al citado, y de más de $\$ 1.00$ para aquellas regiones en que la vida es más cara y en las que este salario no bastaría para salvar de la miseria al trabajador."

Texto da exposição de motivos sobre o tema: "El establecimiento de ocho horas de trabajo es un beneficio para la totalidad de los trabajadores, aplicable generalmente sin necesidad de modificaciones para casos determinados. No sucede lo mismo con el salario mínimo de un peso, y sobre esto hay que hacer una advertencia en extremo importante. Las condiciones de vida no son iguales en toda la República: hay regiones en México en que la vida resulta mucho más cara que en el resto del país. En esas regiones los jornales son más altos, pero á pesar de esto el trabajador sufre allí tanta miseria como la que sufren con más bajos salarios los trabajadores en los puntos donde es más barata la existencia. [...] Es, pues, preciso prevenir tal injusticia, y al formularse detalladamente la ley del trabajo deberán expresarse las excepciones para la aplicación del salario mínimo de $\$ 1.00$, estableciendo para aquellas regiones en que la vida es más cara, y en que ahora ya se gana ese jornal, un salario mayor de $\$ 1.00$. Debe procurarse que todos los trabajadores obtengan en igual proporción los beneficios de esta ley." Programa del Partido Liberal Mexicano, publicado em $1^{\circ}$ de julho de 1906. Íntegra disponível em: MEXICO, Secretaria de Gobernación: Unidade General de Asuntos Jurídicos. http://www.ordenjuridico.gob.mx/Constitucion/CH6.pdf Consulta realizada em 15/12/2015.

${ }_{442}$ Programa del Partido Liberal Mexicano, publicado em $1^{\circ}$ de julho de 1906. Íntegra disponível em: MEXICO, Secretaria de Gobernación: Unidade General de Asuntos Jurídicos. http://www.ordenjuridico.gob.mx/Constitucion/CH6.pdf Consulta realizada em 15/12/2015.
} 
trabalhadores passariam a ser também consumidores e, consequentemente, impulsionariam o mercado interno, demandando maiores produções das fábricas ${ }^{443}$.

A última norma da seção sobre Capital e Trabalho do Programa do Partido Liberal Mexicano estabelece a obrigatoriedade do descanso dominical. Não aparece nem nas normas do Programa do Partido Liberal, nem em qualquer outro documento revolucionário a demanda pelo direito de férias. É verdade que a noção de que um período de descanso anual deveria ser garantido aos trabalhadores ainda não estava difundida em 1906. A legislação brasileira, vanguardista, em 1925 garante 15 dias de descanso remunerado por ano trabalhado ${ }^{444}$. Só em 1936, uma Convenção da Organização Internacional do Trabalho estimula que os países garantam em seus ordenamentos jurídicos o mínimo de seis dias de descansos consecutivos, no mínimo, para trabalhadores que tiverem completado um ano de emprego ${ }^{445}$.

Está no Programa do Partido Liberal Mexicano, porém, uma norma que visa a impedir que os empregadores burlem o tempo máximo e o salário mínimo estipulados. Vislumbra-se que, com esta norma, buscavam estabelecer algumas sanções em caso de descumprimento. $\mathrm{O}$ próprio programa, porém, não determina quais ${ }^{446}$. Também o trabalho é absolutamente proibido para crianças menores de catorze anos ${ }^{447}$. Esta norma é muito mais pretensiosa em sua limitação do que proposta por Porfírio Díaz seis meses depois, em janeiro de 1907, a qual estabelece sete anos como idade mínima para o trabalho.

\footnotetext{
${ }^{443}$ No texto do Programa: "impulsarán notablemente el desarrollo (...) Pero si estos hambrientos dejan de serlo; si llegan á estar en condiciones de satisfacer sus necesidades normales; en una palabra, si su trabajo les es bien o siquiera regularmente pagado, consumirán infinidad de artículos de que hoy están privados, y harán necesaria una gran producción de esos artículos. Para lograr estos dos objetos no hay más que aplicar por una parte la ley del jornal mínimo y el trabajo máximo, y por otra la obligación del terrateniente de hacer productivos todos sus terrenos, so pena de perderlos." Programa del Partido Liberal Mexicano, publicado em $1^{\circ}$ de Julho de 1906. Íntegra disponível em: MEXICO, Secretaria de Gobernación: Unidade General de Asuntos Jurídicos. http://www.ordenjuridico.gob.mx/Constitucion/CH6.pdf Consulta realizada em 15/12/2015.

${ }^{444}$ No decreto n. 4.982, de 24 de dezembro de 1925, assinado pelo Presidente Arthur Bernardes, está o seguinte dispositivo: "Art. $1^{\circ} \mathrm{A}$ empregados e operarios de estabelecimentos commerciaes, industriaes e bancarios e de instituições de caridade e beneficencia no Districto Federal e nos Estados, senão annualmente concedidos 15 dias de férias, sem prejuizo dos respectivos ordenados, diarias, vencimentos e gratificações".

${ }^{445}$ A íntegra da Convenção n. 52 da Organização Internacional do Trabalho (OIT), de 4 de junho de 1936, pode ser encontrada em: http://www.oitbrasil.org.br/node/521 Consulta realizada em 15/12/2015.

446 "23 - Adoptar medidas para que con el trabajo á destajo los patronos no burlen la aplicación del tiempo máximo y salario mínimo." Programa del Partido Liberal Mexicano, publicado em $1^{\circ}$ de julho de 1906. Íntegra disponível em: http://www.ordenjuridico.gob.mx/Constitucion/CH6.pdf Consulta realizada em $15 / 12 / 2015$.

447 "24.- Prohibir en lo absoluto el empleo de niños menores de catorce años." Programa del Partido Liberal Mexicano, publicado em $1^{\circ}$ de julho de 1906. Íntegra disponível em:

http://www.ordenjuridico.gob.mx/Constitucion/CH6.pdf Consulta realizada em 15/12/2015.
} 
Além dessas propostas, o Programa do Partido Liberal Mexicano também afirma ser necessário, para melhorar as condições de vida do trabalhador, o fim das tiendas de raya e, paralelamente, a extinção de todas as dívidas anteriores e a proibição de pagamento com qualquer outro meio que não "dinero efectivo", prevendo, ainda, que deve haver penas severas para casos de descumprimento dessa regra. Também propõe a manutenção e garantia de bom ambiente de trabalho e moradia, o que inclui higiene e precauções contra situações e lugares perigosos. Em caso de acidentes de trabalho, os empregadores seriam obrigados a indenizar os acidentados. As normas estabelecem também proteções aos arrendatários e meeiros, como trabalhadores autônomos que guardam, porém, uma posição semisubordinada em relação aos proprietários das terras em que trabalham. Por fim, o Programa estabelece que todas as empresas sediadas no México devem reservar a maioria de seus postos de trabalho aos nascidos no país, e proibe que mexicanos e estrangeiros desempenhando a mesma função recebam salários diferentes ${ }^{448}$. A "pensión á obreros que han agotado sus energías en el trabajo", uma espécie de aposentadoria por esgotamento de forças, embora mencionada na exposição de motivos não está explícita na parte normativa do documento, quiçá por mero esquecimento.

Apesar das ausências, é notável como as normas propostas pelo Partido Liberal Mexicano propõem uma proteção ampla e, se fossem aplicadas, efetiva ao trabalhador, visando a de fato reequilibrar a relação entre capital e trabalho, nos limites daquele momento histórico. Mesmo sendo o primeiro, talvez esse seja o documento mais

448 “25.- Obligar á los dueños de minas, fábricas, talleres, etc., á mantener las mejores condiciones de higiene en sus propiedades y á guardar los lugares de peligro en un estado que preste seguridad á la vida de los operarios.

26.- Obligar á los patronos o propietarios rurales á dar alojamiento higiénico á los trabajadores, cuando la naturaleza del trabajo de éstos exija que reciban albergue de dichos patronos o propietarios.

27.- Obligar á los patronos á pagar indemnización por accidentes del trabajo.

28.- Declarar nulas las deudas actuales de los jornaleros de campo para con los amos.

29.- Adoptar medidas para que los dueños de tierras no abusen de los medieros.

30.- Obligar á los arrendadores de campos y casas á que indemnicen á los arrendatarios de sus propiedades por las mejoras necesarias que dejen en ellas.

31.- Prohibir á los patrones, bajo severas penas, que paguen al trabajador de cualquier otro modo que no sea como dinero efectivo prohibir y castigar que se impongan multas á los trabajadores o se les hagan descuentos de su jornal o se retarde el pago de raya por más de una semana o se niegue al que se separe del trabajo el pago inmediato de lo que tiene ganado; suprimir las tiendas de raya.

32.- Obligar á todas las empresas ó negociaciones á no ocupar entre sus empleados y trabajadores sino una minoría de extranjeros. No permitir en ningún caso que trabajos de la misma clase se paguen peor al mexicano que al extranjero en el mismo establecimiento, o que á los mexicanos se les pague en otra forma que á los extranjeros." Programa del Partido Liberal Mexicano, publicado em 1º de julho de 1906. Íntegra disponível em: http://www.ordenjuridico.gob.mx/Constitucion/CH6.pdf Consulta realizada em $15 / 12 / 2015$. 
completo sobre direitos dos trabalhadores produzido por uma organização política que participará dos levantes revolucionários que se seguirão nos próximos anos .

\subsubsection{La sucesión presidencial en 1910 (1908), o Plan de San Luís Potosí (1910) e a criação do Departamento del Trabajo: Madero e a questão trabalhista}

Logo após Porfírio Díaz ter declarado a um jornalista estadunidense, em 1908, que não concorreria às eleições de 1910, o cenário político mexicano se transforma: oposição e governistas passam a querer reunir forças para ocupar o espaço político que ficaria vazio com a saída de Díaz. Nesse contexto, Francisco Madero e outros liberais descontentes com as arbitrariedades do governo central, começam a organizar o Partido Antireeleicionista. Um dos documentos que impulsionam essa organização é o livro de diagnósticos e propostas para o México La sucesión presidencial en 1910, publicado em 1908.

Duas seções do livro são dedicadas à greve de Cananea e aos conflitos em Río Blanco. Tanto em um caso como em outro, os episódios são exemplos, no livro, da truculência e da falta de democracia por que passava o México sob o comando de Porfírio Díaz. Muito embora Madero deixasse claro não ser totalmente favorável às reivindicações dos trabalhadores - isso fica explícito em trechos como "En estos casos, se comprende que se encontraría bastante perplejo cualquier árbitro para saber á quien daba la razón, puesto que el principal punto de la controversia era esencialmente económico." - repudiava de forma veemente a forma como os conflitos eram encerrados.

Em relação aos conflitos em Río Blanco, Madero tem uma interpretação peculiar sobre o início do conflito, pouco presente em outros pesquisadores sobre o tema. Segundo Madero, os industriais decidiram pelo lockout (fechamento) de quase todas as indústrias têxteis dos estados centrais do México, durante a greve nas fábricas de Puebla e Tlaxcala, para impedir que seus trabalhadores contribuíssem, mandassem insumos para que os grevistas de Puebla e Tlaxcala pudessem sustentar sua paralisação. Bernardo García tem um longo trabalho sobre as origens dos trabalhadores de Orizaba, e chama atenção para a enorme quantidade de operários vindos de Puebla. Essa informação corrobora a interpretação de Madero - que, no mais, por ser da elite agrária mexicana, deveria ter uma boa circulação entre os industriais do centro do país. 
O lockout, assim, parece ter sido uma maneira de boicotar diretamente a greve em Puebla, segundo Madero. E muito embora ele declare que seria difícil a um árbitro saber quem estava com a razão, por ser uma questão supostamente econômica, em outro trecho de seu livro afirma que a repressão de Porfírio Díaz significa dizer aos trabalhadores " Está bien que mueran de hambre; pero que se mueran en orden, en silencio, sin protestar, sin intentar organizarse para la defensa de sus derechos!" 449. Por fim, Madero encerra o trecho em que trata dos trabalhadores fazendo uma acusação grave a Díaz: “'El General Díaz permanece impasible ante las catástrofes obreras; lo único que le conmueve es que peligre su poder, pues su principal papel con sirte en ser el celoso guardián del absolutismo!" ${ }^{450}$. Não se pode acusar o autor de La sucesión presidencial en 1910 da mesma indiferença de Díaz à causa operária.

Não necessariamente ao lado do trabalhador, Francisco Madero sabe que os direitos dos trabalhadores do campo e da cidade mexicanos são um grande problema social para o México. Ao final de seu longo livro de diagnóstico, porém, afirma que quanto mais extenso for um programa de um partido político, mais princípios ele trará. Quanto mais princípios, menos pessoas estarão dispostas a concordar com todos e, portanto, menos pessoas ele atrairá. Partindo dessa constatação política simplória, Madero afirma que o programa do Partido Antirreeleicionista deverá ser "lo más conciso posible" $^{451}$.

O Programa do Partido Antirreelecionista de la República, aprovado na Convenção do Partido em 15 de abril de 1910, não segue à risca esse princípio, porém. Entre os objetivos dos candidatos à presidência, Francisco Madero, e à vice-presidência Francisco Vázquez Gómez, estava: “Mejorar la condición material, intelectual y moral del obrero, creando escuelas-talleres". Também estava prevista a "expedición de leyes sobre pensiones o indemnizaciones por accidentes del trabajo y combatiendo el alcoholismo y el juego"452. Além dessas propostas, há também uma menção ao

\footnotetext{
. ${ }^{449}$ MADERO, Francisco. "La sucesión presidencial en 1910". Coahuila: Biblioteca del Político, INEPAC, 1908. In CARMONA, Doralicia. Memoria política de México. Guanajuato: Universidade de Guanajuato, 2014. <http://www.memoriapoliticademexico.org/Textos/6Revolucion/1910LSP.pdf> Consulta realizada em 26/10/2015, p. 67.

450 . Ibid., p. 68.

${ }^{451}$ Ibid., p. 98.

452 A íntegra do Programa do Partido Antireelecionista, aprovado em Convenção do Partido em 15 de abril de 1910, pode ser encontrada em: BIBLIOTECA GARAY. 500 años de México en documentos. México,

2011.http://www.biblioteca.tv/artman2/publish/1910_215/Programa_politico_aprobado_en_la_Convenci on_del_Gr_1466.shtml Consulta realizada em 16/12/2015.
} 
problema do excesso de estrangeiros entre os funcionários das empresas ferroviárias. Historiadores afirmam que, se o Programa do Partido Antireelecionista não é mais sucinto, não é por desejo de Madero, mas sim por influência direta dos irmãos Vázquez Gomez.

Mais fiel ao princípio da concisão defendido no livro de Madero de 1908, o Plan de San Luís Potosí, publicado em outubro 1910 com o objetivo principal de convocar a revolução para o dia 20 de novembro, não traz nenhum direito ou garantia e nenhuma menção às condições de vida do trabalhador. O único direito social presente no Plan de San Luís Potosí está no artigo $3^{\circ}$, que afirma ser necessário devolver às comunidades mestiças e indías as terras das quais elas foram despojadas por abuso (este é o conceito do plano) da ley de baldíos. Mesmo essa proposta foi pouco privilegiada no curto período em que Francisco Madero governou, como já analisado no capítulo 1.

A relação de Madero com os direitos do trabalhador não se encerra com o Plan de San Luís Potosí, porém. Após a renúncia de Porfírio Díaz, Francisco León de la Barra assumiu a presidência provisória. No período em que governou, elaborou um projeto de lei, divulgado em 22 de setembro de 1911 e transformado em lei em 15 de dezembro, depois de aprovada pelo Congresso dos Estados Unidos Mexicanos e sancionada pelo então Presidente Francisco Madero. Foi Madero, assim, que criou como instituição o Departamento del Trabajo, responsável por levantar e organizar dados e informações sobre as relações de trabalho no México - e publicá-las e difundilas periodicamente, bem como por promover tímidas políticas públicas de assistência ao trabalhador. No decreto, um exemplo dessa função é a facilitação do transporte para trabalhadores que precisem se deslocar pelo país em virtude das oportunidades de trabalho.

Por fim, o Departamento del Trabajo deveria intermediar contratos de trabalho quando as partes solicitassem a participação do Estado e mediar conflitos entre trabalhadores e empregadores, funcionando como árbitro sempre que chamado a participar. O departamento foi criado para desempenhar o papel de mediador de conflitos e propositor de soluções negociadas, como uma das estratégias para que os eles não se transformassem em repressão violenta, como criticado por Madero. Obviamente, esta solução institucional encontrava limites no grau de disponibilidade dos empregadores para melhorar as condições de vida de seus trabalhadores - 
principalmente se isso gerasse mais custos - e em quanto o Estado estaria disposto a contrariar interesses do lado do conflito detentor de poder econômico ${ }^{453}$.

Com a aprovação da lei de dezembro de 1911 e a instalação do Departamento del Trabajo, houve o reconhecimento institucional de que a questão das relações de trabalho no México mereciam atenção e atuação governamental. Apesar disso, as propostas que figuram entre as competências do Departamento são tímidas, uma vez que o poder público só atuaria em casos aos quais fosse chamado. Não há entre as normas a possibilidade de, a partir dos dados sobre trabalho e emprego levantados e organizados, formular propostas para melhorar as condições de vida dos trabalhadores. Do ponto de vista da regulação direta das condições de trabalho, o Departamento fica muito aquém das propostas apresentadas no Programa do Partido Liberal.

\subsubsection{Plan Político-Social (1911)}

Em 18 de março de 1911, com a causa maderista vivendo o ápice de adesões e volume de tropas, um grupo de líderes políticos e militares dos estados do centro e sul do México publicam seu Plan Político-Social. O objetivo do documento, tal como está explícito no artigo $3^{\circ}$, é reconhecer Francisco I. Madero como chefe da revolução e, portanto, afirmar que passam a lutar contra o governo autoritário de Porfírio Díaz. O artigo $4^{\circ}$ reafirma a Constituição de 1857 como lei suprema, e adere ao lema do Partido Antirreleicionista "voto libre y no reelección". O documento representa, segundo os próprios autores, dez mil mexicanos dos Estados de Guerrero, Michoacán; Tlaxcala, Campeche, Puebla e Distrito Federal. Esses dez mil revolucionários, porém, ao decidir entrar na luta maderista, preferiram expor as próprias razões por que lutavam. Ao invés

\footnotetext{
${ }^{453}$ A lei de 15 de dezembro de 1911 dispõe: "Art. $1^{\circ}$ Se establece una oficina denominada "Departamento del Trabajo", dependiente de la Secretaría de Fomento, Colonización e Industria.

Art. $2^{\circ}$ El Departamento del Trabajo estará encargado: 1. De reunir, ordenar y publicar datos e informaciones relacionados con el trabajo, en toda la República; 2. Servir de intermediario en todos los contratos de braceros y empresarios, cuando los interesados lo soliciten; 3. Procurar facilitar en el transporte de los obreros a las localidades donde fueren contratados; 4. Procurar el arreglo equitativo en los casos de conflicto entre empresarios y trabajadores, y servir de árbitro en sus diferencias, siempre que así lo solicitenlos interesados.

Art. $3^{\circ}$ Los datos e informaciones relacionados con el trabajo se darán a conocer periódicamente en una publicación consagrada a este objeto, la cual se distribuirá profusamente entre los particulares o empresas, negociaciones, cámaras de comercio, agricultura e industria, autoridades etc., así como entre los centros interesados en estas noticias, tanto nacionales como extranjeros." A íntegra da lei pode ser encontrada em CARMONA, Doralicia. Memoria política de México. Guanajuato: Universidade de Guanajuato, 2014: http://www.memoriapoliticademexico.org/Textos/6Revolucion/1911DFT.html Consulta realizada em $16 / 12 / 2015$.
} 
de simplesmente subscrever o Plan de San Luís Potosí, elaboraram o próprio plano, permeado de normas para que, vencida a luta, fossem ampliados os direitos sociais da população mexicana.

Entre os Estados subscritores, Puebla, Tlaxcala e Distrito Federal concentravam uma parte significativa da indústria têxtil do país e haviam vivido cinco anos antes os conflitos decorrentes da greve seguida pelo lockout, ambos longos e conflituosos. Os revolucionários também não passaram ao largo da questão agrária, como visto no capítulo 2 - até porque os conflitos relacionados à terra estavam presentes em praticamente todos os estados mexicanos. Dada a memória então recente dos conflitos de 1906-1907, e considerando que as condições de vida da população operária não haviam mudado muito em cinco anos, a questão trabalhista não poderia ser ignorada por esses representantes. O Plan Político-Social de março de 1911, cujos âmbitos de influência que quer ter na conjuntura do México ficam explícitos no nome, faz as seguintes propostas em seu texto:

X.- Se aumentarán los jornales a los trabajadores de ambos sexos, tanto del campo como de la ciudad, en la relación con los rendimientos del capital, para cuyo fin se nombrarán comisiones de personas competentes para el caso, las cuales dictaminarán, en vista de los datos que necesiten para esto;

XI.- Las horas de trabajo no serán menos de ocho ni pasarán de nueve;

XII.- Las empresas extranjeras establecidas en la República, emplearán, en sus trabajos, la mitad cuando menos, de nacionales mexicanos, tanto en los puestos subalternos, como en los superiores, con los mismos sueldos, consideraciones y prerrogativas que concedan a sus compatriotas;

(...)XV.- Quedan abolidos los monopolios, de cualquiera clase que sean.

¡Abajo la Dictadura! Voto Libre y No Reelección. ${ }^{454}$

454 A íntegra do Plan Político-Social, de 18 de março de 1911, pode ser encontrada em: http://www.bibliotecas.tv/zapata/1911/z18mar11.html Consulta realizada em 07/11/2015. 


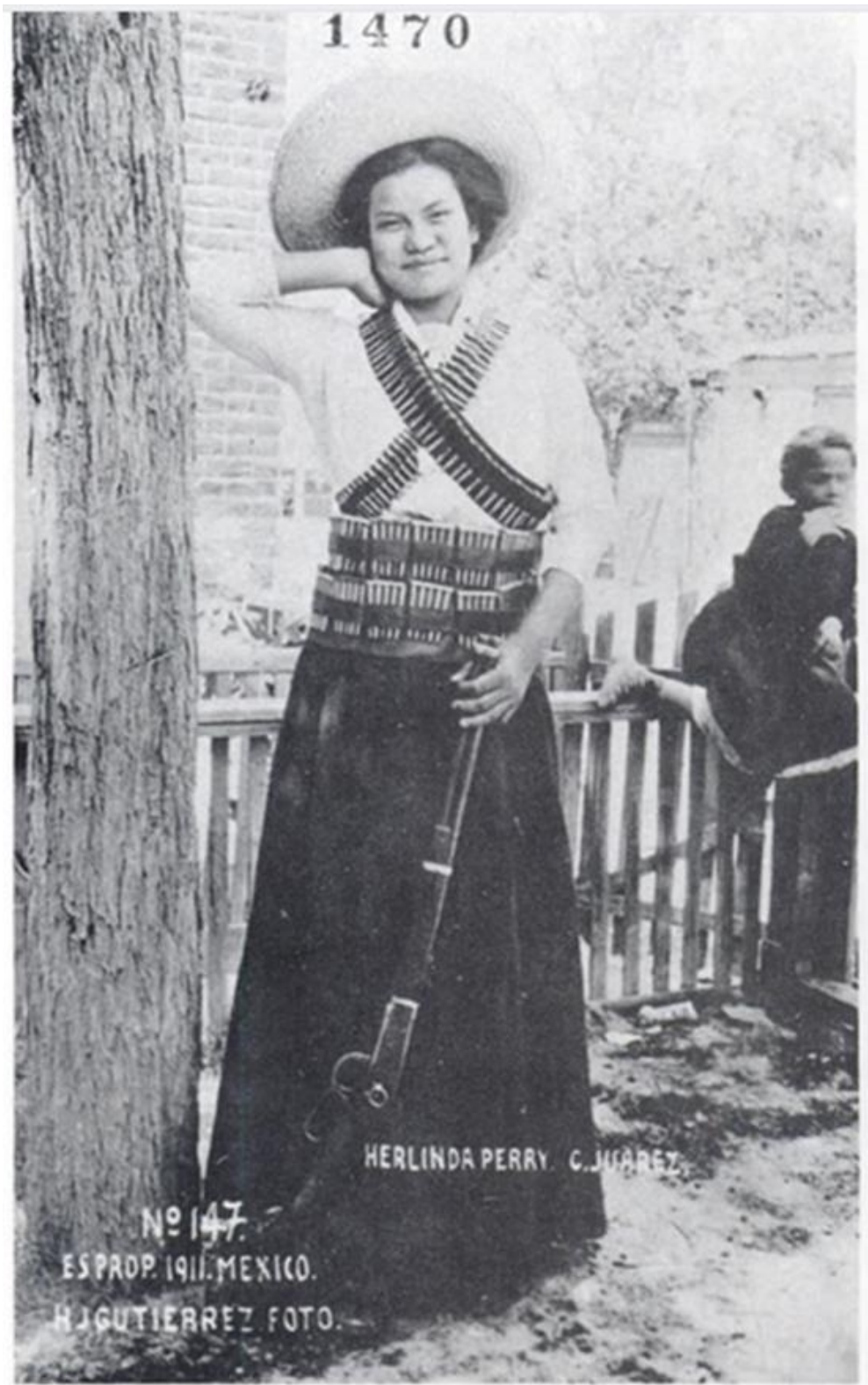

Foto de uma "Adelita", denominação usada para descrever mulheres que participavam dos confrontos armados da Revolução Mexicana no norte do México. A foto foi tirada em Ciudad Juárez, sem data.

A igualdade entre os sexos no mercado de trabalho é reivindicação exclusiva do Plan PolíticoSocial de 1911. A previsão normativa volta a aparecer apenas no art. 123 da Constitição de 1917. Para além das diferenças salariais e de cargos entre mexicanos e estrangeiros, entre trabalhadores industriais e do campo, também a desigualdade entre os sexos desfavorecia as mulheres. Além de ser o único a apresentar explicitamente esta preocupação em seu texto, o Plan Político-Social é o único documento do período a trazer entre os subscritores uma mulher. Dolores Jiménez y Muro morava na Cidade do México e foi responsável por promover a divulgação do documento no dia em que os embates tiveram início. O texto do Plan Político-Social ainda veta quaisquer desigualdades salariais ou de cargos entre mexicanos e estrangeiros, e defende que seja obrigatória a contratação de mexicanos para o preenchimento de $50 \%$ dos postos de trabalho, quer sejam eles subalternos ou de chefia.

Os insurgentes propõem que a jornada de trabalho não seja menor do que oito horas, nem maior do que nove. Pode-se especular que o limite mínimo inferior da jornada de trabalho tem por objetivo impedir fraudes em contratos de trabalho que, sob 
pretexto de diminuírem a jornada - sem diminuí-la de fato -, diminuam o valor do salário mínimo fixado. O último item do Programa defende o fim de qualquer monopólio, repetindo o disposto no artigo 28 da Constituição de 1857.

A importância do Plan Político-Social reside no fato de ser um documento de apoio à luta maderista - e implicitamente também ao Plan de San Luís Potosí. Este apoio, porém, não é feito sem reservas. E as reservas se devem ao fato de o Plan de San Luís Potosí ser lacônico no que tange alguns direitos sociais, sobretudo aqueles ligados às relações de trabalho. O Plan Político-Social declara apoio e preenche lacunas sociais na formulação do Plan de San Luís.

O Plan de Ayala, subscrito por participantes do movimento zapatista do Estado de Morelos em novembro de 1911, teve uma função parecida. Diferentemente do Plan Político-Social, foi formulado quando Francisco Madero já havia sido eleito presidente da república, em um momento em que já estava claro que Madero não empreenderia esforços para realizar a promessa agrária prometida no artigo $3^{\circ}$ do Plan de San Luís Potosí. Além do momento histórico diferente do Plan Político-Social, também a prioridade era diferente. O ponto central de sua complementação em relação a direitos sociais não trata dos direitos dos trabalhadores, mas à propriedade de terra no México. Semelhante em espírito é o Plan de Tacubaya, publicado por correligionários de Emilio Vázquez Gómez, em 31 de outubro de 1911. Insatisfeitos com as decisões da presidência de Francisco Madero, que tentava realizar um governo de coalizão com os apoiadores do governo de Porfírio Díaz após uma revolução, romperam os laços e chamaram os mexicanos a continuar na luta, por um governo mais democrático, melhores condições de vida e mais justa distribuição de terras.

\subsubsection{Plan de la Empacadora (março 1912)}

Os planos de Ayala e Tacubaya questionavam a presidência de Francisco Madero a partir da realidade do centro-sul do país. Tacubaya é uma vila nos arredores da Cidade do México e Ayala, local em que o movimento zapatista se formou, é um distrito do Estado de Morelos, que faz fronteira com o Estado do México. Também ao norte do país, mais especificamente em Chihuahua, surgiram movimentos de questionamento da legitimidade da presidência de Francisco Madero. Embora Francisco Villa permanecesse leal ao então presidente da república, dois movimentos de 
questionamento surgiram no estado em que ele atuava. O Plan de Santa Rosa ${ }^{455}$, de 3 de fevereiro de 1912, reúne pessoas em torno do lema "Tierra y Justícia". O documento defende ser necessária uma nova regulação da terra, denuncia a traição política de Madero por não dar atenção a essa questão e não trata de problemas relacionados ao trabalho. Embora tivesse uma proposta bastante ousada para organização fundiária mexicana, em função da pouca força militar e política de seus subscritores, o documento não ganhou maior notoriedade histórica.

No mesmo Estado de Chihuahua, em 25 de março de 1912, Pascual Orozco importante líder militar da etapa antirreelecionista da revolução - declara seu rompimento com Francisco Madero em texto cheio de palavras e expressões fortes. Com um ataque direto à pessoa de Madero que, segundo Orozco, teria protagonizado inúmeros malfeitos ao Estado mexicano, convoca o povo mexicano a continuar em armas para defender seus interesses. Entre os ataques dirigidos a Madero, uma suposta violação da soberania nacional, pois segundo Orozco o presidente "de manera perjudicial y humillante para la Nación, ha puesto en manos del Gobierno Americano los destinos de la Patria, por medio de complacencias indignas y de promesas que afectan a su nacionalidad e integridad" ${ }^{456}$.

Além de expor longamente as razões que levaram ao rompimento político com Madero, o Plan de la Empacadora, como ficou conhecido o documento firmado por Orozco em março de 1912, também apresenta propostas para quando a revolução convocada for vitoriosa. Entre as propostas há algumas que dizem respeito diretamente ao problema das relações de trabalho:

34 Para mejorar y enaltecer la situación de la clase obrera, se implantarán desde luego las siguientes medidas:

I. Supresión de las tiendas de raya bajo el sistema de vales, libretas o carta-cuentas.

II. Los jornales de los obreros serán pagados totalmente en dinero

\footnotetext{
455 A íntegra do Plan de Santa Rosa, de 3 de fevereiro de 1912, pode ser encontrada em CARMONA, Doralicia. Memoria política de México. Guanajuato: Universidade de Guanajuato, 2014: http://www.memoriapoliticademexico.org/Textos/6Revolucion/1912-PSR.html Consulta realizada em 16/12/2015.

${ }^{456}$ A íntegra do Manifesto redigido por Pascual Orozco em 8 de março de 1912 e a íntegra do Plan de la Empacadora, também de Orozco, de 25 de março de 1912 podem ser consultados em CARMONA, Doralicia. Memoria política de México. Guanajuato: Universidade de Guanajuato, 2014: http://www.memoriapoliticademexico.org/Textos/6Revolucion/1912-M-PO.html e http://www.memoriapoliticademexico.org/Textos/6Revolucion/1912MPO.html Consulta realizada em 21/11/2015.
} 
efectivo.

III. Se reducirán las horas de trabajo, siendo éstas diez horas como máximum para los que trabajen a jornal y 12 para los que lo hagan a destajo.

IV. No se permitirá que trabajen en las fábricas niños menores de diez años, y los de esta edad hasta la de diez y seis sólo trabajarán seis horas al día.

V. Se procurará el aumento de jornales armonizando los intereses del capital y del trabajo, de manera que no se determine un conflicto económico que entorpezca el progreso industrial del país.

VI. Se exigirá a los propietarios de fábricas que alojen a los obreros en condiciones higiénicas, que garanticen su salud y enaltezcan su condición. ${ }^{457}$

O Plan de la Empacadora não é o documento revolucionário mais ousado em relação à proteção do trabalhador. O Partido Liberal Mexicano, em seu programa de 1906, propunha uma jornada máxima de oito horas diárias. Já o Plan Político-Social, de 1911, estipulava uma jornada mínima de oito horas e máxima de nove. Orozco afirma que devem ser reduzidas as horas de trabalho diárias, mas propõe que a jornada máxima seja de dez horas diárias para aqueles que trabalham por dia, podendo chegar a doze para os trabalhadores que recebam por peça produzida ou tarefa realizada. O plano orozquista é o primeiro a apresentar essa forma de trabalho (por peça, por tarefa) como variável para garantir ou não proteções ao trabalhador. Outro elemento que deve ser levado em conta em relação à jornada de trabalho, segundo Orozco, é a idade do trabalhador: entre 10 e 16 anos, as crianças só poderiam trabalhar seis horas diárias. Em relação à proposta de Porfírio Díaz em 1907, que autorizava o trabalho infantil a partir dos sete anos, proibir crianças de até dez anos de trabalhar e reduzir a carga horária para aqueles que têm entre dez e dezesseis não é limitação desprezível, considerando os parâmetros da época, quando o objetivo é proteger a infância.

Tímido em relação à jornada de trabalho, Orozco é intransigente em relação às tiendas de raya: nenhum mecanismo de contabilização de crédito ou pagamento por vale deve existir e as próprias tiendas devem ser extintas. Os empregados devem

\footnotetext{
${ }^{457}$ A íntegra do Manifesto redigido por Pascual Orozco em 8 de março de 1912 e a íntegra do Plan de la Empacadora, também de Orozco, de 25 de março de 1912 podem ser consultados em Doralicia Carmona. Memoria Política de México. Guanajuato: Universidade de Guanajuato, 2014: http://www.memoriapoliticademexico.org/Textos/6Revolucion/1912-M-PO.html e http://www.memoriapoliticademexico.org/Textos/6Revolucion/1912MPO.html Consulta realizada em $21 / 11 / 2015$.
} 
receber em dinheiro e devem ser livres para comprar no estabelecimento que lhes for mais conveniente ou que oferecer produtos ao menor preço.

Se a forma de pagamento e a garantia da liberdade de uso do salário são preocupações de Orozco, o mesmo não se pode dizer do quanto deve ser pago ao trabalhador. Como orientação geral, devem ser elevados os valores dos jornales, mas a "harmonização" dos interesses entre empregadores e empregados (capital e trabalho) deve ser buscada, para que não atrapalhe o que parece ser seu principal objetivo: o progresso industrial do país. Também há entre as normas uma preocupação com a higiene e a salubridade dos alojamentos sob responsabilidade das fábricas - e aqui Orozco pode estar se referindo tanto aos lugares de trabalho como às moradias dos trabalhadores.

Antes de tratar das questões específicas sobre a relação de trabalho, os artigos 32 e 33 do plano de Orozco propõem a nacionalização das linhas férreas mexicanas para reverter o domínio estrangeiro sobre elas. Segundo as normas orozquistas, deveria ser incluída nos orçamentos anuais do governo federal uma rubrica especialmente destinada a comprar ações das empresas que então controlavam as linhas. A norma inclui a proibição de que o governo venda as ações que já possui dessas empresas. Segundo Orozco, para além da importância estratégica da nacionalização das linhas férreas, há ainda uma relação direta com a maior contratação de mexicanos para trabalhar nas empresas ferroviárias. Para tornar possível a substituição dos trabalhadores estrangeiros pelos mexicanos, o plano orozquista prevê a oferta estatal de capacitação técnica. A mesma norma afirma, ainda, que necessariamente os salários de mexicanos e estrangeiros devem ser iguais ${ }^{458}$.

27 Por ninguna causa ni motivo, por imperiosos que sean, se concederán al Ejecutivo facultades extraordinarias para legislar en

\footnotetext{
458 “32 A fin de impedir que el control del Gobierno en los Ferrocarriles Nacionales se menoscabe, el Gobierno no podrá deshacerse, por causa alguna, de las acciones que posee; sino por el contrario, y para acelerar de manera efectiva la completa nacionalización de las líneas, se creará anualmente en el presupuesto de egresos una partida destinada a la compra de mayor número de acciones de dicha empresa. 33 Igualmente, para hacer efectiva la nacionalización del personal de las mismas líneas, el Gobierno cuidará de fomentar el adelanto práctico y técnico del personal mexicano y exigirá de la empresa la más rápida substitución posible de empleados extranjeros por mexicanos, así como que, en igualdad de aptitudes, se paguen a los mexicanos iguales sueldos que a los extranjeros." A íntegra do Plan de la Empacadora, de 25 de março de 1912, escrito por Pascual Orozco, pode ser consultada em CARMONA, Doralicia. Memoria política de México. Guanajuato: Universidade de Guanajuato, 2014: http://www.memoriapoliticademexico.org/Textos/6Revolucion/1912-M-PO.html Consulta realizada em $17 / 12 / 2015$.
} 
ningún ramo de la Administración Pública, excepción hecha del ramo de Guerra, para la movilización y dirección del Ejército y Guardia Nacional en caso de guerra extranjera. ${ }^{459}$

Orozco parece estabelecer uma relação especial com o direito. Na exposição de motivos, afirma que aqueles que lutarem a seu lado terão "o direito como escudo" 460 . Além disso, tema inédito nos textos revolucionários, o artigo 27 do plano impede que o Poder Executivo legisle sobre a administração pública. Necessariamente as leis deverão ser elaboradas pelo Poder Legislativo. Essa convicção orozquista em tudo contraria a afirmação de Venustiano Carranza, no decreto em que convoca o Congresso Constituinte em 1916. Nele, afirma que as reformas constitucionais poderiam ser feitas por ele, sem a necessidade de um Congresso Constituinte para deliberar. Afirma ter tomado a decisão pela convocação apenas para que sua legitimidade não fosse questionada, circunstância que seria ruim para o país, segundo ele.

Apesar de ter alguns aspectos interessantes, o Plan de la Empacadora ficou maculado pela história política posterior de seu autor. Pascual Orozco se insurgiu contra Madero em março de 1912 e protagonizou alguns enfrentamentos com as tropas federais. Quase um ano depois, porém, Orozco firmou uma aliança com Victoriano Huerta no golpe contra Madero, em fevereiro de 1913. Huerta, como brevemente apresentado no primeiro capítulo, foi um militar oportunista, responsável por defender o Presidente em uma insurreição de parte de seu exército. Em meio aos enfrentamentos, traiu Madero que, em decorrência da traição, foi preso e morto.

\footnotetext{
${ }^{459}$ A íntegra do Manifesto redigido por Pascual Orozco em 8 de março de 1912 e a íntegra do Plan de la Empacadora, também de Orozco, de 25 de março de 1912, podem ser consultados em CARMONA, Doralicia. Memoria Política de México. Guanajuato: Universidade de Guanajuato, 2014: http://www.memoriapoliticademexico.org/Textos/6Revolucion/1912-M-PO.html e http://www.memoriapoliticademexico.org/Textos/6Revolucion/1912MPO.html Consulta realizada em $21 / 11 / 2015$.

460 "Y a eso os llamamos; a que de pie muramos por la raza y por la Patria, con el Derecho por escudo, la dignidad por guía, nuestro valor por norma, y nuestra fe en el triunfo como único galardón de nuestro esfuerzo." A íntegra do Plan de la Empacadora, escrito por Pascual Orozco, de 25 de março de 1912 pode ser consultada em CARMONA, Doralicia. Memoria política de México. Guanajuato: Universidade de Guanajuato, 2014: http://www.memoriapoliticademexico.org/Textos/6Revolucion/1912-M-PO.html Consulta realizada em 17/12/2015.
} 


\subsubsection{Reglamento para las Fábricas de Hilados y Tejidos en la República (1912): o primeiro contrato coletivo de trabalho industrial do México}

Francisco Madero assume a Presidência do México em novembro de 1911 e, ainda em dezembro do mesmo ano, uma greve tem início na região das indústrias têxteis de Puebla, Tlaxcala, Veracruz e México. Elas são a continuidade de paralisações que já vinham ocorrendo nos diferentes estados ao longo de 1911. Muito embora o governo de Madero tenha suscitado numerosas críticas em diversos setores da sociedade mexicana, entre elas não figura nenhuma por praticar atos de repressão contra movimentos grevistas nos moldes em que aconteciam durante o governo de Porfírio Díaz. O Departamento del Trabajo, recém-criado em dezembro de 1911, enfrentava seu primeiro grande desafio ao realizar o papel de mediação entre as muitas partes em confronto, já que havia inúmeras fábricas envolvidas. Apesar da mediação e tentativas de conciliação, os conflitos e as paralisações continuaram. Uma solução procedimental, então, foi proposta: ao invés da resolução completa para os conflitos, uma solução provisória seria acordada e, para além dela, seria agendada uma convenção para discutir condições de trabalho e normas que deveriam reger as relações na indústria têxtil. Julho de 1912 foi o mês escolhido para a relização da Convencion de Industriales, como ficou conhecida.

Assim, no dia 2 de julho de 1912, industriais e representantes do Departamento del Trabajo se reuniram na Cidade do México para tentar elaborar um regulamento conjunto e acordado que normatizasse as condutas, direitos e deveres de administradores e empregados da indústria. Os trabalhadores participaram apenas indiretamente das negociações, de modo quediariamente seus representantes organizados recebiam e podiam comentar e sugerir alterações sobre as deliberações tomadas pelos representantes do Departamento del Trabajo e dos industriais. Ao final,cento e quinze fábricas aderiram ao regulamento ${ }^{461}$. Esse documento é

\footnotetext{
461 "Estuvieron representadas en esa Convención ciento quince fábricas, de manera que puede decirse que la mayoría de los fabricantes han hecho el pacto solemne de reducir la jornada de trabajo; elevar los salarios y establecer reglas equitativas para la valorización del trabajo." A íntegra do Informe de Francisco I. Madero, pronunciado frente à XXVI Legislatura para abertura das Sessões Ordinarias, em 16 de setembro de 1913, está disponível em:

http://www.biblioteca.tv/artman2/publish/1912_213/Informe_de_Francisco_I_Madero_pronunciado_ante la 100 printer.shtml Consulta realizada em 18/12/2015.
} 
considerado um marco, por ser o primeiro acordo coletivo de trabalho da história do México $^{462}$.

Ao comprometerem-se com normas que têm validade para várias indústrias, os administradores renunciavam à discricionariedade ilimitada que antes tinham para decidir sobre os procedimentos e normas que deveriam valer em suas fábricas. Quebrase, segundo Bortz, a ideia de que o contrato de trabalho surge a partir de uma negociação de duas individualidades. Com o contrato coletivo, chama-se a atenção para o fato de que as circunstâncias que envolvem as relações de trabalho são sociais e coletivas, tanto na posição dos empregadores quanto na dos empregados.

A critical component of the liberal concept of private property was the idea of work as an individual matter, one of individual choice and responsability. Therefore, the labor contract could only be a matter between two individuals acting voluntarily, an owner offering a job and a worker accepting it. A further assault on the old liberalism and its broad definition of property rights came through replacement of the individual work contract by colective contracts.

In the new labor relation system, the most important role of trade unions was representing workers in their contractual arrengement with owners. ${ }^{463}$

Uma instituição coletiva de representação para os trabalhadores é, segundo Bortz, uma grande novidade nas relações de trabalho. Condições e formas de contratação e demissão, regras, horários e tarefas para postos de trabalho específicos, contratos coletivos anteriores às próprias adesões individuais: ter influência sobre todas essas variáveis é conquista da organização dos trabalhadores em entidades que os representam.

Além disso, no caso do México de 1912, o fato de o local de decisão sobre questões ligadas às relações de trabalho sair da fábrica individual e passar a uma

\footnotetext{
462 "The 1912 reglamento was thus Mexico's first industry-wide collective contract. It contained more protections for laborers than had existed in the past. The formalization of rules somewhat rationalized the situation of workers previously dependent on the opinions of bosses. Prior to the reglamento, bosses prevailed over workers. After reglamento, workers' opinions counted.” BORTZ, Jeffrey L. "The legal and contratual limits to private property rights in mexican industry during the revolution". In BORTZ, Jeffrey; HABER, Stephen. The Mexican economy, 1870-1930: essays on the economic history of institutions, revolution, and growth. Califórnia: Stanford University Press, 2002, p. 277.

${ }^{463}$ BORTZ, Jeffrey L. "The legal and contratual limits to private property rights in mexican industry during the revolution". In BORTZ, Jeffrey; HABER, Stephen. The Mexican economy, 1870-1930: essays on the economic history of institutions, revolution, and growth. Califórnia: Stanford University Press, 2002, p. 273.
} 
instância coletiva, composta por cento e quinze fábricas do mesmo setor, por si só representava uma transformação no modo de organização do cotidiano laboral. Além disso, a decisão diminuía significativamente a possibilidade de que arbitrariedades fossem cometidas pelos adminitradores contra os empregados. Se houvesse um conflito dentro da fábrica, havia, a partir do acordo, uma instância externa a quem recorrer, que funcionaria como árbitro ou mediador relativamente neutro para o conflito.

Obviamente essas garantias formais ainda encontraram resistência, pois eram um primeiro passo em um contexto em que a posição do trabalhador era amplamente desfavorável. E se é verdade que a forma de aprovação deste regulamento partiu da constatação de que os operários poderiam atuar coletivamente, por meio de seus representantes organizados em sindicatos, o texto do documento produzido não refletiu essa conclusão: em seus vinte artigos não havia nenhuma menção ou autorização à existência dos sindicatos ou ao direito de greve. Seja como for, o documento elaborado na convenção de julho e que passou a valer em $1^{\circ}$ de agosto de 1912 se dividia em duas partes: Reglamento e Tarifa.

Embora a definição de que a tarifa mínima de 1,20 peso a ser paga para um trabalhador por dia de trabalho fosse importante, era na primeira parte do documento, chamada Reglamento em que estavam as normas com potencial mais transformador para as relações de trabalho nas fábricas. No Reglamento estipulava-se uma jornada máxima de trabalho de 10 horas diárias (nove para jornadas noturnas) e definia-se que as horas extras trabalhadas receberiam uma remuneração maior. De forma parecida com a solução dada por Porfírio Díaz, os conflitos deveriam ser inicialmente reportados para órgãos internos das fábricas, que necessariamente deveriam responder em um prazo de 10 dias. Empregados e empregadores assumiam também obrigações e deveres de respeito recíproco. Os empregados deveriam, segundo o regulamento, manter-se concentrados no trabalho, preservar o maquinário, chegar ao trabalho e manter-se sóbrio enquanto estiver desempenhando suas funções, não fumar e nem portar materiais inflamáveis nas dependências da fábrica e tratar com respeito a seus superiores. Já os empregadores e chefes de fábrica não poderiam, em nenhuma hipótese, tratar mal, ofender ou violentar seus empregados seja por meio de fala ou ações.

No mesmo regulamento, foram previstos feriados e um dia de descanso semanal; direito à moradia para a família dos trabalhadores nos arredores da fábrica quando estes tivessem de se deslocar em função do emprego; proibição de contratação de crianças 
menores de catorze anos; assistência médica e indenização para aqueles que sofressem acidentes de trabalho; pagamento sempre em dinheiro e, em casos de demissão, necessidade de notificação oito dias antes de efetivada a rescisão contratual. $\mathrm{O}$ artigo $5^{\circ}$ do regulamento previa ainda que, para casos de incapacidade de resolver conflitos diretamente nas instituições da fábrica, seria criado um Tribunal de Arbitragem, de composição mista (paritária), que seria chamado a decidir.

Muito embora o Reglamento tenha sido elaborado em conjunto com o representante da Secretaria de Fomento e membro do Departamento del Trabajo Antonio Ramos Pedrueza, o ordenamento jurídico mexicano não possuía instrumentos para identificar o documento produzido como um verdadeiro contrato coletivo. Assim, embora suas cláusulas representassem de alguma forma o acordo que havia sido firmado, elas não tinham força vinculante para o Poder Judiciário. Sem estruturas estatais que garantissem seu cumprimento, faltava às normas força vinculante, afirma Suarez-Potts $^{464}$.

Mesmo assim, Bortz defende que o processo de reivindiação de melhores condições de trabalho iniciado em dezembro de 1911, com negociação intermediária em janeiro de 1912 e, por fim, o regulamento acordado e publicado em julho de 1912 são marcos institucionais fundamentais na história do direito do trabalho no México ${ }^{465}$.

Bortz, que possui um livro sobre o movimento operário no México de 1910 a 1923 chamado A revolução dentro da revolução (Revolution within the Revolution) ${ }^{466}$, afirma, ainda, que a radicalização do movimento de trabalhadores foi a responsável por esse grupo ter alcançado avanços no Reglamento de 1912. Tais conquistas serão reafirmadas no decreto de Carranza em 1915 e definitivamente incorporadas no ordenamento jurídico mexicano apenas na Constituição de 1917. A explicação do

\footnotetext{
${ }^{464}$ Sobre o significado jurídico do Reglamento, esclarecedora a posição de William Suarez-Potts "On July 17, Ramos Pedrueza completed an industry-wide agreement or convention (reglamento) covering factory working conditions. It was broader and fairer to workers than Díaz's arbitral award of January 1907; still, it lacked the legitimacy of law or a collective contract. No representativee of labor had coauthored directly the agreement's writing; and it wal legally unenforceable without further state action". SUAREZPOTTS, William J. The making of law: the Supreme Court and labor legislation in México, 1875-1931. Stanford: Stanford University Press, 2012, p. 115.

465،"The November 1911 strike, the January 1912 agreement and the July 1912 contract represented significant milestones in Mexican labour history”. BORTZ, Jeffrey. The revolution, the labour regime and conditions of work in the cotton textile industry in Mexico, 1910-1927. Journal of Latin American Studies, Vol. 32, No. 3 (Oct., 2000). Cambridge: Cambridge University Press, 2000, p. 679. Disponível em: http://www.jstor.org/stable/158614 Consulta realizada em 18/12/2015.

${ }^{466}$ BORTZ, Jeffrey. Revolution within the revolution: cotton textile workers and the Mexican labor regime, 1910-1923. Stanford: Stanford University Press, 2008.
} 
caminho percorrido pelo México para chegar ao artigo 123 da Constiuição passa necessariamente, segundo Bortz, pelas greves e mobilizações de 1911 e 1912. Tais movimentações políticas culminaram e tiveram suas reivindicações e avanços corporificados com a edição do Reglamento para las fábricas de hilados y tejidos en la Republica, aprovado pela Convención de Industriales em julho de 1912.

The available evidence indicates that Mexican industrial workers were quite radical, though more in practice than in theory. Rodney Anderson argued that on the eve of revolution, Mexico's industrial workers combined radical goals with traditional methods. During the revolution, the radical goals intensified and the traditional methods radicalised. Textile workers successfully challenged the authority of owners and supervisors at work, murdering bosses, overthrowing factory rules and carrying out strikes to gain control over the workplace. They took advantage of the political anarchy let loose by the revolution to institutionalize their challenge through unions. The combination of institutional and non-institutional challenges to authority in the context of the collapse of national power crushed the old work place hegemony. In this regard, workers compelled, and participated in, the restructuring of the country's labour regime. Workers did not limit their challenge to economic issues, but also included cultural, social and institutional goals. ${ }^{467}$

Inúmeras greves, ocupações de fábricas, mortes de chefes e supervisores autoritários ocorreram até que as condições amplamente exploradoras do trabalho dos mexicanos operários mudasse. Francisco Madero, em seu informe de 16 de setembro de 1912 ao Congresso Mexicano, afirma que teria havido setenta greves desde a criação do Departamento del Trabajo ${ }^{468}$, embora as grandes mobilizações mencionadas neste capítulo (Cananea, Río Blanco e a greve de 1912) tenham se restringido aos setores de mineração e indústria têxtil. Além deles, também os trabalhadores das empresas ferroviárias e destilarias de petróleo eram bastante organizados e realizaram

\footnotetext{
${ }^{467}$ BORTZ, Jeffrey. The revolution, the labour regime and conditions of work in the cotton textile industry in Mexico, 1910-1927. Journal of Latin American Studies, Vol. 32, No. 3 (Oct., 2000). Cambridge: CambridgeUniversity Press, 2000, p. 678. Disponível em: $<$ http://www.jstor.org/stable/158614> Consulta realizada em 18/12/2015.

468 "La labor del Departamento hasta hoy, ha sido de notoria utilidad, pues en el curso de este año ha intervenido con éxito en el arreglo de setenta huelgas que se han efectuado en diversas fábricas, y ha prestado sus buenos oficios en todas las dificultades suscitadas entre obreros y patrones por diferentes motivos y en varias regiones del país, alcanzando buenos resultados con su intervención, porque casi siempre contó con la buena disposición de los industriales.” A íntegra do Informe de Francisco I. Madero, pronunciado frente à XXVI Legislatura para abertura das Sessões Ordinarias, em 16 de setembro de 1913, está disponível em:

http://www.biblioteca.tv/artman2/publish/1912_213/Informe_de_Francisco_I_Madero_pronunciado_ante la 100 printer.shtml Consulta realizada em 18/12/2015.
} 
paralisações e greves no período para demandar melhores condições de trabalho, tomando parte no contexto de época capaz de institucionalizar avanços na legislação garantidora de direitos aos trabalhadores. Segundo Bortz, a ausência de um estado organizado no período revolucionário possibilitou e incentivou que os trabalhadores se organizassem para reivindicar direitos e realizassem os enfrentamentos necessários para essa mudança.

A formulação de Bortz expõe a sua visão sobre a mobilização operária durante o período da Revolução Mexicana: ela teria se beneficiado da revolução, e não feito diretamente parte dela. Estudar o movimento operário entre 1910 e 1917 é, de alguma forma, analisar uma história paralela à história política revolucionária que se desenvolvia no país. Enquanto a questão da terra estava diretamente relacionada com os levantes armados que foram responsáveis pelo fim dos governos de Díaz e Huerta, o movimento operário tinha como foco principal a demanda por melhores condições de trabalho. Saber se o governo de Porfírio Díaz era autoritário ou não, se Francisco Madero estava sendo leal ao prometido no Plan de San Luís Potosí não eram questões que pareciam lhes dizer respeito.

O relativo descolamento entre o movimento operário da segunda década do século XX e a Revolução Mexicana tende a diminuir - mas não acabar - com a criação de uma instância nacional de representação dos trabalhadores, a Casa del Obrero Mundial, em julho de 1912.

\subsubsection{A Casa del Obrero Mundial: apolitismo, sindicalismo e a adesão à Revolução}

Em 13 de junho de 1913, passados apenas quatro meses do golpe sofrido por Francisco Madero e do início do governo autoritário de Victoriano Huerta, os trabalhadores reunidos na Casa del Obrero Mundial (COM) decidem publicar uma declaração para que não tivesse sequência um boato de serem conspiradores contra o governo de Huerta. Afirmam:

La Casa del Obrero no conspira; más aun, no hace ni puede hacer política, porque sus estatutos sindicalistas se lo prohíben. Esta Casa ha profesado siempre la tesis de los actuales directores intelectuales de la campana mundial obrera, que predican la "acción directa" del trabajador contra el capitalista, o sea la lucha apoyada en organizaciones sindicales, que dirigen las huelgas, precisan las 
reclamaciones del proletariado y las sostienen y hacen efectivas en la practica, esgrimiendo como arma la unión inquebrantable de las mayorías trabajadoras contra la codicia y los privilegios de la minoría capitalista.

La acción directa, así entendida, excluye la labor política, pues los sindicalistas no queremos que el obrero se distraiga de su gran objetivo, la lucha de clases, para perder su tiempo, su energía y su fe en mezquinas y siempre ineficaces maniobras políticas. [...] I. La Casa del Obrero Mundial, fiel a sus principios y a sus tradiciones sindicalistas, declara que no hace ni hará política. ${ }^{469}$

A organização operária parece ter clareza sobre os limites de sua organização sindical: não tem por objetivo "fazer política", mas sim promover ações diretas dos trabalhadores contra os capitalistas. Não desejam participar da grande política institucional, mas sim realizar greves, paralisações, boicotes, manifestações. A luta do trabalhador contra seus empregadores é a verdadeira luta contra o capital. Todo governo institucional está, em alguma medida, a serviço dos capitalistas. Por isso, não interessa aos trabalhadores discutí-los ou disputá-los: a única opção é combatê-los, indistintamente. O manifesto vem responder as "acusações" de conspiração feitas após discurso de Isidro Falabela criticando Huerta. Seu discurso fora realizado durante o $1^{\circ}$ de maio de 1913; primeiro feriado do Dia do Trabalho comemorado no México. Ao contrário do movimento camponês mexicano de 1913 - zapatistas e villistas incluídos as lideranças dos operários mexicanos não pareciam diferenciar Porfírio Díaz, Francisco Madero e Victoriano Huerta. Todos faziam parte de uma força social que deveria ser combatida.

A criação do Departamento del Trabajo em 1911 e a mediação nas fábricas têxteis em 1912 não pareceram ser diferentes da violência sofrida em 1906 e 1907 nas greves de Cananea e Río Blanco. Dado que todos representavam "o governo" e "a política", para os trabalhadores de 1913 não parecia haver nenhum motivo para conspirar contra Victoriano Huerta. Ou melhor: fazer política fugia do escopo da organização em que atuavam, supostamente preocupada apenas com a luta de classes.

A Casa del Obrero Mundial (COM) foi uma organização fundada em julho de 1912, inicialmente como um centro de estudos autogerido, um local em que seria

\footnotetext{
${ }^{469}$ A íntegra da declaração de apolitismo, publicada pela Casa del Obrero Mundial em 13 de junho de 1913 pode ser encontrada em CARMONA, Doralicia. Memoria política de México. Guanajuato: Universidade de Guanajuato, 2014: http://www.memoriapoliticademexico.org/Textos/6Revolucion/1913DecP-COM.html Consulta realizada em 20/12/2015.
} 
oferecida formação para os trabalhadores. Seus fundadores partiam da hipótese de que trabalhadores ilustrados organizariam as lutas em suas fábricas de forma mais eficiente e assim estariam mais bem preparados para enfrentar o capital. Em função dessas características iniciais, no ato de criação seus fundadores não elaboraram nem estatutos, nem declarações de princípios ${ }^{470}$. Em 22 de setembro de 1912, dia em que a sede da Casa foi inaugurada, foi divulgado o manifesto do Grupo Anarquista Luz, já inativo mas que tinha alguns de seus ex-membros diretamente envolvidos na fundação e inauguração da COM. É esse manifesto que expressa, segundo os próprios fundadores, os ideais e objetivos defendidos e realizados pela Casa del Obrero Mundial no início de sua organização:

1. Ilustrar a una gente esclavizada e ignorante.

2. Derrocar los tormentos de la humanidad: clero, gobierno y capital.

3. No servir a las ambiciones de charlatanes políticos, porque ningún hombre tiene el derecho de gobernar a otro.

4. Dar a conocer que todos los hombres son iguales porque todos están regidos por las mismas leyes naturales y no arbitrarias.

5. Exigir explicaciones de los ricos opulentos con respecto a sus riquezas, al gobierno con respecto a su autoridad, y a los representantes de dios bandido por sus poderes celestiales.

6. Devastar las instituciones sociales generadas por los torturadores y los holgazanes.

7. Ganar la libertad para el trabajador esclavizado.

8. Utilizar la verdad como la última arma contra la desigualdad.

9. Luchar contra el miedo, el terrible tirano del pueblo.

10. Marchar adelante hacia la redención, hacia la nación universal en donde todos puedan vivir con respecto mutuo, en absoluta libertad, sin paternales figuras políticas nacionales, sin los dioses en el cielo o ricos insolentes. ${ }^{471}$

\footnotetext{
470 “Originada más por las circunstancias que por un propósito ya definido de instituirla, no se elaboraron estatutos, ni declaración de principios. Funcionó simple y sencillamente como centro de divulgación doctrinaria de ideas avanzadas, siendo Jacinto Huitrón su primer administrador y Luís Méndez su primer tesorero". MORALES JIMÉNEZ, Alberto; ESTEVES, José; GIL, Ramón. La Casa del Obrero Mundial. Cidade do México: Ediciones Hormiga Libertária, 2007, p. 143-144.

${ }^{471}$ A íntegra do manifesto do Grupo Anarquista Luz, de 22 de setembro de 1912, pode ser encontrada em CARMONA, Doralicia. Memoria política de México. Guanajuato: Universidade de Guanajuato, 2014: http://www.memoriapoliticademexico.org/Efemerides/9/22091912.html Consulta realizada em 20/12/2015.
} 
Interessante notar que o primeiro objetivo é o de formação. O segundo é a derrubada do clero, do governo e do capital. Coerente com os ideais anarquistas, o manifesto afirma no terceiro item que nenhum homem tem direito de governar outro. Racionalistas, acreditavam que a verdade é a arma contra a desigualdade e daí decorre a aposta na formação intelectual dos trabalhadores, na "ilustração", como defendem no primeiro objetivo. Para além das formações, a Casa del Obrero Mundial incentivava a criação de sindicatos que representassem categorias de trabalhadores, como uma encubadora de organização política operária. Os sindicatos de diferentes setores industriais, por sua vez, aderiam à COM como em uma federação de segmentos, com representação proporcional às categorias representadas.

Como fica evidente no manifesto do Grupo Luz, o movimento operário mexicano teve uma forte influência anarquista. Isso é verdade desde o final do século XIX, quando o movimento surgiu, organizado em sindicatos, e também no Gran Círculo de Obreros de México, fundado em 1872. Apesar terem clareza sobre a diferença entre o mutualismo e o sindicalismo ${ }^{472}$ - e serem filiados ao segundo - havia uma recusa consciente e declarada de tomar parte na política institucional. Essa posição era defendida sobretudo pelos setores anarquistas do Gran Círculo de Obreros de México, que disputavam protagonismo com os autointitulados socialistas. Essa organização chegou a ter oito mil trabalhadores na única década em que foi ativo. No ensaio de participação da vida política nacional esteve a causa da repressão sofrida pelo Gran Círculo e, consequência última, do fim de sua capacidade organizativa do movimento operário. O simples debate sobre se deveriam apoiar ou se opor ao governo de Díaz, levou à perseguição e morte dos líderes contra o governo e ao esvaziamento da entidade, de modo que o movimento de trabalhadores só voltaria a se reorganizar no México no início do século XX.

Foi no século XIX, porém, que a influência anarquista se consolidou. Plotino Rhodakanaty, grego nascido em Atenas em 1828, passou partes de sua vida na Áustria, Alemanha e França e veio ao México em 1861 interessado em obter uma colônia agrícola em terreno oferecido pelo governo mexicano a estrangeiros que fossem se

472 O mutualismo tem como objetivo criar instituições (caixas, bancos) de solidariedade entre os trabalhadores ou populações locais (são forjados outros vínculos de sociedade; não necessariamente o local ou tipo de trabalho) para casos de acidente, viuvez e diversas causas de incapacidade para o trabalho. Seu objetivo principal não é, como nos sindicatos, organização e ação para exigir melhores condições de trabalho e vida garantidas pelos empregadores, mas sim estabelecer cotas de mútuo socorro. Assim, os próprios trabalhadores cedem partes de seus salários para socorrer quem não tem condições temporárias ou permanentes de garantir a própria existência. 
instalar no país, de acordo com a Lei de 1854 (ver seção 2.2.1.7). Na colônia que obteria, desejava construir um falanstério inspirado nas ideias de Charles Fourrier. Em sua estadia francesa, conheceu pessoalmente Pierre-Joseph Proudhon e, nos primeiros anos em que morou no México, publicou a Cartilha socialista, de Fourrier. Intelectual com textos e publicações próprias, foi um dos grandes responsáveis pela difusão mexicana das ideias anarquistas e socialistas. Em texto de lavra própria publicado em 1878, expõe sua desconfiança com qualquer forma de organização governamental:

\section{El Estado es el padrastro del pueblo (1878)}

El poder gubernamental y la libertad democrática no pueden ser compatibles porque toda forma de gobierno positivo tiene que matar necesariamente la idea de la igualdad perfecta.

Los que se dicen liberales y admiten un gobierno, carecen de sentido racional y pertenecen a la raza maldecida de los falsos apóstoles de la democracia.

A esa raza despreciable de los 'políticos', que engañan al pueblo por medio de planes embusteros, que no tienen la dignidad de cumplir cuando encumbran al poder, sino que antes bien se congratulan con la ignorancia y el sufrimiento de las masas, eludiendo las esperanzas de la conciencia pública.

La república no necesita de ese simulacro de tiranía, que se llama gobierno, para desarrollar sus instituciones democráticas, bástale sí, y con ello es suficiente para su organización económica, la administración del municipio libre, soberano y único para el arreglo del mecanismo social. ${ }^{473}$

Rhodakanaty e os autores anarquistas que ele ajudou a difundir - além de Proudhon e Fourrier, Kropotkin e Bakunin - tiveram bastante influência nas organizações do movimento operário mexicano. Defender que aqueles que elaboram planos políticos para serem implementados quando se tornarem governo são charlatães, despreocupados com a realização da liberdade e com a melhora da qualidade de vida da população pobre, desqualifica quase todos os movimentos revolucionários do México no início do século XX. Seja o Partido Liberal Mexicano e seu programa, seja o movimento zapatista e o procedimento estabelecido no Plan de Ayala, os revolucionários mexicanos elaboravam planos e propostas a serem implementadas quando a revolução fosse vitoriosa e eles estivessem no poder.

\footnotetext{
473 RHODAKANATY, Plotino. Obras. Edição, prólogo e notas de Carlos Illades. Cidade do México: Universidade Nacional Autónoma de México, 1988. P. 63.
} 
Para Rhodakanaty - assim como para alguns setores do movimento camponês o município é a unidade básica da democracia. Qualquer instância com pretensões de atuação que estrapolasse as fronteiras municipais tenderia ao autoritarismo. Seja como for, a desconfiança com o governo e com a própria forma de organização política esteve sempre presente entre os líderes operários. Isso explica, talvez, a declaração de 1913 de que a Casa del Obrero Mundial "no hace ni puede hacer política, porque sus estatutos sindicalistas se lo prohíben" e também que a ação direta exclui o trabalho político".

Importante notar que essa declaração é dada em um contexto extremo: o presidente eleito de acordo com as regras democráticas do período, Francisco Madero, sofrera um golpe militar e fora morto, em ação liderada por Victoriano Huerta, que se tornou presidente. A alguns quilômetros de distância da Cidade do México, no Estado de Morelos, na Villa de Ayala, Zapata e os zapatistas - antes fervorosos críticos de Francisco Madero - repudiavam o golpe e enxergavam na atitude de Huerta novas razões para lutar. Também Francisco Villa se insurgiu contra o que se anunciava como um governo ainda mais nefasto para os camponeses do que o de Madero. Carranza, Obregon e outros lutaram contra o ataque à ordem constitucional. O documento da Casa del Obrero Mundial de junho de 1913 deixa claro que o movimento operário não teve a mesma percepção: se todo o governo é ruim, aparentemente não lhes era possível identificar que alguns são piores do que outros.

Um ano e meio mais tarde, porém, em 20 de fevereiro de 1915, a neutralidade política não pareceu mais ser um caminho viável. Entre março de 1913 e julho de 1914 o país foi tomado por conflitos armados contra o governo de Huerta. Em julho, após a renúncia de Huerta, as tensões entre as correntes revolucionárias já estavam claras. Fracassada a tentativa de harmonização de posições na Convenção de Aguascalientes, zapatistas e villistas, por vezes agrupados no que podemos chamar de convencionistas, lutaram contra Carranza, que preservou a alcunha de Exército Constitucionalista. Passados alguns meses de luta entre correntes revolucionárias, a Casa del Obrero Mundial decide tomar posição.

En atención a que los obreros de la Casa del Obrero Mundial se adhieren al Gobierno constitucionalista, encabezado por el ciudadano Venustiano Carranza, se ha acordado hacer constar las cláusulas que normarán las relaciones de dicho gobierno con los obreros y las de éstos con aquél, para determinar la forma en que los obreros han de prestar su colaboración a la causa constitucionalista, los ciudadanos 
Rafael Quintero, Carlos M. Rincón, Rosendo Salazar, Juan Tudó, Salvador Gonzalo García, Rodolfo Aguirre, Roberto Valdez y Celestino Gazca, nombrados en comisión ante el Primer Jefe del Ejército Constitucionalista, Encargado del Poder Ejecutivo, por el Comité Revolucionario de la Ciudad de México, el cual a su vez, representa la Casa del Obrero Mundial, y por el Lic. Rafael Zubarrán, Secretario de Gobernación, en representación del citado Primer Jefe.

$1^{\text {a }}$. El Gobierno constitucionalista reitera su resolución, expresada por decreto de 12 de diciembre del año próximo pasado, de mejorar, por medio de leyes apropiadas, la condición de los trabajadores, expidiendo durante la lucha todas las leyes que sean necesarias para cumplir aquella resolución. ${ }^{474}$

O apoio conferido pela COM é, note-se, ao "gobierno constitucionalista" liderado por Carranza. O manifesto é publicado quase um mês após a publicação do Decreto de Carranza de 29 de janeiro de 1915, analisado na seção 3.4.10, que lista uma série de direitos dos trabalhadores que seriam respeitados caso o governo constitucionalista efetivamente se instalasse no território mexicano. O manifesto afirma também que serão criados os "batallones rojos", partes do exército constitucionalista formados por trabalhadores de certa forma vinculados à COM. O manifesto de fevereiro de 1915 não só declarava apoio a Carranza, rompendo com o princípio da neutralidade política, mas também incentivava os trabalhadores que fossem à luta, organizados em batalhões de operários. Para justificar essa guinada, o texto do manifesto expõe suas razões e procedimentos. Em primeiro lugar, parece ser necessário "suspender la organización gremial sindicalista y entrar en distinta fase de actividad" ${ }^{475}$. Ou seja, a partir do manifesto a COM fica suspensa e tem início outra organização, outra atividade principal. Para manter a coerência, os líderes da COM afirmam que lutar ao lado do exército constitucionalista já não é mais luta sindical.

A decisão por levar os trabalhadores organizados para esse outro lugar de atuação, por sua vez, se justificaria "en vista de la necesidad apremiante de impulsar e intensificar la Revolución que más se acerca en sus ideas a la aspiración unánime de

\footnotetext{
${ }^{474}$ A íntegra do Manifesto da Casa del Obrero Mundial, de 20 de fevereiro de 1915, em apoio ao governo Constitucionalista, disponível em CARMONA, Doralicia. Memoria política de México. Guanajuato: Universidade de Guanajuato, 2014:

http://www.memoriapoliticademexico.org/Textos/6Revolucion/1915MCO.html Consulta realizada em $\frac{20 / 12 / 2015}{475}$

475 . Ibid.
} 
mejoramiento económico y social que ha servido de orientación a las agrupaciones de resistencia contra la opresión del capitalismo" ${ }^{476}$.

Curiosamente, o Manifesto-Pacto entre o Exército Constitucionalista e a Casa del Obrero Mundial é o único documento da COM que respeita a forma jurídica de escrita. Tem início com uma exposição de motivos (os trechos citados nos parágrafos anteriores foram extraídos dessa primeira parte), e passa-se às normas propriamente ditas. Entre as normas, o artigo primeiro diz respeito ao compromisso assumido pelo governo constitucionalista de melhorar a situação do trabalhador por meio de leis. Interessante notar a transformação ideológica que permitiu que os líderes da COM passassem de uma postura cética e desconfiada de qualquer forma de governo para a aposta e crença na possibilidade de transformação das suas condições de trabalho por meio de leis. Seja como for, o artigo $1^{\circ}$ vincula o governo constitucionalista com a efetivação e a proteção legal dos direitos dos trabalhadores.

Com exceção do artigo $1^{\circ}$ e do artigo $3^{\circ}$, em que o governo constitucionalista se compromete a atender as "justas reclamaciones de los obreros en los conflictos que puedan suscitarse entre ellos y los patrones" 477 , a maioria das normas da parte dispositiva do documento tem por objetivo organizar os operários para a luta.

Assim, o artigo $2^{\circ}$ afirma que os trabalhadores pegarão em armas para colaborar com o triunfo da Revolução. Organização de listas com nomes de trabalhadores de cada cidade que estavam dispostos a lutar é o objeto do artigo $5^{\circ}$; submissão à hierarquia do exército constitucionalista, o do art. $4^{\text {o}}$; propaganda em favor da revolução constitucionalista, para aumentar a simpatia dos outros trabalhadores e da população em geral, do art. $6^{\circ}$; organização em comitês revolucionários, do art. $7^{\circ}$; e a denominação de "rojos" para os batalhões de trabalhadores consta do art. $8^{\circ}$.

O documento foi firmado por Rafael Zubarán Capmany, que seria o responsável por elaborar um projeto de lei em abril de 1915, com uma proposta de regulação das relações de trabalho. A partir do pacto, batalhões vermelhos foram criados e trabalhadores colaboraram para a vitória definitiva do Exército Constitucionalista no México de 1915 e a consolidação do governo de Venustiano Carranza.

\footnotetext{
${ }^{476}$ A íntegra do Manifesto da Casa del Obrero Mundial, de 20 de fevereiro de 1915, em apoio ao governo Constitucionalista, disponível em CARMONA, Doralicia. Memoria política de México. Guanajuato: Universidade de Guanajuato, 2014:

http://www.memoriapoliticademexico.org/Textos/6Revolucion/1915MCO.html Consulta realizada em 20/12/2015

477 Ibid.
} 
Em outubro de 1915, seis meses depois da declaração de apoio ao Exército Constitucionalista, a COM publica mais um documento, dizendo que, mesmo durante sua atuação como braço do exército, estimulou a criação de sindicatos nos confins da República. Segundo o manifesto, no período de luta armada em "Yucatán, Campeche, Tabasco, Chiapas, Tehuantepec, Veracruz, Tamaulipas, Querétaro, Jalisco, Hidalgo, Colima, Nuevo León, Michoacán, etc., se han fundado sindicatos y se han organizado miles de trabajadores " ${ }^{, 478}$. Segundo o documento, a organização dos trabalhadores e o estímulo à criação de sindicatos foram atividades que a Casa del Obrero Mundial não abandonou.

O mesmo documento afirma que "para tener derechos es precise conquistarlos", que a luta armada estava prestes a terminar e que, depois de seu fim, os trabalhadores colheriam os frutos por terem lutado. Infelizmente eles não poderiam estar mais errados. Praticamente encerrados os conflitos, tendo outros Estados nacionais reconhecido Carranza como governo de fato do México, o bem-estar esperado pelos trabalhadores não se efetivou. Baixos salários e péssimas condições de trabalho, como existiam antes, se somaram ao aumento do custo de vida: os alimentos que deixaram de ser produzidos e foram destruídos em função dos conflitos armados ficaram mais caros. Dado esse contexto, em 30 de julho de 1916, os trabalhadores - organizados em sindicatos e também na Casa del Obrero Mundial - convocaram uma greve geral. A adesão de trabalhadores de empresas responsáveis por serviços públicos como transporte e energia elétrica na Cidade do México foi o estopim para que Carranza publicasse, em $1^{\circ}$ de agosto, um decreto que supostamente puniria com pena de morte qualquer apoio à greve.

Muitos líderes grevistas foram presos, nenhum condenado à morte, mas a ameaça de Carranza foi suficiente para desmobilizar o movimento grevista, sem que sequer tivesse se iniciado a fase de negociação, discussão das reivindicações e apresentação de propostas dos empresários. Carranza já tinha indicado, meses antes, em 3 de fevereiro de 1916, que não estaria satisfeito com a organização e atuação dos trabalhadores. "Prejudicar a consolidação da ordem"479 era a principal razão alegada

\footnotetext{
478 A íntegra do Manifesto da Casa del Obrero Mundial, de 5 de outubro de 1915, em CARMONA, Doralicia. Memoria política de México. Guanajuato: Universidade de Guanajuato, 2014: <http://www.memoriapoliticademexico.org/Textos/6Revolucion/1915Reint-COM.html> Consulta realizada em 20/12/2015.

${ }^{479}$ Discurso de Venustiano Carranza em 3 de fevereiro de 1916: "El gobierno emanado de la revolución ha estimado al obrero y le ha prestado todo su apoyo en sus demandas justas; pero entre ese elemento del
} 
por Carranza para ser contra os movimentos grevistas. Ele não parecia constrangido em coibir uma greve de maneira violenta quando, um ano e meio antes havia buscado apoio entre os membros de Casa del Obrero Mundial para a luta constitucionalista.

Em fevereiro de 1915, a prática e os discursos dos trabalhadores organizados deixava clara sua opção pela forma de atuação a que chamavam de ação direta, ou seja: enfrentamento dos empresários e donos de fábrica por greves, paralisações, boicotes e similares. A aliança em 1915 e a extrema repressão de Carranza em 1916 indicavam uma virada política incoerente e, em alguma medida, desleal com aqueles que o haviam apoiado. O governo de Carranza reprimiu os grevistas de julho e agosto de 1916. E, com a repressão e a prisão de líderes, impediu o movimento operário de participar da vida política do México por mais alguns anos. Apenas em 1918 surge uma nova organização nacional de trabalhadores: a Confederación Regional Obrera Mexicana. A organização do sindicalismo anarquista nacional ficou, por alguns anos, restrita a seus âmbitos locais ou setoriais.

\subsubsection{Regulação das relações de trabalho nos diferentes estados mexicanos: a revolução faz suas regras}

Apesar de a organização nacional dos trabalhadores ter sido desarticulada por meio da ação violenta de Carranza, a Casa del Obrero Mundial deixou como legado para o México uma série de sindicatos e organizações operárias espalhadas por diferentes estados, em diferentes setores produtivos. Essas organizações descentralizadas foram responsáveis por inúmeros momentos de confrontos e reivindicação de direitos. Assim, o fim da Casa del Obrero Mundial não signifcou de maneira alguma o fim do movimento operário mexicano.

No México, os primeiros documentos normativos que protegeram direitos dos trabalhadores não foram nacionais, mas sim estaduais. Quer por meio de decretos de governadores; quer por líderes militares que exercíam de fato o poder na região, normas

trabajo llamado a la prosperidad, se han introducido, deslizándose a manera de serpiente venenosa, algunos arteros y ruines agitadores que, indignos de todo miramiento, introducen la cizaña bajo el falaz pretexto de trabajar por el mejoramiento obrero y fomentan huelgas disolviendo la unidad del trabajo y perjudicando la consolidación del orden.” Em CARMONA, Doralicia. Memoria política de México. Guanajuato: Universidade de Guanajuato, 2014.

<http://www.memoriapoliticademexico.org/Efemerides/9/22091912.html > Consulta realizada em $21 / 12 / 2015$. 
estaduais foram criadas com o objetivo de regular juridicamente as relações de trabalho em seus territórios. Nesta seção são apresentados alguns desses documentos normativos $^{480}$.

Em 30 de abril de 1904, no Estado do México (onde está o Distrito Federal ou Cidade do México, capital do país), o governador José Vicente Villada aprovou lei que ampliava a responsabilidade civil dos patrões por acidentes de trabalho. $\mathrm{O}$ artigo $3^{\circ}$ dispunha então:

Cuando un motivo de trabajo se encargue a los trabajadores asalariados o que disfruten del sueldo a que se hace referencia en el articulo anterior y en el 1787 del código civil, sufran éstos algún accidente, que les cause muerte o una lesión o enfermedad que les impida trabaja, la empresa o negociación que reciba sus servicios estará obligada a pagar, sin perjuicio del salario que debiera devengar por causa de trabajo. Los gastos que origine y los gastos de la inhumación en su caso ministrado. Además a la familia que dependa del fallecido; de un auxilio igual al importe de 15 días; del salario o sueldo que devengaba. ${ }^{481}$

Uma mudança em um dos artigos do Código Civil do Estado do México foi o responsável pela alteração das hipóteses de responsabilidade dos empregadores frente a trabalhadores acidentados. Garantia de indenização dos custos decorrentes do tratamento médico derivado do acidente, o salário devido no período em que o trabalhador ficou impedido de trabalhar, quinze dias de salário para a família que perder um membro em virtude de acidente de trabalho: a responsabilidade dos empregadores não era muito grande, mesmo quando consideradas hipóteses graves como a morte. Frente à prática de absoluta desresponsabilização vigente, porém, era um avanço. Mais

\footnotetext{
${ }^{480}$ Não se pretende que a listagem apresentada nesta seção seja exaustiva de todas as legislações estaduais sobre relações de trabalho existentes. A metodologia para identificar quais normas deveriam ser objeto de análise foi percorrer obras que têm por objeto o desenvolvimento histórico da legislação trabalhista mexicana. A partir das referências feitas às legislações estaduais anteriores à 1917, construiu-se o corpus desta seção. Obras consultadas: HERZOG, Jesus. Breve historia de la Revolución Mexicana: la etapa constitucionalista y la lucha de facciones. $14^{\mathrm{a}}$ reimp. Cidade do México: Fondo de Cultura Económica do México, 1995. GARCIA CANTÚ, Gastón. El pensamiento de la reacción mexicana. Historia documental tomo II (1860-1926). Cidade do México: Universidad Autónoma de México, 1994, p. 272. BUEN LOZANO, Nestor de . "El nacimiento del derecho del trabajo". In BUEN LOZANO, Nestor de; MORGADO VALENZUELA, Emilio (org). Instituciones de derecho del trabajo y de la seguridad social. Cidade do México: Instituto de Investigaciones Jurídicas, 1997, p. 38. NAIME, Alexander. La evolucion de la administracion publica del trabajo en el Estado de Mexico. Toluca: Secretaría del Trabajo, 1983,p. 26. ROJAS SANDOVAL, Javier. Apuntes para la historia de la reglamentacion de las relaciones laborales en Nuevo Leon. Nuevo León: Cuarto Congreso Nacional de Estudios del Trabajo, Universidad Autónoma de Nuevo León, 2003.

${ }^{481}$ CUEVA, Mario de la. El nuevo derecho mexicano del trabajo. Tomo I. Cidade do México: Editorial Porrúa, 1999, p.46-47. Apud ROJAS SANDOVAL, Javier. Apuntes para la historia de la reglamentacion de las relaciones laborales en Nuevo León. Nuevo León: Cuarto Congreso Nacional de Estudios del Trabajo, Universidad Autónoma de Nuevo León, 2003, p. 6.
} 
importante que isso, a alteração no Código Civil do Estado do México de 1904 determinava que, sempre que ocorresse um acidente em ambiente laboral, estaria presumido que ele decorreu do trabalho realizado. Essa previsão tinha inspiração em uma lei belga de reparação dos danos, sancionada por Leopoldo II em 24 de dezembro de $1903^{482}$. Para afastar a presunção de responsabilidade - que se aproxima da responsabilidade objetiva contemporânea - os empregadores têm de provar que o acidente não foi causado pelo trabalho, mas sim por alguma imprudência, imperícia do trabalhador ou outras causas de natureza semelhante a essas. O ônus da prova é do empregador, de acordo com as normas de 1904.

Em 1906, no Estado de Nuevo León, o governador Bernardo Reyes também aprovou uma lei que previa indenizações por acidentes de trabalho para trabalhadores de seu Estado. Bernardo Reyes foi figura importante na política nacional mexicana, já que era bastante próximo de Porfírio Díaz e foi cotado para concorrer como vice-presidente em sua chapa. Além disso, participou da Decena Trágica, golpe militar contra Francisco Madero, tendo morrido no confronto com as tropas leais a Madero, em 1913.

Sua Ley sobre Accidentes de Trabajo del Estado de Nuevo León, de 1906, definia o conceito de acidente como "el acontecimiento funesto que proviene de la acción repentina de una causa violenta, fortuita y exterior." ${ }^{483}$ Ação repentina, causa violenta, fortuita e exterior são os adjetivos usados para caracterizar esse sinistro. Notese que não estão incluídas na definição nenhuma doença ou enfermidade decorrente do ambiente ou das condições de trabalho permanentes e cotidianas. Apenas ocorrendo um evento algo imprevisível e repentino estaria configurada a condição prévia para as indenizações de que trata a lei. Ao contrário da legislação do Estado do México, no Estado de Nuevo León o ônus da prova era do trabalhador. Em um conflito, era ele quem deveria provar que a situação não se enquadrava em nenhuma das três hipóteses presentes no artigo primeiro da lei:

art. $1^{\circ}$ El propietario de cada empresa de los que se enumeran en esta ley, será responsable civilmente de los accidentes que ocurran a sus empleados y operarios en el desempeño de su trabajo o con ocasión de ésta. Sin dar origen a responsabilidad civil del patrón los accidentes que se deban a alguna de estas causas:

\footnotetext{
${ }^{482}$ NAIME, Alexander. La evolucion de la administracion publica del trabajo en el Estado de Mexico. Toluca: Secretaría del Trabajo, 1983, p. 41.

483 ROJAS SANDOVAL, Javier. Apuntes para la historia de la reglamentacion de las relaciones laborales en Nuevo León. Nuevo León: Cuarto Congreso Nacional de Estudios del Trabajo, Universidad Autónoma de Nuevo León, 2003, p. 10.
} 
I.- Fuerza mayor extraña a la industria de que se trata.

II.- Negligencia inexcusable o culpa grave de la víctima.

III.- Intento del empleado u operario de causar el daño. ${ }^{484}$

Negligência inescusável da vítima era motivo que levaria à exclusão de responsabilidade dos patrões em casos de acidente de trabalho nos ambientes laborais. Também a força maior (eventos climáticos, externos, sem responsabilidade direta daqueles que dirigem a fábrica) e a intenção deliberada de causar o dano são excludentes de responsabilidade para os empregadores. Essas três hipóteses de exclusão foram incluídas, muito embora na exposição de motivos e debates do Projeto de Lei de Bernardo Reyes houvesse uma longa análise sobre "el riesgo inherente a una profesión o trabajo determinados (...) independientemente de la falta del patrón o del obrero" ${ }^{485}$. Do ponto de vista teórico, o projeto de lei defendia que os riscos de ocorrerem acidentes no ambiente de trabalho - e suas respectivas indenizações - deveriam estar previstos e ser incluídos entre os custos de produção daqueles que são responsáveis por empreendimentos econômicos. Assim, se não houvesse ninguém a ser responsabilizado, a empresa deveria assumir os ônus econômicos do acidente. O problema é que no próprio projeto de lei foram incluídas três exceções, sujeitas a interpretações extensivas.

\footnotetext{
${ }^{484}$ CUEVA, Mario de la. El nuevo derecho mexicano del trabajo. Tomo I. Cidade do México: Editorial Porrúa, 1999, p.48. Apud ROJAS SANDOVAL, Javier. Apuntes para la historia de la reglamentacion de las relaciones laborales en Nuevo Leon. Cuarto Congreso Nacional de Estudios del Trabajo. Nuevo León: Universidad Autónoma de Nuevo León, 2003,.p. 10.

${ }^{485}$ Sandoval realiza uma análise sobre os debates acerca da necessidade de indenização independente de culpa ou responsabilidade dos empregadores que estavam presentes na exposição de motivos da lei de 1906: “Al decir de los autores de la iniciativa de la Ley sobre Accidentes de Trabajo del Estado de Nuevo León de 1906, en la formulación teórica para la reglamentación de los accidentes de trabajo concurrieron dos criterios: el jurídico y el de la economía política. Este último establecía que todo industrial así como estaba obligado a crear fondos para hacerle frente a los gastos de mantenimiento del inventario de las construcciones y la maquinaria, es decir el capital muerto, de la misma manera debía considerar la necesidad de crear reservas para compensar el factor humano de la industria, afectado por los accidentes que pudiera ocurrirle. (...) En el considerando tercero de la iniciativa de ley se establecía que el grado de riesgo y peligrosidad que afectaban a los trabajadores era producto de las condiciones creadas por el desarrollo de la industria: las nuevas formas de energía empleadas como el vapor, la electricidad, la maquinaria, que hacían de la fábrica y el taller espacios peligrosos; al mismo tiempo por la mayor exigencia de los rápidos procesos de producción mecanizados que terminaban por afectar la habilidad del trabajador para tomar las precauciones necesarias. La conclusión de todo ello era que ni el patrón ni el trabajador podían ser responsables por las nuevas condiciones laborales y su grado de riesgo. El centro principal de los legisladores que debatieron la Ley sobre Accidentes de Trabajo, fue la teoría del 'riesgo profesional'. Los diputados neoleoneses lo definían como '...el riesgo inherente a una profesión o trabajo determinados...independientemente de la falta del patrón o del obrero.' ROJAS SANDOVAL, Javier. Apuntes para la historia de la reglamentacion de las relaciones laborales en Nuevo León. Cuarto Congreso Nacional de Estudios del Trabajo. Nuevo Léon: Universidad Autónoma de Nuevo León, 2003, p. 7.
} 
Duas delas diziam respeito à intencionalidade ou negligência da vítima e a terceira projetava a causa a algum elemento externo à lógica da produção.

Essas razões eram motivo frequente de exclusão de responsabilidade. A Ley sobre Accidentes de Trabajo del Estado de Nuevo León, aparentemente protetiva porque, de forma mais ampla do que sua equivalente de 1904, estabelecia indenizações que poderiam se estender por até 18 meses, dificultava o acesso à compensação econômica para o acidente. Para que o trabalhador recebesse de fato o auxílio, teria que percorrer um calvário que passava inclusive por ações judiciais. Assim, o artigo 17 da lei de 1906 estabelece que o juiz competente para julgar disputas relacionadas às indenizações por acidentes de trabalho era o "Juez de Letras de la Fracción Judicial correspondiente". Também nesse ponto o procedimento para ter o direito à indenização garantido é mais fácil na legislação do Estado do México. Na mudança ao Código Civil estadual de 1904, estabelece-se que "las contiendas laborales serían tramitadas en la vía sumaria por la autoridad judicial" ${ }^{486}$. O procedimento sumário e o ônus da prova sob a responsabilidade do empregador diminuíam significativamente a possibilidade de a indenização não ser concedida por questões formais, o que não exclui a lealdade de classe entre juízes.

Em 1908, Bernardo Reys promoveu mais uma alteração legislativa com o objetivo de aumentar a proteção legal dos trabalhadores em Nuevo León: incluiu no Código Penal do Estado a pena de fraude contra empregadores que deixassem de pagar o salário de seus empregados. Essa penalização, porém, só era aplicável aos representantes de sociedades anônimas, seus sócios ou gerentes, em caso de admistração fraudulenta ou perdulária.

A essas três regulamentações pré-revolucionárias outras vieram se somar. Desde 1914, líderes militares instituíram novas regulamentações trabalhistas nos estados em que venceram batalhas e tomaram o controle do governo, ainda que esse controle fosse precário e fundado em vitórias militares. "General del Ejército Constitucionalista"487;

\footnotetext{
${ }^{486}$ NAIME, Alexander. La Evolucion de la Administracion Publica del Trabajo en el Estado de Mexico. Toluca: Secretaría del Trabajo, 1983. P. 26.

487 É assim que se apresenta Pablo González, dos Estados de Puebla e Tlaxcala, em documento que decreta a abolição de todas as dívidas dos trabalhadores, em 3 de setembro de 1914.A íntegra do decreto em CARMONA, Doralicia. Memoria política de México. Guanajuato: Universidade de Guanajuato, 2014: $<\quad$ http://www.memoriapoliticademexico.org/Textos/6Revolucion/1914-DADP-PG.html> Consulta realizada em 22/12/2015.
} 
"Gobernador constitucionalista y Comandante Militar" $" 488$ eram duas das expressões que os caudilhos utilizavam para afirmar sua legitimidade em editar normas que valeriam nos estados controlados (ou governados) por eles em documentos que criam direitos para trabalhadores. Assim, é inequívoca a associação entre os líderes militares e a vitória revolucionária - e a criação da normatividade que regula as relações de trabalho.

A primeira delas, de 7 de maio de 1914, de autoria do comandante militar Antonio I. Villarreal, curiosamente também é do Estado de Nuevo León, que já possuía decretos pré-revolucionários sobre acidentes de trabalho e previa penas severas para os empregadores que deixassem de pagar os salários de seus empregados. $\mathrm{O}$ artigo $1^{\circ}$ do curto decreto dispõe "1) Queda estrictamente prohibido exigir trabajos personales en compensación de deudas" ${ }^{\sharp 89}$. Os outros três artigos são derivados da proibição de vincular o trabalho a dívidas. $\mathrm{O}$ artigo $2^{\circ}$ prevê castigos severos, embora não especifique quais; o $3^{\circ}$ impõe que os patrões deem publicidade ao decreto, fixandoo em lugar visível e, por fim, o $4^{\circ}$ artigo afirma que existiriam inspetores para verificar o cumprimento das normas anteriores.

Alberto Fuentes, comandante militar, também foi um dos primeiros líderes revolucionários a formular normas de proteção ao trabalhador. No Decreto 23 de agosto de 1914, no Estado de Aguascalientes institui, por meio dos artigos $1^{\circ}$ e $2^{\circ}$, ser obrigatório um dia de descanso semanal. O primeiro artigo se preocupa inclusive em garantir "que el día consta de veinte y cuatro horas." $"$, para impedir que mudanças de turno diminuam o direito que quer estabelecer. $\mathrm{O}$ artigo $3^{\circ}$ estabelece nove horas como jornada de trabalho máxima diária, e o art. $4^{\circ}$ impõe que essas quatro horas não sejam consecutivas. O decreto afirma que fábricas que têm de trabalhar ininterruptamente devem contratar empregados em número suficiente para que suas normas não sejam violadas. Inclui explicitamente em sua proteção os trabalhadores que oferecem serviços

\footnotetext{
${ }^{488}$ É assim que se apresenta Alberto Fuentes, do Estado de Aguascalientes, em decreto sobre jornada de trabalho e descansos semanais obrigatórios, de 23 de agosto de 1914. A íntegra do decreto em CARMONA, Doralicia. Memoria política de México. Guanajuato: Universidade de Guanajuato, 2014: $<$ http://www.memoriapoliticademexico.org/Textos/6Revolucion/1914-DDS-AF.html > Consulta realizada em 22/12/2015.

489 ROJAS SANDOVAL, Javier. Apuntes para la historia de la reglamentacion de las relaciones laborales en Nuevo León. Cuarto Congreso Nacional de Estudios del Trabajo. Nuevo León: Universidad Autónoma de Nuevo León, 2003,.p. 27.

${ }^{490}$ A íntegra do decreto de Alberto Fuentes, Estado de Aguascalientes, em 23 de agosto de 1914 em CARMONA, Doralicia. Memoria política de México. Guanajuato: Universidade de Guanajuato, 2014: <http://www.memoriapoliticademexico.org/Textos/6Revolucion/1914-DDS-AF.html > Consulta realizada em 22/12/2015.
} 
domésticos. Exclui, no entanto, cocheiros e vendedores ambulates. O último artigo do decreto estabelece que " $7^{\circ}$ La limitación del trabajo no será en ningún caso objeto de disminución de salario." ${ }^{491}$.

\section{No Estado de Jalisco, em 2 de setembro de 1914, o general Manuél Dieguez} expede um decreto estipulando um salário mínimo de setenta e cinco centavos e a obrigatoriedade de descanso dominical ${ }^{492}$. Um dia mais tarde, Pablo González, chefe do exército constitucionalista "noreste", publica o Decreto de 3 de setembro de 1914, válido para os Estados de Puebla e Tlaxcala. Seu principal objetivo é abolir as dívidas e a servidão por dívidas de todos os trabalhadores, rurais e urbanos. Curto o decreto, seu terceiro e último artigo estabelece uma multa alta para casos de descumprimento: “ 3 '. El que contravenga esta disposición, exigiendo deudas pasadas a las clases menesterosas, sufrirá una pena de $\$ 100.00$ a $\$ 5,000.00 ” .493$

"Eulalio Gutiérrez, general de Brigada del Ejército Constitucionalista, Gobernador y Comandante Militar del Estado de San Luís Potosî”, decreta em 15 de setembro de 1914, uma "Ley sobre sueldos dos peones" $"$ " Logo em seu primeiro artigo impõe a jornada máxima de nove horas e o pagamento mínimo de setenta e cinco centavos de peso. O Estado de San Luís Potosí possui riquezas minerais e, como consequência, concentra empresas mineradoras. A legislação proposta por Eulálio Gutiérrez é a primeira a levar em conta a especificidade do trabalho em minas para estabelecer diferenças: “En las minas el salario mínimo será de \$1.25 (un peso veinte y cinco centavos) diarios." $" 495$. Antecedente do contemporâneo "adicional por insalubridade", o valor maior de salário compensaria as condições cotidianas pouco saudáveis. Também no decreto estão: proibição de diminuição dos salários, caso se praticassem valores mais altos (art. $1^{\circ}$ ); proibição de realizar descontos de valores em

\footnotetext{
491 A íntegra do decreto de Alberto Fuentes, Estado de Aguascalientes, em 23 de agosto de 1914 em CARMONA, Doralicia. Memoria política de México. Guanajuato: Universidade de Guanajuato, 2014: <http://www.memoriapoliticademexico.org/Textos/6Revolucion/1914-DDS-AF.html > Consulta realizada em 22/12/2015.

492 CÓRDOVA, Arnaldo. La ideología de la Revolución Mexicana: la formación del nuevo régimen. $8^{\mathrm{a}}$ edição. Cidade do México: Ediciones Era, 1980, p. 173.

493 A íntegra do decreto de Pablo González, para os Estados de Puebla e Tlaxcala, em 3 de setembro de 1914 em CARMONA, Doralicia. Memoria política de México. Guanajuato: Universidade de Guanajuato, 2014: < http://www.memoriapoliticademexico.org/Textos/6Revolucion/1914-DADP-PG.html > Consulta realizada em 22/12/2015.

${ }^{494}$ A íntegra do decreto de Eulálio Gutierrez, Ley sobre sueldos dos peones, de 15 de setembro de 1914, para San Luís Potosí em CARMONA, Doralicia. Memoria política de México. Guanajuato: Universidade de Guanajuato, 2014: <http://www.memoriapoliticademexico.org/Textos/6Revolucion/19140915-DecEG-

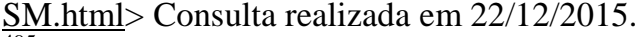
495 Ibid.
} 
função de consumo de água e lenha nas casas oferecidas pelas empresas - moradias essas que teriam de apresentar as melhores condições de higiene e conforto $\left(\operatorname{art} .2^{\circ}\right.$ ); pagamento semanal, em dinheiro (art. $3^{\circ}$ ); proibição de tiendas de raya (art. $4^{\circ}$ ); possibilidade de ter algumas cabeças de gado sem pagar valores adicionais pelo pasto que utilizarem (art. $5^{\circ}$ ) e, em caso de cessão de terras para plantio, o pagamento não poderá ultrapassar $25 \%$ da colheita (art. 10 $)$; prescrição de dívidas anteriores em 31 de dezembro de 1914 (art. 6º); proibição a quaisquer limites à liberdade de ir e vir dos empregados $\left(\operatorname{art} .7^{\circ}\right)$.

Os artigos seguintes tratam de proibições relacionadas à retenção dos salários devidos e a limites nos descontos que podem ser feitos em função de adiantamentos anteriores. Por fim, o art. 12 cria um Departamento del Trabajo no Estado de San Luís Potosí, responsável por zelar pelo cumprimento da lei, além de ser possível instância de resolução de conflitos. No primeiro artigo transitório, uma cláusula impede que os trabalhadores renunciem os direitos que a lei lhes confere. $\mathrm{O}$ artigo $4^{\circ}$ das normas transitórias autoriza que as autoridades estatais imponham multas para os casos de descumprimento de suas regras. Os movimentos de trabalhadores da mineração e suas reivindicações constantes por melhores condições de trabalho foram co-responsáveis pelo detalhamento normativo desse decreto.

Luis F. Domínguez, que também se apresenta como "Gobernador Militar", em Decreto de 19 de setembro de 1914 para o Estado de Tabasco, extingue as dívidas dos trabalhadores do campo e declara estar abolido o regime de servidão por dívidas $\left(\right.$ arts. $1^{\circ}$ e $2^{\circ}$ ) e afirma que qualquer trabalhador nessas condições que que se estabeleça no território de Tabasco será libertado (art. $3^{\circ}$ ). No artigo $4^{\circ}$ estabelece setenta e cinco centavos de peso como valor diário mínimo a ser pago aos trabalhadores que recebam algum benefício (moradia, alimentação) de suas fazendas empregadoras. Para aqueles sem qualquer benefício, dispõe que o valor mínimo deve ser de um peso. No art. $6^{\circ}$ estabelece oito horas como jornada máxima e, no artigo $7^{\circ}$, a multa de cem pesos para fazendeiros que descumprirem as regras. Surpreendente, o art. $8^{\circ}$ estabelece "Toda persona que denuncie las infracciones anteriores tendrá un treinta por ciento sobre el importe de las multas." ${ }^{496}$. Esta é a única legislação do período que oferece um prêmio para aqueles cidadãos que colaborarem com o cumprimento e a fiscalização das normas

\footnotetext{
${ }^{496}$ A íntegra do decreto de Luis F. Domiguez para o Estado de Tabasco, de 19 de setembro de 1914, em: CONTRERAS, Mario; TAMAYO, Jesus. México en el siglo XX 1913-1920. Textos y documentos, Tomo II. Cidade do México: Universidad Autónoma de México, 1989, p. 178.
} 
estabelecidas. Além da fiscalização pelos cidadãos, o decreto prevê também a existência de inspetores $\left(\operatorname{art} .9^{\circ}\right)$. Por fim, o decreto estabelece que "12 Todo hacendado o propietario que azote a los peones o les imponga cualquier otro castigo corporal sufrirá una pena de uno a seis meses de prisión inconmutables." ${ }^{497}$. Também novidade na regulação de Tabasco, a proibição - punida com pena restritiva de liberdade em caso de descumprimento - de castigos físicos, açoites aos trabalhadores.

O Governador provisório Coronel Perez Romero decretou, em 4 de outubro de 1914 para o Estado de Veracruz, a obrigatoriedade do descanso dominical, e impôs multa de duzentos pesos ao mês em caso de descumprimento ${ }^{498}$. Dois dias depois, em 6 de outubro de 1914, o governador interino também do Estado de Veracruz expede um decreto em que reconhece e autoriza as associações de trabalhadores e os sindicatos. É a primeira norma a reconhecer este tipo de organização no país ${ }^{499}$. Em uma profusão de normas praticamente simultâneas no mesmo Estado, um decreto de 19 de outubro de 1914 do general Cândido Aguilar que introduz, em seu artigo 12, as "Juntas de Administración Civil". Essa instituição era responsável por ouvir "las quejas de patrones y obreros y dirimirán las diferencias que entre ellos se susciten, oyendo a los representantes de gremios y sociedades y en casos necesarios al correspondiente inspector del gobierno" 500 e sua criação em Veracruz teve influência nos debates constituintes sobre a regulação das relações de trabalho.

\section{Em 28 de outubro de 1914, no Estado de Michoacán, o general Gertrudis}

Sánchez estabelecia o valor mínimo de setenta e cinco centavos de peso como pagamento de um dia de trabalho de nove horas para trabalhadores do campo. Tinha por objetivo melhorar "la situación precaria de los peones de campo y demás trabajadores rurales cuyos emolumentos no satisfacen [...], las más urgentes necesidades"501.

\footnotetext{
497 Ibid.

${ }^{498}$ GONZÁLEZ SIERRA, José. Revolución y derecho obrero: Veracruz 1914 - 1916. In Anuário IV. Jalapa: Centro de Investigaciones Historicas Universidad Veracruzeana, 1986. p. 124.

499 BUEN LOZANO, Nestor de. "El nacimiento del derecho del trabajo". In BUEN LOZANO, Nestor de; MORGADO VALENZUELA, Emilio (org). Instituciones de derecho del trabajo y de la seguridad social. Cidade do México: Instituto de Investigaciones Jurídicas, 1997, p. 38.

500 PUIG HERNÁNDEZ, Carlos Alberto. “¿Juntas o tribunales de trabajo?”. In KURCZYN, Patricia Villalobos (Coord.). ¿Hacia un nuevo derecho del trabajo?. Cidade do México: Instituto de Investigaciones Jurídicas de la Universidad Nacional Autónoma de México, 2003, p. 108.

${ }^{501}$ OCHOA SERRANO, Álvaro. "Revolución y liderazgo en Atacheo". In PAREDES, Carlos; TERÁN, Marta (coord.). Autoridad y gobierno indígena en Michoacán: ensayos a través de su Historia. Volume II. Michoacán: Instituto Nacional de Antropología y História de la Universidad Michoacana de San Nicolás de Hidalgo, 2003, p. 491.
} 


\title{
Em 11 de dezembro de 1915, Salvador Alvarado publica seu decreto $\mathbf{n}^{\circ} 392$
}

sobre garantias ao trabalho, em Yucatán, Estado que ocupa uma península do Estado mexicano no extremo sudeste do golfo do México. Alvarado, general do Exército Constitucionalista responsável por aquela região do país, toma o poder em março de 1915 e, uma vez obtida a estabilidade para governar, passa a realizar uma série de reformas na legislação local. Com 137 artigos e XI Capítulos, o documento normativo de Alvarado antecipa e, talvez, seja um dos responsáveis pela ampla regulamentação da Constituição Mexicana de 1917. Os deputados yucatecos que participaram do Congresso Constituinte no final de 1916, defenderam a forma de regulamentação proposta por Salvador Alvarado, e obtiveram enorme influência em seu texto final.

\begin{abstract}
Durante la realización del Congreso Constituyente de Querétaro (1916-1917), los diputados por Yucatán, todos muy allegados al general Alvarado, se encargaron de representar el proyecto estatal alvaradista.

En el caso concreto del artículo 123, la participación de la diputación yucateca (especialmente la del líder obrero Héctor Victoria) resultó crucial para la adopción de un proyecto amplio de legislación laboral, en contraposición de la propuesta de Venustiano Carranza. ${ }^{502}$
\end{abstract}

Até a chegada do general Salvador Alvarado em Mérida, em 15 de março de 1915, Yucatán era um Estado quase alheio à Revolução Mexicana. Os quase três anos que sucederam a conquista foram revolucionários para a vida dos que habitavam o Estado, em função das profundas transformações que promoveu Salvador Alvarado em seu governo, que se estendeu de março de 1915 a fevereiro de 1918 e contou com 753 decretos $^{503}$. Salvador Alvarado era do Estado de Sinaloa, mas se declarava sonorense (quem nasce no Estado de Sonora). Mexicano do norte, tinha participado da fundação do Partido Liberal Mexicano, em 1906, e da greve de Cananea. Por ter tomado parte na greve dos mineiros, teve que se exilar nos Estados Unidos, no Arizona. Nos anos que passou por lá, tornou-se fluente em inglês e entrou em contato com uma série de reflexões internacionais sobre as questões sociais prementes do início do século XX.

\footnotetext{
502 IBARRA ROMO, Mauricio. La ley del trabajo de Salvador Alvarado. In.Alegatos en línea 2. Cidade do México: Universidad Autónoma Metropolitana, janeiro a abril de 1986.

${ }^{503}$ CORTINA QUIJANO, Aurora. Los Congresos Feministas de Yucatán en 1916 y su influencia en la legislación local y federal. Cidade do México: Instituto de Investigaciones Jurídicas, Universidad Nacional Autónoma de México, 1986, p. 164.
} 
Cosmopolita em um estado extremamente periférico do México, marcado por uma luta separatista no século XIX, Salvador Alvarado tinha uma difícil tarefa. Apesar de periférico, Yucatán possuía uma indústria bastante lucrativa, figurando entre os estados mais ricos do país. Sisal (henequén) é o produto nobre extraído do agave sisalana, planta nativa de Yucatán que, como tal, tinha seu cultivo extensivo bastante favorecido pelas condições climáticas e geográficas da região. . Assim, o trabalho de cultivo da terra e a indústria de extração e transformação da fibra da planta em fios e produtos eram o eixo da produção local. Nessa grande e lucrativa atividade econômica, havia muitos empregados.

Por meio da publicação de um conjunto de decretos - então chamados de leis que regulamentavam as principais tensões sociais presentes na realidade yucateca (não muito diferentes das tensões gerais presentes na realidade mexicana, diga-se), Alvarado acreditava estar realizando o ideal da Revolução Constitucionalista. Talvez, ao invés de realizar o ideal revolucionário, Salvador Alvarado estivesse formulando em Yucatán seu programa mais avançado:

La Revolución Constitucionalista cumple en Yucatán su Programa de Reformas Sociales. Legisló ya sobre Educación y acerca del procedimiento para repartir la tierra. Ahora viene a satisfacer una necesidad ingente que el Estado reclama: otorgar garantías al trabajo.

(...) La defensa del obrero es en México una de las conquistas gloriosas de la triunfante revolución;

Y es necesaria la intervención del Estado para evitar el abuso de los acaudalados, que en la lucha económica cuentan con los elementos de combate que emplean en obstaculizar la realización de los beneficios que la Revolución trata de impartir a las clases bajas, dejando al obrero, que todo lo produce, privado, como en tiempos anteriores, del goce de la vida que su trabajo le proporciona justamente.

Que bajo este plan, la ley se preocupa muy seriamente por de finir las responsabilidades y derechos que a cada uno incumben, preceptuando clara y concisamente aquello a lo que tiene derecho cada grupo para encarrilar por vía libre, el mundo de las actividades hacia una finalidad de concordia y de igualdad ante la ley y ante los hombres. ${ }^{504}$

${ }^{504}$ Texto integral do Decreto n. 392 (Ley del Trabajo), expedido por Salvador Alvarado em 11 de dezembro de 1915, em: BIBLIOTECA GARAY. 500 años de México en documentos. México, 2011. <http://www.biblioteca.tv/artman2/publish/1915 210/Ley_del Trabajo_de_Salvador_Alvarado_1371.sht ml> Consulta realizada em $21 / 12 / 2015 . \quad$ E também em: <http://constitucion1917.gob.mx/es/Constitucion1917/Ley_del_Trabajo_del_Estado_de_Yucatan> 
Educação e distribuição de terras foram as regulamentações principais que antecederam o decreto sobre direito dos trabalhadores em 11 de dezembro de 1915. Também a defesa do trabalhador estava, para o então governador, entre as conquistas imperativas da revolução pela qual havia lutado. Na exposição de motivos que antecede os dispositivos normativos, deixará clara sua concepção de Estado: é uma instituição que necessariamente deve intervir para impedir o abuso dos ricos, para reverter e equilibrar a posição desigual de forças em que trabalhadores e empregadores se encontram. Além disso, no Estado que intervém na realidade social, a lei assume um papel fundamental, o de definir direitos e responsabilidades de cada grupo.

Para além da clareza sobre as funções que deveriam ser assumidas por um Estado Social, que estava sendo concebido teoricamente naquele exato momento histórico; tratou ainda da liberdade de trabalho, da qual deriva a liberdade de contratar, chamando atenção, porém, para a desigualdade de posições das partes contratantes, justificativa para a intervenção estatal. Alvarado faz referência, na exposição de motivos, a um decreto anterior no qual criou um conselho de conciliação e arbitragem, que teria como objetivo resolver de maneira célere os conflitos laborais. Com o mesmo objetivo, cria Tribunais Industriais (segundo ele a rapidez na resolução de conflitos laborais teria especial importância, pois os conflitos envolvem o meio de subsistência do trabalhador $)^{505}$. Por fim, afirma que, ao estabelecer por meio da lei direitos e obrigações de patrões e operários, procura aproximar interesses e responder " $a$ la tendencia de armonía y solidaridad que el Gobierno de la Revolución quiere imprimir a todas las relaciones entre el capital y el trabajo." 506.

Em deslize de idealismo, Alvarado aparentemente acredita ser possível promover a harmonia e a solidariedade entre empregadores e empregados. Sua extensa

\footnotetext{
505 "La frecuencia con que se suceden en Yucatán los conflictos entre capitalistas y obreros ha impuesto la necesidad de solucionarlos por medios pacíficos, cediendo a las justas exigencias del trabajo sin detrimento del capital. A este efecto se expidió el Decreto número 59 de 14 de mayo del año en curso, creando un Consejo de Conciliación y Tribunal de Arbitraje, que desde que se instituyó ha venido funcionando regularmente, solucionando con prontitud y eficacia todos los conflictos surgidos. (...)La importancia trascendental de la cuestión obrera cuya especial naturaleza requiere procedimientos sumarísimos, impone la necesidad indeclinable de establecer tribunales industriales que impartan justicia inmediata y oportuna, sin la lentitud desesperante de los enjuiciamientos ordinarios. Texto integral do Decreto n. 392 (Ley del Trabajo), expedido por Salvador Alvarado em 11 de dezembro de 1915, em: BIBLIOTECA GARAY. 500 años de México en documentos. México, 2011. <http://www.biblioteca.tv/artman2/publish/1915_210/Ley_del_Trabajo_de_Salvador_Alvarado_1371.sht ml> Consulta realizada em 21/12/2015.

506 Texto integral do Decreto n. 392 (Ley del Trabajo), expedido por Salvador Alvarado em 11 de dezembro de 1915, em: BIBLIOTECA GARAY. 500 años de México en documentos. México, 2011. < http://www.biblioteca.tv/artman2/publish/1915_210/Ley_del_Trabajo_de_Salvador_Alvarado_1371.sht

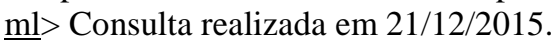


carta normativa, porém, não deixa dúvidas de que cabe ao Estado proteger um dos lados, sem confiar que esses bons sentimentos permeiem a relação laboral. O texto da exposição de motivos prossegue a justificar os dispositivos normativos que seguirão na segunda parte da publicação: salário mínimo para sobrevivência digna de um trabalhador com família, descanso semanal capaz de garantir a saúde e a continuidade do trabalhador em sua função laboral, higiene nas oficinas, prevenção contra acidentes de trabalho e, no caso de ocorrerem, indenização, entre outros. Encerra o texto afirmando que "la Revolución triunfante viene a remediar el malestar social". Alvarado parece ser bastante fiel a esse objetivo quando se analisam seus experimentos normativos para Yucatán.

Em relação especificamente à Ley del Trabajo, quando são cotejados os seus 137 artigos com as frações do artigo 123 da Constituição Mexicana de 1917, percebe-se quão importante foi essa regulamentação yucateca para os avanços consolidados nacionalmente por meio da Constituição. Se não a ordem ou exatamente a norma criada, os temas regulados pela lei e pelo artigo constitucional têm justaposição quase perfeita.

O primeiro capítulo da lei de Alvarado, nomeado "Disposiciones generales" possui 24 artigos e neles inúmeras definições: o que são considerados patrões e operários, conceito de fábrica, o que é e como pode ser firmado um contrato de trabalho, o que é um convênio industrial (contrato coletivo mediado por organização de trabalhadores), entre outras. Para além das definições, claramente as normas do decreto de 1915 visam a estimular as associações de trabalhadores. O artigo $4^{\circ}$, por exemplo, afirma que os trabalhadores não associados não serão beneficiados por aumentos salariais negociados pelas entidades representativas ${ }^{507}$. Ao contrário da lei yucateca, a constituição apenas permite - mas não estimula, nem condiciona o exercício de direitos - a agremiação de trabalhadores e patrões em sindicatos e associações laborais.

O segundo capítulo (arts. 25 a 53) trata da obrigatoriedade de atuação do Conselho de Conciliação e Arbitragem para a resolução de conflitos entre patrões e empregados. O terceiro capítulo tem como título "Derechos y obligaciones de los patronos y obreros Conclusión de contratos y convenios industriales" e abrange desde o art. 54 até o art. 70, normatizando as condutas de respeito entre as pessoas e ao espaço e

\footnotetext{
${ }^{507}$ Texto integral do Decreto n. 392 (Ley del Trabajo), expedido por Salvador Alvarado em 11 de dezembro de 1915, em: BIBLIOTECA GARAY. 500 años de México en documentos. México, 2011. <http://www.biblioteca.tv/artman2/publish/1915 210/Ley_del Trabajo_de_Salvador_Alvarado_1371.sht $\underline{\text { ml }}>$ Consulta realizada em 21/12/2015.
} 
instrumentos de trabalho devidas tanto pelos operários quanto pelos patrões. Além disso, são previstas as hipóteses de interrupção do contrato de trabalho com e sem justa causa, além de suas condições. O quarto capítulo, "Jornada Máxima", traz as normas relativas ao tempo de trabalho e suas especificidades (arts. 71 a 73). O quinto capítulo traz normas que regulam as especificidades do trabalho feminino e infantil (arts. 74 a 82). Os salários são regulados apenas no capítulo sexto (arts. 83 a 91); higiene e segurança nas fábricas, no capítulo sétimo (arts. 92 a 103); acidentes de trabalho, no oitavo capítulo (arts. 104 a 119). O capítulo nono é dedicado às greves (arts. 120 a 129); o décimo às penas aplicáveis àqueles que descumprirem os dispositivos legais (arts. 130 a 134) e, por fim, o último capítulo versa sobre a sociedade mutualista que deve ser criada pelo Estado para que os trabalhadores tenham alguma forma de seguridade social para velhice e morte precoce, com filhos órfãos.

A quantidade e a especificidade das normas produzidas em Yucatán impressionam, sobretudo quando comparadas às produções contemporâneas de outros estados e líderes militares. Algumas surpreendem pelo inusitado: o artigo 73 prevê, por exemplo, que a semana de trabalho tem seis dias - reservando um para o descanso, portanto. Estabelece, surpreendentemente, um limite máximo de jornada semanal: 44 horas. Isso significa, e está explícito nesse artigo, que na semana de seis dias, já contabilizado um dia de descanso, necessariamente haverá mais meio período livre. Mais: os trabalhadores podem abrir mão desse meio período semanal e acumulá-lo por três meses de forma a ter uma semana completa de descanso. Essa norma é a versão rudimentar das férias, que foram previstas na Constituição de 1917 apenas para os funcionários públicos.

Além dessa, no artigo 83 os trabalhadores são divididos em três categorias: trabalhadores, aprendizes e serventes domésticos. Para cada uma delas, há um valor mínimo a ser pago pelo dia de trabalho: para os trabalhadores como gênero, dois pesos de jornal (alto valor, comparativamente às normas dos outros estados); para os aprendizes, um peso e, por fim, para os serventes domésticos, cinquenta centavos. Essa tentativa de classificação, essa diferenciação de situações é a tônica do documento normativo de Alvarado. Jornadas diferenciadas para trabalhadores do campo, carpinteiros e ferreiros de oito horas diárias e quarenta e quatro semanais; trabalhadores de escritórios públicos e privados, de oito horas e meia e quarenta e oito horas 
semanais; para trabalhadores de hoteis e cafés, de oito horas e meia e cinquenta e uma horas semanais.

Contra esse estilo minucioso, que diferencia situações específicas, as normas presentes no artigo 123 da Constituição são gerais e valem para todos os trabalhadores. Maiores especificidades foram deixadas à cargo das legislações estaduais que, porém, não podem contrariar o disposto na Constituição.

Considerando: que nadie tiene derecho a lo superfluo mientras los que trabajan carecen de lo necesario:

Que toca hoy a la Revolución resolver el problema del trabajo:

Que nivelar clases es la única manera de establecer el equilibrio de entidades que siempre se han mantenido en pugna, determinante esencial de los conflictos habidos entre el capital y el trabajo;(...)

Que en tanto no tengan los obreros elementos bastantes para alimentar y educar a sus hijos; en tanto no haya en los hogares lo indispensable para hacer de ellos el recinto de felicidad anhelada por los que tienen alguna bien encaminada aspiración; en tanto no haya tela para cubrir las desnudeces de la familia, la Revolución debe mirar con horror las suntuosas mansiones, los lujosos automóviles y el inmoral derroche en orgiásticas bacanales, que son un ultraje a la miseria y un estigma al trabajo mal retribuido y una afrentosa negación de la dignidad humana. ${ }^{508}$

Para encerrar a análise da regulamentação do trabalho de Salvador Alvarado, vale analisar mais alguns trechos dos considerandos que precedem a parte dispositiva do documento normativo, porque eles deixam entrever a ideologia que anima seu autor, que se autoentitula "francamente socialista". Seu primeiro considerando, que abre o decreto, afirma que ninguém deve ter acesso ao supérfluo enquanto aqueles que trabalham não tenham o necessário para sobreviver. A ideia da diminuição da desigualdade, por sua vez, está presente em diversas partes do texto. Quer quando Alvarado aposta na diminuição das diferenças sociais para diminuir os casos de conflitos laborais, quer quando condena veementemente todo o luxo praticado pelas elites mexicanas quando há trabalhadores em situação decarência. Essa inconformidade com a extrema desigualdade social, explícita em seu texto, foi um dos motes a impelir

\footnotetext{
508 Texto integral do Decreto n. 392 (Ley del Trabajo), expedido por Salvador Alvarado em 11 de dezembro de 1915, em: BIBLIOTECA GARAY. 500 años de México en documentos. México, 2011. <http://www.biblioteca.tv/artman2/publish/1915 210/Ley_del Trabajo_de_Salvador_Alvarado_1371.sht $\underline{\text { ml }}>$ Consulta realizada em 21/12/2015.
} 
que Alvarado criasse uma legislação tão ampla de proteção e garantias aos trabalhadores.

Em 14 de dezembro de 1915, no Estado de Hidalgo, o general Nicolás Flores publicou sua “Ley sobre Accidentes de Trabajo”. Embora o decreto protejesse os trabalhadores que eventualmente viessem a sofrer um acidente de trabalho, este não era o seu diferencial. A grande novidade dessa norma era o fato de ser autorizada a criação de companhias seguradoras, às quais empresas e fábricas poderiam se associar e transmitir os riscos do ambiente de trabalho. Assim, se um acidente ocorresse, não mais o empregador de forma direta seria obrigado a pagar os dias de afastamento, o tratamento médico, a eventual indenização. A responsabilidade recairia sobre a companhia de seguros. ${ }^{509}$

Por fim, em 27 de outubro de 1916, às vésperas do Congresso Constituinte, Gustavo Espinoza Mireles, do Estado de Coahuila, sanciona a "Ley del Trabajo", que continha uma regulamentação das formas de celebração do contrato coletivo de trabalho. Para isso, confere à organização, que figurará como parte do contrato coletivo, personalidade jurídica. Com essa regulamentação, também o Estado de Coahuila, assim como nos Estados de Veracruz e de Yucatán, as associações de trabalhadores estavam legalizadas ${ }^{510}$. Além disso, essa lei foi uma das primeiras compilações normativas a garantir ao trabalhador o direito à participação "de los beneficios" da produção ${ }^{511}$, ou seja, nos lucros.

Apresentados os inúmeros documentos normativos que regulavam as relações de trabalho em diferentes estados mexicanos, torna-se quase obrigatório perguntar o porquê de sua proliferação. Elaborados por generais e governadores constitucionalistas, surgiram principalmente após a derrota de Victoriano Huerta. Concentrados entre agosto e outubro de 1914, mas com publicações que se seguiram até o Congresso

\footnotetext{
${ }^{509}$ NARVÁEZ HERNÁNDEZ, José Ramón. Historia de las instituciones jurídicas de los estados de la República Mexicana. México: Universidad Nacional Autónoma de México, 2010. P. 17.

${ }^{510}$ MACÍAS VÁZQUEZ, María Carmen. Antecedentes históricos de la cláusula de exclusión en México. Cidade do México: UNAM, Instituto de Investigaciones Jurídicas, 2002. p. 67

511 MÉXICO. Crônica parlamentária. Cidade do México: Camara de Diputados, 1986. Em

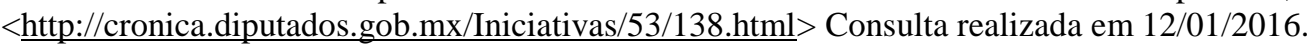


Constituinte de 1916, as suas existências mostram pelo menos que a questão das condições de trabalho dos mexicanos eram um tema do Exército Constitucionalista. Pode-se, no entanto, apenas especular sobre se esse tema era tão presente porque preocupava-lhes a situação do trabalhador mexicano genuinamente, ou se a edição desses decretos respondia a uma tática. No caso da segunda opção, há ainda duas hipóteses: tática para ganhar legitimidade e estabelecer-se no poder recém conquistado, ou seja, uso da juridificação como estratégia para obter a legitimidade do exercício do poder, por um lado; ou tática com o objetivo de aproximar novos aliados dispostos a lutar no embate entre as correntes revolucionárias que já estava no horizonte. Como os decretos tinham conteúdos diferentes, e foram criados em estados com contextos de trabalho diversos, é difícil identificar uma causa ou motivação comum a todos. Contudo, é inegável a preocupação sincera de Salvador Alvarado com as condições de vida da classe operária. O mesmo não se pode garantir de Pablo González, por exemplo.

Dada a quantidade de normas em um curto espaço de tempo, é possível supor uma orientação central - talvez proveniente do primer jefe Carranza - de usar a edição de normas trabalhistas para mostrar controle sobre o Estado. Ou, pelo menos, de usar a estratégia de regular a sociedade, por meio de decretos elaborados pelos próprios caudilhos, sem a mediação de um órgão colegiado, como forma de consolidar seu domínio sobre um território. Soma-se a essa orientação geral, talvez, a questão das relações de trabalho permearem muitas das relações sociais e se apresentarem como um problema tanto no campo, quanto nas cidades, em todos os estados do país. Assim, o diganóstico constitucionalista parecia ser de que o México e as relações de trabalho, tal como a situação conflituosa no campo, demandavam uma intervenção normativa estatal. Os líderes militares ofereceram um esboço dela entre os anos de 1914-1916.

No mais, as regulações estaduais eram bastante limitadas e rudimentares para resolver ou melhorar a situação dos trabalhadores de seus estados. Exceção que confirma a regra é a normatização de Salvador Alvarado e, talvez, em grau muito inferior, a de Eulálio Gutiérrez. Entender como, a partir de fórmulas tão simplistas propostas pouco tempo antes, o Congresso Constituinte mexicano chegou à formulação do artigo 123 é intrigante. Certamente houve a colaboração de Alvarado, de Rafael Zubarán Capmany e inspiração em modelos internacionais, explicitadas no caso de Zubarán. Seja como for, o salto de complexidade das normas de proteção dos trabalhadores é notável para tão curto espaço de tempo. Por fim, uma nota histórica: 
após várias das regulamentações das relações de trabalho apresentadas nesta seção, publicadas no segundo semestre de 1914, a Casa del Obrero Mundial adere, em fevereiro de 1915, à luta constitucionalista. Ao longo da pesquisa não encontramos trabalho que relacionasse os dois eventos, nem mesmo fontes primárias que sugerissem qualquer relação de causalidade entre eles. Seja como for, a coincidência de datas é notável.

\subsubsection{Decretos de 29 de janeiro de 1915 e 22 de junho de 1915 (Venustiano Carranza)}

Dias antes de a Casa del Obrero Mundial aderir à luta constitucionalista, Venustiano Carranza aderiu ao movimento constitucionalista de propor regulamentações sobre direito do trabalho e decidiu modificar a Constituição de 1857 por meio de um decreto, contrariando o artigo 127 da Constituição ${ }^{512}$, que estabelecia que qualquer alteração constitucional deveria ser aprovada por dois terços dos membros do Congresso.

A emenda proposta por Carranza alterava o inciso (fração na terminologia jurídica mexicana) X do artigo 72 da Constituição de 1857:

\section{Constituição Mexicana de 1857}

72. El congreso tiene facultad:(...)

\section{Redação original:}

X. Para establecer las bases generales de la legislacion mercantil.

\section{Alteração decretada em 29 de janeiro de 1915:}

X.- Para legislar en toda la República, sobre minería, comercio, Instituciones de Crédito y Trabajo. ${ }^{513}$,

\footnotetext{
512 "127. La presente Constitución puede ser adicionada o reformada. Para que las adiciones o reformas lleguen á ser parte de la Constitucion, se requiere que el congreso de la Union, por el voto de las dos terceras partes de sus individuos presentes, acuerde las reformas o adiciones, y que éstas sean aprobadas por la mayoría de las legislaturas de los Estados. El congreso de la Union hará el cómputo de los votos de las legislaturas y la declaracion de haber sido aprobadas las adiciones o reformas." Constitución Política de la República Mexicana de 1857, promulgada em 5 de fevereiro de 1857. Cidade do México: Instituto de Investigaciones Jurídicas. 〈http://www.juridicas.unam.mx/infjur/leg/conshist/pdf/1857.pdf > Consulta realizada em 11/01/2016.

${ }^{513}$ A íntegra do decreto de Carranza de 29 de janeiro de 1915 está disponível em: BIBLIOTECA VIRTUAL DEL ESTADO DE JALISCO. Guadalajara: Poder Legislativo del Estado de Jalisco, 2009. <http://congresojal.gob.mx/bibliotecavirtual/libros/legislacionprecosntitucional1915.pdf > p. 28. Consulta realizada em 22/12/2015.
} 
A mudança do início de 1915, assim, dizia respeito unicamente à possibilidade de o Congresso mexicano legislar nacionalmente sobre direito do trabalho. Antes da mudança constitucional, poderia se interpretar que essa competência era unicamente reservada aos estados federados. Autorizada a legislação federal, o passo seguinte foi solicitar ao secretário de gobernación, cargo máximo da Secretaria à qual o Departamento del Trabajo estava submetido, um projeto de lei federal que regulasse as relações de trabalho. Rafael Zubarán Capmany foi o responsável por propor uma primeira versão desse projeto de lei. Sua versão preliminar, em projeto, foi apresentada em 12 de abril de 1915, cerca de dois meses e meio mais tarde.

Para justificar a mudança constitucional, Carranza afirma existirem no México "dolorosas realidades de la esclavitud por medio del trabajo, transmitiéndose de padres a hijos en algunas regiones del país; de la explotación del obrero conforme al sistema industrial ${ }^{\text {"514, }}$, que deveriam ser revertidas por meio da intervenção normativa estatal. Além disso, afirma que a tentativa de deixar a cargo dos diferentes estados a juridificação desse tema não foi capaz de impedir a situação degradante dos trabalhadores mexicanos. Assim, estaria justificada a mudança constitucional que autoriza que ao menos parte da regulação seja válida para todo o território mexicano.

Para além da autorização constitucional para a existência de uma legislação federal em questões trabalhistas, meses mais tarde, após a apresentação da proposta de Zubarán de um código de trabajo completo, Carranza editou ainda um decreto que dizia respeito à realidade laboral dos trabalhadores mexicanos. Em 22 de junho de 1915, foi publicado o decreto que obrigava os municípios (ayuntamientos) a construir e a zelar pela manutenção de prédios em que houvesse mercados acessíveis a toda a população. Segundo a exposição de motivos do decreto, seu objetivo é enfrentar o "odioso monopolio, por medio de las llamadas 'tiendas de raya"" 515 constituído pela instalação de lojas sob a direção direta dos proprietários das fábricas ou propriedades rurais, ou de seus amigos e subordinados mais próximos. Ao invés de se proibir a existência de tiendas de raya, ou ainda proibir qualquer pagamento como vale, impondo que os

\footnotetext{
${ }^{514}$ A íntegra do decreto de Carranza de 29 de janeiro de 1915 está disponível em: BIBLIOTECA VIRTUAL DEL ESTADO DE JALISCO. Guadalajara: Poder Legislativo del Estado de Jalisco, 2009. <http://congresojal.gob.mx/bibliotecavirtual/libros/legislacionprecosntitucional1915.pdf > p. 28. Consulta realizada em 22/12/2015.

515 A íntegra do decreto de Carranza de 22 de junho de 1915 está disponível em: BIBLIOTECA VIRTUAL DEL ESTADO DE JALISCO. Guadalajara: Poder Legislativo del Estado de Jalisco, 2009. <http://congresojal.gob.mx/bibliotecavirtual/libros/legislacionprecosntitucional1915.pdf > p. 41. Consulta realizada em 22/12/2015.
} 
jornales ou as rayas (como eram conhecidas) fossem pagas com dinheiro em moeda corrente, como tantos governadores e líderes militares haviam proposto em suas diferentes regulamentações estaduais, Carranza preferiu obrigar os municípios a manterem comércios paralelos e supostamente garantirem a concorrência. Afirma em sua exposição de motivos: "el Poder público debe intervenir facilitando en los mencionados lugares el establecimiento de mercados abiertos al libre comercio, que en virtud natural de la competencia, traiga consigo una baja racional en los precios y una extensión mayor en la variedad de los artículos comerciales" ${ }^{, 516 .}$

A medida escolhida por Carranza não parece adequada para resolver o problema que quer enfrentar. Caso não venha acompanhada da obrigatoriedade de que os empregadores paguem seus trabalhadores com moeda de uso corrente - com pesos mexicanos - de nada adianta haver opções de comércio: eles deveriam necessariamente usar seus salários nas tiendas de raya dos patrões, responsáveis por pagar o salário em espécie. Além disso, o único artigo das disposições transitórias também deixa implícito que a norma tem mais objetivo de marcar posição política - e ganhar eventualmente a simpatia dos trabalhadores - do que a intenção de efetivamente resolver o problema. Nele lê-se que a lei só começará a valer quando "se hayan efectuado las elecciones municipales y haya quedado organizado el Poder Judicial en la República" 517. A efetividade da própria lei está sujeita às eleições municipais e ao reestabelecimento do Poder Judiciário. Carranza teve oportunidade, entre 12 de abril e 22 de junho de 1915, de aprovar e decretar o projeto de lei elaborado por Rafael Zubarán Capmany, muito mais amplo sobre a situação da classe trabalhadora e com proposta mais efetiva para o enfrentamento das tiendas de raya. No entanto, passados alguns meses do projeto de Zubarán pronto e entregue a Carranza, ele preferiu editar essa lei paliativa que, além disso, só teria efeitos em um futuro algo distante. Essas decisões de Venustiano Carranza colocam em xeque sua genuína intenção de melhorar as condições de vida da classe trabalhadora. Ao invés disso, ele poderia estar usando a edição de normas apenas com finalidades populistas, para aparentar defender um determinado segmento da população sem efetivamente fazê-lo. Tal aparência, por sua vez, teria por objetivo

\footnotetext{
${ }^{516}$ A íntegra do decreto de Carranza de 22 de junho de 1915 está disponível aqui: BIBLIOTECA VIRTUAL DEL ESTADO DE JALISCO. Guadalajara: Poder Legislativo del Estado de Jalisco, 2009. $<$ http://congresojal.gob.mx/bibliotecavirtual/libros/legislacionprecosntitucional1915.pdf > p. 41. Consulta realizada em 22/12/2015.

517 Ibid. p. 42.
} 
aumentar sua legitimidade para governar e para ganhar o embate com os outros setores revolucionários.

\subsubsection{Projeto de Lei de 12 de abril de 1915 (Rafael Zubarán Capmany)}

Sempre que Venustiano Carranza editava documentos normativos na função de primer jefe - depois da morte de Francisco Madero, portanto -, eles tinham pretensão de validade nacional. Assim, seu secretário de gobernación Rafael Zubarán Capmany o mesmo que meses antes participara das negociações para a adesão da Casa del Obrero Mundial à luta constitucionalista- elaborara um projeto de lei com o propósito de tornálo lei nacional. Publicado em 12 de abril de 1912 como projeto, tinha por objetivo realizar os mais altos anseios revolucionários. Segundo o início de sua exposição de motivos, o documento fazia parte de um esforço de "expedición de leyes para mejorar la condición del peón rural, del obrero, del minero y en general de todas las clases proletárias, clases cuyo concurso ha sido ampliamente utilizado pela Revolución". 518

O concurso de classes proletárias foi "utilizado" pela Revolução. Muito embora o verbo escolhido não seja lisonjeiro, Zubarán quer chamar a atenção para o fato de os peões, os mineiros, os trabalhadores urbanos e as classes baixas em geral terem sido determinantes para o sucesso da Revolução Mexicana e para a derrocada de dois chefes autoritários - Díaz e Huerta. Além da luta contra o autoritarismo, as classes populares lutaram também para melhorar suas próprias condições de vida (o que explicitaram em inúmeros documentos), anseio que deveria ser respondido por aqueles que venceram a revolução por meio de uma nova organização social. Todo esse raciocínio está na exposição de motivos de Zubarán. Normas que têm por objetivo regular as relações de trabalho nas fábricas e nas fazendas e produções rurais visariam a cumprir esse objetivo, segundo o secretário.

É possível supor que o decreto regulamentador de Salvador Alvarado, no Estado de Yucatán, tenha tido influências de normas internacionais para a regulamentação do trabalho. Se houve tais influências, porém, ele não as deixou explícitas em sua

\footnotetext{
${ }^{518}$ A íntegra do projeto de lei que tinha por objetivo regular as relações de trabalho, de Rafael Zubarán Capmany, publicado em 12 de abril de 1915, disponível em: Dirección General de Bibliotecas (DGB). Cidade do México: Secretaría de Educación Pública: Consejo Nacional para la Cultura y las Artes, 2013. http://dgb.conaculta.gob.mx/coleccion_sep/libro_pdf/50000006389.pdf\#toolbar=0 $\quad$ p. 3-4. Consulta realizada em $21 / 12 / 2015$.
} 
exposição de motivos. Já Zubarán, não só afirma que sua equipe estudou normativas internacionais, mas indica quais países tiveram mais influência na proposta final:

Para formar este proyecto, se han tenido a la vista disposiciones análogas existentes en países cultos, como Holanda, Bélgica, Francia, Alemania, España, Italia y algunos Estados de la Unión Americana, las opiniones de Institutos y otras corporaciones, dedicados al estudio de la materia, los proyectos de reputados estadistas, así como también las disposiciones existentes de la legislación patria, y las opiniones de algunos empresarios y obreros que, por su conocimiento práctico del asunto, están en condiciones, de ministrar ditos de positiva utilidad y de sugerir apreciaciones y puntos de vista que, de seguro, escaparían a quienes, aun bien documentados en cuanto al aspecto teórico del asunto, no lo estuvieran respecto del puramente práctico. $[\ldots]^{519}$

Ora, os países cultos, europeus (além de alguns poucos estados norteamericanos) serviram de inspiração para as normas elaboradas e organizadas por Zubarán Capmany. Lado a lado com o projeto de Salvador Alvarado, este documento de abril de 1915 teve enorme influência na elaboração do artigo 123 da Constituição Mexicana de 1917. E, por meio dele, a recepção mexicana de referências internacionais sobre o direito do trabalho. Se o projeto como um todo contou com referências às legislações holandesas, belgas, francesas, alemãs, espanholas, italianas e norte americanas, especificamente em relação ao contrato coletivo de trabalho, Zubarán afirma ter se inspirado em dois projetos de lei franceses (de 1906 e 1910) e em um projeto de lei sueco, também de 1910.

Assim, o fato de diversos outros países do mundo também estarem preocupados e juridificando suas próprias relações de trabalho tem influência - e é natural que haja nas propostas de regulação mexicanas, adaptadas, porém, à realidade do país latinoamericano.

Ainda em sua exposição de motivos, Zubarán chama atenção para o fato de que não foi eficiente a decisão da Constituição de 1857 de deixar aos estados a definição dos direitos trabalhistas. Inúmeras contradições e, principalmente, omissões se verificaram a partir dessa orientação. Afirma que a própria realidade do trabalhador mexicano torna

\footnotetext{
${ }^{519}$ A íntegra do projeto de lei que tinha por objetivo regular as relações de trabalho, de Rafael Zubarán Capmany, publicado em 12 de abril de 1915, está disponível em: Dirección General de Bibliotecas (DGB). Cidade do México: Secretaría de Educación Pública: Consejo Nacional para la Cultura y las Artes, 2013. http://dgb.conaculta.gob.mx/coleccion_sep/libro_pdf/50000006389.pdf\#toolbar=0 p. 4. Consulta realizada em 21/12/2015.
} 
indiscutível a necessidade de uma lei federal que regulamente as relações de trabalho. Essa regulamentação, por sua vez, deve respeitar uma característica importante da relação entre capital e trabalho:

\begin{abstract}
Por otra parte, la legislación vigente sobre este asunto es notoriamente deficiente, tanto por anticuada, cuanto porque está inspirada en un criterio ultra-individualista, tal como ha dominado en el mundo entero hasta mediados de la última centuria. Las relaciones entre el capital y el trabajo han venido tomando desde entonces un carácter de hostilidad que antes no tuvieron, y que se ha exacervado a medida que el desarrollo del régimen capitalista, cuyas manifestaciones más claras han sido el maquinismo y la concentración de la industria en grandes fábricas, ha hecho más frecuentes las ocasiones de conflicto entre esos dos factores de la producción, cuyo concurso armonioso constituye hoy un ideal muy lejano. Sustituir el criterio ultra-individualista que antes predominó, por otro menos estrecho, dada la importancia social del asunto, la que justifica su consideración desde el punto de vista del derecho público. ${ }^{520}$
\end{abstract}

Nas poucas normas da Constituição de 1857 que tratavam sobre o trabalho, vigorava uma visão ultra-individualista. Essa visão, segundo Zubarán, é ultrapassada e precisava ser superada para que a regulação da atividade laboral fosse efetiva. Em seu texto, demonstra não ter a ingenuidade de Salvador Alvarado quando defende a conciliação de interesses entre patrões e empregados: uma convivência harmoniosa entre capital e trabalho é um ideal muito longínquo, e talvez nunca alcançável, dadas as especificidades da forma de organização da produção na sociedade capitalista.

Tendo em vista as características específicas dessa forma de produção que visa o lucro, o conflito entre trabalhadores e patrões deve ser visto como um conflito coletivo, que opõe grupos de pessoas com interesses parecidos em cada um dos lados. Constatada a característica coletiva do conflito, de diferentes grupos sociais em oposição, a regulação das relações deve se dar necessariamente pelo direito público.

Para realizar esse objetivo, Zubarán apresenta em abril de 1915 um projeto de lei com cem artigos divididos em sete capítulos: I - Disposiciones generales; II - Derechos y obligaciones de los patronos y de los obreros; III - Jornada máxima y salario mínimo;

${ }^{520}$ A íntegra do projeto de lei que tinha por objetivo regular as relações de trabalho, de Rafael Zubarán Capmany, publicado em 12 de abril de 1915, está disponível em: Dirección General de Bibliotecas (DGB). Cidade do México: Secretaría de Educación Pública: Consejo Nacional para la Cultura y las Artes, 2013. http://dgb.conaculta.gob.mx/coleccion_sep/libro_pdf/50000006389.pdf\#toolbar=0 p. 5. Consulta realizada em 21/12/2015. 
IV - Reglamento del taller; V - Terminación del contrato; VI - Contrato colectivo del trabajo; VII - Disposiciones complementarias. Ainda na exposição de motivos, destaca algumas normas dignas de justificação em cada um deles.

Nos primeiros artigos do projeto de lei, nas chamadas disposiciones generales, consta uma definição sobre o que pode ser considerado um contrato de trabalho e em que circunstâncias contratos de prestação de serviços devem ser regidos pelo direito comum. Nesse último caso, o projeto de lei formula duas hipóteses: contratos em que o serviço e os materiais empregados são fornecidos por quem está sendo contratado, sendo os dois igualmente importantes; também aqueles concernentes a prestadores de serviço que oferecem seus trabalhos ao público em geral - e não a um patrão específico - devem ser regidos pelo direito comum, e não pelas normas especiais do direito do traballho.

Todas as outras circunstâncias em que uma pessoa se obriga a trabalhar para outra deveriam ser regidas pelas normas estabelecidas no projeto de lei de Zubarán. Ao contrário do que costumeiramente se admitia no México, de acordo com o art. $4^{\circ}$ do projeto de lei "el contrato de trabajo sólo podrá celebrarse por tiempo fijo o para una obra determinada" ${ }^{521}$. A Constituição de 1857 era omissa quanto à forma e o tempo de duração dos contratos; assim, em regra assinavam-se contratos por tempo indeterminado, prática que o projeto de lei queria modificar (o de Alvarado, em Yucatán, seguia o mesmo sentido). Essa mudança provavelmente tinha a intenção de proteger o trabalhador contra situações de vinculação perpétua geradas por meio de dívidas artificialmente criadas para esse fim.

O projeto dispõe que os contratos de trabalho podem ser celebrados verbalmente ou por escrito, exceção em casos de menores de dezoito anos ou para os estrangeiros. Além disso, devem ser estabelecidos com precisão os serviços a serem executados e a quantidade e a forma de pagamento. $\mathrm{O}$ artigo $8^{\circ}$ declara serem nulas todas as cláusulas contratuais que contrariarem os direitos políticos e "naturais" dos trabalhadores (entre eles, o exercício da liberdade de ir e vir e de decidir a qual trabalho deseja ou não se submeter), além dos direitos estabelecidos na própria lei.

\footnotetext{
${ }^{521}$ A íntegra do projeto de lei que tinha por objetivo regular as relações de trabalho, de Rafael Zubarán Capmany, publicado em 12 de abril de 1915, está disponível em: Dirección General de Bibliotecas (DGB). Cidade do México: Secretaría de Educación Pública: Consejo Nacional para la Cultura y las Artes, 2013. http://dgb.conaculta.gob.mx/coleccion_sep/libro_pdf/50000006389.pdf\#toolbar=0 p. 26. Consulta realizada em 21/12/2015.
} 
Nenhum desses dispositivos, porém, tinham merecido qualquer menção de Zubarán em sua exposição de motivos. Polêmica, e digna de nota, era a norma que dispunha sobre quem teria a capacidade civil para firmar contratos de trabalho:

Art. 11 - Todos los que hayan cumplido dieciocho años, aun cuando fueren mujeres casadas, tienen capacidad legal para celebrar contratos de trabajo, para percibir la retribución convenida y para ejercitar las acciones que nazcan del contrato, sin necesidad de ninguna autorización. ${ }^{522}$

$\mathrm{O}$ artigo polêmico conferia às mulheres - maiores de dezoito anos, tal como os homens - capacidade civil plena para decidir vender sua própria força de trabalho. Com essa norma, diminuía-se o poder marital e rompia-se com a prática mexicana de pedir autorização para os maridos para que suas mulheres pudessem trabalhar. Ainda sobre capacidade para contratar, salvo em circunstâncias excepcionais previstas no projeto de lei, menores de doze anos não poderiam trabalhar. Entre doze e dezoito anos, o contrato de trabalho deveria ser autorizado pelos responsáveis - pais ou maridos - e se limitar a seis horas diárias.

Também no primeiro capítulo da lei, prazo para que uma ação judicial relacionada a questões trabalhistas pode ser proposta (um ano a partir do fim do contrato de trabalho); o direito que todos os trabalhadores têm de obter um documento que informe, ao fim do contrato, a data de início, a data de término e o tipo de atividades realizadas.

O segundo capítulo do projeto de lei (arts. 18 a 25, trata dos "Derechos y obligaciones de los patronos y de los obreros". Para além do respeito e consideração que devem permear as relações entre patrões e empregados, reciprocamente, os patrões ficam obrigados, por força do artigo 20 do projeto de lei, a garantir que o ambiente de trabalho tenha boas condições de higiene e que não prejudique a saúde de seus empregados; que haja ações preventivas de acidentes, que realize o pagamento nos dias estipulados, que não promova qualquer tipo de diferenciação entre trabalhadores de

\footnotetext{
${ }^{522}$ A íntegra do projeto de lei que tinha por objetivo regular as relações de trabalho, de Rafael Zubarán Capmany, publicado em 12 de abril de 1915, está disponível em: Dirección General de Bibliotecas (DGB). Cidade do México: Secretaría de Educación Pública: Consejo Nacional para la Cultura y las Artes, 2013. http://dgb.conaculta.gob.mx/coleccion_sep/libro_pdf/50000006389.pdf\#toolbar=0 p. 28. Consulta realizada em 21/12/2015.
} 
diferentes nacionalidades, que garanta habitações cômodas e com condições de higiene adequadas, que forneça alimentação apropriada, que garanta os materiais necessários e condizentes com o trabalho, que indenize os trabalhadores em casos de negligência e ordens inadequadas quando essas trouxerem algum prejuízo ao trabalhador, sobretudo se gerarem acidentes de trabalho. $\mathrm{O}$ artigo 21 obriga os patrões a pagarem salários equivalentes nos casos em que trabalhadores são remunerados por peças produzidas e ficam impossibilitados de trabalhar em função da ausência de insumos causada pelo próprio patrão.

O artigo 22, espelho do artigo 20, apresenta uma lista de obrigações dos trabalhadores em relação a seus patrões. A primeira delas trata-se do dever de respeito à autoridade e à direção de seus patrões - e delegados - em tudo o que dissesse respeito à realização do trabalho: intensidade, cuidado e esmero na realização das atividades sob sua responsabilidade, no local de trabalho indicado; respeito às normas do regulamento da indústria ou oficina em que trabalhe; precaução, para não causar danos a si mesmo, aos colegas de trabalho ou a terceiros e ao maquinário da indústria. Muito embora todos os empregados devessem ser, de acordo com o projeto de lei, cuidadosos para não colocar em risco nem a própria saúde, nem o maquinário e os equipamentos que pertençam ao local de trabalho, uma das frações (incisos) do artigo 22 afirma explicitamente que os trabalhadores não são responsáveis pelo desgaste natural de equipamentos que usem cotidianamente, devendo indenizar a empresa ou seus patrões apenas nos casos em que o dano for causado por negligência ou desobediência a ordens expressas. Por fim, regulam-se os casos de produtos imperfeitos, substituições e pró́bese a divulgação de segredos de fabricação.

Na lista de obrigações dos trabalhadores do art. 22, a fração VII foi a que pareceu mais polêmica a Zubarán, que teceu considerações sobre ela em sua exposição de motivos: em situações de perigo iminente o trabalhador teria o dever de realizar horas de trabalho extras. Em sua justificativa, Zubarán afirma que haveria nesses casos uma solidariedade de interesses, já que o perigo iminente deve significar um perigo à própria existência da fábrica ou da linha de produção. E, nesses casos, é o próprio emprego do trabalhador que estaria em risco caso a fábrica sucumbisse.

O terceiro capítulo do projeto de lei de Zubarán determina a jornada máxima e o salário mínimo (artigos 26 a 42). Para jornada máxima, estipula oito horas de trabalho efetivo, contadas a partir da entrada no local de trabalho, descontando-se os períodos de 
descanso e de alimentação. Em caso de serem necessárias horas extras, aceitas de comum acordo, elas devem ser sobreremuneradas em pelo menos $50 \%$ (art. 28). A jornada máxima para aqueles que são menores, entre doze e dezoito anos, deve ser de seis horas (art. 29). Todos os trabalhadores têm direito a um dia de descanso semanal (art. 30). Nos quinze dias após o parto, é proibido o trabalho às mulheres que, no entanto, terão direito ao salário tal como se tivessem trabalhado.

Art. 33 - La cuantía del salario será estipulada libremente en el contrato; pero en ningún caso podrá convenirse salario que no satisfaga las necesidades materiales del obrero, y las demás indispensables para llenar las exigencias de una vida decorosa. ${ }^{523}$

Ao contrário de diversos decretos aprovados nos diferentes estados mexicanos, Zubarán decide não definir o valor exato do salário mínimo. A razão, que está tanto na exposição de motivos quanto no texto que segue no próprio artigo, deriva supostamente do fato de o México contar com diferentes custos de vida, sendo muito variável o valor necessário para garantir uma "vida decorosa". O projeto prefere criar um órgão responsável por definir, em cada região do México, um valor mínimo a ser aplicado. O artigo 34, por sua vez, tem intenção parecida com a de Carranza meses depois: diminuir a força das tiendas de raya. Assim, obriga que os empregadores realizem os pagamentos com moedas de curso legal, restando proibidos quaisquer outros meios de pagamento ou a obrigação de gastar ("investir") o salário em lojas específicas. O projeto também proibe que os salários sejam descontados ou embargados. Excepcionalmente, estabelece um limite para o valor de dívida que um empregador poderia contrair com seus empregadores e qual a porcentagem do seu próprio salário poderia ser não paga.

Curioso notar que o projeto de lei de Zubarán não hesita em estabelecer a jornada máxima de oito horas - bastante avançada na proteção ao trabalhador para a época. No entanto, decide não estipular um salário mínimo correspondente. Suas razões parciais na exposição de motivos do projeto de lei:

\footnotetext{
${ }^{523}$ A íntegra do projeto de lei que tinha por objetivo regular as relações de trabalho, de Rafael Zubarán Capmany, publicado em 12 de abril de 1915, está disponível em: Dirección General de Bibliotecas (DGB). Cidade do México: Secretaría de Educación Pública: Consejo Nacional para la Cultura y las Artes, 2013. http://dgb.conaculta.gob.mx/coleccion_sep/libro_pdf/50000006389.pdf\#toolbar=0 p. 32. Consulta realizada em 21/12/2015.
} 
La resistencia orgánica al influjo del esfuerzo, no es indefinida, sino que tiene un punto, más allá del cual, el esfuerzo desgasta gravemente los resortes de la vida; produciendo el agotamiento. Y si esto es verdad, y nadie duda que lo sea, es natural sentirse inclinado a no permitir que se exija al ser humano un esfuerzo mayor que el que humanamente puede resistir sin poner en peligro la conservación de su éxistencia. El Estado tiene un interés, más aún, tiene un deber que cumplir, evitando el sacrificio de seres humanos que, por su situación desvalida, se matan trabajando para poder vivir. ${ }^{524}$

Evitar o esgotamento dos trabalhadores é uma tarefa do Estado. Essa parece ser a convicção de Zubarán no trecho da exposição de motivos, até porque os trabalhadores são tratados como mais um dos fatores de produção, ou mesmo insumos, a serem garantidos e preservados também para o bem da produtividade nacional. Tendo em vista o desenvolvimento nacional, o estoque de mão de obra, e também a proteção e a qualidade de vida dos trabalhadores, o projeto de lei determina que a jornada máxima é de oito horas. A mesma convicção não se verifica quando se trata de definir o preço da força de trabalho. Talvez seu liberalismo (social, é verdade) acredite que as leis da demanda e da oferta regularão melhor do que o Estado esse mercado.

Muito embora o valor não fosse definido, a lei determinava a forma de pagamento (moeda de curso legal), o lugar (dentro das instalações, protegido de pilhagens) e o impedimento de desconstos excessivos. Apenas a definição do valor fica de fora, restringindo-se o projeto a um conceito: salário suficiente para garantir uma vida decorosa.

O quarto capítulo do projeto de lei de Zubarán trata da forma de instituir e modificar o "Reglamento del taller" (artigos 43-51), referente aos regulamentos internos das indústrias, estabelecendo limites que impediriam arbitrariedades, segundo a exposição de motivos. São eles fixação do documento em lugar permanente e visível, para garantir a publicidade; registro no departamento do trabalho; impedimento de que as normas dos regulamentos contradigam os dispositivos legais; modificações informadas e sujeitas às observações dos trabalhadores; forma de estabelecer penalidades por descumprimento de ordens etc. Zubarán excluiu deliberadamente a possibilidade de os trabalhadores terem voz e voto na discussão para aprovação e

${ }^{524}$ A íntegra do projeto de lei que tinha por objetivo regular as relações de trabalho, de Rafael Zubarán Capmany, publicado em 12 de abril de 1915, está disponível em: Dirección General de Bibliotecas (DGB). Cidade do México: Secretaría de Educación Pública: Consejo Nacional para la Cultura y las Artes, 2013. http://dgb.conaculta.gob.mx/coleccion_sep/libro_pdf/50000006389.pdf\#toolbar=0 p. 9. Consulta realizada em 21/12/2015. 
modificação dos regulamentos internos, como era proposta em outros países, pois a considerou uma pretensão exagerada dos trabalhadores. Por outro lado, foram proibidas as multas por infrações disciplinares, que deveriam ser penalizadas por outros meios, como perda de dias de feriado.

O capítulo quinto especifica por sua vez as hipóteses de "Terminación del contrato" (artigos 52 a 62). Como a regra prevista no primeiro capítulo é de que os contratos serão sempre por tempo ou por tarefa determinada, seu fim natural é o fim do período contratado ou o fim da tarefa realizada. Pelo contrário, "El patrono no podrá despedir al obrero, ni éste retirarse del servicio, antes del vencimiento del término convencional o legal del contrato, o-de la conclusión de la obra, sino con motivo justificado." 525

O contrato só se extingue, em casos excepcionais que não cheguem até o fim do seu objeto, por meio de motivos justificados, sendo que dez artigos dispõem as situações nas quais isso pode acontecer. As situações previstas vão desde força maior, comum acordo, até o que se conhece contemporaneamente como justa causa, ou seja, descumprimento de deveres funcionais básicos, como o empregado ter praticado contra o patrão, ou vice-versa, maus tratos ou violência física, falta de pagamento e divulgação de segredos industriais, entre outros.

Nesse capítulo é interessante a menção, mesmo que indireta, à possibilidade de existirem organizações de trabalhadores e de patrões:

Art. 58. -Nunca será motivo justificado por parte del patrono para despedir al obrero, o de éste para retirarse del servicio, el hecho de que uno $\mathrm{u}$ otro ingresen a corporaciones patronales u obreras, o que ejerciten sus derechos naturales, civiles o políticos.

Não só as corporações de trabalhadores são admitidas, como em nenhuma circunstância uma filiação pode ser motivo para represália. Além da adesão a sindicatos, também o exercício de direitos civis e políticos é garantido a todos os trabalhadores, não estando sujeito a restrições por parte dos patrões. Por fim, em casos de rescisão

\footnotetext{
${ }^{525}$ A íntegra do projeto de lei que tinha por objetivo regular as relações de trabalho, de Rafael Zubarán Capmany, publicado em 12 de abril de 1915, está disponível em: Dirección General de Bibliotecas. Cidade do México: Secretaría de Educación Pública: Consejo Nacional para la Cultura y las Artes, 2013. http://dgb.conaculta.gob.mx/coleccion_sep/libro_pdf/50000006389.pdf\#toolbar=0 p. 37. Consulta realizada em 21/12/2015.
} 
contratual sem motivo justificado, fica obrigado a indenizar aquele que rescindiu o contrato. Em todos os casos, o pagamento dos valores devidos a título de salário será feito no mesmo dia da rescisão, afirma o projeto.

O capítulo sexto traz as normas relativas ao "Contrato colectivo del trabajo" (artigos 63 a 79). Zubarán chama atenção para o fato de os ditos contratos coletivos não serem efetivamente contratos, mas sim convenções, acordos que determinariam as cláusulas e os limites dos contratos individuais. Segundo a exposição de motivos do projeto, este é um dos capítulos que mais rompe com a lógica individualista contratual relacionada ao trabalho, pois seu formato inovador (para a época) permitiria a ação dos grupos coletivos nas relações trabalhistas. De inspiração francesa e sueca, o convênio prévio define quais condições estarão presentes nos contratos individuais que venham a ser celebrados. Um coletivo de trabalhadores negociando tais condições tem muito mais força do que um trabalhador que individualmente decida discutir os termos de sua contratação. Assim, o formato também garante ao trabalhador maior poder na negociação das obrigações e deveres presentes em seu contrato de trabalho e essa é a razão mais clara de sua existência.

Para além da afirmação da possibilidade genérica de realizar contratos coletivos, o projeto de lei também define em que circunstâncias esse contrato pode se dar: somente uma corporação operária ou sindicato legalmente constituído pode firmar um contrato coletivo; para ser um sindicato, por sua vez, é necessário que reúna pelo menos cinco trabalhadores. Sua constituição deve se dar por escrito, ser pública e registrada junto a um órgão público municipal (uma secretaria que, a partir da lei, passaria a ter essa função). No mesmo órgão municipal, deveriam ser registrados os próprios contratos coletivos firmados, também com o objetivo de garantir sua publicidade e coercibilidade. Por fim, deveriam ser favorecidos pelos contratos firmados apenas os trabalhadores filiados aos sindicatos ou corporações operárias que tiverem realizado o contrato. Trabalhadores do mesmo setor que não fizessem parte de seus coletivos, não seriam abrangidos pelas cláusulas do contrato negociado.

O sétimo e último capítulo do projeto de lei de Zubarán chama-se "disposiciones complementarias" (artigos 80 a 100). O primeiro artigo estabelece que os créditos devidos aos trabalhadores têm preferência na ordem de pagamento em caso de falência ou insolvência mercantil (art. 80). Entre as disposições complementares, está também a competência da justiça comum para apreciar questões ligadas às relações de trabalho 
(art. 82). O próprio artigo expõe uma interpretação da Constituição de 1857 que proibiria a criação de qualquer tribunal temático especial. O artigo 83, porém, afirma que os processos relacionados a questões trabalhistas deveriam ser sumários, reduzindose o rito ordinário ao mínimo.

O artigo 87, segundo a exposição de motivos de Zubarán, tem por objetivo estimular e proteger o trabalhador em uma situação específica, mas frequente no México de 1915: a migração para outras regiões e lugares de trabalho. A norma dispõe que, se o empregador foi responsável pelos custos da viagem que levou o trabalhador até o local de trabalho - em distâncias maiores do que vinte quilômetros - encerrado o contrato, o empregador será responsável por levar o trabalhador de volta a seu local de origem.

Por fim, o artigo 88 obriga o Departamento del Trabajo a criar mecanismos para que a lei fosse cumprida e servir de mediador em casos de conflito. O mesmo Departamento é responsável por dirimir dúvidas sobre as normas do projeto de lei, caso surgissem no momento em que fosse implementado. Os artigos 89 a 93 contém uma série de normas cujo objetivo final é impedir a prática de tiendas de raya controladas pelos patrões ou seus aliados, que praticavam preços abusivos e possuíam mecanismos de constrangimento dos trabalhadores. São elas: liberdade para a circulação de mercadorias, proibição de pagar com vales, que, quando existirem, tenham de forma bastante clara os preços de seus produtos e que se pratique a compra e venda imediata, sem marcações e dívidas em aberto.

Os artigos seguintes visam a proteger a liberdade de ir e vir dos trabalhadores, tema especialmente sensível para aqueles que moram em alojamentos e residências industriais. Os artigos 99 e 100 estabelecem multas de vinte a cem pesos e privação de liberdade equivalente, nos casos em que não for possível pagar o valor determinado. Por fim, nas disposições transitórias, o projeto estabelece um prazo de três meses para que as indústrias se adequem às regras da lei, sobretudo para que elaborem seus regulamentos internos.

Essa longa e detalhada regulamentação sobre as relações de trabalho proposta por Rafael Zubarán Capmany pode não ser a mais protetiva do trabalhador. Para comprovar isso, basta lembrar que ela deixa de estipular um valor para o salário mínimo, prevê uma situação em que o trabalhador é obrigado a cumprir horas extras de trabalho e abre exceções para o funcionamento de tiendas de raya. Mesmo assim, se 
fosse implementada, modificaria profundamente o equilíbrio de forças entre patrões e empregados, sendo, nacionalmente, a proposta mais avançada até o momento de sua publicação.

En la redacción misma del proyecto se ha procurado prescindir intencionalmente de todo tecnicismo jurídico o económico, y se ha procurado que la expresión de cada concepto se hiciera en lenguaje llano, buscando siempre la mayor claridad, aun a costa de irregularidades en el lenguaje y de redundancias en las frases, no perdiendo de vista la consideración de que esta ley ha de correr de mano en mano entre los obreros; y que si hay bastantes que por su actual cultura están capacitados para entender y asimilar sin esfuerzo los preceptos legales, hay por desgracia muchos todavía que no podrían tomar una perfecta inteligencia de la significación y alcance de los preceptos, si no se les presentaran en lenguaje llano y corriente, $\mathrm{y}$ aun en locuciones usuales y a las veces hasta triviales. ${ }^{526}$

Ainda na exposição de motivos, Zubarán deixa claro seu objetivo quando o projeto fosse aprovado. Desejava que ele passasse de mão em mão, que ele de fato fosse conhecido pelos trabalhadores, a quem deveria proteger contra arbitrariedades. Interessante notar que, tendo em vista esse objetivo, seu redator preocupou-se especialmente com a linguagem em que ele seria escrito: linguagem clara, sem duplos sentidos, por vezes repetitiva. O sacrifício estilístico era necessário em nome de um valor mais importante: que o texto fosse compreendido claramente pelos destinatários da norma.

No entanto, apesar de todo o esforço de reflexão, direito comparado e redação, o projeto de lei de Zubarán permaneceu apenas um projeto, sem aplicação prática. Por decisão de Venustiano Carranza, que, em junho de 1915, publicou outro decreto paliativo que só aparentava extinguir os abusos das tiendas de raya. Muito mais restrito em seus objetivos do que o projeto de lei apresentado meses antes por Zubarán, nem sua proposta de encerrar com a prática de pagamento salarial via tienda de raya ele conseguia realizar, como já analisado na seção 3.4.10.

\footnotetext{
${ }^{526}$ A íntegra do projeto de lei que tinha por objetivo regular as relações de trabalho, de Rafael Zubarán Capmany, publicado em 12 de abril de 1915, está disponível em: Dirección General de Bibliotecas (DGB). Cidade do México: Secretaría de Educación Pública: Consejo Nacional para la Cultura y las Artes, 2013. http://dgb.conaculta.gob.mx/coleccion_sep/libro_pdf/50000006389.pdf\#toolbar=0 p. 23. Consulta realizada em 21/12/2015.
} 
A Soberana Convención de Aguascalientes, meses depois, redigiu uma proposta de normas para prevenção de acidentes do trabalho em outubro de 1915 e, em 1916, a questão trabalhista figurou também em seu Programa de Reformas Políticos-Sociales. Nenhuma delas, porém, teve a mesma abrangência que o projeto de Zubarán Capmany. Com pretensões de validade nacional, ele foi a tentativa mais ampla de regulação das relações laborais e, talvez por suas altas pretensões, tenha sido abortado por Carranza. Seu impacto só se fez sentir ao influenciar a redação do artigo 123 da Constituição de 1917, um ano e meio depois.

\subsubsection{A Soberana Convención Revolucionaria e o trabalho: Ley sobre accidentes del trabajo (1915); Proyecto de Ley General del Trabajo (1915) e Programa de Reformas Político-Sociales (1916)}

Em 6 de novembro de 1914, a Soberana Convención Revolucionária de Aguascalientes viveu uma cisão: ao aceitar a renúncia de Venustiano Carranza como primer jefe no exercício do Poder Executivo e indicar como presidente provisório Eulálio Gutiérrez, o grupo de líderes revolucionários abertamente negava a Carranza o protagonismo que ele próprio considerava ter. Neste momento, Carranza desconsidera as decisões da convenção que ele mesmo tinha inicialmente convocado para, sediado na cidade de Veracruz, exercer um governo paralelo. A partir dessa cisão, mais bem explicada no primeiro capítulo do presente trabalho, carrancistas (auto-intitulados constitucionalistas) e convencionistas voltaram à luta armada, buscando ter efetivo controle do país.

Os projetos de lei dos líderes constitucionalistas nos diferentes estados, a mudança constitucional levada a cabo por meio de decreto, o projeto de lei de Rafael Zubarán Capmany e a proibição das tiendas de raya concorriam, lado a lado com a luta armada, pela disputa simbólica sobre quem governava efetivamente o país.

Esse esforço foi também realizado pelo Consejo Ejecutivo de la Soberana Convención Revolucionária e pelos Zapatistas, com algum atraso. O primeiro documento normativo que visava estabelecer melhores relações de trabalho para os mexicanos, também com pretensões de validade nacional, foi a Ley sobre Accidentes del Trabajo, de 27 de outubro de 1915. Seus onze artigos visam a "proteger a las clases trabajadoras contra la acción tiránica y explotadora de los detentadores de los medios 
de producción de la riqueza"527. Logo em seu artigo primeiro estabelece de forma bastante ampla as responsabilidades dos patrões e proprietários de terras por todos os acidentes ocorridos nas dependências de trabalho, não podendo "en ningún caso alegar para eximirse de su obligación culpa o negligencia de la víctima" ${ }^{528}$ a não ser que seja o caso de força maior, sem qualquer relação com as atividades laborais desenvolvidas. A norma convencionista é aquela que oferece maior proteção ao trabalhador, quando comparada a todas as outras estaduais formuladas até então. $\mathrm{O}$ artigo segundo, por sua vez, inclui na definição de acidente de trabalho as doenças laborais causadas por contato constante com substâncias químicas ou a submissão a condições de trabalho degradantes.

$\mathrm{O}$ artigo terceiro e o quarto estabelecem os valores das indenizações para casos de acidentes, que variam desde o pagamento de jornales para os dias de afastamento até três anos de salário nos casos mais graves - morte ou incapacidade laboral permanente. Como instância para resolução de conflitos a lei indica uma instituição criada pela própria convenção: as Juntas de Reformas Revolucionarias. As ações devem ser propostas no prazo de um ano e, se os acidentes tiverem se produzido em função de imprudência, dolo ou culpa do empregador, além das indenizações pode haver também responsabilização penal. Por fim, a própria lei estabelece sua forma de divulgação: seu texto deve ser publicado, divulgado e afixado em todos os centros de trabalho, em local visível.

Dias depois, em 7 de novembro de 1915, o mesmo Consejo Ejecutivo de la Soberana Convención Revolucionária publica seu Proyecto de la Ley General del Trabajo $^{529}$. Logo no primeiro artigo, o projeto de lei garante a todos os trabalhadores o direito de aproveitar o produto integral de seu trabalho. Os artigos seguintes tratam da socialização dos meios de produção daqueles empresários que, ao falecer, não deixaram sucessores. Essas empresas deveriam passar a ser geridas pelas autoridades municipais,

\footnotetext{
${ }^{527}$ A íntegra da Ley sobre Accidentes del Trabajo, publicada em 27 de outubro de 1915 pela Soberana Convención Revolucionária disponível em: BIBLIOTECA GARAY. 500 años de México en documentos. México, 2011. <http://www.bibliotecas.tv/zapata/1915/z27oct15.htm> Consulta realizada em 21/12/2015. ${ }^{528}$ A íntegra da Ley sobre Accidentes del Trabajo, publicada em 27 de outubro de 1915 pela Soberana Convención Revolucionária disponível em: BIBLIOTECA GARAY. 500 años de México en documentos. México, 2011. <http://www.bibliotecas.tv/zapata/1915/z27oct15.htm> Consulta realizada em 21/12/2015. ${ }^{529}$ A íntegra do Proyecto de la Ley General del Trabajo, publicada em 7 de novembro de 1915 pela Soberana Convención Revolucionária disponível em: BIBLIOTECA GARAY. 500 años de México en documentos. México, 2011. 〈http://www.bibliotecas.tv/zapata/1915/z07nov15.htm> Consulta realizada em 21/12/2015.
} 
assim como aquelas que fossem prejudiciais à sociedade, por praticar monopólios, por exemplo.

O artigo sexto estabelece a jornada de trabalho de oito horas, sendo obrigatório o descanso dominical. A exemplo do projeto de Zubarán, o projeto convencionista também não estabelece salário mínimo, deixando a cargo das Juntas de Reformas Revolucionarias sua definição, devendo ser o suficiente para garantir "la subsistencia humilde pero completa de los trabajadores y de las familias de éstos" ${ }^{530}$. Curiosamente o projeto de lei reforça a punição penal que já existia no ordenamento jurídico mexicano para a vagabundagem (vagancia). A única diferença para com a regra já existente era seu alvo, pois o projeto de lei da Soberana Convención determina que "Los que vivan de sus rentas serán considerados vagos mientras no tengan una ocupación que sea productiva y útil a la sociedad" ${ }^{531}$. Ou seja: aqueles que não trabalham por terem uma condição financeira privilegiada, não por não conseguirem encontrar emprego. $\mathrm{O}$ projeto de lei se encerra afirmando sua própria validade para todo o território mexicano. Apesar de curta, a proposta de normatização convencionista é bastante avançada nos tópicos que regula.

Por fim, em 18 de abril de 1916, a Soberana Convención Revolucionária publica seu documento mais conhecido: o Programa de Reformas Político-Sociales. Nele, a questão agrária ocupa o primeiro capítulo (artigos $1^{\circ}$ a $5^{\circ}$ ) e, logo em seguida, está a questão operária (artigos $6^{\circ}$ a $9^{\circ}$ ). Programa extremamente enxuto em todos os temas, limita-se ao essencial, talvez como estratégia de comunicação. Em relação aos problemas ligados ao cotidiano dos trabalhadores, estabelece os temas que deverão ser objeto de regulamentação e definição em futuras legislações convencionistas:

Art. 6. Precaver de la miseria y del futuro agotamiento a los trabajadores, por medio de oportunas reformas sociales y económicas, como son: una educación moralizadora, leyes sobre accidentes del trabajo y pensiones de retiro, reglamentación de las horas de labor, disposiciones que garanticen la higiene y seguridad en los talleres,

\footnotetext{
530 A íntegra do Proyecto de la Ley General del Trabajo, publicada em 7 de novembro de 1915 pela Soberana Convención Revolucionária está disponível em: BIBLIOTECA GARAY. 500 años de México en documentos. México, 2011. <http://www.bibliotecas.tv/zapata/1915/z07nov15.htm> Consulta realizada em 21/12/2015.

531 A íntegra do Proyecto de la Ley General del Trabajo, publicada em 7 de novembro de 1915 pela Soberana Convención Revolucionária disponível em: BIBLIOTECA GARAY. 500 años de México en documentos. México, 2011. <http://www.bibliotecas.tv/zapata/1915/z07nov15.htm> Consulta realizada em $21 / 12 / 2015$.
} 
fábricas y minas, y en general por medio de una legislación que haga menos cruel la explotación del proletariado. ${ }^{532}$

Prevenir casos de miséria e esgotamento, educação, acidentes de trabalho, aposentadorias, quantidade máxima de horas por jornada, condições e ambiente limpo e salubre, e menos crueldade nas relações de trabalho estão entre os futuros objetos de regulamentação almejados pela já bastante enfraquecida Convenção Revolucionária. Além desses temas, o próprio documento apresenta alguns outros: reconhecimento da personalidade jurídica das organizações de trabalhadores $\left(\operatorname{art} 7^{\circ}\right.$ ); reconhecimento do direito de greve e de boicote de todos os trabalhadores (art. $8^{\circ}$ ) e, por fim, supressão de todas as tiendas de raya e dos pagamentos em formato de vale. Apesar de bastante enxuto, o Programa contempla algumas das principais questões dos trabalhadores mexicanos.

O fato de o documento ter sido publicado quando os convencionistas já estavam praticamente derrotados, porém, fez com que tivesse pouquíssima aplicação prática. Seja como for, embora derrotados militarmente, os convencionistas e os acordos a que conseguiram chegar nessa tentativa de democracia revolucionária também tiveram sua influência na elaboração final da Constituição de 1917.

\subsection{O artigo 123 da Constituição dos Estados Unidos Mexicanos de 1917}

Ao contrário da antiga questão agrária mexicana, as relações e condições de trabalho passam a ser um problema separado do próprio problema da terra apenas no final do século XIX. É no início do século XX que os movimentos operários mexicanos ganham força organizativa, notadamente com as greves de Cananea e Río Blanco. Muito embora o Programa do Partido Liberal Mexicano, de 1906, já trouxesse propostas bastante avançadas, a preocupação era praticamente inexistente nos documentos revolucionários que informaram o levante maderista em novembro 1910.

\footnotetext{
${ }^{532}$ A íntegra do Programa de Reformas Político-Sociales de la Soberana Convención Revolucionária, de 18 de abril de 1916, está em: CARMONA, Doralicia. Memoria política de México. Guanajuato: Universidade de Guanajuato, 2014. Disponível em:

$\langle$ http://www.memoriapoliticademexico.org/Textos/6Revolucion/1916PRP.html $>$ Consulta realizada em $27 / 12 / 2015$
} 
Com exceção do Plan Político-Social elaborado por apoiadores da luta maderista, de março de 1911, e do Plan de la Empacadora, de Pascual Orozco, em clara oposição a Madero, as condições de vida dos trabalhadores mexicanos estavam ausentes das propostas e reivindicações das diferentes correntes revolucionárias. Somente a partir de maio de 1914, e principalmente a partir de agosto do mesmo ano (após renúncia de Huerta, em julho), quando os líderes do Exército Constitucionalista passaram a se consolidar no controle político de diferentes estados mexicanos, é que o direito do trabalho volta à tona, por meio de decretos que instituem novas regras para as relações de trabalho.

Esse instantâneo interesse dos constitucionalistas pelas condições de trabalho que, a essa altura, já vislumbravam o conflito entre as diferentes correntes revolucionárias - parece ter sido parte de uma estratégia para obter para si uma bandeira própria. Zapatistas, villistas e convencionistas já tinham se apropriado simbolicamente da defesa de uma organização fundiária mais justa. O fato de os zapatistas terem sofrido pessoalmente a injusta apropriação de terras comunitárias promovida por Díaz aumentava significativamente suas legitimidades para discutir e propor soluções para a questão.

Os constitucionalistas, cuja bandeira inicial - o respeito à Constituição, vilipendiada pela ação autoritária de Huerta - já tinha se realizado com a renúncia do presidente inconstitucional, precisava de um novo impulso simbólico para a segunda fase da luta, entre as correntes revolucionárias. A escolha parece ter sido a defesa dos direitos do trabalhador, opção mais simbólica do que efetiva, como mostram a maioria dos documentos normativos dos líderes constitucionalistas, restritos em seus propósitos. Mais eloquente do que os documentos estaduais, são as movimentações de Venustiano Carranza: primeiro, decreta uma mudança constitucional para autorizar legislações federais sobre direito do trabalho, pede para que um de seus secretários (Zubarán) elabore um projeto de lei sobre a matéria. Pronto o projeto de lei, decide não transformá-lo em lei de fato. Ao invés disso, publica um decreto de abrangência muito mais restrita, voltado a supostamente acabar com as tiendas de raya. Seu esforço é vão e o próprio texto normativo diz isso: o enfrentamento dos comércios ilegais só acabará quando os municípios forem capazes de promover a concorrência, e quando as instâncias judiciais forem instaladas nas regiões. 
Os convencionistas, após perceberem a movimentação de Carranza e dos constitucionalistas, também formularam suas próprias normas de proteção ao trabalhador, muito mais avançadas e efetivas - se fossem aplicadas - do que as carrancistas. No entanto, os documentos chegaram tarde: no segundo semestre de 1915, os constitucionalistas já haviam se consolidado como o grupo defensor dos direitos do trabalhador e já tinham conseguido trazer para seu lado da luta até a Casa del Obrero Mundial. Os carrancistas venceram o embate simbólico e aparentavam ser o grupo que mais defenderia - uma vez no governo - os direitos dos trabalhadores. Obtida a vitória e à frente do governo, rapidamente a imagem cuidadosamente forjada se desfez: A repressão de Carranza à greve geral de 30 de julho de 1916 mostrou que seu interesse pelas condições de vida dos trabalhadores era apenas instrumental para ganhar uma guerra que se combatia com armas e sangue, mas também com ideias e legitimidade.

Em setembro de 1916, Carranza convoca eleições para um Congresso Constituinte que seria responsável por elaborar uma nova Constituição para o México do início do século XX. No início dos trabalhos, encaminha ao Congresso uma versão preliminar bastante tímida no que tange direitos sociais pelos quais a Constituição de 1917 ficaria conhecida. Pode-se afirmar que, se a Constituição tem características notáveis, elas não são de responsabilidade de Carranza, mas sim dos deputados constituintes que compuseram o Congresso de 1916-1917.

No projeto inicial encaminhado para o Congresso, o trabalho estava regulamentado apenas no artigo $5^{\circ}$ da Constituição - e não também no art. 123, entre as competências legislativas do Congresso, como consolidou-se na versão final. O texto de Carranza praticamente repete o texto da Constituição de 1857 ao afirmar que ninguém poderá ser obrigado a trabalhar sem a justa retribuição e sem seu consentimento ${ }^{533}$. Acrescenta ainda duas exceções para a liberdade de trabalho: se a obrigação for

533 O texto integral do Projeto de Constituição encaminhado por Venustiano Carranza ao Congresso Constituyente, em 6 de dezembro de 1916, está disponível em: Diário de los debates del Congreso Constituyente, 6 de diciembre de 1916. Centenario de la Constitución Política de los Estados Unidos Mexicanos 1917. Cidade do México: Instituto Nacional de Estudios Históricos de las Revoluciones de México (INEHRM), 2015, p. 345.

<http://www.constitucion1917.gob.mx/work/models/Constitucion1917/Resource/251/1/images/016.pdf> Consulta realizada em 28/12/2015. 
derivada de decisão judicial, deve ser cumprida (hipótese especialmente cruel para os trabalhadores) e em caso de serviços públicos obrigatórios (serviço militar, eleitorado e jurado). $\mathrm{O}$ texto do artigo $5^{\circ}$ da proposta carrancista de Constituição inclui, ainda, outras garantias à liberdade e institui o contrato por tempo determinado de, no máximo, um ano.

Mais uma vez Carranza oferece provas de sua falta de compromisso com os direitos dos trabalhadores. Pode-se argumentar que entre as constituições do resto do mundo não havia nenhuma a incluir em seu texto extensos direitos de categorias. $\mathrm{O}$ que Carranza fez foi seguir o estilo de normas, a técnica legislativa, a forma costumeira com que as constituições até então vinham sendo escritas. Seja como for, mesmo neste curto texto não houve a intenção clara de melhorar as condições de vida dos trabalhadores mexicanos.

Já o artigo 123 é bastante extenso. Suas trinta frações têm pretensões de regular um amplo espectro de temas relacionados a questões laborais. Válido para todos os tipos de trabalhadores - já que no caput afirma-se sua validade para "todo contrato de trabajo" - a primeira fração do artigo define a jornada máxima válida para o México: oito horas. Além dessa definição, muitas outras estão presentes nas vinte e nove frações seguintes: trabalho noturno proibido para menores de doze anos, com jornada máxima de sete horas; proibição de trabalho de crianças menores de doze anos; obrigatoriedade de um dia de descanso semanal e de um mês de licença remunerada para mulheres que tiverem filhos; proibição de promover discriminação salarial em função de nacionalidade ou sexo; proibição de descontos, embargos ou compensações nos salários dos trabalhadores; obrigação de pagamento em moeda de curso legal (pesos); aumento de $100 \%$ na remuneração de horas extras trabalhadas, que devem ser realizadas de acordo com um limite máximo (três horas, três vezes consecutivas); garantia de moradia digna para os trabalhadores que vivam nas propriedades de seus empregadores; garantia de serviços básicos nas comunidades que sejam formadas a partir das residências de trabalhadores (mercados públicos, escolas, enfermarias, prédios para serviços municipais, centros recreativos); responsabilidade dos empregadores por acidentes de trabalho e doenças laborais, que deverão ser indenizadas; responsabilidade por manter o ambiente de trabalho em condições de higiene e salubridade, além de realizar ações preventivas de acidentes. 
O artigo 123 da Constituição dos Estados Unidos Mexicanos de 1917 estabelece ainda que empresários e trabalhadores têm direito a fundarem associações de classe ou sindicatos para defenderem seus interesses. Trabalhadores têm direito também a realizarem greves e empresários, paralisações. Os "paros" patronais, como indica a fração XIX do artigo, só são admissíveis como estratégia para o controle de preços para que a superprodução não prejudique os empresários. Depende também de prévia autorização da Junta de Conciliación y Arbitraje, definida na fração IX. Já as greves serão consideradas lícitas - de acordo com a fração XVIII, "cuando tengan por objeto conseguir el equilibrio entre los diversos factores de la producción, armonizando los derechos del trabajo con los del capital.". Por outro lado, após uma observação sobre as greves de servidores públicos - que deveriam notificar as autoridades sobre a existência da greve com dez dias de antecedência - o texto da fração segue "Las huelgas serán consideradas como ilícitas únicamente cuando la mayoría de los huelguistas ejerciera actos violentos contra las personas o las propiedades"534.

Assim, se por um lado devem ser consideradas lícitas as greves que queiram alcançar equilíbrio e harmonia entre capital e trabalho, elas só serão consideradas ilícitas quando a maioria dos trabalhadores praticar atos violentos. Assim, a hipótese de declaração de greve ilícita é bastante restritiva de acordo com a Constituição mexicana. O texto da fração XVIII foi o que sucitou os maiores debates no Congresso Constituinte $^{535}$. O projeto original da comissão responsável pela redação do artigo propôs o seguinte texto, posteriormente modificado: "Las huelgas serán lícitas cuando, empleando medios pacíficos, lleven por objeto conseguir el equilibrio entre los factores capital y trabajo, para realizar la justa distribución de los beneficios". Nem justa distribuição dos benefícios da produção, nem meios pacíficos foram admitidos como critérios para considerar uma greve lícita, mas sim a harmonia e o equilíbrio entre capital e trabalho.

\footnotetext{
${ }^{534}$ O texto original da Constituição dos Estados Unidos Mexicanos, publicada em 5 de fevereiro de 1917, pode ser encontrado em: Diário Oficial de 5 de fevereiro de 1917. Centenario de la Constitución Política de los Estados Unidos Mexicanos 1917. Cidade do México: Instituto Nacional de Estudios Históricos de las Revoluciones de México (INEHRM), 2015.

$<$ http://www.juridicas.unam.mx/infjur/leg/conshist/pdf/1917.pdf > Consulta realizada em 28/12/2015.

${ }^{535}$ Os debates sobre a redação do artigo 123 constitucional podem ser encontrados, na íntegra, em: Congreso Constituyente de los Estados Unidos Mexicanos - Debates Notables - artículo 123 en materia laboral. Centenario de la Constitución Política de los Estados Unidos Mexicanos 1917. Cidade do México: Instituto Nacional de Estudios Históricos de las Revoluciones de México (INEHRM), 2015. <http://www.constitucion1917.gob.mx/work/models/Constitucion1917/Resource/251/1/images/022.pdf> Consulta realizada em 28/12/2015.
} 
O texto incluído ao final da fração, porém, que afirma só poder ser considerada ilícita uma greve em que a maioria dos grevistas usem violência acabou por, se for interpretada estritamente, aumentar a capacidade de ação grevista dos trabalhadores.

O texto do artigo 123 segue com a afirmação de competência da Junta de Conciliación y Arbitraje para resolver em primeira instância conflitos entre capital e trabalho. A fração XX estabelece ainda a composição da junta: metade de seus membros deveriam ser representantes dos patrões e a outra metade, dos trabalhadores. Somem-se a esses membros, um representante do governo. Talvez essa seja uma das normas mais inovadoras da Constituição de 1917, por garantir tamanha capacidade de fala e decisão para os trabalhadores, já que a própria Constituição atribui uma série de competências importantes para essa mesma Junta.

O texto segue com consequências para casos em que patrões e empregados se recusem a se submeter à decisão da Junta (rescisão contratual e, no caso de patrões, três meses de salário de multa), além dos direitos dos trabalhadores em casos de demissão sem justa causa (ou por causa ilícita) e interrupção dos serviços em função de falta de probidade dos patrões. O artigo determina também a preferência dos créditos trabalhistas em circunstâncias de quebra ou interrupção das atividades empresariais; limitação das dívidas à pessoa que as contraiu; proteção de bens de família (casas que sirvam de moradia familiar não podem responder por dívidas); serviços de promoção de emprego a serem proporcionados pelo governo; e obrigação governamental de criar e incentivar caixas seguradoras populares capazes de ratear os custos sociais entre os economicamente ativos, com o objetivo de manter economicamente as famílias e os trabalhadores que fiquem inválidos, desempregados, percam a vida, , sofram acidentes ou outras causas impeditivas do trabalho.

Por fim, a fração XXVII do artigo 123 afirma serem nulas e sem efeitos vinculantes todas as cláusulas que, mesmo estando em contratos de trabalho escritos, contrariem os seus dispositivos e, de forma geral, visem a renunciar direitos estabelecidos na Constituição e nas normas reguladoras do trabalho que venham a ser criadas.

Com exceção da ausência de definição de um salário mínimo nacional - já que a fração VI determina, sem estipular um valor, que o salário mínimo deve "satisfacer las necesidades normales de la vida del obrero, su educación y sus placeres honestos, 
considerándolo como jefe de familia." 536 e a fração IX estabelece que os valores mínimos serão definidos por comissões especiais em cada município - as normas do artigo 123 da Constituição de 1917 garantem de forma ampla inúmeros direitos dos trabalhadores.

É verdade que boa parte dessas normas já tinha sido objeto de regulação estadual, sobretudo de Salvador Alvarado em Yucatán, ou constava do projeto de lei de Zubarán Capmany. O fato de tais garantias aos trabalhadores terem sido incluídas no próprio texto constitucional, como integrantes nobres da nova ordem jurídico-político mexicana, sugere um contexto de elaboração da própria Constituição muito favorável à juridificação de direitos. Ao reconstruir em linhas gerais a história das reivindicações e propostas jurídicas para a regulação das relações laborais ao longo do século XX, este capítulo teve a inteção de desvendar alguns traços e características desse especial contexto que possibilitou tamanho avanço institucional e jurídico corporificado na Constituição. Se ainda assim a decisão dos deputados constituintes parece em alguma medida surpreendente por sua qualidade e abrangência - e parece -, resta apenas dizer que, se alguns passos foram dados para a compreensão do momento histórico que possibilitou a edição da Constituição Mexicana de 1917, muitos ainda precisavam ser dados.

\footnotetext{
${ }^{536}$ Texto original da Constituición Política de los Estados Unidos Mexicanos, de 5 de fevereiro de 1917. Em Centenario de la Constitución Política de los Estados Unidos Mexicanos 1917. México, Instituto Nacional de Estudios Históricos de las Revoluciones de México (INEHRM), 2015. $<$ http://www.juridicas.unam.mx/infjur/leg/conshist/pdf/1917.pdf > Consulta realizada em 06/01/2016.
} 


\title{
ANEXO DO CAPÍTULO 3
}

\section{CONSTITUCIÓN POLÍTICA DE LOS ESTADOS UNIDOS MEXICANOS ${ }^{537}$}

\author{
TÍTULO SEXTO
}

\section{DEL TRABAJO Y DE PREVISIÓN SOCIAL}

Art. 123. - El Congreso de la Unión y las Legislaturas de los Estados deberán expedir leyes sobre el trabajo, fundadas en las necesidades de cada región, sin contravenir a las bases siguientes, las cuales regirán el trabajo de los obreros, jornaleros, empleados, domésticos y artesanos, y de una manera general todo contrato de trabajo:

I. - La duración de la jornada máxima será de ocho horas.

II . - La jornada máxima de trabajo nocturno será de siete horas. Quedan prohibidas las labores insalubres o peligrosas para las mujeres en general y para los jóvenes menores de diez y seis años. Queda también prohibido a unas y otros el trabajo nocturno industrial; y en los establecimientos comerciales no podrán trabajar después de las diez de la noche.

III. - Los jóvenes mayores de doce años y menores de diez y seis, tendrán como jornada máxima la de seis horas. El trabajo de los niños menores de doce años no podrá ser objeto de contrato.

IV. - Por cada seis días de trabajo deberá disfrutar el operario de un día de descanso, cuando menos.

V. - Las mujeres, durante los tres meses anteriores al parto, no desempeñarán trabajos físicos que exijan esfuerzo material considerable. En el mes siguiente al parto disfrutarán forzosamente de descanso, debiendo percibir su salario íntegro y conservar su empleo y los derechos que hubieren adquirido por su contrato. En el periodo de la lactancia tendrán dos descansos extraordinarios por día, de media hora cada uno, para amamantar a sus hijos.

VI. - El salario mínimo que deberá disfrutar el trabajador será el que se considere suficiente, atendiendo las condiciones de cada región, para satisfacer las necesidades normales de la vida del obrero, su educación y sus placeres honestos, considerándolo como jefe de familia. En toda empresa agrícola, comercial, fabril o minera, los trabajadores tendrán derecho a una participación en las utilidades, que será regulada como indica la fracción IX.

VII. - Para trabajo igual debe corresponder salario igual, sin tener en cuenta sexo ni nacionalidad.

VIII. - El salario mínimo quedará exceptuado de embargo, compensación o descuento.

IX. - La fijación del tipo de salario mínimo y de la participación en las utilidades a que se refiere la fracción VI, se hará por comisiones especiales que se formarán en cada

\footnotetext{
${ }^{537}$ Texto original da Constituición Política de los Estados Unidos Mexicanos, de 5 de fevereiro de 1917. Em Centenario de la Constitución Política de los Estados Unidos Mexicanos 1917. México, Instituto Nacional de Estudios Históricos de las Revoluciones de México (INEHRM), 2015. < http://www.juridicas.unam.mx/infjur/leg/conshist/pdf/1917.pdf > Consulta realizada em 06/01/2016.
} 
Municipio, subordinadas a la Junta Central de Conciliación, que se establecerá en cada Estado.

X. - El salario deberá pagarse precisamente en moneda de curso legal, no siendo permitido hacerlo efectivo con mercancías, ni con vales, fichas o cualquier otro signo representativo con que se pretenda substituir la moneda.

XI. - Cuando por circunstancias extraordinarias deban aumentarse las horas de jornada, se abonará como salario por el tiempo excedente, un ciento por ciento más de lo fijado para las horas normales. En ningún caso el trabajo extraordinario podrá exceder de tres horas diarias, ni de tres veces consecutivas. Los hombres menores de diez y seis años y las mujeres de cualquiera edad, no serán admitidos en esta clase de trabajos.

XII. - En toda negociación agrícola, industrial, minera o cualquiera otra clase de trabajo, los patronos estarán obligados a proporcionar a los trabajadores, habitaciones cómodas e higiénicas, por las que podrán cobrar rentas que no excederán del medio por ciento mensual del valor catastral de las fincas. Igualmente deberán establecer escuelas, enfermerías y demás servicios necesarios a la comunidad. Si las negociaciones estuvieren situadas dentro de las poblaciones, y ocuparen un número de trabajadores mayor de cien, tendrán la primera de las obligaciones mencionadas.

XIII. - Además, en estos mismos centros de trabajo, cuando su población exceda de doscientos habitantes, deberá reservarse un espacio de terreno que no será menor de cinco mil metros cuadrados, para el establecimiento de mercados públicos, instalación de edificios destinados a los servicios municipales y centros recreativos. Queda prohibido en todo centro de trabajo el establecimiento de expendios de bebidas embriagantes y de casas de juego de azar.

XIV. - Los empresarios serán responsables de los accidentes del trabajo y de las enfermedades profesionales de los trabajadores, sufridas con motivo o en ejercicio de la profesión o trabajo que ejecuten; por lo tanto, los patronos deberán pagar la indemnización correspondiente, según que haya traído como consecuencia la muerte o simplemente incapacidad temporal o permanente para trabajar, de acuerdo con lo que las leyes determinen. Esta responsabilidad subsistirá aún en el caso de que el patrono contrate el trabajo por un intermediario.

XV. - El patrono estará obligado a observar en la instalación de sus establecimientos, los preceptos legales sobre higiene y salubridad, y adoptar las medidas adecuadas para prevenir accidentes en el uso de las máquinas, instrumentos y materiales de trabajo, así como a organizar de tal manera éste, que resulte para la salud y la vida de los trabajadores la mayor garantía compa tible con la naturaleza de la negociación, bajo las penas que al efecto establezcan las leyes.

XVI. - Tanto los obreros como los empresarios tendrán derecho para coaligarse en defensa de sus respectivos intereses, formando sindicatos, asociaciones profesionales, etc.

XVII. - Las leyes reconocerán como un derecho de los obreros y de los patronos, las huelgas y los paros.

XVIII. - Las huelgas serán lícitas cuando tengan por objeto conseguir el equilibrio entre los diversos factores de la producción, armoniza ndo los derechos del trabajo con los del capital. En los servicios públicos será obligatorio para los trabajadores dar aviso, con diez días de anticipación, a la Junta de Conciliación y Arbitraje, de la fecha señalada para la suspensión del trabajo. Las huelgas serán consideradas como ilícitas 
únicamente cuando la mayoría de los huelguistas ejerciere actos violentos contra las personas o las propiedades, o en caso de guerra, cuando aquellos pertenezcan a los establecimientos y servicios que dependan del Gobierno. Los obreros de los establecimientos fabriles militares del Gobierno de la República, no estarán comprendidos en las disposiciones de esta fracción, por ser asimilados al Ejército Nacional.

XIX. - Los paros serán lícitos únicamente cuando el exceso de producción haga necesario suspender el trabajo para mantener los precios en un límite costeable, previa aprobación de la Junta de Conciliación y Arbitraje.

XX. - Las diferencias o los conflictos entre el capital y el trabajo, se sujetarán a la decisión de una Junta de Conciliación y Arbitraje, formada por igual número de representantes de los obreros y de los patronos, y uno del Gobierno.

XXI. - Si el patrono se negare a someter sus diferencias al Arbitraje o a aceptar el laudo pronunciado por la Junta, se dará por terminado el contrato de trabajo y quedará obligado a indemnizar al obrero con el importe de tres meses de salario además de la responsabilidad que le resulte del conflicto. Si la negativa fuere de los trabajadores, se dará por terminado el co ntrato de trabajo.

XXII. - El patrono que despida a un obrero sin causa justificada, o por haber ingresado a una asociación o sindicato, o por haber tomado parte en una huelga lícita, estará obligado, a elección del trabajador, a cumplir el contrato o a indemnizarlo con el importe de tres meses de salario. Igualmente tendrá esta obligación cuando el obrero se retire del servicio por falta de probidad de parte del patrono o por recibir de él malos tratamientos, ya sea en su persona o en la de su cónyuge, padres, hijos o hermanos. El patrono no podrá eximirse de esta responsabilidad, cuando los malos tratamientos provengan de dependientes o familiares que obren con el consentimiento o tolerancia de él.

XXIII. - Los créditos en favor de los trabajadores por salario o sueldos devengados en el último año y por indemnizaciones, tendrán preferencia sobre cualquiera otros en los casos de concurso o de quiebra.

XXIV. - De las deudas contraídas por los trabajadores a favor de sus patronos, de sus asociados, familiares o dependientes, sólo será responsable el mismo trabajador, y en ningún caso y por ningún motivo se podrá exigir a los miembros de su familia, ni serán exigibles dichas deudas por la cantidad excedente del sueldo del trabajador en un mes.

XXV. - El servicio para la colocación de los trabajadores, será gratuito para éstos, ya se efectúe por oficinas municipales, bolsas del trabajo o por cualquiera otra institución oficial o particular.

XXVI. - Todo contrato de trabajo celebrado entre un mexicano y un empresario extranjero, deberá ser legalizado por la autoridad municipal competente y visado por el Cónsul de la Nación a donde el trabajador tenga que ir, en el concepto de que además de las cláusulas ordinarias, se especificará claramente que los gastos de repatriación quedan a cargo del empresario contratante.

XXVII. - Serán condiciones nulas y no obligarán a los contrayentes, aunque se expresen en el contrato:

(a). Las que estipulen una jornada inhumana por lo notoriamente excesiva, dada la índole del trabajo. 
(b). Las que fijen un salario que no sea remunerador a juicio de las Juntas de Conciliación y Arbitraje.

(c). Las que estipulen un plazo mayor de una semana para la percepción del jornal.

(d). Las que señalen un lugar de recreo, fonda, café, taberna, cantina o tienda para efectuar el pago de salario, cuando no se trate de empleados en esos establecimientos.

(e). Las que entrañen obligación directa o indirecta de adquirir los artículos de consumo en tiendas o lugares determinados.

(f). Las que permitan retener el salario en concepto de multa.

(g). Las que constituyan renuncia hecha por el obrero de las indemnizaciones a que tenga derecho por accidente del trabajo, y enfermedades profesionales, perjuicios ocasionados por el incumplimiento del contrato o despedírsele de la obra.

(h). Todas las demás estipulaciones que impliquen renuncia de algún derecho consagrado a favor del obrero en las leyes de protección y auxilio a los trabajadores.

XXVIII. - Las leyes determinarán los bienes que constituyan el patrimonio de la familia, bienes que serán inalienables, no podrán sujetarse a gravámenes reales ni embargos, y serán transmisibles a título de herencia con simplificación de las formalidades de los juicios sucesorios.

XXIX. - Se consideran de utilidad social: el establecimiento de Cajas de Seguros Populares, de invalidez, de vida, de cesación involuntaria de trabajo, de accidentes y otros con fines análogos, por lo cual, tanto el Gobierno Federal como el de cada Estado, deberán fomentar la organización d e Instituciones de esta índole, para infundir e inculcar la previsión popular.

XXX. - Asimismo serán consideradas de utilidad social, las sociedades cooperativas para la construcción de casas baratas e higiénicas, destinadas a ser adquiridas en propiedad, por los trabajadores en plazos determinados. 


\section{CONCluSÃo}

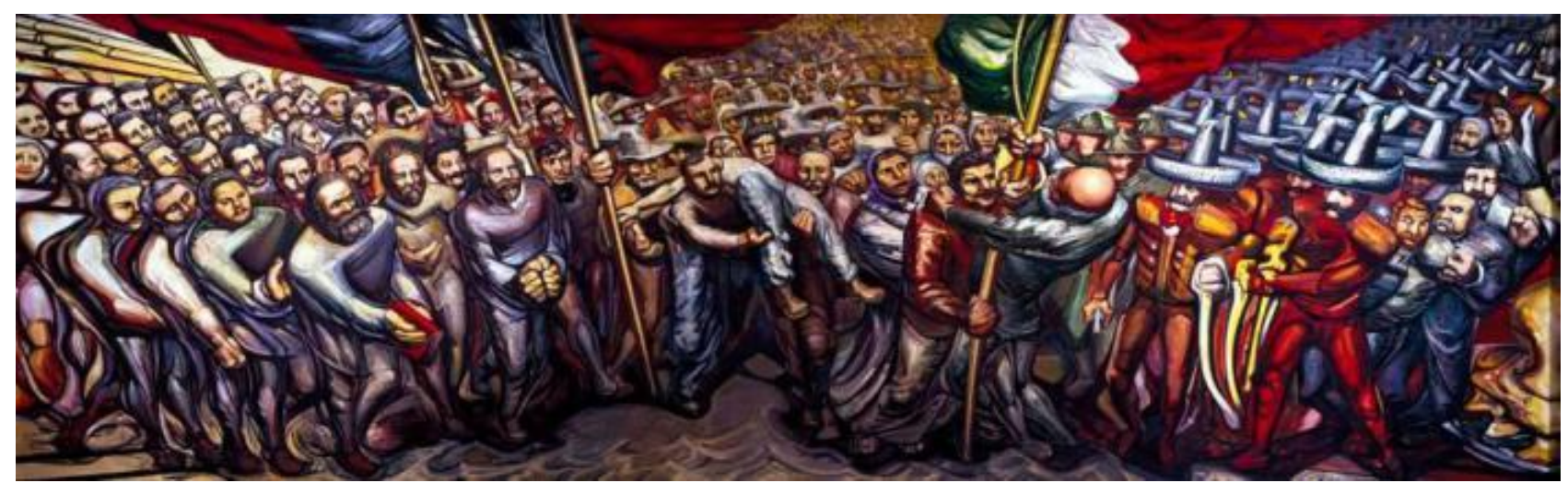

Trecho do mural "Del porfirismo a la Revolución” (1957-1966), de David Alfaro Siqueiros. Reprodução: Museo Nacional de História del Castillo de Chapultepec

Las revoluciones son revoluciones, es decir, estados patológicos y críticos de las sociedades y constituyen situaciones anormales; las revoluciones son sacudimientos políticos que una clase social inferior efectúa para librarse de la presión de otra clase privilegiada. Su modo de efectuarse es un brusco y rápido sacudimiento, y el medio empleado, la fuerza. Las revoluciones implican desconocimiento de la autoridad y del poder de las clases privilegiadas, y tienen por objeto directo y principal la destrucción de una fuerza social y la creación de otra nueva fuerza social surgida de las clases revolucionarias. ${ }^{538}$ (Arnaldo Córdova)

"Las verdaderas reformas sociales las han hecho los Poderes Legislativos, y las verdaderas reformas, señores, una vez más lo repito, nunca se han hecho en los momentos de tranquilidad; se han hecho en los momentos de agitación social; si no se hacen en los momentos de agitación social, ya no se hicieron."539 (Luís Cabrera, exposição de motivos de seu Projeto de Lei Agrária)

\footnotetext{
${ }^{538}$ Arnaldo Córdova. La ideología de la Revolución Mexicana - la formación del nuevo régimen. $8^{\mathrm{a}}$ Edición. Ciudad del México: Ediciones Era, 1980, p. 141.

${ }^{539}$ A íntegra do discurso e do Projeto de Lei Agrária de Luís Cabrera, apresentados em 3 de dezembro de 1912 para a XXV Legislatura do Congreso Mexicano, em: CARMONA, Doralicia. Memoria Política de México. México: Universidade de Guanajuato, 2014.

<http://www.memoriapoliticademexico.org/Textos/6Revolucion/1912REP.html >. Consulta realizada em 02/01/2015.
} 
Como o México de 1917 foi capaz de produzir a primeira constituição social da história? Considerando ser o México um país periférico, distante do centro de produção ideológica; considerando que suas instituições eram novas, já que havia conquistado sua independência cerca de um século antes; considerando que o século XIX foi extremamente conturbado no país, com disputas travadas entre liberais e conservadores, invasões estrangeiras, perda de território e até a tentativa de reinstalação da monarquia; considerando que o período de estabilidade política do final do século XIX e início do século XX tinha sido forjado por meio de um governo autoritário, com limitado espaço para o exercício democrático, para a organização política, para o exercício da liberdade de expressão e para o embate de ideias e propostas de reorganização da sociedade; tudo isso considerado, a Constituição Política dos Estados Unidos Mexicanos de $1917^{540}$ pode ser mesmo tida como um feito.

Em vigor há quase cem anos e notável pela presença de inúmeras normas que reconhecem direitos sociais, a Constituição Mexicana já foi vertida para treze línguas indígenas ainda praticadas no México ${ }^{541}$ e sofreu 225 decretos de reforma ${ }^{542}$.

Em seu artigo 27, a Constituição propõe um conceito novo de propriedade privada, ao estabelecer que todo o território e as riquezas naturais do solo do país são propriedades da nação. É somente a nação quem tem o direito de ceder, com limites, o domínio sobre partes de seu território a particulares. Não são, assim, seres humanos particulares que têm direito sobre um pedaço de terra. É a nação mexicana a titular do direito de constituir domínios sobre seu território. De acordo com a redação constitucional, abrem-se múltiplas possibilidades de restrição que o domínio privado pode sofrer a partir da noção básica de que a proprietária das terras é a coletividade, e não os indivíduos. O longo artigo constitucional apresenta então uma série de normas

\footnotetext{
${ }^{540}$ Texto original da Constituición Política de los Estados Unidos Mexicanos, de 5 de fevereiro de 1917. Em Centenario de la Constitución Política de los Estados Unidos Mexicanos 1917. México, Instituto Nacional de Estudios Históricos de las Revoluciones de México (INEHRM), 2015. <http://www.juridicas.unam.mx/infjur/leg/conshist/pdf/1917.pdf> Consulta realizada em 06/01/2016.

${ }^{541}$ As treze línguas para as quais há versão da Constituição Mexicana de 1917 são: Maya, Huasteco de occidente, Tseltal, Tsotsil, Ch'ol, Otomí del centro, Mazahua de oriente, Matlatzinca, Purépecha, Totonaco de la costa, tepehua del norte, Náhuatl de la Huasteca Potosina, Náhuatl central de Veracruz. Todas as versões disponíveis em: 100 años Constitución 1917-2017. Cidade do México: Instituto de Investigaciones Jurídicas de la UNAM, 2015. <http://www.100constitucion.unam.mx/constituciononline/> Consulta realizada em 08/01/2016.

${ }^{542}$ Todas as reformas - desde a primeira em julho de 1921, até a última realizada, 225a , em julho de 2015 - disponíveis em: 100 años Constitución 1917-2017. Cidade do México: Instituto de Investigaciones Jurídicas de la UNAM, 2015. <http://www.100constitucion.unam.mx/constitucion-online/> Consulta realizada em 08/01/2016.
} 
indicando quais seriam as possíveis restrições decorrentes da reconhecida supremacia do interesse coletivo sobre o domínio privado.

Já o artigo 123 institui uma série de direitos dos trabalhadores. Define a jornada máxima de oito horas de trabalho (sete para o trabalho noturno); torna obrigatórios um dia de descanso semanal e um mês de licença remunerada para mulheres que tiverem filhos; proíbe a discriminação salarial em função de nacionalidade ou sexo; proíbe a realização de descontos, embargos ou compensações sobre os salários dos trabalhadores; institui o aumento em cem por cento no valor pago para as horas extras trabalhadas, bem como limites à sua realização; garante moradia digna para os trabalhadores que vivam nas propriedades de seus empregadores; atribui responsabilidade objetiva dos empregadores por acidentes de trabalho e doenças laborais, que deverão ser indenizados; institui a obrigação para os empregadores de manter o ambiente de trabalho em condições de higiene e salubridade, além de realizar ações preventivas de acidentes, entre outros direitos.

Além dos dois artigos mais conhecidos, a Constituição também traz entre suas normas o direito à educação laica em estabelecimentos de ensino oficiais (estatais) e privados, além do direito à educação primária gratuita nos estabelecimentos oficiais $\left(\operatorname{art.} 3^{\circ}\right)$. Laicidade do Estado, liberdade religiosa e restrições severas à atuação de entidades religiosas, que não são dotadas de personalidade jurídica (arts.24 e 130); proteção da mulher nas relações de trabalho, com a já mencionada proibição de discriminações salariais em função do sexo (art.123); e autonomia política dos municípios (art.115) são outras disposições que tornam a Constituição Mexicana de 1917 notável.

O objetivo desta tese foi descrever e analisar o desenrolar revolucionário mexicano - principalmente a partir dos planos e documentos jurídicos produzidos pelos diferentes grupos que dele participaram -, para tentar compreender o ambiente que possibilitou as formulações originais e as garantias de direitos previstas na Constituição.

Ela é o resultado de uma imensa insurreição popular - estima-se mais de um milhão de mortos - gerada como reação a uma situação de extrema injustiça, violência, exclusão e desigualdade. Aqueles que participaram dessa revolução formularam suas reivindicações e propostas em muitos planos, discursos, cartas, artigos de jornal e documentos normativos. Assim, além de lutar com armas, os mexicanos insurgentes disputaram as concepções sobre como o México deveria se organizar como sociedade. 
Seus desejos de construção de um país mais justo, com menos exploração do trabalho assalariado e mais distribuição das riquezas, naturais e produzidas, bem como sua indignação com uma situação que era o oposto de seus anseios, inspiraram a luta e contribuíram para a reflexão e elaboração simbólica da época. Assim, inspiraram também o texto constitucional produzido em meio à Revolução. O constituinte mexicano de 1917 teve a dignidade e a honestidade intelectual para realizar uma boa análise da conjuntura que gerou a necessidade de elaboração de uma nova constituição e para consolidar em textos normativos o que era anseio social.

Muitas das formulações adotadas pelos constituintes já tinham sido objeto de debate e de textos de ao menos uma instância deliberativa coletiva da revolução - a Soberana Convención Revolucionaria de Aguascalientes -, além de inúmeros planos, decretos e leis anteriores. Apesar de representar uma síntese digna de reconhecimento em função de seu estilo, as formulações propostas pelas comissões do Congresso Constituinte se alimentaram, elas também, de produções sociais que extrapolavam e muito o restrito coletivo de deputados que as compunham. Por todos esses motivos, conclui-se que a Constituição Política dos Estados Unidos Mexicanos de 1917 é produto da Revolução Mexicana que a antecedeu.

\section{Quem venceu a Revolução Mexicana?}

Se é verdade que a Constituição Mexicana é produto do processo revolucionário anterior ao Congresso Constituinte que a elaborou, é razoável supor que ela incorporaria as ideias de seu grupo vencedor. Mas terá sido isso o que ocorreu? Do ponto de vista militar, não há dúvida de que Venustiano Carranza e os carrancistas foram vitoriosos nos embates que se travaram entre as diferentes correntes do processo revolucionário entre 1915-16. A vitória ideológica, porém, já não é tão evidente.

A discussão sobre os legados - positivos e negativos - da Revolução Mexicana mistura-se com a reflexão a respeito de qual grupo social teria vencido a disputa de ideias e modelos capazes de definir qual era a melhor forma de reorganizar a sociedade mexicana depois do fim da revolução. Arnaldo Córdova, em seu livro "La ideología de la Revolución Mexicana", afirma que o grande vencedor foi o passado mexicano e sua tradição liberal: 
En México, la revolución nace acompañada de una candente defensa del pasado. Desde luego, el pasado no es el porfirismo, sino la tradición libertaria que se da a partir de la Revolución de Independencia, se desenvuelve en el largo período de la lucha de los liberales contra los conservadores y culmina con el triunfo de la República en las guerras de Reforma y contra la intervención francesa. (...) El verdadero pasado de México es su tradición liberal. $^{543}$ (grifado no original)

A defesa do passado seria o grande objetivo da Revolução Mexicana, sob a ótica de Córdova. O liberalismo do século XIX, inspirador do movimento de reforma, seria então o grande vencedor da revolução. Também John Womack Jr., em seu clássico livro sobre "Zapata y la Revolución Mexicana", fala sobre como a Revolução Mexicana estaria imbuída de sentimentos passadistas. O passado defendido pela revolução de Womack, porém, é diferente do passado de Córdova:

Éste es un libro acerca de unos campesinos que no querían cambiar y que, por eso mismo, hicieron una revolución. Nunca imaginaron un destino tan singular. Lloviera o tronase, llegaran agitadores de fuera o noticias de tierras prometidas fuera de su lugar, lo único que querían era permanecer en sus pueblos y aldeas, puesto que en ellos habían crecido y en ellos, sus antepasados, por centenas de años, vivieron y murieron: en ese diminuto estado de Morelos del centro-sur de México. ${ }^{54}$

$\mathrm{O}$ anseio dos índios de manter e permanecer em sua forma comunitária e coletiva de vida no campo teria sido a verdadeira causa da insurreição no Estado de Morelos, no qual o movimento zapatista floresceu. Cockcroft, por sua vez, fala dos parcos resultados que teriam sido alcançados pela revolução:

Como resultado, la Revolución de 1910-1917 hizo poco más que derrocar a Porfírio Díaz y transformar parte de la ideología del cambio social. El intenso conflicto de clase de aquel período perdura todavía en nuestros días; en efecto, ha crecido a una nueva tasa combinada y desigual, como se concluye en este prefacio. El único resultado positivo de la Revolución de 1910-1917 fue la Constitución de 1917, que expresaba el cambio de ideología para el desarrollo continuo (aunque todavía capitalista) de México.

\footnotetext{
${ }^{543}$ CÓRDOVA, Arnaldo. La ideología de la Revolución Mexicana - la formación del nuevo régimen. $8^{\mathrm{a}}$ Edición. Ciudad del México: Ediciones Era, 1980, p. 87.

${ }^{544}$ WOMACK Jr., John. Zapata y la Revolución Mexicana. Trad. Francisco González Aramburo. $26^{\mathrm{a}}$ Ed. Cidade do México: Siglo Ventiuno Editores, 2004. P. XI.
} 
La Constitución, sin embargo, raramente se ha respetado en la práctica. El artículo 123 se ha ignorado o violado desde la supresión de la huelga ferrocarrilera de 1959. El artículo 27 ha tenido poco efecto desde 1940; así lo sugieren los hechos de 1970: un neolatifundismo y la mitad de la población rural sin tierras. ${ }^{545}$

Córdova, Womack e Cockcroft são importantes historiadores da Revolução Mexicana. Fazem parte de uma corrente historiográfica que se dedica a analisar o processo revolucionário sem julgamentos positivos prévios. Por vezes são classificados de historiadores revisionistas, por não aderirem à visão laudatória e muitas vezes simplista a respeito de seu objeto de estudos. Apesar do evidente mérito dos trabalhos dos três autores, a presente tese se contrapõe à visão expressa nos trechos acima $\operatorname{citados}^{546}$.

O liberalismo do meio do século XIX não precisou enfrentar a industrialização nascente, a exploração extrema e as condições de trabalho degradantes do início do século XX. Também não viu o processo de concentração fundiária realizada no final do século XIX e início do XX. Afirmar, como faz Córdova, que o liberalismo da Reforma foi o vencedor da revolução é ignorar as especificidades do contexto histórico em que a Revolução Mexicana se deu. Um dos objetivos da Revolução Mexicana foi obter uma ação estatal contrária à política concentradora e garantidora de privilégios aos terratenientes que se costumava praticar até então. Se o Estado foi capaz de conferir terras a grandes proprietários, desejava-se que esse mesmo Estado assumisse o papel inverso do que estava acostumado a realizar. O resultado dessa luta foi uma Constituição que instituíu um Estado social, responsável por intervir na realidade para "hacer una distribución equitativa de la riqueza pública"547, como se afirmava no famoso artigo 27. A Revolução não gerou um estado liberal do século XIX, mas fez surgir, por meio das obrigações impostas pela Constituição, uma série de novas

545 COCKCROFT, James. Precursores intelectuales de la revolucion mexicana: 1900-1913. $24^{\mathrm{a}}$. ed. Cidade do México: Siglo Veintiuno Editores, 2004. P. 3

${ }^{546}$ Vale notar que, muito embora as obras de Córdova e Cockcroft efetivamente sejam coerentes com o trecho citado, o mesmo não vale para o início de Womack. Sua obra sobre o Zapata traz uma visão bastante abrangente acerca do movimento revolucionário que se organizou em torno de Zapata. Se o início do movimento esteve ligado a um sentimento de resistência à mudança, Womack reconhece no zapatismo e convencionismo que compôs inúmeras formulações para a reorganização futura da sociedade mexicana.

${ }^{547}$ Texto original da Constituición Política de los Estados Unidos Mexicanos, de 5 de fevereiro de 1917. Em Centenario de la Constitución Política de los Estados Unidos Mexicanos 1917. México, Instituto Nacional de Estudios Históricos de las Revoluciones de México (INEHRM), 2015. < http://www.juridicas.unam.mx/infjur/leg/conshist/pdf/1917.pdf > Consulta realizada em 06/01/2016. 
atribuições ao Estado nascente, com muito mais obrigações do que seu antecessor, que passou a ser chamado de Estado de Bem-Estar Social.

É interessante notar que Womack não afirma, em seu livro, que o desejo de volta ao passado tenha sido a tônica do movimento zapatista ao longo de toda a revolução. Considera tão somente que esse foi o sentimento inicial que teria levado à revolta. $\mathrm{O}$ texto que citamos acima, no entanto, talvez por figurar na abertura da obra, tem sido muitas vezes usado para realizar uma interpretação geral sobre a sua visão da Revolução Mexicana. Na verdade, seus resultados permitem ver que, embora esse sentimento estivesse entre as causas do início da revolução, o desenrolar revolucionário levou-a muito mais longe. Os documentos produzidos pela Soberana Convención Revolucionária de Aguascalientes, que em 1915 já havia se tornado predominantemente zapatista, sobre as mais diversas questões sociais da realidade mexicana - incluindo direitos dos trabalhadores -, são a prova de que o movimento de Morelos não ficou limitado ao desejo de manter sua forma de vida rural centenária.

Em relação ao texto de Cockcroft, é bastante curioso notar o tom desdenhoso da afirmação segundo a qual "El único resultado positivo de la Revolución de 1910-1917 fue la Constitución de 1917”. Com temos insistido, porém, a Constituição - esse "único resultado positivo" - foi uma realização considerável na história das lutas sociais. Para ter uma ideia mais clara a respeito da conquista que ela representou, basta recordar algumas palavras de Ricardo Flores Magón, escritas pouco antes da Revolução. Em carta de 1908 enviada a seu irmão, ele considerava a hipótese fantasiosa de que "el milagro se realiza y que en el caso especial de nuestra lucha, el congreso ordena el reparto de las tierras, la jornada de ocho horas y el salario no menor de un peso" ${ }^{„ 548}$.

\footnotetext{
548 Transcrevo a seguir parte da carta que debate os efeitos da Revolução, escrita por Ricardo Flores Magón a seu irmão Enrique Flores Magón, em 13 de junho de 1908: "Ustedes saben también como yo que ninguna revolución logra hacer prevalecer después del triunfo y hacer prácticos los ideales que la inflamaron y esto sucede porque se confía que el nuevo gobierno hará lo que debió hacer el pueblo durante la revolución.

Siempre ha sucedido lo mismo. En todas partes se enarbola una bandera con reformas más o menos importantes; se agrupan alrededor de ella los humildes; se lucha; se derrama más o menos abundantemente la sangre, y si triunfa la revolución, se reúne un congreso encargado de reducir a leyes los ideales que hicieron al pueblo tomar las armas y batirse. Al congreso van individuos de toda clase de ideales, avanzados unos, retrógrados otros, moderados otros más, y en la lucha de todas esas tendencias las aspiraciones de la revolución se marchitan, se desvirtúan y después de largos meses, cuando no después de largos años, se vienen aprobando leyes [en las] que ni siquiera se adivinan los ideales por los cuales dio su sangre el desdichado pueblo. Pero supongamos que por un milagro se dicten leyes en las que brillen con toda su pureza los ideales de la revolución, cosa que nunca se ha visto ciertamente, porque muy pocos diputados tienen los mismos ideales que el pueblo que empuñó las armas; supongamos que el milagro se realiza y que en el caso especial de nuestra lucha, el congreso ordena el reparto de las tierras, la jornada de ocho horas y el salario no menor de un peso ¿podremos esperar que los terratenientes se
} 
Esse "milagre", de que Ricardo Flores Magón como anarquista tanto duvidava apenas nove anos antes, aconteceu no México em 1917, depois de muitos anos de lutas. Com exceção da definição do valor exato para o salário mínimo, ele se realizou nos exatos termos que Flores Magón ousou vislumbrar, como sonho. Os deputados constituintes mexicanos tinham consciência da novidade institucional que estavam propondo, e durante os debates do Congresso Constituinte não eram tomados por falsa modéstia. Nas palavras de Alfonso Cravioto:

(...) así como Francia, después de su revolución, ha tenido el alto honor de consagrar en la primera de sus cartas magnas los inmortales derechos del hombre, así la revolución mexicana tendrá el orgullo legítimo de mostrar al mundo que es la primera en consignar en una Constitución los sagrados derechos de los obreros. ${ }^{549}$

Tal como Cockcroft, Flores Magón não acreditava que, mesmo na improvável hipótese de o texto ser aprovado, as elites mexicanas aceitassem a decisão do congresso imaginário e a norma produzisse algum efeito. É verdade que a luta pela aprovação de uma constituição, uma lei, um decreto é apenas o primeiro passo para que se realize o potencial que a própria norma projeta para a realidade, ou seja, para que aquele dever ser encontre seu caminho até a efetivação. Isso é verdade sobretudo quando há partes da sociedade (que concentram riquezas e poder) contrárias a essa efetivação. Mas seria inconsequente - como buscamos mostrar ao longo do presente estudo - ignorar a

cruzarán de brazos para dejar escapar lo que los hace poderosos y les permite vivir en la holganza? Los dueños de toda clase de empresas donde se emplean brazos ¿no cerrarán sus negociaciones o, al menos, no disminuirán el número de obreros que emplean, para obligar al gobierno a revocar la ley con la amenaza del hambre del pueblo, fingiendo que les es materialmente imposible pagar más por menos horas de trabajo?

Agotados los recursos para la revolución, el pueblo se encontraría en una condición más difícil que aquella por la cual se vió obligado a rebelarse. (...) Los ricos se rebelarán cuando se trate de hacer práctico el Programa del partido liberal, en caso de que, por un verdadero y único milagro en la historia de las revoluciones de los pueblos, se hubieran conservado intactos los ideales de la revolución después de su triunfo.

Como anarquistas sabemos bien todo esto. Sabemos bien lo que hay que esperar del mejor gobierno que pueda pesar sobre cualquier pueblo, y, como anarquistas, debemos poner todo lo que esté a nuestro alcance para que la revolución que está en vísperas de estallar dé al pueblo todos los beneficios que sea posible conquistar." Arnaldo Córdova. La ideología de la Revolución Mexicana - la formación del nuevo régimen. $8^{\mathrm{a}}$ Edición. Ciudad del México: Ediciones Era, 1980, p. 175 e Archivo Electrónico Ricardo Flores Magón. <http://archivomagon.net/obras-completas/correspondencia-1899-1922/c-1908/cor265/> Consulta realizada em 09/01/2016.

${ }^{549}$ Diario de los debates del Congreso Constituyente, 1916-1917. Centenario de la Constitución Política de los Estados Unidos Mexicanos 1917. México, Instituto Nacional de Estudios Históricos de las Revoluciones de México (INEHRM), 2015. Também em CÓRDOVA, Arnaldo. La ideología de la Revolución Mexicana - la formación del nuevo régimen. $8^{\mathrm{a}}$ Edición. Ciudad del México: Ediciones Era, 1980, p. 232. 
importância desse primeiro passo, como produto longa e ricamente elaborado de uma luta dolorosa.

A inclusão formal de um direito ou da proposta de uma mudança social como previsão normativa no ordenamento jurídico é, assim, apenas um primeiro passo. O segundo passo, nesse sentido, é convencer os membros dos aparelhos estatais coativos a realizarem e derivarem as consequências práticas da existência daquela norma. Esse segundo passo, muitas vezes, demanda outras tantas lutas e pressões. Contudo, a não observância das normas presentes em um ordenamento jurídico, sobretudo na Constituição, gera um ônus de legitimidade para os poderes públicos, que com sua conduta se posicionam no campo da inconstitucionalidade ou ilegalidade, o que é politicamente constrangedor no debate público.

Ainda sobre a Constituição Mexicana, Cockcroft afirma - sem maiores comprovações - que ela não teria sido respeitada na prática. Estudar as consequências e efeitos da Constituição de 1917 não foi objeto deste trabalho. Mas como a afirmação foi citada, é importante dizer que, depois de mais alguns anos de embate, principalmente durante a Presidência de Lázaro Cárdenas (1934-1940), estima-se que 18 milhões de hectares tenham sido distribuídos por meio do procedimento e sob o regime de propriedade coletiva previstos no artigo 27 da Constituição. Ao todo, calcula-se que o México possuía, na década de 1940, 25 milhões de hectares em regime comunal, a maior parte deles distribuídos e formalizados depois da Constituição de 1917. Considerando que a área total do país é de 197 milhões de hectares, a reforma agrária realizada por Cárdenas abrangeu cerca de 10 por cento do território mexicano, cujos títulos foram concedidos a comunidades de camponeses, para usufruto coletivo. Entre os beneficiários, uma parte significativa de índios e mestiços.

Em relação aos direitos trabalhistas, afirma Cockcroft que desde a greve dos trabalhadores de ferrovias em 1959 os direitos constitucionais estariam sendo ignorados ou violados. Se é verdade que todas as conquistas trabalhistas foram perdidas desde $1959^{550}$, os muitos trabalhadores que se beneficiaram dessas conquistas entre $1917 \mathrm{e}$ 1959 - jornada de trabalho de oito horas, pagamentos aumentados para horas extras,

\footnotetext{
${ }^{550}$ Infelizmente, os limites de tempo desta pesquisa não me permitiram conhecer a fundo a história das transformações na Constituição e os limites de sua efetivação ao longo do século XX. É possível que inúmeras pressões nacionais e internacionais (Estados Unidos da América e áreas de livre comércio incluídos entre elas) no sentido de diminuir direitos trabalhistas tenha impulsionado reformas no direito do trabalho constitucional mexicano. Seja como for, parece muito forte, no entanto, a afirmação de Cockcroft de que todo o artigo 123 está sendo ignorado ou violado.
} 
descanso semanal obrigatório, licença maternidade de um mês, entre outros impensáveis antes da revolução - não podem ser tão levianamente esquecidos. O texto de Cockcroft afirma ainda que o intenso conflito de classes continua. Também Córdova menciona em outra passagem de seu livro (para reafirmar sua tese de que há mais continuidades do que rupturas no México pós-revolucionário) que a permanência da propriedade privada indica que a nova sociedade permanecia afirmando o individualismo como conceito organizador $^{551}$. Em sentido semelhante, Vicente Lombardo Toledano afirma que o Estado mexicano não quer se identificar com nenhum dos grupos sociais: nem opressores, nem oprimidos ${ }^{552}$.

Essas reflexões indicam o sentido da crítica de parte da historiografia sobre o legado da Revolução Mexicana: ela não realizou, como revolução, o objetivo de acabar com o capitalismo, com a propriedade privada ou com a luta de classes. Consequentemente, ela promoveu somente parcos (diriam os historiadores dessa corrente) avanços reformistas.

A reconstrução da história do direito que este trabalho se propôs não admite avaliação tão negativa acerca de uma revolução que possibilitou a criação da primeira constituição a garantir direitos sociais. A aprovação dos artigos 27 e 123 na Constituição de 1917 - e os efeitos que poderiam produzir e que efetivamente produziram - não podem ser considerados pouco quando se toma como ponto de partida a sociedade mexicana pré-revolucionária, e foram o fruto dura e laboriosamente amadurecido de uma luta que, a par da violência e intensidade bélica, mostrou sustentada consciência nos debates simbólicos, cristalizados em planos, congressos e projetos.

\footnotetext{
${ }^{551}$ Pese a todo lo nuevo que había aportado la Revolución, el nuevo sistema social, como podrá verse, parecía continuar, en lo fundamental, la línea de desarrollo inaugurada por el porfirismo. La lucha contra los privilegios, de orden político en esencia, no había abolido la desigualdad real de los mexicanos, y con el princípio de la propiedad privada la nueva sociedad se estructuraba sobre la base del más claro individualismo. CÓRDOVA, Arnaldo. La ideología de la Revolución Mexicana - la formación del nuevo régimen. $8^{\text {a }}$ Edición. Ciudad del México: Ediciones Era, 1980, p. 287.

552 "El Estado Mexicano acepta la división de la sociedad en oprimidos y opresores; pero no quiere considerarse incluido en ningún grupo. Considera necesario elevar y proteger las condiciones actuales del proletariado, hasta colocarle en situación semejante ala del capital, en la lucha de clases; pero quiere mantener intacta su libertad de acción y su poder, sin sumarse a ninguna de las clases contendientes, para seguir siendo el fiel de la balanza, el mediador y el juez de lavida social." LOMBARDO TOLEDANO, Vicente. La Libertad Sindical en México. Talleres Linotipográficos”La Lucha”. México, 1926. P. 84-85.
} 
Além disso, afirmar que a Revolução Mexicana alcançou pouco porque "El intenso conflicto de clase de aquel período perdura todavía", ou porque a propriedade privada continuava sendo uma instituição organizadora da vida em sociedade é afirmar que a Revolução Mexicana não cumpriu objetivos a que não se propôs ${ }^{553}$. Em relação especificamente à propriedade privada, instituiu e incentivou a sua apropriação coletiva por comunidades rurais. Não se pode, nesse contexto, afirmar que a detenção e a administração comunitária sobre bens imóveis seja um reforço do individualismo

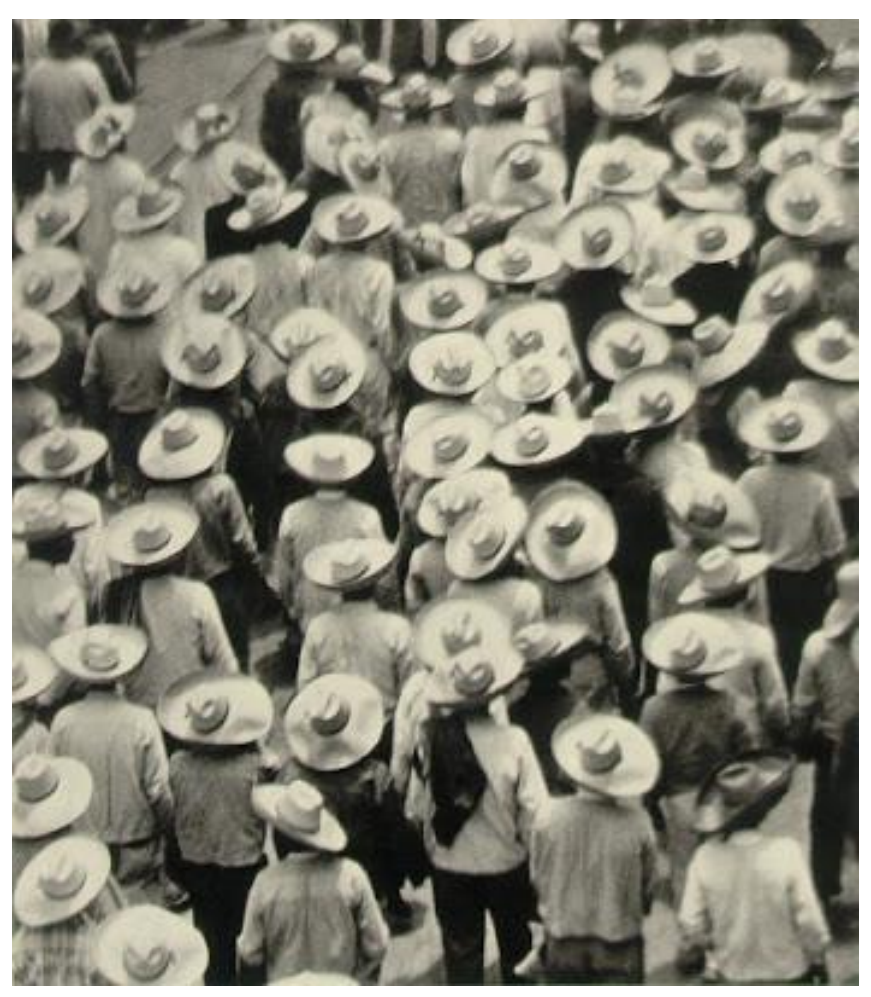

Campesinos. Tina Modotti, 1922. liberal, como afirmou Córdova. Além disso, em nenhum momento o fim da propriedade privada dos meios de produção foi um ideal a ser alcançado para os mexicanos no início do século XX. Também em nenhum momento os camponeses ou os trabalhadores desejaram tomar o Estado e implementar seu governo de classe, como forma de acabar com o seu conflito. Fim da luta de classes, da propriedade privada dos meios de produção são objetivos externos à própria história dessa revolução.

\footnotetext{
${ }^{553}$ Em livro que discute a historiografia sobre a Revolução Mexicana com Jean Meyer, John Womack Jr. chama a atenção para o fato: "John Womack: Yo creo que el problema de quién ganó, si la revolución o la contrarrevolución, es en parte un problema semántico. Es decir, desde 1917, por lo de los bolcheviques, la palabra 'revolución' ha tenido un sentido muy diferente del que tuvo en el siglo pasado. Lo que ocurre es que la Revolución Mexicana empezó cuando esa palabra quería decir algo muy diferente. Al triunfar al estilo del siglo XIX, se ha hecho una propaganda maravillosa para aprovechar el sentido que la palabra ha adquirido en el siglo XX. Recordemos que cuando esos hombres comenzaron su revolución, la llamaban muy seriamente revolución, pero no estaban pensando para nada en el socialismo. Unos se decían socialistas porque les dolía la conciencia cuando veían gente pobre: pero entre ese sentimiento y un compromiso político con el socialismo, hay un trecho enorme. De modo que cuando aquellos hombres se decían revolucionarios, eso significaba lo que se hizo en Italia en 1860, lo que se hizo en Portugal en 1910: una revolución perfectamente liberal burguesa. No tenían la menor intención de hacer una revolución socialista. Entonces, al hablar de su traición, se les está acusando de no haber hecho algo que, como decía Jean, nunca habían propuesto." MEYER, Jean; WOMACK Jr., John. Diálogos sobre la historiografía de la Revolución Mexicana. Cidade do México: Centro de estudios mexicanos y centroamericanos, 2006. Disponível em: 〈http://books.openedition.org/cemca/2122> Consulta realizada em $08 / 01 / 2016$.
} 
Devemos então retornar à pergunta sobre quem venceu a Revolução Mexicana.

Venustiano Carranza venceu militarmente, convocou um Congresso Constituinte, foi eleito Presidente da República em 1917 e governou até 1920, quando foi sucedido por Álvaro Obregón que lutou ao lado dos carrancistas (obtendo importantes vitórias contra o exército villista, entre 1914 e 1916). Qualquer que seja o critério adotado - quem encerrou os conflitos com mais pessoas em suas fileiras; quem conseguiu propor a reorganização das instituições políticas; quem governou de fato no período pós-revolucionário -, Carranza foi o vencedor.

No entanto, ao comparar o projeto de Constituição elaborado por Carranza para o Congresso Constituinte de $1916-17^{554}$ e a Constituição que foi efetivamente aprovada $^{555}$ percebemos claramente que, ao menos em relação ao modelo de Constituição, ele foi derrotado. Pode-se afirmar que a forma da Constituição não deve entrar no cálculo da disputa política, afinal Carranza só teria repetido uma forma antiga, tradicional e liberal de conceber e escrever as constituições. A aprovação de um texto radicalmente diferente de suas propostas iniciais não necessariamente significaria uma afronta a Carranza, mas sim uma capacidade do constituinte mexicano de vislumbrar o que poderia ser diferente em uma carta de intenções políticas naquele momento histórico. Diminuir a importância simbólica da derrota sofrida por Carranza no Congresso Constituinte torna-se mais difícil quando é realizada a análise detalhada dos importantes documentos normativos produzidos por ele no início de 1915.

Sua lei agrária, o famigerado Decreto de 6 de janeiro de 1915, declara nulas todas as vendas, demarcações, cessões de terras coletivas dos pueblos, rancherías ou comunidades que estivessem em "contravención a lo dispuesto en la Ley de 25 de junio de 1856" ${ }^{556}$. Em outros dois trechos do decreto, Carranza menciona a ocupação ou invasão ilegal dos ejidos. Em sua exposição de motivos ele condenava ações injustas

\footnotetext{
${ }^{554} \mathrm{O}$ texto integral do Projeto de Constituição encaminhado por Venustiano Carranza ao Congresso Constituyente, em 6 de dezembro de 1916, em: Diário de los debates del Congreso Constituyente, 6 de diciembre de 1916. Centenario de la Constitución Política de los Estados Unidos Mexicanos 1917. México, Instituto Nacional de Estudios Históricos de las Revoluciones de México (INEHRM), 2015. 〈http://www.constitucion1917.gob.mx/work/models/Constitucion1917/Resource/251/1/images/016.pdf> Consulta realizada em 28/12/2015. P. 345.

${ }^{555}$ Texto original da Constituición Política de los Estados Unidos Mexicanos, de 5 de fevereiro de 1917. Em Centenario de la Constitución Política de los Estados Unidos Mexicanos 1917. México, Instituto Nacional de Estudios Históricos de las Revoluciones de México (INEHRM), 2015. $<$ http://www.juridicas.unam.mx/infjur/leg/conshist/pdf/1917.pdf > Consulta realizada em 06/01/2016.

${ }^{556}$ A íntegra do Decreto de Venustiano Carranza, de 6 de janeiro de 1915, em: MÉXICO. Secretaria de Gobernación: Unidade General de Asuntos Jurídicos.

$<$ http://www.ordenjuridico.gob.mx/Constitucion/CH15.pdf $>$ Consulta realizada em 03/01/2015.
} 
realizadas "a pretexto de cumplir con la Ley de 25 de junio de 1856". Ora, o decreto afirmava explicitamente querer reverter as cessões e vendas de terras feitas em desacordo com a legalidade produzida pelo século XIX. Os administradores, "a pretexto de cumprir" a lei, quando na verdade não cumpriam, cometeram injustiças. Por isso, era preciso reverter as ilegalidades. O que foi feito de acordo com a lei, porém, deveria ser mantido. Esses são os comandos que estão no texto do decreto de 6 de janeiro de 1915 . A análise da lei do século XIX a que ele faz referência, porém, não admite essa interpretação: as cessões e vendas de terras coletivas dos camponeses, índios e mestiços, apesar de muito injustas porque desconsideravam muitos anos de posse efetiva e pacífica, foram em sua grande maioria feitas nos limites e de acordo com a legalidade. As leis do século XIX eram injustas, e não a prática em desacordo com a legalidade. Não havia como Carranza alegar ignorância quanto a esse ponto. Luís Cabrera, corresponsável pela redação do decreto de 1915, havia apresentado em 1912 um longo diagnóstico sobre as origens do problema agrário mexicano para a XXVI Legislatura do Congresso Mexicano ${ }^{557}$. A Ley Lerdo, de 25 de junho de 1856, era indicada como um importante vetor das injustiças que foram cometidas desde então.

Ao realizar essa inversão, afirmar que o que deveria ser anulado, corrigido e revertido eram as ilegalidades injustas - e não as injustiças legais - do século XIX, Carranza tinha a intenção de tornar seu decreto sem efeitos. Não foi assim, porém, que o documento foi recebido pelo momento histórico. Contra a literalidade do texto normativo, as normas propostas foram apropriadas como uma autorização efetiva para começar o processo de reversão da enorme concentração fundiária do campo mexicano. A regulamentação que o governador constitucionalista Salvador Alvarado propõe para o Estado de Yucatán ${ }^{558}$, também analisada no capítulo 2, é uma das provas dessa apropriação mais ampla do que o texto de Carranza permitia.

Na Constituição Mexicana de 1917, por sua vez, o decreto de 6 de janeiro de 1915 é citado e constitucionalizado. "Todas las tierras, bosques y aguas de que hayan

\footnotetext{
${ }^{557}$ A íntegra do discurso e do Projeto de Lei Agrária de Luís Cabrera, apresentados em 3 de dezembro de 1912 para a XXVI Legislatura do Congreso Mexicano, em: Doralicia Carmona. Memoria Política de México. Guanajuato: Universidade de Guanajuato, 2014.

<http://www.memoriapoliticademexico.org/Textos/6Revolucion/1912REP.html > . Consulta realizada em 02/01/2015.

${ }^{558}$ Decreto regulamentador da Ley agraria carrancista no Estado de Yucatán, de 3 de dezembro de 1915, por Salvador Alvarado. Em Centenario de la Constitución Política de los Estados Unidos Mexicanos 1917. México, Instituto Nacional de Estudios Históricos de las Revoluciones de México (INEHRM), 2015. <http://constitucion1917.gob.mx/es/Constitucion1917/Ley_Agraria_>. Consulta realizada em 05/01/2016.
} 
sido privadas las corporaciones referidas, serán restituidas a éstas con arreglo al Decreto de 6 de enero de 1915, que continuará en vigor como ley constitucional." 559 Ao contrário do decreto de 1915, porém, o texto constitucional adota seus próprios critérios para admitir a restituição de terras às corporações civis: devem ser revertidas todas as cessões realizadas "desde la ley de 25 de junio de 1856" 560. Ou seja, embora o Congresso Constituinte tenha prestado homenagens ao decreto carrancista de janeiro de 1915, divergiu completamente no critério que deveria ser utilizado para realizar as restituições das propriedades coletivas. Todas as cessões, demarcações e vendas feitas desde 1856 deveriam ser revertidas, e não apenas aquelas em contravenção ao que dispunha a lei. $\mathrm{O}$ constituinte mexicano admite por meio do texto constitucional que o que aconteceu no México desde o século XIX foram injustiças legais.

Se a parcial derrota ideológica de Venustiano Carranza já parece clara no caso da regulação fundiária que se forjou na Constituição de 1917, os direitos dos trabalhadores previstos no artigo 123 tornam-na evidente. Carranza não queria (ou se adequava a pressões dos setores mais conservadores da sociedade) que o México possuísse uma ampla regulação das relações de trabalho. Novamente, é o estudo da história das regulamentações que possibilita essa interpretação. Carranza publicou um decreto em 29 de janeiro de 1915, uma alteração constitucional que determinava que, entre as competências do Congresso, estaria a de "legislar en toda la República, sobre minería, comercio, Instituciones de Crédito y Trabajo." ${ }^{561}$. Tratava-se de uma norma que autorizava um órgão federal a legislar sobre o tema antes de competência estadual, e nada dizia sobre o conteúdo que seria legislado. Concomitantemente, solicitou ao seu secretário de governo, Rafael Zubarán Capmany, que elaborasse um projeto de lei sobre direito do trabalho. Em 12 de abril de 1915, pouco mais de dois meses depois do decreto de Carranza, Zubarán apresentou sua proposta, bastante ampla, de "Proyecto de

\footnotetext{
${ }^{559}$ Texto original da Constituición Política de los Estados Unidos Mexicanos, de 5 de fevereiro de 1917. Em Centenario de la Constitución Política de los Estados Unidos Mexicanos 1917. México, Instituto Nacional de Estudios Históricos de las Revoluciones de México (INEHRM), 2015. $<$ http://www.juridicas.unam.mx/infjur/leg/conshist/pdf/1917.pdf > Consulta realizada em 06/01/2016.

${ }^{560}$ Texto original da Constituición Política de los Estados Unidos Mexicanos, de 5 de fevereiro de 1917. Em Centenario de la Constitución Política de los Estados Unidos Mexicanos 1917. México, Instituto Nacional de Estudios Históricos de las Revoluciones de México (INEHRM), 2015. $<$ http://www.juridicas.unam.mx/infjur/leg/conshist/pdf/1917.pdf > Consulta realizada em 06/01/2016.

561 A íntegra do decreto de Carranza de 29 de janeiro de 1915 está disponível aqui: $<$ http://congresojal.gob.mx/bibliotecavirtual/libros/legislacionprecosntitucional1915.pdf > P. 28. Consulta realizada em 22/12/2015.
} 
Ley sobre Contrato de Trabajo" ${ }^{562}$. Carranza, que não tinha nenhum constrangimento em assumir pessoalmente o exercício do poder legislativo, não transformou o texto em lei.

Ao invés disso, em 22 de junho de 1915, publicou um decreto sobre tiendas de raya - um entre os muitos problemas dos trabalhadores mexicanos. No lugar de declarar a extinção dessa instituição nefasta, proibindo as práticas que vinculassem o pagamento de salário semanal (raya) a compras em estabelecimentos comerciais específicos, ou a realização do pagamento com vales, Carranza criou para o poder público uma obrigação: a de criar centros comerciais em todos os povoados em que o Ayuntamiento (menor unidade política mexicana de então) "lo juzgue conveniente" 563 . A risível proposta carrancista para o enfrentamento do grave problema de pagamento por meio de vales que deveriam ser utilizados em estabelecimentos comerciais vinculados aos donos das empresas ou seus protegidos (estabelecimentos esses que praticavam preços maiores do que o mercado) era propor - e não obrigar - que os municípios construíssem zonas comerciais nos povoados que julgassem convenientes. Enquanto isso, o projeto de Rafael Zubarán Capmany, com propostas mais consistentes para resolver o mesmo problema, permanecia na gaveta. Em sua proposta de artigo 34, Zubarán definia “El pago de la retribución deberá hacerse en moneda del curso legal, quedando prohibido el uso de fichas, tarjetas, boletos o cualesquiera otros objetos o signos representativos de dicha moneda." 564 .

Essa sucessão de fatos e normas indica de forma clara a pouca disposição de Carranza para regular as relações de trabalho no México. Uma vez mais, sua proposta inicial de texto constitucional e o artigo 123 efetivamente aprovado pela Constituição Mexicana de 1917 demonstraram sua derrota ideológica, ainda que parcial. Boa parte da historiografia sobre a Revolução Mexicana é carrancista. Neste trabalho, a história do direito e dos embates jurídicos vividos no período que antecedeu a elaboração da Constituição contribuem para uma reavaliação dessa tendência.

\footnotetext{
${ }^{562}$ A íntegra do projeto de lei que tinha por objetivo regular as relações de trabalho, de Rafael Zubarán Capmany, publicado em 12 de abril de 1915, disponível aqui: $<$ http://dgb.conaculta.gob.mx/coleccion_sep/libro_pdf/50000006389.pdf\#toolbar=0> Consulta realizada em 21/12/2015. P. 3-4.

${ }^{563}$ A íntegra do decreto de Carranza de 22 de junho de 1915 está disponível aqui: <http://congresojal.gob.mx/bibliotecavirtual/libros/legislacionprecosntitucional1915.pdf > P. 41. Consulta realizada em 22/12/2015.

${ }^{564}$ A íntegra do decreto de Carranza de 22 de junho de 1915 está disponível aqui: <http://congresojal.gob.mx/bibliotecavirtual/libros/legislacionprecosntitucional1915.pdf > P. 41. Consulta realizada em 22/12/2015.
} 
Afirmar que Carranza venceu a Revolução Mexicana e que, portanto, realizou-se a profecia maldita de que as classes dominantes, ao fim e ao cabo, participaram da revolução para que tudo permanecesse como estava, é uma visão bastante parcial do que aconteceu no México naqueles anos. Desconsidera exatamente o feito jurídico que foi a Constituição Mexicana de 1917. Carranza foi derrotado exatamente em seu objetivo de estabilizar politicamente o Estado Mexicano sem realizar (ou prometer juridicamente realizar) transformações sociais consideráveis, que garantissem mais terras às comunidades de camponeses e diversos direitos trabalhistas.

Muito embora Carranza tenha sido bastante hábil no uso simbólico dos instrumentos jurídicos que tinha à sua disposição - ao parecer prometer algo que, literalmente, não desejava cumprir, como tentou fazer por meio do Decreto de 6 de janeiro de 1915 -, os anseios sociais defendidos por armas se impuseram. Naquele contexto, parecer prometer devolver as terras era o mesmo que devolver - as artimanhas literais do texto normativo foram desconsideradas para prevalecer o sentido geral que a época (e não o autor) conferiam a elas. O sentido atribuído ao decreto de 6 de janeiro de 1915 pela sociedade mexicana de 1915-1916 saiu do controle deCarranza. Assim como o Congresso Constituinte convocado por ele para realizar a enorme tarefa de redigir uma Constituição em apenas dois meses também saiu do controle. Apesar do pouco tempo, os constituintes mexicanos fizeram da Constituição um monumento em homenagem à Revolução e às forças que a plasmaram.

Toda Constitución Política fundamental, emanada de una revolución política victoriosa, aunque haya sido impuesta por una minoría, debe ser considerada, como la más exacta expresión de la voluntad nacional, porque resume la acción de los que la imponen, la sanción de los que consienten, y la impotencia de los que la resisten. ${ }^{565}$

\footnotetext{
${ }^{565}$ A. Molina Enríquez. Postulados generales de la Constitución de Querétaro que sirven de base al artículo 27. Boletín de la Secretaria de Gobernación, p. 11. Apud CORDOVA, Arnaldo. La ideología de la Revolución Mexicana - la formación del nuevo régimen. $8^{\mathrm{a}}$ Edición. Ciudad del México: Ediciones Era, 1980, p. 227.
} 


\section{Por que os anseios de transformação social se expressavam por meio da forma jurídica no México revolucionário?}

Zapatistas, villistas, maderistas, orozquistas, carrancistas, convencionistas, constitucionalistas: praticamente todos os grupos que participaram da Revolução Mexicana e tiveram em algum momento identidade política própria ${ }^{566}$ formularam planos e documentos com suas propostas para transformar a realidade mexicana.

Muitos desses documentos assumiam uma clara forma jurídica. Além da divisão em duas partes - exposição de motivos e parte dispositiva -, os textos apresentavam suas razões iniciais por meio de "considerandos" e usavam a linguagem do futuro, de como "deverá ser quando" algo acontecer; "declaram que deve ser feita" a divisão de terras; "se propõem a realizar a reforma para garantir" direitos aos trabalhadores. A linguagem que indica, almeja, impõe a existência de um dever ser futuro se soma à generalidade e abstração das normas. Com exceção das declarações de apoio a uma pessoa ou grupo político, ou ainda a declaração de que alguém é "jefe de la Revolución", os textos dos documentos normativos são genéricos e abstratos: instituem uma nova realidade jurídica válida para todos e todas as situações que se enquadrem em seus pressupostos e hipóteses. Generalidade, abstração, igualdade frente a norma: os textos dos planos incorporam as características típicas das normas jurídicas.

Assim, apenas a título de exemplo, está no Plan de Ayala (1911) dos zapatistas "por esta causa se expropiarán sin previa indemnización de la tercera parte de esos monopolios a los poderosos propietarios de ellos, a fin de que los pueblos y ciudadanos de México obtengan ejidos, colonias, fundos legales." 567; na Ley Agrária (1915) dos villistas "Se declara de utilidad pública el fraccionamiento de las grandes propiedades territoriales en la porción excedente del límite que se fije conforme a los artículos anteriores" ${ }^{\text {,68; }}$; no Programa de Reformas Político-Sociales (1916) da Soberana

\footnotetext{
566 Embora em diferentes momentos do desenrolar revolucionário haja diferentes sobreposições, aproximações e distanciamentos entre os membros dos grupos acima citados.

567 A íntegra do Plan de Ayala, publicado pelos zapatistas em 25 de novembro de 1911, pode ser consultada em: Doralicia Carmona. Memoria Política de México. México: Universidade de Guanajuato, 2014. <http://www.memoriapoliticademexico.org/Textos/6Revolucion/1911PDA.html> Consulta realizada em 21/11/2015.

${ }^{568}$ Ley Agraria de Francisco Villa, publicada em 24 de maio de 1915. Em Biblioteca Garay. 500 años de México en documentos. Cidade do México, 2011.

<http://www.biblioteca.tv/artman2/publish/1915 210/Ley_Agraria_del_General_Francisco_Villa_211.sht $\underline{\mathrm{ml}}>$ Consulta realizada em 05/01/2016.
} 
Convención Revolucionaria de Aguascalientes "La Revolución se propone realizar las siguientes reformas: (...) Dar garantías a los trabajadores, reconociéndoles el derecho de huelga y el de boicotage. "569

Será essa apenas uma questão estilística, uma escolha casual ou aleatória ligada à forma de expressão - absolutamente independente do fenômeno jurídico - ou ela deixa entrever certa relação, crença, confiança ligada ao potencial transformador das normas jurídicas? E, no mesmo sentido, essa opção estaria relacionada com o fato de o México ter sido capaz de formular a primeira constituição social do mundo?

Ao adotar essa forma de escrita de seus anseios de transformação social as diferentes correntes revolucionárias mexicanas decidiram deliberadamente disputar a forma-direito que seria responsável por ordenar a sociedade. Assumiram, assim, que o conteúdo das normas jurídicas estava também sujeito ao resultado da luta social que eles vinham travando. E que não se tratava de uma batalha perdida contra uma forma que lhes era necessariamente desfavorável, mas de uma disputa que poderia ser vencida ${ }^{570}$.

Pode-se dizer que a história da Constituição Mexicana de 1917 é uma história de movimentos revolucionários camponeses (aos quais se somaram alguns trabalhadores urbanos) que decidiram lutar por uma distribuição mais justa da riqueza natural e social do México. Entre suas principais táticas de luta estava a disputa da forma jurídica que a nova organização social iria assumir. O embate de concepções jurídicas sobre como reordenar a realidade fundiária e política estava quase em pé de igualdade com as lutas travadas por meio das armas. Isso explica de alguma forma a enorme quantidade de documentos político-normativos produzidos no período. Os revolucionários pareciam resolvidos a influenciar a forma de organização da sociedade por meio da edição de

\footnotetext{
${ }^{569}$ A íntegra do Programa de Reformas Político-Sociales de la Soberana Convención Revolucionária, de 18 de abril de 1916, em: Doralicia Carmona. Memoria Política de México. México: Universidade de Guanajuato, 2014. Disponível aqui:

<http://www.memoriapoliticademexico.org/Textos/6Revolucion/1916PRP.html> Consulta realizada em $27 / 12 / 2015$.

${ }^{570}$ A visão contrária, de que nunca valeria a pena disputar o direito já que ele seria apenas superestrutura e reflexo das relações de produção que estariam na base da organização social ou, por outro lado, forma de mascarar a dominação de classe - diferentes relações causais entre estrutura, o modo de produção e reprodução social, e superestrutura, o direito - é reproduzida em parte da literatura marxista. Nessa interpretação estreita da teoria marxista, o direito não mereceria atenção ou não poderia ser usado como um meio de alteração radical da realidade. Em Hespanha, reproduzindo a visão difundida para criticá-la: "Uma das vezes essa função será a de fornecer os instrumentos repressivos necessários à dominação de classe, outras das vezes será - em contrapartida - a de encobrir essa dominação por meio do estabelecimento de uma série de regras de convivência pretensamente abstractas e supraclassistas." HESPANHA, António M. A história do direito na história social. Lisboa: Livros Horizonte, 1978. P. 25.
} 
documentos e normas. Desejavam apresentar seu modo próprio de pensar e organizar a realidade mexicana.

Como já exposto acima, essa opção talvez tenha sido responsável pelo fato de os movimentos revolucionários agrários e populares terem saído parcialmente vitoriosos ao fim do processo, muito embora derrotados nas armas. As normas presentes na Constituição Mexicana de 1917 são a prova da parcial vitória, muito embora nem todas as disputas tenham sido vencidas (a delegação para os estados definirem os tamanhos máximos de propriedade fundiária permitidos e definirem o valor do salário mínimo capaz de garantir uma vida familiar digna foram derrotas, por exemplo). Isso mostra apenas que o texto constitucional é resultado dos embates ideológicos, de projetos normativos de sociedade, existentes à época. Embate não é consenso; as formulações também não haveriam de ser apenas favoráveis a um dos lados da disputa, sobretudo se ela foi derrotada. A avaliação que emerge a partir dessas constatações é que a Constituição Mexicana pode ser considerada o resultado de um processo democrático que, imerso em um ambiente de conflito armado, se realizava fora de instituições formais de produção legislativa. O embate e o debate de propostas de regulação jurídica para a sociedade se realizava ao longo do processo revolucionário, mesmo não havendo um espaço institucionalizado de deliberação. Quando em 1916 esse espaço foi criado, refletiu os debates que já vinham ocorrendo na sociedade mexicana insurgente.

A opção pela forma jurídica, nesse contexto, não pode ser considerada como meramente acessória. Ao contrário, ela parece assumir importância central, tanto como tendência geral inscrita no processo revolucionário como nas consequências desse processo, particularmente a elaboração da Constituição de 1917 que, como explicitamos na seção anterior, pode ser considerada a maior vitória - ocorrida essencialmente no plano simbólico e jurídico - das forças que lutavam por justiça social. Os zapatistas explicitam sua decisão por esse instrumento também ao encerrar seu principal documento político - o Plan de Ayala - com o lema “Justicia y Ley”. Pode-se apenas especular sobre o porquê da aposta de alguns movimentos revolucionários mexicanos pela elaboração normativa de seus anseios. Talvez a crença no direito para esses grupos derive do fato de que, quando usado contra as comunidades indígenas rurais mexicanas, ele tenha sido muito efetivo. Um raciocínio que passe pela afirmação de que, já que o direito (e o Estado que o implementa) pode ser o instrumento para realizar a injustiça sobre a realidade das terras, isso significa que esse instrumento tem poder, e 
eventualmente poder suficiente para reverter essas mesmas injustiças, ou mesmo instituir uma nova justiça. Além disso, a forma ejido de propriedade comunal (assim como tierras de repartimiento, fundos legales e outros) foi formalizada na legislação colonial do México. Normas jurídicas da colônia foram responsáveis por garantir aos pueblos suas terras comunais. Em um determinado momento da história fundiária mexicana suas comunidades tinham sido beneficiadas pelo direito que lhes garantiu formalmente a posse das terras que eram efetivamente suas, protegendo-as durante um período contra terceiros.

Essas são razões conjunturais, extraídas da história e das relações que aqueles grupos revolucionários estabeleceram com o direito. Talvez se some a esses fatores conjunturais um ainda mais profundo. $\mathrm{O}$ "dever ser" normativo pode ser uma forma propícia, adequada, favorável à elaboração textual de desejos sobre como deve ser a sociedade. Mas essa particular aptidão para formular projetos sociais ganha relevância devido a características muito específicas do texto jurídico, ou melhor, do papel que ele é chamado a desempenhar - e que lhe é reconhecido - na sociedade. Nesse sentido, o historiador português António Manuel Hespanha oferece uma análise bastante perspicaz sobre o que o direito teria de específico em relação a outras práticas capazes de produzir efeito de sentido:

Se todas [práticas jurídicas, políticas, ideológicas] produzem um 'efeito de sentido' - ou seja, uma valoração dos factos sociais -, o efeito produzido pela prática jurídica ('efeito de jurisdicidade') tem isso de característico que é o accionar (ou, pelo menos, pôr em condições de serem accionados) os aparelhos repressivos do Estado. Daqui pode-se dizer que a prática jurídica não se limita a transformar a 'consciência' dos homens (como as práticas ideológicas), mas produz transformações nas próprias relações sociais. ${ }^{571}$

Hespanha chama a atenção para o fato de que as normas jurídicas, ao mesmo tempo em que expõem uma concepção de mundo ou uma formulação de como as relações sociais deveriam ser, explicitando propostas para a construção de uma forma de sociedade, também são capazes de acionar as instituições estatais responsáveis por sua efetividade. Nesse sentido, o direito é uma linguagem de poder porque vem acompanhada da capacidade de constranger o aparato estatal a responder a ela. Além

\footnotetext{
${ }^{571}$ HESPANHA, António M. A história do direito na história social. Lisboa: Livros Horizonte, 1978. P.34.
} 
disso, Hespanha afirma que a forma jurídica tem uma especial capacidade de produzir legitimidade para o exercício do poder:

Tal como a prática política, a prática jurídica tem por objecto a transformação-manutenção das relações sociais. Mas o seu objectivo constitui, na verdade, um específico modo de actuação sobre elas com isto de característico que o de gerar um sentimento colectivo de legitimidade quanto à intervenção coercitiva do aparelho repressivo do Estado (produção do efeito a que chamarei 'de jurisdicidade'). ${ }^{572}$

Muito provavelmente os mexicanos tenham percebido essas características da linguagem jurídica na prática. E é nessas características que encontramos a resposta ao questionamento com que abrimos esta seção. Se isso é verdade, as razões que levaram os movimentos revolucionários mexicanos a escolher a forma jurídica para escrever seus anseios de transformação social transcendem as contingências da Revolução Mexicana. Elas traduzem, por meio de um exemplo fático de inegável proporção e relevância histórica, como foi a Revolução Mexicana, algo importante a respeito das possibilidades da forma jurídica como vetor da transformação social.

\section{O direito na história e a história do direito}

António Manuel Hespanha, em seu livro “A história do direito na história social”, propõe uma sociologia da historiografia jurídica portuguesa. Nela analisa a crise vivida pela disciplina "História do Direito" a partir da segunda metade do século XIX. Se no início do século a história jurídica tinha uma função clara, a de "desvalorizar a ordem social e jurídica pré-burguesa, apresentando-a como fundada na irracionalidade, no preconceito e na injustiça" ${ }^{573}$, a afirmação que se seguiu, de que o direito iluminista racional apenas reconhecia a normatividade que emanava de uma fonte "natural", retirou-lhe o objeto de estudos. Se o direito não é humano e contingente - e, portanto, sujeito às determinações de seu momento histórico; se ele é natural e descoberto pela razão, não há história do direito a ser feita.

\footnotetext{
${ }^{572}$ HESPANHA, António M. A história do direito na história social. Lisboa: Livros Horizonte, 1978. P.34.

${ }^{573}$ HESPANHA, António M. A história do direito na história social. Lisboa: Livros Horizonte, 1978. P.9.
} 
Nesse contexto de crise, chama a atenção para a função ideológica que o estudo e a disciplina da história do direito voltam a assumir em meados do século $\mathrm{XX}$ em Portugal:

(...) o principal substrato ideológico dos historiadores do direito (...) dos anos trinta e quarenta (...) tem o sentido fundamental de sacralizar a tradição, de opor a evolução espontânea (o direito consuetudinário) à ruptura revolucionária (ou mesmo legislativa); e, pelo menos nos manuais escolares, é esta a concepção geralmente veiculada acerca da natureza do direito e de sua evolução. ${ }^{574}$

O sentido que o autor percebe é o de um elogio às formas costumeiras de produção normativa e a crítica à origem revolucionária ou legislativa do direito. Apesar de criticar a postura que essa vertente historiográfica adota para suas pesquisas, o texto segue chamando a atenção para a importância do estudo da história do direito para a própria compreensão do fenômeno jurídico. E também sobre a importância de tratá-la como um objeto de pesquisa independente, irredutível em suas especificidades também em relação às histórias política e ideológica, talvez as mais próximas. Reconhece, paralelamente, a "impossibilidade de uma história global, que reduza toda a realidade humana a um único nível, agrupando todos os fenómenos à volta de um só pólo." 575 Afirma então:

Fazer história do direito a história de um nível específico da actividade humana abre importantes perspectivas teóricas. Permite, por um lado, dissolver o principal fundamento filosófico do idealismo. Por detrás das principais correntes do idealismo jurídico está, de facto, a crença em que é no 'homem' - na sua razão, na sua experiência vital, no seu espírito - que se deve buscar a origem dos valores jurídicos. Agora, pelo contrário, vamos encontrar como entidade constituinte do direito (i.e., responsável pela existência e sentido dos valores jurídicos) a estrutura historicamente determinada de um aparelho produtivo; um aparelho institucional criado, é certo, pelos homens e no qual os homens actuam, mas cuja lógica - interrelacionada, de resto, com a de outros 'aparelhos' e dependente, em última instância, da lógica global da totalidade social - não está na disponibilidade dos individuos ou, mesmo, das classes. Por isso, se este entendimento exclui a explicação do direito com o recurso a entidades ideais como 'boa razão', o 'espírito do povo', a 'natureza das coisas', a 'lógica material', o 'sentimento do justo', não deixa de excluir, também, o recurso explicativo à 'vontade ou interesses da

\footnotetext{
${ }^{574}$ HESPANHA, António M. A história do direito na história social. Lisboa: Livros Horizonte, 1978. P.14.

${ }^{575}$ HESPANHA, António M. A história do direito na história social. Lisboa: Livros Horizonte, 1978. P.18.
} 
classe dominante'. ${ }^{576}$ (grifado no original)

Eleger o direito e suas especificidades como um objeto de estudo histórico exclui, para Hespanha e para este trabalho, uma explicação simplista sobre sua função e funcionamento na sociedade. O direito, como meio capaz de formular com palavras como a sociedade deve ser, ou, dito de outra forma, como se almeja organizar a sociedade em que se vive, não pode ser considerado mero instrumento de dominação de classes.

O estudo dogmático do direito muitas vezes apresenta seu objeto como uma série de normas tal como elas são no momento histórico em que se estuda. Adquirem características estáticas: são assim e é assim que devem ser. Essa perspectiva desconsidera inclusive o devir normativo que se realiza no momento em que os órgãos competentes elaboram suas próprias interpretações sobre o significado dos textos legais. Nesse contexto, a história do direito tem importância para colocar as decisões legislativas na história. Para incentivar a percepção de que, se o ordenamento jurídico de um determinado tempo e lugar tem certas características, elas derivam do momento histórico em que ele foi criado, e não devem ser naturalizadas. Como produto da ação humana, o direito é necessariamente imperfeito, mutável, sujeito a pressões e a interesses de grupos humanos, tanto no momento de sua elaboração quanto de sua aplicação. O direito está necessariamente na história e chamar a atenção para esse fato já é, per si, importante.

Além disso, a visão estreita do direito daqueles que enxergam nessa forma social uma representação perfeita da vontade ou interesses da classe dominante, fica explícita quando as normas jurídicas oferecem resistência à realização de seus anseios ${ }^{577}$. A Revolução Mexicana é um exemplo desse caso. Como prática social, o direito não está à disposição de nenhuma das classes, já que pode ser praticado por todas elas, sendo sempre objeto de disputas simbólicas.

A redução da complexidade do fenômeno jurídico na realidade social identificando-o com apenas uma classe e retirando-o do espaço de enfrentamento de

\footnotetext{
${ }^{576}$ HESPANHA, António M. A história do direito na história social. Lisboa: Livros Horizonte, 1978. P.23.

577 “(...) o direito é uma forma particular, entre outras, da política. (...) Mas o que não fica explicado é aquele facto já referido por Marx de, em certos momentos, o interesse político de uma classe ter de ser sacrificado à indisponibilidade da forma jurídica." HESPANHA, António M. A história do direito na história social. Lisboa: Livros Horizonte, 1978. P. 32-33.
} 
ideias, concepções, propostas sobre a forma de organizar a sociedade - é prejudicial tanto para o estudo da história quanto para a percepção sobre ser ou não possível a disputa política em torno do fenômeno jurídico. Nesse sentido, verifica-se a importância da história do direito para desconstruir as visões simplificadoras.

Esta tese teve como objetivo inicial elaborar uma interpretação sobre a história do direito mexicano; queria-se identificar quais elementos e debates jurídicos haviam possibilitado a formulação da Constituição Mexicana de 1917, com todas as suas especiais características. A análise dos textos de planos, decretos normativos e outros documentos revolucionários - fontes primárias escritas em linguagem jurídica - trouxe importantes elementos para a compreensão e interpretação da própria Revolução Mexicana. A história do direito que foi contada contribui para novos olhares sobre aquele momento histórico, levando a discordâncias e divergências frente à historiografia consagrada. Levou também a conclusões importantes acerca do papel do direito na história, e particularmente na história das revoluções.

Como já foi mencionado, a historiografia sobre a Revolução Mexicana é bastante diversificada quanto à avaliação do processo revolucionário como um todo e também quanto à avaliação sobre suas principais lideranças (ver introdução). A interpretação deste trabalho sobre a figura de Carranza e de seu significado político só foi possível a partir da análise dos documentos jurídicos produzidos no período. Também para a avaliação de Emiliano Zapata e Francisco Villa, os documentos estudados e seu contexto de elaboração foram fundamentais. Apenas para citar um exemplo significativo, a visão caricata de Villa como um líder popular tosco, inconsistente politicamente e ávido por poder pessoal às vésperas da Convención de Aguascalientes não era condizente com o documento que produziu em conjunto com Álvaro Obregón, expondo as razões de não concordar com a forma como Carranza havia convocado o congresso de líderes. Suas razões, relacionadas à forma de composição proposta para a convenção, eram razoáveis. Também a identidade ideológica alegada entre o decreto de 6 de janeiro de 1915 e o artigo 27 da Constituição não se sustenta depois da análise de seus respectivos textos e contextos. Mais importante do que esses exemplos pontuais: a avaliação do significado da Constituição Mexicana de 1917 influencia a percepção sobre o saldo geral, positivo, da Revolução Mexicana, como já exposto nesta conclusão. 
A partir dessa história específica e determinada, pode-se perceber a relevância de se realizar histórias dos direitos como uma das metodologias capazes de colaborar com a compreensão geral dos diferentes momentos históricos. Podemos falar aqui na importância de se realizar pesquisas em história do direito. Por outro lado, investigar as possibilidades e os limites que os instrumentos jurídicos possuem para estimular, produzir e potencializar transformações sociais - tema recorrente ao longo da tese e desta conclusão - poderia ser objeto de pesquisas que se dedicam à importância do direito na história.

Ao final da história jurídica da Revolução Mexicana há a criação de uma nova forma jurídica, conhecida como constituição social. Essa nova forma, que amplia as funções do Estado e garante direitos sociais, por sua vez, foi replicada em diversos países desde 1917, a começar pela Alemanha de 1919, e passando pelo Brasil de 1988, entre muitos outros. Muitos analistas políticos e sociais, bem como muitos juristas, afirmam a disfuncionalidade desta específica forma jurídica - constituição social - para a organização da vida em sociedade do século XXI. A Constituição seria "inchada", deixaria fora do âmbito facilitado das decisões legislativas e políticas uma série de questões que não deveriam, segundo sua ótica, ser constitucionalizadas. Em geral, os críticos à ordem jurídica organizada por meio de uma constituição social também são aqueles que defendem que o Estado nacional deveria cumprir menos funções na organização da vida em sociedade.

Contar a história da primeira constituição social do mundo é também contar a história dessa forma que nasceu em um ambiente de debate sobre quais seriam as funções a serem assumidas pelo Estado e, sobretudo, já nasceu um pouco disfuncional. Depois de estudar a história da Revolução Mexicana e o ambiente em que a Constituição Mexicana de 1917 foi elaborada parece claro que essa mesma constituição enfrentaria inúmeros desafios para ser efetivada na prática. Ela se apresenta, assim, como representação dos anseios populares e democráticos de um período histórico. Mas ela não promete em nenhum momento que a concretização efetiva desses anseios seria fácil ou pouco conflituosa. 
Não se deve esperar tal promessa de um documento normativo que sintetize os desejos de transformação social, já que, ao se dispor a ser instrumento de transformação, necessariamente será um pouco disfuncional em relação à realidade que quer regular. $\mathrm{E}$ essa mesma realidade certamente oferecerá resistências. Isso não significa, por outro lado, que seja vã a tarefa de elaborar e consolidar em um texto tais pretensões, com expectativa de durabilidade no tempo e reconhecido formalmente como uma constituição, capaz de orientar as ações estatais. A história da Constituição Mexicana de 1917 é também um convite à reflexão sobre o significado, a importância e os inúmeros desafios que as constituições sociais enfrentam para efetivar os anseios que estão nelas explicitados. 


\section{BIBLIOGRAFIA}

\section{MéXICO E REVOLUÇÃo MEXICANA}

ALESSIO ROBLES, Miguel. Historia política de la Revolución. Ediciones Botas. México, 1938.

ANNA, Timothy. "La independencia de México y América Central". In BETHELL, Leslie (org.). Historia de America Latina. Vol. 5 - La independencia. Trad. Àngels Sòla. Barcelona: Editorial Crítica, 1991.

ÁVILA ESPINOSA, Felipe Arturo. Las corrientes revolucionarias y la Soberana Convención. $1^{\text {a }}$. ed. México, D.F.: Instituto Nacional de Estudios Históricos de las Revoluciones de México, 2014. 524 p. Disponível em http://www.inehrm.gob.mx/work/models/inehrm/Resource/455/1/images/Las_corrientes _revolucionarias_y_la_soberana_convencion_Felipe_Avila.pdf

AZUELA, Mariano. Los de Abajo. Cidade do México: Fondo de Cultura Economica, 2010.

BETHELL, Leslie (org.) História da América Latina vol. V: de 1870 a 1930. Trad. Geraldo Gerson de Souza. São Paulo: Edusp, 2008.

BIBLIOTECA GARAY. 500 años de México en documentos. México, 2011. <http://www.biblioteca.tv $>$ Consulta realizada em 21/12/2015.

BORTZ, Jeffrey. The Revolution, the Labour Regime and Conditions of Work in the Cotton Textile Industry in Mexico, 1910-1927. Cambridge University Press. Journal of Latin American Studies, Vol. 32, No. 3 (Oct., 2000), pp. 671-703. Disponível em: http://www.jstor.org/stable/158614 Consulta realizada em 18/12/2015.

; HABER, Stephen. The Mexican Economy, 1870-1930: essays on the economic history of institutions, revolution, and growth. Califórnia: Stanford University Press, 2002.

The Legal and Contratual Limits to Private Property Rights in Mexican Industry During the Revolution. In BORTZ, Jeffrey; HABER, Stephen. The Mexican Economy, 1870-1930: essays on the economic history of institutions, revolution, and growth. Stanfor: Stanford University Press, 2002. P. 255-288.

Revolution within the revolution: Cotton Textile Workers and the Mexican Labor Regime, 1910-1923. Stanford: Stanford University Press, 2008. 253 p. 
BUEN LOZANO, Nestor de. El nacimiento del derecho del trabajo. In BUEN LOZANO, Nestor de; MORGADO VALENZUELA, Emilio (org). Instituciones de derecho del trabajo y de la seguridad social. Cidade do México: Instituto de Investigaciones Jurídicas, 1997.

CAMÍN, Héctor Aguilar; MEYER, Lorenzo. A la sombra de la Revolución Mexicana. Ciudad de México: Aguilar, León y Cal Editores. 4a . Edição, 1990. P. 28.

CARBÓ, Margarita. "La Reforma y la Intervención: El campo en llamas". In Historia de la cuestión agraria mexicana: La tierra y el poder, 1800-1910. Cidade do México: Siglo XXI/Centro de Estudios Históricos del Agrarismo en México, pp. 82-174.

CARMONA, Doralicia. Memoria Política de México. México: Universidade de Guanajuato, 2014. <http://www.memoriapoliticademexico.org/> Consulta realizada em: 21/12/2015.

CARPIZO, Jorge. La Constitución Mexicana de 1917. 2a . ed. México, DF: UNAM, 1973.

CARR, David Charles Wright; VIDAL, Luis Enrique Ferro; SOTO, Ricardo Contreras (coord.). La memoria histórica de los pueblos subordinados. Eumed.net (Universidad de Málaga/Fundación Universitaria Andaluza Inca Garcilaso), 2012.

CASTILLO, José R. del. Historia de la Revolución social de México. México, 1915.

COATSWORTH, John H. Indispensable Railroads in a Backward Economy: The Case of Mexico. In Journal of Economic History, nº 39, 4, 1979. P. 939-960.

COCKCROFT, James. Precursores intelectuales de la revolucion mexicana: 19001913. 24a . ed. Cidade do México: Siglo Veintiuno Editores, 2004.

CÓRDOVA, Arnaldo. La ideología de la Revolución Mexicana - la formación del nuevo régimen. $8^{\text {a }}$ Edición. Ciudad del México: Ediciones Era, 1980.

CORTINA QUIJANO, Aurora. Los Congresos Feministas de Yucatán en 1916 y su influencia en la legislación local y federal. Cidade do México: Instituto de Investigaciones Jurídicas, Universidad Nacional Autónoma de México, 1986.

CUEVA, Mario de la. El nuevo derecho mexicano del trabajo. Tomo I. Cidade do México: Editorial Porrúa, 1999.

Aspectos históricos-jurídicos del problema agrario en México. Segunda de dos partes: del México independiente al Constituyente de 1917. In Revista de la Facultad de Derecho de la Universidad Nacional Autónoma de México (UNAM). Número 235 de 2001.

FABELA, Isidro. Historia diplomática de la Revolución Mexicana. Tomo I. Fondo de Cultura Económica. México-Buenos Aires, 1958. 
FERREIRO GALGUERA, Juan. Libertad de imprenta en México: hacia una ley federal de comunicación social. Anuario da Facultade de Dereito da Universidade da Coruña. Universidade da Coruña: Servicio de Publicaciones, 2001.

FIGUEROA ESQUER, Raúl (org.). Correspondencia Diplomática de Salvador Bermúdez de Castro, Ministro de España en México, Tomo V. (De enero de 1847 a julio de 1848). México: ITAM - Instituto Tecnológico Autónomo de México / Instituto Nacional de Estudios Históricos de las Revoluciones de México, 2013.

FLORES, Imer B. La Constitución de 1857 y sus Reformas: a 150 años de su promulgación. In VALADÉS, Diego; CARBONELL, Miguel (Coord.). El Proceso Constituyente Mexicano. A 150 Años de la Constitución de 1857 y 90 de la Constitución de 1917. Instituto De Investigaciones Jurídicas De La Universidad Nacional Autónoma De México, 2007.

FLORES MAGÓN, Ricardo. Los pobres son la fuerza: discursos de Ricardo Flores Magón. $1^{\text {a }}$ Ed. Ciudad Autónoma de Buenos Aires: EGodot Argentina, 2015. E-book.

Semilla Libertaria. Tomo II. P. 60-61. Disponível em: Archivo Electrónico Ricardo Flores Magón. Cidade do México: Instituto Nacional de Antropología e História. $\quad<$ http://archivomagon.net/wpcontent/uploads/flores_magonricardo_semilla_libertaria_1923.pdf $>$ Consulta realizada em $05 / 10 / 2015$.

Tierra y Libertad. Archivo Electrónico Ricardo Flores Magón. Cidade do México: Instituto Nacional de Antropología e História. <http://archivomagon.net/obrascompletas/obra-literaria-1910-1917/teatro/tierralibertad/ Consulta realizada em 30/09/2015.

FRASER, Donald J. La política de desamortización en las comunidades indígenas, 1856-1872. In Historia Mexicana. Vol. 21, No. 4, en el Centenario de la muerte de Benito Juárez (Abril-Jun. de 1972).

Disponível

em

<http://www.jstor.org/stable/25135316?seq=1\#page_scan_tab_contents $>$ Consulta realizada em 11/08/2015.

GARCÍA DÍAZ, Bernardo. Migraciones internas a Orizaba y formación de la clase obrera en el porfiriato. In NOVELO, Victoria (org.). Historia y cultura obrera. Cidade do México: Instituto Mora; Centro de Investigaciones y Investigaciones en Antropología Social La Casa Chata, 1999. P. 104-137.

Apuntes sobre la Huelga de Río Blanco. In Anuario II del Centro de Estudios Históricos de la Universidad Veracruzana, Vera Cruz, 1979.

GARCÍA CANTÚ, Gastón. El socialismo em México. 4ª Reedición. Ciudad del México: Ediciones Era, 1986.

GARFIAS, Luis. La Revolución Mexicana - compendio histórico político militar. $7^{\mathrm{a}}$. reimpresión. Ciudad de México: Panorama Editorial, 2001. 
GILLY, Adolfo. La revolución interrumpida. $1^{\mathrm{a}}$ ed. digital. Cidade do México: Ediciones Era, 2013.

GÓMEZ-GALVARRIATO, Aurora. Measuring the Impact of Institutional Change in Capital-Labor Relations in the Mexican Textile Industry, 1900-1930. In BORTZ, Jeffrey; HABER, Stephen. The Mexican Economy, 1870-1930: essays on the economic history of institutions, revolution, and growth. Califórnia: Stanford University Press, 2002. P. 289-323.

GONZÁleZ NAVARRO, Moisés. Población y sociedade em México (1900-1970). Ciudad de México: Universidad Autónoma de México, 1974.

GONZÁLEZ SIERRA, José. Revolución y derecho obrero: Veracruz 1914 - 1916. In Anuário IV. Jalapa: Centro de Investigaciones Historicas Universidad Veracruzeana, 1986. P. 117-140.

HERZOG, Jesus Silva. Breve Historia de la Revolución Mexicana - Los antecedentes y la Etapa Maderista. Fondo de Cultura Económica do México. 15ª Reimpressão. Cidade do México, 1997.

Breve Historia de la Revolución Mexicana - La etapa constitucionalista y la lucha de facciones. Fondo de Cultura Económica do México. 14 ${ }^{\mathrm{a}}$. Reimpressão. Cidade do México, 1995.

Trayectoria ideológica de la Revolución Mexicana y otros ensayos. $1^{\mathrm{a}}$ reimp. Cidade do México: Fondo de Cultura Econômica, 1994.

HUERTA CUEVAS, Enrique. Ingeniería institucional y estabilidad política. El México revolucionario, 1908-1920. Tese de mestrado, Puebla, Benemérita Universidad Autónoma de Puebla, Facultad de Derecho y Ciencias Sociales, 2013, pp. 75-98. Disponível em: https://enriquehuertacuevas.wordpress.com/tag/el-congresoconstituyente-mexicano-de-1916-1917/ Consulta realizada em 04/12/2015.

IBARRA ROMO, Mauricio. La ley del trabajo de Salvador Alvarado. In Revista Alegatos en línea n. 2 - janeiro a abril de 1986. Cidade do México: Universidad Autónoma Metropolitana (UAM).

JARQUÍN, María Teresa (org.). Origen y evolución de hacienda en México: siglos XVI al XX. Memorias del simposio realizado del 27 al 30 de septiembre de 1989.1 a ed.. Toluca: Instituto Nacional de Antropología y Historia, 1990.

KATZ, Friedrich. O México: A República Restaurada e o Porfiriato, 1867-1910. In BETHELL, Leslie (org.) História da América Latina vol. V: de 1870 a 1930. Trad. Geraldo Gerson de Souza. São Paulo: Edusp, 2008.

Pancho Villa - Vol. 1. Trad. Paloma Villegas. México: Ediciones Era, 1998.

La servidumbre agraria en México en la época porfiriana. $9^{\mathrm{a}}$ reimp. Cidade do México: Ediciones Era, 2004 
KNIGHT, Alan. La Revolución Mexicana. Del Porfiriato al nuevo régimen constitucional. Trad. Luis Cortés Bargalló, rev. da trad. Argelia Castillo Cano. México: Fóndo de Cultura Económica, 2010.

KOURÍ, Emilio. La invención del ejido. Revista Nexos. jan. 2015. Disponível em: <http://www.nexos.com.mx/?p=23778 > Consulta realizada em 04/01/2016.

LAMBERT, Jaques. América Latina: estruturas sociais e instituições políticas. Trad. Lólio Lourenço de Oliveira e Almir de Oliveira Aguiar. 2a edição refundida. São Paulo: Ed. Nacional: Ed. da Universidade de São Paulo, 1979.

LEAL, Juan Felipe. Del mutualismo al sindicalismo en México: 1843-1911. 2a . ed. Cidade do México: Juan Pablos Editor, 2012.

LONCÁN, Alfonso Herranz. El Impacto Directo del Ferrocarril sobre el Crecimiento Económico Argentino durante la Primera Globalización. Revista Uruguaya de Historia Económica 1 (1), 2011. P. 34-52.

LUPANO, Maria Marta. Cuando la ficción se convierte en realidad. Las huelgas de Cananea y Río Blanco, en México, en clave de historia urbana. Buenos Aires: Instituto de Arte Americano e Investigaciones Estatísticas, 2015.

MACÍAS VÁZQUEZ, María Carmen. Antecedentes históricos de la cláusula de exclusión en México. Cidade do México: UNAM, Instituto de Investigaciones Jurídicas, 2002.

MADERO, Francisco. La sucesión presidencial em 1910. Biblioteca del Político, INEPAC. Coahuila, 1908. In CARMONA, Doralicia. Memoria política de México. Guanajuato:Universidade de Guanajuato, 2014. 〈http://www.memoriapoliticademexico.org/Textos/6Revolucion/1910LSP.pdf>

Consulta realizada em 26/10/2015

MAGAÑA, Gildardo. Emiliano Zapata y el Agrarismo en México. Tomos I a V. Instituto Nacional de Estudios Históricos de la Revolución Mexicana. México, 1a ed. 1937. Edición facsimilar 1985. Tomo I. p. 117-119. Disponível em:

http://biblioteca.diputados.gob.mx/janium/bv/md/LXII/emiliano_zapata_agra_mex.pdf

Consulta realizada em 02/11/2015.

MANCISIDOR, José. História de la Revolución Mexicana. El Gusano de Luz. México, 1958.

MARTÍNEZ BÁEZ, Antonio e outros. La Constitución de 1917 y la Economia mexicana. Universidad Nacional Autónoma de México. Escuela Nacional de Economia. México, 1958.

MAZA, Francisco de la. Código de colonización y terrenos baldíos de la República Mexicana: años de 1451 a 1892. Oficina Tip. De la Secretaría de Fomento, México, 1893. 
MÉXICO, Secretaria de Desarrollo Agrario, Territorial y Urbano. Colonizar y desamortizar. Disponível em: <http://www.sedatu.gob.mx/sraweb/conoce-lasecretaria/historia/colonizar-y-desamortizar/>. Consulta realizada em 10 de agosto de 2015 .

Diario de los debates del congreso constituyente de Querétaro, 1916-1917, tomo I y II, México, Cámara de Diputados, LX Legislatura, 2009.

Crônica parlamentária. Cidade do México: Camara de Diputados, 1986. Em <http://cronica.diputados.gob.mx/Iniciativas/53/138.html> Consulta realizada em 12/01/2016.

Colonizar y desamortizar. Cidade do México: Secretaria de Desarrollo Agrario, Territorial y Urbano de México, . Disponível em: $<$ http://www.sedatu.gob.mx/sraweb/conoce-la-secretaria/historia/colonizar-ydesamortizar/> Consultado em 10 de agosto de 2015.

MEYER, Jean, La revolución mexicana 1910-1940. Barcelona: Dopesa, 1973.

.; WOOMACK Jr., John. Diálogos sobre la historiografía de la Revolución Mexicana. Cidade do México: Centro de estudios mexicanos y centroamericanos, 2006. Disponível em: <http://books.openedition.org/cemca/2122> Consulta realizada em 08/01/2016.

MORA DONATTO, Cecilia. Aspectos históricos-jurídicos del problema agrario en México. Primera de dos partes: de la época prehispánica a la Independencia. In Revista de la Facultad de Derecho de la Universidad Nacional Autónoma de México (UNAM). Número 229-234; Enero-Diciembre de 2000.

MORALES JIMÉNEZ, Alberto; ESTEVES, José; GIL, Ramón. La Casa del Obrero Mundial. Cidade do México: Ediciones Hormiga Libertária, 2007.

NAIME, Alexander. La evolucion de la administracion publica del trabajo en el Estado de Mexico. Toluca: Secretaría del Trabajo, 1983.

NARVÁEZ HERNÁNDEZ, José Ramón. Historia de las instituciones jurídicas de los estados de la República Mexicana. México: Universidad Nacional Autónoma de México, 2010.

NEXOS. Volvámos con Pancho Villa: Una entrevista con Friedrich Katz. Revista Nexos, 1.11.1986. Em < http://www.nexos.com.mx/?p=4687> Consulta realizada em $05 / 01 / 2016$.

OBREGÓN, Álvaro. Ocho Mil kilómetros en campaña. Cidade do México: Fondo de Cultura Económica, 1959.

OCHOA SERRANO, Álvaro. Revolución y liderazgo en Atacheo. In PAREDES, Carlos; TERÁN, Marta (coord.). Autoridad y gobierno indígena en Michoacán: ensayos a través de su Historia. Volume II. Michoacán: Instituto Nacional de Antropología y História de la Universidad Michoacana de San Nicolás de Hidalgo, 2003. 
PUIG HERNÁNDEZ, Carlos Alberto. ¿Juntas o tribunales de trabajo? In KURCZYN, Patricia Villalobos (Coord.). ¿Hacia un nuevo derecho del trabajo? Cidade do México: Instituto de Investigaciones Jurídicas de la Universidad Nacional Autónoma de México, 2003.

RABASA, Emilio O. Historia de las constituciones mexicanas. Cidade do México: UNAM

Instituto de Investigaciones Jurídicas de la UNAM, 2000.

REED, John. México Insurgente. São Paulo: Boitempo, 2010.

RHODAKANATY, Plotino. Obras. Edição, prólogo e notas de Carlos Illades. Cidade do México: Universidade Nacional Autónoma de México, 1988.

ROA, Fernando González. El aspecto agrario de la Revolución mexicana. Departamento de Aprovisionamientos Generales, Dirección de Talleres Gráficos, México, DF, 1919, p. 82. Disponível em: UNAM. Cidade do México: Instituto de Investigaciones Jurídicas. 〈http://biblio.juridicas.unam.mx/libros/libro.htm?l=2885> Consulta realizada em 23/07/2015.

ROJAS SANDOVAL, Javier. Apuntes para la historia de la reglamentación de las relaciones laborales en Nuevo Leon. Nuevo León: Cuarto Congreso Nacional de Estudios del Trabajo, Universidad Autónoma de Nuevo León, 2003.

ROMERO SOTELO, María Eugenia; JÁUREGUI, Luis. México 1821-1867: Población y crecimiento económico. Cidade do México: Facultad de Economía / UNAM, 2003.

ROUAIX, Pastor. Génesis de los Artículos 27 y 123 de la Constitución Política de 1917. Puebla, Pue., 1945.

SAKA, Mark Saad. For God and Revolution: Priest, Peasant, and Agrarian Socialism in the Mexican Huasteca. Albuquerque, NM: University of New Mexico Press, 2013.

SANCHEZ, Evelyne. Los proyectos de colonización en el segundo imperio y el fortalecimiento del Estado Mexicano. In Historia mexicana. 2013, 250, Cidade do México: El Colegio de México, A.C. Disponível em <hal-00943702>. Consulta realizada em 01/09/1015.

SCORZA, Manuel. Bom dia para os defuntos. Trad. Hamílcar de Garcia. Rio de Janeiro: Civilização Brasileira, 1978.

SUAREZ-POTTS, William J. The making of law: the Supreme Court and labor legislation in México, 1875-1931. Stanford, Stanford University Press: 2012. 347 p.

TOLEDANO, Vicente Lombardo. La Libertad Sindical en México. Talleres Linotipográficos”La Lucha”. México, 1926. P. 84-85. 
URBINA VILLAGÓMEZ, Mirtha Leonela Urbina. Reconstrucción de una memoria negada: La lucha agraria de las comunidades indígenas en el Bajío y la Sierra Gorda (1876-1884). In CARR, David Charles Wright; FERRO VIDAL, Luis Enrique; CONTRERAS SOTO, Ricardo (coord.). La memoria histórica de los pueblos subordinados. Málaga: Eumed.net (Universidad de Málaga/Fundación Universitaria Andaluza Inca Garcilaso), 2012,

VÁZQUEZ GÓMEZ, Francisco. Memorias políticas 1909-1913. Ciudad do México: 1933, Imprenta Mundial. P. 400.

VERA ESTAÑOL, Jorge. La Revolución Mexicana. Orígenes y resultados. Editorial Porrúa, S.A. México, 1957.

VILLA, Joaquín. Sesión de la legislatura del estado de México de 9 de octubre de 1826, in Actas del Congreso Constituyente del Estado de México. Toluca: Imprenta del gobierno del Estado, 1826, vol. VIII.

VILLEGAS MORENO, Gloria PORRÚA VENERO, Miguel Angel (Coord.) Enciclopedia Parlamentaria de México, del Instituto de Investigaciones Legislativas de la Cámara de Diputados, LVI Legislatura. México. Primera edición, 1997. Serie III. Documentos. Volumen I. Leyes y documentos constitutivos de la Nación mexicana. Tomo III.

VOS, Jan de. Una legislación de graves consecuencias - el acaparamiento de tierras baldías en México, con el pretexto de colonización, 1821-1910. In Historia Mexicana: Revista del Centro de Estudios Históricos de el Colégio de México, vol. 34, n. 133, octubre-diciembre 1984.

WOMACK JR., John. Zapata y la Revolución Mexicana. Secretaría de Educación Pública y Siglo XXI Editores. México, $1^{\text {a }}$ ed. 1969. Reimpresión 1985. 443 pp.

WRIGHT, David Charles; VIDAL, Luis Enrique Ferro; SOTO, Ricardo Contreras (coord.). La memoria histórica de los pueblos subordinados. Eumed.net (Universidad de Málaga/Fundación Universitaria Andaluza Inca Garcilaso), 2012.

ZARCO, Francisco. Historia del Congreso Extraordinario Constituyente de 1856 y 1857. México, Imprenta de Ignacio Cumplido, 1857. 


\section{GERAL}

ARENDT, Hannah. As origens do totalitarismo. São Paulo: Cia das Letras, 2006.

. Sobre a Revolução. Trad. Denise Bottmann. São Paulo: Companhia das Letras, 2011.

BENJAMIN, Walter. Sobre o Conceito de História. In Magia e técnica, arte e política. Ensaios sobre literatura e história da cultura. São Paulo: Brasiliense, 1994.

BERCOVICI, Gilberto. Entre o Estado Total e o Estado Social - Atualidade do debate sobre direito, Estado e economia na República de Weimar. São Paulo, 2003. Tese (Livre Docência) - Faculdade de Direito, Universidade de São Paulo.

BOBBIO, Norberto. Dicionário de Política / Norberto Bobbio, Nicola Matteuci e Gianfranco Pasquino. Coord. Tradução de João Ferreira. $5^{\text {a }}$. Ed. Brasília, São Paulo: UNB: Imprensa Oficial do Estado, 2000.

BONAVIDES, Paulo. Do Estado liberal ao Estado social. 6a. Ed. São Paulo. Malheiros, 1996.

CANOTILHO, José Joaquim Gomes. Direito Constitucional e Teoria da Constituição. $3^{\text {a }}$. Ed. Coimbra. Almedina, 2002.

CERVANTES SAAVEDRA, Miguel de. El Ingenioso Hidalgo de Dom Quijote de la Mancha. Madrid: Saturnino Calleja, 1904.

COUTINHO, Carlos Nelson. A dualidade de poderes - Estado, revolução e democracia na teoria marxista. São Paulo: Editora Brasiliense, 1987.

DARNTON, Robert. O Beijo de Lamourette - Mídia, Cultura e Revolução. Trad. Denise Botmann. São Paulo: Companhia das Letras, 1990.

ENGELS, Friedrich. A origem da família, da propriedade privada e do Estado. 2a ed. São Paulo: Expressão popular, 2010, p. 218.

.; KAUTSKY, Karl. O Socialismo Jurídico. Tradução Lívia Cotrim e Márcio Brilharinho Naves. $2^{\text {a }}$ ed. rev. São Paulo: Boitempo, 2012.

FARIA, José Eduardo. Crise Constitucional e Restauração da Legitimidade. Porto Alegre: Fabris, 1985.

. Entre a Rigidez e a Mudança: A constituição no Tempo. Revista Brasileira de Direito Constitucional, São Paulo, n. 6, nov. 2003.

. Poder e Legitimação (uma introdução à política do direito). São Paulo: Perspectiva. 1978. 
FAUSTO, Ruy. A esquerda difícil: em torno do paradigma e do destino das revoluções do século XX. São Paulo: Perspectiva, 2007.

FORSTHOFF, Ernst. Stato di Diritto in Transformazione. Giufre, Milano, 1973.

GIDDENS, Anthony; TURNER, Jonathan (Org.). Teoria Social Hoje. Trad. Gilson César Cardoso de Sousa. São Paulo: Unesp, 1999.

HALliDAY, F. Revolution and World Politics. Durham: Duke Univ Press, 1999.

HESPANHA, António M. A história do direito na história social. Lisboa: Livros Horizonte, 1978.

HOLANDA, Sérgio Buarque de. Raízes do Brasil. São Paulo: Companhia das Letras, 1995 (26 edição).

JESSOP, Bob. State Theory: Putting the Capitalist State in its place. Cambridge: Polity Press, 1990.

KAUTSKY, K. The dictatorship of the proletariat. Westport (Conn.): Greenwood Press, 1981.

KIRCHHEIMER, Otto. Weimar - und was dann? Analyse einer Verfassung. In: Politik und Verfassung. Frankfurt am Main: Suhrkamp, 1964. p. 9-56.

Weimar - and what then? - An Analysis of a Constitution. In: BURIN, Frederic S.; SHELL, Kurt L. (Ed.). Politics, Law, and Social Change - Selected Essays of Otto Kirchheimer. New York: Columbia University, 1969. p. 33-74.

KOSELLECK, Reinhart. "Critérios históricos do conceito moderno de revolução". In Futuro Passado: Contribuição à Semântica dos Tempos Históricos. Trad. Wilma Patrícia Maas, Carlos Almeida Pereira; Rev. da trad. César Benjamin. Rio de Janeiro: Contraponto: Ed. PUC-Rio, 2006.

LOPES, José Reinaldo de Lima. Direito e Mudança Social. São Paulo. 1991.

LOWY, Michael. La teoria de la revolución en el joven Marx. Trad. Francisco Gonzales Aramburu. Buenos Aires: Siglo XXI argentina editores, 1972.

LUKÁCS, György. Notas críticas sobre a Crítica da Revolução Russa, de Rosa Luxemburgo. In História e Consciência de Classe: estudos sobre a dialética marxista. Trad. Rodnei Nascimento; rev. da tradução Karina Jannini. $2^{a}$ ed. São Paulo: Editora WMF Martins Fontes, 2012.

LUXEMBURGO, Rosa. A Revolução Russa. In Textos Escolhidos: Volume II, 19141919. Organização, tradução e notas Isabel Loureiro. São Paulo: Editora Unesp, 2011.

MALIA, M. History's Locomotives: revolutions and the making of the modern world. New Haven: Yale University Press, 2006. 
MARCUSE, Herbert. Razão e Revolução. Completar referência. Rio de Janeiro: Paz e Terra, 2009.

MARX, Karl. Crítica do Programa de Gotha. Seleção, tradução e notas de Rubens Enderle. São Paulo: Boitempo, 2012.

NEUMANN, Franz. Rechtsstaat, the Division of Powers and Socialism. In Social Democracy and the Rule of Law. Keith Tribe (Editor). Traduzido por Leena Tanner e Keith Tribe. London: Allen \& Unwin: 1987. pp. 66-84.

. The Social Significance of the Basic Laws in the Weimar Constitution. In Social Democracy and the Rule of Law. Keith Tribe (Editor). Traduzido por Leena Tanner e Keith Tribe. London: Allen \& Unwin: 1987. pp. 27-43.

SCHEUERMAN, William. Between the Norm and The Exception : the Frankfurt School and The rule of law. Massachusetts Institute of Technology, 1997.

SCHMITT, Carl. Legalidad y Legitimidad. Trad. José Diaz García, Aguilar Ediciones, Madrid, 1971, (original Legalität und Legitimität publicado em 1932).

. Legalität und Legitimität. 7ª ed., Duncker \& Humblot, Berlim, 2005. (publicação original de 1932).

SKOCPOL, T. Estados e Revoluções Sociais. Lisboa: Ed. Presença, 1985.

TALMON, J. The Origins of Totalitarian Democracy. Londres: Secker and Warburg, 1952.

WALT, Stephen M. Revolution and War. Ithaca e Londres: Cornell University Press, 1997.

WEBER, Max. Economia y Sociedad. Fondo de Cultura Económica, Cidade do México, 1981.

. Os três tipos de dominação legítima, In Sociologia. COHN, Gabriel (Organizador), São Paulo: Editora Ática. Pp. 128-141. 


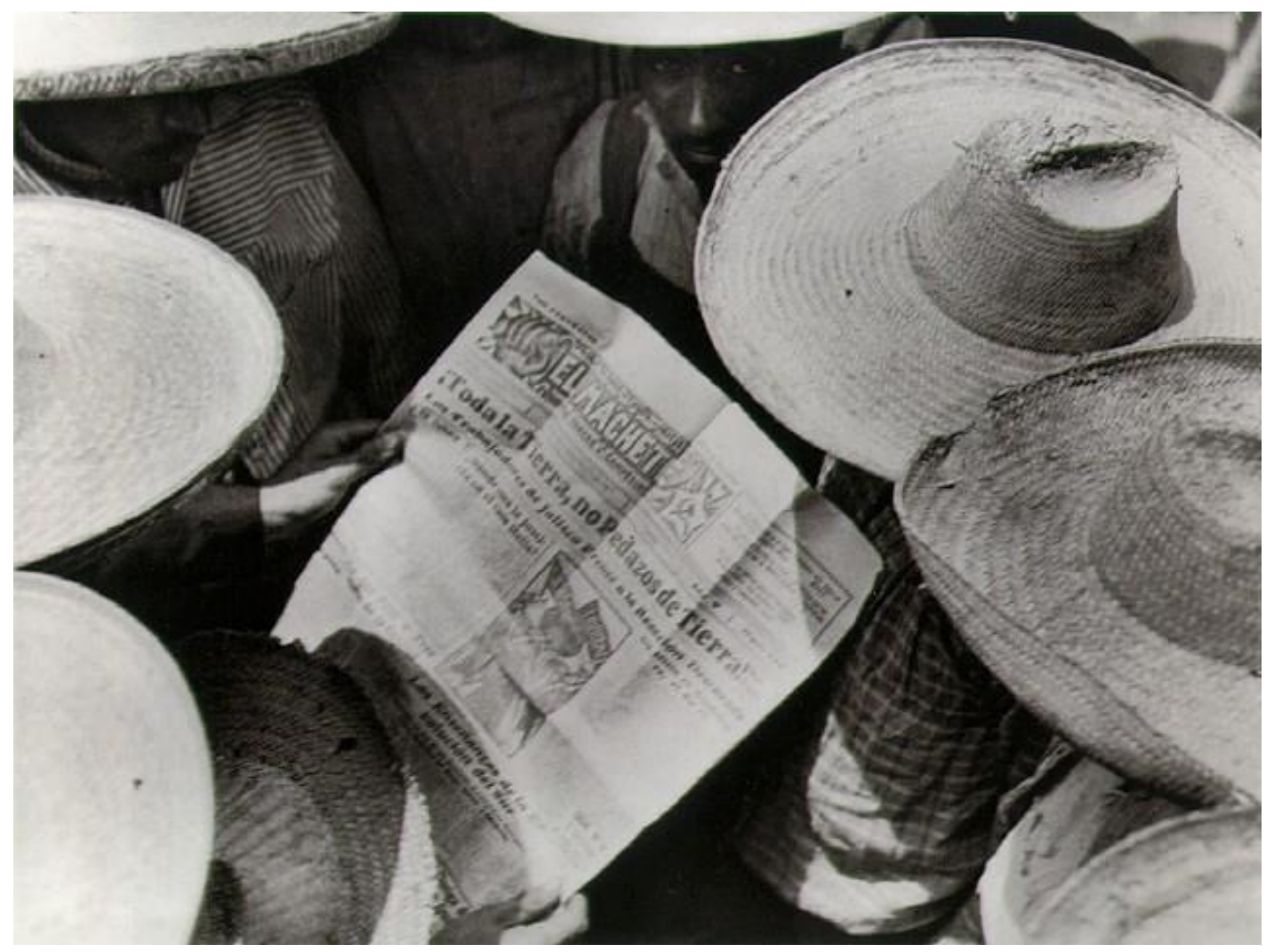

Tina Modotti. El Machete. Década de 1920.

Leis, Decretos, Planos Revolucionários $\mathrm{E}$ OUTRas Fontes PRIMÁRIAS CITADAS, EM ORDEM CRONOLÓGICA

\section{Las Siete Partidas del Rey D. Alfonso El Sabio}

Data: Entre 1256 e 1265 / Autor: Rey D. Alfonso X, Glosadas por D. Gregorio Lopez

Fonte: Biblioteca Valenciana - Colección: BV Fondo antiguo - Ubicación: BV Biblioteca Nicolau Primitiu

<http://bivaldi.gva.es/es/catalogo_imagenes/grupo.cmd?path=1010762> p. 370.

Consulta realizada em: 17/12/2015.

Decreto de 17 de novembro de 1810, publicado por José María Morelos. Decreta a extinção das castas. Em: CARMONA, Doralicia. Memoria Política de México. Guanajuato: Universidade de Guanajuato, 2014.

<http://www.memoriapoliticademexico.org/Textos/1Independencia/1810HMS.html >

Consultado em 13/07/2015.

Decreto de 29 de novembro de $\mathbf{1 8 1 0}$, publicado por Miguel Hidalgo y Costilla. Determina a extinção da escravidão em território mexicano. Em CARMONA, Doralicia. Memoria Política de México. Guanajuato: Universidade de Guanajuato, 2014. <http://www.memoriapoliticademexico.org/Textos/1Independencia/1810-MMHESC.html> Consulta em 13/07/2015. 
Decreto de 5 de dezembro de 1810, publicado por Miguel Hidalgo y Costilla. Determina que a posse das terras seja garantida seus "naturales". Em CARMONA, Doralicia. Memoria Política de México. Guanajuato: Universidade de Guanajuato, 2014.

http://www.memoriapoliticademexico.org/Textos/1Independencia/1810DOD.html> Consulta realizada em 13/07/2015.

Plan de Iguala, de 24 de fevereiro de 1821. Disponível em: CARMONA, Doralicia. Memoria Política de México. Guanajuato: Universidade de Guanajuato, 2014. <http://www.memoriapoliticademexico.org/Textos/1Independencia/1821PDI.html >

Consulta realizada em 29/12/2015.

Decreto de 4 de janeiro de 1823, de Agustín Iturbide. Em: MAZA, Francisco de la. Código de colonización y terrenos baldíos de la República Mexicana: años de 1451 a 1892. Cidade do México: Oficina Tip. de la Secretaría de Fomento, 1893,p. 171 a 176. Disponível em: <http://bdh-rd.bne.es/viewer.vm?id=0000013888\&page=1> Consulta realizada em 27/07/2015.

Decreto de 14 de outubro de 1823, editado pelo Congreso Mexicano.

Disponível em: BIBLIOTECA GARAY. 500 años de México en documentos. México, 2011.

<http://www.biblioteca.tv/artman2/publish/1823_122/Decreto_Formaci_n_de_la_provi ncia_del_Itsmo_printer.shtml > Consulta realizada em 14/07/2015.

Decreto de 18 de agosto de 1824, editado pelo Congreso Mexicano. Disponível em: CARMONA, Doralicia. Memoria Política de México. Guanajuato: Universidade de Guanajuato, 2014.

<http://www.memoriapoliticademexico.org/Textos/2ImpDictadura/1824DGF.html $>$

Consultado em 14/07/2015.

Constituição Federal de los Estados-Unidos Mexicanos, de 4 de outubro de 1824. Disponível em: CARMONA, Doralicia. Memoria Política de México. Guanajuato: Universidade de Guanajuato, 2014.

<http://www.memoriapoliticademexico.org/Textos/2ImpDictadura/1824CFEUM.html>

Consulta realizada em 14/07/2015.

Decreto de 6 de abril de 1830, chamada Ley de Colonización, em: CARMONA, Doralicia. Memoria Política de México. Guanajuato: Universidade de Guanajuato, 2014. $\quad<$ http://www.memoriapoliticademexico.org/Textos/2ImpDictadura/1830colo.html $>$ Consulta realizada em 12/01/2016.

Decreto de 27 de novembro de 1846, cria Dirección de Colonización.

FIGUEROA ESQUER, Raúl (org.). Correspondencia Diplomática de Salvador Bermúdez de Castro, Ministro de España en México, Tomo V. (De enero de 1847 a julio de 1848). Cidade do México: ITAM - Instituto Tecnológico Autónomo de México y Instituto Nacional de Estudios Históricos de las Revoluciones de México, 2013, p. 2190. 
Decreto de 8 de dezembro de 1846, regulamenta a Dirección de Colonización. FIGUEROA ESQUER, Raúl (org.). Correspondencia Diplomática de Salvador Bermúdez de Castro, Ministro de España en México, Tomo V. (De enero de 1847 a julio de 1848). Cidade do México: ITAM - Instituto Tecnológico Autónomo de México y Instituto Nacional de Estudios Históricos de las Revoluciones de México, 2013, p. 2191-2192.

Decreto de 11 de janeiro de 1847. Financiamento de guerra contra os EUA.

Em: CARMONA, Doralicia. Memoria Política de México. Guanajuato: Universidade de Guanajuato, 2014.

<http://www.memoriapoliticademexico.org/Textos/2ImpDictadura/1841LAQ.html >

Consulta realizada em 12/01/2016.

Decreto de 20 de agosto de 1853 que proíbia a vagancia (vagabundagem), pode ser encontrada em CARMONA, Doralicia. Memoria Política de México. Guanajuato: Universidade de Guanajuato, 2014.

<http://www.memoriapoliticademexico.org/Textos/2ImpDictadura/1853LCV.html >

Consulta realizada em 10/12/2015.

Decreto de 16 de fevereiro de 1854, sobre colonização.

Em: MAZA, Francisco de la. Código de colonización y terrenos baldíos de la República Mexicana: años de 1451 a 1892. Cidade do México: Oficina Tip. de la Secretaría de Fomento, 1893, p. 563.

Ley Juárez ou Ley de Administración de Justicia y Orgánica de los Tribunales de la Nación, de 23 de novembro de 1855. CARMONA, Doralicia. Memoria Política de México. Guanajuato: Universidade de Guanajuato, 2014.

<http://www.memoriapoliticademexico.org/Textos/3Reforma/1855LEJ.html >. Consulta realizada em 12/08/2015.

Decreto de 31 de março de 1856 sobre os bens da Igreja no Estado de Puebla. Em: CARMONA, Doralicia. Memoria Política de México. Guanajuato: Universidade de Guanajuato, 2014.

<http://www.memoriapoliticademexico.org/Textos/3Reforma/1856-D-BDO-IC.html >

Consulta realizada em 12/08/2015.

Voto de Ponciano Arriaga sobre direito de propriedade, de 23 de junho de 1856. Em CARMONA, Doralicia. Memoria Política de México. México: Universidade de Guanajuato, 2014. <http://www.memoriapoliticademexico.org/Textos/3Reforma/1856PA-VPart.html > Consulta realizada em 12/01/2016.

Ley de desamortización de los bienes de las corporaciones civiles y eclesiásticas Ley Lerdo, de 25 de junho de 1856. Em: BIBLIOTECA GARAY. 500 años de México en documentos. México, 2011.

$<$ http://www.biblioteca.tv/artman2/publish/1856_149/Ley_Lerdo_Ley_de_desamortizac i_n_de_bienes_de_la_i_247.shtml > Consulta realizada em 03/01/2016. 
Constitución Política de la República Mexicana de 1857, promulgada em 5 de fevereiro de 1857. Cidade do México: Instituto de Investigaciones Jurídicas. $\langle$ http://www.juridicas.unam.mx/infjur/leg/conshist/pdf/1857.pdf $>$ Consulta realizada em 11/01/2016.

Ley de Nacionalización de los Bienes del Clero Regular y Secular, de 12 de julho de 1859. Em CARMONA, Doralicia. Memoria Política de México. Guanajuato: Universidade de Guanajuato, 2014.

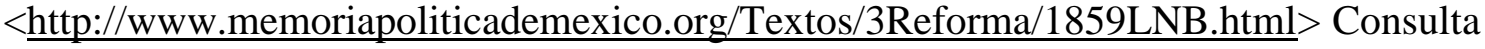
realizada em 17/08/2015.

Decreto de 13 de julho de 1859, que regulamenta a Lei de Nacionalização dos Bens do Clero. Em: CARMONA, Doralicia. Memoria Política de México. Guanajuato: Universidade de Guanajuato, 2014.

<http://www.memoriapoliticademexico.org/Textos/3Reforma/1859RLN.html >

Consulta realizada em 18/08/2015.

Ley sobre Libertad de Cultos, de 4 de dezembro de 1860. Em: CARMONA, Doralicia. Memoria Política de México. Guanajuato: Universidade de Guanajuato, 2014.

〈http://www.memoriapoliticademexico.org/Textos/3Reforma/1860LLC.html >

Consulta realizada em 18 de agosto de 2015.

Ley sobre Ocupación y Enajenación de Terrenos Baldíos, de 20 de julho de 1863.

MAZA, Francisco de la. Código de colonización y terrenos baldíos de la República Mexicana: años de 1451 a 1892. Cidade do México: Oficina Tip. de la Secretaría de Fomento, 1893, p. 729-735. http://bdh-rd.bne.es/viewer.vm?id=0000013888\&page=1

Decreto bilingue sobre Fundo Legal y Ejidos, con tradução para o Azteca (Nahuatl), de 16 de setembro de 1866. Em: LIBRARIES DIGITAL COLLECTIONS of University of Texas at Santo Antonio. Santo Antonio: University of Texas at Santo Antonio, 2011. <http://digital.utsa.edu/cdm/ref/collection/p15125coll6/id/1398>. Consultado em 12/01/2016.

Tratado de Miramar, de 10 de abril de 1867. Em: BIBLIOTECA GARAY. 500 años de México en documentos. México, 2011.

$<$ http://www.biblioteca.tv/artman2/publish/1864_161/El_Tratado_de_Miramar_1388.sh $\underline{\text { tml }}>$ Consulta realizada em 03/01/2016.

Decreto de 31 de maio de 1875, sobre colonização. Em: CARMONA, Doralicia. Memoria Política de México. Guanajuato: Universidade de Guanajuato, 2014. <http://www.memoriapoliticademexico.org/Textos/5RepDictadura/1875DCO.html >

Consulta realizada em 22/07/2015.

Plan Socialista proclamado por los representantes de los pueblos de los estados de Querpetaro y Guanajuato, do início de junho de 1879. Em:

$<$ http://anarquiamx.blogspot.com.br/2011/12/plan-socialista-de-la-sierra-gorda$\underline{1879 . h t m l}>$ Site consultado em 29/07/2015. 
Plan Socialista de Sierra Gorda, de 15 de julho de 1879. Em: CARMONA, Doralicia. Memoria Política de México. Guanajuato: Universidade de Guanajuato, 2014. <http://www.memoriapoliticademexico.org/Textos/5RepDictadura/1879-PS-SG.html> Consulta realizada em 30/07/2015.

Lei de 15 de dezembro de 1883, sobre terrenos baldios. Em: CARMONA, Doralicia. Memoria política de México. Guanajuato: Universidade de Guanajuato, 2014. <http://www.memoriapoliticademexico.org/Textos/5RepDictadura/1883LTB.html> Consulta realizada em 22/07/2015.

Código de Minas de 22 de novembro de 1884. Em: ARCHIVO HISTÓRICO DE PEMEX. Fuentes para la historia del Petroleo en México. http://petroleo.colmex.mx/images/stories/archivos/misc/CODIGO_DE_MINAS_1884.p df Consulta realizada em 14 de setembro de 2015.

Ley sobre ocupación y enajenación de terrenos baldíos de los Estados Unidos Mexicanos de 26 de março de 1894. Em: UNAM. Instituto de Investigaciones Jurídicas, Universidad Nacional Autónoma de México.

〈www.biblio.juridicas.unam.mx/libros/2/940/39.pdf $>$ Consulta realizada em 22/07/2015.

Ley General de Instituciones de Credito, de 19 de março de 1897. Em: CARMONA, Doralicia. Memoria política de México. Guanajuato: Universidade de Guanajuato, 2014. <http://www.memoriapoliticademexico.org/Textos/5RepDictadura/1897LGD.html >

Consulta realizada em 14 de setembro de 2015.

Primeira edição do hebdomadário Regeneración, de 7 de agosto de 1900. Archivo Electrónico Ricardo Flores Magón. Cidade do México: Instituto Nacional de Antropología e História. <http://archivomagon.net/wp-content/uploads/e1n1.pdf> Consulta realizada em 30/09/2015.

Ley del Petróleo, de 24 de dezembro de 1901. Em: BIBLIOTECA GARAY. 500 años de México en documentos. México, 2011.

<http://www.biblioteca.tv/artman2/publish/1901_204/Ley_del_Petr_leo_emitida_por_P orfirio_D_az_1407.shtml>CConsulta realizada em 14 de setembro de 2015.

Programa del Partido Liberal Mexicano, publicado em $1^{\circ}$ de julho de 1906. Íntegra em: MEXICO. Cidade do México: Secretaria de Gobernación: Unidade General de Asuntos Jurídicos. <http://www.ordenjuridico.gob.mx/Constitucion/CH6.pdf> Consulta realizada em 23/09/2015.

Documento de reivindicações dos mineiros de Cananea, publicado em $1^{0}$ de junho de 1906, em: CARMONA, Doralicia. Memoria política de México. Guanajuato: Universidade de Guanajuato, 2014:

$<$ http://www.memoriapoliticademexico.org/Textos/5RepDictadura/1906-HC-

MFR.html> Consulta realizada em 12/12/2015. 
Relato completo dos conflitos ocorridos a partir do início da greve em Cananea,

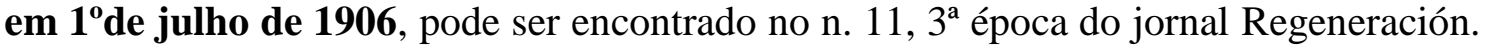
O facsímile da edição impressa pode ser consultado em: Archivo Electrónico Ricardo Flores Magón. Cidade do México: Instituto Nacional de Antropología e História. $<$ http://archivomagon.net/wp-content/uploads/e3n11.pdf $>$ Consulta realizada em $11 / 12 / 2015$.

Reglamento de Trabajo del Centro Industrial Mexicano - Decreto de 4 de janeiro de 1907, editado por Porfírio Díaz em: CARMONA, Doralicia. Memoria política de México. Guanajuato: Universidade de Guanajuato, 2014.

<http://www.memoriapoliticademexico.org/Textos/5RepDictadura/1907LPD.html >

Consulta realizada em 12/12/2015.

Periódico Revolución. Ano 1, Número 1. De $1^{\circ}$ de junho de 1907. Fac-símile disponível em: Archivo Electrónico Ricardo Flores Magón. Cidade do México: Instituto Nacional de Antropología e História. <http://archivomagon.net/wpcontent/uploads/rev_n1.pdf > Consulta realizada em 14/12/2015.

Entrevista de Porfírio Díaz a James Creelman, da revista 'The Pearson's Magazine, em 18 de março de 1908. Em BIBLIOTECA GARAY. 500 años de México en documentos. México, 2011.

$<$ http://www.bibliotecas.tv/zapata/bibliografia/indices/entrevista_diaz_creelman01.html $>$. Consulta realizada em 09/09/2015.

Carta de Ricardo Flores Magón a Enrique Flores Magón de 13 de junho de 1908. Archivo Electrónico Ricardo Flores Magón. Cidade do México: Instituto Nacional de Antropología e História. <http://archivomagon.net/obras-completas/correspondencia$\underline{1899-1922 / \mathrm{c}-1908 / \mathrm{cor} 265 />}$ Consulta realizada em 09/01/2016.

Sentença do Ministro Seráfico Robles de 1908, secretário do Supremo Tribunal de Justiça do Estado de Sonora, no processo que estabeleceu penas para os grevistas e que descreve o início dos conflitos, em 10 de agosto de 1908, pode ser acessada na íntegra em: Revista Relaciones 118, Primavera de 2009, vol. XXX.

$<$ http://www.revistarelaciones.com/files/revistas/118/pdf/documento.pdf $>$ Consulta realizada em 12/12/2015.

Programa del Partido Antireeleccionista, de 15 de abril de 1910. Em: BIBLIOTECA GARAY. 500 años de México en documentos. México, 2011.

<http://www.biblioteca.tv/artman2/publish/1910_215/Programa_politico_aprobado_en la_Convencion_del_Gr_1466.shtml $>$ Consulta realizada em 16/12/2015.

Plan de San Luís Potosí, de 5 de outubro de 1910. Em: CARMONA, Doralicia. Memoria política de México. Guanajuato: Universidade de Guanajuato, 2014. $<$ http://www.memoriapoliticademexico.org/Textos/6Revolucion/1910PSL.html $>$

Consulta realizada em 31/10/2015. 
Ley de Suspensión de Garantias, de 16 de março de 1911. Em: BIBLIOTECA GARAY. 500 años de México en documentos. México, 2011.

<http://www.bibliotecas.tv/zapata/1911/z13mar11.html> Consulta realizada em 02/11/2015.

Plan Político-Social, de 18 de março de 1911 Em: BIBLIOTECA GARAY. 500 años de México en documentos. México, 2011. <http://www.bibliotecas.tv/zapata/1911/z18mar11.html > Consulta realizada em 07/11/2015.

Discurso proferido por Porfírio Díaz em $1^{\circ}$ de abril de 1911. Em: BIBLIOTECA GARAY. 500 años de México en documentos. México, 2011.

$<$ http://www.biblioteca.tv/artman2/publish/1911_214/Discurso_de_Porfirio_D_az_al_a brir_las_sesiones_or_531.shtml> Consulta realizada em 04/11/2015.

Manifesto à nação publicado por Porfírio Díaz em 07 de maio de 1911. Em CARMONA, Doralicia. Memoria política de México. Guanajuato: Universidade de Guanajuato, 2014.

<http://www.memoriapoliticademexico.org/Textos/6Revolucion/1911MAX.html>

Consulta realizada em 04/11/2015.

Manifesto de Emiliano Zapata em 27 de agosto de 1911. Em: CARMONA, Doralicia. Memoria política de México. Guanajuato: Universidade de Guanajuato, 2014. <http://www.memoriapoliticademexico.org/Textos/6Revolucion/1911APM.html>

Consulta realizada em 21/11/2015.

Manifiesto del Partido Liberal Mexicano, de 23 de setembro de 1911. Em: UNAM. Cidade do México: Instituto de Investigaciones Jurídicas. <http://info5.juridicas.unam.mx/libros/6/2625/54.pdf> Consulta realizada em 06 de outubro de 2015.

Plan Felicista, de 16 de outubro de 1911, de Félix Díaz. Em: BIBLIOTECA GARAY. 500 años de México en documentos. México, 2011.

<http://www.biblioteca.tv/artman2/publish/1912_213/Proclama_de_F_lix_D_az_o_Plan _Felicista_1843.shtml> Consulta realizada em 21/11/2015.

Plan de Tacubaya, de 31 de outubro de 1911. Em: CARMONA, Doralicia. Memoria política de México. Guanajuato: Universidade de Guanajuato, 2014. <http://www.memoriapoliticademexico.org/Textos/6Revolucion/1911PDT.html>

Consulta realizada em 21/11/2105.

Plan de la Soledad, de 16 de novembro de 1911, de Bernardo Reyes. Em: CARMONA, Doralicia. Memoria política de México. Guanajuato: Universidade de Guanajuato, 2014.

<http://www.memoriapoliticademexico.org/Textos/6Revolucion/1911PBR.html>

Consulta realizada em 21/11/2015. 
Plan de Ayala, publicado pelos zapatistas em 25 de novembro de 1911. Em: CARMONA, Doralicia. Memoria política de México. Guanajuato: Universidade de Guanajuato, 2014.

<http://www.memoriapoliticademexico.org/Textos/6Revolucion/1911PDA.html >

Consulta realizada em 21/11/2015.

Emendas constitucionais nos artigos 78 e 109 da Constituição Mexicana de 1857, de 27 de novembro de 1911, sancionado por Francisco Madero. Em: MÉXICO. Secretaria de Gobernación: Unidade General de Asuntos Jurídicos.

<http://www.ordenjuridico.gob.mx/Constitucion/CH13.pdf > Consulta realizada em $21 / 11 / 2015$.

Lei que cria o Departamento del Trabajo, de 15 de dezembro de 1911. Em CARMONA, Doralicia. Memoria política de México. Guanajuato: Universidade de Guanajuato, 2014:

<http://www.memoriapoliticademexico.org/Textos/6Revolucion/1911DFT.html >

Consulta realizada em 16/12/2015.

Plan de Santa Rosa, de 3 de fevereiro de 1912. Em CARMONA, Doralicia. Memoria política de México. Guanajuato: Universidade de Guanajuato, 2014. <http://www.memoriapoliticademexico.org/Textos/6Revolucion/1912-PSR.html >

Consulta realizada em 16/12/2015.

Relatório da Comisión Nacional Agraria, de 7 de fevereiro de 1912. está em: CARMONA, Doralicia. Memoria política de México. Guanajuato: Universidade de Guanajuato, 2014. http://www.memoriapoliticademexico.org/Textos/6Revolucion/1912-PD-CNA.html Consulta realizada em 02/01/2016.

Decreto de 24 de fevereiro de 1912, para el deslinde de tierras, sancionado por Francisco Madero. Em: CARMONA, Doralicia. Memoria Política de México. México: Universidade de Guanajuato, 2014.

<http://www.memoriapoliticademexico.org/Textos/6Revolucion/1912DDT.html >

Consulta realizada em 02/01/2016.

Manifesto de Pascual Orozco, de 8 de março de 1912. Em CARMONA, Doralicia. Memoria política de México. Guanajuato: Universidade de Guanajuato, 2014: <http://www.memoriapoliticademexico.org/Textos/6Revolucion/1912-M-PO.html> Consulta realizada em 21/11/2015.

Plan de la Empacadora, de 25 de março de 1912. Em CARMONA, Doralicia. Memoria política de México. Guanajuato: Universidade de Guanajuato, 2014: <http://www.memoriapoliticademexico.org/Textos/6Revolucion/1912MPO.html>

Consulta realizada em 21/11/2015.

Informe de Madero à XXV Legislatura do Congresso Nacional Mexicano de $1^{\circ}$ de abril de 1912. Em: BIBLIOTECA GARAY. 500 años de México en documentos. México, 2011. <http://www.biblioteca.tv/artman2/publish/1912_213/Informe_de_Francisco_I_Madero _pronunciado_ante la 99. shtml $>$ Consulta realizada em 02/01/2015. 
Decreto de 3 de junho de 1912, assinado por Francisco Madero, sobre instituição de impostos. Em: CARMONA, Doralicia. Memoria política de México. Guanajuato: Universidade de Guanajuato, 2014.

<http://www.memoriapoliticademexico.org/Textos/6Revolucion/1912-PI-IEPC.html>

Consulta realizada em 22/11/2015.

Informe de Francisco I. Madero, de 16 de setembro de 1912, pronunciado frente à XXVI Legislatura para abertura das Sessões Ordinárias do Congreso Mexicano. Em: BIBLIOTECA GARAY. 500 años de México en documentos. México, 2011.

$<$ http://www.biblioteca.tv/artman2/publish/1912_213/Informe_de_Francisco_I_Madero _pronunciado_ante_la_100_printer.shtml > Consulta realizada em 18/12/2015.

Manifesto do Grupo Anarquista Luz, de 22 de setembro de 1912. Em CARMONA, Doralicia. Memoria política de México. Guanajuato: Universidade de Guanajuato, 2014: <http://www.memoriapoliticademexico.org/Efemerides/9/22091912.html > Consulta realizada em 20/12/2015.

Íntegra da proposta de reforma constitucional de Juan Sarabia e exposição de motivos de 24 de outubro de 1912. Em: BIBLIOTECA GARAY. 500 años de México en documentos. México, 2011.

$<$ http://www.biblioteca.tv/artman2/publish/1912_213/Proyecto_sobre_Cuesti_n_Agrari a_presentado_a_la_XX_103_printer.shtml> Consulta realizada em 04/01/2016.

Projeto de Lei Agrária de Luís Cabrera, de 3 de dezembro de 1912. Em: CARMONA, Doralicia. Memoria Política de México. México: Universidade de Guanajuato, 2014.

<http://www.memoriapoliticademexico.org/Textos/6Revolucion/1912REP.html >

Consulta realizada em 02/01/2015.

Pacto de la Ciudadela ou da Embajada, de 18 de fevereiro de 1913. Em: CARMONA, Doralicia. Memoria Política de México. Guanajuato: Universidade de Guanajuato, 2014.

<http://www.memoriapoliticademexico.org/Textos/6Revolucion/1913PCE.html>

Consulta realizada em 23/11/2015.

Texto "Yo Acuso", de Luis Manoel Rojas, em 23 de fevereiro de 1913. Em: CARMONA, Doralicia. Memoria Política de México. Guanajuato: Universidade de Guanajuato, 2014. <http://www.memoriapoliticademexico.org/Textos/6Revolucion/1913-YA-.html> Consulta realizada em 23/11/2015.

Manifesto de Emiliano Zapata, de 4 de março de 1913. Em CARMONA, Doralicia. Memoria política de México. Guanajuato: Universidade de Guanajuato, 2014. $<$ http://www.memoriapoliticademexico.org/Textos/6Revolucion/1913-M-

ZEDGH.html> Consulta realizada em 23/11/2015. 
Plan de Guadalupe, de 26 de março de 1913. Em: CARMONA, Doralicia. Memoria Política de México. Guanajuato: Universidade de Guanajuato, 2014. <http://www.memoriapoliticademexico.org/Textos/6Revolucion/1913PGP.html> Consulta realizada em 23/11/2015.

Decreto n. 1 de Venustiano Carranza, em 20 de abril de 1913. Em: CARMONA, Doralicia. Memoria Política de México. Guanajuato: Universidade de Guanajuato, 2014. <http://www.memoriapoliticademexico.org/Textos/6Revolucion/1913-D-VCEC.html> Consulta realizada em 23/11/2015.

Decreto n. 3, de Venustiano Carranza, em 26 de abril de 1913. Em: CARMONA, Doralicia. Memoria Política de México. Guanajuato: Universidade de Guanajuato, 2014. <http://www.memoriapoliticademexico.org/Textos/6Revolucion/1913-DCCDI.html> Consulta realizada em 23/11/2015.

Decreto de 14 de maio de 1913, de Venustiano Carranza. Em: CARMONA, Doralicia. Memoria Política de México. Guanajuato: Universidade de Guanajuato, 2014. <http://www.memoriapoliticademexico.org/Textos/6Revolucion/1913-D-VCPVL.html> Consulta realizada em 23/11/2015.

Decreto de 4 de julho de 1913, de Venustiano Carranza. Em: UNAM. Cidade do México: Instituto de Investigaciones Jurídicas. <http://biblio.juridicas.unam.mx/libros/6/2883/13.pdf > Consulta realizada em 23/11/2015.

Reformas ao Plan de Ayala, de 30 de maio de 1913. Em: MÉXICO. Secretaria de Gobernación: Unidade General de Asuntos Jurídicos. <http://www.ordenjuridico.gob.mx/Constitucion/CH9.pdf $>$ Consulta realizada em 12/01/2016.

Declaração de apolitismo da Casa del Obrero Mundial, de 13 de junho de 1913. Em CARMONA, Doralicia. Memoria política de México. Guanajuato: Universidade de Guanajuato, 2014:

$<$ http://www.memoriapoliticademexico.org/Textos/6Revolucion/1913DecPCOM.html> Consulta realizada em 20/12/2015.

Documento que realiza repartição de terras nos Estados de Nuevo León y Tamaulipas, de 6 de agosto de 1913, por Lucio Blanco. Em: BIBLIOTECA GARAY. 500 años de México en documentos.México, 2011. <http://www.biblioteca.tv/artman2/publish/1913_212/Revoluci_n_y_R_gimen_Constitu cionalista_Documento_424_Primer_reparto_de tierras_realizado_por_la_Revoluci_n

Acta_suscrita_por_el_general_Lucio_Blanco_comandante_de_las_fuerzas_constitucion alistas_de_los_Estados_de_Nuevo_Le_n_y_Tamaulipas_printer.shtml> Consulta realizada em 03/01/2016.

Decretos de Victoriano Huerta, de 10 e 11 de outubro de 1913. Em: BIBLIOTECA GARAY. 500 años de México en documentos. México, 2011. <http://www.biblioteca.tv/artman2/publish/1913_212/Decretos_y_manifiesto_de_Victo riano_Huerta_que_ord_1396.shtml> Consulta realizada em 24/11/2015. 
Decreto de Francisco Villa, de 21 de dezembro de 1913, válido para o Estado de Chihuahua. Em CARMONA, Doralicia. Memoria política de México. Guanajuato: Universidade de Guanajuato, 2014.

<http://www.memoriapoliticademexico.org/Textos/6Revolucion/1913-D-FV.html >

Consulta realizada em 05/01/2016.

Pacto de Torreón, de 8 de julho de 1914. Em: BIBLIOTECA GARAY. 500 años de México en documentos.México, 2011.

<http://www.biblioteca.tv/artman2/publish/1914_211/Pacto_de_Torre_n_Reformas_al_ Plan_de_Guadalupe_227.shtml>Consulta realizada em 30/11/2015.

Manifesto de Milta Alta, por Emiliano Zapata, em agosto de 1914. Em: CARMONA, Doralicia. Memoria política de México. Guanajuato: Universidade de Guanajuato, 2014.

<http://www.memoriapoliticademexico.org/Textos/6Revolucion/1914APM.html>

Consulta realizada em 25/11/2015.

Carta de Emiliano Zapata a Woodrow Wilson, de 23 de agosto de 1914. Em BIBLIOTECA GARAY. 500 años de México en documentos. Cidade do México, 2011. <http://www.bibliotecas.tv/zapata/1914/z23ago14.html> Consulta realizada em 04/01/2016.

Decreto de 23 de agosto de 1914 para o Estado de de Aguascalientes. Regulamento jornada de trabalho e descansos semanais obrigatórios, elaborado por Alberto Fuentes. Em CARMONA, Doralicia. Memoria política de México. Guanajuato: Universidade de Guanajuato, 2014: <http://www.memoriapoliticademexico.org/Textos/6Revolucion/1914-DDS-AF.html > Consulta realizada em 22/12/2015.

Decreto de 3 de setembro de 1914 para os Estados de Puebla e Tlaxcala. Abolição de todas as dívidas dos trabalhadores, decretada por Pablo González. Em CARMONA, Doralicia. Memoria política de México. Guanajuato: Universidade de Guanajuato, 2014: <http://www.memoriapoliticademexico.org/Textos/6Revolucion/1914-DADP-PG.html > Consulta realizada em 22/12/2015.

Decreto de Emiliano Zapata, de 8 de setembro de 1914. Declara a nacionalização dos bens dos inimigos da revolução,. Em CARMONA, Doralicia. Memoria política de México. Guanajuato: Universidade de Guanajuato, 2014.

<http://www.memoriapoliticademexico.org/Textos/6Revolucion/1914DecEZ.html> Consulta realizada em 04/01/2016.

Documento de Álvaro Obregón e Francisco Villa para Venustiano Carranza, em 9 de setembro de 1914. Em: CARMONA, Doralicia. Memoria política de México. Guanajuato: Universidade de Guanajuato, 2014.

<http://www.memoriapoliticademexico.org/Textos/6Revolucion/1914MVC-AO-

FV.html> Consulta realiza-da em 30/11/2015. 
Resposta de Venustiano Carranza, de 13 de setembro de 1914, ao documento de Obregon e Villa, de 9 de setembro de 1914. Em: CARMONA, Doralicia. Memoria política de México. Guanajuato: Universidade de Guanajuato, 2014.

<http://www.memoriapoliticademexico.org/Textos/6Revolucion/1914RPC.html>

Consulta realizada em 30/11/2015.

Lei sobre sueldos dos peones para o Estado de San Luís Potosí, de 15 de setembro de 1914, Decretada por Eulálio Gutierrez. Em CARMONA, Doralicia. Memoria política de México. Guanajuato: Universidade de Guanajuato, 2014: $<$ http://www.memoriapoliticademexico.org/Textos/6Revolucion/19140915-DecEG-

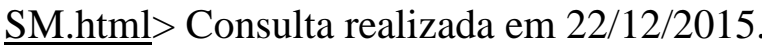

Decreto de 19 de setembro de 1914 para o Estado de Tabasco, por Luis F. Domiguez. Em: CONTRERAS, Mario; TAMAYO, Jesus. México en el siglo XX 19131920. Textos y documentos, Tomo II. Cidade do México: Universidad Autónoma de México, 1989, p. 178.

Manifesto de 22 de setembro de 1914, em que Francisco Villa oficialmente rompe com o Exército Constitucionalista e com Venustiano Carranza. Em: CARMONA, Doralicia. Memoria política de México. Guanajuato: Universidade de Guanajuato, 2014. http://www.memoriapoliticademexico.org/Textos/6Revolucion/1914MFV.html

Consulta realizada em 30/11/2015.

Carta de Francisco Villa para Emiliano Zapata, em 22 de setembro de 1914. Em: CARMONA, Doralicia. Memoria política de México. Guanajuato: Universidade de Guanajuato, 2014. <http://www.memoriapoliticademexico.org/Textos/6Revolucion/1914-C-FV-EZ.html> Consulta realizada em 30/11/2015.

Ata da sessão de 14 de outubro de 1914 da Convenção de Aguascalientes. Em: CARMONA, Doralicia. Memoria política de México. Guanajuato: Universidade de Guanajuato, 2014. <http://www.memoriapoliticademexico.org/Textos/6Revolucion/1914-DCR-DS.html> Consulta realizada em 01/12/2015.

Carta que Venustiano Carranza encaminha aos membros da Convenção de Aguascalientes em 23 de outubro de 1914. Em: CARMONA, Doralicia. Memoria política de México. Guanajuato: Universidade de Guanajuato, 2014. <http://www.memoriapoliticademexico.org/Textos/6Revolucion/1914MCA.html> Consulta realizada em 02/12/2015.

Discurso de Paulino Martinez, proferido na Convenção de Aguascalientes, em 27 de outubro de 1914. Em: CARMONA, Doralicia. Memoria política de México. Guanajuato: Universidade de Guanajuato, 2014.

<http://www.memoriapoliticademexico.org/Textos/6Revolucion/1914-DDZ-CA.html> Consulta realizada em 02/12/2015. 
Manifesto da Convenção de Aguascalientes de 6 de novembro de 1914. Em: CARMONA, Doralicia. Memoria política de México. Guanajuato: Universidade de Guanajuato, 2014.

<http://www.memoriapoliticademexico.org/Textos/6Revolucion/1914MAC.html>

Consulta realizada em 02/12/2015.

Lei Agrária de Venustiano Carranza. Decreto de 6 de janeiro de 1915. Em: MÉXICO. Secretaria de Gobernación: Unidade General de Asuntos Jurídicos. <http://www.ordenjuridico.gob.mx/Constitucion/CH15.pdf $>$ Consulta realizada em 03/01/2015.

Decreto de 29 de janeiro de 1915, expedido por Venustiano Carranza. Amplia competência do Congresso para legislar sobre direito do trabalho. Em: BIBLIOTECA VIRTUAL DEL ESTADO DE JALISCO. Guadalajara: Poder Legislativo del Estado de Jalisco, 2009.

$<$ http://congresojal.gob.mx/bibliotecavirtual/libros/legislacionprecosntitucional1915.pdf $>$ p. 28. Consulta realizada em 22/12/2015.

Manifesto da Casa del Obrero Mundial, de 20 de fevereiro de 1915. Em CARMONA, Doralicia. Memoria política de México. Guanajuato: Universidade de Guanajuato, 2014.

<http://www.memoriapoliticademexico.org/Textos/6Revolucion/1915MCO.html >

Consulta realizada em 20/12/2015.

Projeto de lei sobre o Contrato de Trabalho, de 12 de abril de 1915, elaborado por Rafael Zubarán Capmany. Em: : Dirección General de Bibliotecas (DGB). Cidade do México: Secretaría de Educación Pública: Consejo Nacional para la Cultura y las Artes, 2013.

$\langle$ http://dgb.conaculta.gob.mx/coleccion_sep/libro_pdf/50000006389.pdf\#toolbar=0 $>$

Consulta realizada em 21/12/2015.

Lei Agrária de Francisco Villa, de 24 de maio de 1915. Em BIBLIOTECA GARAY. 500 años de México en documentos. Cidade do México, 2011.

$<$ http://www.biblioteca.tv/artman2/publish/1915_210/Ley_Agraria_del_General_Franci sco_Villa_211.shtml $>$ Consulta realizada em 05/01/2016.

Decreto de 22 de junho de 1915, expedido por Venustiano Carranza. Sobre Tiendas de Raya. Em: BIBLIOTECA VIRTUAL DEL ESTADO DE JALISCO. Guadalajara: Poder Legislativo del Estado de Jalisco, 2009.

<http://congresojal.gob.mx/bibliotecavirtual/libros/legislacionprecosntitucional1915.pdf

$>$ p. 41. Consulta realizada em 22/12/2015.

Lei Agrária zapatista-convencionista, de 26 de outubro de 1915. em: BIBLIOTECA GARAY. 500 años de México en documentos. Cidade do México, 2011. <http://www.bibliotecas.tv/zapata/1915/z22oct15.htm> Consulta realizada em 04/01/2016. 
Lei sobre Acidentes de Trabalho, de 27 de outubro de 1915, aprovada pela Soberana Convención Revolucionaria. Em: BIBLIOTECA GARAY. 500 años de México en documentos. México, 2011. <http://www.bibliotecas.tv/zapata/1915/z27oct15.htm $>$ Consulta realizada em $21 / 12 / 2015$.

Projeto da Lei Geral do Trabalho, de 7 de novembro de 1915, aprovada pela Soberana Convención Revolucionária. Em: BIBLIOTECA GARAY. 500 años de México en documentos. México, 2011.

<http://www.bibliotecas.tv/zapata/1915/z07nov15.htm> Consulta realizada em 21/12/2015.

Decreto regulamentador da Lei Agrária de Carranza para Estado de Yucatán, de 3 de dezembro de 1915. Expedido por Salvador Alvarado. Em: Centenario de la Constitución Política de los Estados Unidos Mexicanos 1917. México, Instituto Nacional de Estudios Históricos de las Revoluciones de México (INEHRM), 2015.

<http://constitucion1917.gob.mx/es/Constitucion1917/Ley_Agraria_>. Consulta realizada em 05/01/2016.

Lei do Trabalho para o Estado de Yucatán. Decreto n. 392 de 11 de dezembro de 1915, expedida por Salvador Alvarado. Em BIBLIOTECA GARAY. 500 años de México en documentos. México, 2011.

$<$ http://www.biblioteca.tv/artman2/publish/1915_210/Ley_del_Trabajo_de_Salvador_A lvarado_1371.shtml > Consulta realizada em 21/12/2015.

Discurso de Venustiano Carranza em 3 de fevereiro de 1916. Em CARMONA, Doralicia. Memoria política de México. Guanajuato: Universidade de Guanajuato, 2014. <http://www.memoriapoliticademexico.org/Efemerides/9/22091912.html > Consulta realizada em 21/12/2015.

Programa de Reformas Político-Sociales de la Soberana Convención Revolucionária, de 18 de abril de 1916. Em: CARMONA, Doralicia. Memoria política de México. Guanajuato: Universidade de Guanajuato, 2014. Disponível em: <http://www.memoriapoliticademexico.org/Textos/6Revolucion/1916PRP.html > Consulta realizada em 27/12/2015.

Decreto de $1^{\circ}$ de agosto de 1916, de Venustiano Carranza, em que são estabelecidas penas para os grevistas. Em: CARMONA, Doralicia. Memoria política de México. Guanajuato: Universidade de Guanajuato, 2014. http://www.memoriapoliticademexico.org/Textos/6Revolucion/1916DCT.html Consulta realizada em 02/12/2015.

Decreto de 14 de setembro de 1916, em que Venustiano Carranza convoca o Congresso Constituinte. Em: MÉXICO. Centenario de la Constitución Política de los Estados Unidos Mexicanos 1917. Cidade do México: Instituto Nacional de Estudios Históricos de las Revoluciones de México (INEHRM), 2015.

http://www.constitucion1917.gob.mx/work/models/Constitucion1917/Resource/251/1/i mages/001.pdf Consulta realizada em 04/12/2015 
Projeto de Constituição encaminhado por Venustiano Carranza ao Congreso Constituyente, em 6 de dezembro de 1916. Em: MÉXICO. Diário de los debates del Congreso Constituyente, 6 de diciembre de 1916. Centenario de la Constitución Política de los Estados Unidos Mexicanos 1917. Cidade do México: Instituto Nacional de Estudios Históricos de las Revoluciones de México (INEHRM), 2015, p. 345. <http://www.constitucion1917.gob.mx/work/models/Constitucion1917/Resource/251/1/ images/016.pdf $>$ Consulta realizada em 28/12/2015.

Debates sobre a redação do artigo 123 constitucional. Em: MÉXICO. Congreso Constituyente de los Estados Unidos Mexicanos - Debates Notables - artículo 123 en materia laboral. Centenario de la Constitución Política de los Estados Unidos Mexicanos 1917. Cidade do México: Instituto Nacional de Estudios Históricos de las Revoluciones de México (INEHRM), 2015.

<http://www.constitucion1917.gob.mx/work/models/Constitucion1917/Resource/251/1/ images/022.pdf> Consulta realizada em 28/12/2015.

Texto original da Constituição Política dos Estados Unidos Mexicanos, de 5 de fevereiro de 1917. Em MÉXICO. Centenario de la Constitución Política de los Estados Unidos Mexicanos 1917. Cidade do México: Instituto Nacional de Estudios Históricos de las Revoluciones de México (INEHRM), 2015.

$<$ http://www.juridicas.unam.mx/infjur/leg/conshist/pdf/1917.pdf $>$ Consulta realizada em 06/01/2016.

Convenção n. 52 da Organização Internacional do Trabalho (OIT), de 4 de junho de 1936. Em: OIT. Brasília: Escritório Brasileiro da Organização Internacional do Trabalho.

<http://www.oitbrasil.org.br/node/521 > Consulta realizada em 15/12/2015.

Exposição de motivos que justifica a inscrição em homenagem aos grevistas de Cananea e Río Blanco na Câmara dos Deputados mexicana, de 5 de junho de 2013, pode ser acessada em: Camara dos Diputados, 2013.

$<$ http://sil.gobernacion.gob.mx/Archivos/Documentos/2013/06/asun_2985062_2013060 5_1370543867.pdf $>$ Consulta realizada em 13/12/2015. 